\section{CH2M HILL ENGINEERING CHANGE NOTICE}

Page 1 of 2 $\triangle \mathrm{DM} \quad \square \mathrm{FM} \quad \square$ TM 1a. ECN 722760 R 4

1b. Proj. ECN

$\mathrm{R}$

\begin{tabular}{|c|c|c|c|c|c|}
\hline $\begin{array}{l}\text { 2. Simple Modification } \\
\qquad \text { Yes } \square \text { No }\end{array}$ & \multicolumn{4}{|c|}{$\begin{array}{l}\text { 3. Design Inputs - For full ECNs, record information on the ECN-1 Form (not } \\
\text { required for Simple Modifications) }\end{array}$} & $\begin{array}{l}\text { 4. Date } \\
\text { September } 7,2005\end{array}$ \\
\hline \multicolumn{4}{|c|}{$\begin{array}{l}\text { 5. Originator's Name, Organization, MSIN, \& Phone No. } \\
\text { S. D. Kozlowski } \\
\text { Waste Feed Nuclear Safety } \\
\text { R3-86, 373-1360 }\end{array}$} & $\begin{array}{l}\text { 6. USQ Number } \\
\text { No. - - } \\
\\
\end{array}$ & $\begin{array}{l}\text { 7. Related ECNs } \\
\text { N/A }\end{array}$ \\
\hline \multicolumn{2}{|c|}{$\begin{array}{l}\text { 8. Title } \\
\text { Atmospheric Dispersion Coefficients and } \\
\text { Radiological/Toxicological Exposure Methodology }\end{array}$} & \multicolumn{2}{|c|}{$\begin{array}{l}\text { 9. Bldg./ Facility No. } \\
\text { Tank Farms }\end{array}$} & $\begin{array}{l}\text { 10. Equipment / Component ID } \\
\text { N/A }\end{array}$ & $\begin{array}{l}\text { 11. Approval Designator } \\
\text { N/A }\end{array}$ \\
\hline \multicolumn{4}{|c|}{$\begin{array}{l}\text { 12. Engineering Documents/Drawings to be Changed (Incl. Sheet \& Rev. Nos.) } \\
\text { RPP-13482, Rev. } 4\end{array}$} & $\begin{array}{l}\text { 13. Safety Designation } \\
\square \text { sc } \square \text { ss } \square \text { Gs } \square \text { N/A }\end{array}$ & $\begin{array}{l}\text { 14. Expedited/Off-Shift } \\
\text { ECN? } \\
\square \text { Yes } \square \text { No }\end{array}$ \\
\hline $\begin{array}{l}\text { 15a. Work Package Number } \\
\text { N/A }\end{array}$ & \multicolumn{2}{|c|}{$\begin{array}{l}\text { 15b. Modification Work Completed } \\
\text { N/A }\end{array}$} & \multicolumn{2}{|c|}{ 15c. Restored to Original Status (TM) } & $\begin{array}{l}\text { 16. Fabrication Support } \\
\text { ECN? } \\
\square \text { Yes } \square \text { No }\end{array}$ \\
\hline
\end{tabular}

17. Description of the Change (Use ECN Continuation pages as needed)

The atmospheric dispersion coefficients used for Tank Farm safety analysis are documented in RPP-13482. RPP-13482 is being revised to include new atmospheric dispersion coefficients that were derived for use in accident scenarios related to the ContactHandled Transuranic/Mixed (CH-TRUM) Waste Packaging Unit (WPU). Appendix N was added in its entirety to Rev. 5.

18. Justification of the Change (Use ECN Continuation pages as needed)

The $\mathrm{CH}$-TRUM WPU is a supplemental treatment technology being developed to receive, dry, and package low-activity, contact-handled transuranic/mixed waste from Tank Farm single-shell tank (SST) systems. To facilitate the analysis of the resultant accident scenarios, new atmospheric dispersion coefficients were derived.

The change supports a preliminary documented safety analysis (PDSA) for the CH-TRUM WPU. However, the project has been placed on hold. The PDSA will be submitted, but will not be approved by DOE at this time. With the project deferred, there can be no impact on the tank farms safety basis. Therefore, a USQ evaluation is not required. Note that the PDSA will undergo formal DOE/ORP review and approval when the project is restarted.
19. ECN Category

\Direct Revision

$\square$ Supplemental $\square$ Void/Cancel

ECN Type

$\square$ Supercedure

$\square$ Revision

\begin{tabular}{|l|l|l|l|}
\hline 20. Distribution & MSIN & Name & MSIN \\
\hline Name & R3-86 & W. B. Scott & H6-60 \\
\hline T. G. Goetz & S7-90 & R. J. Stevens & R2-58 \\
\hline J. M. Grigsby & R2-12 & A. R. Tedeschi & H6-19 \\
\hline E. C. Heubach & S7-90 & W. L. Cowley & R3-86 \\
\hline M. J. Higuera & H6-60 & Central Files (Original + 1) & B1-07 \\
\hline D. H. Irby & R3-86 & & \\
\hline S. D. Kozlowski & S7-90 & & \\
\hline L. J. Kripps & & & \\
\hline
\end{tabular}

Release Stamp

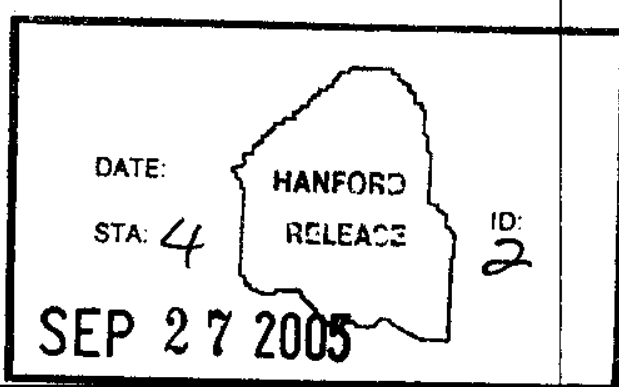




\section{CH2M HILL ENGINEERING CHANGE NOTICE}

Page 2 of 2

囚 DM $\square$ FM $\square$ TM

1a. ECN 722760 R 4

1b. Proj. ECN

R

21. Revisions Planned (Include a brief description of the contents of each revision)

N/A

Note: All revisions shall have the approvals of the affected organizations as identified in block 11 "Approval Designator," on page 1 of this ECN.

23. Commercial Grade Item Dedication Numbers (associated with this design change)

N/A

24. Engineering Data Transmittal Numbers (associated with this design change, e.g., new drawings, new documents)

N/A

25. Other Non Engineering (not in HDCS) documents that need to be modified due to this change

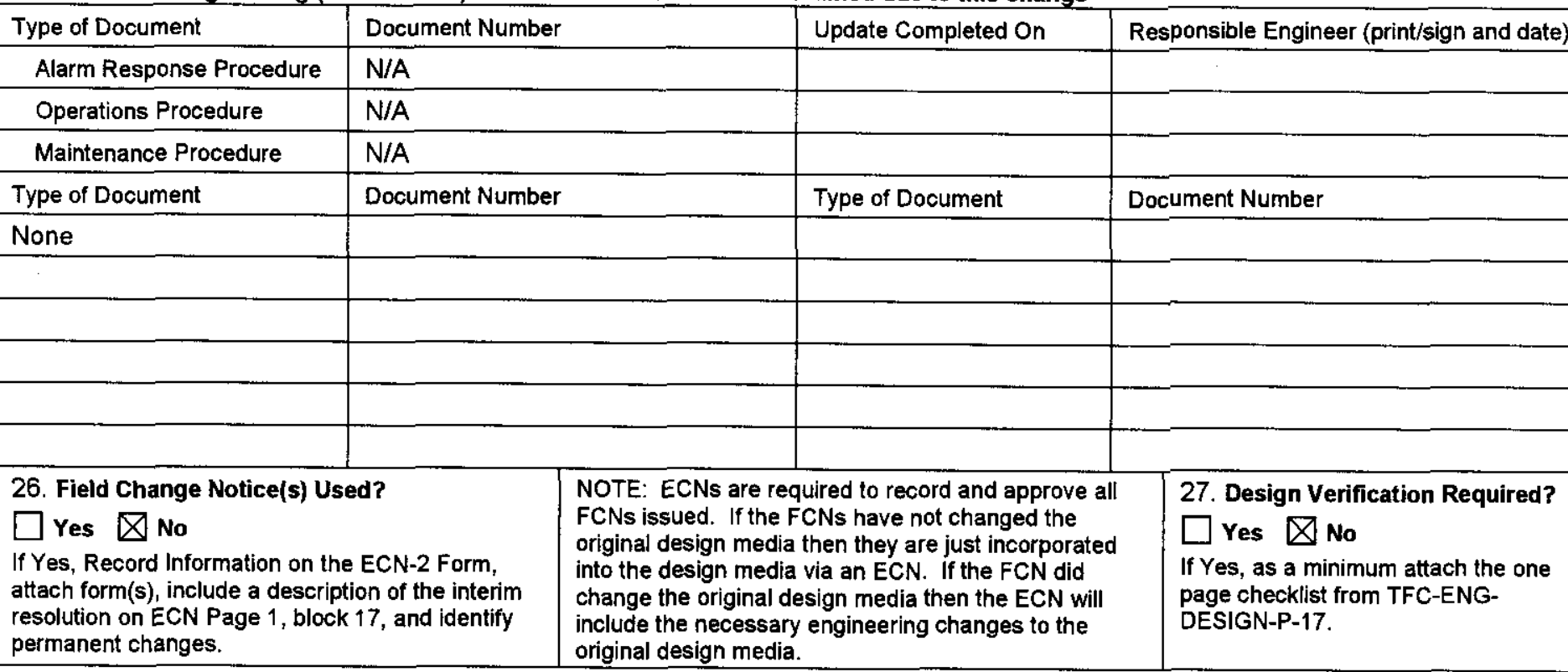

28. Approvals

Design Authority

Resp. Engineer S. D. Kozlowski

Resp. Manager J.M. Grigsby

Quality Assurance

IS\&H Engineer

NS\&L Engineer S. D. Kozlowski

Environ. Engineer

Engineering Checker

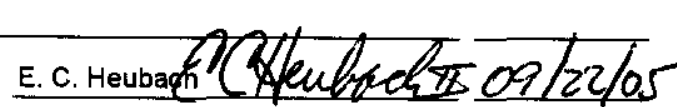

Originator/Design Agent

Professional Engineer

Project Engineer

Quality Assurance

Safety

Designer

Environ. Engineer

Other

Other

DEPARTMENT OF ENERGY / OFFICE OF RIVER PROTECTION

Signature or a Control Number that tracks the Approval Signature

ADDITIONAL SIGNATURES 


\title{
Atmospheric Dispersion Coefficients and Radiological and Toxicological Exposure Methodology for Use in Tank Farms
}

\author{
S.D. Kozlowski \\ CH2M HILI Hanford Group, Inc. \\ Richland, WA 99352 \\ U.S. Department of Energy Contract DE-AC27-99RL14047

$\begin{array}{lll}\text { EDT/ECN: } & 722760 \mathrm{R} 4 & \text { UC: N/A } \\ \text { Cost Center: } 7 \text { G520 } & \text { Charge Code: } 501546 \\ \text { B\&R Code: } & \text { N/A } & \text { Total Pages: } 317\end{array}$ \\ Key Words: Atmospheric dispersion, dose calculation, GXQ, X/Q, \\ radiological, toxicological, DBVS, CH-TRUM
}

\begin{abstract}
This report presents the atmospheric dispersion coefficients used in Tank Farm safety analyses. The basic equations for calculating radiological and toxicological exposures are also included. This revision deals with the atmospheric dispersion coefficients used for the accident analyses for the Contact-Handled Transuranic/Mixed (CH-TRUM) Waste Packaging Unit (WPU) operations.
\end{abstract}

TRADEMARK DISCLAIMER. Reference herein to any specific commercial product, process, or service by trade name, trademark, manufacturer, or otherwise, does not necessarily constitute or imply its endorsement, recommendation, or favoring by the United States Government or any agency thereof or its contractors or subcontractors.

Printed in the United States of America. To obtain copies of this document, contact: Document Control Services, P.O. Box 950, Mailstop H6-08, Richland WA 99352, Phone (509) 372-2420; Fax (509) 376-4989.

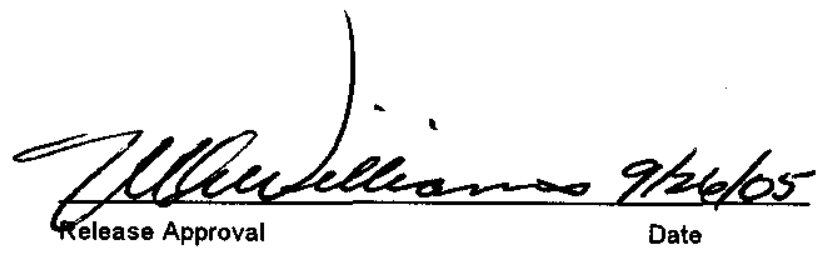

Approved For Public Release 


\section{Tank Farm Contractor (TFC) \\ RECORD OF REVISION}

(1) Document Number
RPP-13482

Page 1

(2) Title

Atmospheric Dispersion Coefficients and Radiological and Toxicological Exposure Methodology for Use in Tank Farms

Change Control Record

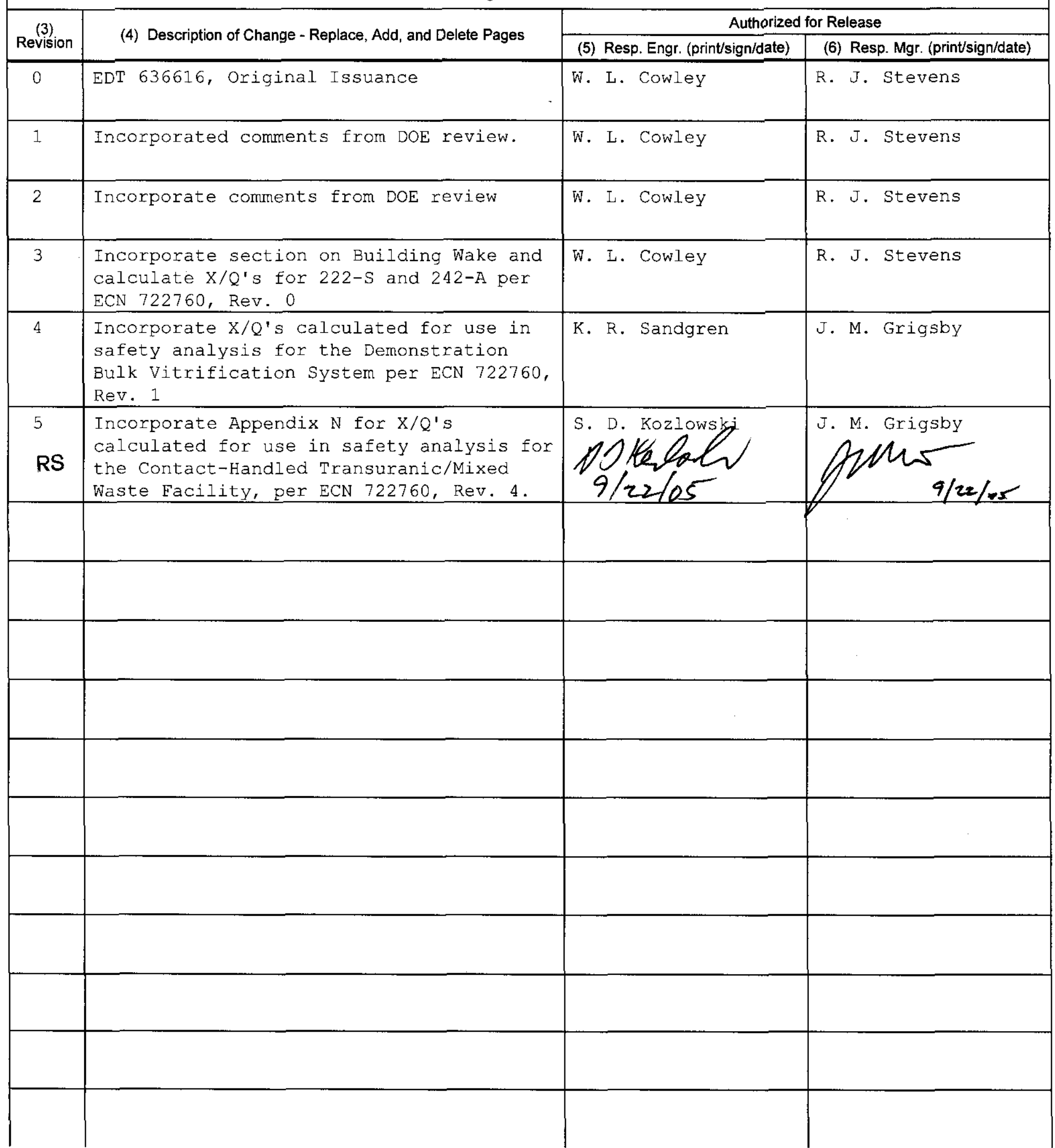


RPP-13482

Revision 5

\section{Atmospheric Dispersion Coefficients and Radiological and Toxicological Exposure Methodology for Use in Tank Farms}

W. L. Cowley

CH2M HILL Hanford Group, Inc.

D. A. Himes

P. D. Rittmann

Fluor Government Group

Date Published

September 2005

Prepared for the U.S. Department of Energy

Assistant Secretary for Environmental Management

Contractor for the U.S. Department of Energy

Office of River Protection under Contract DE-AC27-99RL14047

\section{CH2NHILL}

Hanford Group, Inc.

P.O. Box 1500

Richland, Washington

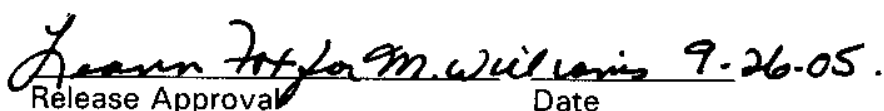


RPP-13482 REV 5

CONTENTS

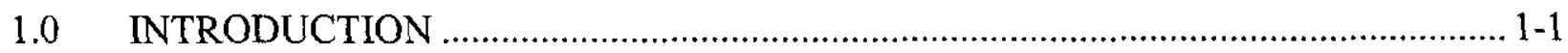

2.0 GXQ CALCULATIONS OF TANK FARM DISPERSION COEFFICIENTS ............... 2-1

2.1 ATMOSPHERIC DISPERSION …………............................................. 2-1

2.2 BASIC DISPERSION CALCULATIONS …………....................................... 2-3

2.2.1 Acute Release Dispersion .................................................................. 2-3

2.2.2 Annual Average Meteorology................................................................ 2-5

2.2.3 50 ${ }^{\text {th }}$ Percentile Meteorology ................................................................ 2-5

2.2.4 Plume Meander ................................................................................ 2-5

2.2.5 Puff Release Dispersion Coefficient .................................................... 2-6

2.2.6 Results of Basic Dispersion Calculations ……….................................... 2-7

2.3 MODIFIED DISPERSION CALCULATIONS …..................................... 2-8

2.3.1 Plume Depletion............................................................................. 2-8

2.3.2 Releases From Short Stacks with Momentum/Thermal Rise ................ 2-14

2.3.3 Large Source Effects........................................................................ 2-17

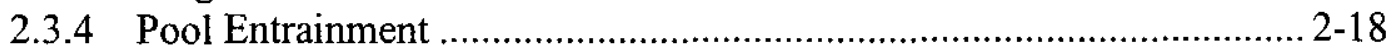

2.3.5 Building Wake Effects ...................................................................... 2-20

2.4 SELECTION OF APPROPRIATE DISPERSION COEFFICIENTS ............... 2-22

2.4.1 Short $(<1 \mathrm{hr})$ or Variable Rate Releases ............................................ 2-22

2.4.2 Release Durations From One to Two Hours.......................................... 2-22

2.4.3 Release Durations Greater Than Two Hours ........................................ 2-23

2.4.4 Puff Releases................................................................................ 2-23

3.0 VERIFICATION OF GXQ VERSION 4.0F CALCULATIONS................................. 3-1

$3.1 \quad$ BASIC DISPERSION COEFFICIENTS ………....................................... 3-1

3.2 DISPERSION COEFFICIENTS WITH PLUME DEPLETION ....................... 3-23

3.3 DISPERSION COEFFICIENTS WITH PLUME RISE ……........................... 3-25

3.4 DISPERSION COEFFICIENTS FOR AREA SOURCES ………………....... 3-27

3.5 AIR TRANSPORT FACTORS FOR POOL SOURCES …………................. 3-28

3.6 BUILDING WAKE ……................................................................ 3-29

3.6.1 Formulas for NRC Regulatory Guide 1.145 Building Wake and

Plume Meander ........................................................................... 3-29

3.6.2 Verification Testing of the GXQ Building Wake and Plume Meander Model ................................................................................. 3-31

3.7 GXQ VERSION 4.0F SOURCE CODE LISTING …................................... 3-36

4.0 RADIOLOGICAL DOSE CALCULATIONS ……................................................ 4-1

$4.1 \quad$ EXPOSURE PATHWAYS................................................................ 4-1

4.2 SOURCE TERM DEVELOPMENT …………........................................ 4-2

4.3 RADIOLOGICAL DOSE CALCULATIONS .......................................... 4-3

5.0 TOXICOLOGICAL EXPOSURE CALCULATIONS................................................ 5-1

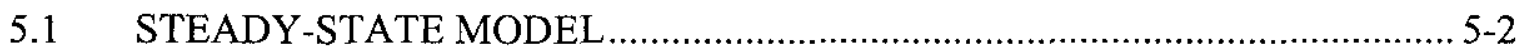

5.2 PUFF RELEASE MODEL …………………........................................ 5-3 
5.3 TOXIC CHEMICAL MIXES $5-4$

6.0 REFERENCES 6-1

\section{APPENDICES}

A PROGRAM LISTING OF THE GXQ CODE VERSION 4.0F A-i

B SAMPLE INPUT FILE AND RUN FILES FOR BASIC DISPERSION COEFFICIENT CALCULATIONS IN SECTION 2.2 .. B-i

C SAMPLE RUN FILES FOR MODIFICATIONS TO THE BASIC DISPERSION COEFFICIENTS. $\mathrm{C}-\mathrm{i}$

D GXQ CDF OUTPUT FOR THE BASE CASE CENTERLINE PLUME D-i

E GXQ CDF OUTPUT FOR THE CENTERLINE PLUME WITH MEANDER ..E-i

F GXQ CDF OUTPUT FOR PUFF RELEASE F-i

G SPECIAL $\chi / Q$ 'S FOR THERMALLY LOFTED RELEASES AND DISPLACED VOLUMES.

$\mathrm{H} \quad$ SPECIAL $\chi / \mathrm{Q}$ S AND $\chi / \mathrm{Q}$ 's FOR PUFF RELEASES DUE TO RAPID VENTING OF UNDERGROUND TANK

I SPECIAL GROUND LEVEL RELEASE $\chi / \mathrm{Q}$ 's WITH PLUME DEPLETION.. I-i

J SPECIAL $\chi / Q$ 'S FOR GASOLINE POOL FIRES $\mathrm{J}-\mathrm{i}$

K SPECIAL $\chi / Q$ 'S FOR RELEASES FROM THE 242-A EVAPORATOR $\mathrm{K}-\mathrm{i}$

L SPECIAL $\chi / Q$ 'S FOR RELEASES FROM THE 222-S LABORATORY $\mathrm{L}-\mathrm{i}$

M SPECIAL $\chi /$ Q'S FOR POOL FIRES AT THE DEMONSTRATION BULK VITRIFICATION SYSTEM

N SPECIAL $\chi / Q$ 's FOR POOL FIRES AT THE CONTACT-HANDLED TRANSURANIC MIXED WASTE PACKAGING UNIT . $\mathrm{N}-\mathrm{i}$

O PEER REVIEW CHECKLISTS $\mathrm{O}-\mathrm{i}$ 
RPP-13482 REV 5

\section{LIST OF FIGURES}

Figure 2-1. Deposition Velocities.

$2-11$

\section{LIST OF TABLES}

Table 2-1. Wind Speed Classifications.

Table 2-2. Atmospheric Stability Classifications. $2-2$

Table 2-3. Site Boundary Distances. $2-4$

Table 2-4. Dispersion Coefficients for 200 Area Tank Farms to Onsite Receptor at $100 \mathrm{~m}$.

Table 2-5. Dispersion Coefficients for 200 Area Tank Farms to Site Boundary Receptor........2-8

Table 2-6. Effects of Plume Depletion with $0.15 \mathrm{~cm} / \mathrm{s}$ Deposition Velocity - Onsite Receptor at $100 \mathrm{~m}$ $2-10$

Table 2-7. Effects of Plume Depletion with $0.15 \mathrm{~cm} / \mathrm{s}$ Deposition Velocity - Site Boundary Receptor. $2-10$

Table 2-8. Terminal Fall Velocities and Deposition Velocities. $2-12$

Table 2-9. All-Sector $95^{\text {th }}$ Percentile, 1-hr $\chi / \mathrm{Q}$ 's for the Onsite Receptor at $100 \mathrm{~m}$. $2-12$

Table 2-10. All-Sector $95^{\text {th }}$ Percentile, 1-hr $\chi / \mathrm{Q}$ 's for the Site Boundary Receptor. $2-13$

Table 2-11. All-Sector $95^{\text {th }}$ Percentile Puff Release $\chi / \mathrm{Qs}$ for the Onsite Receptor at $100 \mathrm{~m}$.

Table 2-12. All-Sector $95^{\text {th }}$ Percentile Puff Release $\chi /$ Qs for the Site Boundary Receptor. .... 2-13

Table 2-13. All-Sector $95^{\text {th }}$ Percentile, 1-hr $\chi / \mathrm{Q}$ 's for the Onsite Receptor at $100 \mathrm{~m}$ for Various Source Conditions $\left(\mathrm{s} / \mathrm{m}^{3}\right)$.

Table 2-14. All-Sector $95^{\text {th }}$ Percentile, 1-hr $\chi / \mathrm{Q}$ 's for the Site Boundary Receptor for Various Source Conditions $\left(\mathrm{s} / \mathrm{m}^{3}\right)$.

Table 2-15. All-Sector $95^{\text {th }}$ Percentile, 1 -hr $\chi / \mathrm{Q}$ 's for the Onsite Receptor at $100 \mathrm{~m}$ for Various Source Widths.

Table 2-16. All-Sector $95^{\text {th }}$ Percentile, 1-hr $\chi / \mathrm{Q}$ 's for the Hanford Site Boundary Receptor for Various Source Widths. 
RPP-13482 REV 5

Table 2-17. Entrainment Coefficients for Onsite Receptor. ................................................. 2-20

Table 2-18. Entrainment Coefficients for Offsite Receptor..................................................2-20

Table 2-19. Example Onsite and Site Boundary $\chi / Q$ 's with Building Wake Correction.......... 2-21

Table 3-1. Horizontal and Vertical Standard Deviations for Each Distance.............................. 3-2

Table 3-2. Plume Reflection Parameter Values........................................................................ 3-3

Table 3-3. Cumulative Probability Distribution for the Worker at $100 \mathrm{~m}$, All Sectors, Centerline Values. (2 sheets).............................................................................. 3-4

Table 3-4. Cumulative Probability Distribution for the Hanford Site Boundary, All Sectors, Centerline Values. (11 sheets) …………………………................... 3-6

Table 3-5. Cumulative Probability Distribution for the Site Boundary, North Sector, Centerline Values. (2 sheets)

Table 3-6. Cumulative Probability Distribution for the Worker at $100 \mathrm{~m}$, North Sector, with Plume Meander. 3-19

Table 3-7. Portion of the GXQ Cumulative Distribution that is Different. .............................. 3-20

Table 3-8. Cumulative Distribution When Equal Values are Combined................................... 3-21

Table 3-9. Calculation of the Annual Average for the Worker at $100 \mathrm{~m}$, East-Southeast Sector. (2 sheets)

Table 3-10. Cumulative Probability Distribution for the Worker at $100 \mathrm{~m}$, All Sectors, Short Duration (Puff) Release.

Table 3-11. Comparison of Plume Depletion Factors for a Ground Deposition Speed of $0.15 \mathrm{~cm} / \mathrm{s}$.

Table 3-12. Comparison of Plume Dispersion Coefficients with Plume Depletion. $3-24$

Table 3-13. Plume Dispersion Coefficients for the $100 \mathrm{ft}^{3} / \mathrm{min}$ Stack with Downwash and Flow Rate Adjustments.

Table 3-14. Effective Release Height and Wind Speed for the $1,000 \mathrm{ft}^{3} / \mathrm{min}$ Stack with ISC2 Plume Rise.

Table 3-15. Plume Dispersion Coefficients for the $1,000 \mathrm{ft}^{3} / \mathrm{min}$ Stack with ISC2 Plume Rise.

Table 3-16. Comparison of Virtual Source Distances for Two Area Sources.

Table 3-17. Comparison of Plume Dispersion Coefficients for the 10-m Wide Source. 


\section{RPP-13482 REV 5}

Table 3-18. Scale Factors for Pool Releases.................................................................... 3-28

Table 3-19. Plume Air Transport Factors for a $10 \mathrm{~m}$ Wide Pool.............................................. 3-29

Table 3-20. Plume Standard Deviations. ........................................................................... 3-31

Table 3-21. Building Wake Factors. …………………..................................................... 3-32

Table 3-22. Plume Meander Parameters. (2 sheets) ……………........................................... 3-32

Table 3-23. Plume Reflection Factors. ……………………................................................. 3-33

Table 3-24. Computed and Calculated Air Transport Factors. (3 sheets) ............................... 3-34 


\section{LIST OF TERMS}

AED

ARF

DCF

DOE

DR

DSA

ICRP

LPF

MACCS

MAR

MOI

NRC

NQA-1

$\chi / \mathrm{Q}$

$\chi / \mathrm{Q}^{\prime}$

$\mathrm{RF}$

SOF

TWA

ULD

USOF aerodynamic equivalent diameter

airborne release fraction

dose conversion factor

U.S. Department of Energy

damage ratio

documented safety analysis

International Commission on Radiological Protection

leakpath factor

MELCOR Accident Consequence Code System

material at risk

maximum offsite individual

U.S. Nuclear Regulatory Commission

Nuclear Quality Assurance

puff dispersion coefficient

atmospheric dispersion coefficient

respirable fraction

sum of fractions

time-weighted average

unit-liter dose

unit release sum of fractions 


\subsection{INTRODUCTION}

This report presents the general methodology of calculating the atmospheric dispersion coefficients $\left(\chi / Q^{\prime}\right)$ to be used in the safety basis documents for the tank farm facilities. Values of $\chi / \mathrm{Q}^{\prime}$ given in this report were generated using the GXQ code Version $4.0 \mathrm{~F}$, which reproduces the statistical treatment of the Hanford Site joint frequency meteorology specified in U.S. Nuclear Regulatory Commission (NRC) Guide 1.145, Atmospheric Dispersion Models for Potential Accident Consequence Assessments at Nuclear Power Plants. GXQ is documented in WHC-SD-GN-SWD-30002, GXQ 4.0 Program Users' Guide, and a listing of the code is shown in Appendix A. Alternate calculations used to verify the GXQ results are contained in the appendices. The alternate calculations are included to demonstrate compliance with Nuclear Quality Assurance (NQA)-1 requirements for software use.

Calculation of the basic dispersion parameters used at the tank farms is discussed in Section 2.2 with results given in Section 2.2.6. Specific assumptions and input used to generate the $\chi / \mathrm{Q}$ 's at the tank farms are discussed. The logarithmic interpolation procedure used to generate $\chi / \mathrm{Q}$ 's used for long-duration ( $>2 \mathrm{hr}$ ) releases is described in detail. A sample input file and a set of run files are listed in Appendix B. Modifications to the basic dispersion coefficients to account for plume depletion, momentum/thermal plume rise, and large source effects are discussed in Section 2.3 with examples calculated. Corresponding sample run files are listed in Appendix C.

The GXQ results were verified using a set of alternate calculations documented in Chapter 3.0. Special GXQ run files used in the independent verification are listed in Appendices D, E, and F.

Chapters 4.0 and 5.0 present detailed discussions of the procedures used to estimate radiological and toxicological exposures using the dispersion coefficients developed in Chapters 2.0 and 3.0. Additional $\chi / \mathrm{Q}^{\prime}$ values that were requested to support the documented safety analysis (DSA) are included as Appendices $\mathrm{G}, \mathrm{H}, \mathrm{I}, \mathrm{J}, \mathrm{K}$, and L. Future requests for $\chi / \mathrm{Q}$ 's will be documented as additional appendices to this report. 


\section{RPP-13482 REV 5}

This page intentionally left blank. 
RPP-13482 REV 5

\subsection{GXQ CALCULATIONS OF TANK FARM DISPERSION COEFFICIENTS}

\subsection{ATMOSPHERIC DISPERSION}

The $\chi / Q^{\prime}$ is defined to be the air concentration at a receptor location per unit release rate of the material at a release location upwind of the receptor. For material given in terms of $\mathrm{Ci}$, for example, the $\chi / \mathrm{Q}^{\prime}$ has units of $\mathrm{Ci} / \mathrm{m}^{3}$ per $\mathrm{Ci} / \mathrm{s}$. This is normally condensed to $\mathrm{s} / \mathrm{m}^{3}$ with the units associated with the material $(\mathrm{Ci}, \mathrm{g}, \mathrm{mg}$, etc.) canceling and, therefore, being completely arbitrary. For toxicological exposures, the exposure level (i.e., the air concentration at the receptor) is proportional to the $\chi / Q^{\prime}$. However, because radiological exposure is cumulative, the exposure is proportional to the time integrated air concentration over the exposure time of the receptor. If the release rate of the material and the atmospheric dispersion are assumed to be constant, a time-integrated dispersion coefficient equal to $(\chi \times \mathrm{T}) /\left(\mathrm{Q}^{\prime} \times \mathrm{T}\right)$, where $\mathrm{T}$ is the release time and the receptor exposure time is applicable. This gives the time-integrated air concentration at the receptor per unit total release of material. Since the $T$ cancels, the time-integrated dispersion coefficient is exactly equal to the $\chi / Q^{\prime}$ if the release rate of the material and the atmospheric dispersion are constant. For this reason, it is convenient to use the instantaneous $\chi / Q^{\prime}$ for both toxicological and radiological exposures, dividing the release into a number of time segments for a radiological exposure if the release rate is varying over time. For toxicological exposures due to very short duration releases, GXQ can calculate puff $\chi /$ Qs that are defined as the maximum instantaneous concentration at the receptor per unit total release (which is assumed to occur in zero time). The puff $\chi / \mathrm{Q}$ has units of, for example, $\mathrm{mg} / \mathrm{m}^{3}$ per mg released. As before, the material units cancel and the net units are $1 / \mathrm{m}^{3}$. This formulation is used only in special circumstances, since very short duration toxicological releases can be averaged over some minimum sampling time to obtain a release rate. The normal steady-state $\chi / Q^{\prime}$ can then be applied.

The GXQ code normally assumes a straight-line, steady-state Gaussian plume dispersion model. The $\chi / Q^{\prime}$ then depends only on the distance from the release point to the receptor and on atmospheric conditions. For acute releases, the receptor is normally assumed to be on the horizontal plume centerline. The site-specific atmospheric condition information is obtained from a table of joint frequencies of occurrence of wind direction, wind speed, and atmospheric stability. Each box in a table of joint frequencies shows the percentage of the time that conditions were recorded corresponding to the combination of wind direction, wind speed, and atmospheric stability associated with that box. These data have been accumulated over a period of 9 yr (1983 through 1991) at the Hanford Meteorology Station located just east of the 200 West Area. Data tables are available for both surface $(10 \mathrm{~m})$ and elevated $(61 \mathrm{~m}$ and $89 \mathrm{~m})$ conditions. Since there are no tall stacks in any of the tank farm facilities, the elevated data are not used.

Wind directions are sorted into 16 sectors corresponding to the compass points N, NNE, NE, etc. These sectors give the direction the wind is blowing toward (not from, as is the usual practice in meteorology). For each sector, the wind speed is classified into one of eight ranges as shown in Table 2-1. Data in each wind speed range are associated in the table with the median wind speed for that range. 
Table 2-1. Wind Speed Classifications.

\begin{tabular}{|c|c|}
\hline Range (m/s) & Median $(\mathbf{m} / \mathbf{s})$ \\
\hline$<1.8$ & 0.89 \\
\hline $1.8-3.6$ & 2.65 \\
\hline $3.6-5.8$ & 4.7 \\
\hline $5.8-8.5$ & 7.15 \\
\hline $8.5-11$ & 9.8 \\
\hline $11-14$ & 12.7 \\
\hline $14-17$ & 15.6 \\
\hline$>17$ & 19 \\
\hline
\end{tabular}

For each sector and wind speed class, the data are sorted into one of seven atmospheric stability classes, shown in Table 2-2.

Table 2-2. Atmospheric Stability Classifications.

\begin{tabular}{|l|c|}
\hline \multicolumn{1}{|c|}{ Stability class } & Pasquill category \\
\hline Extremely unstable & A \\
\hline Moderately unstable & B \\
\hline Slightly unstable & C \\
\hline Neutral & D \\
\hline Slightly stable & E \\
\hline Moderately stable & F \\
\hline Extremely stable & G \\
\hline
\end{tabular}

The atmospheric stability is directly related to the change in air temperature with height above the ground. If a mass of air is raised some distance, it (1) expands due to the decrease in pressure, and (2) expands or contracts due to the change in temperature after it comes to equilibrium with the surrounding air. If the air temperature decreases with height (the usual condition) at just the right rate, then the two effects exactly cancel and the mass of air stays where it is. There is no driving force to move it either up or down. This is referred to as "neutral" stability.

If the air temperature decreases more rapidly with increasing height, then the raised air mass becomes denser than the surrounding air. It then tends to sink back to its original height and resists any movement up or down. This condition is referred to as "stable." In stable atmospheric conditions, vertical mixing is suppressed and the atmosphere tends to stratify. This condition is associated with low wind speeds and produces low dispersion conditions that result 
in higher downwind concentrations of released material. If, on the other hand, the air temperature decreases less rapidly with height, the raised air mass becomes less dense than the surrounding air and tends to rise further. Thus, any displacement causes an accelerated movement in the same direction. Such a condition is referred to as "unstable." Unstable atmospheric conditions are characterized by rapid vertical mixing leading to a fairly constant vertical temperature profile. This produces highly dispersive conditions that reduce the downwind concentration of released material.

The extent of vertical mixing is limited to some height above the ground referred to as the mixing layer height. At this height, there is a more rapid decrease of air temperature with height that causes the plume of material to be effectively reflected back downward. At the Hanford Site, this mixing layer height can vary greatly with the day-night cycle and with the seasons, but for purposes of accident analysis has historically been assumed to be $1,000 \mathrm{~m}$. This mixing layer would have a significant effect on the $\chi / \mathrm{Q}^{\prime}$ only under unstable atmospheric conditions, or at very great distances where the plume has spread vertically enough to be reflected off the top of the mixing layer. Worst-case meteorology for acute ground-level releases occurs under stable conditions so that the mixing layer depth has little effect over distances considered here. For elevated releases, the mixing layer depth can have a considerable effect since worst-case meteorology is generally in the unstable range (at least close to the release point) because such conditions cause the plume to reach the ground closer to the stack. There are no tall stacks in the tank farms, however, so this is not a concern.

\subsection{BASIC DISPERSION CALCULATIONS}

Unless otherwise stated, the $\chi / \mathrm{Q}^{\prime}$ and $\chi / \mathrm{Q}$ calculations described in this section and Section 2.3 are performed using the GXQ code, which is the primary software utility used to estimate dispersion coefficients on the Hanford Site. GXQ is an expert program. This means that the code is intended to be used only by highly qualified individuals who are knowledgeable of the limits and applicability of the various models implemented. Although some error checking is provided, it is possible to select a combination of models that may not be compatible with each other, or may not be appropriate for the application. Inappropriate input to the code can result in meaningless results that look reasonable, and that produce no error messages in the code output. It is up to the user to ensure that the models selected are compatible and appropriate to the problem. The user should consult WHC-SD-GN-SWD-30002 and its references, or other similar text, to understand the workings of the code and the model limitations.

\subsubsection{Acute Release Dispersion}

The GXQ code can use the joint frequency data to calculate a $\chi / Q$ ', which is exceeded some specified percentage of the time according to the methods specified in NRC 1.145. This can be done based on the data for one sector at a time or based on the combined data over all sectors. Details of the GXQ code input required to calculate the various types of $\chi / \mathrm{Q}$ 's described in this section can be found in WHC-SD-GN-SWD-30002. In accordance with NRC 1.145, bounding individual sector $\chi / \mathrm{Q}$ 's are $99.5^{\text {th }}$ percentile (i.e., exceeded $0.5 \%$ of the time), while bounding overall (all sectors) $\chi / Q$ 's are $95^{\text {th }}$ percentile (i.e., exceeded $5 \%$ of the time). These bounding 
$\chi / \mathrm{Q}$ 's represent minimum dispersion conditions that result in maximum downwind concentrations (i.e., exceeded only a small fraction of the time) and generally correspond to low wind speeds with stable atmospheric conditions.

$\chi / Q$ 's can be evaluated for an individual receptor (such as a nearby facility), at a specific distance (such as $100 \mathrm{~m}$ ) in all sectors around the release point, or around an irregular boundary where a distance is given for each sector. In the case of the irregular boundary, the distance in each sector is defined to be the minimum distance in a $45^{\circ}$ sector centered on the $22.5^{\circ}$ direction sector in question in accordance with NRC 1.145. For the combined tank farms facilities, the distances to the Hanford Site boundary have been established (in the DSA) and are given in Table 2-3.

Table 2-3. Site Boundary Distances.

\begin{tabular}{|c|c|}
\hline Sector & $\begin{array}{c}\text { Minimum distance within } \\
\mathbf{a ~ 4 5 ~}^{\mathbf{0}} \text { sector }(\mathbf{m})\end{array}$ \\
\hline S & 15,360 \\
\hline SSW & 15,360 \\
\hline SW & 13,200 \\
\hline WSW & 11,100 \\
\hline W & 11,100 \\
\hline WNW & 11,100 \\
\hline NW & 10,800 \\
\hline NNW & 8,690 \\
\hline N & 8,690 \\
\hline NNE & 8,670 \\
\hline NE & 10,430 \\
\hline ENE & 10,530 \\
\hline E & 11,160 \\
\hline ESE & 15,190 \\
\hline SE & 21,050 \\
\hline SSE & 15,360 \\
\hline
\end{tabular}

For simple acute (one-time, short duration) releases lasting less than $1 \mathrm{hr}$, or for releases with a highly variable rate, the overall (all sectors) $95^{\text {th }}$ percentile $\chi / Q^{\prime}$ is normally used to calculate downwind radiological doses or toxicological concentrations at a receptor location in accordance with DOE-STD-3009-94, Preparation Guide for U.S. Department of Energy Nonreactor Nuclear Facility Documented Safety Analyses, Appendix A, "Evaluation Guideline." This $\chi / Q^{\prime}$ is commonly referred to as the " $1-\mathrm{hr}$ " $\chi / \mathrm{Q}$ '. 


\subsubsection{Annual Average Meteorology}

The annual average $\chi / Q^{\prime}$ is calculated for a sector by summing all the frequency-weighted $\chi / Q^{\prime}$ s for all the atmospheric stability classes and wind speed bins for that sector. This value represents the annual average $\chi / Q^{\prime}$ over all conditions having a wind speed in the direction of the sector in question multiplied by the probability of the wind blowing toward that sector. This is normally done assuming the "sector-averaged" plume meander model where the concentration of the material is constant across the width of the sector ( $\mathrm{ipm}=3$ ). This value is suitable for calculating the consequences in a particular sector of a constant-rate release that occurs over a period of at least $1 \mathrm{yr}$. The annual average $\chi / \mathrm{Q}^{\prime}$ can also be used to evaluate the consequences of an acute release in a particular sector under average meteorological conditions if the $\chi / Q^{\prime}$ is divided by the probability of the wind blowing in that sector (i.e., the wind is assumed to be blowing in that sector for the duration of the release). This probability is given as part of the code output, or GXQ can make the correction directly (see WHC-SD-GN-SWD-30002, Section 4.4.1).

\subsection{3 $50^{\text {th }}$ Percentile Meteorology}

For beyond design basis or beyond evaluation basis events, it is permissible to use $\chi / \mathrm{Q}$ 's based on $50^{\text {th }}$ percentile meteorology (i.e., exceeded $50 \%$ of the time). The $50^{\text {th }}$ percentile $\chi / Q$ 's can also be used to demonstrate the degree of conservatism in results based on $95^{\text {th }}$ percentile meteorology. If a $50^{\text {th }}$ percentile $\chi / Q^{\prime}$ is evaluated for a particular sector, the joint frequency data for that sector must be normalized, i.e., divided by the frequency of the wind blowing into that sector since this frequency is generally much less than $50 \%$. The GXQ code can be set to do this normalization during the calculation of the $\chi / \mathrm{Q}^{\prime}(\mathrm{inorm}=\mathrm{T})$. The $50^{\text {th }}$ percentile $\chi / \mathrm{Q}^{\prime}$ s are also often used to represent "average" conditions for an acute release.

\subsubsection{Plume Meander}

The correlation parameters used to generate the 1-hr $\chi / \mathrm{Q}$ 's are based on dispersion data averaged over less than $1 \mathrm{hr}$. If a release occurs over a longer duration ( $1 \mathrm{hr}$ or more), it is subjected to more lateral spreading due to random changes in wind direction. This effect is referred to as plume meander. If the release occurs at a reasonably constant rate with a duration of $1 \mathrm{hr}$ or more, a correction may be made for plume meander. For release durations of at least $1 \mathrm{hr}$, but no more than $2 \mathrm{hr}$, the GXQ code can generate plume meander corrected $\chi / \mathrm{Q}$ 's using the model in NRC 1.145. Such $\chi / \mathrm{Q}$ 's are referred to as " 2 -hr" $\chi / \mathrm{Q}$ 's.

For releases with durations of more than $2 \mathrm{hr}$ and up to $1 \mathrm{yr}(8,760 \mathrm{hr})$, a hand-calculated logarithmic interpolation procedure can be used to account for the plume meander effect. The interpolation is between the $95^{\text {th }}$ percentile 2-hr $\chi / \mathrm{Q}^{\prime}$ and the annual average $\chi / \mathrm{Q}^{\prime}$, and is done graphically by plotting $\chi / \mathrm{Q}^{\prime}$ versus release duration on log-log paper and drawing a straight line between the two points. This can be done analytically by using the following formula (Equation 2-1). The logs can be either base 10 or natural. 


$$
\frac{\log \left(\mathrm{X} / Q^{\prime}\right)_{T_{r e l}}-\log \left(\mathrm{X} / Q^{\prime}\right)_{2 h r}}{\log \left(\mathrm{X} / Q^{\prime}\right)_{1 y r}-\log \left(\mathrm{X} / Q^{\prime}\right)_{2 h r}}=\frac{\log \left(T_{r e l}\right)-\log (2 h r)}{\log (8,760 h r)-\log (2 h r)}
$$

where:

$$
\begin{aligned}
T_{\text {rel }} & =\text { release duration (hours) between } 2 \mathrm{hr} \text { and } 8,760 \mathrm{hr} \\
\left(\chi / Q^{\prime}\right)_{2 h r} & =2-\mathrm{hr} \chi / \mathrm{Q}^{\prime}\left(\mathrm{s} / \mathrm{m}^{3}\right) \\
\left(\chi / Q^{\prime}\right)_{1 y r} & =\text { annual average } \chi / \mathrm{Q}^{\prime}\left(\mathrm{s} / \mathrm{m}^{3}\right) \\
\left(\chi / Q^{\prime}\right)_{\text {Trel }} & =\chi / \mathrm{Q}^{\prime} \text { for release duration } \mathrm{T}_{\mathrm{rel}}\left(\mathrm{s} / \mathrm{m}^{3}\right) .
\end{aligned}
$$

This formula can be written more directly as Equation 2-2:

$$
\left(\mathrm{X} / \mathrm{Q}^{\prime}\right)_{\mathrm{T}_{\mathrm{rel}}}=\left(\mathrm{X} / \mathrm{Q}^{\prime}\right)_{2 \mathrm{hr}}\left(\frac{\mathrm{T}_{\mathrm{rel}}}{2 \mathrm{hr}}\right)^{\text {slope }}
$$

where:

$$
\text { slope }=\frac{\log \left(\frac{\left(\mathrm{X} / Q^{\prime}\right)_{1 y r}}{\left(\mathrm{X} / Q^{\prime}\right)_{2 h r}}\right)}{\log \left(\frac{8760 h r}{2 h r}\right)}
$$

The most commonly encountered logarithmically interpolated $\chi / \mathrm{Q}$ 's are for $8 \mathrm{hr}$ and $24 \mathrm{hr}$. It should be carefully noted that this discussion of the effect of release duration on the diffusion coefficient applies only to radiological dose calculations because the dose is proportional to the time integral of air concentration. Either the $1-\mathrm{hr}$ steady-state $\chi / \mathrm{Q}^{\prime}$ or puff $\chi / \mathrm{Q}$ is always used for toxicological exposures because peak air concentration is the operative parameter.

\subsubsection{Puff Release Dispersion Coefficient}

Because the peak air concentration of the released material as the plume passes the receptor is of primary concern for toxic releases, the 1-hr $\chi / \mathrm{Q}^{\prime}$ can always be used. One of the assumptions inherent in the steady-state $\chi / \mathrm{Q}^{\prime}$, however, is that there is diffusion only in the lateral (y and $\mathrm{z}$ ) directions. Movement in the windward ( $\mathrm{x}$ ) direction is assumed to be solely due to gross air movement (i.e., wind) with no diffusion. For example, assuming a wind speed of $1 \mathrm{~m} / \mathrm{s}$, a release with a duration of $1 \mathrm{sec}$ will produce a plume that is $1 \mathrm{~m}$ long. The plume will remain $1 \mathrm{~m}$ long no matter how far it travels downwind and will spread only laterally (hence the term "spreading disk model"). In reality, the plume would lengthen due to diffusion in the x-direction 
as it traveled downwind thereby decreasing the concentration of material in the plume. For extremely short release durations, therefore, the steady-state $\chi / Q^{\prime}$ may be overly conservative and a puff $\chi / Q\left(1 / \mathrm{m}^{3}\right)$ that gives peak concentration per unit total release instead of release rate can be used. For longer release durations, the puff $\chi / \mathrm{Q}$ is overly conservative because it assumes a zero release time. In reality, any release takes some time and therefore stretches out the plume, thereby reducing the concentration.

There is a cross-over point with respect to release time where the puff and steady-state models will give the same number. For release times less than this, the puff model will give a lower concentration, while for longer release times the steady-state model will give lower concentrations. However, both the steady-state and the puff models are always conservative. A trial and error approach can be used where both models are tried and the lower dispersion coefficient used. Alternatively, for any particular receptor, it can be shown theoretically that the cross-over release time is just equal to the ratio of the steady-state $\chi / Q^{\prime}$ to the puff $\chi / \mathrm{Q}$. For the onsite receptor at $100 \mathrm{~m}$, the cross-over release time is on the order of a few seconds, while for the Hanford Site boundary receptor, it is a few hundred seconds. Historically, these transition release times have been assumed to be $3.5 \mathrm{sec}$ and $350 \mathrm{sec}$, respectively. Exact numbers can, however, easily be determined in any given situation. The modeling of the puff $\chi / \mathrm{Q}$ in the GXQ code assumes a zero release time; however, initial source volume and concentration can be accounted for (see Section 2.3.3). Puff $\chi / Q$ 's can be calculated using GXQ by setting ipuff $=1$ and the release duration equal to zero.

For chemicals whose toxic effects are immediate (i.e., concentration-dependent), a peak 15-min average can be used to determine the receptor exposure. If the release duration is less than $15 \mathrm{~min}$, the averaging time is the actual release duration down to a minimum of $1 \mathrm{~min}$. (See Chapter 5.0 for a more detailed discussion of how to determine averaging times for toxic releases.) For very short releases, therefore, the total release is normally divided by $60 \mathrm{sec}$ to obtain a release rate which yields a peak 1-min average air concentration using the steady-state (1-hr) $\chi / \mathrm{Q}^{\prime}$. This usually produces a lower concentration at the onsite receptor as compared to using a puff model. The puff $\chi / \mathrm{Q}$ can, however, produce a lower peak concentration at the Hanford Site boundary and may be useful in some scenarios. Puff $\chi /$ Qs for instantaneous point releases are therefore provided for use by the analyst. It should be carefully noted that the puff model is only applicable to toxic releases. Radiological doses are proportional to the timeintegrated air concentration and therefore do not depend on the release duration.

\subsubsection{Results of Basic Dispersion Calculations}

The dispersion coefficients resulting from the basic models discussed above are shown in Tables 2-4 and 2-5 for the onsite receptor at $100 \mathrm{~m}$ and the Hanford Site boundary receptor, respectively. The logarithmically interpolated $8-\mathrm{hr} \chi / \mathrm{Q}$ 's are shown in Tables 2-4 and 2-5. The corresponding run files are listed in Appendix B. 
Table 2-4. Dispersion Coefficients for 200 Area Tank Farms to Onsite Receptor at $100 \mathrm{~m}$.

\begin{tabular}{|l|c|c|c|c|}
\hline \multicolumn{1}{|c|}{$\begin{array}{c}\text { Meteorological } \\
\text { condition }\end{array}$} & $\begin{array}{c}\mathbf{1 - h r} \chi / \mathbf{Q}^{\prime} \\
\left(\mathbf{s} / \mathbf{m}^{\mathbf{3}}\right)\end{array}$ & $\begin{array}{c}\mathbf{2 - h r} \chi / \mathbf{Q}^{\prime} \\
\left(\mathbf{s} / \mathbf{m}^{\mathbf{3}}\right)\end{array}$ & $\begin{array}{c}\mathbf{8}-\mathbf{h r} \chi / \mathbf{Q}^{\prime} \\
\left(\mathbf{s} / \mathbf{m}^{3}\right)\end{array}$ & $\begin{array}{c}\text { Maximum } \\
\text { puff } \chi / \mathbf{Q}\left(\mathbf{1} / \mathbf{m}^{3}\right)\end{array}$ \\
\hline $\begin{array}{l}95^{\text {th }} \text { Percentile } \\
\text { overall }\end{array}$ & $3.28 \mathrm{E}-2$ & $9.40 \mathrm{E}-3$ & $5.58 \mathrm{E}-3$ & $8.88 \mathrm{E}-3$ \\
\hline $\begin{array}{l}\text { Annual average } \\
\text { maximum sector }\end{array}$ & $4.03 \mathrm{E}-4$ & -- & -- & - \\
\hline $\begin{array}{l}50^{\text {th }} \text { Percentile } \\
\text { maximum sector }\end{array}$ & $5.33 \mathrm{E}-3$ & $2.27 \mathrm{E}-3$ & $1.71 \mathrm{E}-3$ & $9.48 \mathrm{E}-4$ \\
\hline
\end{tabular}

Note: The 2-hr and 8-hr $\chi / \mathrm{Q}$ 's include the effects of plume meander averaged over $2 \mathrm{hr}$ and $8 \mathrm{hr}$, respectively.

Table 2-5. Dispersion Coefficients for 200 Area Tank Farms to Site Boundary Receptor.

\begin{tabular}{|l|c|c|c|c|}
\hline \multicolumn{1}{|c|}{$\begin{array}{c}\text { Meteorological } \\
\text { condition }\end{array}$} & $\begin{array}{c}\mathbf{1 - h r} \chi / \mathbf{Q}^{\prime} \\
\left(\mathbf{s} / \mathbf{m}^{3}\right)\end{array}$ & $\begin{array}{c}\mathbf{2 - h r} \chi / \mathbf{Q}^{\prime} \\
\left(\mathbf{s} / \mathbf{m}^{\mathbf{3}}\right)\end{array}$ & $\begin{array}{c}\mathbf{8 - h r} \chi / \mathbf{Q}^{\prime} \\
\left(\mathbf{s} / \mathbf{m}^{3}\right)\end{array}$ & $\begin{array}{c}\text { Maximum } \\
\mathbf{p u f f} \chi / \mathbf{Q}\left(\mathbf{1} / \mathbf{m}^{3}\right)\end{array}$ \\
\hline $\begin{array}{l}95^{\text {th }} \text { Percentile } \\
\text { overall }\end{array}$ & $2.22 \mathrm{E}-5$ & $1.74 \mathrm{E}-5$ & $7.90 \mathrm{E}-6$ & $5.06 \mathrm{E}-8$ \\
\hline $\begin{array}{l}\text { Annual average } \\
\text { maximum sector }\end{array}$ & $1.47 \mathrm{E}-7$ & - & -- & - \\
\hline $\begin{array}{l}50^{\text {th }} \text { Percentile } \\
\text { maximum sector }\end{array}$ & $4.48 \mathrm{E}-6$ & $3.83 \mathrm{E}-6$ & $2.23 \mathrm{E}-6$ & $1.04 \mathrm{E}-8$ \\
\hline
\end{tabular}

Note: The 2-hr and 8-hr $\chi / \mathrm{Q}$ 's include the effects of plume meander averaged over $2 \mathrm{hr}$ and $8 \mathrm{hr}$, respectively.

\subsection{MODIFIED DISPERSION CALCULATIONS}

In addition to the basic dispersion plume models already discussed, modifications can be applied to account for other effects such as plume depletion due to particle fallout, plume rise due to thermal buoyancy and/or momentum effects, and source size and volume rate effects. Such corrections to the basic model tend to be scenario specific; however, examples are given here for typical ranges of parameters applicable to tank farms so that the methodology and code run files can be shown in detail for the benefit of analysts. WHC-SD-GN-SWD-30002 and its references should be consulted to obtain a complete understanding of the various models and their applications. As previously mentioned, GXQ is an expert code and these modifications should be implemented only by qualified analysts who understand the limits and applicability of the models used. Sample run files for the various cases shown in this section are listed in Appendix C.

\subsubsection{Plume Depletion}

The concentration of material in the plume will, in general, decrease not only due to diffusion into the surrounding air, but also due to deposition onto the ground at the plume-ground 
interface. The operative parameter is the "deposition velocity" defined to be the rate of deposition per unit area per unit concentration of the material just above the ground. This would have units, for example, $\mathrm{Ci} / \mathrm{s}$ per $\mathrm{m}^{2}$ per $\mathrm{Ci} / \mathrm{m}^{3}$. The arbitrary units of material quantity (in this case $\mathrm{Ci}$ ) cancel out, leaving the dimensions of a velocity, i.e., $\mathrm{m} / \mathrm{s}$ (hence the term deposition "velocity"). The random vorticity in the air outdoors is on the order of $1 \mathrm{~cm} / \mathrm{s}$ so that particles with gravitational fall velocities less than this value will tend to stay suspended and follow the gross air movements. For small particles less than about $10 \mu \mathrm{m}$ having a fall velocity less than roughly $1 \mathrm{~cm} / \mathrm{s}$, the deposition velocity represents an interaction coefficient between the material in the plume and the ground (including vegetation), and has very little to do with the fall velocities of the particles in still air. Generally, a gas will exhibit a ground deposition rate due to its chemical activity that will be characterized by a deposition velocity. Larger particles $(>10 \mu \mathrm{m})$ will show a net downward drift equal to their gravitational fall velocity. In this case, the deposition velocity is just equal to the gravitational fall velocity of the particles.

Plume depletion in GXQ is calculated using the Chamberlain model described in TID-24190, Meteorology and Atomic Energy - 1968. This model reduces the source strength to match the integrated loss from the plume from the source to the receptor or, equivalently, assumes that the plume is mixed vertically (i.e., ground reflection is assumed to be less than the amount of material lost to deposition at the plume-ground interface). This is strictly valid only for small particles $(<10 \mu \mathrm{m})$. In general, the model will give overly conservative results for larger particles with respect to doses at a receptor since it assumes vertical mixing within the plume. In reality, a plume composed of large particles will be tilted downward into the ground with no ground reflection. For this reason, larger particles are commonly assumed to fall to the ground near the source, and to not reach the receptors in significant amounts unless the source is elevated.

An actual release incident in 1985, apparently due to accidental pressurization of a line leading to an open nozzle in a closed diversion box, was analyzed in HNF-SD-WM-CN-096, Refined Radiological and Toxicological Consequences of Bounding Spray Leak Accidents in the Tank Farm Waste Transfer Pits. This incident occurred during favorable meteorological conditions immediately after a new layer of snow had fallen, and as such, presented a highly unusual opportunity to gather very accurate background-free surface contamination samples at various distances downwind of the release point. With these measurements, along with air sampler data, it was possible to back out a deposition velocity of $0.15 \mathrm{~cm} / \mathrm{s}$ using the Chamberlain model. This is very close to the generic value of $0.1 \mathrm{~cm} / \mathrm{s}$ usually recommended for deposition velocity of respirable particulates (i.e., $<10 \mu \mathrm{m}$ ). The effects of plume depletion with a $0.15 \mathrm{~cm} / \mathrm{s}$ deposition velocity on the $95^{\text {th }}$ percentile, $1-\mathrm{hr}, 2-\mathrm{hr}$, and annual average $\chi / \mathrm{Q}$ 's and puff $\chi / \mathrm{Q}$ s for onsite and offsite receptors are shown in Tables 2-6 and 2-7. 
Table 2-6. Effects of Plume Depletion with $0.15 \mathrm{~cm} / \mathrm{s}$ Deposition Velocity Onsite Receptor at $100 \mathrm{~m}$.

\begin{tabular}{|l|c|c|c|}
\hline \multicolumn{1}{|c|}{$\chi / \mathbf{Q}^{\prime}$ type } & $\chi / \mathbf{Q}^{\prime}$ with no depletion & $\begin{array}{c}\chi / \mathbf{Q}^{\prime} \text { with } \\
\mathbf{d e p l e t i o n} \\
\left(\mathbf{s} / \mathbf{m}^{\mathbf{3}} \mathbf{)}\right.\end{array}$ & Reduction factor \\
\hline 1-hr (no plume meander) & $3.28 \mathrm{E}-2$ & $2.84 \mathrm{E}-2$ & 0.866 \\
\hline 2-hr (with plume meander) & $9.40 \mathrm{E}-3$ & $8.49 \mathrm{E}-3$ & 0.903 \\
\hline Annual average & $4.03 \mathrm{E}-4$ & $3.75 \mathrm{E}-4$ & 0.931 \\
\hline Puff & $8.88 \mathrm{E}-3$ & $8.29 \mathrm{E}-3$ & 0.934 \\
\hline
\end{tabular}

Table 2-7. Effects of Plume Depletion with $0.15 \mathrm{~cm} / \mathrm{s}$ Deposition Velocity Site Boundary Receptor.

\begin{tabular}{|l|c|c|c|}
\hline \multicolumn{1}{|c|}{$\chi / \mathbf{Q}^{\prime}$ type } & $\begin{array}{c}\chi / \mathbf{Q}^{\prime} \text { with no depletion } \\
\left(\mathbf{s} / \mathbf{m}^{\mathbf{3}} \mathbf{)}\right.\end{array}$ & $\begin{array}{c}\chi / \mathbf{Q}^{\prime} \text { with } \\
\text { depletion } \\
\left(\mathbf{s} / \mathbf{m}^{3}\right)\end{array}$ & Reduction factor \\
\hline 1-hr (no plume meander) & $2.22 \mathrm{E}-5$ & $1.14 \mathrm{E}-5$ & 0.514 \\
\hline 2-hr (with plume meander) & $1.74 \mathrm{E}-5$ & $8.88 \mathrm{E}-6$ & 0.510 \\
\hline Annual average & $1.47 \mathrm{E}-7$ & $1.01 \mathrm{E}-7$ & 0.687 \\
\hline Puff & $5.06 \mathrm{E}-8$ & $3.42 \mathrm{E}-8$ & 0.676 \\
\hline
\end{tabular}

The reduction is larger for the Hanford Site boundary receptor because of the longer transport time and hence more plume depletion, but the effect in both cases is relatively small because of the small particle size range implied by the $0.15 \mathrm{~cm} / \mathrm{s}$ deposition velocity.

The transition between small particle and large particle behaviors is not sharp, but is spread over the particle size range from about $3 \mu \mathrm{m}$ to about $35 \mu \mathrm{m}$, depending on the particle density and characteristics as shown in Figure 2-1, taken from DOE/TIC-27601, Atmospheric Science and Power Production. The $\mathrm{K}=\mathrm{V}_{\mathrm{T}}$ lines show the theoretical terminal fall velocities for densities of 1,4 , and $11.5 \mathrm{~g} / \mathrm{cm}^{3}$. This figure clearly shows the departure of the deposition velocity from the gravitational fall velocity for fall velocities below about $1 \mathrm{~cm} / \mathrm{s}$. The major parameter for smaller particles is the roughness height of the surface (including vegetation).

Estimates of both the aerodynamic surface roughness height, $z_{o}$, and the air friction velocity, $u *$, are needed to predict deposition velocities. The aerodynamic surface roughness is about 0.15 of the vegetation and physical roughness height of the surface. Estimates of aerodynamic surface roughness for different surfaces and wind speeds are given in DOE/TIC-27601, Table 12.6. Based on this information, a value of $10 \mathrm{~cm}$ has been assumed at the Hanford Site (grass and low shrubs) for low wind speeds. The air friction velocity was estimated based on the logarithmic description of the wind speed profile above the ground given by DOE/TIC-27601 (Equation 2-3).

$$
u=\frac{u_{*}}{k} \ln \frac{z+z_{0}}{z_{0}}
$$




\section{RPP-13482 REV 5}

where:

$$
\begin{aligned}
& z=\text { reference wind speed height } \\
& k=\text { von Karman's constant which is approximately equal to } 1.4
\end{aligned}
$$

Based on a low wind speed $(1 \mathrm{~m} / \mathrm{s})$ at a reference height of $10 \mathrm{~m}$, an air friction velocity of $0.1 \mathrm{~m} / \mathrm{s}$ has been assumed.

Figure 2-1. Deposition Velocities.

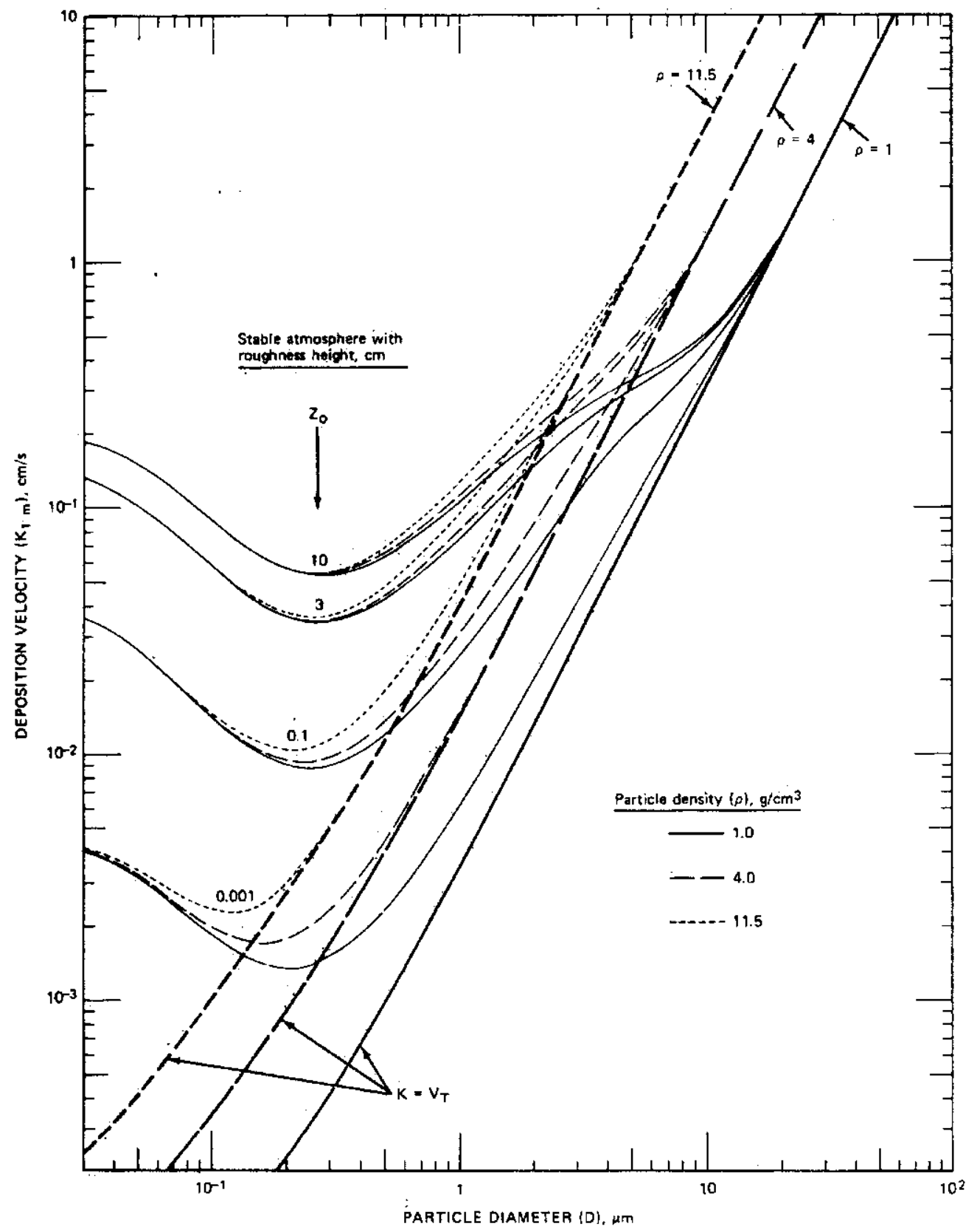

Fig. 12.4 Predicted deposition velocities at $1 \mathrm{~m}$ for $u_{0},-10 \mathrm{~cm} / \mathrm{s}$ and particle densities of 1,4, and $11.5 \mathrm{~g} / \mathrm{cm}^{3}$. 
Deposition velocities from Figure 2-1 are shown as a function of size for spherical particles with a density of $1 \mathrm{~g} / \mathrm{cm}^{3}$, i.e., in terms of aerodynamic equivalent diameter (AED), in Table 2-8. The theoretical terminal gravitational fall velocities are shown for comparison. Note that the observed deposition velocity begins to depart from the theoretical gravitational fall velocity for particles smaller than about $10 \mu \mathrm{m}$.

Table 2-8. Terminal Fall Velocities and Deposition Velocities.

\begin{tabular}{|c|c|c|}
\hline $\begin{array}{c}\text { Particle size (AED) } \\
(\mu \mathrm{m})\end{array}$ & $\begin{array}{c}\text { Terminal fall velocity } \\
(\mathbf{c m} / \mathbf{s})\end{array}$ & $\begin{array}{c}\text { Deposition velocity } \\
(\mathbf{c m} / \mathbf{s})\end{array}$ \\
\hline 2 & 0.01 & 0.2 \\
\hline 10 & 0.3 & 0.5 \\
\hline 20 & 1 & 1 \\
\hline 50 & 7 & 7 \\
\hline
\end{tabular}

Note:

$\mathrm{AED}=$ aerodynamic equivalent diameter.

One-hour $\chi / \mathrm{Q}$ 's and puff $\chi / \mathrm{Qs}$ corrected for deposition were calculated using the GXQ code (WHC-SD-GN-SWD-30002) over this transitional particle size range (idep =1). The release was assumed to be at ground level (release height $=0$ ). Dispersion coefficients with deposition effects were calculated for all sectors $\left(95^{\text {th }}\right.$ percentile overall) at a $100-\mathrm{m}$ radius and at all sectors around the Hanford Site boundary at distances defined in Table 2-3.

The resulting 1-hr $\chi / \mathrm{Q}$ 's and puff $\chi / \mathrm{Qs}$ are shown in Tables 2-9 through 2-12 for onsite and site boundary, respectively. The reduction factors relative to the $\chi / \mathrm{Q}$ 's and puff $\chi / \mathrm{Q}$ s with no plume depletion are also shown for comparison. These results were extracted from the development of $\chi / \mathrm{Q}$ 's for a specific accident in the DSA described in more detail in Appendix I.

Table 2-9. All-Sector $95^{\text {th }}$ Percentile, 1 -hr $\chi / \mathrm{Q}$ 's for the Onsite Receptor at $100 \mathrm{~m}$.

\begin{tabular}{|c|c|c|c|}
\hline $\begin{array}{c}\text { Particle size (AED) } \\
(\mu \mathrm{m})\end{array}$ & $\begin{array}{c}\chi / Q^{\prime} \text { with no } \\
\text { depletion }\left(s / m^{3}\right)\end{array}$ & $\begin{array}{c}\chi / Q^{\prime} \text { with depletion } \\
\left(\mathrm{s} / \mathrm{m}^{3}\right)\end{array}$ & Reduction factor \\
\hline 2 & \multirow{4}{*}{$3.28 \mathrm{E}-2$} & $2.71 \mathrm{E}-2$ & 0.83 \\
\hline 10 & & $2.11 \mathrm{E}-2$ & 0.64 \\
\hline 20 & & $1.38 \mathrm{E}-2$ & 0.42 \\
\hline 50 & & $1.43 \mathrm{E}-3$ & 0.044 \\
\hline
\end{tabular}

Note:

$\mathrm{AED}=$ aerodynamic equivalent diameter. 
Table 2-10. All-Sector $95^{\text {th }}$ Percentile, 1-hr $\chi / \mathrm{Q}$ 's

for the Site Boundary Receptor.

\begin{tabular}{|c|c|c|c|}
\hline $\begin{array}{c}\text { Particle size (AED) } \\
(\mu \mathbf{m})\end{array}$ & $\begin{array}{c}\chi / \mathbf{Q}^{\prime} \text { with no } \\
\text { depletion }\left(\mathbf{s} / \mathbf{m}^{\mathbf{3}}\right)\end{array}$ & $\begin{array}{c}\chi / \mathbf{Q}^{\prime} \text { with depletion } \\
\left(\mathbf{s} / \mathbf{m}^{3}\right)\end{array}$ & Reduction factor \\
\hline 2 & & $8.86 \mathrm{E}-6$ & 0.40 \\
\hline 10 & \multirow{3}{*}{$2.22 \mathrm{E}-5$} & $3.62 \mathrm{E}-6$ & 0.16 \\
\hline 20 & & $1.61 \mathrm{E}-6$ & 0.073 \\
\hline 50 & & $6.28 \mathrm{E}-8$ & 0.0028 \\
\hline
\end{tabular}

Note:

$\mathrm{AED}=$ aerodynamic equivalent diameter.

Table 2-11. All-Sector $95^{\text {th }}$ Percentile Puff Release $\chi / \mathrm{Qs}$ for the Onsite Receptor at $100 \mathrm{~m}$.

\begin{tabular}{|c|c|c|c|}
\hline $\begin{array}{c}\text { Particle size (AED) } \\
(\mu \mathrm{m})\end{array}$ & $\begin{array}{c}\chi / Q \text { with no } \\
\text { depletion }\left(1 / \mathrm{m}^{3}\right)\end{array}$ & $\begin{array}{c}\chi / Q \text { with depletion } \\
\left(1 / \mathrm{m}^{3}\right)\end{array}$ & Reduction factor \\
\hline 2 & \multirow{4}{*}{$8.88 \mathrm{E}-3$} & $7.83 \mathrm{E}-3$ & 0.88 \\
\hline 10 & & $5.67 \mathrm{E}-3$ & 0.64 \\
\hline 20 & & $2.75 \mathrm{E}-3$ & 0.31 \\
\hline 50 & & $6.21 \mathrm{E}-4$ & 0.070 \\
\hline
\end{tabular}

Note:

$\mathrm{AED}=$ aerodynamic equivalent diameter.

Table 2-12. All-Sector $95^{\text {th }}$ Percentile Puff Release $\chi / \mathrm{Qs}$ for the Site Boundary Receptor.

\begin{tabular}{|c|c|c|c|}
\hline $\begin{array}{c}\text { Particle size (AED) } \\
(\mu \mathrm{m})\end{array}$ & $\begin{array}{c}\chi / Q \text { with no } \\
\text { depletion }\left(1 / \mathrm{m}^{3}\right)\end{array}$ & $\begin{array}{c}\chi / Q \text { with depletion } \\
\left(1 / \mathrm{m}^{3}\right)\end{array}$ & Reduction factor \\
\hline 2 & \multirow{4}{*}{$5.06 \mathrm{E}-8$} & $3.17 \mathrm{E}-8$ & 0.63 \\
\hline 10 & & $1.95 \mathrm{E}-8$ & 0.39 \\
\hline 20 & & $8.35 \mathrm{E}-9$ & 0.17 \\
\hline 50 & & $2.81 \mathrm{E}-10$ & 0.0056 \\
\hline
\end{tabular}

Note:

$\mathrm{AED}=$ aerodynamic equivalent diameter.

The effects of deposition can provide a considerable reduction in the $\chi / \mathrm{Q}^{\prime}$, particularly for the longer transport distances to the Hanford Site boundary. The Chamberlain model, however, should be considered unrealistic and overly conservative for particle sizes much greater than about $20 \mu \mathrm{m}$ AED. In addition, each such calculation is performed for only one particle size. An actual release would involve a range of particle sizes with a size distribution that is not usually known. Particle deposition must therefore be applied with care on a case-by-case basis using an effective particle size or some size-grouping scheme. Also, if plume depletion is considered, resuspension may become a factor. Resuspension, however, is usually argued to be negligible compared to the plume inhalation dose unless the receptor is assumed to remain in the contaminated area for a long period of time (i.e., years). 


\subsubsection{Releases From Short Stacks with Momentum/Thermal Rise}

Releases in tank farms can occur from short stacks on ventilation systems with upward momentum and/or thermal buoyancy effects. Normally, credit cannot be taken for a stack unless it is at least $2 \frac{1}{2}$ times higher than any nearby buildings. In tank farms, however, many of these ventilation system stacks are far from any buildings and so can be credited with reducing exposures to nearby receptors. Additional plume rise can occur if the release has an initial upward momentum, or if the initial temperature of the effluent is higher than that of the surrounding air. Source volume rate effects (i.e., an initial source concentration) can also be accounted for by using a virtual source model (iflow $=1$ ). That is, a virtual point source is placed upwind of the actual release point at such a distance as to give the plume the required dimensions as it passes over the actual release point. In GXQ, a virtual source correction is made so that the initial plume at the source is given a non-zero size to account for the initial volume rate and initial concentration of material. The initial lateral plume width is based on the stack diameter. The initial vertical plume spread is based on the exhaust flow rate such that the concentration in the initial plume matches the source concentration coming out of the stack (see WHC-SD-GN-SWD-30002, Section 4.2.4).

Two models are available in GXQ to account for plume rise. The first (MELCOR Accident Consequence Code System [MACCS] buoyant plume rise model, irise $=1$ ) is used only for thermally buoyant plumes (such as those from a fire). The second (ISC2 momentum/buoyancy plume rise model, irise $=2$ ) also includes momentum rise due to an initial upward velocity of the plume (such as fan-driven flow out of a stack). The second model will be of most use in tank farms and is the one demonstrated here. In conjunction with plume rise from a stack, three other models are normally incorporated. First, an entrainment model is turned on to account for the turbulent mixing of the plume with the ambient air at the top of the stack (ientr =1). This produces an initial dispersion of the plume beyond that required to account only for the initial concentration. Second, a correction is made for the fact that the wind speed normally increases with height due to the planetary boundary layer effect (iwind $=1$ ). This will be a minor correction for the short stacks in tank farms. Third, a down-wash model can be turned on to account for the part of the plume sucked into the wake formed behind the top of the stack (iwash =1). This should be an insignificant effect for the small stack diameters and the high stack air velocities normally encountered at the tank farms.

In general, elevated releases can produce a maximum $\chi^{\prime} \mathrm{Q}^{\prime}$ at a distance beyond $100 \mathrm{~m}$ due to the fact that the plume may not have spread down to the receptor height at that distance. For the relatively low elevated releases from tank farms ventilation stacks, this is not expected to be a problem in these cases. If necessary, the $\chi / \mathrm{Q}^{\prime}$ can be evaluated under these conditions at $10-\mathrm{m}$ intervals from about $50 \mathrm{~m}$ out to $100 \mathrm{~m}$ to ensure that the plume has descended to the receptor height, and that the $\chi / \mathrm{Q}^{\prime}$ is decreasing as it passes $100 \mathrm{~m}$. It is also possible to have a few "bumps" in the $\chi / \mathrm{Q}^{\prime}$ beyond $100 \mathrm{~m}$ due to the discrete binning of the data into stability classes and wind speed intervals. The plume from an elevated release tends to "hit the ground" closest to the release point under unstable atmospheric conditions and low wind speeds. Further out, there is a series of shifts to more stable conditions that can produce a few minor oscillations in the $\chi / Q^{\prime}$. This is not a real (physical) effect, but is an artifact of the calculational method and is generally not significant. 
A set of $95^{\text {th }}$ percentile, 1-hr $\chi / \mathrm{Q}$ 's were calculated using GXQ to demonstrate the effects of having an elevated source with an initial volume rate, rather than the more usual ground level point source approximation. The point source approximation implies an infinite concentration at zero distance from the source. A model assuming an initial source volume rate will exhibit an initial source concentration at zero distance. Three cases were calculated for a short stack $(9.5 \mathrm{ft})$ release. This is about the shortest stack at tank farms. The receptor height was assumed to be $2 \mathrm{~m}$. The following cases are shown:

1. A point source with infinite concentration at zero distance (the regular DSA $\chi / Q^{\prime}$ ).

2. A source with an initial volume rate of either 100 or $1,000 \mathrm{ft}^{3} / \mathrm{min}$, but with no momentum effects. That is, the source plume is assumed to issue from the top of the stack, but to have no initial upward velocity. The plume centerline will therefore remain level with the top of the stack.

3. A source with an initial volume rate of either 100 or $1,000 \mathrm{ft}^{3} / \mathrm{min}$ and with an initial upward momentum. That is, the source air is assumed to be exiting from a short stack $(9.5 \mathrm{ft}$ or $2.90 \mathrm{~m})$ with a diameter of $10 \mathrm{in}$. pointing vertically upward. This gives some additional elevation to the plume.

The results are provided in Tables 2-13 and 2-14 for an onsite receptor at $100 \mathrm{~m}$ and a receptor at the Hanford Site boundary. These are all $95^{\text {th }}$ percentile overall (i.e., all sectors) $\chi / Q$ 's with no plume meander.

Table 2-13. All-Sector $95^{\text {th }}$ Percentile, $1-\mathrm{hr} \chi / \mathrm{Q}$ 's for the Onsite Receptor at $100 \mathrm{~m}$ for Various Source Conditions $\left(\mathrm{s} / \mathrm{m}^{3}\right)$.

\begin{tabular}{|c|c|c|c|}
\hline \multirow[b]{2}{*}{ Source assumptions } & \multicolumn{3}{|c|}{ Source volume rate } \\
\hline & $\begin{array}{l}0 \mathrm{ft}^{3} / \mathrm{min} \\
\left(0 \mathrm{~m}^{3} / \mathrm{s}\right)\end{array}$ & $\begin{array}{c}100 \mathrm{ft}^{3} / \mathrm{min} \\
\left(0.0472 \mathrm{~m}^{3} / \mathrm{s}\right)\end{array}$ & $\begin{array}{l}1,000 \mathrm{ft}^{3} / \mathrm{min} \\
\left(0.472 \mathrm{~m}^{3} / \mathrm{s}\right)\end{array}$ \\
\hline $\begin{array}{l}\text { Point source - } \\
\text { No initial plume volume - } \\
\text { Ground-level release }\end{array}$ & $3.28 \mathrm{E}-2$ & -- & - \\
\hline $\begin{array}{l}\text { Initial source volume rate - } \\
\text { No initial momentum - } \\
\text { Elevated release }\end{array}$ & -- & $1.68 \mathrm{E}-2$ & $1.44 \mathrm{E}-2$ \\
\hline $\begin{array}{l}\text { Initial source volume rate - } \\
\text { Initial upward momentum } \\
\text { from 10-in.-diameter stack }\end{array}$ & -- & $1.41 \mathrm{E}-2$ & $1.85 \mathrm{E}-3$ \\
\hline
\end{tabular}


Table 2-14. All-Sector $95^{\text {th }}$ Percentile, 1 -hr $\chi / \mathrm{Q}$ 's for the Site Boundary Receptor for Various Source Conditions $\left(\mathrm{s} / \mathrm{m}^{3}\right)$.

\begin{tabular}{|c|c|c|c|}
\hline \multirow[b]{2}{*}{ Source assumptions } & \multicolumn{3}{|c|}{ Source volume rate } \\
\hline & $\begin{array}{l}0 \mathrm{ft}^{3} / \mathrm{min} \\
\left(0^{3} \mathrm{~m}^{3} / \mathrm{s}\right)\end{array}$ & $\begin{array}{c}100 \mathrm{ft}^{3} / \mathrm{min} \\
\left(0.0472 \mathrm{~m}^{3} / \mathrm{s}\right)\end{array}$ & $\begin{array}{r}1,000 \mathrm{ft}^{3} / \mathrm{min} \\
\left(0.472 \mathrm{~m}^{3} / \mathrm{s}\right)\end{array}$ \\
\hline $\begin{array}{l}\text { Point source - } \\
\text { No initial plume volume - } \\
\text { Ground-level release }\end{array}$ & $2.22 \mathrm{E}-5$ & -- & -- \\
\hline $\begin{array}{l}\text { Initial source volume rate - } \\
\text { No initial momentum - } \\
\text { Elevated release }\end{array}$ & -- & $2.21 \mathrm{E}-5$ & $2.21 \mathrm{E}-5$ \\
\hline $\begin{array}{l}\text { Initial source volume rate - } \\
\text { Initial upward momentum } \\
\text { from 10-in.-diameter stack }\end{array}$ & -- & $2.21 \mathrm{E}-5$ & $2.18 \mathrm{E}-5$ \\
\hline
\end{tabular}

The values for the point source model correspond to the $95^{\text {th }}$ percentile overall $\chi / \mathrm{Q}$ 's with no plume meander in Tables 2-4 and 2-5. This model assumes a zero source volume rate implying an infinite source concentration at zero distance. For this reason, it tends to be overly conservative at very short distances $(<100 \mathrm{~m})$. However, this feature of the standard model has little effect at larger distances such as the Hanford Site boundary because the dilution of the plume in transit dominates any initial dilution at the source. This source is assumed to be at ground level with the receptor at ground level also.

The second case takes account of the initial source volume rate, but takes no credit for initial dilution due to turbulent mixing or plume rise due to the initial velocity of the effluent that is implied by the initial volume rate. The lower volume rate $\left(100 \mathrm{ft}^{3} / \mathrm{min}\right)$ coupled with the plume elevation produces a considerable reduction of the $\chi / \mathrm{Q}^{\prime}$ at $100 \mathrm{~m}$, but has little effect at the Hanford Site boundary because of the large amount of mixing and dilution that occurs in transit. The larger $1,000 \mathrm{ft}^{3} / \mathrm{min}$ initial volume rate produces a slightly greater reduction of the $100 \mathrm{~m}$ $\chi / \mathrm{Q}$, but still has little effect at the Hanford Site boundary. For elevated releases from short stacks, the receptor height (assumed here to be $2 \mathrm{~m}$ ) must be taken into account. The plume centerline (level with the top of the stack) is therefore only $0.9 \mathrm{~m}$ above the receptor. (For tall stacks [e.g., $200 \mathrm{ft}$ ], the receptor height is not significant and is usually ignored.)

The third case has the addition of an initial source velocity and momentum based on the equivalent diameter of the duct or opening through which the source volume rate emanates. In this case, a round opening with a diameter of $10 \mathrm{in} .(25.4 \mathrm{~cm})$ was assumed. It was further assumed that the initial source velocity is directed vertically upward giving a momentum plume rise. The temperature of the source plume was assumed to be at the same temperature as ambient so that there is no buoyancy effect due to a temperature difference. Additional effects accounted for include a correction for variation of wind speed with height, and initial air entrainment due to turbulent mixing at the source caused by the upward velocity of the air stream. The $100 \mathrm{ft}^{3} / \mathrm{min}$ volume rate produces a slightly larger reduction of the $\chi / \mathrm{Q}^{\prime}$ at $100 \mathrm{~m}$, but still has little effect at the Hanford Site boundary because of the large amount of mixing and dilution that occurs in transit. The larger $1,000 \mathrm{ft}^{3} / \mathrm{min}$ initial volume rate produces a much greater reduction of the $100 \mathrm{~m} \chi / \mathrm{Q}^{\prime}$ due to the higher effective plume height, but has little effect at the Hanford Site boundary. 
Note that for releases that are elevated at the source due to a short stack, upward momentum, or thermal lofting, the worst-case receptor elevation may not be at ground level. In these cases receptor elevations ( $\mathrm{z}$ ) of 0,1 , and $2 \mathrm{~m}$ should be checked as well as downwind distances ( $\mathrm{x}$ ) beyond $100 \mathrm{~m}$ to determine which combination of parameters produces the worst case. For a thermally lofted release from or near a large building, the plume may be trapped within the building wake (see WHC-SD-GN-SWD-30002, Section 4.3.1) for wind speeds above a critical value. This test is activated by inserting a non-zero building height in the GXQ input. More discussion about the building wake effect is given in Section 2.3.5.

\subsubsection{Large Source Effects}

The simple Gaussian plume model assumes a point source. However, for some accident scenarios, such as entrainment from a pool, the source may have significant dimensions compared to the distance to the receptor. The initial lateral spread of the source will reduce the concentration at the receptor. To correct for this effect, the MACCS building wake model in GXQ can be used (iwake =2). The width of the source perpendicular to the wind direction is simply entered as the initial plume width in the GXQ input. Note that a plume meander correction should not be applied to a $\chi / Q^{\prime}$ corrected for source width, i.e., a source-width correction should be applied only to the 1-hr $\chi / \mathrm{Q}^{\prime}$.

The effects of an initial source width on $95^{\text {th }}$ percentile $\chi / Q$ 's are shown in Tables 2-15 and 2-16. In the case of an effective circular pool, the receptor distance is measured from the center of the pool and the source width corresponds to the pool diameter.

Table 2-15. All-Sector $95^{\text {th }}$ Percentile, 1 -hr $\chi / \mathrm{Q}$ 's for the Onsite Receptor at $100 \mathrm{~m}$ for Various Source Widths.

\begin{tabular}{|c|c|c|c|}
\hline \multirow{2}{*}{$\begin{array}{c}\text { Source width } \\
(\mathbf{m})\end{array}$} & $\begin{array}{c}\text { Point source } \\
\chi / \mathbf{Q}^{\prime} \\
\left(\mathbf{s} / \mathbf{m}^{\mathbf{3}}\right)\end{array}$ & $\begin{array}{c}\chi / \mathbf{Q}^{\prime} \text { Corrected for } \\
\text { source width } \\
\left(\mathbf{s} / \mathbf{m}^{\mathbf{3}} \mathbf{)}\right.\end{array}$ & Reduction factor \\
\hline \multirow{3}{*}{30} & \multirow{3}{*}{$3.28 \mathrm{E}-2$} & $2.24 \mathrm{E}-2$ & 0.683 \\
\hline 20 & & $1.66 \mathrm{E}-2$ & 0.506 \\
\hline 50 & & $9.21 \mathrm{E}-3$ & 0.281 \\
\hline 100 & & $5.44 \mathrm{E}-3$ & 0.166 \\
\hline
\end{tabular}


Table 2-16. All-Sector $95^{\text {th }}$ Percentile, 1-hr $\chi /$ Q's for the Hanford Site Boundary Receptor for Various Source Widths.

\begin{tabular}{|c|c|c|c|}
\hline $\begin{array}{l}\text { Source width } \\
\text { (m) }\end{array}$ & $\begin{array}{c}\text { Point source } \\
\chi / \mathbf{Q}^{\prime} \\
\left(\mathbf{s} / \mathbf{m}^{3}\right) \\
\end{array}$ & $\begin{array}{c}\chi / Q^{\prime} \text { Corrected for } \\
\text { source width } \\
\left(\mathbf{s} / \mathbf{m}^{3}\right)\end{array}$ & Reduction factor \\
\hline 10 & \multirow{4}{*}{$2.22 \mathrm{E}-5$} & $2.21 \mathrm{E}-5$ & 0.996 \\
\hline 20 & & $2.20 \mathrm{E}-5$ & 0.991 \\
\hline 50 & & $2.16 \mathrm{E}-5$ & 0.973 \\
\hline 100 & & $2.10 \mathrm{E}-5$ & 0.946 \\
\hline
\end{tabular}

A non-zero source size can have a considerable effect on the exposure of the onsite receptor at $100 \mathrm{~m}$, but the effect decreases with increasing distance. Note that a pool can subject the onsite receptor to a direct gamma dose in addition to an inhalation dose from material entrained at the pool surface. The direct dose contribution should be evaluated on a case-by-case basis.

A puff release of toxic material can also be corrected for an initial puff volume by using the MACCS building wake model in GXQ (iwake $=2$ ) with the puff model turned on (ipuff $=1$ ) and the release duration set equal to zero. A special conversion must be made, however, since the MACCS building wake model assumes a Gaussian distribution, whereas the released material concentration is assumed to be uniform over the initial cloud volume. Based on an initial cloud volume, $V$, derived from ideal gas laws or other considerations, and assuming a hemispherical initial cloud of material with its center at ground level, the initial cloud can be defined in terms of the building height $(\mathrm{Hb})$ and width $(\mathrm{Wb})$ in the MACCS building wake model. Starting with the definitions of the building width and height in terms of the diffusion parameters in the MACCS model shown in WHC-SD-GN-SWD-30002, Section 4.2.2, and the basic definition of the puff $\chi / \mathrm{Q}$ shown in Section 4.1.2, it can easily be shown that the effective radius of the hemisphere in terms of the MACCS building wake model initial plume dimensions in the GXQ input is given by Equation 2-4:

$$
R_{e f f}=\frac{2.15}{\sqrt{2 \pi}}(2 \mathrm{~V})^{1 / 3}=1.08 \mathrm{~V}^{1 / 3}
$$

The initial plume height $(H b)$ is then just equal to $R_{e f f}$, while the initial plume width $(W b)$ is $2 R_{\text {eff. }}$.

\subsubsection{Pool Entrainment}

For the special case of wind entrainment from a liquid pool, the release concentration at the receptor is determined not only by the $\chi / Q^{\prime}$, but also by the rate of entrainment of material from the surface of the pool. The rate of entrainment depends on the size of the pool and is also a sensitive function of the wind speed. Since the $\chi / \mathrm{Q}^{\prime}$ is inversely proportional to wind speed and the pool entrainment rate increases with increasing wind speed, these are competing effects and cannot be analyzed separately. The GXQ code contains an option specifically designed to handle pool entrainment cases. When this option is turned on (isrc $=2$ ), the $\chi / \mathrm{Q}^{\prime}$ is multiplied by a power function of wind speed given by $c u^{a}$ where $u$ is the wind speed $(\mathrm{m} / \mathrm{s})$ and $c$ and $a$ are 
user-specified constants. The $95^{\text {th }}$ percentile of the parameter $\left(\chi / Q^{\prime}\right)\left(c u^{a}\right)$ is found instead of just $\chi / \mathrm{Q}^{\prime}$. It is usual practice to make $c=1$ and to fold the actual constant multiplier into the source term formulation. It is also usual practice to correct for the width of the pool as discussed in Section 2.3.3.

The appropriate wind speed function was developed in TWR-3958, Refined Consequence Analysis of Subsurface Leaks from TWRS Facilities that Result in a Surface Pool, based on data in DOE-HDBK-3010-94, Airborne Release Fractions/Rates and Respirable Fractions for Nonreactor Nuclear Facilities, and is given by Equation 2-5:

$$
M R R=2.14 \times 10^{-15} F_{p} u^{3.762}
$$

where:

$$
\begin{aligned}
M R R & =\text { mass release rate }\left(\mathrm{kg} / \mathrm{m}^{2} \mathrm{~s}\right) \\
F_{p} & =\text { "fetch," or distance across the pool in the direction of the wind, }(\mathrm{m}) \\
u & =\text { wind speed }(\mathrm{m} / \mathrm{s}) .
\end{aligned}
$$

In order to obtain the total release rate, $Q^{\prime}$, the mass release rate must be multiplied by the pool area $\left(\mathrm{m}^{2}\right)$. If the release rate in terms of $\mathrm{L} / \mathrm{s}$ is required, then divide by the liquid density $(\mathrm{kg} / \mathrm{L}$, or equivalently $\mathrm{g} / \mathrm{cm}^{3}$ ). To obtain a total release, $Q$, for a radiological dose, multiply by the receptor exposure time (s). Since the receptor is normally assumed to be directly downwind of the center of a circular pool, the fetch is normally assumed to be the diameter of the pool. The radiological dose, $D$, due to entrainment from a liquid pool is then given by Equation 2-6:

$$
D=2.14 \times 10^{-15} \frac{A T F_{p}}{\rho}\left(\frac{X}{Q^{\prime}} u^{3.762}\right)(B R)(U L D)
$$

where:

$$
\begin{aligned}
A & =\text { pool area }\left(\mathrm{m}^{2}\right) \\
T & =\text { receptor exposure time }(\mathrm{s}) \\
\rho & =\text { liquid density } \\
B R & \left.=\text { receptor breathing rate (normally } 3.33 \mathrm{E}-4 \mathrm{~m}^{3} / \mathrm{s}\right) \\
U L D & =\text { unit-liter dose }(\mathrm{Sv} / \mathrm{L} \text { or } \mathrm{rem} / \mathrm{L}) \text { for the liquid in the pool. }
\end{aligned}
$$

The $\left(\chi / Q^{\prime} u^{3.762}\right)$ is the parameter calculated by GXQ.

The toxic sum of fractions (SOF) for a continuous release is given by Equation 2-7:

$$
S O F=2.14 \times 10^{-I S} \frac{A F_{p}}{\rho}\left(\frac{X}{Q^{\prime}} u^{3.762}\right)(U S O F)
$$

where:

$$
\begin{aligned}
& \text { USOF }= \text { unit release rate sum of fractions for continuous releases for the liquid in } \\
& \text { the pool and the receptor in question. }
\end{aligned}
$$


The $95^{\text {th }}$ percentile parameter $\left(\chi / Q^{\prime} u^{3.762}\right)$ for a range of pool sizes (corrected for pool width) is shown in Tables 2-17 and 2-18 for the onsite and Hanford Site boundary receptors, respectively. Note that the distance to the receptor is measured from the center of the pool and the fetch is assumed equal to the pool diameter. The width of the pool was corrected for using the pool diameter as the initial plume width as discussed in Section 2.3.3. A sample GXQ runfile is given in Appendix C. The onsite receptor is normally subject to a direct shine dose from the pool in addition to the inhalation dose from entrained material.

Table 2-17. Entrainment Coefficients for Onsite Receptor.

\begin{tabular}{|c|c|c|}
\hline $\begin{array}{c}\text { Pool diameter } \\
(\mathbf{m})\end{array}$ & $\begin{array}{c}\text { Pool area } \\
\left(\mathbf{m}^{2}\right)\end{array}$ & $\chi / \mathbf{Q}^{\prime} \mathbf{u}^{3.762}$ \\
\hline 10 & $7.85 \mathrm{E}+1$ & $3.32 \mathrm{E}+0$ \\
\hline 20 & $3.14 \mathrm{E}+2$ & $2.35 \mathrm{E}+0$ \\
\hline 30 & $7.07 \mathrm{E}+2$ & $1.83 \mathrm{E}+0$ \\
\hline 40 & $1.26 \mathrm{E}+3$ & $1.47 \mathrm{E}+0$ \\
\hline 50 & $1.96 \mathrm{E}+3$ & $1.28 \mathrm{E}+0$ \\
\hline 60 & $2.83 \mathrm{E}+3$ & $1.09 \mathrm{E}+0$ \\
\hline 70 & $3.85 \mathrm{E}+3$ & $1.00 \mathrm{E}+0$ \\
\hline 80 & $5.03 \mathrm{E}+3$ & $9.27 \mathrm{E}-1$ \\
\hline 90 & $6.36 \mathrm{E}+3$ & $8.61 \mathrm{E}-1$ \\
\hline 100 & $7.85 \mathrm{E}+3$ & $8.04 \mathrm{E}-1$ \\
\hline
\end{tabular}

Table 2-18. Entrainment Coefficients for Offsite Receptor.

\begin{tabular}{|c|c|c|}
\hline $\begin{array}{c}\text { Pool diameter } \\
(\mathbf{m})\end{array}$ & $\begin{array}{c}\text { Pool area } \\
\left(\mathbf{m}^{\mathbf{2}} \mathbf{)}\right.\end{array}$ & $\chi / \mathbf{Q}^{\mathbf{\prime}} \mathbf{u}^{\mathbf{3 . 7 6 2}}$ \\
\hline 10 & $7.85 \mathrm{E}+1$ & $2.01 \mathrm{E}-3$ \\
\hline 20 & $3.14 \mathrm{E}+2$ & $2.01 \mathrm{E}-3$ \\
\hline 30 & $7.07 \mathrm{E}+2$ & $2.00 \mathrm{E}-3$ \\
\hline 40 & $1.26 \mathrm{E}+3$ & $2.00 \mathrm{E}-3$ \\
\hline 50 & $1.96 \mathrm{E}+3$ & $1.99 \mathrm{E}-3$ \\
\hline 60 & $2.83 \mathrm{E}+3$ & $1.99 \mathrm{E}-3$ \\
\hline 70 & $3.85 \mathrm{E}+3$ & $1.98 \mathrm{E}-3$ \\
\hline 80 & $5.03 \mathrm{E}+3$ & $1.98 \mathrm{E}-3$ \\
\hline 90 & $6.36 \mathrm{E}+3$ & $1.97 \mathrm{E}-3$ \\
\hline 100 & $7.85 \mathrm{E}+3$ & $1.97 \mathrm{E}-3$ \\
\hline
\end{tabular}

\subsubsection{Building Wake Effects}

If a release occurs from a building, the material will become mixed with the building wake within a short distance so that the release plume will initially have some size corresponding to the cross-section of the building perpendicular to the wind direction causing a reduction in the 
downwind concentration. At Hanford, the NRC Regulatory Guide 1.145 model is used to account for building wake effects. This model can be turned on in GXQ by setting iwake $=1$ and including the building width and height $(\mathrm{m})$. Note that the Regulatory Guide 1.145 building wake model is coupled with the plume meander correction. If both models are turned on (iwake $=1$ and $i p m=1$ ) with nonzero building dimensions, the larger of the two effects is applied. Note also that the building wake effect is not a time-averaged effect like plume meander. The mixing of the release with the building wake is assumed to occur quickly due to local vorticity around the building and to be complete by the time the plume reaches the onsite receptor at $100 \mathrm{~m}$. The building wake effect can therefore be applied to toxicological as well as radiological consequence calculations.

The building dimensions assumed for the building wake model are the building height $(\mathrm{m})$ and the minimum building width as seen from any direction $(\mathrm{m})$. The operative parameter in the NRC building wake model (iwake $=1$ ) is the building cross-sectional area so that a $10 \mathrm{~m}$ high by $30 \mathrm{~m}$ wide building will have the same effect as a $30 \mathrm{~m}$ high by $10 \mathrm{~m}$ wide building.

Formulation of dimensions of irregularly shaped buildings should be done with this in mind. That is, reasonable dimensions should be assumed that approximate the minimum vertical crosssection of the building when viewed from any direction. Cross-sections for facilities at Hanford are typically around $300 \mathrm{~m}^{2}$, but this should be determined on a case-by-case basis. As with elevated plumes, building wake effects tend to decrease with distance as the vertical and lateral extent of the plume increases. Even for a sizable building, therefore, the building wake correction tends to be important only for the onsite receptor. It should also be noted that the maximum building wake correction allowed in the NRC model is a reduction of the $\chi / \mathrm{Q}^{\prime}$ by a factor of 3. In addition, NRC Regulatory Guide 1.145 dictates that unless a stack is at least 2.5 times higher than any nearby building, the release must be assumed to mix with the building wake and a stack release model cannot be used.

Sample calculations of $\chi / Q$ 's with building wake corrections are shown in Table 2-19 for minimum building cross-sections from $100 \mathrm{~m}^{2}$ to $500 \mathrm{~m}^{2}$. The $\chi / \mathrm{Q}$ 's for zero building size are just the point release 1-hr $\chi / \mathrm{Q}$ 's shown previously in Tables 2-4 and 2-5 and are shown for comparison along with associated reduction factors.

Table 2-19. Example Onsite and Site Boundary $\chi / \mathrm{Q}$ 's with Building Wake Correction.

\begin{tabular}{|c|c|c|c|c|}
\hline $\begin{array}{c}\text { Minimum } \\
\text { building cross- } \\
\text { section }\left(\mathbf{m}^{\mathbf{2}}\right)\end{array}$ & \multicolumn{2}{|c|}{ Onsite receptor at $\mathbf{1 0 0} \mathbf{~ m}$} & \multicolumn{2}{c|}{ Site boundary receptor } \\
\cline { 2 - 5 } & $\chi / \mathbf{Q}^{\prime} \mathbf{( s / \mathbf { m } ^ { \mathbf { 3 } } )}$ & Reduction & $\chi / \mathbf{Q}^{\prime} \mathbf{( s / \mathbf { m } ^ { \mathbf { 3 } } )}$ & Reduction \\
\hline 0 & $3.28 \mathrm{E}-2$ & -- & $2.22 \mathrm{E}-5$ & -- \\
\hline 100 & $1.24 \mathrm{E}-2$ & 0.378 & $2.22 \mathrm{E}-5$ & 1.00 \\
\hline 200 & $1.09 \mathrm{E}-2$ & 0.333 & $2.22 \mathrm{E}-5$ & 1.00 \\
\hline 300 & $1.09 \mathrm{E}-2$ & 0.333 & $2.21 \mathrm{E}-5$ & 0.996 \\
\hline 400 & $1.09 \mathrm{E}-2$ & 0.333 & $2.21 \mathrm{E}-5$ & 0.996 \\
\hline 500 & $1.09 \mathrm{E}-2$ & 0.333 & $2.20 \mathrm{E}-5$ & 0.991 \\
\hline
\end{tabular}

The modeling of releases with building wake effects is applied to DSA accident analyses in Appendices K and L. 


\subsection{SELECTION OF APPROPRIATE DISPERSION COEFFICIENTS}

This section discusses the selection of appropriate $\chi / Q^{\prime}$ from the previous sections for radioactive and toxic chemical releases based on the scenario of interest. These guidelines outline the specific dispersion coefficients to be used for most accident scenarios. As discussed in Section 2.3, scenario-specific calculations can be made invoking plume depletion, plume rise, virtual source, and/or entrainment models where appropriate.

\subsubsection{Short ( $<1 \mathrm{hr})$ or Variable Rate Releases}

For accident scenarios with release durations less than $1 \mathrm{hr}$, the bounding $\left(95^{\text {th }}\right.$ percentile overall) $\chi / \mathrm{Q}^{\prime}$ (known as the 1-hr $\chi / \mathrm{Q}^{\prime}$ ) should be used. The 1-hr $\chi / \mathrm{Q}^{\prime}$ should also be used where the release has a longer duration, but has a variable rate (such as an exponentially decreasing rate). The corresponding $50^{\text {th }}$ percentile $\chi / Q$ 's may be used for beyond design basis accidents. Comparison of $50^{\text {th }}$ percentile and $95^{\text {th }}$ percentile values can also give an estimate for the degree of conservatism in an analysis. These $\chi / \mathrm{Q}$ 's are provided in Tables 2-4 and 2-5 for the onsite receptor (worker) and the Hanford Site boundary receptor (MOI), respectively. Plume depletion, plume rise, and large source corrections can be applied to both the $95^{\text {th }}$ and $50^{\text {th }}$ percentile 1-hr $\chi / \mathrm{Q}$ 's.

Since the 1-hr $\chi / \mathrm{Q}$ ' represents an "instantaneous" concentration at the receptor location, it can be used for toxic chemical releases where the release is given in terms of a release rate. Furthermore, since plume depletion, plume rise, and large source corrections represent continuous, rather than time averaging effects, these modifications can be applied to toxic releases.

\subsubsection{Release Durations From One to Two Hours}

For accident scenarios with a release duration of at least $1 \mathrm{hr}$ where the release rate is approximately constant, the bounding $\left(95^{\text {th }}\right.$ percentile overall) $\chi / \mathrm{Q}^{\prime}$ with plume meander (known as the 2 -hr $\left.\chi / \mathrm{Q}^{\prime}\right)$ may be used. The corresponding $50^{\text {th }}$ percentile $\chi / \mathrm{Q}^{\prime}$ s may be used for beyond design basis accidents. Comparison of $50^{\text {th }}$ percentile and $95^{\text {th }}$ percentile values can also give an estimate for the degree of conservatism in an analysis. These $\chi / \mathrm{Q}$ 's are provided in Tables 2-4 and 2-5 for the onsite 100-m receptor (worker) and the Hanford Site boundary receptor (MOI), respectively. Plume depletion and plume rise corrections can be applied to both the $95^{\text {th }}$ and $50^{\text {th }}$ percentile 2-hr $\chi / \mathrm{Q}^{\prime}$ s. The large source correction, however, cannot be applied to the 2-hr $\chi / \mathrm{Q}^{\prime}$ because it already incorporates a plume mender correction (which assumes a point source). Plume meander (i.e., variations in wind direction) will have less effect on a plume from an extended source. Thus, combining the two modifications would overcorrect the $\chi / Q^{\prime}$ in the nonconservative direction.

Since the plume meander correction represents a time averaging effect over $1 \mathrm{hr}$, and the operative parameter for toxic releases is a maximum concentration at the receptor, the $2-\mathrm{hr} \chi / \mathrm{Q}^{\prime}$ cannot ordinarily be used for toxic chemical releases. As discussed in Chapter 4.0, the maximum averaging time for chemicals with an immediate (i.e., concentration-dependent) effect, such as 
those usually of concern in tank farms, is $15 \mathrm{~min}$. The 1 -hr $\chi / \mathrm{Q}^{\prime}$ therefore should be used in such cases.

\subsubsection{Release Durations Greater Than Two Hours}

For accident scenarios with release durations from $2 \mathrm{hr}$ to $1 \mathrm{yr}(8,760 \mathrm{hr})$ where the release rate is approximately constant over the release duration, a logarithmically interpolated $\chi / \mathrm{Q}^{\prime}$, as discussed in Section 2.2.4, may be used. The interpolation is between the 2-hr $\chi / \mathrm{Q}^{\prime}$ (with plume meander) and the annual average $\chi / Q^{\prime}$ shown in Tables 2-4 and 2-5 for the onsite (worker) and Hanford Site boundary (MOI) receptors, respectively. This produces a bounding (i.e., $95^{\text {th }}$ percentile) $\chi / \mathrm{Q}^{\prime}$ averaged over the longer release duration. As an example, interpolated $\chi / \mathrm{Q}$ 's for a constant-rate 8-hr release are shown in Tables 2-4 and 2-5.

Plume depletion and plume rise corrections can be applied, but not the large source correction for the reasons discussed in Section 2.4.2. Also for reasons previously discussed, the extendedduration $\chi / Q^{\prime}$ cannot be applied to toxic chemical releases.

\subsubsection{Puff Releases}

The puff release model can be used only for very short duration toxic chemical releases. As discussed in Section 2.2.5, the puff model (which assumes a zero release duration) is advantageous only for the Hanford Site boundary (MOI) receptor where the actual release duration is less than several hundred seconds. Plume depletion, plume rise, and large source corrections can be applied to the puff release model. Details of specific applications of the puff release model as applied to accident analyses in the DSA are shown in Appendix H. 
RPP-13482 REV 5

This page intentionally left blank. 


\subsection{VERIFICATION OF GXQ VERSION 4.0F CALCULATIONS}

This chapter provides hand calculations to verify that the dispersion coefficients $\left(\chi / Q^{\prime}\right)$ listed in previous sections are correct. In each case, GXQ calculates the $\chi / Q$ 's for the various receptor distances and directions at the wind speeds and stability classes found in the wind data file (JOINTFRE.IN). These $\chi / Q$ 's, along with the associated frequency, are then sorted to construct the cumulative probability distribution used in the calculation of $95^{\text {th }}$ or $50^{\text {th }}$ percentile $\chi / \mathrm{Q}$ 's. The $95^{\text {th }}$ percentile is calculated from a distribution that includes data for all 16 wind transport directions, while the $50^{\text {th }}$ percentile is calculated from distributions for each wind transport direction.

All of the GXQ Version 4.0F cases were run with the icdf flag set to true so that the cumulative distributions would be printed out. Verification was then a matter of calculating $\chi / Q$ 's, sorting them, and constructing the cumulative distribution table for comparison with the GXQ output. Because GXQ calculates the $\chi / \mathrm{Q}$ 's in one subroutine and does the sorting and interpolation in other subroutines, the verification of the sorting and interpolation is not performed every time. To verify the other cases, it is sufficient to verify that the $\chi / \mathrm{Q}$ 's are calculated as described in WHC-SD-GN-SWD-30002.

\subsection{BASIC DISPERSION COEFFICIENTS}

For the basic case, there were two concerns. First, the $100 \mathrm{~m}$ distance is the same in all 16 directions, while the Hanford Site boundary distances vary. Thus, the sorting and interpolation process was checked for both cases. Table 3-1 shows the standard deviation in the horizontal (y) and vertical (z) directions for each distance of interest. These parameters are used in the basic dispersion calculations. The plume reflection parameter (fref) is calculated when the vertical standard deviation is less than 1.2 times the mixing layer depth $(1,000 \mathrm{~m})$. These are shown in Table 3-2. Because most of the vertical standard deviations for stability class A are greater than $1,200 \mathrm{~m}$, the only value for fref calculated is at the $100 \mathrm{~m}$ distance. The class A column was omitted from Table 3-2.

Table 3-3 shows the hand-calculated $\chi / Q$ 's along with the probabilities and cumulative probabilities for the onsite worker at $100 \mathrm{~m}$. Because the distances are the same in all 16 transport directions, the joint frequencies are the sum of the frequencies in all 16 directions. These were compared with the GXQ output shown in Appendix D. The numbers are the same to four significant digits.

Table 3-4 shows the hand-calculated $\chi / \mathrm{Q}$ 's along with the probabilities and cumulative probabilities for the receptors at the Hanford Site boundary. Because the distances vary with direction, the number of entries in the table is greater. These were compared with the GXQ output shown in Appendix D. The numbers are the same to four significant digits. 
Table 3-1. Horizontal and Vertical Standard Deviations for Each Distance.

\begin{tabular}{|c|c|c|c|c|c|c|c|c|}
\hline \multicolumn{9}{|c|}{ Horizontal standard deviations (m) } \\
\hline $\begin{array}{l}\text { Transport } \\
\text { direction }\end{array}$ & $\begin{array}{l}\text { Distance } \\
\text { (m) }\end{array}$ & $\mathbf{A}$ & B & $\mathbf{C}$ & $\mathbf{D}$ & $\mathbf{E}$ & $\mathbf{F}$ & G \\
\hline All & 100 & 23.41 & 17.61 & 13.37 & 9.415 & 6.695 & 4.621 & 3.079 \\
\hline$S$ & 15,360 & 2,208 & 1,660 & 1,261 & 887.9 & 631.3 & 435.8 & 290.3 \\
\hline SSW & 15,360 & 2,208 & 1,660 & 1,261 & 887.9 & 631.3 & 435.8 & 290.3 \\
\hline SW & 13,200 & 1,925 & 1,448 & 1,100 & 774.3 & 550.6 & 380.0 & 253.2 \\
\hline WSW & $11, \overline{100}$ & 1,647 & 1,238 & 940.3 & 662.1 & 470.8 & 325.0 & 216.5 \\
\hline $\mathrm{W}$ & 11,100 & 1,647 & 1,238 & 940.3 & 662.1 & 470.8 & 325.0 & 216.5 \\
\hline WNW & 11,100 & 1,647 & 1,238 & 940.3 & 662.1 & 470.8 & 325.0 & 216.5 \\
\hline NW & 10,800 & 1,606 & 1,208 & 917.3 & 645.9 & 459.3 & 317.0 & 211.2 \\
\hline NNW & 8,690 & 1,320 & 992.7 & 753.8 & 530.8 & 377.5 & 260.5 & 173.6 \\
\hline $\mathrm{N}$ & 8,690 & 1,320 & 992.7 & 753.8 & 530.8 & 377.5 & 260.5 & 173.6 \\
\hline NNE & 8,970 & 1,358 & 1,022 & 775.7 & 546.2 & 388.4 & 268.1 & 178.6 \\
\hline NE & 10,430 & 1,557 & 1,171 & 888.9 & 625.9 & 445.1 & 307.2 & 204.7 \\
\hline ENE & 10,530 & 1,570 & 1,181 & 896.6 & 631.3 & 448.9 & 309.9 & 206.4 \\
\hline $\mathrm{E}$ & 11,160 & 1,655 & 1,244 & 944.9 & 665.4 & 473.1 & 326.6 & 217.6 \\
\hline ESE & 15,190 & 2,186 & 1,644 & 1,248 & 879.0 & 625.0 & 431.4 & 287.4 \\
\hline SE & 21,050 & 2,935 & 2,207 & 1,676 & 1,180 & 839.2 & 579.3 & 385.9 \\
\hline SSE & 15,360 & 2,208 & 1,660 & 1,261 & 887.9 & 631.3 & 435.8 & 290.3 \\
\hline \multicolumn{9}{|c|}{ Vertical standard deviations (m) } \\
\hline $\begin{array}{l}\text { Transport } \\
\text { direction }\end{array}$ & $\begin{array}{c}\text { Distance } \\
\text { (m) }\end{array}$ & $\mathbf{A}$ & $\mathbf{B}$ & $\mathbf{C}$ & D & $\mathbf{E}$ & $\mathbf{F}$ & $\mathbf{G}$ \\
\hline All & 100 & 14.30 & 10.89 & 7.500 & 4.557 & 3.489 & 2.247 & 1.360 \\
\hline $\mathrm{S}$ & 15,360 & 140,115 & 2,175 & 736.0 & 169.2 & 93.31 & 53.74 & 32.20 \\
\hline SSW & 15,360 & 140,115 & 2,175 & 736.0 & 169.2 & 93.31 & 53.74 & 32.20 \\
\hline SW & 13,200 & 102,012 & 1,842 & 641.1 & 155.5 & 87.56 & 50.98 & 30.55 \\
\hline WSW & 11,100 & 70,967 & 1,523 & 547.5 & 141.1 & 81.30 & 47.92 & 28.71 \\
\hline $\mathrm{W}$ & 11,100 & 70,967 & 1,523 & 547.5 & 141.1 & 81.30 & 47.92 & 28.71 \\
\hline WNW & 11,100 & 70,967 & 1,523 & 547.5 & 141.1 & 81.30 & 47.92 & 28.71 \\
\hline NW & 10,800 & 67,010 & 1,478 & 534.0 & 138.9 & 80.34 & 47.45 & 28.43 \\
\hline NNW & 8,690 & 42,503 & 1,165 & 438.1 & 122.8 & 73.01 & 43.76 & 26.22 \\
\hline $\mathrm{N}$ & 8,690 & 42,503 & 1,165 & 438.1 & 122.8 & 73.01 & 43.76 & 26.22 \\
\hline NNE & 8,970 & 45,422 & 1,206 & 450.9 & 125.0 & 74.05 & 44.29 & 26.54 \\
\hline NE & 10,430 & 62,292 & 1,422 & 517.3 & 136.2 & 79.13 & 46.85 & 28.07 \\
\hline ENE & 10,530 & 63,549 & 1,437 & 521.8 & 136.9 & 79.46 & 47.01 & 28.17 \\
\hline $\mathrm{E}$ & 11,160 & 71,773 & 1,532 & 550.2 & 141.5 & 81.49 & 48.02 & 28.77 \\
\hline ESE & 15,190 & 136,887 & 2,148 & 728.6 & 168.2 & 92.88 & 53.53 & 32.08 \\
\hline SE & 21,050 & 271,073 & 3,073 & 980.8 & 201.4 & 106.2 & 59.71 & 35.79 \\
\hline SSE & 15,360 & 140,115 & 2,175 & 736.0 & 169.2 & 93.31 & 53.74 & 32.20 \\
\hline
\end{tabular}




\section{RPP-13482 REV 5}

Table 3-2. Plume Reflection Parameter Values.

\begin{tabular}{|c|c|c|c|c|c|c|c|}
\hline $\begin{array}{c}\text { Transport } \\
\text { direction }\end{array}$ & $\begin{array}{c}\text { Distance } \\
(\mathbf{m})\end{array}$ & $\mathbf{B}$ & $\mathbf{C}$ & $\mathbf{D}$ & $\mathbf{E}$ & $\mathbf{F}$ & $\mathbf{G}$ \\
\hline All & 100 & 2.000 & 2.000 & 2.000 & 2.000 & 2.000 & 2.000 \\
\hline S & 15,360 & 5.447 & 2.100 & 2.000 & 2.000 & 2.000 & 2.000 \\
\hline SSW & 15,360 & 5.447 & 2.100 & 2.000 & 2.000 & 2.000 & 2.000 \\
\hline SW & 13,200 & 4.616 & 2.031 & 2.000 & 2.000 & 2.000 & 2.000 \\
\hline WSW & 11,100 & 3.818 & 2.005 & 2.000 & 2.000 & 2.000 & 2.000 \\
\hline W & 11,100 & 3.818 & 2.005 & 2.000 & 2.000 & 2.000 & 2.000 \\
\hline WNW & 11,100 & 3.818 & 2.005 & 2.000 & 2.000 & 2.000 & 2.000 \\
\hline NW & 10,800 & 3.705 & 2.004 & 2.000 & 2.000 & 2.000 & 2.000 \\
\hline NNW & 8,690 & 2.926 & 2.000 & 2.000 & 2.000 & 2.000 & 2.000 \\
\hline N & 8,690 & 2.926 & 2.000 & 2.000 & 2.000 & 2.000 & 2.000 \\
\hline NNE & 8,970 & 3.027 & 2.000 & 2.000 & 2.000 & 2.000 & 2.000 \\
\hline NE & 10,430 & 3.566 & 2.002 & 2.000 & 2.000 & 2.000 & 2.000 \\
\hline ENE & 10,530 & 3.603 & 2.003 & 2.000 & 2.000 & 2.000 & 2.000 \\
\hline E & 11,160 & 3.840 & 2.005 & 2.000 & 2.000 & 2.000 & 2.000 \\
\hline ESE & 15,190 & 5.381 & 2.092 & 2.000 & 2.000 & 2.000 & 2.000 \\
\hline SE & 21,050 & 7.546 & 2.501 & 2.000 & 2.000 & 2.000 & 2.000 \\
\hline SSE & 15,360 & 5.447 & 2.100 & 2.000 & 2.000 & 2.000 & 2.000 \\
\hline
\end{tabular}

Notes:

The plume reflection parameters are calculated from the vertical standard deviations out to the third reflection term. Release height is zero, and receptor elevation is zero. Mixing depth is $1,000 \mathrm{~m}$.

Values are not given for stability class A because they are larger than $1,200 \mathrm{~m}$. Note that the plume reflection factor at $100 \mathrm{~m}$ for class $\mathrm{A}$ is 2.000 . 
Table 3-3. Cumulative Probability Distribution for the Worker at $100 \mathrm{~m}$, All Sectors, Centerline Values. (2 sheets)

\begin{tabular}{|c|c|c|c|c|}
\hline $\begin{array}{c}\text { Stability } \\
\text { class }\end{array}$ & $\begin{array}{l}\text { Wind speed } \\
\qquad(\mathrm{m} / \mathrm{s})\end{array}$ & $\begin{array}{c}\text { Dispersion } \\
\text { coefficient } \\
\left(\mathrm{s} / \mathrm{m}^{3}\right)\end{array}$ & $\begin{array}{c}\text { Observed } \\
\text { frequency } \\
(\%)\end{array}$ & $\begin{array}{c}\text { Cumulative } \\
\text { frequency } \\
\text { (\%) }\end{array}$ \\
\hline G & 0.89 & $8.540 \mathrm{E}-02$ & 1.87 & 0.935 \\
\hline$F$ & 0.89 & $3.444 \mathrm{E}-02$ & 4.16 & 3.950 \\
\hline $\mathrm{G}$ & 2.65 & $2.868 \mathrm{E}-02$ & 3.20 & 7.630 \\
\hline $\mathrm{G}$ & 4.7 & $1.617 \mathrm{E}-02$ & 1.85 & 10.155 \\
\hline E & 0.89 & $1.531 \mathrm{E}-02$ & 5.45 & 13.805 \\
\hline$F$ & 2.65 & $1.157 \mathrm{E}-02$ & 7.23 & 20.145 \\
\hline $\mathrm{G}$ & 7.15 & $1.063 \mathrm{E}-02$ & 0.02 & 23.770 \\
\hline $\mathrm{D}$ & 0.89 & $8.337 \mathrm{E}-03$ & 7.42 & 27.490 \\
\hline $\mathrm{F}$ & 4.7 & $6.522 \mathrm{E}-03$ & 3.98 & 33.190 \\
\hline $\mathrm{E}$ & 2.65 & $5.142 \mathrm{E}-03$ & 8.57 & 39.465 \\
\hline $\mathrm{F}$ & 7.15 & $4.287 \mathrm{E}-03$ & 0.29 & 43.895 \\
\hline $\mathrm{G}$ & 19 & 4.000 E-03 & 0.01 & 44.045 \\
\hline $\mathrm{C}$ & 0.89 & $3.567 \mathrm{E}-03$ & 1.17 & 44.635 \\
\hline $\mathrm{F}$ & 9.8 & $3.128 \mathrm{E}-03$ & 0.03 & 45.235 \\
\hline $\mathrm{E}$ & 4.7 & $2.899 \mathrm{E}-03$ & 7.12 & 48.810 \\
\hline D & 2.65 & $2.800 \mathrm{E}-03$ & 9.21 & 56.975 \\
\hline $\mathrm{F}$ & 15.6 & 1.965 E-03 & 0.02 & 61.590 \\
\hline $\mathrm{E}$ & 7.15 & $1.906 \mathrm{E}-03$ & 3.71 & 63.455 \\
\hline $\mathrm{B}$ & 0.89 & $1.866 \mathrm{E}-03$ & 1.21 & 65.915 \\
\hline $\mathrm{F}$ & 19 & $1.613 \mathrm{E}-03$ & 0.08 & 66.560 \\
\hline D & 4.7 & $1.579 \mathrm{E}-03$ & 5.73 & 69.465 \\
\hline E & 9.8 & $1.390 \mathrm{E}-03$ & 0.95 & 72.805 \\
\hline $\mathrm{C}$ & 2.65 & $1.198 \mathrm{E}-03$ & 1.69 & 74.125 \\
\hline E & 12.7 & $1.073 \mathrm{E}-03$ & 0.19 & 75.065 \\
\hline A & 0.89 & $1.068 \mathrm{E}-03$ & 2.80 & 76.560 \\
\hline D & 7.15 & $1.038 \mathrm{E}-03$ & 3.46 & 79.690 \\
\hline$E$ & 15.6 & $8.735 \mathrm{E}-04$ & 0.04 & 81.440 \\
\hline D & 9.8 & $7.571 \mathrm{E}-04$ & 1.49 & 82.205 \\
\hline E & 19 & $7.172 \mathrm{E}-04$ & 0.19 & 83.045 \\
\hline $\mathrm{C}$ & 4.7 & $6.754 \mathrm{E}-04$ & 0.82 & 83.550 \\
\hline $\mathrm{B}$ & 2.65 & $6.266 \mathrm{E}-04$ & 1.69 & 84.805 \\
\hline $\mathrm{D}$ & 12.7 & $5.842 \mathrm{E}-04$ & 0.43 & 85.865 \\
\hline $\mathrm{D}$ & 15.6 & $4.756 \mathrm{E}-04$ & 0.11 & 86.135 \\
\hline $\mathrm{C}$ & 7.15 & $4.439 \mathrm{E}-04$ & 0.39 & 86.385 \\
\hline $\mathrm{D}$ & 19 & $3.905 \mathrm{E}-04$ & 0.11 & 86.635 \\
\hline
\end{tabular}




\section{RPP-13482 REV 5}

Table 3-3. Cumulative Probability Distribution for the Worker at $100 \mathrm{~m}$, All Sectors, Centerline Values. (2 sheets)

\begin{tabular}{|c|c|c|c|c|}
\hline $\begin{array}{c}\text { Stability } \\
\text { class }\end{array}$ & $\begin{array}{c}\text { Wind speed } \\
(\mathbf{m} / \mathbf{s})\end{array}$ & $\begin{array}{c}\text { Dispersion } \\
\text { coefficient } \\
\left(\mathbf{s} / \mathbf{m}^{\mathbf{3}}\right)\end{array}$ & $\begin{array}{c}\text { Observed } \\
\text { frequency } \\
\mathbf{( \% )}\end{array}$ & $\begin{array}{c}\text { Cumulative } \\
\text { frequency } \\
\mathbf{( \% )}\end{array}$ \\
\hline A & 2.65 & $3.588 \mathrm{E}-04$ & 5.76 & 89.570 \\
\hline B & 4.7 & $3.533 \mathrm{E}-04$ & 0.93 & 92.915 \\
\hline C & 9.8 & $3.239 \mathrm{E}-04$ & 0.20 & 93.480 \\
\hline C & 12.7 & $2.499 \mathrm{E}-04$ & 0.06 & 93.610 \\
\hline B & 7.15 & $2.322 \mathrm{E}-04$ & 0.46 & 93.870 \\
\hline C & 15.6 & $2.035 \mathrm{E}-04$ & 0.03 & 94.115 \\
\hline A & 4.7 & $2.023 \mathrm{E}-04$ & 2.98 & 95.620 \\
\hline B & 9.8 & $1.694 \mathrm{E}-04$ & 0.19 & 97.205 \\
\hline C & 19 & $1.671 \mathrm{E}-04$ & 0.03 & 97.315 \\
\hline A & 7.15 & $1.330 \mathrm{E}-04$ & 1.56 & 98.110 \\
\hline B & 12.7 & $1.308 \mathrm{E}-04$ & 0.05 & 98.915 \\
\hline B & 15.6 & $1.064 \mathrm{E}-04$ & 0.01 & 98.945 \\
\hline A & 9.8 & $9.702 \mathrm{E}-05$ & 0.73 & 99.315 \\
\hline B & 19 & $8.740 \mathrm{E}-05$ & 0.02 & 99.690 \\
\hline A & 12.7 & $7.486 \mathrm{E}-05$ & 0.16 & 99.780 \\
\hline A & 15.6 & $6.095 \mathrm{E}-05$ & 0.04 & 99.880 \\
\hline A & 19 & $5.004 \mathrm{E}-05$ & 0.04 & 99.920 \\
\hline
\end{tabular}

The interpolation to calculate the $95^{\text {th }}$ percentile $\chi / \mathrm{Q}^{\prime}$ is between the second and third rows of numbers. The calculation is shown below for reference. The result agrees with the value shown in the first column of Table 2-4.

$$
\left(\frac{0.03444-0.02868 \mathrm{~s} / \mathrm{m}^{3}}{3.950-7.630 \%}\right)(5-7.630 \%)+0.02868 \mathrm{~s} / \mathrm{m}^{3}=0.03280 \mathrm{~s} / \mathrm{m}^{3}
$$


Table 3-4. Cumulative Probability Distribution for the Hanford Site Boundary, All Sectors, Centerline Values. (11 sheets)

\begin{tabular}{|c|c|c|c|c|c|}
\hline $\begin{array}{l}\text { Stability } \\
\text { class }\end{array}$ & $\begin{array}{l}\text { Wind speed } \\
(\mathbf{m} / \mathbf{s})\end{array}$ & $\begin{array}{c}\text { Receptor } \\
\text { distance } \\
(m)\end{array}$ & $\begin{array}{c}\text { Dispersion } \\
\text { coefficient } \\
\left(\mathbf{s} / \mathbf{m}^{3}\right)\end{array}$ & $\begin{array}{c}\text { Observed } \\
\text { frequency } \\
(\%)\end{array}$ & $\begin{array}{c}\text { Cumulative } \\
\text { frequency } \\
(\%)\end{array}$ \\
\hline G & 0.89 & 8,690 & 7.859 E-05 & 0.31 & 0.155 \\
\hline G & 0.89 & 8,970 & $7.546 \mathrm{E}-05$ & 0.09 & 0.355 \\
\hline $\mathrm{G}$ & 0.89 & 10,430 & $6.226 \mathrm{E}-05$ & 0.10 & 0.450 \\
\hline $\mathrm{G}$ & 0.89 & 10,530 & $6.151 \mathrm{E}-05$ & 0.09 & 0.545 \\
\hline $\mathrm{G}$ & 0.89 & 10,800 & $5: 956$ E-05 & 0.13 & 0.655 \\
\hline $\mathrm{G}$ & 0.89 & 11,100 & $5.753 \mathrm{E}-05$ & 0.34 & 0.890 \\
\hline $\mathrm{G}$ & 0.89 & 11,160 & $5.714 \mathrm{E}-05$ & 0.22 & 1.170 \\
\hline $\mathrm{G}$ & 0.89 & 13,200 & $4.624 \mathrm{E}-05$ & 0.08 & 1.320 \\
\hline $\mathrm{G}$ & 0.89 & 15,190 & 3.879 E-05 & 0.14 & 1.430 \\
\hline $\mathrm{G}$ & 0.89 & 15,360 & $3.826 \mathrm{E}-05$ & 0.23 & 1.615 \\
\hline $\mathrm{F}$ & 0.89 & 8,690 & $3.137 \mathrm{E}-05$ & 0.61 & 2.035 \\
\hline $\mathrm{F}$ & 0.89 & 8,970 & $3.012 \mathrm{E}-05$ & 0.23 & 2.455 \\
\hline $\mathrm{G}$ & 2.65 & 8,690 & $2.640 \mathrm{E}-05$ & 0.43 & 2.785 \\
\hline $\mathrm{G}$ & 0.89 & 21,050 & $2.590 \mathrm{E}-05$ & 0.14 & 3.070 \\
\hline $\mathrm{G}$ & 2.65 & 8,970 & $2.534 \mathrm{E}-05$ & 0.08 & 3.180 \\
\hline $\mathrm{F}$ & 0.89 & 10,430 & $2.485 \mathrm{E}-05$ & 0.22 & 3.330 \\
\hline $\mathrm{F}$ & 0.89 & 10,530 & 2.455 E-05 & 0.27 & 3.575 \\
\hline $\mathrm{F}$ & 0.89 & 10,800 & 2.377 E-05 & 0.28 & 3.850 \\
\hline $\mathrm{F}$ & 0.89 & 11,100 & 2.296 E-05 & 0.68 & 4.330 \\
\hline $\mathrm{F}$ & 0.89 & 11,160 & $2.281 \mathrm{E}-05$ & 0.48 & 4.910 \\
\hline $\mathrm{G}$ & 2.65 & 10,430 & $2.091 \mathrm{E}-05$ & 0.10 & 5.200 \\
\hline $\mathrm{G}$ & 2.65 & 10,530 & $2.066 \mathrm{E}-05$ & 0.20 & 5.350 \\
\hline $\mathrm{G}$ & 2.65 & 10,800 & $2.000 \mathrm{E}-05$ & 0.20 & 5.550 \\
\hline $\mathrm{G}$ & 2.65 & 11,100 & $1.932 \mathrm{E}-05$ & 0.22 & 5.760 \\
\hline $\mathrm{G}$ & 2.65 & 11,160 & $1.919 \mathrm{E}-05$ & 0.82 & 6.280 \\
\hline $\mathrm{F}$ & 0.89 & 13,200 & $1.846 \mathrm{E}-05$ & 0.12 & 6.750 \\
\hline G & 2.65 & 13,200 & $1.553 \mathrm{E}-05$ & 0.02 & 6.820 \\
\hline $\mathrm{F}$ & 0.89 & 15,190 & $1.549 \mathrm{E}-05$ & 0.36 & 7.010 \\
\hline $\mathrm{F}$ & 0.89 & 15,360 & $1.527 \mathrm{E}-05$ & 0.59 & 7.485 \\
\hline $\mathrm{G}$ & 4.7 & 8,690 & $1.488 \mathrm{E}-05$ & 0.16 & 7.860 \\
\hline $\mathrm{G}$ & 4.7 & 8,970 & $1.429 \mathrm{E}-05$ & 0.01 & 7.945 \\
\hline G & 2.65 & 15,190 & $1.303 \mathrm{E}-05$ & 0.69 & 8.295 \\
\hline $\mathrm{E}$ & 0.89 & 8,690 & $1.298 \mathrm{E}-05$ & 0.64 & 8.960 \\
\hline $\mathrm{G}$ & 2.65 & 15,360 & $1.285 \mathrm{E}-05$ & 0.14 & 9.350 \\
\hline $\mathrm{E}$ & 0.89 & 8,970 & $1.244 \mathrm{E}-05$ & 0.21 & 9.525 \\
\hline
\end{tabular}


Table 3-4. Cumulative Probability Distribution for the Hanford Site Boundary, All Sectors, Centerline Values. (11 sheets)

\begin{tabular}{|c|c|c|c|c|c|}
\hline $\begin{array}{l}\text { Stability } \\
\text { class }\end{array}$ & $\begin{array}{l}\text { Wind speed } \\
\qquad(\mathrm{m} / \mathrm{s})\end{array}$ & $\begin{array}{c}\text { Receptor } \\
\text { distance } \\
\text { (m) }\end{array}$ & $\begin{array}{c}\text { Dispersion } \\
\text { coefficient } \\
\left(\mathrm{s} / \mathrm{m}^{3}\right)\end{array}$ & $\begin{array}{c}\text { Observed } \\
\text { frequency } \\
(\%)\end{array}$ & $\begin{array}{c}\text { Cumulative } \\
\text { frequency } \\
(\%)\end{array}$ \\
\hline $\mathrm{G}$ & 4.7 & 10,430 & $1.179 \mathrm{E}-05$ & 0.02 & 9.640 \\
\hline $\mathrm{G}$ & 4.7 & 10,530 & $1.165 \mathrm{E}-05$ & 0.09 & 9.695 \\
\hline $\mathrm{G}$ & 4.7 & 10,800 & $1.128 \mathrm{E}-05$ & 0.01 & 9.745 \\
\hline $\mathrm{G}$ & 4.7 & 11,100 & $1.089 \mathrm{E}-05$ & 0.01 & 9.755 \\
\hline $\mathrm{G}$ & 4.7 & 11,160 & $1.082 \mathrm{E}-05$ & 0.56 & 10.040 \\
\hline $\mathrm{F}$ & 2.65 & 8,690 & $1.053 \mathrm{E}-05$ & 0.89 & 10.765 \\
\hline $\mathrm{F}$ & 0.89 & 21,050 & $1.034 \mathrm{E}-05$ & 0.32 & 11.370 \\
\hline $\mathrm{E}$ & 0.89 & 10,430 & $1.015 \mathrm{E}-05$ & 0.25 & 11.655 \\
\hline $\mathrm{F}$ & 2.65 & 8,970 & $1.012 \mathrm{E}-05$ & 0.21 & 11.885 \\
\hline$E$ & 0.89 & 10,530 & $1.003 \mathrm{E}-05$ & 0.29 & 12.135 \\
\hline G & 7.15 & 8,690 & 9.783 E-06 & 0.01 & 12.285 \\
\hline $\mathrm{E}$ & 0.89 & 10,800 & $9.692 \mathrm{E}-06$ & 0.31 & 12.445 \\
\hline E & 0.89 & 11,100 & $9.343 \mathrm{E}-06$ & 1.05 & 13.125 \\
\hline $\mathrm{E}$ & 0.89 & 11,160 & $9.276 \mathrm{E}-06$ & 0.49 & 13.895 \\
\hline $\mathrm{G}$ & 2.65 & 21,050 & $8.698 \mathrm{E}-06$ & 0.30 & 14.290 \\
\hline $\mathrm{F}$ & 2.65 & 10,430 & $8.346 \mathrm{E}-06$ & 0.27 & 14.575 \\
\hline $\mathrm{F}$ & 2.65 & 10,530 & $8.245 \mathrm{E}-06$ & 0.46 & 14.940 \\
\hline $\mathrm{F}$ & 2.65 & 10,800 & $7.985 \mathrm{E}-06$ & 0.39 & 15.365 \\
\hline $\mathrm{F}$ & 2.65 & 11,100 & $7.712 \mathrm{E}-06$ & 0.42 & 15.770 \\
\hline $\mathrm{F}$ & 2.65 & 11,160 & $7.660 \mathrm{E}-06$ & 1.60 & 16.780 \\
\hline$E$ & 0.89 & 13,200 & $7.419 \mathrm{E}-06$ & 0.28 & 17.720 \\
\hline G & 4.7 & 15,190 & $7.346 \mathrm{E}-06$ & 0.84 & 18.280 \\
\hline G & 4.7 & 15,360 & $7.244 \mathrm{E}-06$ & 0.02 & 18.710 \\
\hline $\mathrm{F}$ & 2.65 & 13,200 & $6.200 \mathrm{E}-06$ & 0.05 & 18.745 \\
\hline $\mathrm{E}$ & 0.89 & 15,190 & $6.161 \mathrm{E}-06$ & 0.44 & 18.990 \\
\hline $\mathrm{E}$ & 0.89 & 15,360 & $6.071 \mathrm{E}-06$ & 1.04 & 19.730 \\
\hline $\mathrm{F}$ & 4.7 & 8,690 & $5.940 \mathrm{E}-06$ & 0.31 & 20.405 \\
\hline $\mathrm{F}$ & 4.7 & 8,970 & $5.703 \mathrm{E}-06$ & 0.03 & 20.575 \\
\hline $\mathrm{D}$ & 0.89 & 8,690 & $5.487 \mathrm{E}-06$ & 0.59 & 20.885 \\
\hline D & 0.89 & 8,970 & $5.236 \mathrm{E}-06$ & 0.19 & 21.275 \\
\hline $\mathrm{F}$ & 2.65 & 15,190 & $5.201 \mathrm{E}-06$ & 1.69 & 22.215 \\
\hline $\mathrm{F}$ & 2.65 & 15,360 & $5.129 \mathrm{E}-06$ & 0.43 & 23.275 \\
\hline $\mathrm{G}$ & 4.7 & 21,050 & $4.904 \mathrm{E}-06$ & 0.13 & 23.555 \\
\hline $\mathrm{G}$ & 7.15 & 15,190 & $4.829 \mathrm{E}-06$ & 0.01 & 23.625 \\
\hline $\mathrm{F}$ & 4.7 & 10,430 & $4.706 \mathrm{E}-06$ & 0.07 & 23.665 \\
\hline $\mathrm{F}$ & 4.7 & 10,530 & 4.649 E-06 & 0.20 & 23.800 \\
\hline
\end{tabular}


Table 3-4. Cumulative Probability Distribution for the Hanford Site Boundary, All Sectors, Centerline Values. (11 sheets)

\begin{tabular}{|c|c|c|c|c|c|}
\hline $\begin{array}{l}\text { Stability } \\
\text { class }\end{array}$ & $\begin{array}{l}\text { Wind speed } \\
(\mathrm{m} / \mathrm{s})\end{array}$ & $\begin{array}{c}\text { Receptor } \\
\text { distance } \\
(\mathrm{m})\end{array}$ & $\begin{array}{c}\text { Dispersion } \\
\text { coefficient } \\
\left(\mathrm{s} / \mathrm{m}^{3}\right)\end{array}$ & $\begin{array}{c}\text { Observed } \\
\text { frequency } \\
(\%)\end{array}$ & $\begin{array}{c}\text { Cumulative } \\
\text { frequency } \\
(\%)\end{array}$ \\
\hline $\mathrm{F}$ & 4.7 & 10,800 & $4.502 \mathrm{E}-06$ & 0.05 & 23.925 \\
\hline E & 2.65 & 8,690 & $4.359 \mathrm{E}-06$ & 0.98 & 24.440 \\
\hline $\mathrm{F}$ & 4.7 & 11,100 & $4.348 \mathrm{E}-06$ & 0.04 & 24.950 \\
\hline $\mathrm{F}$ & 4.7 & 11,160 & $4.319 \mathrm{E}-06$ & 1.19 & 25.565 \\
\hline $\mathrm{D}$ & 0.89 & 10,430 & $4.195 \mathrm{E}-06$ & 0.21 & 26.265 \\
\hline $\mathrm{E}$ & 2.65 & 8,970 & $4.176 \mathrm{E}-06$ & 0.21 & 26.475 \\
\hline $\mathrm{D}$ & 0.89 & 10,530 & $4.137 \mathrm{E}-06$ & 0.17 & 26.665 \\
\hline $\mathrm{E}$ & 0.89 & 21,050 & 4.015 E-06 & 0.45 & 26.975 \\
\hline D & 0.89 & 10,800 & $3.986 \mathrm{E}-06$ & 0.43 & 27.415 \\
\hline $\mathrm{F}$ & 7.15 & 8,690 & 3.904 E-06 & 0.03 & 27.645 \\
\hline $\mathrm{D}$ & 0.89 & 11,100 & $3.829 \mathrm{E}-06$ & 1.86 & 28.590 \\
\hline $\mathrm{D}$ & 0.89 & 11,160 & $3.798 \mathrm{E}-06$ & 0.40 & 29.720 \\
\hline $\mathrm{F}$ & 4.7 & 13,200 & $3.495 \mathrm{E}-06$ & 0.01 & 29.925 \\
\hline $\mathrm{F}$ & 2.65 & 21,050 & $3.473 \mathrm{E}-06$ & 0.82 & 30.340 \\
\hline$E$ & 2.65 & 10,430 & $3.410 \mathrm{E}-06$ & 0.29 & 30.895 \\
\hline E & 2.65 & 10,530 & 3.367 E-06 & 0.48 & 31.280 \\
\hline $\mathrm{E}$ & 2.65 & 10,800 & $3.255 \mathrm{E}-06$ & 0.47 & 31.755 \\
\hline E & 2.65 & 11,100 & $3.138 \mathrm{E}-06$ & 0.78 & 32.380 \\
\hline E & 2.65 & 11,160 & $3.115 \mathrm{E}-06$ & 1.58 & 33.560 \\
\hline $\mathrm{F}$ & 7.15 & 10,430 & 3.093 E-06 & 0.01 & 34.355 \\
\hline $\mathrm{F}$ & 7.15 & 10,530 & $3.056 \mathrm{E}-06$ & 0.02 & 34.370 \\
\hline $\mathrm{D}$ & 0.89 & 13,200 & $2.971 \mathrm{E}-06$ & 0.59 & 34.675 \\
\hline $\mathrm{F}$ & 4.7 & 15,190 & $2.933 \mathrm{E}-06$ & 1.60 & 35.770 \\
\hline $\mathrm{F}$ & 4.7 & 15,360 & 2.892 E-06 & 0.16 & 36.650 \\
\hline $\mathrm{F}$ & 9.8 & 8,690 & $2.849 \mathrm{E}-06$ & 0.01 & 36.735 \\
\hline $\mathrm{F}$ & 7.15 & 11,160 & $2.839 \mathrm{E}-06$ & 0.07 & 36.775 \\
\hline $\mathrm{E}$ & 2.65 & 13,200 & $2.492 \mathrm{E}-06$ & 0.11 & 36.865 \\
\hline $\mathrm{E}$ & 4.7 & 8,690 & $2.458 \mathrm{E}-06$ & 0.47 & 37.155 \\
\hline D & 0.89 & 15,190 & 2.420 E-06 & 0.44 & 37.610 \\
\hline D & 0.89 & 15,360 & $2.381 \mathrm{E}-06$ & 2.00 & 38.830 \\
\hline $\mathrm{E}$ & 4.7 & 8,970 & $2.355 \mathrm{E}-06$ & 0.12 & 39.890 \\
\hline $\mathrm{E}$ & 2.65 & 15,190 & $2.069 \mathrm{E}-06$ & 1.68 & 40.790 \\
\hline E & 2.65 & 15,360 & $2.039 \mathrm{E}-06$ & 0.88 & 42.070 \\
\hline $\mathrm{F}$ & 4.7 & 21,050 & 1.958 E-06 & 0.32 & 42.670 \\
\hline $\mathrm{F}$ & 7.15 & 15,190 & $1.928 \mathrm{E}-06$ & 0.08 & 42.870 \\
\hline $\mathrm{E}$ & 4.7 & 10,430 & $1.923 \mathrm{E}-06$ & 0.18 & 43.000 \\
\hline
\end{tabular}


Table 3-4. Cumulative Probability Distribution for the Hanford Site Boundary, All Sectors, Centerline Values. (11 sheets)

\begin{tabular}{|c|c|c|c|c|c|}
\hline $\begin{array}{l}\text { Stability } \\
\text { class }\end{array}$ & $\begin{array}{l}\text { Wind speed } \\
(\mathrm{m} / \mathrm{s})\end{array}$ & $\begin{array}{c}\text { Receptor } \\
\text { distance } \\
\text { (m) }\end{array}$ & $\begin{array}{c}\text { Dispersion } \\
\text { coefficient } \\
\left(\mathbf{s} / \mathbf{m}^{3}\right)\end{array}$ & $\begin{array}{c}\text { Observed } \\
\text { frequency } \\
(\%)\end{array}$ & $\begin{array}{c}\text { Cumulative } \\
\text { frequency } \\
(\%)\end{array}$ \\
\hline $\mathrm{F}$ & 7.15 & 15,360 & $1.901 \mathrm{E}-06$ & 0.05 & 43.115 \\
\hline $\mathrm{E}$ & 4.7 & 10,530 & $1.898 \mathrm{E}-06$ & 0.39 & 43.335 \\
\hline $\mathrm{D}$ & 2.65 & 8,690 & $1.843 \mathrm{E}-06$ & 0.88 & 43.970 \\
\hline $\mathrm{E}$ & 4.7 & 10,800 & $1.835 \mathrm{E}-06$ & 0.15 & 44.485 \\
\hline $\mathrm{G}$ & 19 & 15,360 & $1.792 \mathrm{E}-06$ & 0.01 & 44.565 \\
\hline $\mathrm{E}$ & 4.7 & 11,100 & $1.769 \mathrm{E}-06$ & 0.13 & 44.635 \\
\hline $\mathrm{D}$ & 2.65 & 8,970 & $1.759 \mathrm{E}-06$ & 0.18 & 44.790 \\
\hline $\mathrm{E}$ & 4.7 & 11,160 & 1.757 E-06 & 1.98 & 45.870 \\
\hline $\mathrm{E}$ & 7.15 & 8,690 & $1.616 \mathrm{E}-06$ & 0.12 & 46.920 \\
\hline $\mathrm{E}$ & 7.15 & 8,970 & $1.548 \mathrm{E}-06$ & 0.08 & 47.020 \\
\hline $\mathrm{D}$ & 0.89 & 21,050 & $1.505 \mathrm{E}-06$ & 0.54 & 47.330 \\
\hline $\mathrm{D}$ & 2.65 & 10,430 & 1.409 E-06 & 0.24 & 47.720 \\
\hline $\mathrm{E}$ & 4.7 & 13,200 & $1.405 \mathrm{E}-06$ & 0.04 & 47.860 \\
\hline $\mathrm{D}$ & 2.65 & 10,530 & 1.389 E-06 & 0.28 & 48.020 \\
\hline $\mathrm{F}$ & 9.8 & 15,360 & $1.387 \mathrm{E}-06$ & 0.02 & 48.170 \\
\hline $\mathrm{E}$ & 2.65 & 21,050 & $1.348 \mathrm{E}-06$ & 1.11 & 48.735 \\
\hline $\mathrm{D}$ & 2.65 & 10,800 & $1.339 \mathrm{E}-06$ & 0.75 & 49.665 \\
\hline $\mathrm{F}$ & 7.15 & 21,050 & $1.287 \mathrm{E}-06$ & 0.03 & 50.055 \\
\hline $\mathrm{D}$ & 2.65 & 11,100 & $1.286 \mathrm{E}-06$ & 1.56 & 50.850 \\
\hline D & 2.65 & 11,160 & $1.276 \mathrm{E}-06$ & 0.69 & 51.975 \\
\hline E & 7.15 & 10,430 & $1.264 \mathrm{E}-06$ & 0.17 & 52.405 \\
\hline $\mathrm{E}$ & 7.15 & 10,530 & $1.248 \mathrm{E}-06$ & 0.30 & 52.640 \\
\hline $\mathrm{E}$ & 7.15 & 10,800 & $1.206 \mathrm{E}-06$ & 0.01 & 52.795 \\
\hline $\mathrm{E}$ & 9.8 & 8,690 & $1.179 \mathrm{E}-06$ & 0.01 & 52.805 \\
\hline $\mathrm{E}$ & 4.7 & 15,190 & $1.167 \mathrm{E}-06$ & 2.50 & 54.060 \\
\hline$E$ & 7.15 & 11,160 & $1.155 \mathrm{E}-06$ & 0.65 & 55.635 \\
\hline $\mathrm{E}$ & 4.7 & 15,360 & $1.150 \mathrm{E}-06$ & 0.41 & 56.165 \\
\hline E & 9.8 & 8,970 & $1.129 \mathrm{E}-06$ & 0.05 & 56.395 \\
\hline $\mathrm{C}$ & 0.89 & 8,690 & $1.083 \mathrm{E}-06$ & 0.08 & 56.460 \\
\hline $\mathrm{D}$ & 4.7 & 8,690 & $1.039 \mathrm{E}-06$ & 0.51 & 56.755 \\
\hline $\mathrm{C}$ & 0.89 & 8,970 & $1.023 \mathrm{E}-06$ & 0.02 & 57.020 \\
\hline $\mathrm{D}$ & 2.65 & 13,200 & 9.977 E-07 & 0.40 & 57.230 \\
\hline $\mathrm{D}$ & 4.7 & 8,970 & $9.916 \mathrm{E}-07$ & 0.13 & 57.495 \\
\hline $\mathrm{E}$ & 7.15 & 13,200 & $9.235 \mathrm{E}-07$ & 0.01 & 57.565 \\
\hline $\mathrm{E}$ & 9.8 & 10,430 & 9.222 E-07 & 0.11 & 57.625 \\
\hline $\mathrm{E}$ & 9.8 & 10,530 & 9.105 E-07 & 0.15 & 57.755 \\
\hline
\end{tabular}


Table 3-4. Cumulative Probability Distribution for the Hanford Site Boundary, All Sectors, Centerline Values. (11 sheets)

\begin{tabular}{|c|c|c|c|c|c|}
\hline $\begin{array}{l}\text { Stability } \\
\text { class }\end{array}$ & $\begin{array}{l}\text { Wind speed } \\
(\mathrm{m} / \mathrm{s})\end{array}$ & $\begin{array}{c}\text { Receptor } \\
\text { distance } \\
(\mathrm{m})\end{array}$ & $\begin{array}{c}\text { Dispersion } \\
\text { coefficient } \\
\left(\mathrm{s} / \mathrm{m}^{3}\right)\end{array}$ & $\begin{array}{r}\text { Observed } \\
\text { frequency } \\
(\%)\end{array}$ & $\begin{array}{c}\text { Cumulative } \\
\text { frequency } \\
(\%)\end{array}$ \\
\hline $\mathrm{E}$ & 12.7 & 8,970 & 8.714 E-07 & 0.01 & 57.835 \\
\hline $\mathrm{F}$ & 15.6 & 15,360 & 8.714 E-07 & 0.02 & 57.850 \\
\hline $\mathrm{E}$ & 9.8 & 11,160 & $8.424 \mathrm{E}-07$ & 0.06 & 57.890 \\
\hline $\mathrm{D}$ & 2.65 & 15,190 & $8.127 \mathrm{E}-07$ & 1.09 & 58.465 \\
\hline $\mathrm{D}$ & 2.65 & 15,360 & $7.996 \mathrm{E}-07$ & 2.09 & 60.055 \\
\hline $\mathrm{D}$ & 4.7 & 10,430 & $7.943 \mathrm{E}-07$ & 0.23 & 61.215 \\
\hline $\mathrm{D}$ & 4.7 & 10,530 & $7.833 \mathrm{E}-07$ & 0.39 & 61.525 \\
\hline $\mathrm{C}$ & 0.89 & 10,430 & $7.787 \mathrm{E}-07$ & 0.02 & 61.730 \\
\hline $\mathrm{E}$ & 7.15 & 15,190 & $7.669 \mathrm{E}-07$ & 1.75 & 62.615 \\
\hline $\mathrm{C}$ & 0.89 & 10,530 & 7.654 E-07 & 0.02 & 63.500 \\
\hline$E$ & 4.7 & 21,050 & 7.602 E-07 & 0.75 & 63.885 \\
\hline $\mathrm{E}$ & 7.15 & 15,360 & 7.557 E-07 & 0.21 & 64.365 \\
\hline $\mathrm{D}$ & 4.7 & 10,800 & $7.547 \mathrm{E}-07$ & 0.25 & 64.595 \\
\hline $\mathrm{C}$ & 0.89 & 10,800 & $7.315 \mathrm{E}-07$ & 0.06 & 64.750 \\
\hline $\mathrm{D}$ & 4.7 & 11,100 & $7.250 \mathrm{E}-07$ & 0.27 & 64.915 \\
\hline $\mathrm{D}$ & 4.7 & 11,160 & 7.193 E-07 & 0.83 & 65.465 \\
\hline $\mathrm{F}$ & 19 & 15,360 & $7.154 \mathrm{E}-07$ & 0.08 & 65.920 \\
\hline $\mathrm{E}$ & 12.7 & 10,430 & $7.116 \mathrm{E}-07$ & 0.04 & 65.980 \\
\hline $\mathrm{E}$ & 12.7 & 10,530 & $7.026 \mathrm{E}-07$ & 0.02 & 66.010 \\
\hline $\mathrm{C}$ & 0.89 & 11,100 & $6.965 \mathrm{E}-07$ & 0.36 & 66.200 \\
\hline $\mathrm{C}$ & 0.89 & 11,160 & $6.898 \mathrm{E}-07$ & 0.04 & 66.400 \\
\hline $\mathrm{D}$ & 7.15 & 8,690 & $6.830 \mathrm{E}-07$ & 0.17 & 66.505 \\
\hline $\mathrm{E}$ & 9.8 & 13,200 & $6.737 \mathrm{E}-07$ & 0.01 & 66.595 \\
\hline $\mathrm{D}$ & 7.15 & 8,970 & $6.518 \mathrm{E}-07$ & 0.11 & 66.655 \\
\hline $\mathrm{E}$ & 12.7 & 11,160 & $6.501 \mathrm{E}-07$ & 0.01 & 66.715 \\
\hline E & 15.6 & 10,430 & $5.793 \mathrm{E}-07$ & 0.01 & 66.725 \\
\hline $\mathrm{D}$ & 4.7 & 13,200 & $5.625 \mathrm{E}-07$ & 0.09 & 66.775 \\
\hline $\mathrm{E}$ & 9.8 & 15,190 & $5.595 \mathrm{E}-07$ & 0.38 & 67.010 \\
\hline $\mathrm{E}$ & 9.8 & 15,360 & 5.514 E-07 & 0.07 & 67.235 \\
\hline D & 7.15 & 10,430 & 5.222 E-07 & 0.25 & 67.395 \\
\hline $\mathrm{E}$ & 12.7 & 13,200 & $5.199 \mathrm{E}-07$ & 0.01 & 67.525 \\
\hline $\mathrm{C}$ & 0.89 & 13,200 & $5.152 \mathrm{E}-07$ & 0.09 & 67.575 \\
\hline $\mathrm{D}$ & 7.15 & 10,530 & $5.149 \mathrm{E}-07$ & 0.38 & 67.810 \\
\hline D & 2.65 & 21,050 & $5.054 \mathrm{E}-07$ & 1.05 & 68.525 \\
\hline $\mathrm{E}$ & 7.15 & 21,050 & $4.997 \mathrm{E}-07$ & 0.41 & 69.255 \\
\hline $\mathrm{D}$ & 9.8 & 8,690 & $4.983 \mathrm{E}-07$ & 0.02 & 69.470 \\
\hline
\end{tabular}


Table 3-4. Cumulative Probability Distribution for the Hanford Site Boundary, All Sectors, Centerline Values. (11 sheets)

\begin{tabular}{|c|c|c|c|c|c|}
\hline $\begin{array}{l}\text { Stability } \\
\text { class }\end{array}$ & $\begin{array}{l}\text { Wind speed } \\
(\mathrm{m} / \mathrm{s})\end{array}$ & $\begin{array}{c}\text { Receptor } \\
\text { distance } \\
(\mathrm{m})\end{array}$ & $\begin{array}{c}\text { Dispersion } \\
\text { coefficient } \\
\left(\mathbf{s} / \mathbf{m}^{3}\right)\end{array}$ & $\begin{array}{l}\text { Observed } \\
\text { frequency } \\
(\%)\end{array}$ & $\begin{array}{c}\text { Cumulative } \\
\text { frequency } \\
(\%)\end{array}$ \\
\hline D & 7.15 & 10,800 & $4.961 \mathrm{E}-07$ & 0.03 & 69.495 \\
\hline $\mathrm{D}$ & 7.15 & 11,100 & $4.766 \mathrm{E}-07$ & 0.02 & 69.520 \\
\hline $\mathrm{D}$ & 9.8 & 8,970 & $4.755 \mathrm{E}-07$ & 0.07 & 69.565 \\
\hline $\mathrm{D}$ & 7.15 & 11,160 & $4.728 \mathrm{E}-07$ & 0.58 & 69.890 \\
\hline $\mathrm{D}$ & 4.7 & 15,190 & $4.582 \mathrm{E}-07$ & 1.46 & 70.910 \\
\hline B & 0.89 & 8,690 & $4.527 \mathrm{E}-07$ & 0.08 & 71.680 \\
\hline $\mathrm{D}$ & 4.7 & 15,360 & $4.508 \mathrm{E}-07$ & 0.73 & 72.085 \\
\hline $\mathrm{B}$ & 0.89 & 8,970 & $4.388 \mathrm{E}-07$ & 0.02 & 72.460 \\
\hline $\mathrm{E}$ & 12.7 & 15,190 & 4.317 E-07 & 0.05 & 72.495 \\
\hline $\mathrm{E}$ & 12.7 & 15,360 & $4.255 \mathrm{E}-07$ & 0.02 & 72.530 \\
\hline $\mathrm{C}$ & 0.89 & 15,190 & $4.114 \mathrm{E}-07$ & 0.04 & 72.560 \\
\hline $\mathrm{C}$ & 0.89 & 15,360 & 4.046 E-07 & 0.34 & 72.750 \\
\hline $\mathrm{B}$ & 0.89 & 10,430 & $3.829 \mathrm{E}-07$ & 0.01 & 72.925 \\
\hline $\mathrm{D}$ & 9.8 & 10,430 & $3.810 \mathrm{E}-07$ & 0.16 & 73.010 \\
\hline $\mathrm{B}$ & 0.89 & 10,530 & $3.796 \mathrm{E}-07$ & 0.03 & 73.105 \\
\hline $\mathrm{D}$ & 9.8 & 10,530 & 3.757 E-07 & 0.24 & 73.240 \\
\hline $\mathrm{B}$ & 0.89 & 10,800 & $3.711 \mathrm{E}-07$ & 0.07 & 73.395 \\
\hline D & 7.15 & 13,200 & $3.698 \mathrm{E}-07$ & 0.03 & 73.445 \\
\hline $\mathrm{D}$ & 12.7 & 8,970 & $3.670 \mathrm{E}-07$ & 0.02 & 73.470 \\
\hline $\mathrm{E}$ & 9.8 & 21,050 & $3.646 \mathrm{E}-07$ & 0.11 & 73.535 \\
\hline $\mathrm{C}$ & 2.65 & 8,690 & $3.638 \mathrm{E}-07$ & 0.16 & 73.670 \\
\hline $\mathrm{B}$ & 0.89 & 11,100 & $3.620 \mathrm{E}-07$ & 0.36 & 73.930 \\
\hline B & 0.89 & 11,160 & $3.602 \mathrm{E}-07$ & 0.04 & 74.130 \\
\hline $\mathrm{E}$ & 15.6 & 15,360 & $3.464 \mathrm{E}-07$ & 0.03 & 74.165 \\
\hline $\mathrm{D}$ & 9.8 & 11,160 & $3.450 \mathrm{E}-07$ & 0.13 & 74.245 \\
\hline $\mathrm{C}$ & 2.65 & 8,970 & $3.435 \mathrm{E}-07$ & 0.02 & 74.320 \\
\hline A & 0.89 & 8,690 & $3.396 \mathrm{E}-07$ & 0.20 & 74.430 \\
\hline $\mathrm{A}$ & 0.89 & 8,970 & 3.300 E-07 & 0.06 & 74.560 \\
\hline $\mathrm{B}$ & 0.89 & 13,200 & $3.096 \mathrm{E}-07$ & 0.10 & 74.640 \\
\hline D & 7.15 & 15,190 & $3.012 \mathrm{E}-07$ & 1.14 & 75.260 \\
\hline $\mathrm{D}$ & 7.15 & 15,360 & $2.963 \mathrm{E}-07$ & 0.25 & 75.955 \\
\hline $\mathrm{D}$ & 12.7 & 10,430 & $2.940 \mathrm{E}-07$ & 0.09 & 76.125 \\
\hline $\mathrm{D}$ & 12.7 & 10,530 & 2.899 E-07 & 0.09 & 76.215 \\
\hline $\mathrm{A}$ & 0.89 & 10,430 & 2.880 E-07 & 0.06 & 76.290 \\
\hline A & 0.89 & 10,530 & $2.855 \mathrm{E}-07$ & 0.06 & 76.350 \\
\hline $\mathrm{D}$ & 4.7 & 21,050 & $2.850 \mathrm{E}-07$ & 0.84 & 76.800 \\
\hline
\end{tabular}


Table 3-4. Cumulative Probability Distribution for the Hanford Site Boundary, All Sectors, Centerline Values. (11 sheets)

\begin{tabular}{|c|c|c|c|c|c|}
\hline $\begin{array}{l}\text { Stability } \\
\text { class }\end{array}$ & $\begin{array}{l}\text { Wind speed } \\
(\mathrm{m} / \mathrm{s})\end{array}$ & $\begin{array}{c}\text { Receptor } \\
\text { distance } \\
(\mathbf{m})\end{array}$ & $\begin{array}{c}\text { Dispersion } \\
\text { coefficient } \\
\left(\mathbf{s} / \mathbf{m}^{3}\right)\end{array}$ & $\begin{array}{c}\text { Observed } \\
\text { frequency } \\
(\%) \\
\end{array}$ & $\begin{array}{c}\text { Cumulative } \\
\text { frequency } \\
(\%)\end{array}$ \\
\hline E & 19 & 15,360 & $2.844 \mathrm{E}-07$ & 0.19 & 77.315 \\
\hline $\mathrm{E}$ & 12.7 & 21,050 & $2.814 \mathrm{E}-07$ & 0.03 & 77.425 \\
\hline A & 0.89 & 10,800 & 2.791 E-07 & 0.17 & 77.525 \\
\hline $\mathrm{B}$ & 0.89 & 15,190 & 2.727 E-07 & 0.05 & 77.635 \\
\hline A & 0.89 & 11,100 & $2.722 \mathrm{E}-07$ & 0.90 & 78.110 \\
\hline $\mathrm{C}$ & 0.89 & 21,050 & $2.721 \mathrm{E}-07$ & 0.10 & 78.610 \\
\hline $\mathrm{A}$ & 0.89 & 11,160 & 2.709 E-07 & 0.10 & 78.710 \\
\hline $\mathrm{B}$ & 0.89 & 15,360 & $2.700 \mathrm{E}-07$ & 0.38 & 78.950 \\
\hline D & 9.8 & 13,200 & $2.698 \mathrm{E}-07$ & 0.01 & 79.145 \\
\hline $\mathrm{D}$ & 12.7 & 11,160 & 2.662 E-07 & 0.03 & 79.165 \\
\hline $\mathrm{C}$ & 2.65 & 10,430 & $2.615 \mathrm{E}-07$ & 0.03 & 79.195 \\
\hline $\mathrm{C}$ & 2.65 & 10,530 & $2.571 \mathrm{E}-07$ & 0.05 & 79.235 \\
\hline $\mathrm{C}$ & 2.65 & 10,800 & 2.457 E-07 & 0.19 & 79.355 \\
\hline $\mathrm{D}$ & 15.6 & 10,430 & $2.393 \mathrm{E}-07$ & 0.03 & 79.465 \\
\hline D & 15.6 & 10,530 & $2.360 \mathrm{E}-07$ & 0.03 & 79.495 \\
\hline $\mathrm{C}$ & 2.65 & 11,100 & $2.339 \mathrm{E}-07$ & 0.35 & 79.685 \\
\hline A & 0.89 & 13,200 & $2.328 \mathrm{E}-07$ & 0.23 & 79.975 \\
\hline $\mathrm{C}$ & 2.65 & 11,160 & $2.317 \mathrm{E}-07$ & 0.08 & 80.130 \\
\hline $\mathrm{D}$ & 9.8 & 15,190 & $2.198 \mathrm{E}-07$ & 0.50 & 80.420 \\
\hline $\mathrm{D}$ & 15.6 & 11,160 & $2.167 \mathrm{E}-07$ & 0.02 & 80.680 \\
\hline$D$ & 9.8 & 15,360 & $2.162 \mathrm{E}-07$ & 0.07 & 80.725 \\
\hline $\mathrm{C}$ & 4.7 & 8,690 & $2.051 \mathrm{E}-07$ & 0.09 & 80.805 \\
\hline $\mathrm{A}$ & 0.89 & 15,190 & $2.051 \mathrm{E}-07$ & 0.10 & 80.900 \\
\hline $\mathrm{B}$ & 0.89 & 21,050 & $2.031 \mathrm{E}-07$ & 0.07 & 80.985 \\
\hline $\mathrm{A}$ & 0.89 & 15,360 & $2.030 \mathrm{E}-07$ & 0.78 & 81.410 \\
\hline $\mathrm{C}$ & 4.7 & 8,970 & $1.937 \mathrm{E}-07$ & 0.02 & 81.810 \\
\hline $\mathrm{D}$ & 7.15 & 21,050 & $1.873 \mathrm{E}-07$ & 0.50 & 82.070 \\
\hline $\mathrm{C}$ & 2.65 & 13,200 & $1.730 \mathrm{E}-07$ & 0.06 & 82.350 \\
\hline $\mathrm{D}$ & 12.7 & 15,190 & $1.696 \mathrm{E}-07$ & 0.07 & 82.415 \\
\hline D & 12.7 & 15,360 & $1.668 \mathrm{E}-07$ & 0.05 & 82.475 \\
\hline A & 0.89 & 21,050 & $1.527 \mathrm{E}-07$ & 0.14 & 82.570 \\
\hline B & 2.65 & 8,690 & $1.520 \mathrm{E}-07$ & 0.17 & 82.725 \\
\hline $\mathrm{C}$ & 4.7 & 10,430 & $1.475 \mathrm{E}-07$ & 0.03 & 82.825 \\
\hline $\mathrm{B}$ & 2.65 & 8,970 & $1.474 \mathrm{E}-07$ & 0.04 & 82.860 \\
\hline $\mathrm{C}$ & 4.7 & 10,530 & $1.449 \mathrm{E}-07$ & 0.06 & 82.910 \\
\hline $\mathrm{C}$ & 4.7 & 10,800 & $1.385 \mathrm{E}-07$ & 0.04 & 82.960 \\
\hline
\end{tabular}


Table 3-4. Cumulative Probability Distribution for the Hanford Site Boundary, All Sectors, Centerline Values. (11 sheets)

\begin{tabular}{|c|c|c|c|c|c|}
\hline $\begin{array}{l}\text { Stability } \\
\text { class }\end{array}$ & $\begin{array}{l}\text { Wind speed } \\
(\mathrm{m} / \mathrm{s})\end{array}$ & $\begin{array}{c}\text { Receptor } \\
\text { distance } \\
\text { (m) }\end{array}$ & $\begin{array}{c}\text { Dispersion } \\
\text { coefficient } \\
\left(\mathrm{s} / \mathrm{m}^{3}\right)\end{array}$ & $\begin{array}{c}\text { Observed } \\
\text { frequency } \\
(\%)\end{array}$ & $\begin{array}{c}\text { Cumulative } \\
\text { frequency } \\
(\%)\end{array}$ \\
\hline $\mathrm{C}$ & 2.65 & 15,190 & $1.382 \mathrm{E}-07$ & 0.10 & 83.030 \\
\hline $\mathrm{D}$ & 9.8 & 21,050 & $1.367 \mathrm{E}-07$ & 0.29 & 83.225 \\
\hline $\mathrm{C}$ & 2.65 & 15,360 & $1.359 \mathrm{E}-07$ & 0.46 & 83.600 \\
\hline $\mathrm{D}$ & 15.6 & 15,360 & $1.358 \mathrm{E}-07$ & 0.03 & 83.845 \\
\hline $\mathrm{C}$ & 7.15 & 8,690 & $1.348 \mathrm{E}-07$ & 0.03 & 83.875 \\
\hline $\mathrm{C}$ & 4.7 & 11,100 & 1.319 E-07 & 0.05 & 83.915 \\
\hline C & 4.7 & 11,160 & $1.306 \mathrm{E}-07$ & 0.09 & 83.985 \\
\hline $\mathrm{B}$ & 2.65 & 10,430 & $1.286 \mathrm{E}-07$ & 0.03 & 84.045 \\
\hline $\mathrm{B}$ & 2.65 & 10,530 & $1.275 \mathrm{E}-07$ & 0.05 & 84.085 \\
\hline C & 7.15 & 8,970 & $1.273 \mathrm{E}-07$ & 0.01 & 84.115 \\
\hline $\mathrm{B}$ & 2.65 & 10,800 & $1.246 \mathrm{E}-07$ & 0.13 & 84.185 \\
\hline $\mathrm{B}$ & 2.65 & 11,100 & $1.216 \mathrm{E}-07$ & 0.37 & 84.435 \\
\hline $\mathrm{B}$ & 2.65 & 11,160 & $1.210 \mathrm{E}-07$ & 0.07 & 84.655 \\
\hline $\mathrm{A}$ & 2.65 & 8,690 & $1.140 \mathrm{E}-07$ & 0.53 & 84.955 \\
\hline $\mathrm{D}$ & 19 & 15,360 & $1.115 \mathrm{E}-07$ & 0.11 & 85.275 \\
\hline $\mathrm{A}$ & 2.65 & 8,970 & $1.108 \mathrm{E}-07$ & 0.12 & 85.390 \\
\hline $\mathrm{D}$ & 12.7 & 21,050 & $1.055 \mathrm{E}-07$ & 0.08 & 85.490 \\
\hline $\mathrm{B}$ & 2.65 & 13,200 & $1.040 \mathrm{E}-07$ & 0.06 & 85.560 \\
\hline $\mathrm{C}$ & 9.8 & 8,690 & $9.837 \mathrm{E}-08$ & 0.01 & 85.595 \\
\hline $\mathrm{C}$ & 4.7 & 13,200 & $9.755 \mathrm{E}-08$ & 0.03 & 85.615 \\
\hline $\mathrm{C}$ & 7.15 & 10,430 & $9.693 \mathrm{E}-08$ & 0.02 & 85.640 \\
\hline $\mathrm{A}$ & 2.65 & 10,430 & 9.672 E-08 & 0.17 & 85.735 \\
\hline A & 2.65 & 10,530 & $9.589 \mathrm{E}-08$ & 0.19 & 85.915 \\
\hline $\mathrm{C}$ & 7.15 & 10,530 & $9.528 \mathrm{E}-08$ & 0.07 & 86.045 \\
\hline A & 2.65 & 10,800 & $9.372 \mathrm{E}-08$ & 0.45 & 86.305 \\
\hline B & 2.65 & 15,190 & $9.158 \mathrm{E}-08$ & 0.09 & 86.575 \\
\hline $\mathrm{A}$ & 2.65 & 11,100 & $9.143 \mathrm{E}-08$ & 1.43 & 87.335 \\
\hline $\mathrm{C}$ & 2.65 & 21,050 & $9.138 \mathrm{E}-08$ & 0.19 & 88.145 \\
\hline A & 2.65 & 11,160 & $9.099 \mathrm{E}-08$ & 0.25 & 88.365 \\
\hline $\mathrm{B}$ & 2.65 & 15,360 & $9.067 \mathrm{E}-08$ & 0.52 & 88.750 \\
\hline $\mathrm{C}$ & 7.15 & 11,160 & 8.587 E-08 & 0.06 & 89.040 \\
\hline $\mathrm{B}$ & 4.7 & 8,690 & $8.572 \mathrm{E}-08$ & 0.08 & 89.110 \\
\hline $\mathrm{B}$ & 4.7 & 8,970 & 8.309 E-08 & 0.02 & 89.160 \\
\hline $\mathrm{A}$ & 2.65 & 13,200 & $7.819 \mathrm{E}-08$ & 0.29 & 89.315 \\
\hline $\mathrm{C}$ & 4.7 & 15,190 & $7.791 \mathrm{E}-08$ & 0.13 & 89.525 \\
\hline $\mathrm{C}$ & 4.7 & 15,360 & $7.662 \mathrm{E}-08$ & 0.16 & 89.670 \\
\hline
\end{tabular}


Table 3-4. Cumulative Probability Distribution for the Hanford Site Boundary, All Sectors, Centerline Values. (11 sheets)

\begin{tabular}{|c|c|c|c|c|c|}
\hline $\begin{array}{l}\text { Stability } \\
\text { class }\end{array}$ & $\begin{array}{l}\text { Wind speed } \\
(\mathrm{m} / \mathrm{s})\end{array}$ & $\begin{array}{l}\text { Receptor } \\
\text { distance } \\
\text { (m) }\end{array}$ & $\begin{array}{c}\text { Dispersion } \\
\text { coefficient } \\
\left(\mathrm{s} / \mathrm{m}^{3}\right)\end{array}$ & $\begin{array}{c}\text { Observed } \\
\text { frequency } \\
(\%)\end{array}$ & $\begin{array}{c}\text { Cumulative } \\
\text { frequency } \\
(\%)\end{array}$ \\
\hline $\mathrm{B}$ & 4.7 & 10,430 & $7.251 \mathrm{E}-08$ & 0.05 & 89.775 \\
\hline B & 4.7 & 10,530 & $7.189 \mathrm{E}-08$ & 0.07 & 89.835 \\
\hline C & 9.8 & 10,430 & $7.072 \mathrm{E}-08$ & 0.02 & 89.880 \\
\hline B & 4.7 & 10,800 & $7.026 \mathrm{E}-08$ & 0.04 & 89.910 \\
\hline $\mathrm{C}$ & 9.8 & 10,530 & $6.952 \mathrm{E}-08$ & 0.05 & 89.955 \\
\hline $\mathrm{A}$ & 2.65 & 15,190 & $6.887 \mathrm{E}-08$ & 0.30 & 90.130 \\
\hline $\mathrm{B}$ & 4.7 & 11,100 & $6.855 \mathrm{E}-08$ & 0.07 & 90.315 \\
\hline B & 4.7 & 11,160 & $6.821 \mathrm{E}-08$ & 0.10 & 90.400 \\
\hline $\mathrm{B}$ & 2.65 & 21,050 & $6.821 \mathrm{E}-08$ & 0.16 & 90.530 \\
\hline A & 2.65 & 15,360 & $6.819 \mathrm{E}-08$ & 1.61 & 91.415 \\
\hline $\mathrm{A}$ & 4.7 & 8,690 & $6.430 \mathrm{E}-08$ & 0.25 & 92.345 \\
\hline $\mathrm{C}$ & 7.15 & 13,200 & $6.413 \mathrm{E}-08$ & 0.01 & 92.475 \\
\hline $\mathrm{C}$ & 9.8 & 11,160 & $6.265 \mathrm{E}-08$ & 0.02 & 92.490 \\
\hline A & 4.7 & 8,970 & $6.249 \mathrm{E}-08$ & 0.07 & 92.535 \\
\hline $\mathrm{B}$ & 4.7 & 13,200 & $5.862 \mathrm{E}-08$ & 0.03 & 92.585 \\
\hline $\mathrm{B}$ & 7.15 & 8,690 & $5.635 \mathrm{E}-08$ & 0.03 & 92.615 \\
\hline $\mathrm{B}$ & 7.15 & 8,970 & $5.462 \mathrm{E}-08$ & 0.01 & 92.635 \\
\hline $\mathrm{C}$ & 12.7 & 10,430 & $5.457 \mathrm{E}-08$ & 0.02 & 92.650 \\
\hline $\mathrm{A}$ & 4.7 & 10,430 & $5.453 \mathrm{E}-08$ & 0.14 & 92.730 \\
\hline A & 4.7 & 10,530 & $5.406 \mathrm{E}-08$ & 0.34 & 92.970 \\
\hline $\mathrm{C}$ & 12.7 & 10,530 & $5.364 \mathrm{E}-08$ & 0.01 & 93.145 \\
\hline $\mathrm{A}$ & 4.7 & 10,800 & $5.284 \mathrm{E}-08$ & 0.10 & 93.200 \\
\hline B & 4.7 & 15,190 & $5.164 \mathrm{E}-08$ & 0.14 & 93.320 \\
\hline A & 4.7 & 11,100 & $5.155 \mathrm{E}-08$ & 0.21 & 93.495 \\
\hline $\mathrm{C}$ & 4.7 & 21,050 & $5.153 \mathrm{E}-08$ & 0.12 & 93.660 \\
\hline $\mathrm{A}$ & 4.7 & 11,160 & $5.130 \mathrm{E}-08$ & 0.35 & 93.895 \\
\hline $\mathrm{A}$ & 2.65 & 21,050 & $5.130 \mathrm{E}-08$ & 0.42 & 94.280 \\
\hline $\mathrm{C}$ & 7.15 & 15,190 & $5.121 \mathrm{E}-08$ & 0.07 & 94.525 \\
\hline $\mathrm{B}$ & 4.7 & 15,360 & $5.112 \mathrm{E}-08$ & 0.21 & 94.665 \\
\hline $\mathrm{C}$ & 7.15 & 15,360 & $5.036 \mathrm{E}-08$ & 0.06 & 94.800 \\
\hline $\mathrm{B}$ & 7.15 & 10,430 & $4.767 \mathrm{E}-08$ & 0.04 & 94.850 \\
\hline $\mathrm{B}$ & 7.15 & 10,530 & $4.726 \mathrm{E}-08$ & 0.08 & 94.910 \\
\hline $\mathrm{B}$ & 7.15 & 11,100 & $4.506 \mathrm{E}-08$ & 0.01 & 94.955 \\
\hline $\mathrm{B}$ & 7.15 & 11,160 & $4.484 \mathrm{E}-08$ & 0.06 & 94.990 \\
\hline $\mathrm{A}$ & 4.7 & 13,200 & $4.408 \mathrm{E}-08$ & 0.10 & 95.070 \\
\hline $\mathrm{C}$ & 15.6 & 10,530 & $4.367 \mathrm{E}-08$ & 0.01 & 95.125 \\
\hline
\end{tabular}


Table 3-4. Cumulative Probability Distribution for the Hanford Site Boundary, All Sectors, Centerline Values. (11 sheets)

\begin{tabular}{|c|c|c|c|c|c|}
\hline $\begin{array}{l}\text { Stability } \\
\text { class }\end{array}$ & $\begin{array}{l}\text { Wind speed } \\
(\mathrm{m} / \mathrm{s})\end{array}$ & $\begin{array}{l}\text { Receptor } \\
\text { distance } \\
\text { (m) }\end{array}$ & $\begin{array}{c}\text { Dispersion } \\
\text { coefficient } \\
\left(\mathrm{s} / \mathrm{m}^{3}\right)\end{array}$ & $\begin{array}{c}\text { Observed } \\
\text { frequency } \\
(\%)\end{array}$ & $\begin{array}{l}\text { Cumulative } \\
\text { frequency } \\
(\%)\end{array}$ \\
\hline A & 7.15 & 8,690 & $4.227 \mathrm{E}-08$ & 0.07 & 95.165 \\
\hline A & 7.15 & 8,970 & $4.108 \mathrm{E}-08$ & 0.04 & 95.220 \\
\hline A & 4.7 & 15,190 & 3.883 E-08 & 0.35 & 95.415 \\
\hline B & 7.15 & 13,200 & $3.853 \mathrm{E}-08$ & 0.01 & 95.595 \\
\hline $\mathrm{B}$ & 4.7 & 21,050 & $3.846 \mathrm{E}-08$ & 0.12 & 95.660 \\
\hline A & 4.7 & 15,360 & 3.844 E-08 & 0.67 & 96.055 \\
\hline $\mathrm{C}$ & 9.8 & 15,190 & $3.736 \mathrm{E}-08$ & 0.03 & 96.405 \\
\hline $\mathrm{C}$ & 9.8 & 15,360 & $3.675 \mathrm{E}-08$ & 0.02 & 96.430 \\
\hline A & 7.15 & 10,430 & $3.585 \mathrm{E}-08$ & 0.11 & 96.495 \\
\hline A & 7.15 & 10,530 & $3.554 \mathrm{E}-08$ & 0.25 & 96.675 \\
\hline $\mathrm{B}$ & 9.8 & 10,430 & $3.478 \mathrm{E}-08$ & 0.02 & 96.810 \\
\hline A & 7.15 & 10,800 & $3.474 \mathrm{E}-08$ & 0.01 & 96.825 \\
\hline $\mathrm{B}$ & 9.8 & 10,530 & $3.448 \mathrm{E}-08$ & 0.04 & 96.850 \\
\hline $\mathrm{B}$ & 7.15 & 15,190 & 3.394 E-08 & 0.07 & 96.905 \\
\hline $\mathrm{A}$ & 7.15 & 11,100 & $3.389 \mathrm{E}-08$ & 0.01 & 96.945 \\
\hline $\mathrm{C}$ & 7.15 & 21,050 & $3.387 \mathrm{E}-08$ & 0.06 & 96.980 \\
\hline $\mathrm{A}$ & 7.15 & 11,160 & $3.372 \mathrm{E}-08$ & 0.25 & 97.135 \\
\hline $\mathrm{B}$ & 7.15 & 15,360 & $3.360 \mathrm{E}-08$ & 0.06 & 97.290 \\
\hline $\mathrm{B}$ & 9.8 & 11,160 & $3.272 \mathrm{E}-08$ & 0.02 & 97.330 \\
\hline $\mathrm{A}$ & 9.8 & 8,690 & 3.084 E-08 & 0.01 & 97.345 \\
\hline A & 9.8 & 8,970 & $2.997 \mathrm{E}-08$ & 0.01 & 97.355 \\
\hline $\mathrm{A}$ & 7.15 & 13,200 & $2.898 \mathrm{E}-08$ & 0.05 & 97.385 \\
\hline $\mathrm{A}$ & 4.7 & 21,050 & 2.892 E-08 & 0.40 & 97.610 \\
\hline $\mathrm{C}$ & 12.7 & 15,190 & $2.883 \mathrm{E}-08$ & 0.01 & 97.815 \\
\hline C & 12.7 & 15,360 & $2.835 \mathrm{E}-08$ & 0.01 & 97.825 \\
\hline B & 12.7 & 10,430 & $2.684 \mathrm{E}-08$ & 0.01 & 97.835 \\
\hline B & 12.7 & 10,530 & $2.660 \mathrm{E}-08$ & 0.02 & 97.850 \\
\hline A & 9.8 & 10,430 & 2.615 E-08 & 0.05 & 97.885 \\
\hline $\mathrm{A}$ & 9.8 & 10,530 & 2.593 E-08 & 0.16 & 97.990 \\
\hline A & 7.15 & 15,190 & $2.553 \mathrm{E}-08$ & 0.25 & 98.195 \\
\hline B & 7.15 & 21,050 & $2.528 \mathrm{E}-08$ & 0.09 & 98.365 \\
\hline $\mathrm{A}$ & 7.15 & 15,360 & $2.527 \mathrm{E}-08$ & 0.19 & 98.505 \\
\hline $\mathrm{B}$ & 12.7 & 11,160 & $2.524 \mathrm{E}-08$ & 0.01 & 98.605 \\
\hline $\mathrm{B}$ & 9.8 & 15,190 & $2.476 \mathrm{E}-08$ & 0.03 & 98.625 \\
\hline $\mathrm{C}$ & 9.8 & 21,050 & $2.471 \mathrm{E}-08$ & 0.05 & 98.665 \\
\hline A & 9.8 & 11,160 & $2.460 \mathrm{E}-08$ & 0.10 & 98.740 \\
\hline
\end{tabular}


Table 3-4. Cumulative Probability Distribution for the Hanford Site Boundary, All Sectors, Centerline Values. (11 sheets)

\begin{tabular}{|c|c|c|c|c|c|}
\hline $\begin{array}{l}\text { Stability } \\
\text { class }\end{array}$ & $\begin{array}{l}\text { Wind speed } \\
(\mathrm{m} / \mathrm{s})\end{array}$ & $\begin{array}{c}\text { Receptor } \\
\text { distance } \\
(\mathrm{m})\end{array}$ & $\begin{array}{c}\text { Dispersion } \\
\text { coefficient } \\
\left(\mathbf{s} / \mathbf{m}^{3}\right)\end{array}$ & $\begin{array}{c}\text { Observed } \\
\text { frequency } \\
(\%)\end{array}$ & $\begin{array}{c}\text { Cumulative } \\
\text { frequency } \\
(\%)\end{array}$ \\
\hline B & 9.8 & 15,360 & 2.452 E-08 & 0.02 & 98.800 \\
\hline $\mathrm{C}$ & 15.6 & 15,360 & 2.308 E-08 & 0.02 & 98.820 \\
\hline $\mathrm{A}$ & 9.8 & 13,200 & 2.114 E-08 & 0.01 & 98.835 \\
\hline A & 12.7 & 10,430 & $2.018 \mathrm{E}-08$ & 0.02 & 98.850 \\
\hline A & 12.7 & 10,530 & $2.001 \mathrm{E}-08$ & 0.06 & 98.890 \\
\hline $\mathrm{C}$ & 12.7 & 21,050 & 1.907 E-08 & 0.01 & 98.925 \\
\hline $\mathrm{A}$ & 7.15 & 21,050 & $1.901 \mathrm{E}-08$ & 0.33 & 99.095 \\
\hline A & 12.7 & 11,160 & $1.899 \mathrm{E}-08$ & 0.02 & 99.270 \\
\hline $\mathrm{C}$ & 19 & 15,360 & $1.895 \mathrm{E}-08$ & 0.03 & 99.295 \\
\hline $\mathrm{A}$ & 9.8 & 15,190 & $1.862 \mathrm{E}-08$ & 0.11 & 99.365 \\
\hline $\mathrm{B}$ & 9.8 & 21,050 & $1.844 \mathrm{E}-08$ & 0.06 & 99.450 \\
\hline $\mathrm{A}$ & 9.8 & 15,360 & $1.844 \mathrm{E}-08$ & 0.04 & 99.500 \\
\hline $\mathrm{A}$ & 15.6 & 10,530 & $1.629 \mathrm{E}-08$ & 0.01 & 99.525 \\
\hline$B$ & 15.6 & 15,360 & $1.540 \mathrm{E}-08$ & 0.01 & 99.535 \\
\hline $\mathrm{A}$ & 12.7 & 15,190 & $1.437 \mathrm{E}-08$ & 0.02 & 99.550 \\
\hline $\mathrm{B}$ & 12.7 & 21,050 & $1.423 \mathrm{E}-08$ & 0.01 & 99.565 \\
\hline A & 12.7 & 15,360 & $1.423 \mathrm{E}-08$ & 0.01 & 99.575 \\
\hline A & 9.8 & 21,050 & $1.387 \mathrm{E}-08$ & 0.24 & 99.700 \\
\hline $\mathrm{B}$ & 19 & 15,360 & $1.265 \mathrm{E}-08$ & 0.02 & 99.830 \\
\hline A & 15.6 & 15,360 & $1.158 \mathrm{E}-08$ & 0.02 & 99.850 \\
\hline A & 12.7 & 21,050 & $1.070 \mathrm{E}-08$ & 0.03 & 99.875 \\
\hline $\mathrm{A}$ & 19 & 15,360 & $9.510 \mathrm{E}-09$ & 0.04 & 99.910 \\
\hline A & 15.6 & 21,050 & 8.714 E-09 & 0.01 & 99.935 \\
\hline
\end{tabular}

The interpolation to calculate the $95^{\text {th }}$ percentile $\chi / Q^{\prime}$ uses numbers from midway down the first page of Table 3-4. The calculation is shown below for reference. This agrees with the value shown in the first column of numbers in Table 2-5.

$$
\left(\frac{2.281 \times 10^{-5}-2.091 \times 10^{-5} \mathrm{~s} / \mathrm{m}^{3}}{4.910-5.200 \%}\right)(5-5.200 \%)+2.091 \times 10^{-5} \mathrm{~s} / \mathrm{m}^{3}=2.222 \times 10^{-5} \mathrm{~s} / \mathrm{m}^{3}
$$

The next part of the basic calculation is the verification of the $50^{\text {th }}$ percentile value. This is calculated from the same $\chi / \mathrm{Q}^{\prime}$ used above for the $1-\mathrm{hr} \chi / \mathrm{Q}^{\prime}$. However, the 16 transport directions are evaluated separately. For the Hanford Site boundary, GXQ indicates the direction with the largest $\chi / \mathrm{Q}^{\prime}$ is north. The cumulative probability distribution for the north direction is shown in Table 3-5. 
When a normalized cumulative distribution is constructed, there is one additional step in the process. This step is the normalization of the curve. To normalize the cumulative distribution, each point is divided by the sum of all the observed frequencies. When normalized, the cumulative frequency distribution begins at $0 \%$ and ends at $100 \%$.

Table 3-5. Cumulative Probability Distribution for the Site Boundary, North Sector, Centerline Values. (2 sheets)

\begin{tabular}{|c|c|c|c|c|}
\hline $\begin{array}{c}\text { Stability } \\
\text { class }\end{array}$ & $\begin{array}{c}\text { Wind speed } \\
\mathbf{( m / s )}\end{array}$ & $\begin{array}{c}\text { Dispersion } \\
\text { coefficient } \\
\left(\mathbf{s} / \mathbf{m}^{\mathbf{3}} \mathbf{)}\right.\end{array}$ & $\begin{array}{c}\text { Observed } \\
\text { frequency } \\
\mathbf{( \% )}\end{array}$ & $\begin{array}{c}\text { Cumulative } \\
\text { frequency } \\
\mathbf{( \% )}\end{array}$ \\
\hline G & 0.89 & $7.859 \mathrm{E}-05$ & 0.17 & 1.950 \\
\hline F & 0.89 & $3.137 \mathrm{E}-05$ & 0.35 & 7.913 \\
\hline G & 2.65 & $2.640 \mathrm{E}-05$ & 0.20 & 14.220 \\
\hline G & 4.7 & $1.488 \mathrm{E}-05$ & 0.07 & 17.317 \\
\hline E & 0.89 & $1.298 \mathrm{E}-05$ & 0.34 & 22.018 \\
\hline F & 2.65 & $1.053 \mathrm{E}-05$ & 0.45 & 31.078 \\
\hline F & 4.7 & $5.940 \mathrm{E}-06$ & 0.14 & 37.844 \\
\hline D & 0.89 & $5.487 \mathrm{E}-06$ & 0.27 & 42.546 \\
\hline E & 2.65 & $4.359 \mathrm{E}-06$ & 0.46 & 50.917 \\
\hline F & 7.15 & $3.904 \mathrm{E}-06$ & 0.02 & 56.422 \\
\hline F & 9.8 & $2.849 \mathrm{E}-06$ & 0.01 & 56.766 \\
\hline E & 4.7 & $2.458 \mathrm{E}-06$ & 0.22 & 59.404 \\
\hline D & 2.65 & $1.843 \mathrm{E}-06$ & 0.35 & 65.940 \\
\hline E & 7.15 & $1.616 \mathrm{E}-06$ & 0.07 & 70.757 \\
\hline E & 9.8 & $1.179 \mathrm{E}-06$ & 0.01 & 71.674 \\
\hline C & 0.89 & $1.083 \mathrm{E}-06$ & 0.04 & 72.248 \\
\hline D & 4.7 & $1.039 \mathrm{E}-06$ & 0.24 & 75.459 \\
\hline D & 7.15 & $6.830 \mathrm{E}-07$ & 0.10 & 79.358 \\
\hline D & 9.8 & $4.983 \mathrm{E}-07$ & 0.02 & 80.734 \\
\hline B & 0.89 & $4.527 \mathrm{E}-07$ & 0.05 & 81.537 \\
\hline C & 2.65 & $3.638 \mathrm{E}-07$ & 0.06 & 82.798 \\
\hline A & 0.89 & $3.396 \mathrm{E}-07$ & 0.10 & 84.633 \\
\hline C & 4.7 & $2.051 \mathrm{E}-07$ & 0.05 & 86.353 \\
\hline B & 2.65 & $1.520 \mathrm{E}-07$ & 0.08 & 87.844 \\
\hline C & 7.15 & $1.348 \mathrm{E}-07$ & 0.02 & 88.991 \\
\hline A & 2.65 & $1.140 \mathrm{E}-07$ & 0.24 & 91.972 \\
\hline C & 9.8 & $9.837 \mathrm{E}-08$ & 0.01 & 94.839 \\
\hline & & & & \\
\hline & & & 0.06 & \\
\hline
\end{tabular}


Table 3-5. Cumulative Probability Distribution for the Site Boundary, North Sector, Centerline Values. (2 sheets)

\begin{tabular}{|c|c|c|c|c|}
\hline $\begin{array}{c}\text { Stability } \\
\text { class }\end{array}$ & $\begin{array}{c}\text { Wind speed } \\
(\mathbf{m} / \mathbf{s})\end{array}$ & $\begin{array}{c}\text { Dispersion } \\
\text { coefficient } \\
\left(\mathbf{s} / \mathbf{m}^{\mathbf{3}}\right)\end{array}$ & $\begin{array}{c}\text { Observed } \\
\text { frequency } \\
\mathbf{( \% )}\end{array}$ & $\begin{array}{c}\text { Cumulative } \\
\text { frequency } \\
\mathbf{( \% )}\end{array}$ \\
\hline B & 4.7 & $8.572 \mathrm{E}-08$ & 0.03 & 95.298 \\
\hline A & 4.7 & $6.430 \mathrm{E}-08$ & 0.12 & 97.018 \\
\hline B & 7.15 & $5.635 \mathrm{E}-08$ & 0.02 & 98.624 \\
\hline A & 7.15 & $4.227 \mathrm{E}-08$ & 0.04 & 99.312 \\
\hline A & 9.8 & $3.084 \mathrm{E}-08$ & 0.01 & 99.885 \\
\hline
\end{tabular}

Notes:

The total fraction for transport to the north is $4.36 \%$. This is the sum of the observed frequencies.

The cumulative distribution has been normalized so that the final sum is $100 \%$.

The first point in the cumulative frequency distribution is half of $0.17 \%$ divided by 0.0436 , which is $1.950 \%$, as shown in the first line of Table 3-5. The second point is the sum of the first observed frequency plus half the second frequency, as shown below:

$$
F_{2}=\frac{0.17 \%+(0.5)(0.35 \%)}{0.0436}=7.913 \%
$$

Each point in the cumulative distribution is calculated as before, except that the resulting cumulative frequencies are divided by the total frequency $(0.0436)$ for this wind direction. In this way, the normalized cumulative probability distribution can be calculated.

The interpolation to calculate the $50^{\text {th }}$ percentile $\chi / Q^{\prime}$ for transport to the north is shown below for reference. This agrees with the value shown in the first column of numbers in Table 2-5.

$$
\left(\frac{5.487 \times 10^{-6}-4.359 \times 10^{-6} \mathrm{~s} / \mathrm{m}^{3}}{42.546-50.917 \%}\right)(50-50.917 \%)+4.359 \times 10^{-6} \mathrm{~s} / \mathrm{m}^{3}=4.482 \times 10^{-6} \mathrm{~s} / \mathrm{m}^{3}
$$

The 2-hr $\chi / \mathrm{Q}$ 's shown in the second column of numbers in Tables 2-4 and 2-5 include plume meander using the method described in NRC 1.145. The horizontal standard deviation is increased by a factor ranging from 1 to 6 . The actual value depends on the stability class, wind speed, and distance. Because the same $\chi / \mathrm{Q}$ 's are calculated for both $95^{\text {th }}$ and $50^{\text {th }}$ percentiles, only the maximum sector (north) for the onsite worker will be compared in detail with GXQ. Hand-calculated $\chi / Q$ 's are shown in Table 3-6. The corresponding GXQ output is shown for comparison in Appendix E. 
Table 3-6. Cumulative Probability Distribution for the Worker at $100 \mathrm{~m}$, North Sector, with Plume Meander.

\begin{tabular}{|c|c|c|c|c|}
\hline $\begin{array}{l}\text { Stability } \\
\text { class }\end{array}$ & $\begin{array}{l}\text { Wind speed } \\
(\mathrm{m} / \mathrm{s})\end{array}$ & $\begin{array}{c}\text { Dispersion } \\
\text { coefficient } \\
\left(\mathbf{s} / \mathrm{m}^{3}\right)\end{array}$ & $\begin{array}{c}\text { Observed } \\
\text { frequency } \\
(\%)\end{array}$ & $\begin{array}{c}\text { Cumulative } \\
\text { frequency } \\
(\%)\end{array}$ \\
\hline $\mathrm{G}$ & 0.89 & $1.423 \mathrm{E}-02$ & 0.17 & 1.950 \\
\hline $\mathrm{G}$ & 4.7 & $1.086 \mathrm{E}-02$ & 0.07 & 4.702 \\
\hline $\mathrm{F}$ & 0.89 & $8.611 \mathrm{E}-03$ & 0.35 & 9.518 \\
\hline $\mathrm{G}$ & 2.65 & $7.564 \mathrm{E}-03$ & 0.20 & 15.826 \\
\hline $\mathrm{E}$ & 0.89 & $5.103 \mathrm{E}-03$ & 0.34 & 22.018 \\
\hline $\mathrm{F}$ & 4.7 & $4.792 \mathrm{E}-03$ & 0.14 & 27.523 \\
\hline $\mathrm{F}$ & 7.15 & $4.287 \mathrm{E}-03$ & 0.02 & 29.358 \\
\hline $\mathrm{D}$ & 0.89 & $4.168 \mathrm{E}-03$ & 0.27 & 32.683 \\
\hline $\mathrm{F}$ & 2.65 & $4.125 \mathrm{E}-03$ & 0.45 & 40.940 \\
\hline $\mathrm{C}$ & 0.89 & $3.567 \mathrm{E}-03$ & 0.04 & 46.560 \\
\hline $\mathrm{F}$ & 9.8 & $3.128 \mathrm{E}-03$ & 0.01 & 47.133 \\
\hline $\mathrm{E}$ & 2.65 & $2.271 \mathrm{E}-03$ & 0.46 & 52.523 \\
\hline $\mathrm{E}$ & 4.7 & $2.271 \mathrm{E}-03$ & 0.22 & 60.321 \\
\hline $\mathrm{E}$ & 7.15 & $1.906 \mathrm{E}-03$ & 0.07 & 63.647 \\
\hline $\mathrm{B}$ & 0.89 & $1.866 \mathrm{E}-03$ & 0.05 & 65.023 \\
\hline $\mathrm{D}$ & 2.65 & $1.672 \mathrm{E}-03$ & 0.35 & 69.610 \\
\hline $\mathrm{E}$ & 9.8 & $1.390 \mathrm{E}-03$ & 0.01 & 73.739 \\
\hline $\mathrm{D}$ & 4.7 & $1.353 \mathrm{E}-03$ & 0.24 & 76.606 \\
\hline $\mathrm{C}$ & 2.65 & $1.198 \mathrm{E}-03$ & 0.06 & 80.046 \\
\hline $\mathrm{A}$ & 0.89 & $1.068 \mathrm{E}-03$ & 0.10 & 81.881 \\
\hline $\mathrm{D}$ & 7.15 & $1.038 \mathrm{E}-03$ & 0.10 & 84.174 \\
\hline $\mathrm{D}$ & 9.8 & $7.571 \mathrm{E}-04$ & 0.02 & 85.550 \\
\hline $\mathrm{C}$ & 4.7 & $6.754 \mathrm{E}-04$ & 0.05 & 86.353 \\
\hline B & 2.65 & $6.266 \mathrm{E}-04$ & 0.08 & 87.844 \\
\hline $\mathrm{C}$ & 7.15 & $4.439 \mathrm{E}-04$ & 0.02 & 88.991 \\
\hline $\mathrm{A}$ & 2.65 & $3.588 \mathrm{E}-04$ & 0.24 & 91.972 \\
\hline $\mathrm{B}$ & 4.7 & $3.533 \mathrm{E}-04$ & 0.03 & 95.069 \\
\hline $\mathrm{C}$ & 9.8 & $3.239 \mathrm{E}-04$ & 0.01 & 95.528 \\
\hline $\mathrm{B}$ & 7.15 & $2.322 \mathrm{E}-04$ & 0.02 & 95.872 \\
\hline $\mathrm{A}$ & 4.7 & $2.023 \mathrm{E}-04$ & 0.12 & 97.477 \\
\hline A & 7.15 & $1.330 \mathrm{E}-04$ & 0.04 & 99.312 \\
\hline $\mathrm{A}$ & 9.8 & $9.702 \mathrm{E}-05$ & 0.01 & 99.885 \\
\hline
\end{tabular}

Notes:

The total fraction for transport to the north is $4.36 \%$. This is the sum of the observed frequencies.

The cumulative distribution has been normalized so that the final sum is $100 \%$. 
The interpolation to calculate the $50^{\text {th }}$ percentile $\chi / Q^{\prime}$ for transport to the north is shown below for reference. This does not agree with the value shown in the second column of numbers in Table 2-4.

$$
\left(\frac{3.128 \times 10^{-3}-2.271 \times 10^{-3} \mathrm{~s} / \mathrm{m}^{3}}{47.133-52.523 \%}\right)(50-52.523 \%)+2.271 \times 10^{-3} \mathrm{~s} / \mathrm{m}^{3}=2.672 \times 10^{-3} \mathrm{~s} / \mathrm{m}^{3}
$$

Table 3-6 reveals a flaw in the method used by GXQ Version 4.0F to construct the cumulative frequency distribution. What GXQ tries to do is combine any $\chi / \mathrm{Q}$ 's that are equal. However, because of the way computers represent real numbers, two identical $\chi / \mathrm{Q}$ 's (class $E$ at $2.65 \mathrm{~m} / \mathrm{s}$ and class $E$ at $4.70 \mathrm{~m} / \mathrm{s}$ ) are slightly different in GXQ. In the hand calculation, they are the same and the sort puts the low wind speed value first. In GXQ, the low wind speed number is slightly smaller, so the test for equality fails and the low wind speed value is placed second. The relevant GXQ output is shown in Table 3-7.

Table 3-7. Portion of the GXQ Cumulative

Distribution that is Different.

\begin{tabular}{|c|c|c|c|c|}
\hline $\begin{array}{c}\text { Stability } \\
\text { class }\end{array}$ & $\begin{array}{c}\text { Wind speed } \\
\mathbf{( m / s )}\end{array}$ & $\begin{array}{c}\text { Dispersion } \\
\text { coefficient } \\
\left(\mathbf{s} / \mathbf{m}^{\mathbf{3}} \mathbf{)}\right.\end{array}$ & $\begin{array}{c}\text { Observed } \\
\text { frequency } \\
\mathbf{( \% )}\end{array}$ & $\begin{array}{c}\text { Cumulative } \\
\text { frequency } \\
\mathbf{( \% )}\end{array}$ \\
\hline $\mathrm{F}$ & 9.8 & $3.128 \mathrm{E}-03$ & 0.01 & 47.133 \\
\hline $\mathrm{E}$ & 4.7 & $2.271 \mathrm{E}-03$ & 0.22 & 49.771 \\
\hline $\mathrm{E}$ & 2.65 & $2.271 \mathrm{E}-03$ & 0.46 & 57.569 \\
\hline $\mathrm{E}$ & 7.15 & $1.906 \mathrm{E}-03$ & 0.07 & 63.647 \\
\hline
\end{tabular}

Notes:

The complete GXQ component data file output is shown in Appendix E.

The $50^{\text {th }}$ percentile dispersion coefficient is $2.271 \mathrm{E}-03 \mathrm{~s} / \mathrm{m}^{3}$.

In Table 3-7, the linear interpolation is between two values that are essentially the same. The result matches the value shown in Table 2-4 for the $50^{\text {th }}$ percentile with plume meander. Note that if the two identical $\chi / Q$ 's are combined first, the cumulative distribution has the values shown in Table 3-8 at that part of the cumulative frequency curve. In addition, the interpolated result is $2.817 \times 10^{-3} \mathrm{~s} / \mathrm{m}^{3}$, which is $24 \%$ larger than the value shown in Table 2-4. 
Table 3-8. Cumulative Distribution When Equal Values are Combined.

\begin{tabular}{|c|c|c|c|c|}
\hline $\begin{array}{c}\text { Stability } \\
\text { class }\end{array}$ & $\begin{array}{c}\text { Wind speed } \\
\mathbf{( m / \mathbf { s } )}\end{array}$ & $\begin{array}{c}\text { Dispersion } \\
\text { coefficient } \\
\left(\mathbf{s} / \mathbf{m}^{\mathbf{3}}\right)\end{array}$ & $\begin{array}{c}\text { Observed } \\
\text { frequency } \\
\mathbf{( \% )}\end{array}$ & $\begin{array}{c}\text { Cumulative } \\
\text { frequency } \\
(\mathbf{\%})\end{array}$ \\
\hline $\mathrm{F}$ & 9.8 & $3.128 \mathrm{E}-03$ & 0.01 & 47.133 \\
\hline $\mathrm{E}$ & 2.65 & $2.271 \mathrm{E}-03$ & 0.68 & 55.046 \\
\hline $\mathrm{E}$ & 7.15 & $1.906 \mathrm{E}-03$ & 0.07 & 63.647 \\
\hline
\end{tabular}

Note:

The $50^{\text {th }}$ percentile dispersion coefficient is $2.817 \mathrm{E}-03 \mathrm{~s} / \mathrm{m}^{3}$.

The annual average $\chi / Q$ 's use a sector-averaged, horizontal standard deviation rather than the numbers shown in Table 3-1. The GXQ values can be verified by calculating the $\chi / \mathrm{Q}$ 's, multiplying them by the frequencies, and summing to get the annual average value for the selected sector. The calculation for the east-southeast sector at $100 \mathrm{~m}$ is shown in Table 3-9. The calculated annual average agrees with the value shown in Table 2-4.

Table 3-9. Calculation of the Annual Average for the Worker at $100 \mathrm{~m}$, East-Southeast Sector. (2 sheets)

\begin{tabular}{|c|c|c|c|c|}
\hline $\begin{array}{l}\text { Stability } \\
\text { class }\end{array}$ & $\begin{array}{l}\text { Wind speed } \\
\qquad(\mathrm{m} / \mathrm{s})\end{array}$ & $\begin{array}{c}\text { Dispersion } \\
\text { coefficient } \\
\left(\mathrm{s} / \mathrm{m}^{3}\right)\end{array}$ & $\begin{array}{c}\text { Observed } \\
\text { frequency } \\
(\%)\end{array}$ & $\begin{array}{c}\text { Weighted } \\
\text { dispersion } \\
\text { coefficient } \\
\left(\mathbf{s} / \mathbf{m}^{3}\right)\end{array}$ \\
\hline $\mathrm{A}$ & 0.89 & $1.596 \mathrm{E}-03$ & 0.10 & 1.596 E-06 \\
\hline B & 0.89 & $2.097 \mathrm{E}-03$ & 0.05 & $1.048 \mathrm{E}-06$ \\
\hline $\mathrm{C}$ & 0.89 & $3.044 \mathrm{E}-03$ & 0.04 & $1.218 \mathrm{E}-06$ \\
\hline $\mathrm{D}$ & 0.89 & $5.010 \mathrm{E}-03$ & 0.44 & $2.204 \mathrm{E}-05$ \\
\hline $\mathrm{E}$ & 0.89 & $6.542 \mathrm{E}-03$ & 0.44 & 2.879 E-05 \\
\hline $\mathrm{F}$ & 0.89 & $1.016 \mathrm{E}-02$ & 0.36 & 3.657 E-05 \\
\hline G & 0.89 & $1.678 \mathrm{E}-02$ & 0.14 & $2.349 \mathrm{E}-05$ \\
\hline A & 2.65 & $5.362 \mathrm{E}-04$ & 0.30 & $1.609 \mathrm{E}-06$ \\
\hline B & 2.65 & 7.043 E-04 & 0.09 & $6.338 \mathrm{E}-07$ \\
\hline $\mathrm{C}$ & 2.65 & $1.022 \mathrm{E}-03$ & 0.10 & $1.022 \mathrm{E}-06$ \\
\hline $\mathrm{D}$ & 2.65 & $1.683 \mathrm{E}-03$ & 1.09 & $1.834 \mathrm{E}-05$ \\
\hline $\mathrm{E}$ & 2.65 & $2.197 \mathrm{E}-03$ & 1.68 & 3.691 E-05 \\
\hline $\mathrm{F}$ & 2.65 & $3.412 \mathrm{E}-03$ & 1.69 & 5.766 E-05 \\
\hline $\mathrm{G}$ & 2.65 & $5.636 \mathrm{E}-03$ & 0.69 & $3.889 \mathrm{E}-05$ \\
\hline A & 4.7 & $3.023 \mathrm{E}-04$ & 0.35 & $1.058 \mathrm{E}-06$ \\
\hline $\mathrm{B}$ & 4.7 & $3.971 \mathrm{E}-04$ & 0.14 & $5.559 \mathrm{E}-07$ \\
\hline $\mathrm{C}$ & 4.7 & $5.764 \mathrm{E}-04$ & 0.13 & 7.493 E-07 \\
\hline D & 4.7 & $9.487 \mathrm{E}-04$ & 1.46 & $1.385 \mathrm{E}-05$ \\
\hline $\mathrm{E}$ & 4.7 & $1.239 \mathrm{E}-03$ & 2.50 & 3.097 E-05 \\
\hline $\mathrm{F}$ & 4.7 & $1.924 \mathrm{E}-03$ & 1.60 & $3.078 \mathrm{E}-05$ \\
\hline
\end{tabular}


Table 3-9. Calculation of the Annual Average for the Worker at $100 \mathrm{~m}$, East-Southeast Sector. (2 sheets)

\begin{tabular}{|c|c|c|c|c|}
\hline $\begin{array}{l}\text { Stability } \\
\text { class }\end{array}$ & $\begin{array}{l}\text { Wind speed } \\
(\mathrm{m} / \mathrm{s})\end{array}$ & $\begin{array}{c}\text { Dispersion } \\
\text { coefficient } \\
\left(\mathbf{s} / \mathbf{m}^{3}\right)\end{array}$ & $\begin{array}{c}\text { Observed } \\
\text { frequency } \\
(\%)\end{array}$ & $\begin{array}{c}\text { Weighted } \\
\text { dispersion } \\
\text { coefficient } \\
\left(\mathbf{s} / \mathbf{m}^{3}\right)\end{array}$ \\
\hline $\mathrm{G}$ & 4.7 & $3.178 \mathrm{E}-03$ & 0.84 & $2.669 \mathrm{E}-05$ \\
\hline A & 7.15 & $1.987 \mathrm{E}-04$ & 0.25 & $4.968 \mathrm{E}-07$ \\
\hline B & 7.15 & $2.610 \mathrm{E}-04$ & 0.07 & $1.827 \mathrm{E}-07$ \\
\hline $\mathrm{C}$ & 7.15 & $3.789 \mathrm{E}-04$ & 0.07 & $2.652 \mathrm{E}-07$ \\
\hline$D$ & 7.15 & $6.236 \mathrm{E}-04$ & 1.14 & $7.109 \mathrm{E}-06$ \\
\hline $\mathrm{E}$ & 7.15 & $8.144 \mathrm{E}-04$ & 1.75 & $1.425 \mathrm{E}-05$ \\
\hline$F$ & 7.15 & $1.265 \mathrm{E}-03$ & 0.08 & $1.012 \mathrm{E}-06$ \\
\hline $\mathrm{G}$ & 7.15 & $2.089 \mathrm{E}-03$ & 0.01 & $2.089 \mathrm{E}-07$ \\
\hline $\mathrm{A}$ & 9.8 & $1.450 \mathrm{E}-04$ & 0.11 & $1.595 \mathrm{E}-07$ \\
\hline $\mathrm{B}$ & 9.8 & $1.904 \mathrm{E}-04$ & 0.03 & $5.713 \mathrm{E}-08$ \\
\hline $\mathrm{C}$ & 9.8 & $2.764 \mathrm{E}-04$ & 0.03 & $8.293 \mathrm{E}-08$ \\
\hline $\mathrm{D}$ & 9.8 & $4.550 \mathrm{E}-04$ & 0.50 & $2.275 \mathrm{E}-06$ \\
\hline$E$ & 9.8 & 5.942 E-04 & 0.38 & $2.258 \mathrm{E}-06$ \\
\hline $\mathrm{F}$ & 9.8 & $9.226 \mathrm{E}-04$ & 0.00 & $0.000 \mathrm{E}+00$ \\
\hline $\mathrm{G}$ & 9.8 & $1.524 \mathrm{E}-03$ & 0.00 & $0.000 \mathrm{E}+00$ \\
\hline $\mathrm{A}$ & 12.7 & $1.119 \mathrm{E}-04$ & 0.02 & $2.238 \mathrm{E}-08$ \\
\hline $\mathrm{B}$ & 12.7 & $1.470 \mathrm{E}-04$ & 0.00 & $0.000 \mathrm{E}+00$ \\
\hline $\mathrm{C}$ & 12.7 & $2.133 \mathrm{E}-04$ & 0.01 & $2.133 \mathrm{E}-08$ \\
\hline $\mathrm{D}$ & 12.7 & $3.511 \mathrm{E}-04$ & 0.07 & $2.458 \mathrm{E}-07$ \\
\hline$E$ & 12.7 & $4.585 \mathrm{E}-04$ & 0.05 & $2.292 \mathrm{E}-07$ \\
\hline
\end{tabular}

The total fraction for transport to the east-southeast is $18.80 \%$. This is the sum of the observed frequencies.

The weighted dispersion coefficients are the product of the dispersion coefficients and the frequency. The sum of the weighted dispersion coefficients is $4.034 \mathrm{E}-04 \mathrm{~s} / \mathrm{m}^{3}$.

The maximum puff concentration factors shown in Tables 2-4 and 2-5 are calculated using a formula similar to the $\chi / \mathrm{Q}$ 's. The standard deviation in the transport direction is assumed to be the same as in the horizontal direction because the release duration is very small. The puff $\chi / \mathrm{Qs}$ are independent of the wind speed. An example calculation is shown in Table 3-10. Note that the units for the normalized air concentrations are $1 / \mathrm{m}^{3}$ rather than $\mathrm{s} / \mathrm{m}^{3}$. Note also that GXQ has correctly combined all $\chi / Q$ s that are equal. 
Table 3-10. Cumulative Probability Distribution for the Worker at $100 \mathrm{~m}$, All Sectors, Short Duration (Puff) Release.

\begin{tabular}{|c|c|c|c|}
\hline $\begin{array}{c}\text { Stability } \\
\text { class }\end{array}$ & $\begin{array}{c}\text { Dispersion } \\
\text { coefficient } \\
\left(\mathbf{1} / \mathbf{m}^{\mathbf{3}} \mathbf{)}\right.\end{array}$ & $\begin{array}{c}\text { Observed } \\
\text { frequency } \\
\mathbf{( \% )}\end{array}$ & $\begin{array}{c}\text { Cumulative } \\
\text { frequency } \\
\mathbf{( \% )}\end{array}$ \\
\hline $\mathrm{G}$ & $9.849 \mathrm{E}-03$ & 6.95 & 3.475 \\
\hline $\mathrm{F}$ & $2.646 \mathrm{E}-03$ & 15.79 & 14.845 \\
\hline $\mathrm{E}$ & $8.120 \mathrm{E}-04$ & 26.22 & 35.850 \\
\hline $\mathrm{D}$ & $3.144 \mathrm{E}-04$ & 27.96 & 62.940 \\
\hline C & $9.471 \mathrm{E}-05$ & 4.39 & 79.115 \\
\hline B & $3.762 \mathrm{E}-05$ & 4.56 & 83.590 \\
\hline A & $1.620 \mathrm{E}-05$ & 14.07 & 92.905 \\
\hline
\end{tabular}

The interpolation to calculate the $95^{\text {th }}$ percentile $\chi / Q$ uses numbers from Table 3-10. The calculation is shown below for reference. This agrees with the value shown in the third column of numbers in Table 2-4. The corresponding GXQ output is shown in Appendix F.

$$
\left(\frac{9.849 \times 10^{-3}-2.646 \times 10^{-3} \mathrm{~s} / \mathrm{m}^{3}}{3.475-14.845 \%}\right)(5-14.845 \%)+2.646 \times 10^{-3} \mathrm{~s} / \mathrm{m}^{3}=8.883 \times 10^{-3} \mathrm{~s} / \mathrm{m}^{3}
$$

Comparing the GXQ output with the corresponding hand calculations shows that the centerline plume and the puff model air transport factors are calculated correctly. The $95^{\text {th }}$ percentile overall site $\chi / Q$ at onsite, as well as offsite locations, matches the hand calculations. When plume meander is included in the calculation, a weakness in the software affects the calculation of $50^{\text {th }}$ percentile values. The $50^{\text {th }}$ percentile result from GXQ at the onsite location was $24 \%$ smaller than the hand calculation indicated it should be. It should be noted that $50^{\text {th }}$ percentile air transport factors are only used in the evaluation of beyond design basis accidents. In these accidents, the quantity of hazardous material released into the air as respirable particles is based on order-of-magnitude estimates. Thus, a small change in the air transport factor has no significance.

\subsection{DISPERSION COEFFICIENTS WITH PLUME DEPLETION}

Having established that GXQ Version $4.0 \mathrm{~F}$ carries out the interpolation to find the $95^{\text {th }}$ and $50^{\text {th }}$ percentile $\chi / Q$ s correctly, the calculation of $\chi / Q$ 's with modifications such as plume depletion, plume rise, and building wake effects will be performed for selected combinations of wind speed and stability class. GXQ was run with ichk $=1$ to show the intermediate parameters that enter these calculations. For example, with plume depletion, the fraction remaining was calculated by hand and compared with the GXQ result. Agreement verifies the GXQ calculation.

The plume depletion factor is the fraction of the initial quantity airborne that is still in the plume or puff at some distance downwind. This fraction ranges from 0 to 1 . The formula used to calculate this factor is shown in WHC-SD-GN-SWD-30002, Section 4.1.3. The depletion factor 
depends only on the vertical standard deviation, the wind speed, and the ground deposition speed. The mixing depth limits the vertical dispersion. Because the horizontal spread of the plume has no effect on the plume depletion factor, the factors are the same for centerline, plume meander, annual average, and puff release $\chi /$ Qs.

The plume depletion factors were calculated at two distances $(100 \mathrm{~m}$ and $10 \mathrm{~km})$, one wind speed $(0.89 \mathrm{~m} / \mathrm{s})$, and all seven stability classes for a deposition speed of $0.15 \mathrm{~cm} / \mathrm{s}$. The hand calculation uses many more integration points than does GXQ, but follows a simple trapezoid rule when calculating the integral. The hand calculations and GXQ results are shown in Table 3-11.

Table 3-11. Comparison of Plume Depletion Factors for a Ground Deposition Speed of $0.15 \mathrm{~cm} / \mathrm{s}$.

\begin{tabular}{|c|c|c|c|c|c|c|}
\hline \multirow{2}{*}{$\begin{array}{c}\text { Stability } \\
\text { class }\end{array}$} & \multicolumn{2}{|c|}{ Hand calculation } & \multicolumn{2}{c|}{ GXQ Version 4.0F } & \multicolumn{2}{c|}{ Percent differences } \\
\cline { 2 - 7 } & $\mathbf{1 0 0} \mathbf{~ m}$ & $\mathbf{1 0} \mathbf{~ k m}$ & $\mathbf{1 0 0} \mathbf{~}$ & $\mathbf{1 0} \mathbf{~} \mathbf{m}$ & $\mathbf{1 0 0} \mathbf{~ m}$ & $\mathbf{1 0} \mathbf{~ k m}$ \\
\hline $\mathrm{A}$ & 0.9584 & 0.9283 & 0.9583 & 0.9282 & $0.01 \%$ & $0.01 \%$ \\
\hline $\mathrm{B}$ & 0.9491 & 0.8964 & 0.9491 & 0.8964 & $0.00 \%$ & $0.00 \%$ \\
\hline $\mathrm{C}$ & 0.9330 & 0.8425 & 0.9330 & 0.8425 & $0.00 \%$ & $0.00 \%$ \\
\hline $\mathrm{D}$ & 0.9045 & 0.7182 & 0.9045 & 0.7182 & $0.00 \%$ & $0.00 \%$ \\
\hline E & 0.8841 & 0.6251 & 0.8841 & 0.6252 & $0.00 \%$ & $0.00 \%$ \\
\hline F & 0.8488 & 0.4890 & 0.8488 & 0.4891 & $0.00 \%$ & $-0.01 \%$ \\
\hline G & 0.7869 & 0.3142 & 0.7869 & 0.3142 & $0.00 \%$ & $-0.01 \%$ \\
\hline
\end{tabular}

The influence of fumigation in the numeric integration is captured in the class A calculations at $10 \mathrm{~km}$. In all cases, GXQ Version $4.0 \mathrm{~F}$ agrees with the hand calculations. The minor differences shown in Table 3-11 can be attributed to the different numeric methods used in the hand calculations and GXQ. To verify that the depletion factors are correctly multiplied by the $\chi / \mathrm{Q}$ 's, the centerline $\chi / \mathrm{Q}$ 's are shown in Table 3-12. The wind speed is $0.89 \mathrm{~m} / \mathrm{s}$, and the downwind distances are $100 \mathrm{~m}$ and $10 \mathrm{~km}$.

Table 3-12. Comparison of Plume Dispersion Coefficients with Plume Depletion.

\begin{tabular}{|c|c|c|c|c|c|c|}
\hline \multirow{2}{*}{$\begin{array}{c}\text { Stability } \\
\text { class }\end{array}$} & \multicolumn{2}{|c|}{ Hand calculation } & \multicolumn{2}{c|}{ GXQ Version $\mathbf{4 . 0 F}$} & \multicolumn{2}{c|}{ Percent differences } \\
\cline { 2 - 7 } & $\mathbf{1 0 0} \mathbf{~ m}$ & $\mathbf{1 0} \mathbf{~ k m}$ & $\mathbf{1 0 0} \mathbf{~}$ & $\mathbf{1 0} \mathbf{~ k m}$ & $\mathbf{1 0 0} \mathbf{~ m}$ & $\mathbf{1 0} \mathbf{~ k m}$ \\
\hline A & $1.024 \mathrm{E}-03$ & $2.777 \mathrm{E}-07$ & $1.024 \mathrm{E}-03$ & $2.777 \mathrm{E}-07$ & $0.01 \%$ & $0.01 \%$ \\
\hline B & $1.771 \mathrm{E}-03$ & $3.566 \mathrm{E}-07$ & $1.771 \mathrm{E}-03$ & $3.565 \mathrm{E}-07$ & $0.00 \%$ & $0.00 \%$ \\
\hline C & $3.328 \mathrm{E}-03$ & $7.078 \mathrm{E}-07$ & $3.328 \mathrm{E}-03$ & $7.078 \mathrm{E}-07$ & $0.00 \%$ & $0.00 \%$ \\
\hline D & $7.541 \mathrm{E}-03$ & $3.205 \mathrm{E}-06$ & $7.541 \mathrm{E}-03$ & $3.205 \mathrm{E}-06$ & $0.00 \%$ & $0.00 \%$ \\
\hline E & $1.353 \mathrm{E}-02$ & $6.716 \mathrm{E}-06$ & $1.353 \mathrm{E}-02$ & $6.717 \mathrm{E}-06$ & $0.00 \%$ & $0.00 \%$ \\
\hline F & $2.924 \mathrm{E}-02$ & $1.282 \mathrm{E}-05$ & $2.924 \mathrm{E}-02$ & $1.282 \mathrm{E}-05$ & $0.00 \%$ & $-0.01 \%$ \\
\hline G & $6.720 \mathrm{E}-02$ & $2.064 \mathrm{E}-05$ & $6.720 \mathrm{E}-02$ & $2.064 \mathrm{E}-05$ & $0.00 \%$ & $-0.01 \%$ \\
\hline
\end{tabular}

Notes:

The plume dispersion coefficients have units of $\mathrm{s} / \mathrm{m}^{3}$.

The wind speed is $0.89 \mathrm{~m} / \mathrm{s}$. The release and receptor elevations are zero. 
From Table 3-12, it is concluded that GXQ correctly calculates the plume depletion $\chi / Q$ 's when no other modeling options (e.g., building wake or plume rise) are used.

\subsection{DISPERSION COEFFICIENTS WITH PLUME RISE}

In these cases, there are combinations of options. The first combination uses only the downwash and flow rate adjustments. The flow rate adjustment increases the standard deviations shown in Table 3-1. The vertical standard deviation also depends on the wind speed. The downwash lowers the release height by $0.230 \mathrm{~m}$ for the $100 \mathrm{ft}^{3} / \mathrm{min}$ case, and not at all for the $1,000 \mathrm{ft}^{3} / \mathrm{min}$ case. The resulting $\chi / \mathrm{Q}$ 's for a wind speed of $0.89 \mathrm{~m} / \mathrm{s}$ and a flow rate of $100 \mathrm{ft}^{3} / \mathrm{min}$ are shown in Table 3-13.

Table 3-13. Plume Dispersion Coefficients for the $100 \mathrm{ft}^{3} / \mathrm{min}$ Stack with Downwash and Flow Rate Adjustments.

\begin{tabular}{|c|c|c|c|c|c|c|}
\hline \multirow{2}{*}{$\begin{array}{c}\text { Stability } \\
\text { class }\end{array}$} & \multicolumn{2}{|c|}{ Hand calculation } & \multicolumn{2}{c|}{ GXQ Version $\mathbf{4 . 0 F}$} & \multicolumn{2}{c|}{ Percent differences } \\
\cline { 2 - 7 } & $\mathbf{1 0 0} \mathbf{~ m}$ & $\mathbf{1 0} \mathbf{~ k m}$ & $\mathbf{1 0 0} \mathbf{~}$ & $\mathbf{1 0} \mathbf{~ k m}$ & $\mathbf{1 0 0} \mathbf{~ m}$ & $\mathbf{1 0} \mathbf{~ k m}$ \\
\hline A & $1.035 \mathrm{E}-03$ & $2.991 \mathrm{E}-07$ & $1.035 \mathrm{E}-03$ & $2.991 \mathrm{E}-07$ & $0.00 \%$ & $0.00 \%$ \\
\hline B & $1.770 \mathrm{E}-03$ & $3.978 \mathrm{E}-07$ & $1.770 \mathrm{E}-03$ & $3.978 \mathrm{E}-07$ & $0.00 \%$ & $0.00 \%$ \\
\hline C & $3.215 \mathrm{E}-03$ & $8.400 \mathrm{E}-07$ & $3.215 \mathrm{E}-03$ & $8.400 \mathrm{E}-07$ & $0.00 \%$ & $0.00 \%$ \\
\hline D & $6.509 \mathrm{E}-03$ & $4.461 \mathrm{E}-06$ & $6.509 \mathrm{E}-03$ & $4.461 \mathrm{E}-06$ & $0.00 \%$ & $0.00 \%$ \\
\hline E & $1.049 \mathrm{E}-02$ & $1.073 \mathrm{E}-05$ & $1.049 \mathrm{E}-02$ & $1.073 \mathrm{E}-05$ & $0.00 \%$ & $0.00 \%$ \\
\hline F & $1.810 \mathrm{E}-02$ & $2.614 \mathrm{E}-05$ & $1.810 \mathrm{E}-02$ & $2.614 \mathrm{E}-05$ & $0.00 \%$ & $0.00 \%$ \\
\hline G & $3.646 \mathrm{E}-02$ & $6.518 \mathrm{E}-05$ & $3.646 \mathrm{E}-02$ & $6.518 \mathrm{E}-05$ & $0.00 \%$ & $0.00 \%$ \\
\hline
\end{tabular}

Notes:

The plume dispersion coefficients have units of $\mathrm{s} / \mathrm{m}^{3}$.

The wind speed is $0.89 \mathrm{~m} / \mathrm{s}$. The release height is $2.9 \mathrm{~m}$ and receptor elevation is $2 \mathrm{~m}$. The stack diameter is $0.254 \mathrm{~m}$ and the exhaust flow rate is $0.472 \mathrm{~m}^{3} / \mathrm{s}$.

The agreement between the hand calculation and GXQ Version 4.0F is good to four significant figures. This means that the models for the flow rate adjustment and stack downwash are correctly implemented in GXQ.

The second combination uses the ISC2 plume rise with the entrainment and wind speed adjustments in addition to the downwash and flow rate adjustments. The entrainment model increases the standard deviations based on the amount of plume rise. This increase becomes less as the distance from the stack increases. For the $100 \mathrm{ft}^{3} / \mathrm{min}$ case, the effective plume height is close enough to the release height that the entrainment adjustment is not used at the lower wind speeds. For the $1,000 \mathrm{ft}^{3} / \mathrm{min}$ case, the entrainment adjustment is larger than the flow rate adjustment at $100 \mathrm{~m}$. At $10 \mathrm{~km}$, the entrainment adjustment is slightly smaller.

The amount of plume rise depends on the stack flow rate, the stack diameter, the wind speed, and the stability class. When the effective plume height is greater than $10 \mathrm{~m}$, the effective wind 
speed increases. The effective plume heights and wind speeds for a wind speed at the stack of $0.89 \mathrm{~m} / \mathrm{s}$ and a flow rate of $1,000 \mathrm{ft}^{3} / \mathrm{min}$ are shown in Table 3-14. The hand calculations and GXQ Version $4.0 \mathrm{~F}$ results agree to four significant digits.

Table 3-14. Effective Release Height and Wind Speed for the $1,000 \mathrm{ft}^{3} / \mathrm{min}$ Stack with ISC2 Plume Rise.

\begin{tabular}{|c|c|c|c|c|c|c|}
\hline \multirow{2}{*}{ Stability class } & \multicolumn{2}{|c|}{ Hand calculation } & \multicolumn{2}{c|}{ GXQ Version 4.0F } & \multicolumn{2}{c|}{ Percent differences } \\
\cline { 2 - 7 } & $\mathbf{H}_{\text {eff }}$ & $\mathbf{U}_{\text {eff }}$ & $\mathbf{H}_{\text {eff }}$ & $\mathbf{U}_{\text {eff }}$ & $\mathbf{H}_{\text {eff }}$ & $\mathbf{U}_{\text {eff }}$ \\
\hline $\mathrm{A}$ & 10.853 & 0.8926 & 10.852 & 0.8926 & $0.01 \%$ & $0.00 \%$ \\
\hline $\mathrm{B}$ & 10.853 & 0.8926 & 10.852 & 0.8926 & $0.01 \%$ & $0.00 \%$ \\
\hline $\mathrm{C}$ & 10.843 & 0.8936 & 10.842 & 0.8936 & $0.01 \%$ & $0.00 \%$ \\
\hline $\mathrm{D}$ & 10.828 & 0.8953 & 10.825 & 0.8953 & $0.02 \%$ & $0.00 \%$ \\
\hline $\mathrm{E}$ & 9.102 & 0.8900 & 9.102 & 0.8900 & $0.00 \%$ & $0.00 \%$ \\
\hline $\mathrm{F}$ & 8.216 & 0.8900 & 8.216 & 0.8900 & $0.00 \%$ & $0.00 \%$ \\
\hline $\mathrm{G}$ & 7.661 & 0.8900 & 7.661 & 0.8900 & $0.00 \%$ & $0.00 \%$ \\
\hline
\end{tabular}

Notes:

The effective plume height has units of $\mathrm{m}$. The effective wind speed has units of $\mathrm{m} / \mathrm{s}$.

The wind speed at the stack is $0.89 \mathrm{~m} / \mathrm{s}$. The release height is $2.9 \mathrm{~m}$ and receptor elevation is $2 \mathrm{~m}$. The stack diameter is $0.254 \mathrm{~m}$ and the exhaust flow rate is $0.472 \mathrm{~m}^{3} / \mathrm{s}$.

The calculated dispersion coefficients are shown in Table 3-15. The hand calculations and GXQ 4.0 F results agree to four significant digits.

Table 3-15. Plume Dispersion Coefficients for the $1,000 \mathrm{ft}^{3} / \mathrm{min}$ Stack with ISC2 Plume Rise.

\begin{tabular}{|c|c|c|c|c|c|c|}
\hline \multirow{2}{*}{ Stability class } & \multicolumn{2}{|c|}{ Hand calculation } & \multicolumn{2}{c|}{ GXQ Version 4.0F } & \multicolumn{2}{c|}{ Percent differences } \\
\cline { 2 - 7 } & $\mathbf{1 0 0} \mathbf{~ m}$ & $\mathbf{1 0} \mathbf{~ k m}$ & $\mathbf{1 0 0} \mathbf{~}$ & $\mathbf{1 0} \mathbf{~} \mathbf{m}$ & $\mathbf{1 0 0} \mathbf{~ m}$ & $\mathbf{1 0} \mathbf{~ k m}$ \\
\hline A & $7.801 \mathrm{E}-04$ & $2.983 \mathrm{E}-07$ & $7.802 \mathrm{E}-04$ & $2.983 \mathrm{E}-07$ & $0.00 \%$ & $0.00 \%$ \\
\hline B & $1.118 \mathrm{E}-03$ & $3.966 \mathrm{E}-07$ & $1.118 \mathrm{E}-03$ & $3.966 \mathrm{E}-07$ & $-0.01 \%$ & $0.00 \%$ \\
\hline C & $1.355 \mathrm{E}-03$ & $8.358 \mathrm{E}-07$ & $1.355 \mathrm{E}-03$ & $8.358 \mathrm{E}-07$ & $-0.02 \%$ & $0.00 \%$ \\
\hline D & $1.005 \mathrm{E}-03$ & $4.417 \mathrm{E}-06$ & $1.006 \mathrm{E}-03$ & $4.417 \mathrm{E}-06$ & $-0.10 \%$ & $0.00 \%$ \\
\hline E & $1.567 \mathrm{E}-03$ & $1.066 \mathrm{E}-05$ & $1.567 \mathrm{E}-03$ & $1.066 \mathrm{E}-05$ & $0.01 \%$ & $0.00 \%$ \\
\hline F & $1.125 \mathrm{E}-03$ & $2.575 \mathrm{E}-05$ & $1.125 \mathrm{E}-03$ & $2.575 \mathrm{E}-05$ & $0.01 \%$ & $0.00 \%$ \\
\hline G & $4.187 \mathrm{E}-04$ & $6.292 \mathrm{E}-05$ & $4.186 \mathrm{E}-04$ & $6.292 \mathrm{E}-05$ & $0.02 \%$ & $0.00 \%$ \\
\hline
\end{tabular}

Notes:

The plume dispersion coefficients have units of $\mathrm{s} / \mathrm{m}^{3}$.

The wind speed is $0.89 \mathrm{~m} / \mathrm{s}$. The release height is $2.9 \mathrm{~m}$ and receptor elevation is $2 \mathrm{~m}$. The stack diameter is $0.254 \mathrm{~m}$ and the exhaust flow rate is $0.472 \mathrm{~m}^{3} / \mathrm{s}$. 


\subsection{DISPERSION COEFFICIENTS FOR AREA SOURCES}

The area source is represented in GXQ using the MACCS building wake model with a building height of zero, and the building width corresponding to the width of the area source. Hand calculations to verify the GXQ calculations are needed only to evaluate the effect of source width on the horizontal standard deviation. The vertical standard deviation is not changed from Table 3-1.

The MACCS model inserts a virtual distance that corresponds to the distance at which the horizontal standard deviation is the width of the source divided by 4.3 . These distances are shown in Table 3-16.

Table 3-16. Comparison of Virtual Source Distances for Two Area Sources.

\begin{tabular}{|c|c|c|c|c|c|c|}
\hline \multirow{2}{*}{ Stability class } & \multicolumn{2}{|c|}{ Hand calculation } & \multicolumn{2}{c|}{ GXQ Version 4.0F } & \multicolumn{2}{c|}{ Percent differences } \\
\cline { 2 - 7 } & $\mathbf{1 0} \mathbf{~}$ & $\mathbf{1 0 0} \mathbf{~}$ & $\mathbf{1 0} \mathbf{~}$ & $\mathbf{1 0 0} \mathbf{~}$ & $\mathbf{1 0} \mathbf{~}$ & $\mathbf{1 0 0} \mathbf{~ m}$ \\
\hline A & 7.753 & 99.26 & 7.753 & 99.26 & $0.00 \%$ & $0.00 \%$ \\
\hline B & 10.63 & 136.1 & 10.63 & 136.1 & $0.00 \%$ & $0.00 \%$ \\
\hline C & 14.42 & 184.6 & 14.42 & 184.6 & $0.00 \%$ & $0.00 \%$ \\
\hline D & 21.26 & 272.2 & 21.26 & 272.2 & $0.00 \%$ & $0.00 \%$ \\
\hline E & 31.01 & 397.0 & 31.01 & 397.0 & $0.00 \%$ & $0.00 \%$ \\
\hline F & 46.75 & 598.5 & 46.75 & 598.5 & $0.00 \%$ & $0.00 \%$ \\
\hline G & 73.30 & 938.5 & 73.30 & 938.5 & $0.00 \%$ & $0.00 \%$ \\
\hline
\end{tabular}

Notes:

The virtual source distances are for source widths of $10 \mathrm{~m}$ and $100 \mathrm{~m}$. The source height is zero.

The virtual source distances have units of meters.

The agreement between the hand calculation and the GXQ output is very good. This verifies that GXQ calculates the virtual distances correctly. To verify that the virtual distances are used correctly in GXQ, the $\chi / \mathrm{Q}$ 's for the 10-m wide source are shown in Table 3-17. The wind speed is $0.89 \mathrm{~m} / \mathrm{s}$, and the downwind distances are $100 \mathrm{~m}$ and $10 \mathrm{~km}$. 
Table 3-17. Comparison of Plume Dispersion Coefficients for the 10-m Wide Source.

\begin{tabular}{|c|c|c|c|c|c|c|}
\hline \multirow{2}{*}{ Stability class } & \multicolumn{2}{|c|}{ Hand calculation } & \multicolumn{2}{c|}{ GXQ Version $\mathbf{4 . 0 F}$} & \multicolumn{2}{c|}{ Percent differences } \\
\cline { 2 - 7 } & $\mathbf{1 0 0} \mathbf{~ m}$ & $\mathbf{1 0} \mathbf{~} \mathbf{m}$ & $\mathbf{1 0 0} \mathbf{~}$ & $\mathbf{1 0} \mathbf{~ k m}$ & $\mathbf{1 0 0} \mathbf{~ m}$ & $\mathbf{1 0} \mathbf{~ k m}$ \\
\hline A & $9.986 \mathrm{E}-04$ & $2.989 \mathrm{E}-07$ & $9.986 \mathrm{E}-04$ & $2.989 \mathrm{E}-07$ & $0.00 \%$ & $0.00 \%$ \\
\hline B & $1.703 \mathrm{E}-03$ & $3.974 \mathrm{E}-07$ & $1.703 \mathrm{E}-03$ & $3.974 \mathrm{E}-07$ & $0.00 \%$ & $0.00 \%$ \\
\hline C & $3.158 \mathrm{E}-03$ & $8.390 \mathrm{E}-07$ & $3.158 \mathrm{E}-03$ & $8.390 \mathrm{E}-07$ & $0.00 \%$ & $0.00 \%$ \\
\hline D & $7.005 \mathrm{E}-03$ & $4.454 \mathrm{E}-06$ & $7.005 \mathrm{E}-03$ & $4.454 \mathrm{E}-06$ & $0.00 \%$ & $0.00 \%$ \\
\hline E & $1.200 \mathrm{E}-02$ & $1.071 \mathrm{E}-05$ & $1.200 \mathrm{E}-02$ & $1.071 \mathrm{E}-05$ & $0.00 \%$ & $0.00 \%$ \\
\hline F & $2.436 \mathrm{E}-02$ & $2.611 \mathrm{E}-05$ & $2.436 \mathrm{E}-02$ & $2.611 \mathrm{E}-05$ & $0.00 \%$ & $0.00 \%$ \\
\hline G & $5.197 \mathrm{E}-02$ & $6.525 \mathrm{E}-05$ & $5.197 \mathrm{E}-02$ & $6.525 \mathrm{E}-05$ & $0.00 \%$ & $0.00 \%$ \\
\hline
\end{tabular}

Notes:

The plume dispersion coefficients have units of $\mathrm{s} / \mathrm{m}^{3}$.

The wind speed is $0.89 \mathrm{~m} / \mathrm{s}$. The release and receptor elevations are zero.

From Table 3-17, it is concluded that GXQ correctly calculates the source-adjusted $\chi / \mathrm{Q}$ 's using the MACCS building wake model when the source height is zero, and no other modeling options are used.

\subsection{AIR TRANSPORT FACTORS FOR POOL SOURCES}

The pool source is represented in GXQ using the MACCS building wake model with a building height of zero, and the building width corresponding to the width of the pool. In addition, the source scale factor option 2 is used to modify the air transport factors by the wind speed raised to the 3.762 power. Hand calculations to verify the GXQ calculations are needed only to evaluate the effect of scaling factors. The scale factors for various wind speeds are shown in Table 3-18.

Table 3-18. Scale Factors for Pool Releases.

\begin{tabular}{|c|c|c|c|}
\hline $\begin{array}{c}\text { Wind speed } \\
(\mathbf{m} / \mathbf{s})\end{array}$ & $\begin{array}{c}\text { Hand } \\
\text { calculation }\end{array}$ & $\begin{array}{c}\text { GXQ } \\
\text { Version 4.0F }\end{array}$ & $\begin{array}{c}\text { Percent } \\
\text { differences }\end{array}$ \\
\hline 0.89 & 0.6451 & 0.6451 & $0.00 \%$ \\
\hline 2.65 & 39.11 & 39.11 & $0.00 \%$ \\
\hline 4.70 & 337.6 & 337.6 & $0.00 \%$ \\
\hline 7.15 & 1,636 & 1,636 & $0.00 \%$ \\
\hline 9.80 & 5,358 & 5,358 & $0.00 \%$ \\
\hline 12.70 & 14,210 & 14,210 & $0.00 \%$ \\
\hline 15.60 & 30,800 & 30,800 & $0.00 \%$ \\
\hline 19.00 & 64,670 & 64,670 & $0.00 \%$ \\
\hline
\end{tabular}

The agreement between the hand calculation and the GXQ output is very good. This verifies that GXQ calculates the wind speed dependent scale factors correctly. To verify that the scale factors 
are used correctly in GXQ, the air transport factors for the 10-m wide source were calculated for a wind speed of $0.89 \mathrm{~m} / \mathrm{s}$. The air transport factors shown in Table 3-17 are multiplied by the scale factor shown in Table 3-18. The resulting air transport factors are shown in Table 3-19.

Table 3-19. Plume Air Transport Factors for a $10 \mathrm{~m}$ Wide Pool.

\begin{tabular}{|c|c|c|c|c|c|c|}
\hline \multirow{2}{*}{ Stability class } & \multicolumn{2}{|c|}{ Hand calculation } & \multicolumn{2}{c|}{ GXQ Version $\mathbf{4 . 0 F}$} & \multicolumn{2}{c|}{ Percent differences } \\
\cline { 2 - 7 } & $\mathbf{1 0 0} \mathbf{~ m}$ & $\mathbf{1 0} \mathbf{~} \mathbf{m}$ & $\mathbf{1 0 0} \mathbf{~}$ & $\mathbf{1 0} \mathbf{~ k m}$ & $\mathbf{1 0 0} \mathbf{~ m}$ & $\mathbf{1 0} \mathbf{~ k m}$ \\
\hline A & $6.442 \mathrm{E}-04$ & $1.928 \mathrm{E}-07$ & $6.442 \mathrm{E}-04$ & $1.928 \mathrm{E}-07$ & $0.00 \%$ & $0.00 \%$ \\
\hline B & $1.099 \mathrm{E}-03$ & $2.563 \mathrm{E}-07$ & $1.099 \mathrm{E}-03$ & $2.563 \mathrm{E}-07$ & $0.00 \%$ & $0.00 \%$ \\
\hline C & $2.037 \mathrm{E}-03$ & $5.412 \mathrm{E}-07$ & $2.037 \mathrm{E}-03$ & $5.412 \mathrm{E}-07$ & $0.00 \%$ & $0.00 \%$ \\
\hline D & $4.518 \mathrm{E}-03$ & $2.873 \mathrm{E}-06$ & $4.518 \mathrm{E}-03$ & $2.873 \mathrm{E}-06$ & $0.00 \%$ & $0.00 \%$ \\
\hline E & $7.738 \mathrm{E}-03$ & $6.911 \mathrm{E}-06$ & $7.738 \mathrm{E}-03$ & $6.911 \mathrm{E}-06$ & $0.00 \%$ & $0.00 \%$ \\
\hline F & $1.571 \mathrm{E}-02$ & $1.684 \mathrm{E}-05$ & $1.571 \mathrm{E}-02$ & $1.684 \mathrm{E}-05$ & $0.00 \%$ & $0.00 \%$ \\
\hline G & $3.353 \mathrm{E}-02$ & $4.209 \mathrm{E}-05$ & $3.353 \mathrm{E}-02$ & $4.209 \mathrm{E}-05$ & $0.00 \%$ & $0.00 \%$ \\
\hline
\end{tabular}

Notes:

The plume air transport factors have units of $\mathrm{s} / \mathrm{m}^{3}$.

The wind speed is $0.89 \mathrm{~m} / \mathrm{s}$. The release and receptor elevations are zero. The pool width is $10 \mathrm{~m}$.

From Table 3-19, it is concluded that GXQ correctly calculates the source-adjusted air transport factors using the MACCS building wake model when the source height is zero, and the wind speed dependent scale factor is also used.

\subsection{BUILDING WAKE}

The ground level release with building wake and plume meander is represented using the model from NRC Regulatory Guide 1.145. Air transport factors without building wake are calculated by setting the building cross-sectional area to zero.

\subsubsection{Formulas for NRC Regulatory Guide 1.145 Building Wake and Plume Meander}

The formulas used in GXQ to implement NRC Regulatory Guide 1.145 are shown below. Note that "MIN" is a function that returns the smaller of the two quantities. Also, "In" is the natural logarithm (base e). On the surface, these formulas look quite different from those given in NRC Regulatory Guide 1.145. However, the only real difference is the inclusion of plume reflection, which increases the $\chi / Q$ for unstable cases at large distances.

Note that the procedure of comparing $\chi / \mathrm{Q}$ adjusted for building wake and plume meander to find the smaller is equivalent to comparing the adjustment factors $\left(\mathrm{F}_{\mathrm{BW}}\right.$ and $\left.\mathrm{F}_{\mathrm{PM}}\right)$ and selecting the larger. If only plume meander or only building wake adjustments are used, then the comparison is unnecessary. 


$$
\begin{aligned}
& (\chi / Q)_{\mathrm{BW}}=\frac{\mathrm{F}_{\text {ref }}}{2 \pi u \sigma_{\mathrm{y}} \sigma_{\mathrm{z}} \mathrm{F}_{\mathrm{BW}}} \quad \text { with } \quad \mathrm{F}_{\mathrm{BW}}=\mathrm{MIN}\left(3,1+\frac{\mathrm{A}_{\mathrm{bdg}}}{2 \pi \sigma_{\mathrm{y}} \sigma_{\mathrm{z}}}\right) \\
& (\chi / \mathrm{Q})_{\mathrm{PM}}=\frac{\mathrm{F}_{\mathrm{ref}}}{2 \pi \mathrm{u} \sigma_{\mathrm{y}} \sigma_{\mathrm{z}} \mathrm{F}_{\mathrm{PM}}} \quad \text { with } \quad \mathrm{F}_{\mathrm{PM}}=\mathrm{M} \text { for } \mathrm{x} \leq 800 \mathrm{~m} \\
& \text { and } \quad \mathrm{F}_{\mathrm{PM}}=1+(\mathrm{M}-1) \frac{\sigma_{\mathrm{y}}(800 \mathrm{~m})}{\sigma_{\mathrm{y}}} \text { for } \mathrm{x}>800 \mathrm{~m} \\
& \text { and } \mathrm{M}=\mathrm{MIN}\left[\mathrm{C},\left(\frac{6}{\mathrm{u}}\right)^{\mathrm{P}}\right] \text { for } \mathrm{u}<6 \mathrm{~m} / \mathrm{s} \text { and } \mathrm{M}=1 \text { otherwise } \\
& \text { and } \mathrm{P}=\frac{\ln \mathrm{C}}{\ln 3}
\end{aligned}
$$

where:

$$
\begin{aligned}
& \text { A bldg }=\text { Cross sectional area of the building in the direction of the wind }\left(\mathrm{m}^{2}\right) \text {. } \\
& \text { Calculated as the product of the effective height and width of the } \\
& \text { building. } \\
& \mathrm{C}=\text { Plume meander constant. Stability classes } \mathrm{A}, \mathrm{B} \text {, and } \mathrm{C} \text { use the value } \\
& \mathrm{C}=1 \text {. Stability class } \mathrm{D} \text { uses } \mathrm{C}=2 \text {. Stability class } \mathrm{E} \text { uses } \mathrm{C}=3 \text {. Stability } \\
& \text { class } \mathrm{F} \text { uses } \mathrm{C}=4 \text {. Stability class } \mathrm{G} \text { uses } \mathrm{C}=6 \text {. } \\
& \mathrm{F}_{\mathrm{BW}}=\text { Building wake adjustment factor, } 1 \leq \mathrm{F}_{\mathrm{BW}} \leq 3 \\
& \mathrm{~F}_{\mathrm{PM}}=\text { Plume meander adjustment factor, } 1 \leq \mathrm{F}_{\mathrm{PM}} \leq 6 \\
& \mathrm{~F}_{\text {ref }}=\text { Plume reflection factor, } \mathrm{F}_{\text {ref }} \geq 2 \text { (see WHC-SD-GN-SWD-30002) } \\
& \mathrm{M}=\text { Plume meander scale factor, } 1 \leq \mathrm{M} \leq 6 \\
& \mathrm{P}=\text { Exponent in the function used to calculate } \mathrm{M} \text {. } \\
& \mathrm{u}=\quad \text { Wind speed near ground level }(\mathrm{m} / \mathrm{s}) \text {. } \\
& \mathrm{x}=\text { Distance from the release location to the receptor location downwind } \\
& \text { (m). } \\
& (\chi / \mathrm{Q})_{\mathrm{BW}}=\text { Air transport factor with the building wake adjustment }\left(\mathrm{s} / \mathrm{m}^{3}\right) \\
& (\chi / \mathrm{Q})_{\mathrm{PM}}=\text { Air transport factor with the plume meander adjustment }\left(\mathrm{s} / \mathrm{m}^{3}\right) \\
& \sigma_{\mathrm{y}}=\text { Horizontal standard deviation function, in } \mathrm{m} \text {. Increases as the distance } \\
& \text { to the receptor downwind increases. Depends on stability class. } \\
& \sigma_{\mathrm{y}}(800 \mathrm{~m})=\text { Horizontal standard deviation function at a distance } 800 \mathrm{~m} \text { downwind } \\
& \text { (m). Depends on stability class. }
\end{aligned}
$$

One additional detail in the calculation of GXQ is the adjustment for mixing layer depth. The vertical standard deviation is allowed to grow until $\sigma_{\mathrm{z}}>1.2 * \mathrm{~h}_{\mathrm{m}}$. After that a fumigation condition is present. The air concentration between the ground and the mixing layer depth $\left(\mathrm{h}_{\mathrm{m}}\right)$ is uniform. In the above equations a new $\sigma_{\mathrm{z}}$ and $\mathrm{R}_{\text {ref }}$ are defined as shown below. 


$$
\text { Fumigation means } \quad \sigma_{z}=\frac{h_{m}}{\sqrt{2 \pi}} \quad \text { and } \quad F_{\text {ref }}=1
$$

\subsubsection{Verification Testing of the GXQ Building Wake and Plume Meander Model}

The first check on the GXQ calculations is the values for the standard deviations. These were shown in Table 3-1, but for different distances. Three distances will be used in these tests: $100 \mathrm{~m} ; 1,000 \mathrm{~m}$; and $10,000 \mathrm{~m}$. The standard deviations are shown in Table 3-20. An additional distance at $800 \mathrm{~m}$ is needed for the plume meander calculation. Because the assumed mixing layer depth is $1,000 \mathrm{~m}$, the fumigation model will be needed for stability classes A and B at $10,000 \mathrm{~m}$.

Table 3-20. Plume Standard Deviations.

\begin{tabular}{|c|c|c|c|c|c|c|c|c|}
\hline \multirow{2}{*}{$\begin{array}{c}\text { Stability } \\
\text { class }\end{array}$} & \multicolumn{4}{|c|}{ Horizontal standard deviation $\left(\sigma_{\mathrm{y}}\right), \mathbf{m}$} & \multirow{2}{*}{$\begin{array}{c}\text { Stability } \\
\text { class }\end{array}$} & \multicolumn{3}{|c|}{ Vertical parameter $\left(\sigma_{z}\right), \mathrm{m}$} \\
\hline & $100 \mathrm{~m}$ & $800 \mathrm{~m}$ & $1,000 \mathrm{~m}$ & $10,000 \mathrm{~m}$ & & $100 \mathrm{~m}$ & $1,000 \mathrm{~m}$ & $10,000 \mathrm{~m}$ \\
\hline A & 23.41 & 153.1 & 187.3 & $1,498.5$ & A & 14.30 & 448.4 & 57,035 \\
\hline $\mathrm{B}$ & 17.61 & 115.2 & 140.9 & $1,126.9$ & $\mathrm{~B}$ & 10.89 & 110.2 & 1,358 \\
\hline $\mathrm{C}$ & 13.37 & 87.44 & 107.0 & 855.7 & $\mathrm{C}$ & 7.500 & 61.11 & 497.8 \\
\hline $\mathrm{D}$ & 9.415 & 61.57 & 75.32 & 602.6 & $\mathrm{D}$ & 4.557 & 31.52 & 133.0 \\
\hline $\mathrm{E}$ & 6.695 & 43.78 & 53.56 & 428.5 & $\mathrm{E}$ & 3.489 & 21.52 & 77.69 \\
\hline F & 4.621 & 30.22 & 36.97 & 295.8 & F & 2.247 & 13.92 & 46.13 \\
\hline $\mathrm{G}$ & 3.079 & 20.13 & 24.63 & 197.0 & $\mathrm{G}$ & 1.360 & 8.420 & 27.64 \\
\hline
\end{tabular}

The building width is $30 \mathrm{~m}$ and the building height is $10 \mathrm{~m}$. Thus the building cross-sectional area is $300 \mathrm{~m}^{2}$. The building wake adjustment factor $\left(\mathrm{F}_{\mathrm{BW}}\right)$ cannot exceed 3.00 as shown in the formulas for the model in NRC Regulatory Guide 1.145. The numbers calculated without this limit are shown in Table 3-21. 
Table 3-21. Building Wake Factors.

\begin{tabular}{|c|c|c|c|}
\hline \multirow{2}{*}{$\begin{array}{c}\text { Stability } \\
\text { class }\end{array}$} & \multicolumn{3}{|c|}{ Building wake factor $\left(\mathrm{F}_{\mathbf{B W}}\right)$} \\
\cline { 2 - 4 } & $\mathbf{1 0 0} \mathbf{~ m}$ & $\mathbf{1 , 0 0 0} \mathbf{~ m}$ & $\mathbf{1 0 , 0 0 0} \mathbf{~ m}$ \\
\hline $\mathrm{A}$ & 1.143 & 1.001 & 1.000 \\
\hline $\mathrm{B}$ & 1.249 & 1.003 & 1.000 \\
\hline $\mathrm{C}$ & 1.476 & 1.007 & 1.000 \\
\hline $\mathrm{D}$ & 2.113 & 1.020 & 1.001 \\
\hline $\mathrm{E}$ & 3.044 & 1.041 & 1.001 \\
\hline $\mathrm{F}$ & 5.598 & 1.093 & 1.003 \\
\hline $\mathrm{G}$ & 12.401 & 1.230 & 1.009 \\
\hline
\end{tabular}

Notes:

The building area used in this table is $300 \mathrm{~m}^{2}$.

The building wake adjustment factor used in the $\chi / Q$ calculation is not allowed to exceed 3.00 .

The plume meander factors (values for $\mathrm{M}$ ) are shown in Table 3-22. Only 3 wind speeds are used because they test the wind speed dependence over its entire range, namely, less than $2 \mathrm{~m} / \mathrm{s}$, between 2 and $6 \mathrm{~m} / \mathrm{s}$, and above $6 \mathrm{~m} / \mathrm{s}$. In addition, the distances chosen lie on both sides of the $800 \mathrm{~m}$ transition distance.

Table 3-22. Plume Meander Parameters. (2 sheets)

\begin{tabular}{|c|c|c|c|c|}
\hline \multirow{2}{*}{$\begin{array}{c}\text { Wind } \\
\text { speed, } \mathbf{~} / \mathbf{s}\end{array}$} & \multirow{2}{*}{$\begin{array}{c}\text { Stability } \\
\text { class }\end{array}$} & \multicolumn{3}{|c|}{ Plume meander factor $\left(\mathbf{F}_{\mathrm{PM}}\right)$} \\
\hline 0.89 & $\mathrm{100} \mathbf{~}$ & $\mathbf{1 , 0 0 0} \mathbf{~ m}$ & $\mathbf{1 0 , 0 0 0} \mathbf{~ m}$ \\
\hline 0.89 & $\mathrm{~A}$ & 1 & 1 & 1 \\
\hline 0.89 & $\mathrm{~B}$ & 1 & 1 & 1 \\
\hline 0.89 & $\mathrm{C}$ & 1 & 1 & 1 \\
\hline 0.89 & $\mathrm{E}$ & 2.000 & 1.817 & 1.102 \\
\hline 0.89 & $\mathrm{~F}$ & 3.000 & 2.635 & 1.204 \\
\hline 0.89 & $\mathrm{G}$ & 6.000 & 3.452 & 1.307 \\
\hline 2.65 & $\mathrm{~A}$ & 1 & 1 & 1.511 \\
\hline 2.65 & $\mathrm{~B}$ & 1 & 1 & 1 \\
\hline 2.65 & $\mathrm{C}$ & 1 & 1 & 1 \\
\hline 2.65 & $\mathrm{D}$ & 1.675 & 1.552 & 1.069 \\
\hline 2.65 & $\mathrm{E}$ & 2.264 & 2.033 & 1.129 \\
\hline 2.65 & $\mathrm{~F}$ & 2.804 & 2.475 & 1.184 \\
\hline 2.65 & $\mathrm{G}$ & 3.792 & 3.282 & 1.285 \\
\hline
\end{tabular}


Table 3-22. Plume Meander Parameters. (2 sheets)

\begin{tabular}{|c|c|c|c|c|}
\hline \multirow{2}{*}{$\begin{array}{c}\text { Wind } \\
\text { speed, } \mathbf{~ m} / \mathbf{s}\end{array}$} & \multirow{2}{*}{$\begin{array}{c}\text { Stability } \\
\text { class }\end{array}$} & \multicolumn{3}{|c|}{ Plume meander factor $\left(\mathbf{F}_{\mathrm{PM}}\right)$} \\
\hline & $\mathbf{1 0 0} \mathbf{~ m}$ & $\mathbf{1 , 0 0 0} \mathbf{~ m}$ & $\mathbf{1 0 , 0 0 0 ~} \mathbf{~}$ \\
\hline 7.15 & $\mathrm{~A}$ & 1 & 1 & 1 \\
\hline 7.15 & $\mathrm{~B}$ & $\mathbf{1}$ & 1 & 1 \\
\hline 7.15 & $\mathrm{C}$ & 1 & 1 & 1 \\
\hline 7.15 & $\mathrm{D}$ & 1 & 1 & 1 \\
\hline 7.15 & $\mathrm{E}$ & 1 & 1 & 1 \\
\hline 7.15 & $\mathrm{~F}$ & 1 & 1 & 1 \\
\hline 7.15 & $\mathrm{G}$ & 1 & 1 & 1 \\
\hline
\end{tabular}

Note:

Wind speeds and distance cover the range of formulas used in GXQ.

The third adjustment factor is the plume reflection parameter. These are listed in Table 3-23. The plume reflection adjustment is not important for most combination of distance and stability. Only at $10,000 \mathrm{~m}$ for the unstable classes $(\mathrm{A}, \mathrm{B}$, and $\mathrm{C}$ ) does plume reflection matter. For class $A$ and $B$ the fumigation model is used, so $\mathrm{F}_{\text {ref }}$ becomes 1.0 for these two cases. The plume reflection parameters at 10,000 $\mathrm{m}$ differ from those shown in Table 3-23 because the plume elevation was very large for some combinations of wind speed and stability class.

Table 3-23. Plume Reflection Factors.

\begin{tabular}{|c|c|c|c|}
\hline \multirow{2}{*}{$\begin{array}{c}\text { Stability } \\
\text { class }\end{array}$} & \multicolumn{3}{|c|}{ Plume reflection factors $\left(\mathrm{F}_{\text {ref }}\right)$} \\
\cline { 2 - 4 } & $\mathbf{1 0 0} \mathbf{~ m}$ & $\mathbf{1 , 0 0 0} \mathbf{~ m}$ & $\mathbf{1 0 , 0 0 0} \mathbf{~ m}$ \\
\hline A & 2.000 & 2.000 & 13.966 \\
\hline B & 2.000 & 2.000 & 3.406 \\
\hline C & 2.000 & 2.000 & 2.001 \\
\hline D & 2.000 & 2.000 & 2.000 \\
\hline E & 2.000 & 2.000 & 2.000 \\
\hline F & 2.000 & 2.000 & 2.000 \\
\hline G & 2.000 & 2.000 & 2.000 \\
\hline
\end{tabular}

Notes:

The mixing layer depth is $1,000 \mathrm{~m}$. The downwind receptor elevation $(z)$ is zero.

All numbers on this table are calculated without considering fumigation for large values of $\sigma_{Z}$.

Note that the adjustment factors shown in Tables 3-21, 3-22, and 3-23 are independent of one another. Tables 3-22 and 3-23 do not depend on building dimensions. Tables 3-21 and 3-22 do not depend on whether plume meander is used. Thus, the $\chi / \mathrm{Q}$ values can be calculated from the numbers shown on these tables. The calculated $\chi / \mathrm{Q}$ numbers are shown in Table 3-24. Also 
shown in Table 3-24 are the $\chi / \mathrm{Q}$ results from GXQ Version 4.0F. The input files are shown in the first attachment. The two sets of numbers are the same. Therefore, the NRC Regulatory Guide 1.145 models are calculated correctly in GXQ Version 4.0F.

Table 3-24. Computed and Calculated Air Transport Factors. (3 sheets)

\begin{tabular}{|c|c|c|c|c|c|c|c|c|}
\hline \multirow{2}{*}{$\begin{array}{c}\text { Distance } \\
\text { (m) }\end{array}$} & \multirow{2}{*}{$\begin{array}{l}\text { Wind } \\
\text { speed } \\
(\mathrm{m} / \mathrm{s})\end{array}$} & \multirow{2}{*}{$\begin{array}{l}\text { Stability } \\
\text { class }\end{array}$} & \multicolumn{3}{|c|}{ Results from GXQ 4.0F } & \multicolumn{3}{|c|}{ Results from hand calculations } \\
\hline & & & $\begin{array}{l}\text { Building } \\
\text { wake }\end{array}$ & $\begin{array}{c}\text { Plume } \\
\text { meander }\end{array}$ & Both & $\begin{array}{l}\text { Building } \\
\text { wake }\end{array}$ & $\begin{array}{l}\text { Plume } \\
\text { meander }\end{array}$ & Both \\
\hline 100 & 0.89 & A & $9.35 \mathrm{E}-04$ & $1.07 \mathrm{E}-03$ & 9.35 E-04 & $9.35 \mathrm{E}-04$ & $1.07 \mathrm{E}-03$ & 9.35 E-04 \\
\hline 100 & 0.89 & B & $1.49 \mathrm{E}-03$ & $1.87 \mathrm{E}-03$ & $1.49 \mathrm{E}-03$ & $1.49 \mathrm{E}-03$ & $1.87 \mathrm{E}-03$ & $1.49 \mathrm{E}-03$ \\
\hline 100 & 0.89 & $\mathrm{C}$ & 2.42 E-03 & $3.57 \mathrm{E}-03$ & $2.42 \mathrm{E}-03$ & $2.42 \mathrm{E}-03$ & $3.57 \mathrm{E}-03$ & 2.42 E-03 \\
\hline 100 & 0.89 & $\mathrm{D}$ & $3.95 \mathrm{E}-03$ & $4.17 \mathrm{E}-03$ & $3.95 \mathrm{E}-03$ & $3.95 \mathrm{E}-03$ & $4.17 \mathrm{E}-03$ & $3.95 \mathrm{E}-03$ \\
\hline 100 & 0.89 & $\mathrm{E}$ & $5.10 \mathrm{E}-03$ & $5.10 \mathrm{E}-03$ & $5.10 \mathrm{E}-03$ & $5.10 \mathrm{E}-03$ & $5.10 \mathrm{E}-03$ & $5.10 \mathrm{E}-03$ \\
\hline 100 & 0.89 & $\mathrm{~F}$ & $1.15 \mathrm{E}-02$ & $8.61 \mathrm{E}-03$ & $8.61 \mathrm{E}-03$ & $1.15 \mathrm{E}-02$ & $8.61 \mathrm{E}-03$ & $8.61 \mathrm{E}-03$ \\
\hline 100 & 0.89 & $\mathrm{G}$ & $2.85 \mathrm{E}-02$ & $1.42 \mathrm{E}-02$ & $1.42 \mathrm{E}-02$ & $2.85 \mathrm{E}-02$ & $1.42 \mathrm{E}-02$ & $1.42 \mathrm{E}-02$ \\
\hline 100 & 2.65 & A & $3.14 \mathrm{E}-04$ & $3.59 \mathrm{E}-04$ & $3.14 \mathrm{E}-04$ & 3.14 E-04 & $3.59 \mathrm{E}-04$ & $3.14 \mathrm{E}-04$ \\
\hline 100 & 2.65 & B & $5.02 \mathrm{E}-04$ & $6.27 \mathrm{E}-04$ & 5.02 E-04 & 5.02 E-04 & $6.27 \mathrm{E}-04$ & 5.02 E-04 \\
\hline 100 & 2.65 & $\mathrm{C}$ & $8.11 \mathrm{E}-04$ & $1.20 \mathrm{E}-03$ & 8.11 E-04 & 8.11 E-04 & $1.20 \mathrm{E}-03$ & 8.11 E-04 \\
\hline 100 & 2.65 & $\mathrm{D}$ & $1.33 \mathrm{E}-03$ & $1.67 \mathrm{E}-03$ & $1.33 \mathrm{E}-03$ & $1.33 \mathrm{E}-03$ & $1.67 \mathrm{E}-03$ & $1.33 \mathrm{E}-03$ \\
\hline 100 & 2.65 & E & $1.71 \mathrm{E}-03$ & $2.27 \mathrm{E}-03$ & $1.71 \mathrm{E}-03$ & $1.71 \mathrm{E}-03$ & $2.27 \mathrm{E}-03$ & $1.71 \mathrm{E}-03$ \\
\hline 100 & 2.65 & $\mathrm{~F}$ & $3.86 \mathrm{E}-03$ & $4.12 \mathrm{E}-03$ & $3.86 \mathrm{E}-03$ & $3.86 \mathrm{E}-03$ & $4.12 \mathrm{E}-03$ & $3.86 \mathrm{E}-03$ \\
\hline 100 & 2.65 & G & $9.56 \mathrm{E}-03$ & $7.56 \mathrm{E}-03$ & $7.56 \mathrm{E}-03$ & $9.56 \mathrm{E}-03$ & $7.56 \mathrm{E}-03$ & $7.56 \mathrm{E}-03$ \\
\hline 100 & 7.15 & A & $1.16 \mathrm{E}-04$ & $1.33 \mathrm{E}-04$ & $1.16 \mathrm{E}-04$ & $1.16 \mathrm{E}-04$ & $1.33 \mathrm{E}-04$ & $1.16 \mathrm{E}-04$ \\
\hline 100 & 7.15 & B & $1.86 \mathrm{E}-04$ & $2.32 \mathrm{E}-04$ & $1.86 \mathrm{E}-04$ & $1.86 \mathrm{E}-04$ & 2.32 E-04 & $1.86 \mathrm{E}-04$ \\
\hline 100 & 7.15 & $\mathrm{C}$ & $3.01 \mathrm{E}-04$ & 4.44 E-04 & $3.01 \mathrm{E}-04$ & $3.01 \mathrm{E}-04$ & 4.44 E-04 & $3.01 \mathrm{E}-04$ \\
\hline 100 & 7.15 & D & $4.91 \mathrm{E}-04$ & $1.04 \mathrm{E}-03$ & $4.91 \mathrm{E}-04$ & $4.91 \mathrm{E}-04$ & $1.04 \mathrm{E}-03$ & $4.91 \mathrm{E}-04$ \\
\hline 100 & 7.15 & $\mathrm{E}$ & $6.35 \mathrm{E}-04$ & $1.91 \mathrm{E}-03$ & $6.35 \mathrm{E}-04$ & $6.35 \mathrm{E}-04$ & $1.91 \mathrm{E}-03$ & $6.35 \mathrm{E}-04$ \\
\hline 100 & 7.15 & F & $1.43 \mathrm{E}-03$ & $4.29 \mathrm{E}-03$ & $1.43 \mathrm{E}-03$ & $1.43 \mathrm{E}-03$ & $4.29 \mathrm{E}-03$ & $1.43 \mathrm{E}-03$ \\
\hline 100 & 7.15 & G & $3.54 \mathrm{E}-03$ & $1.06 \mathrm{E}-02$ & $3.54 \mathrm{E}-03$ & 3.54 E-03 & $1.06 \mathrm{E}-02$ & 3.54 E-03 \\
\hline 1,000 & 0.89 & A & $4.26 \mathrm{E}-06$ & $4.26 \mathrm{E}-06$ & $4.26 \mathrm{E}-06$ & $4.26 \mathrm{E}-06$ & $4.26 \mathrm{E}-06$ & $4.26 \mathrm{E}-06$ \\
\hline 1,000 & 0.89 & B & $2.30 \mathrm{E}-05$ & $2.30 \mathrm{E}-05$ & $2.30 \mathrm{E}-05$ & $2.30 \mathrm{E}-05$ & $2.30 \mathrm{E}-05$ & $2.30 \mathrm{E}-05$ \\
\hline 1,000 & 0.89 & $\mathrm{C}$ & $5.43 \mathrm{E}-05$ & $5.47 \mathrm{E}-05$ & $5.43 \mathrm{E}-05$ & 5.43 E-05 & 5.47 E-05 & $5.43 \mathrm{E}-05$ \\
\hline 1,000 & 0.89 & D & $1.48 \mathrm{E}-04$ & $8.29 \mathrm{E}-05$ & $8.29 \mathrm{E}-05$ & $1.48 \mathrm{E}-04$ & $8.29 \mathrm{E}-05$ & 8.29 E-05 \\
\hline 1,000 & 0.89 & $\mathrm{E}$ & $2.98 \mathrm{E}-04$ & $1.18 \mathrm{E}-04$ & $1.18 \mathrm{E}-04$ & $2.98 \mathrm{E}-04$ & $1.18 \mathrm{E}-04$ & $1.18 \mathrm{E}-04$ \\
\hline 1,000 & 0.89 & $\mathrm{~F}$ & $6.36 \mathrm{E}-04$ & $2.01 \mathrm{E}-04$ & $2.01 \mathrm{E}-04$ & $6.36 \mathrm{E}-04$ & $2.01 \mathrm{E}-04$ & 2.01 E-04 \\
\hline 1,000 & 0.89 & $\mathrm{G}$ & $1.40 \mathrm{E}-03$ & $3.39 \mathrm{E}-04$ & $3.39 \mathrm{E}-04$ & $1.40 \mathrm{E}-03$ & $3.39 \mathrm{E}-04$ & $3.39 \mathrm{E}-04$ \\
\hline 1,000 & 2.65 & A & $1.43 \mathrm{E}-06$ & $1.43 \mathrm{E}-06$ & $1.43 \mathrm{E}-06$ & $1.43 \mathrm{E}-06$ & $1.43 \mathrm{E}-06$ & $1.43 \mathrm{E}-06$ \\
\hline 1,000 & 2.65 & B & $7.71 \mathrm{E}-06$ & $7.74 \mathrm{E}-06$ & 7.71 E-06 & $7.71 \mathrm{E}-06$ & 7.74 E-06 & $7.71 \mathrm{E}-06$ \\
\hline
\end{tabular}


Table 3-24. Computed and Calculated Air Transport Factors. (3 sheets)

\begin{tabular}{|c|c|c|c|c|c|c|c|c|}
\hline \multirow{2}{*}{$\begin{array}{c}\text { Distance } \\
\text { (m) }\end{array}$} & \multirow{2}{*}{$\begin{array}{l}\text { Wind } \\
\text { speed } \\
(\mathrm{m} / \mathrm{s})\end{array}$} & \multirow{2}{*}{$\begin{array}{l}\text { Stability } \\
\text { class }\end{array}$} & \multicolumn{3}{|c|}{ Results from GXQ 4.0F } & \multicolumn{3}{|c|}{ Results from hand calculations } \\
\hline & & & $\begin{array}{c}\text { Building } \\
\text { wake }\end{array}$ & $\begin{array}{c}\text { Plume } \\
\text { meander }\end{array}$ & Both & $\begin{array}{c}\text { Building } \\
\text { wake }\end{array}$ & $\begin{array}{c}\text { Plume } \\
\text { meander }\end{array}$ & Both \\
\hline 1,000 & 2.65 & $\mathrm{C}$ & $1.82 \mathrm{E}-05$ & $1.84 \mathrm{E}-05$ & $1.82 \mathrm{E}-05$ & $1.82 \mathrm{E}-05$ & $1.84 \mathrm{E}-05$ & $1.82 \mathrm{E}-05$ \\
\hline 1,000 & 2.65 & $\mathrm{D}$ & $4.96 \mathrm{E}-05$ & $3.26 \mathrm{E}-05$ & $3.26 \mathrm{E}-05$ & $4.96 \mathrm{E}-05$ & $3.26 \mathrm{E}-05$ & $3.26 \mathrm{E}-05$ \\
\hline 1,000 & 2.65 & E & $1.00 \mathrm{E}-04$ & $5.13 \mathrm{E}-05$ & $5.13 \mathrm{E}-05$ & $1.00 \mathrm{E}-04$ & $5.13 \mathrm{E}-05$ & $5.13 \mathrm{E}-05$ \\
\hline 1,000 & 2.65 & $\mathrm{~F}$ & $2.14 \mathrm{E}-04$ & $9.43 \mathrm{E}-05$ & $9.43 \mathrm{E}-05$ & 2.14 E-04 & $9.43 \mathrm{E}-05$ & 9.43 E-05 \\
\hline 1,000 & 2.65 & $G$ & $4.71 \mathrm{E}-04$ & $1.76 \mathrm{E}-04$ & $1.76 \mathrm{E}-04$ & $4.71 \mathrm{E}-04$ & $1.76 \mathrm{E}-04$ & $1.76 \mathrm{E}-04$ \\
\hline 1,000 & 7.15 & A & $5.30 \mathrm{E}-07$ & $5.30 \mathrm{E}-07$ & $5.30 \mathrm{E}-07$ & $5.30 \mathrm{E}-07$ & $5.30 \mathrm{E}-07$ & $5.30 \mathrm{E}-07$ \\
\hline 1,000 & 7.15 & B & $2.86 \mathrm{E}-06$ & $2.87 \mathrm{E}-06$ & $2.86 \mathrm{E}-06$ & $2.86 \mathrm{E}-06$ & $2.87 \mathrm{E}-06$ & $2.86 \mathrm{E}-06$ \\
\hline 1,000 & 7.15 & $\mathrm{C}$ & $6.76 \mathrm{E}-06$ & $6.81 \mathrm{E}-06$ & $6.76 \mathrm{E}-06$ & $6.76 \mathrm{E}-06$ & $6.81 \mathrm{E}-06$ & $6.76 \mathrm{E}-06$ \\
\hline 1,000 & 7.15 & D & $1.84 \mathrm{E}-05$ & $1.88 \mathrm{E}-05$ & $1.84 \mathrm{E}-05$ & $1.84 \mathrm{E}-05$ & $1.88 \mathrm{E}-05$ & 1.84 E-05 \\
\hline 1,000 & 7.15 & $\mathrm{E}$ & $3.71 \mathrm{E}-05$ & $3.86 \mathrm{E}-05$ & $3.71 \mathrm{E}-05$ & $3.71 \mathrm{E}-05$ & $3.86 \mathrm{E}-05$ & $3.71 \mathrm{E}-05$ \\
\hline 1,000 & 7.15 & $\mathrm{~F}$ & $7.92 \mathrm{E}-05$ & $8.65 \mathrm{E}-05$ & $7.92 \mathrm{E}-05$ & $7.92 \mathrm{E}-05$ & 8.65 E-05 & $7.92 \mathrm{E}-05$ \\
\hline 1,000 & 7.15 & G & $1.75 \mathrm{E}-04$ & $2.15 \mathrm{E}-04$ & $1.75 \mathrm{E}-04$ & $1.75 \mathrm{E}-04$ & $2.15 \mathrm{E}-04$ & $1.75 \mathrm{E}-04$ \\
\hline 10,000 & 0.89 & A & $2.99 \mathrm{E}-07$ & $2.99 \mathrm{E}-07$ & $2.99 \mathrm{E}-07$ & $2.99 \mathrm{E}-07$ & $2.99 \mathrm{E}-07$ & $2.99 \mathrm{E}-07$ \\
\hline 10,000 & 0.89 & B & $3.98 \mathrm{E}-07$ & $3.98 \mathrm{E}-07$ & $3.98 \mathrm{E}-07$ & $3.98 \mathrm{E}-07$ & $3.98 \mathrm{E}-07$ & $3.98 \mathrm{E}-07$ \\
\hline 10,000 & 0.89 & $\mathrm{C}$ & 8.40 E-07 & $8.40 \mathrm{E}-07$ & $8.40 \mathrm{E}-07$ & 8.40 E- 07 & $8.40 \mathrm{E}-07$ & 8.40 E-07 \\
\hline 10,000 & 0.89 & D & $4.46 \mathrm{E}-06$ & $4.05 \mathrm{E}-06$ & $4.05 \mathrm{E}-06$ & $4.46 \mathrm{E}-06$ & $4.05 \mathrm{E}-06$ & 4.05 E-06 \\
\hline 10,000 & 0.89 & $\mathrm{E}$ & $1.07 \mathrm{E}-05$ & $8.92 \mathrm{E}-06$ & $8.92 \mathrm{E}-06$ & 1.07 E-05 & 8.92 E-06 & 8.92 E-06 \\
\hline 10,000 & 0.89 & $\mathrm{~F}$ & $2.61 \mathrm{E}-05$ & $2.01 \mathrm{E}-05$ & $2.01 \mathrm{E}-05$ & 2.61 E-05 & $2.01 \mathrm{E}-05$ & $2.01 \mathrm{E}-05$ \\
\hline 10,000 & 0.89 & $\mathrm{G}$ & $6.51 \mathrm{E}-05$ & $4.35 \mathrm{E}-05$ & $4.35 \mathrm{E}-05$ & $6.51 \mathrm{E}-05$ & 4.35 E-05 & $4.35 \mathrm{E}-05$ \\
\hline 10,000 & 2.65 & $\mathrm{~A}$ & $1.00 \mathrm{E}-07$ & 1.00 E-07 & $1.00 \mathrm{E}-07$ & $1.00 \mathrm{E}-07$ & $1.00 \mathrm{E}-07$ & $1.00 \mathrm{E}-07$ \\
\hline 10,000 & 2.65 & B & 1.34 E-07 & $1.34 \mathrm{E}-07$ & $1.34 \mathrm{E}-07$ & $1.34 \mathrm{E}-07$ & $1.34 \mathrm{E}-07$ & $1.34 \mathrm{E}-07$ \\
\hline 10,000 & 2.65 & $\mathrm{C}$ & $2.82 \mathrm{E}-07$ & $2.82 \mathrm{E}-07$ & $2.82 \mathrm{E}-07$ & $2.82 \mathrm{E}-07$ & $2.82 \mathrm{E}-07$ & $2.82 \mathrm{E}-07$ \\
\hline 10,000 & 2.65 & $\mathrm{D}$ & $1.50 \mathrm{E}-06$ & $1.40 \mathrm{E}-06$ & $1.40 \mathrm{E}-06$ & $1.50 \mathrm{E}-06$ & $1.40 \mathrm{E}-06$ & $1.40 \mathrm{E}-06$ \\
\hline 10,000 & 2.65 & $\mathrm{E}$ & $3.60 \mathrm{E}-06$ & $3.20 \mathrm{E}-06$ & 3.20 E-06 & $3.60 \mathrm{E}-06$ & 3.20 E-06 & 3.20 E-06 \\
\hline 10,000 & 2.65 & $\mathrm{~F}$ & $8.77 \mathrm{E}-06$ & 7.43 E-06 & $7.43 \mathrm{E}-06$ & 8.77 E-06 & $7.43 \mathrm{E}-06$ & $7.43 \mathrm{E}-06$ \\
\hline 10,000 & 2.65 & G & $2.19 \mathrm{E}-05$ & $1.72 \mathrm{E}-05$ & $1.72 \mathrm{E}-05$ & $2.19 \mathrm{E}-05$ & $1.72 \mathrm{E}-05$ & 1.72 E-05 \\
\hline 10,000 & 7.15 & A & $3.72 \mathrm{E}-08$ & $3.72 \mathrm{E}-08$ & $3.72 \mathrm{E}-08$ & 3.72 E-08 & 3.72 E-08 & $3.72 \mathrm{E}-08$ \\
\hline 10,000 & 7.15 & B & $4.95 \mathrm{E}-08$ & 4.95 E-08 & $4.95 \mathrm{E}-08$ & $4.95 \mathrm{E}-08$ & $4.95 \mathrm{E}-08$ & 4.95 E-08 \\
\hline 10,000 & 7.15 & $\mathrm{C}$ & $1.05 \mathrm{E}-07$ & $1.05 \mathrm{E}-07$ & $1.05 \mathrm{E}-07$ & $1.05 \mathrm{E}-07$ & $1.05 \mathrm{E}-07$ & $1.05 \mathrm{E}-07$ \\
\hline 10,000 & 7.15 & $\mathrm{D}$ & $5.55 \mathrm{E}-07$ & $5.55 \mathrm{E}-07$ & $5.55 \mathrm{E}-07$ & $5.55 \mathrm{E}-07$ & 5.55 E-07 & $5.55 \mathrm{E}-07$ \\
\hline 10,000 & 7.15 & $\mathrm{E}$ & $1.34 \mathrm{E}-06$ & $1.34 \mathrm{E}-06$ & $1.34 \mathrm{E}-06$ & $1.34 \mathrm{E}-06$ & $1.34 \mathrm{E}-06$ & $1.34 \mathrm{E}-06$ \\
\hline 10,000 & 7.15 & $\mathrm{~F}$ & $3.25 \mathrm{E}-06$ & $3.26 \mathrm{E}-06$ & $3.25 \mathrm{E}-06$ & 3.25 E-06 & $3.26 \mathrm{E}-06$ & $3.25 \mathrm{E}-06$ \\
\hline 10,000 & 7.15 & $\mathrm{G}$ & $8.10 \mathrm{E}-06$ & $8.18 \mathrm{E}-06$ & $8.10 \mathrm{E}-06$ & $8.10 \mathrm{E}-06$ & $8.18 \mathrm{E}-06$ & 8.10 E-06 \\
\hline
\end{tabular}


Table 3-24. Computed and Calculated Air Transport Factors. (3 sheets)

\begin{tabular}{|c|c|c|c|c|c|c|c|c|}
\hline \multirow{2}{*}{$\begin{array}{c}\text { Distance } \\
(\mathrm{m})\end{array}$} & $\begin{array}{c}\text { Wind } \\
\text { speed } \\
(\mathrm{m} / \mathrm{s})\end{array}$ & $\begin{array}{c}\text { Stability } \\
\text { class }\end{array}$ & \multicolumn{3}{|c|}{ Results from GXQ 4.0F } & \multicolumn{3}{|c|}{ Results from hand calculations } \\
\cline { 4 - 8 } & & $\begin{array}{c}\text { Building } \\
\text { wake }\end{array}$ & $\begin{array}{c}\text { Plume } \\
\text { meander }\end{array}$ & Both & $\begin{array}{c}\text { Building } \\
\text { wake }\end{array}$ & $\begin{array}{c}\text { Plume } \\
\text { meander }\end{array}$ & Both \\
\hline
\end{tabular}

Notes:

Units for the air transport factors are $\mathrm{s} / \mathrm{m}^{3}$. These are time-integrated air concentrations at the receptor location.

The "Building wake" columns show the $\chi / \mathrm{Q}$ without plume meander.

The "Plume meander" columns show the $\chi / \mathrm{Q}$ without building wake.

The "Both" columns show the $\chi / Q$ with both building wake and plume meander adjustments.

\subsection{GXQ VERSION 4.0F SOURCE CODE LISTING}

GXQ Version 4.0F is written in the FORTRAN ${ }^{1}$ language. A few of the 1990 FORTRAN enhancements have been used. The name of the file is GXQ4F.F. The source code is listed in Appendix A.

\footnotetext{
' FORTRAN is a trademark of Lahey Computer Systems, Inc., Incline Village, Nevada.
} 


\subsection{RADIOLOGICAL DOSE CALCULATIONS}

The risk evaluation guideline for exposure to radioactive materials is given in the DSA, Chapter 3.0.

\subsection{EXPOSURE PATHWAYS}

The radiological dose received by a receptor is a time-integrated dose, i.e., the exposure rate from the various pathways must be integrated over the exposure time of the receptor. The total radiological dose received by an individual is the sum of the dose contributions from internal and external pathways. The external exposure pathways include direct radiation from the passing plume of material (submersion), direct radiation from material on the ground that has fallen out of the passing plume (ground shine), and direct radiation from a radioactive source, such as a pool of liquid on the ground. Submersion doses are generally of concern only for plumes containing very short-lived (and therefore very active) gases such as those due to a criticality. For the types of releases of concern in tank farms, the submersion dose will be negligible compared to inhalation doses from the passing plume. Likewise, doses from ground shine are negligible compared to inhalation doses from the associated air plume unless the receptor is exposed for a long period of time (years) after the plume passes. Direct shine from a radioactive source, however, is an important contributor to the total dose to the onsite receptor for scenarios involving a pool of liquid on the ground, such as waste transfer line breaks. Any such direct dose to the Hanford Site boundary receptor is negligible due to geometric attenuation.

The major internal exposure pathway of concern at tank farms is the inhalation pathway. Exposure through the inhalation pathway occurs when an accident results in a release of airborne radioactive material that is transported downwind and inhaled by the receptor. A second source for the inhalation pathway is radioactive material that has been deposited on the ground during plume passage and then re-suspended. The dose contribution from inhalation of re-suspended material is generally orders of magnitude less than that from the inhalation of the material in the primary plume, however, and so is not normally considered.

The other internal exposure pathway is ingestion. DOE-STD-3009-94, Appendix A, Section A3, recommends that slow developing pathways, such as ingestion, not be included in the consequence calculations used to identify safety systems, structures, and components. The DSA does not include ingestion in consequence calculations.

Exposure through the ingestion pathway occurs when radioactive material that has been deposited offsite is ingested, either by eating crops grown in, or animals raised on contaminated soil, or through drinking contaminated water or milk. Potential doses from the ingestion pathway are not included in the comparison to risk guidelines because there are U.S. Department of Energy (DOE), state, and federal programs in place to prevent ingestion of contaminated food in the event of an accident. The primary determinant of exposure from the ingestion pathway is the effectiveness of public health measures (i.e., interdiction) rather than the severity of the accident itself. The ingestion pathway, if it occurs, is a slow-to-develop pathway and is not considered an immediate threat to an exposed population in the same sense as airborne plume 
exposures. A method of including doses from ingestion of leafy vegetables and fruit during the first $24 \mathrm{hr}$ following the accident was developed using the GENII code (PNL-6584, GENII-The Hanford Environmental Radiation Dosimetry Software System). The contribution from the ingestion pathway during the first $24 \mathrm{hr}$ was found to be a minor component of the total dose to the offsite receptor. The current version of the GENII code (Version 1.485) is based on dose conversion factors (DCF) from International Commission on Radiological Protection (ICRP) (ICRP-26, Recommendations of the International Commission on Radiological Protection), and is considered obsolete. It is recommended, therefore, that if a total offsite dose including the 24-hr ingestion dose is desired, that the inhalation dose be adjusted by a factor of 1.1 to envelop the effect of the ingestion dose.

\subsection{SOURCE TERM DEVELOPMENT}

Inhalation doses are directly proportional to the time-integrated air concentration of the radioactive material at the receptor location. The time-integrated concentration at the receptor is in turn proportional to the total release of radioactive material at the source location during the exposure time of the receptor. This total release is commonly referred to as the "source term." The source term for inhalation dose is normally considered to include only respirable particle sizes; that is, particles with AEDs of $10 \mu \mathrm{m}$ or less. The AED is the diameter of a spherical particle with a density of $1 \mathrm{~g} / \mathrm{cm}^{3}$ that has the same gravitational fall velocity as the actual particle in question. A particle with an AED of $10 \mu \mathrm{m}$ is considered to have a fall velocity less than the average speed of random vorticity of the air outdoors. Respirable particles therefore tend to flow with the air and to have a very low settling rate. Particles larger than respirable size are generally assumed to fall out relatively close to the source with only a small fraction reaching the receptor under the stable, low wind speed conditions normally used to maximize doses in an accident analysis.

The source term, i.e., the amount of respirable material released to the air at the accident location, is calculated in terms of five factors as follows:

$$
\text { Source Term }=\text { MAR } \times D R \times A R F \times R F \times L P F
$$

A detailed discussion of the five factors is given in DOE-HDBK-3010-94, Section 1.2; however, summary definitions are given here.

- MAR is the Material at Risk. This is the total amount of radioactive material (in $\mathrm{g}, \mathrm{Ci}, \mathrm{L}$, etc.) available to be acted on by the accident stresses. Generally, this is the maximum inventory reasonably expected to be present in the facility, process, or activity. The MAR is dependent on the scenario. For example, for a spill, the MAR could be the contents of only one container, but for a seismic event, it could be the entire contents of a building.

- DR is the Damage Ratio. This is the fraction of the MAR actually impacted by the accident-generated conditions. There is an obvious interdependence in the definitions of MAR and DR. Material determined not to be affected by the accident forces could be excluded from the MAR, or it could be included and accounted for using the DR. 
- ARF is the Airborne Release Fraction. This is the fraction of the material impacted by the accident conditions that is suspended in the air as an aerosol in the immediate vicinity of the accident event and is thus available for transport. The ARF can also be given in terms of an airborne release rate, which must be multiplied by a release time to arrive at the ARF. This often occurs, for example, in cases of air entrainment from liquid pools or powder beds.

- RF is the Respirable Fraction. This is the fraction of the particles (by mass or activity) suspended at the event site that can be transported through the air and inhaled into the human respiratory system. This fraction is normally assumed to include particles with diameters of $10 \mu \mathrm{m}$ AED or less. In many cases, the RF is unknown and in such cases it is usual to set $R F=1$ for conservatism. In some cases, the RF can be estimated based on the particle size mix of the material being released (such as a powder). Care should be taken, however, because some release scenarios (such as pool or powder bed entrainment) preferentially release the finer particles, leaving the larger particles behind. In such cases, the RF is normally set equal to 1 .

- LPF is the Leakpath Factor. This is the fraction of material in the aerosol transported through some confinement, such as a building or a ventilation system with long ducts and/or filters. This is generally estimated based on the leak paths involved (which can be multiple in series or parallel) with associated losses by depletion mechanisms, specified filter efficiencies, etc. Note that for unmitigated scenarios, the LPF is normally set equal to 1 .

These five factors involved in the estimation of the source term are discussed in much greater detail in DOE-HDBK-3010-94. The analyst should be thoroughly familiar with this material. Values of ARF and RF derived from experimental data are given for many types of scenarios in DOE-HDBK-3010-94, which is a standard source for this type of information. The MAR and DR must be determined by the analyst based on the details of the specific case at hand. The estimation of the LPF for a mitigated scenario, if required, is probably the most difficult and demanding part of the analysis, requiring a high degree of knowledge and experience.

\subsection{RADIOLOGICAL DOSE CALCULATIONS}

The basic formulation of inhalation dose due to a release to the air is given by Equation 4-1:

$$
\mathrm{D}=\mathrm{Q}\left(\frac{\chi}{\mathrm{Q}^{\prime}}\right)(\mathrm{BR})(\mathrm{DCF})
$$

where:

$D=$ inhalation dose

$Q=$ total release at the source point

$\chi / Q^{\prime}=$ atmospheric dispersion coefficient

$B R=$ receptor breathing rate

$D C F=$ dose conversion factor for the radionuclide involved. 
In the usual case of multiple radionuclide inventories, the dose due to each radionuclide must be calculated and the results summed. The factors above must have mutually consistent dimensions. Typically, $Q$ has units of $\mathrm{Ci}, \chi / \mathrm{Q}$ has units of $\mathrm{s} / \mathrm{m}^{3}, B R$ is terms of $\mathrm{m}^{3} / \mathrm{s}$, and $D C F$ is rem/ $\mathrm{Ci}$ inhaled. It should be noted that, for radiological doses, the release rate is not a consideration as long as the receptor is exposed to the entire release. For example, if the release duration is doubled, the plume becomes twice as long, but the concentration is cut in half. The time-integrated air concentration at the receptor during the passage of the plume is therefore the same as before.

If the radioactive material is in the form of a gas or aerosol (e.g., coming from an exhaust system), the effects of the initial dilution at the source can be accounted for by the GXQ code as discussed in Section 2.3.2. The effect of an initial source concentration and volume source rate can also be approximated using a modified form of Equation 4-1 (Section 3.4 of NUREG/CR-6331, Atmospheric Relative Concentrations in Building Wakes), depicted here as Equation 4-2:

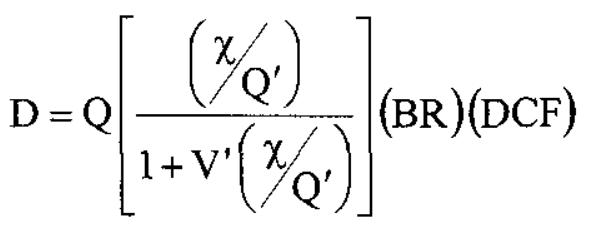

where:

$$
V^{\prime}=\text { volumetric rate of the source. }
$$

Most releases at tank farms are given in terms of liters of waste aerosolized into the air. The DCF then becomes a unit-liter dose (ULD) having units of dose per liter of material inhaled as aerosol. The ULD includes the effects of all the radionuclides in the particular mix. A different ULD is therefore required for each type of waste (liquids, solids, double-shell tank waste, single-shell tank waste, etc.). ULDs for the various tank waste phases are developed in RPP-5924, Radiological Source Terms for Tank Farms Safety Analysis.

The maximum exposure time for the onsite or Hanford Site boundary receptor is normally $8 \mathrm{hr}$ in accordance with DOE-STD-3009-94, Appendix A. For scenarios with long release durations, $Q$ is the release during the first $8 \mathrm{hr}$ following start of the release event. The breathing rate, $B R$, is normally taken to be the ICRP-66, Human Respiratory Tract Model for Radiological Protection, light-activity breathing rate of $3.33 \mathrm{E}-4 \mathrm{~m} \mathrm{~m}^{3} / \mathrm{s}$. If the Hanford Site boundary receptor exposure time is $24 \mathrm{hr}$ or more, and if the release rate is relatively constant over that time, the $24-\mathrm{hr}$ average breathing rate of $2.57 \mathrm{E}-4 \mathrm{~m} \mathrm{~m}^{3} / \mathrm{s}$ can be used. The usual form of the inhalation dose formula applicable to tank farms is shown in Equation 4-3: 


\section{RPP-13482 REV 5}

$$
\mathrm{D}=\mathrm{Q}\left(\frac{\chi}{\mathrm{Q}^{\prime}}\right)(\mathrm{BR})(\mathrm{ULD})
$$

where:

$$
\begin{aligned}
D & =\text { inhalation dose to receptor (rem or } \mathrm{Sv}) \\
Q & =\text { liters of respirable tank waste released }(\mathrm{L}) \\
\chi / Q^{\prime} & =\text { atmospheric dispersion coefficient }\left(\mathrm{s} / \mathrm{m}^{3}\right) \\
B R & =\text { breathing rate }\left(\mathrm{m}^{3} / \mathrm{s}\right) \\
U L D & =\text { dose per unit liter of waste inhaled as aerosol }(\mathrm{rem} / \mathrm{L} \text { or } \mathrm{Sv} / \mathrm{L}) .
\end{aligned}
$$

The $\chi / \mathrm{Q}$ ' to be used (1-hr, 2-hr, logarithmically averaged, etc.) will depend on the scenario. If the release rate is approximately constant over at least $1 \mathrm{hr}$, then the 2-hr $\chi / \mathrm{Q}^{\prime}$ (i.e., with plume meander) is used. If the release duration is less than $1 \mathrm{hr}$, or if the release rate is variable (e.g., exponentially decreasing), then the $1-\mathrm{hr} \chi / \mathrm{Q}$ ' (i.e., without plume meander) is used. If the release has a duration greater than $2 \mathrm{hr}$ with an approximately constant rate over that duration, then a logarithmically averaged $\chi / Q^{\prime}$ can be used as discussed in Section 2.2.4. The $50^{\text {th }}$ percentile $\chi / Q$ 's may be used for beyond design basis accidents and for comparative calculations to determine the degree of conservatism in bounding calculations. The puff $\chi / \mathrm{Qs}$ are not applicable to radiological releases. 


\section{RPP-13482 REV 5}

This page intentionally left blank. 


\subsection{TOXICOLOGICAL EXPOSURE CALCULATIONS}

The risk evaluation guideline for exposure to toxic chemicals is given in the DSA, Section 3.3.1.

For release durations of $15 \mathrm{~min}$ or more, concentrations for comparison with the appropriate guidelines should be calculated as the peak 15-min time-weighted average (TWA) at the receptor points of interest. For release durations of less than $15 \mathrm{~min}$, concentrations for comparison with guidelines may be calculated over a shorter time period but, as a practical lower time limit, not less than $1 \mathrm{~min}$. The chemicals and guidelines used for calculating the chemical consequences of releasing tank waste are given in RPP-8369, Chemical Source Terms for Tank Farms Safety Analyses.

For the chemicals in tank waste, exposure duration is not the prime consideration. For practical reasons (e.g., limitations of instantaneous concentration monitoring for many chemicals), the peak 15-min TWA concentration at the receptor may be used except for those substances that may cause immediate irritation or severe toxicity when exposures are short (e.g., sodium hydroxide or ammonia). In such cases, if the release scenario being analyzed gives rise to peak concentrations significantly higher than the peak 15 -min TWA concentration, then a shorter averaging time corresponding to the release duration (not less than $1 \mathrm{~min}$ ) should be used. The 1-min minimum is rooted in biological (or physiological) considerations. If one gets a whiff of something irritating, the immediate response is to stop breathing and get away from the source. The most dangerous materials are those that have no odor or other warning properties at toxic concentrations, but for the most part, such chemicals are not of concern here.

For accident analysis purposes, most toxic chemical mixes of concern at tank farms (e.g., aerosolized waste, sodium hydroxide, or ammonia) should be assumed to have consequences that are immediate (i.e., concentration dependent) rather than being dependent on the total quantity taken up by the body (i.e., integrated dose dependent). Toxicological consequences of a release are based on the peak air concentration at the receptor location that occurs any time during the duration of the release. For release durations longer than 15 min, the peak 15-min average concentration during the duration of the release is used for concentration-dependent chemicals. If the release duration is less than $15 \mathrm{~min}$, the concentration is averaged over the actual release time down to a minimum of $1 \mathrm{~min}$. For a release duration less than $1 \mathrm{~min}$, the release can therefore be characterized as a continuous release with a rate $(\mathrm{mg} / \mathrm{s})$ given by the total release (in $\mathrm{mg}$ ) divided by $60 \mathrm{sec}$. A short release can also be treated using the puff model where the release is assumed to take place in zero time and to spread in all three dimensions as the cloud moves downwind. Either the steady-state or puff model (whichever gives the lower result) can be used. Both models are always conservative.

Other chemicals have toxic effects that are dose-dependent, i.e., the severity of the effect increases as the total quantity of the chemical absorbed increases. For these chemicals only, the average exposure concentration over a longer period (up to $1 \mathrm{hr}$ ) may be used.

It should be emphasized that these categories are not mutually exclusive. There are chemicals that elicit concentration-dependent responses at high concentrations that also produce dose-related responses at lower concentrations. For example, acute exposure to high 
concentrations of benzene can affect the central nervous system, while exposures at lower levels can cause hematopoietic effects and leukemia. Chemicals such as beryllium, chloroform, ethylene oxide, and formaldehyde can also produce dose-dependent effects at low concentrations and display acute toxicity at high concentrations.

If it is known that the toxic effects of a chemical are not concentration-dependent, but depend on the total quantity of chemical taken up by the body (i.e., dose dependent), then the peak 1-hr average concentration may be used.

\subsection{STEADY-STATE MODEL}

If it is assumed that the toxic material is released at some average rate over some period of time, the peak concentration at the receptor is obtained directly from the definition of the steady-state $\chi / Q^{\prime}$ as shown by Equation 5-1:

$$
\mathrm{C}=\mathrm{Q}^{\prime}\left(\frac{\chi}{\mathrm{Q}^{\prime}}\right)
$$

where:

$$
\begin{aligned}
C & =\text { peak concentration }\left(\mathrm{mg} / \mathrm{m}^{3}\right) \\
Q^{\prime} & =\text { toxic material release rate }(\mathrm{mg} / \mathrm{s}) \\
\chi / Q^{\prime} & =\text { steady-state } 1-\mathrm{hr} \text { dispersion coefficient }\left(\mathrm{s} / \mathrm{m}^{3}\right) .
\end{aligned}
$$

If the toxic material is in the form of a gas or aerosol (e.g., coming from a short stack), the effects of the initial dilution at the source can be accounted for by the GXQ code as discussed in Section 2.3.2. The effect of an initial source concentration and volume source rate can also be approximated using a modified form of Equation 5-1 (NUREG/CR-6331), shown here as Equation 5-2:

$$
\mathrm{C}=\mathrm{S} \mathrm{V}^{\prime}\left[\frac{\left(\chi / \mathrm{Q}^{\prime}\right)}{1+\mathrm{V}^{\prime}\left(\chi / \mathrm{Q}^{\prime}\right)}\right]
$$

where:

$$
\begin{aligned}
S & =\text { toxic material concentration at source }\left(\mathrm{mg} / \mathrm{m}^{3}\right) \\
V^{\prime} & =\text { volumetric rate of source }\left(\mathrm{m}^{3} / \mathrm{s}\right) .
\end{aligned}
$$

If the toxic material is in the form of an aerosol suspended in the air by some mechanism such as a spray, the peak concentration can also be calculated as shown in Equation 5-3. 


$$
\mathrm{C}=\rho\left(10^{3} \frac{\mathrm{cm}^{3}}{\mathrm{~L}}\right)\left(10^{3} \frac{\mathrm{mg}}{\mathrm{g}}\right) \mathrm{Q}^{\prime}\left(\frac{\chi}{\mathrm{Q}^{\prime}}\right)
$$

where:

$$
\begin{aligned}
\rho & =\text { density of source material }\left(\mathrm{g} / \mathrm{cm}^{3}\right) \\
Q^{\prime} & =\text { toxic material release rate }(\mathrm{L} / \mathrm{s}) .
\end{aligned}
$$

\subsection{PUFF RELEASE MODEL}

If it is assumed that the toxic material is released over a period of time that is very short compared to the transit time to the receptor, the peak concentration at the receptor may be calculated using the puff $\chi / Q$. Note that the puff $\chi / Q$ gives the concentration at the receptor location $(\chi)$ per unit total release at the release point $(Q)$ and has dimensions of $1 / \mathrm{m}^{3}$ as shown in Equation 5-4:

$$
\mathrm{C}=\mathrm{Q}\left(\frac{\chi}{\mathrm{Q}}\right)
$$

where:

$$
\begin{aligned}
C & =\text { peak concentration }\left(\mathrm{mg} / \mathrm{m}^{3}\right) \\
Q & =\text { total release of toxic material }(\mathrm{mg}) \\
\chi / \mathrm{Q} & =\text { puff dispersion coefficient }\left(1 / \mathrm{m}^{3}\right) .
\end{aligned}
$$

If the release of toxic material is initially in the form of a cloud of gas or aerosol (e.g., from an explosion or tank rupture), the effects of the initial dilution at the source can be accounted for by the GXQ code using an initial source size correction as discussed in Section 2.3.3. The effect of an initial source concentration and volume can also be approximated using a modified form of Equation 5-2 (easily derived from Equation 5-2), as shown here by Equation 5-5:

$$
\mathrm{C}=\mathrm{SV}\left[\frac{(\chi / \mathrm{Q})}{1+\mathrm{V}(\chi / \mathrm{Q})}\right]
$$

where:

$$
\begin{aligned}
& S=\text { toxic material concentration in the initial cloud }\left(\mathrm{mg} / \mathrm{m}^{3}\right) \\
& V=\text { initial volume of source }\left(\mathrm{m}^{3}\right) .
\end{aligned}
$$


If the toxic material is in the form of an aerosol suspended in the air by some fast mechanism such as a short-duration spray, the peak concentration can also be calculated as shown in Equation 5-6:

$$
\mathrm{C}=\rho\left(10^{3} \frac{\mathrm{cm}^{3}}{\mathrm{~L}}\right)\left(10^{3} \frac{\mathrm{mg}}{\mathrm{g}}\right) \mathrm{Q}\left(\frac{\chi}{\mathrm{Q}}\right)
$$

where:

$$
\begin{aligned}
& \rho=\text { density of source material }\left(\mathrm{g} / \mathrm{cm}^{3}\right) \\
& Q=\text { total release of toxic material }(\mathrm{L}) .
\end{aligned}
$$

At some value of the release duration, the steady-state (i.e., 1-hr) $\chi / \mathrm{Q}^{\prime}$ will yield the same concentration as the puff $\chi / \mathrm{Q}$. If the release duration is less than this cross-over value, it is advantageous to use the puff model. If the release duration is greater than the cross-over value, it is advantageous to use the steady-state model. Note that both models are always conservative. Each model, if used outside its range of application, will tend to be overly conservative. As discussed in Section 2.2.4, it can be shown that for any particular receptor location the cross-over release duration is just the ratio of the steady-state $\chi / Q^{\prime}$ to the puff $\chi / Q$. Using the basic values for the $95^{\text {th }}$ percentile coefficients in Tables 2-4 and 2-5, the cross-over release duration times are $3.7 \mathrm{sec}$ and $439 \mathrm{sec}$ for the onsite and Hanford Site boundary receptors, respectively. A very short duration release can always be averaged over at least $1 \mathrm{~min}$ so that it is always advantageous to use the steady-state model for the onsite receptor. For the site boundary receptor, on the other hand, it is advantageous to use the puff model for release durations less than $439 \mathrm{sec}(7 \mathrm{~min}, 19 \mathrm{sec})$.

\subsection{TOXIC CHEMICAL MIXES}

The formulas in Sections 5.1 and 5.2 are applied to only one chemical or analyte at a time. If there is more than one chemical in the toxic material, the SOF rule is applied. The concentration of each chemical is divided by the risk guideline for that species. These fractions of risk guidelines are then summed over all the chemical species in the mix. If the sum is less than 1 , the mix is below guideline concentration at the receptor location. If the risk guideline is in terms of ppm (parts per million by volume), it can be converted to $\mathrm{mg} / \mathrm{m}^{3}$ at standard temperature and pressure by using Equation 5-7:

$$
m g / m^{3}=p p m \frac{(M W)\left(10^{3} \mathrm{mg} / \mathrm{g}\right)\left(10^{3} \mathrm{~L} / \mathrm{m}^{3}\right)}{(22.4 \mathrm{~L} / \mathrm{mole})\left(10^{6} \mathrm{ppm}\right)}
$$

where:

$$
M W=\text { molecular weight of the toxic species }(\mathrm{g} / \mathrm{mole})
$$


For other than standard conditions, e.g., in a tank headspace, the molar gas volume $(22.4 \mathrm{~L} / \mathrm{mole})$ should be corrected for the actual conditions using the standard gas laws.

The basic equation for concentration at the receptor in the steady-state model can be used to obtain the SOF for a mixture of chemicals as shown in Equation 5-8:

$$
\sum_{j} \frac{C_{j}}{R G_{j}}=\left(\frac{\chi}{Q^{\prime}}\right) \sum_{j} \frac{Q_{j}^{\prime}}{R G_{j}}
$$

where:

$$
R G_{j}=\text { risk guideline for the } \mathrm{j}^{\text {th }} \text { species. }
$$

Reformulating the release rate, $Q_{j}{ }_{j}$, in terms of a volume release rate $(\mathrm{L} / \mathrm{s})$ times a waste concentration $(\mathrm{mg} / \mathrm{L})$ for each species, yields Equation 5-9:

$$
\sum_{j} \frac{C_{j}}{R G_{j}}=V^{\prime}\left(\frac{\chi}{Q^{\prime}}\right) \sum_{j} \frac{c_{j}}{R G_{j}}
$$

where:

$$
\begin{aligned}
& V^{\prime}=\text { volume release rate of the waste mixture }(\mathrm{L} / \mathrm{s}) \\
& c_{j}=\text { concentration of species } \mathrm{j} \text { in the waste mixture }\left(\mathrm{g} / \mathrm{L} \times 10^{6}=\mathrm{mg} / \mathrm{m}^{3}\right) .
\end{aligned}
$$

The summation on the right side of Equation 5-9 is a dimensionless number referred to as the unit (release rate) sum of fractions (USOF) for continuous releases. In tank farms, many of the waste mixes have been characterized in terms of USOF (RPP-8369). Since the $R G_{j}$ is a function of consequence guideline and whether the receptor is a worker or a member of the public, the USOFs must be tabulated for both consequence guidelines ("moderate" and "high" consequence thresholds) and for both types of receptors. The SOFs for a particular consequence guideline and receptor is therefore given by Equation 5-10:

$$
\sum_{j} \frac{C_{j}}{R G_{j}}=V^{\prime}\left(\frac{\chi}{Q^{\prime}}\right)(\text { USOF })
$$

In an analogous way, the SOF using the puff model is given by Equation 5-11:

$$
\sum_{j} \frac{C_{j}}{R_{j}}=V\left(\frac{\chi}{Q}\right)(U S O F)
$$

where:

$$
\begin{aligned}
V= & \text { total volume of material released } \\
\text { USOF }= & \text { unit release sum of fractions for puff releases (which have also been } \\
& \text { tabulated for many types of waste in tank farms) }
\end{aligned}
$$




\section{RPP-13482 REV 5}

In both cases, the puff $\chi / \mathrm{Q}$ can be corrected for initial source volume rate or volume as discussed in Sections 5.1 and 5.2, respectively. If the SOFs (the left side of Equations 5-10 and 5-11) is less than 1 , the concentration at the receptor location is less than the consequence guideline in question for that mix. 


\subsection{REFERENCES}

DOE-HDBK-3010-94, 2001, Airborne Release Fractions/Rates and Respirable Fractions for Nonreactor Nuclear Facilities, U.S. Department of Energy, Washington, D.C.

DOE-STD-3009-94, 2002, Preparation Guide for U.S. Department of Energy Nonreactor Nuclear Facility Documented Safety Analyses, Change Notice No. 2, U.S. Department of Energy, Washington, D.C.

DOE/TIC-27601, 1984, Atmospheric Science and Power Production, U.S. Department of Energy, Washington, D.C.

HNF-SD-WM-CN-096, 1997, Refined Radiological and Toxicological Consequences of Bounding Spray Leak Accidents in the Tank Farm Waste Transfer Pits, Rev. 0-A, Fluor Daniel Northwest, Richland, Washington.

ICRP-26, 1977, Recommendations of the International Commission on Radiological Protection, Annals of the International Commission on Radiological Protection, Volume 1, Number 3, Elsevier Science, Tarrytown, New York.

ICRP-66, 1994, Human Respiratory Tract Model for Radiological Protection, International Commission on Radiological Protection, Elsevier Science, Tarrytown, New York.

NRC 1.145, 1982, Atmospheric Dispersion Models for Potential Accident Consequence Assessments at Nuclear Power Plants, U.S. Nuclear Regulatory Commission Guide, Rev. 1, U.S. Nuclear Regulatory Commission, Washington, D.C.

NUREG/CR-6331, 1997, Atmospheric Relative Concentrations in Building Wakes, Rev. 1, Pacific Northwest National Laboratory, Richland, Washington.

PNL-6584, 1988, GENII - The Hanford Environmental Radiation Dosimetry Software System, Pacific Northwest Laboratory, Richland, Washington.

RPP-5924, 2005, Radiological Source Terms for Tank Farms Safety Analysis, Rev. 4-A, CH2M HILL Hanford Group, Inc., Richland, Washington.

RPP-8369, 2003, Chemical Source Terms for Tank Farms Safety Analyses, Rev. 2, CH2M HILL Hanford Group, Richland, Washington.

TID-24190, 1968, Meteorology and Atomic Energy - 1968, D. H. Slade, ed., U.S. Atomic Energy Commission/Division of Technical Information, Washington, D.C.

TWR-3958, 1999, Refined Consequence Analysis of Subsurface Leaks from TWRS Facilities that Result in a Surface Pool, Rev. 0, Fluor Daniel Northwest, Richland, Washington.

WHC-SD-GN-SWD-30002, 1994, GXQ 4.0 Program Users' Guide, Rev. 1, Westinghouse Hanford Company, Richland, Washington. 
RPP-13482 REV 5

This page intentionally left blank. 


\section{RPP-13482 REV 5}

APPENDIX A

PROGRAM LISTING OF THE GXQ CODE VERSION 4.0F 
RPP-13482 REV 5

This page intentionally left blank. 


\section{APPENDIX A}

\section{PROGRAM LISTING OF THE GXQ CODE VERSION 4.0F}

! CHANGE HISTORY :

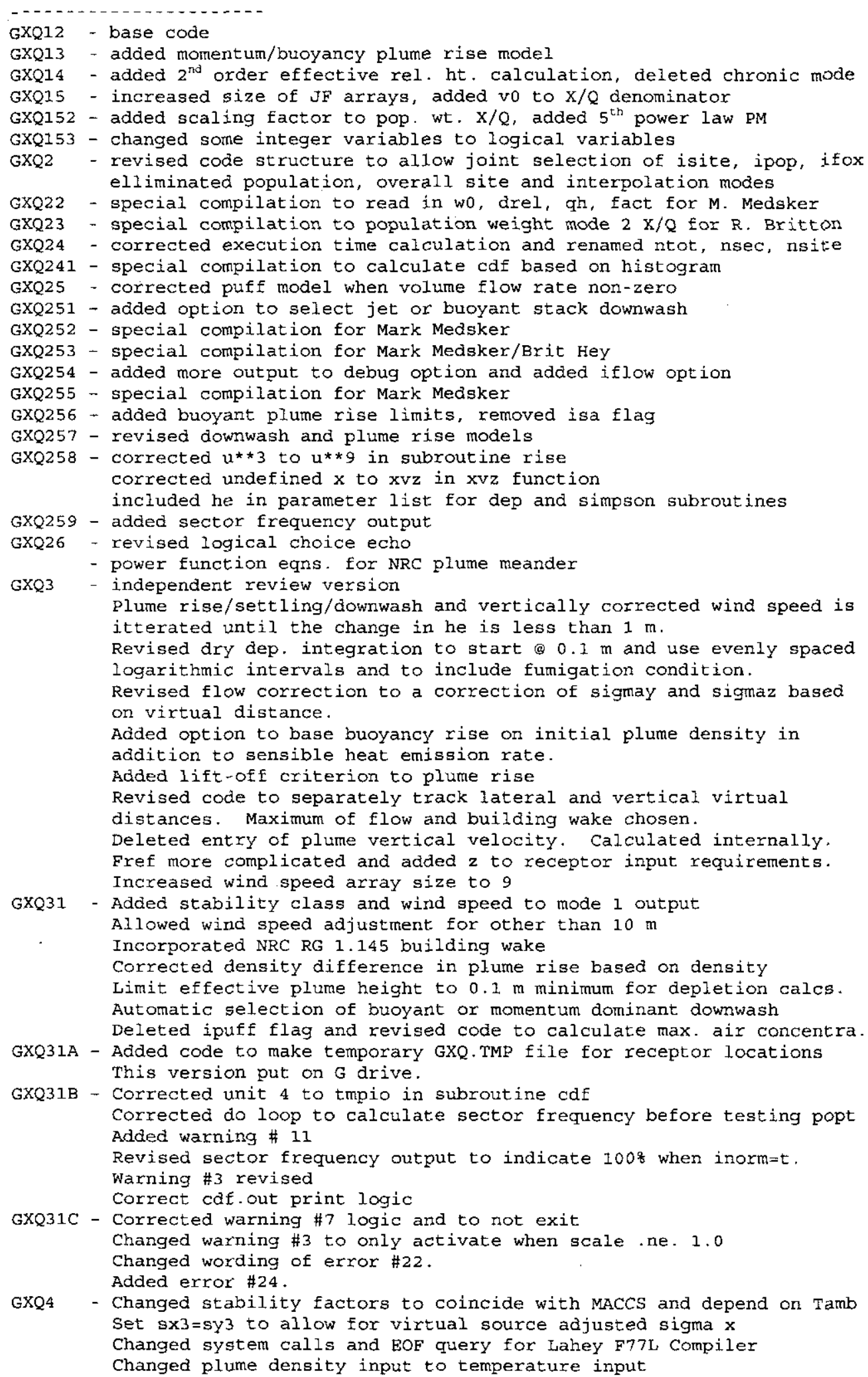




\section{RPP-13482 REV 5}

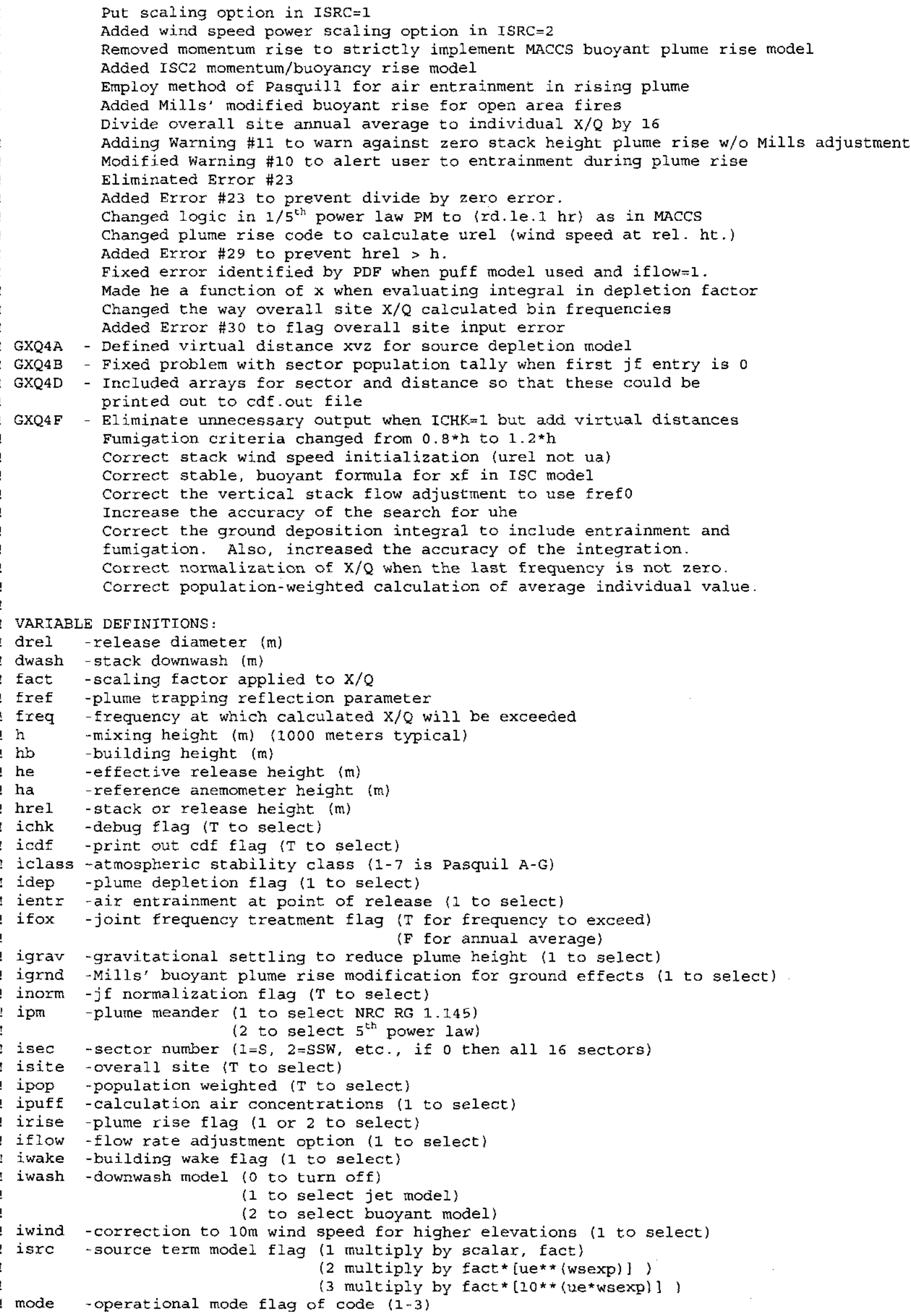




\section{RPP-13482 REV 5}

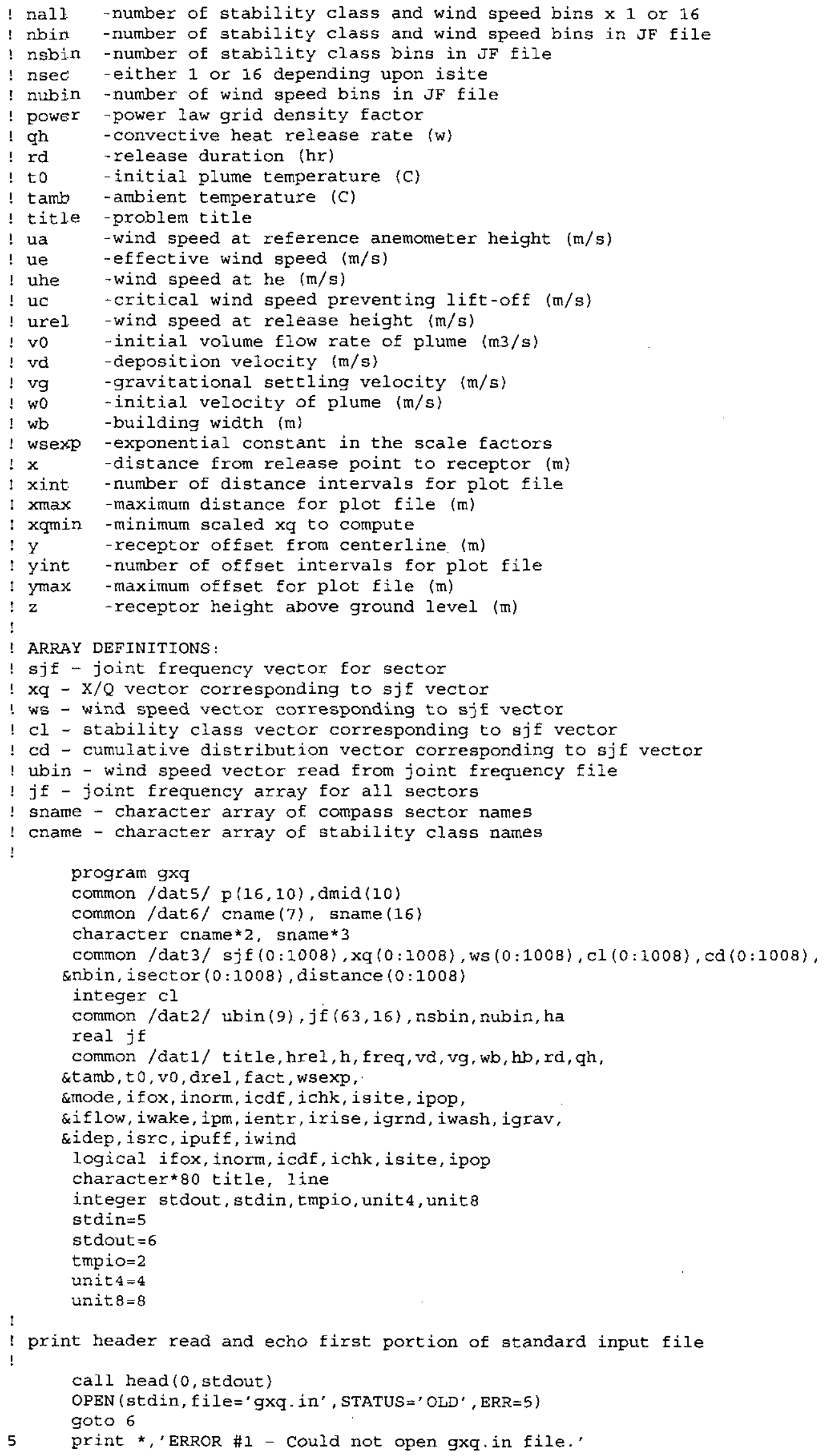




\section{RPP-13482 REV 5}

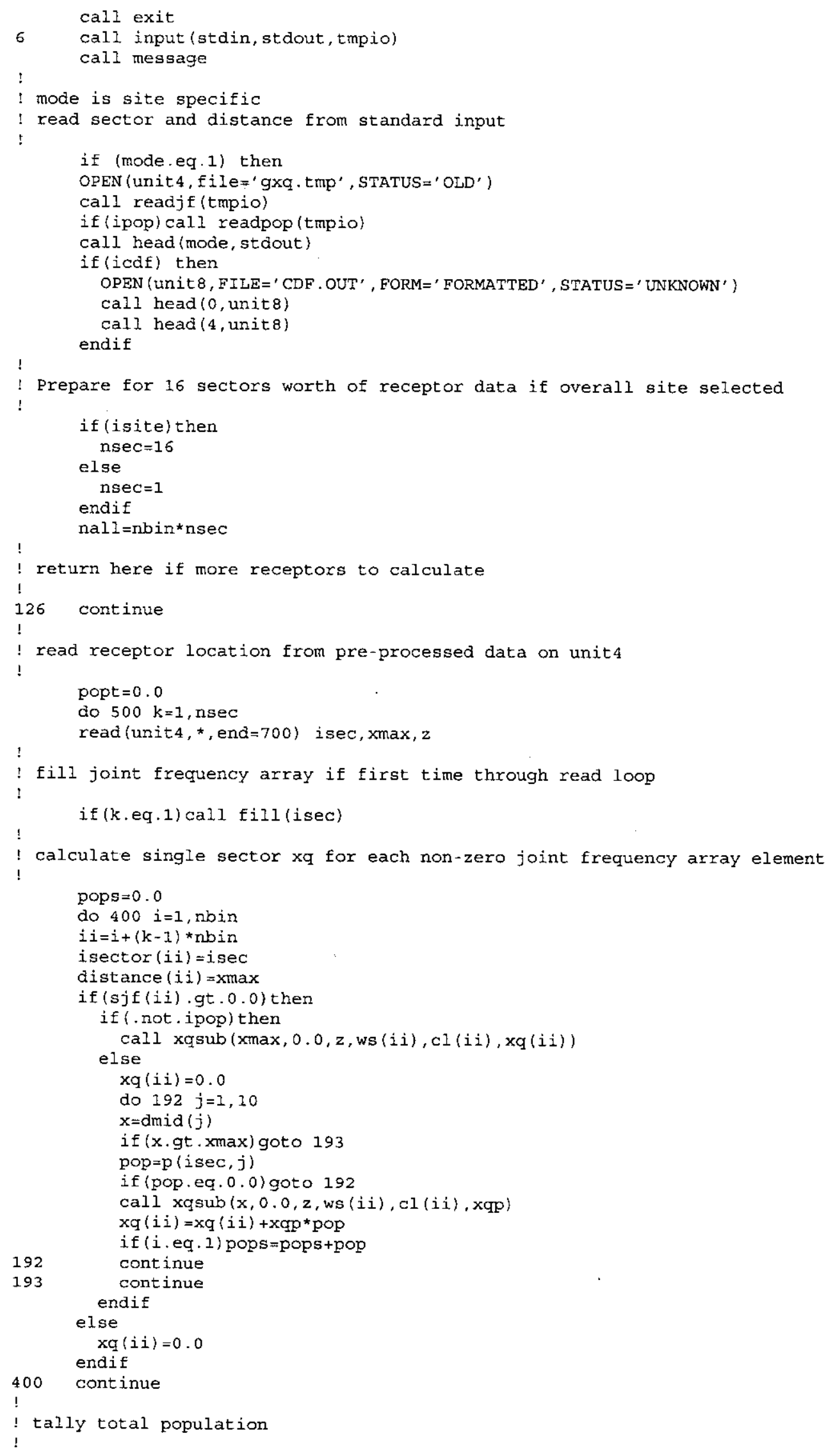




\section{RPP-13482 REV 5}

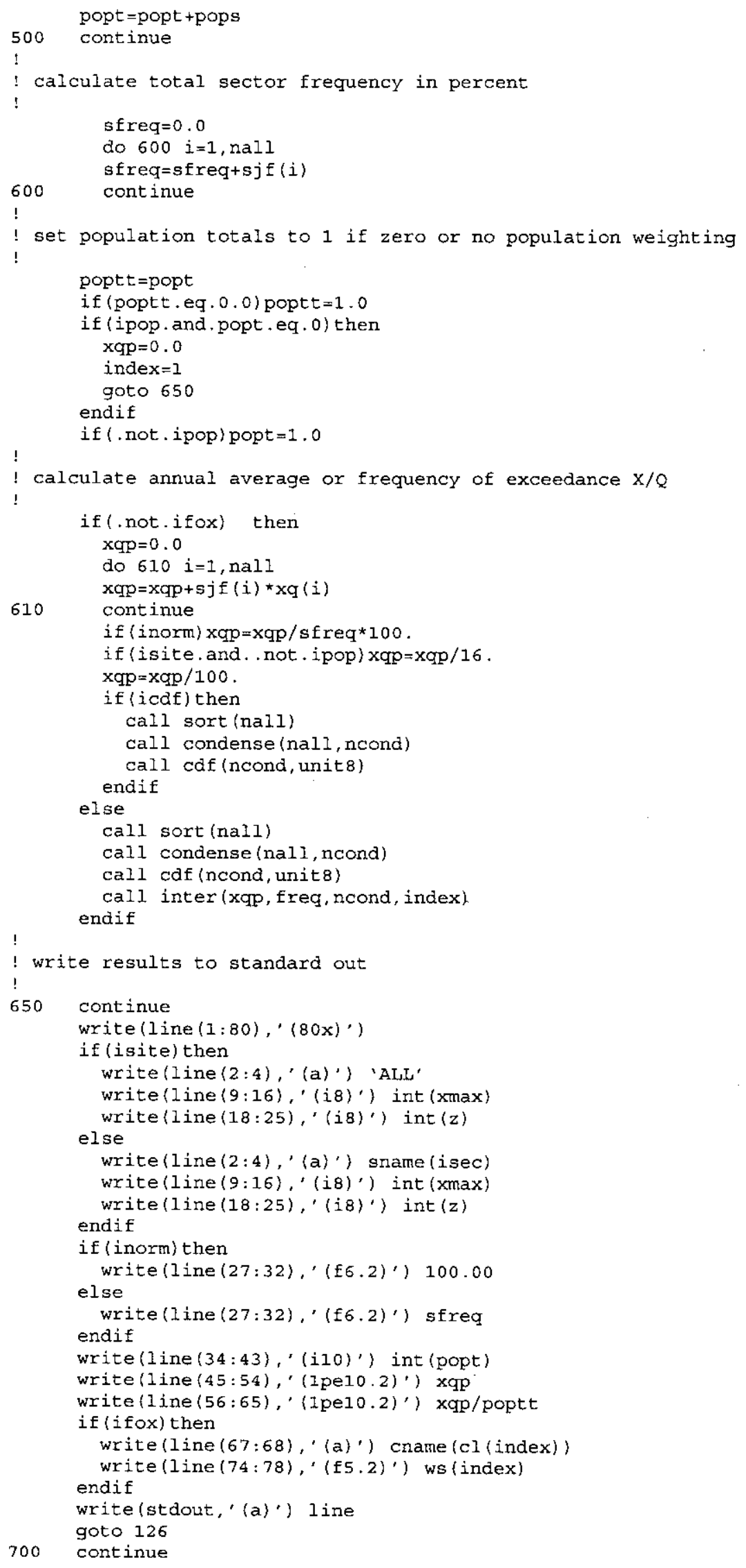




\section{RPP-13482 REV 5}

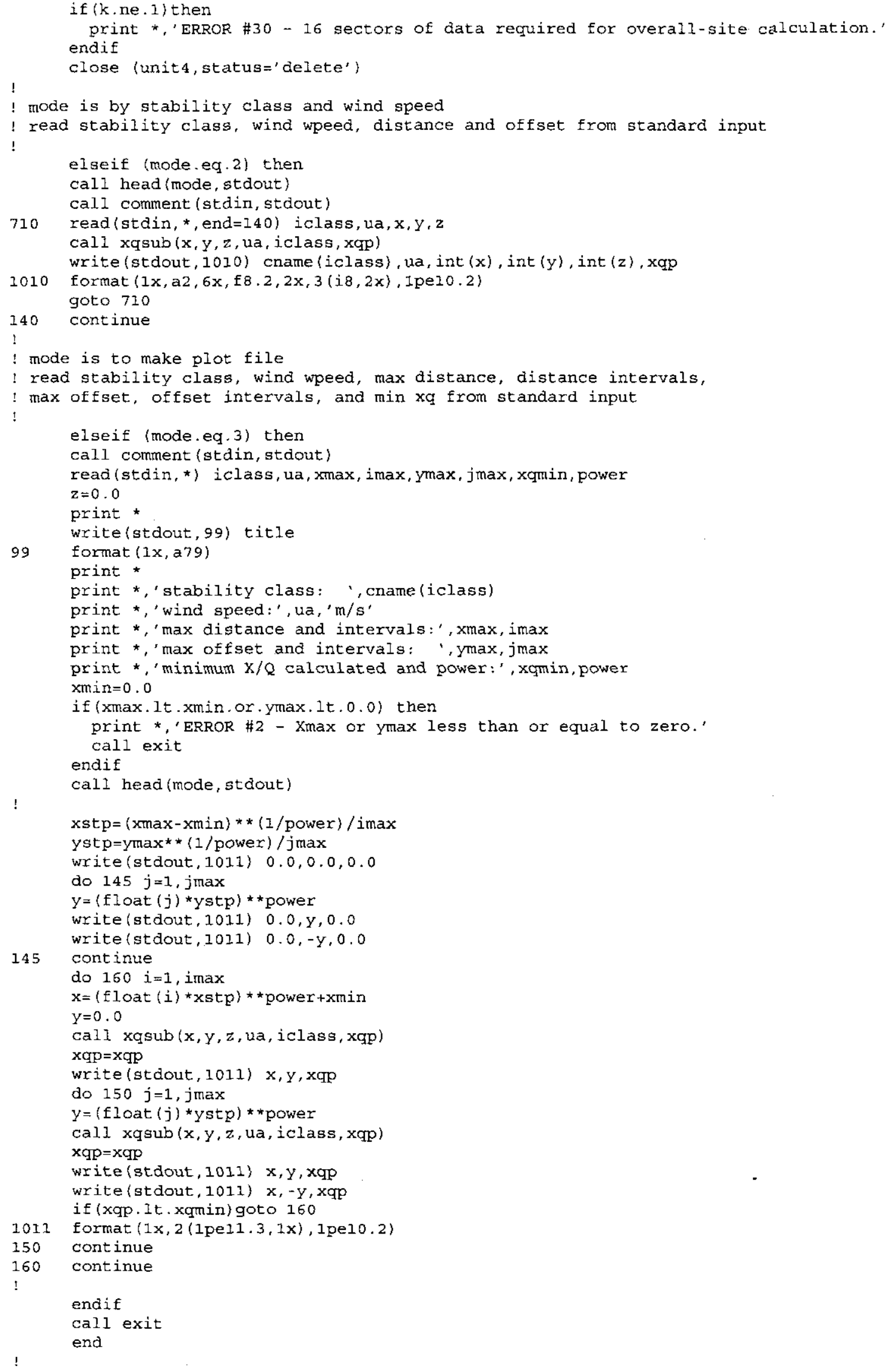




\section{RPP-13482 REV 5}

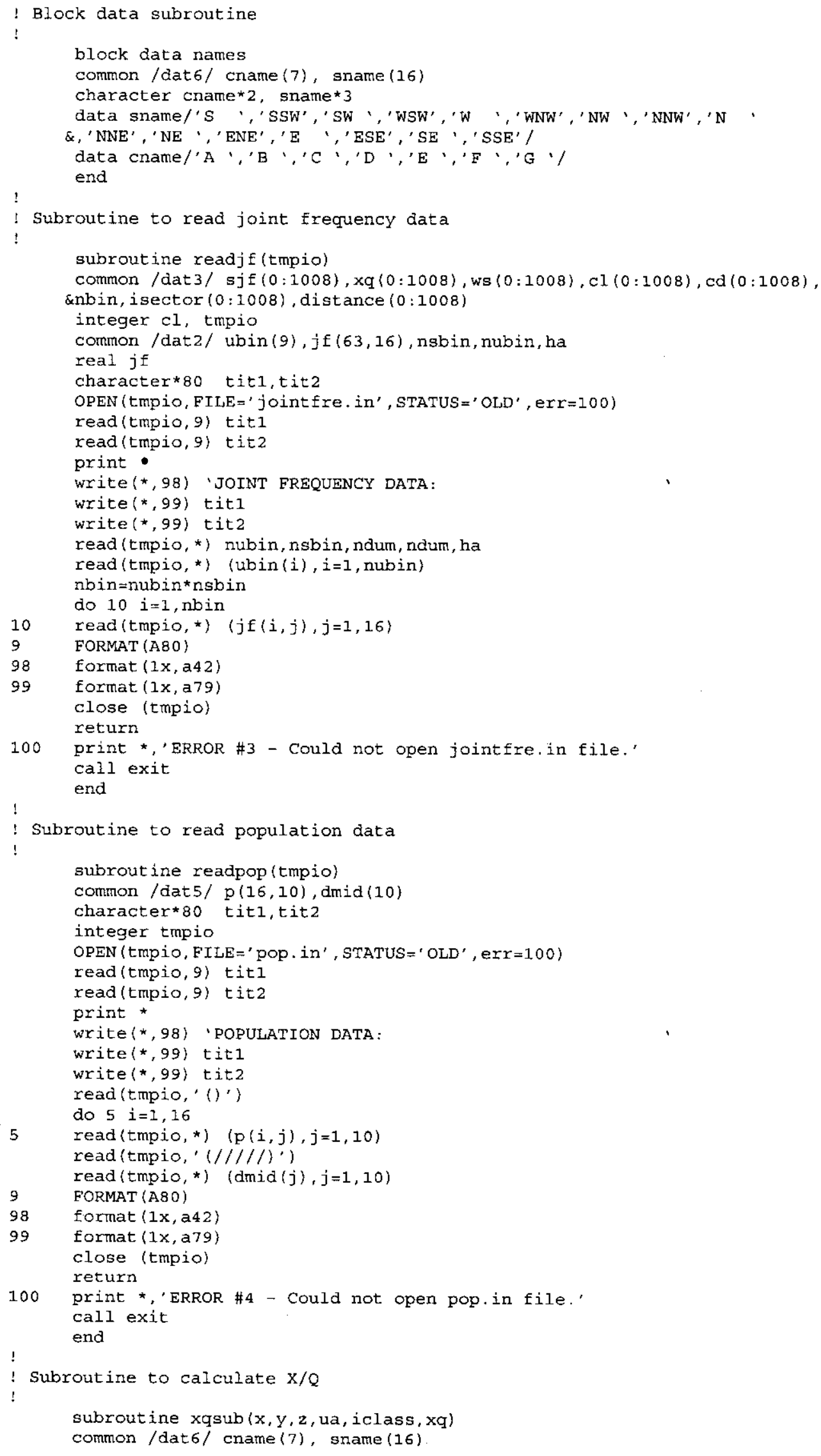




\section{RPP-13482 REV 5}

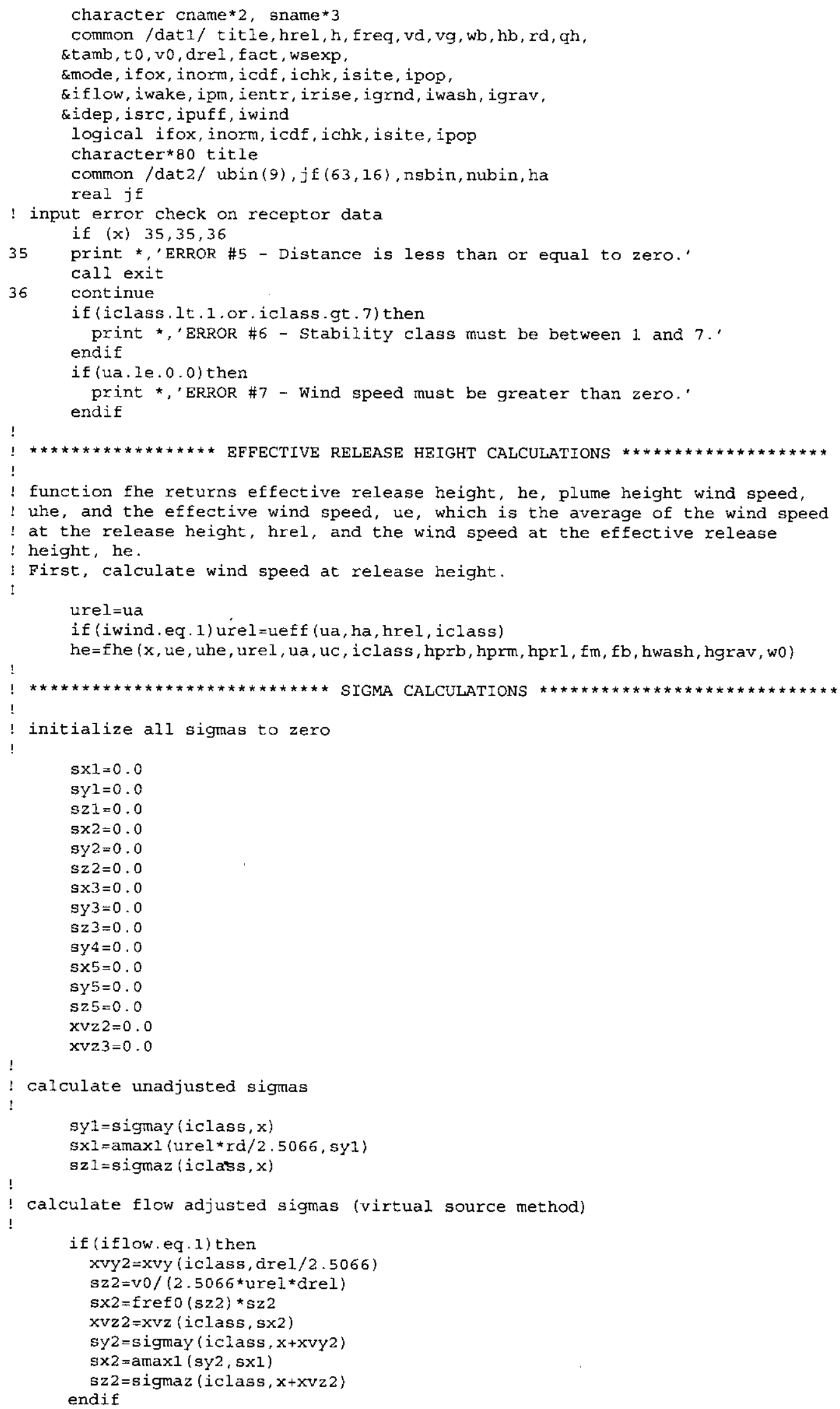




\section{RPP-13482 REV 5}

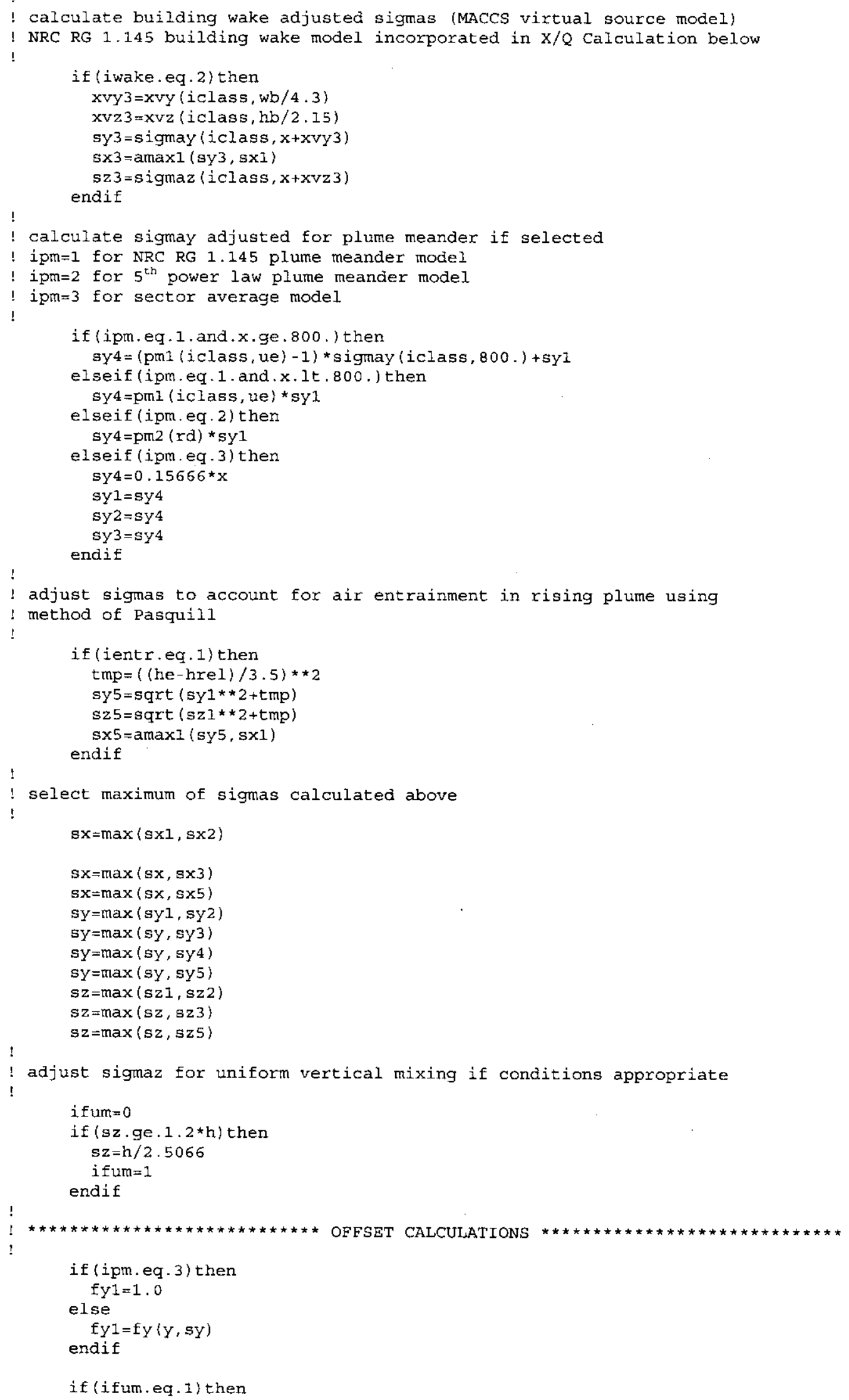




\section{RPP-13482 REV 5}

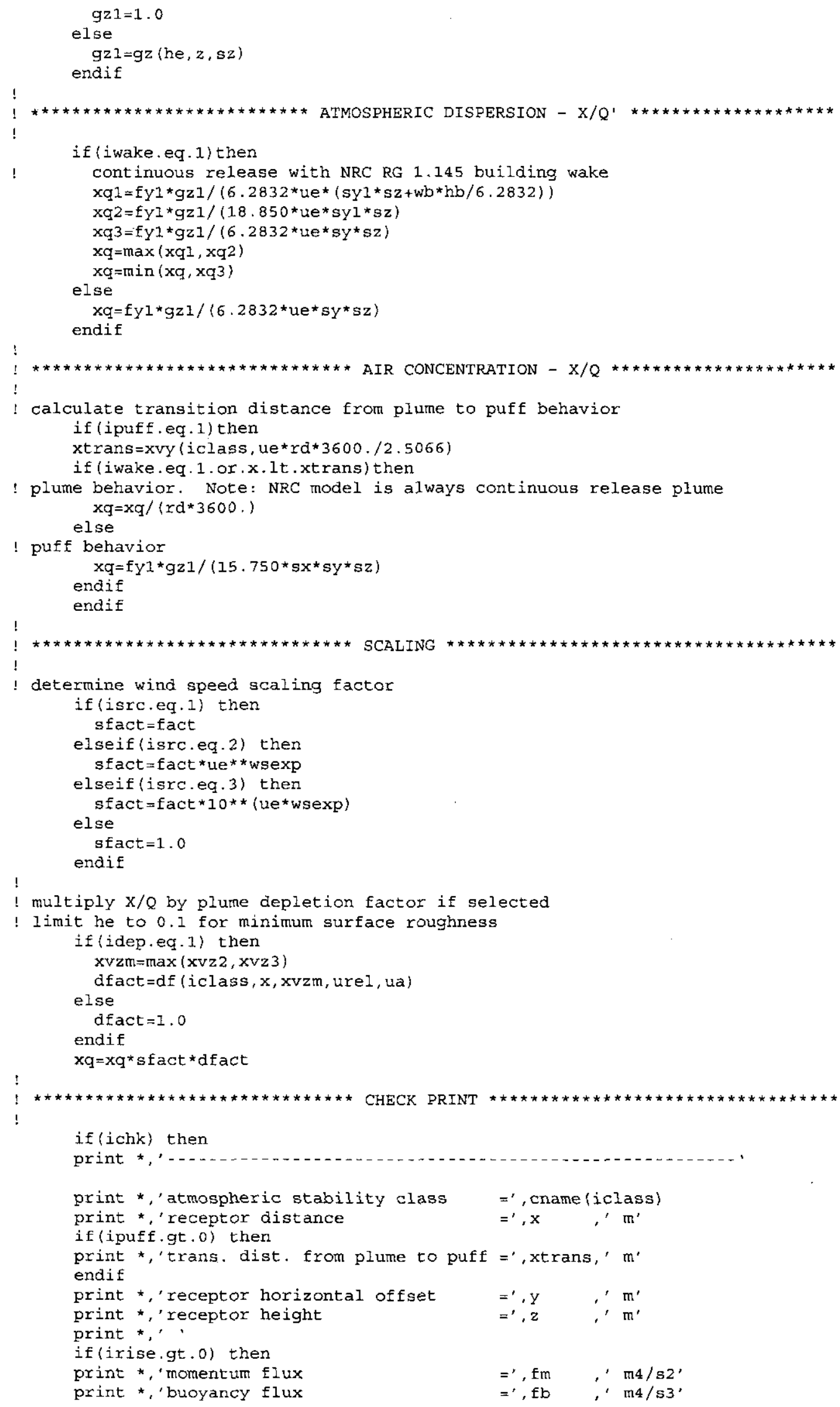




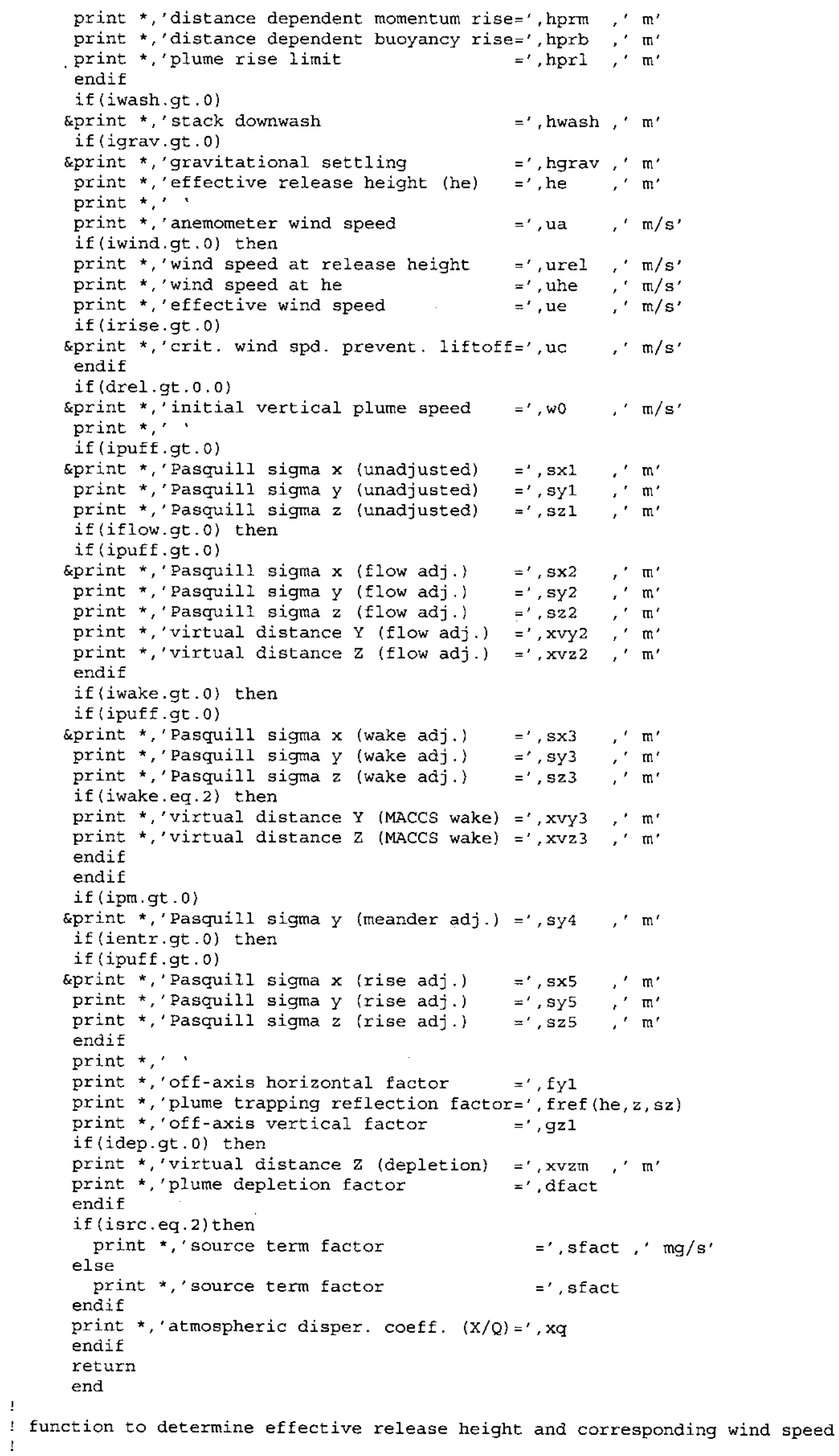




\section{RPP-13482 REV 5}

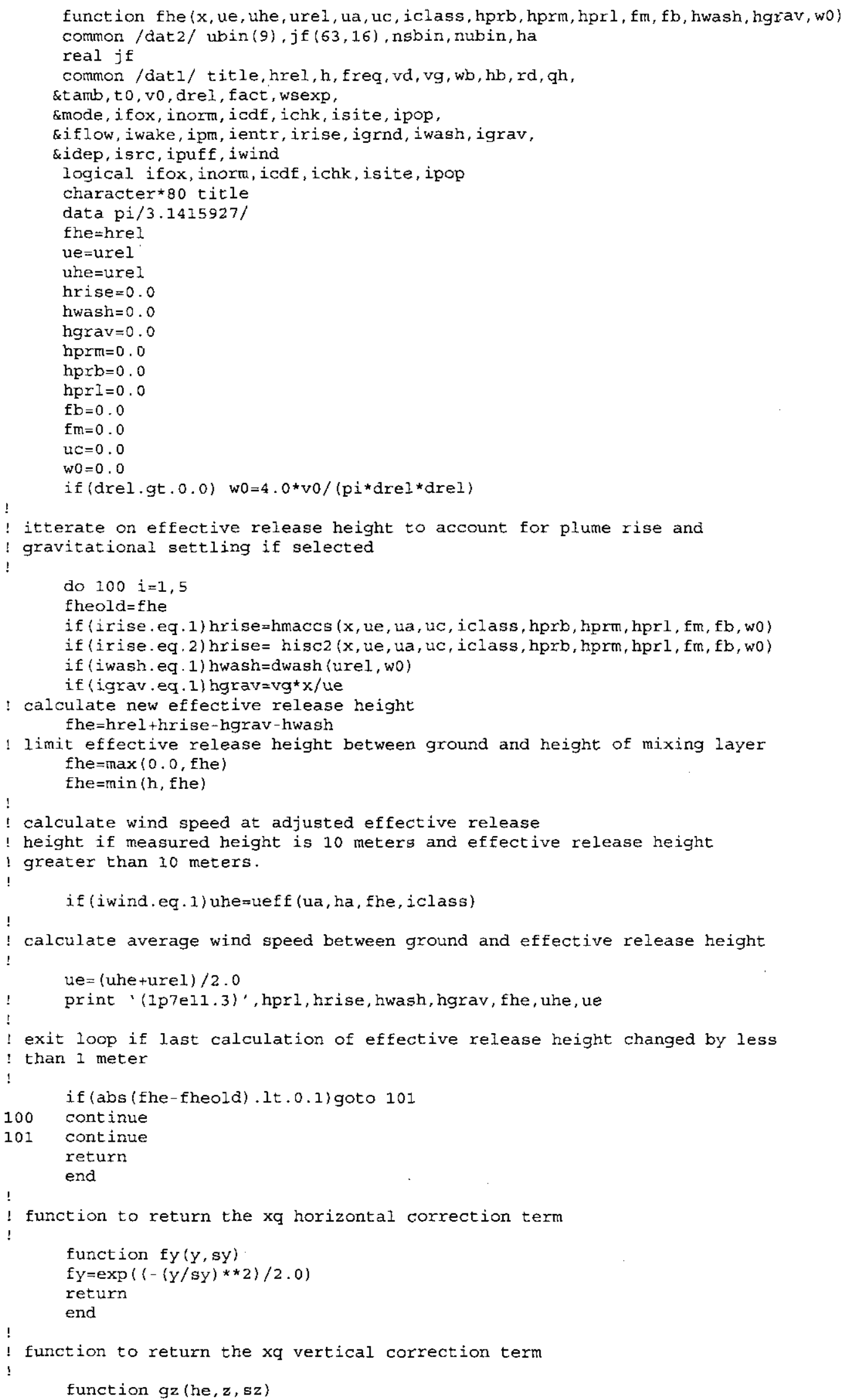




\section{RPP-13482 REV 5}

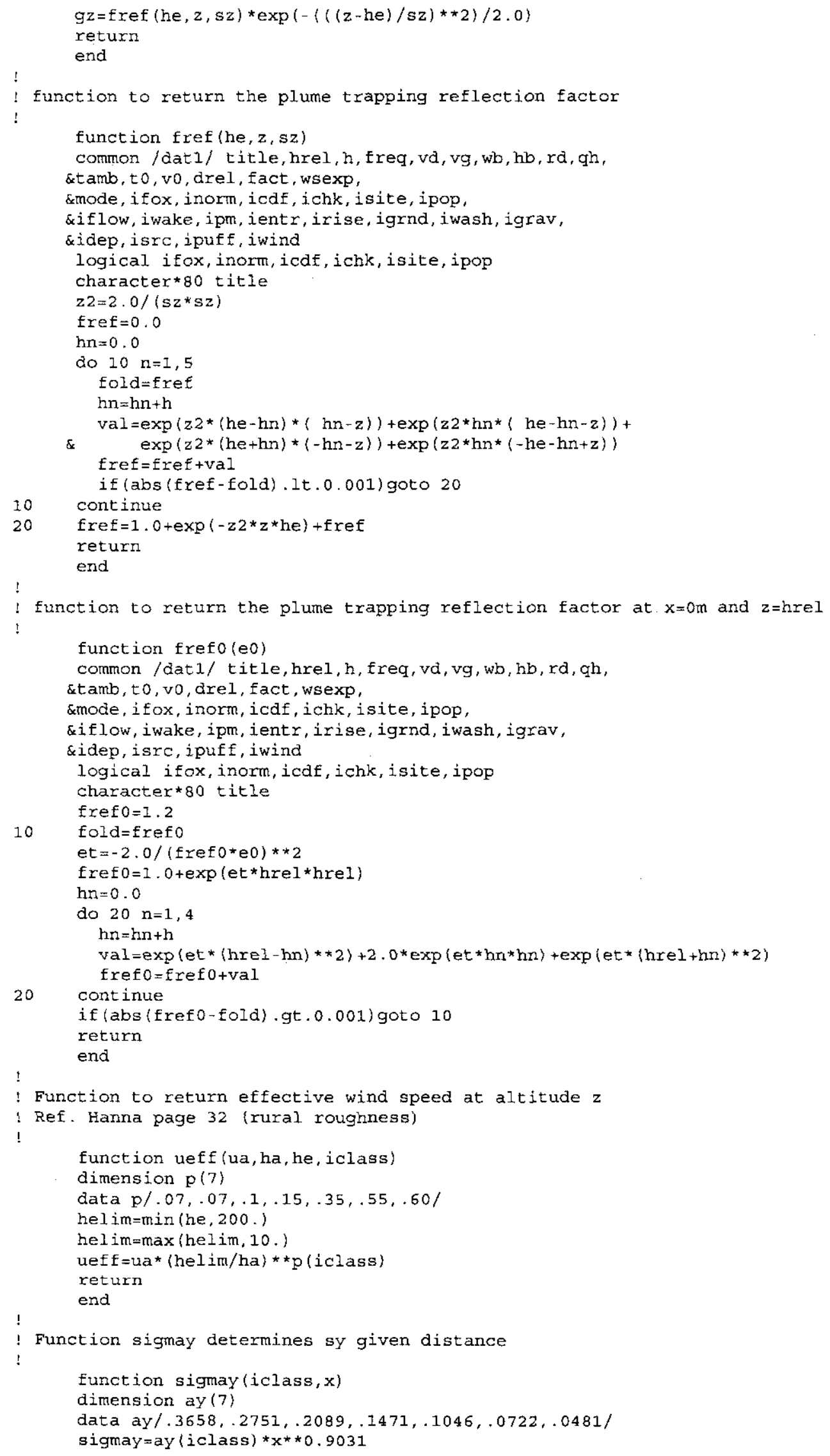


RPP-13482 REV 5

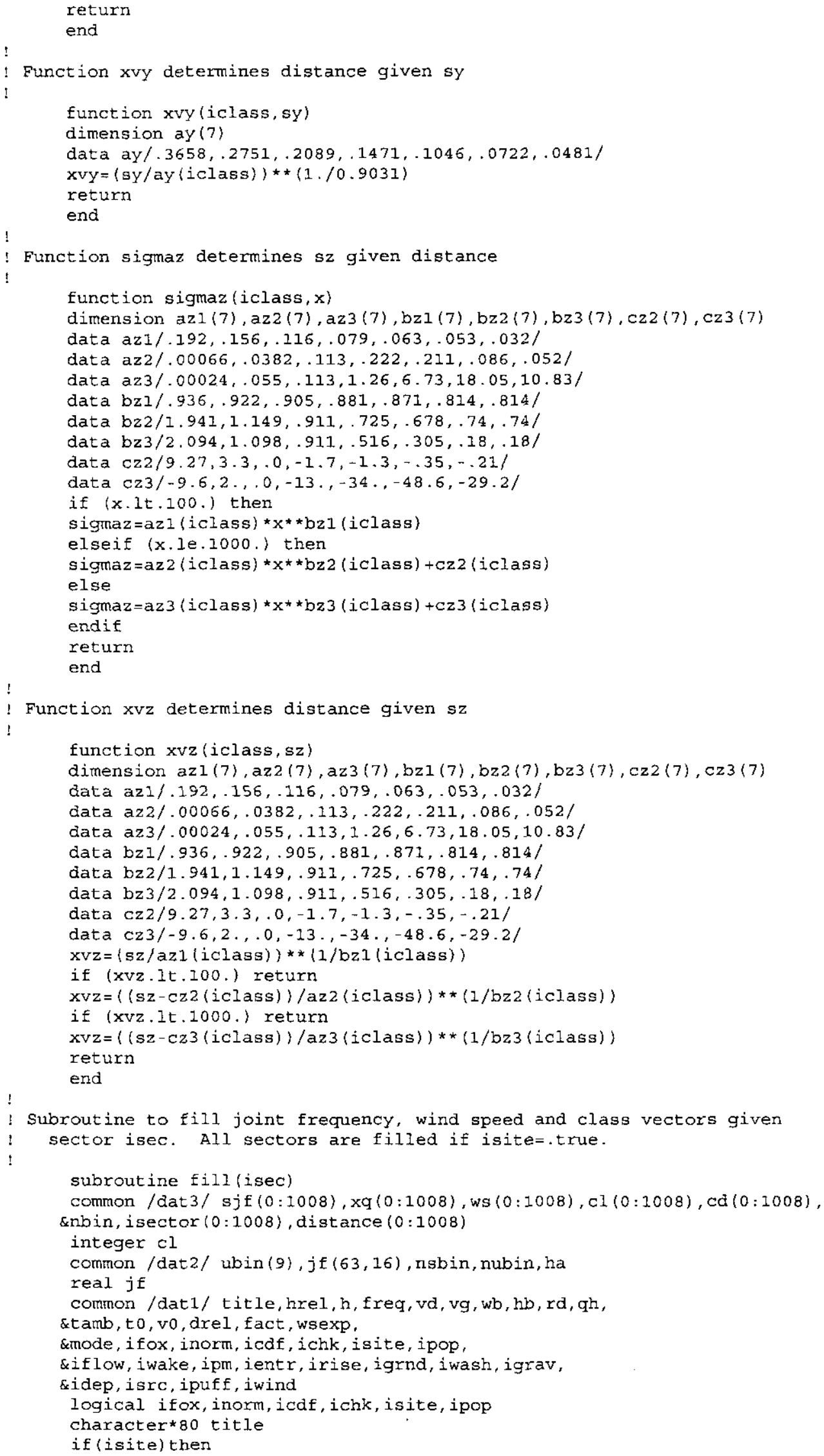




\section{RPP-13482 REV 5}

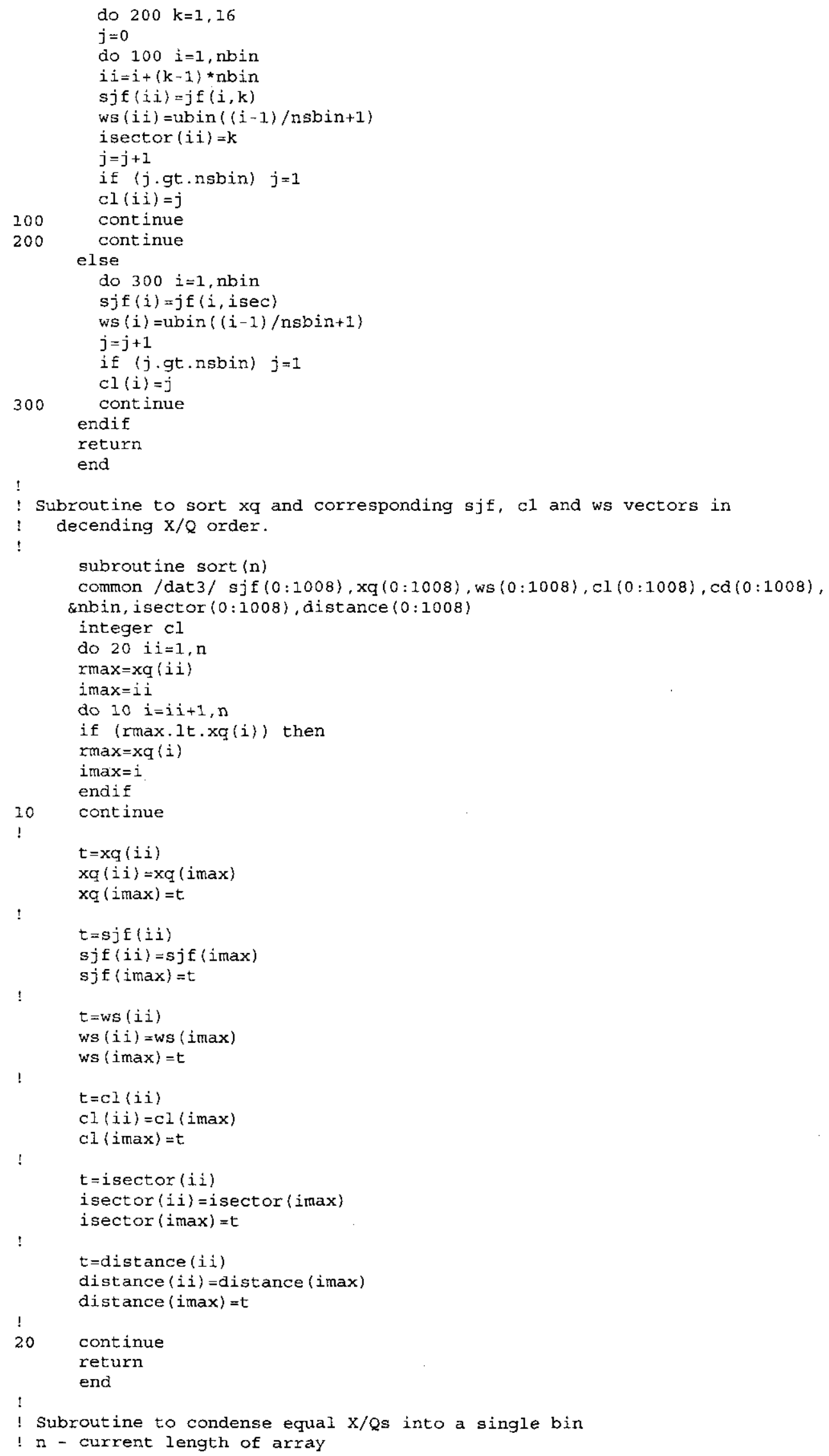




\section{RPP-13482 REV 5}

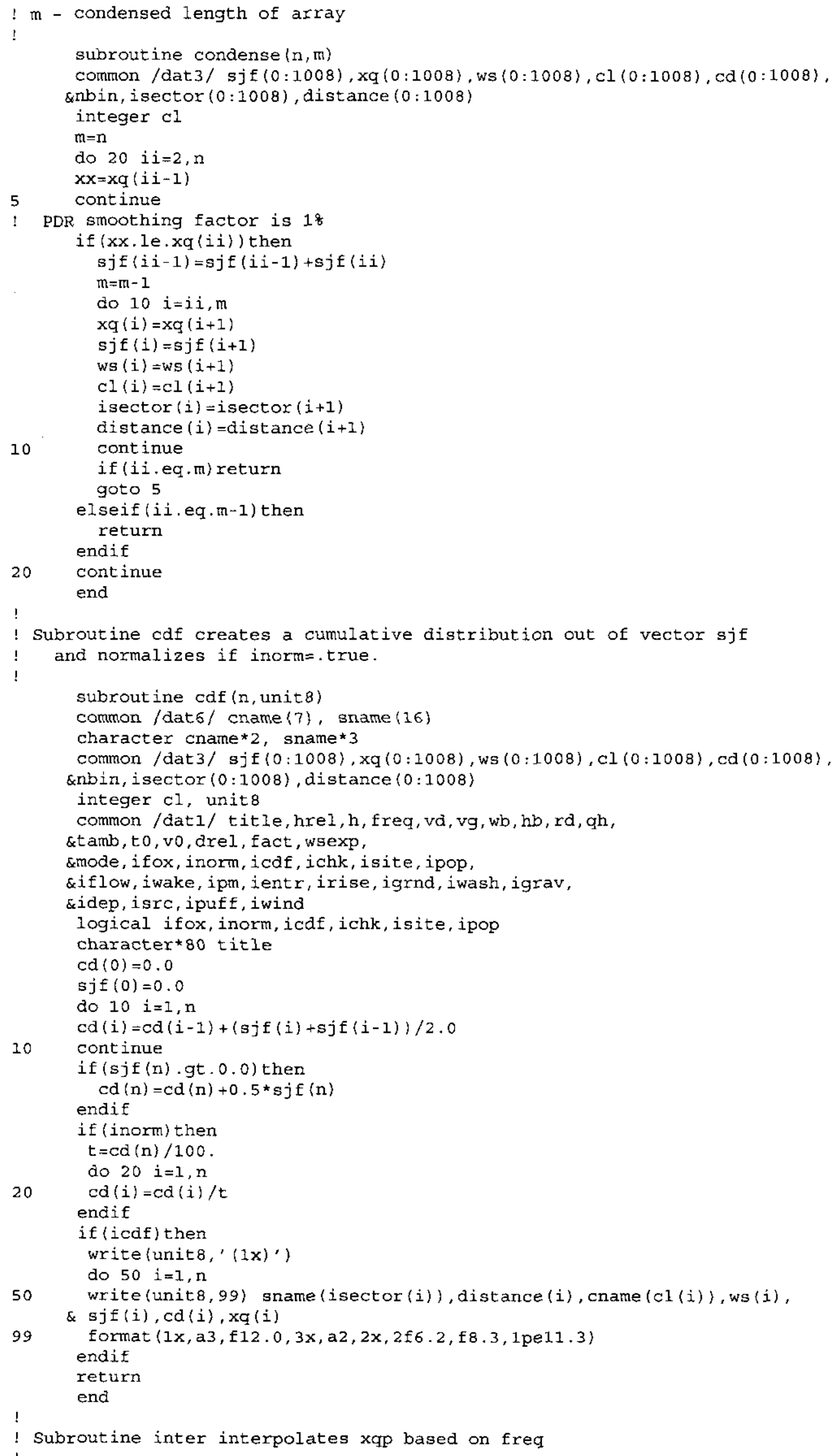




\section{RPP-13482 REV 5}

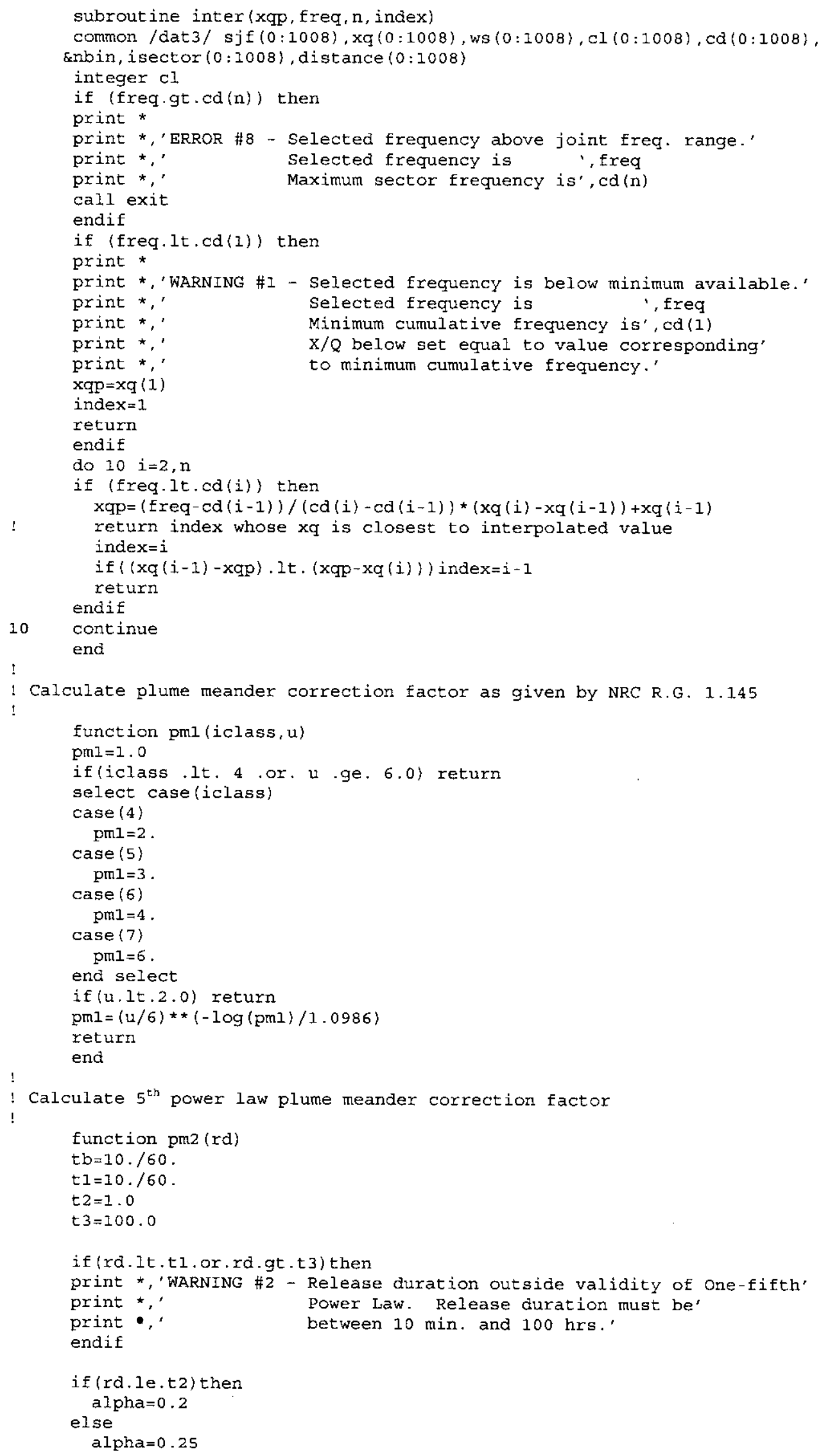




\section{RPP-13482 REV 5}

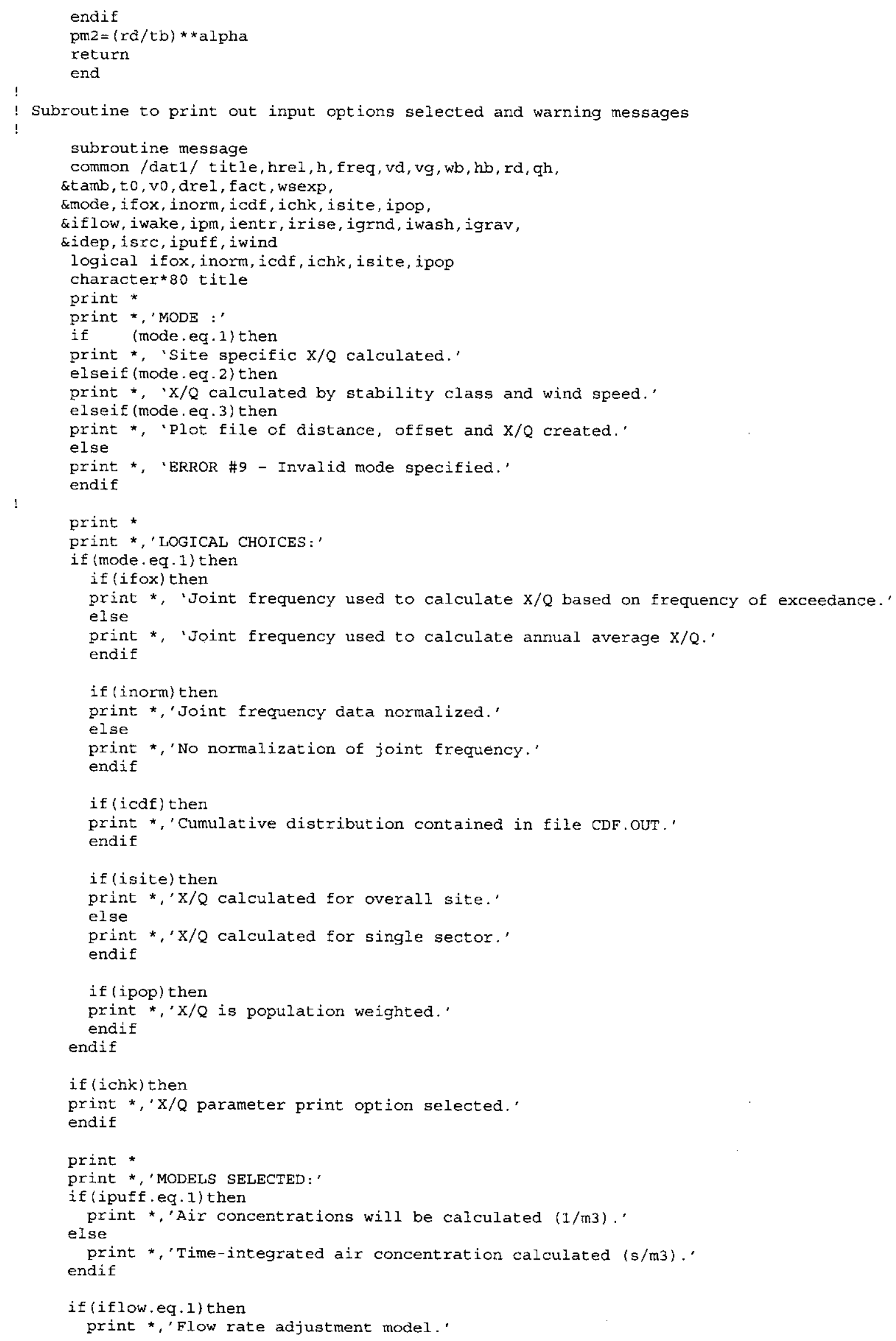




\section{RPP-13482 REV 5}

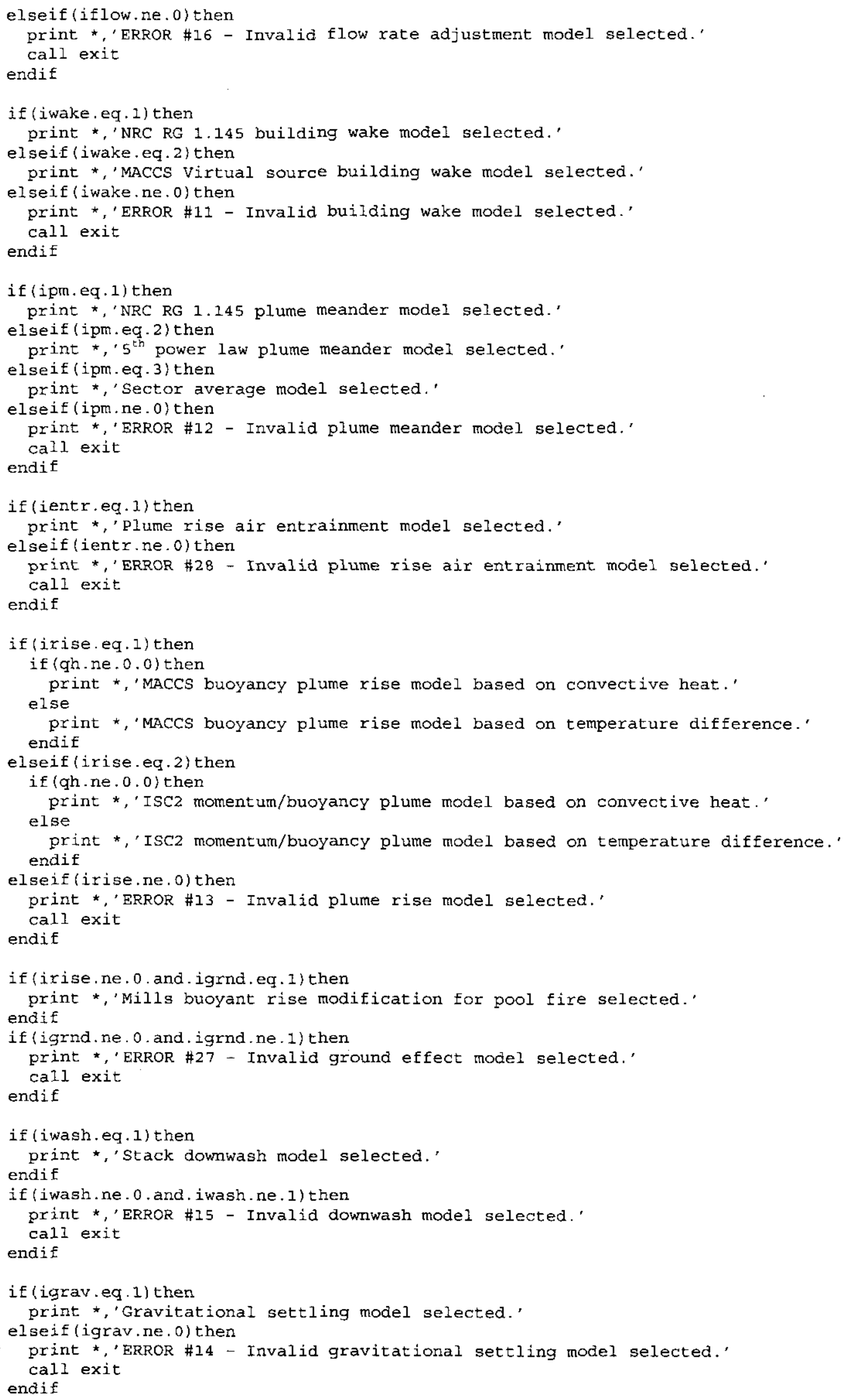




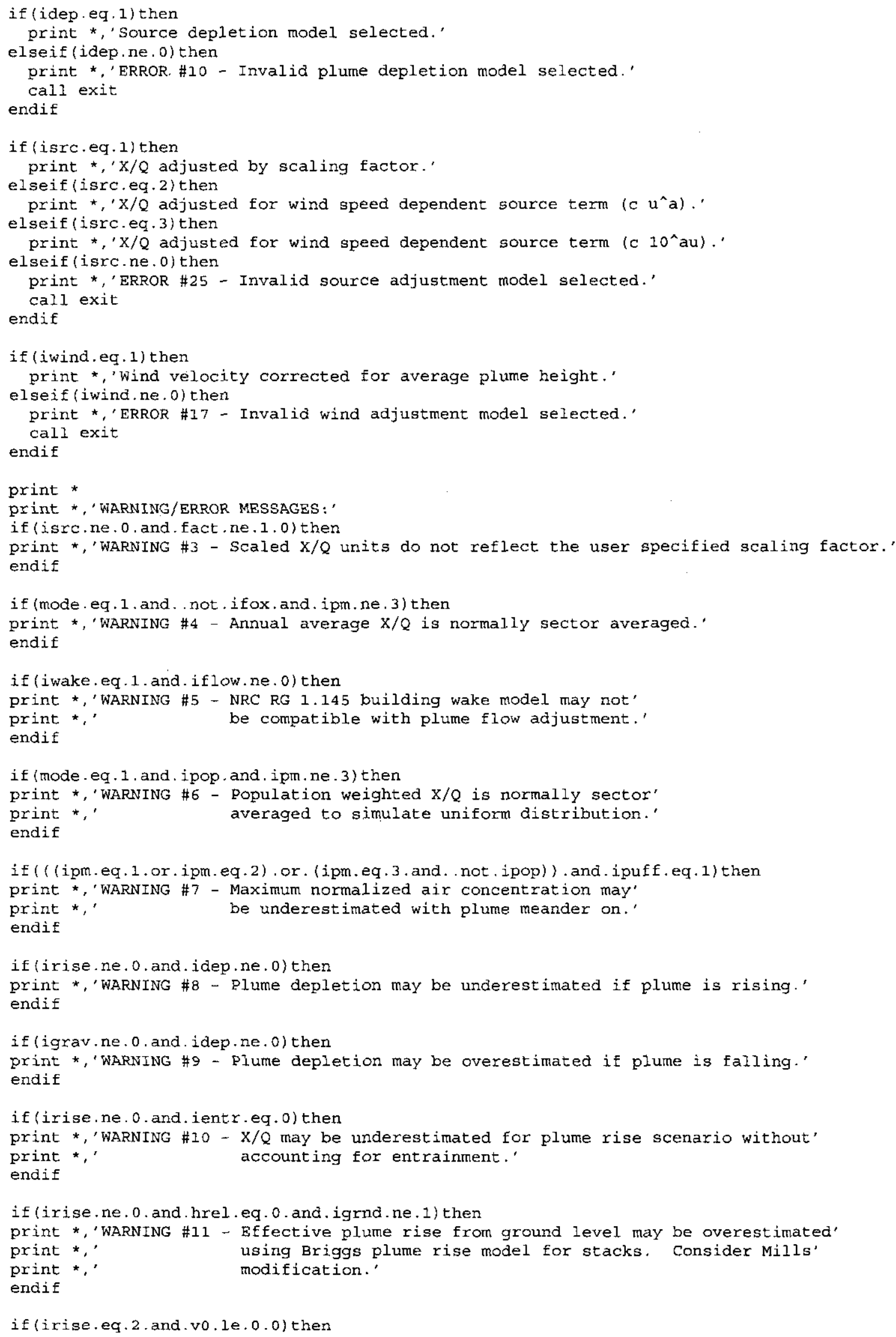




\section{RPP-13482 REV 5}

(vo)

print *,'ERROR \#18 - Momentum rise requires non-zero initial vertical plume flow rate

endif

if (irise.ne.0.and.drel.le.0.0) then

print *,'ERROR \#19 - Plume rise requires non-zero release diameter (d).'

call exit

endif

if (iwash.ne.0.and.drel.le.0.0) then

print *,'ERROR \#20 - Stack down wash requires non-zero release diameter (d).'

call exit

endif

if (iflow. ne.0.and.drel.le.0.0) then

print *,'ERROR \#21 - Flow adjustment requires non-zero release diameter (d).' call exit

endif

if (isrc.eq. 2 . and.ipuff.eq.1) then

print *,'ERROR \#26 - Evaporation model inconsistent with puff source.'

call exit

endif

if (iwake.eq.1.and.ipuff.eq.1.and.rd.eq.0) then

print *,'ERROR \#23 - puff model requires non-zero release duration.'

call exit

endif

if (hrel.gt.h) then

print *,'ERROR \#29 - Code does not handle releases above mixing layer.'

call exit

endif

return

end

! Subroutine head prints output headers

subroutine head $(\mathrm{n}, \mathrm{i})$

common /dat1/ title, hrel, h, freq, vd, vg, wb, hb, rd, qh,

\&tamb, to , vo, drel, fact, wsexp,

\&mode, ifox, inorm, icdf, ichk, isite, ipop,

\&iflow, iwake, ipm, ientr, irise, igrnd, iwash, igrav,

sidep, isrc, ipuff, iwind

logical ifox, inorm, icdf, ichk, isite, ipop

character $* 80$ title

character $\star 80$ line

character $* 11$ ctime

character*8 ciate

if (n.gt.0) write(i, $(/ /, 1 x, a, /)$ ') title

if $(\mathrm{n} . \mathrm{eq} .0)$ then

write $(i, 900)$

format

$\& /$,

\&/"

$\& / \prime$

$\& /{ }^{\prime}$

$\& /$,

$\& /$,

\&/' General Purpose Atmospheric Dispersion Code

\&/" Produced by Fluor Federal Services, Inc.

$\& /$, ,

\&/' Users Guide documented in WHC-SD-GN-SWD-30002 Rev. 1. '

$\& /$ "Validation documented in WHC-SD-GN-SWD-30003 Rev. 1 . '

\&/" Code Custodian is: Paul D. Rittmann, PhD CHP

\& ${ }^{\prime} \quad$ Fluor Fedexal Services, Inc. E6-17'

$\& / . \quad$ p.o. Box 1050

\&/. Richland, WA 99352-1050

\&/. (509) $376-8715$ 


\section{RPP-13482 REV 5}

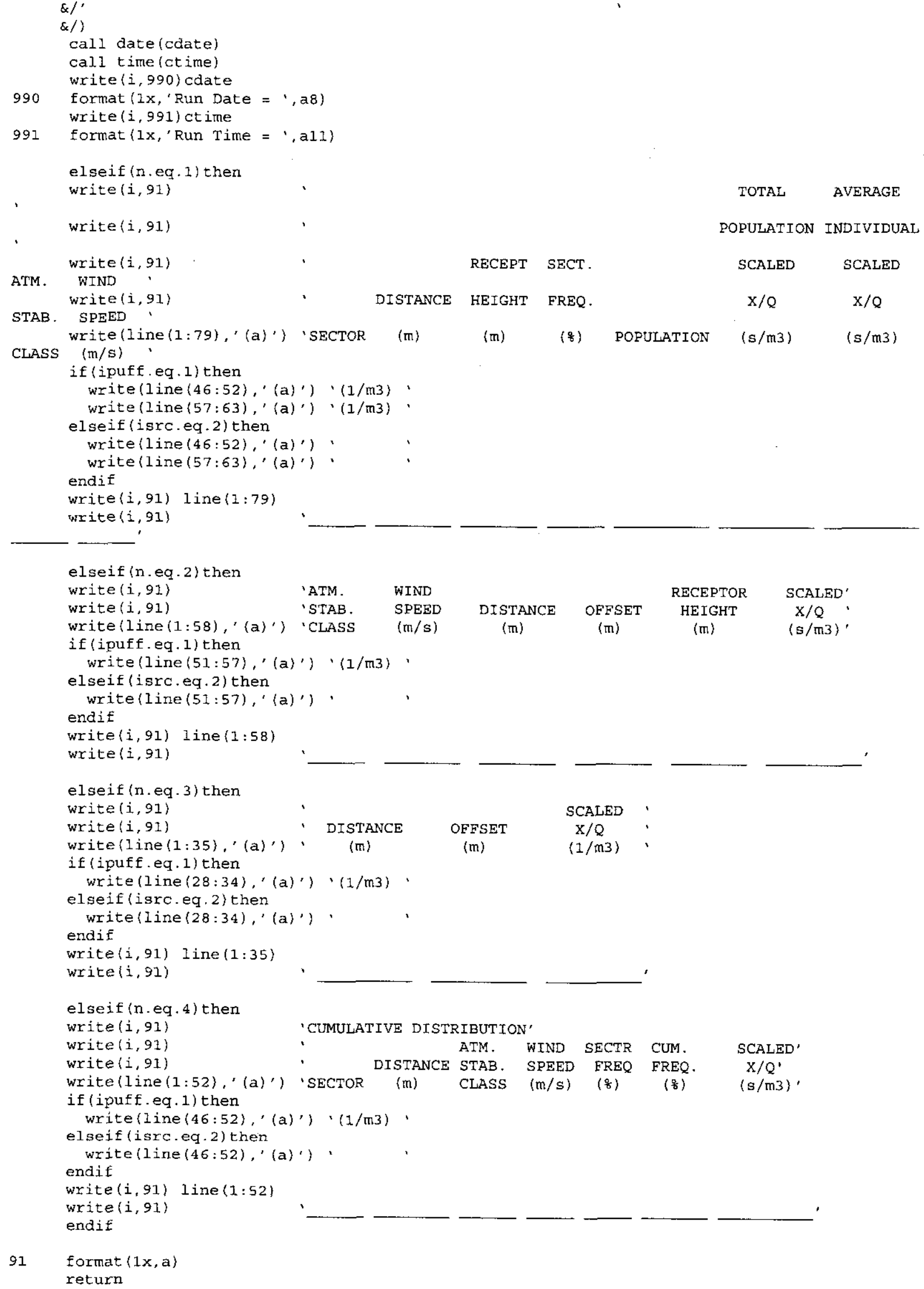

RP 


\section{RPP-13482 REV 5}

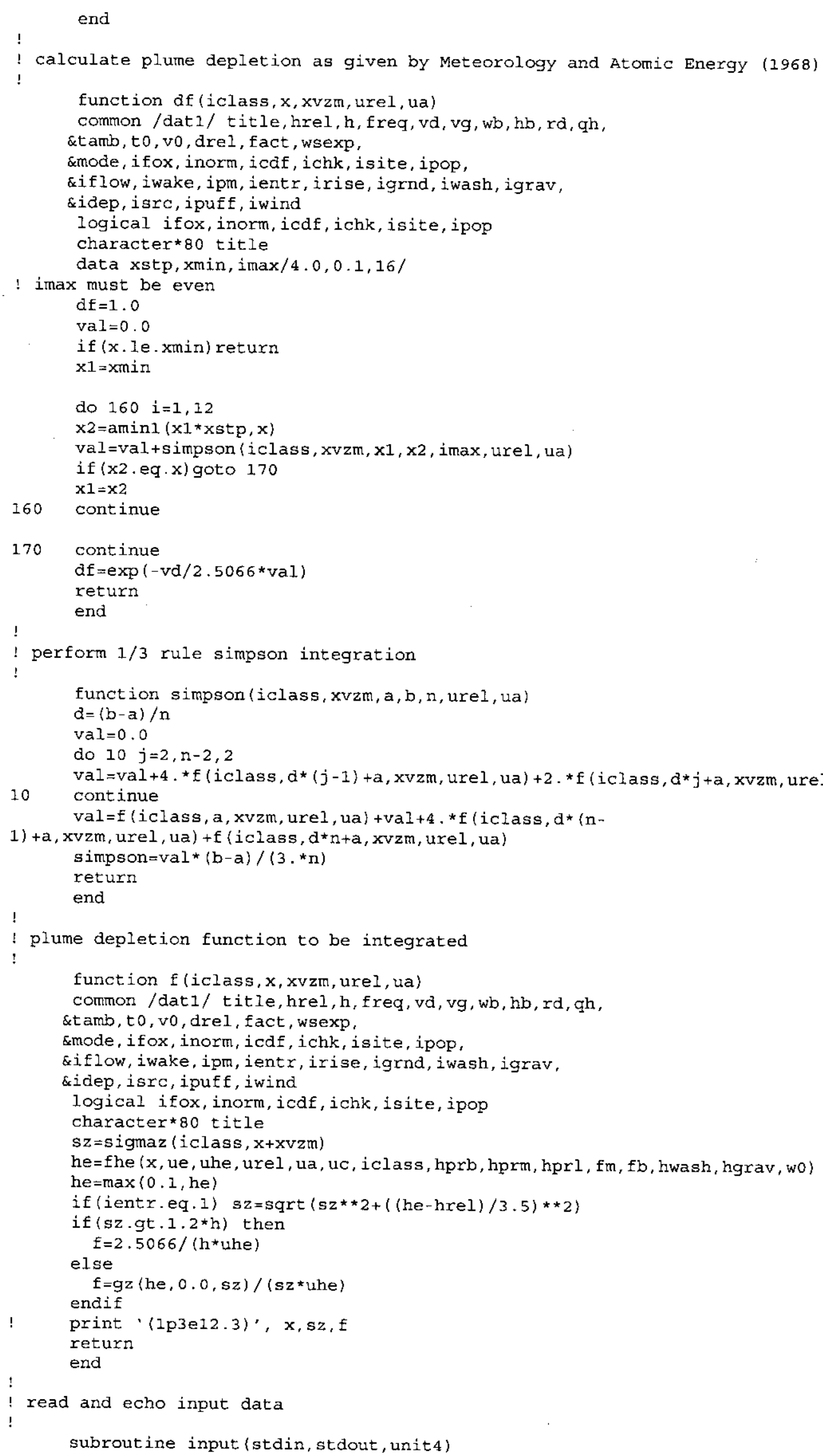




\section{RPP-13482 REV 5}

common /dat2/ ubin(9), jf(63,16), nsbin, nubin, ha

real jf

common /datl/ title, hrel, h, freq, vd, vg, wb, hb, rd, qh,

\&tamb, to, vo, drel, fact, wsexp,

smode, ifox, inorm, icdf, ichk, isite, ipop.

\&iflow, iwake, ipm, ientr, irise, igrnd, iwash, igrav,

\&idep, isre, ipuff, iwind

logical ifox, inorm, icdf, ichk, isite, ipop

character $* 80$ title

integer stdin, stdout, unit 4

write (stdout, '(/)')

write (stdout, 98)

format ( $1 \mathrm{x}$, 'INPUT ECHO:')

read(stdin, 9) title

FORMAT (A80)

write (stdout, 99) title

format (1x, a 79)

call comment (stdin, stdout)

read (stdin, *) mode

write (stdout, 91) mode

call comment (stdin, stdout)

read (stdin, *) ifox, inorm, icdf, ichk, isite, ipop

write (stdout, 92) ifox, inorm, icdf, ichk, isite, ipop

call comment (stdin, stdout)

read (stdin, *) ipuff, idep, isrc, iwind

write (stdout, 93) ipuff, idep, isre, iwind

call comment (stdin, stdout)

read (stdin, *) iwake, ipm, iflow, ientr

write (stdout, 93) iwake, ipm, iflow, ientr

call comment (stdin, stdout)

read (stdin, *) irise, igrnd, iwash, igrav

write (stdout, 93) irise, igrnd, iwash, igrav

91 format $(5 \mathrm{x}$, i1)

92 format $(5 x, 12(11,5 x))$

93 format $\langle 5 x, 12(i 1,5 x)\}$

call comment (stdin, stdout)

read (stdin, *) hrel, ha, h, freq

write (stdout, 1000) hrel, ha, h, freq

call comment (stdin, stdout)

read(stdin, *) wb, hb, rd, vd, vg

write (stdout, 1000) wb, hb, rd, vd, vg

call comment (stdin, stdout)

read (stdin, *) tamb, to, vo, drel, qh

write (stdout, 1000) tamb, to, vo, drel, gh

call comment (stdin, stdout)

read $(\operatorname{stain}, *) \quad$ fact, wsexp

write (stdout, 1000) fact, wsexp

call comment (stdin, stdout)

1000 format $(3 x, 6(1$ pel $3,5,2 x))$

! Unit changes

tamb=tamb +273.0

to $=$ to $0+273.0$

!

! For mode 1 allow zero entries as input shortcut meaning all sectors

1

if (mode.eq.1) then

OPEN (unit4, file='gxq.tmp', STATUS= 'UNKNOWN')

$100 \quad$ read (stdin, *, err $=102$, end $=200$ ) isec, $x$ max, $z$

GOTO 104

102 print *,'ERROR \#24 - GXQ encountered an error reading the receptor location data.'

line."

print *,

Most likely this is caused by a carriage return after the last

CONTINUE

if (isec.1t.0.or. isec.gt. I6) then

print *,'ERROR \#22 - Sector must be an integer from 0 to $16 . '$

call exit

endif

if (isec.eq. 0) then 


\section{RPP-13482 REV 5}

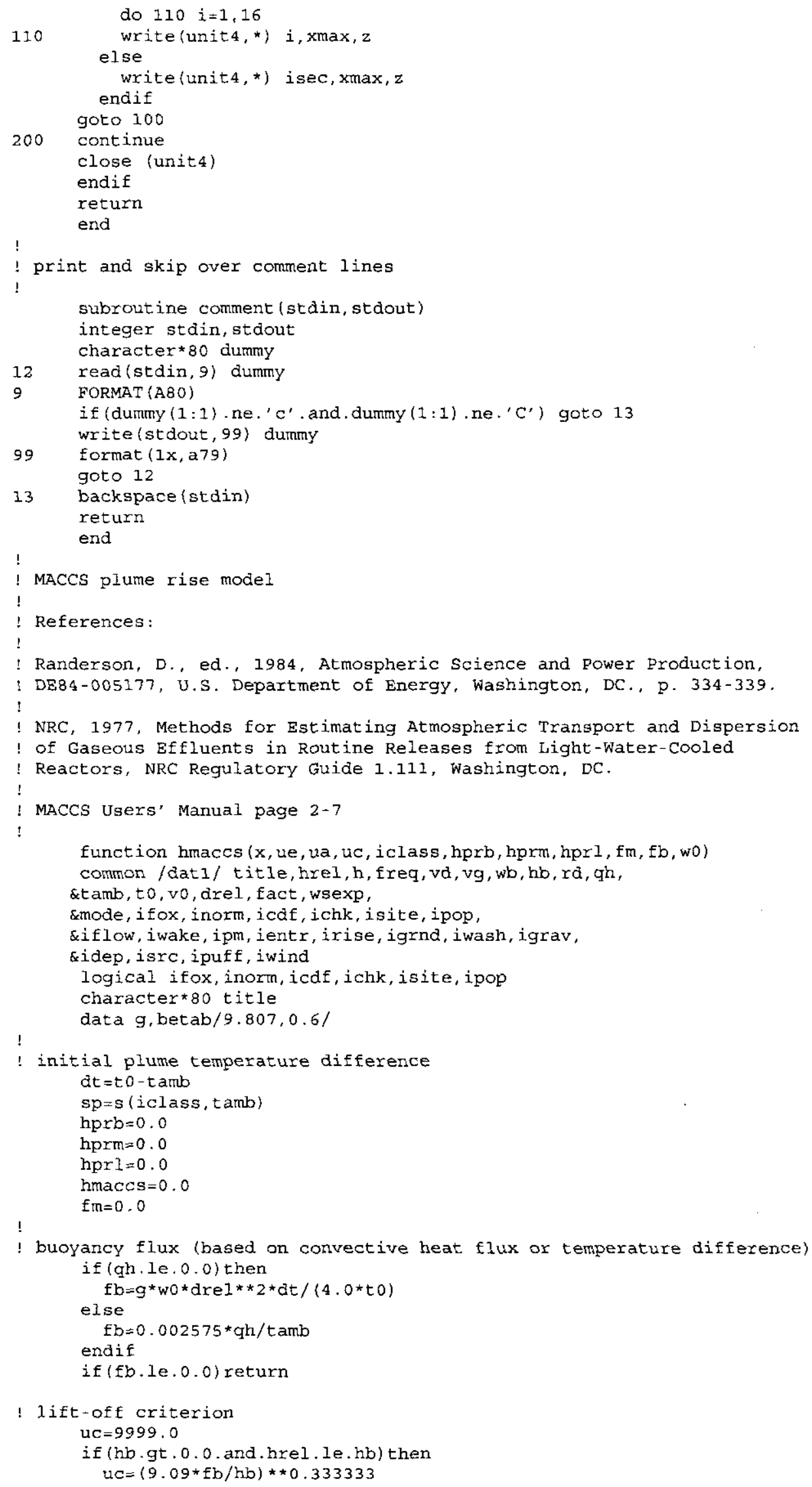




\section{RPP-13482 REV 5}

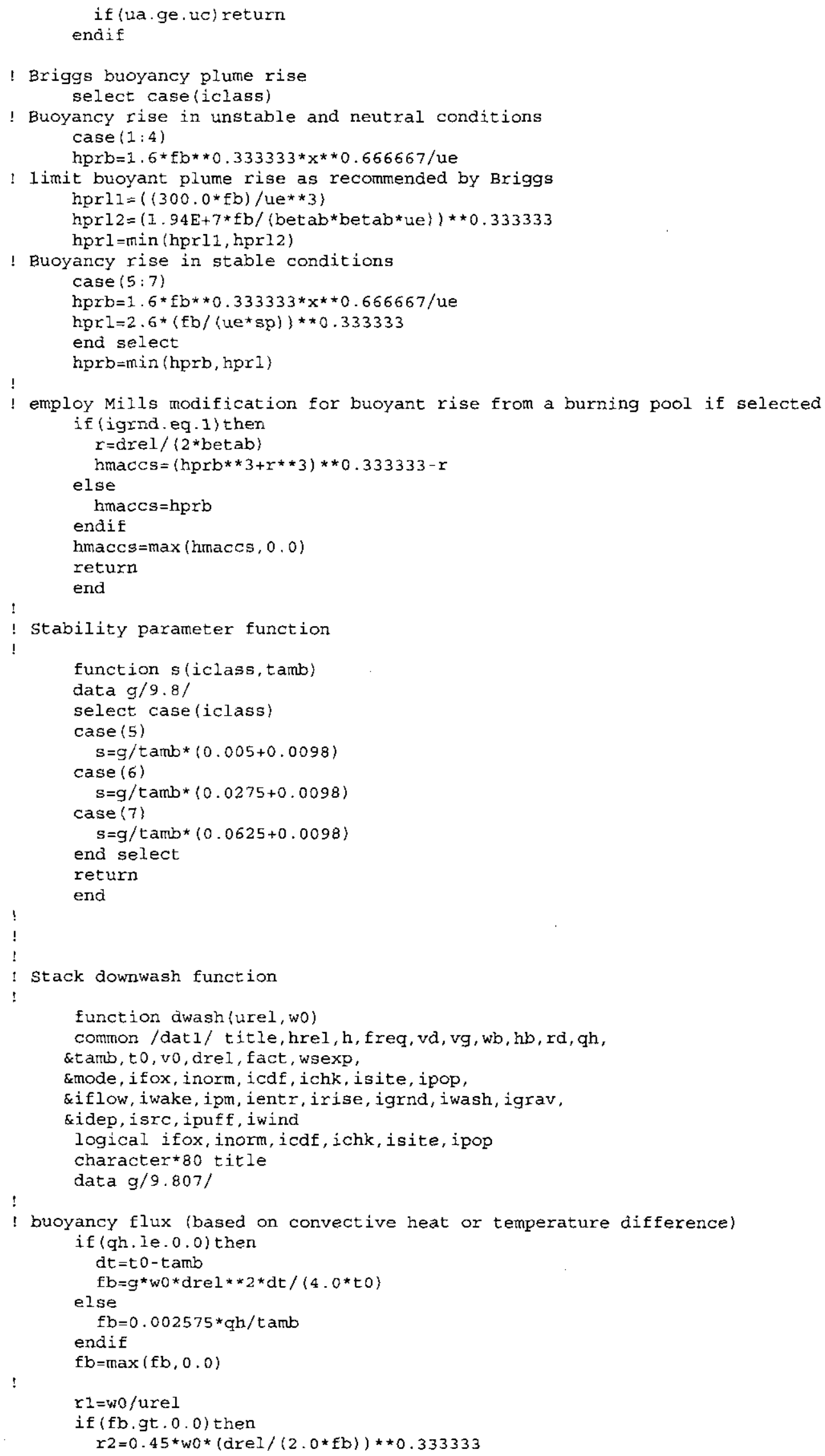




\section{RPP-13482 REV 5}

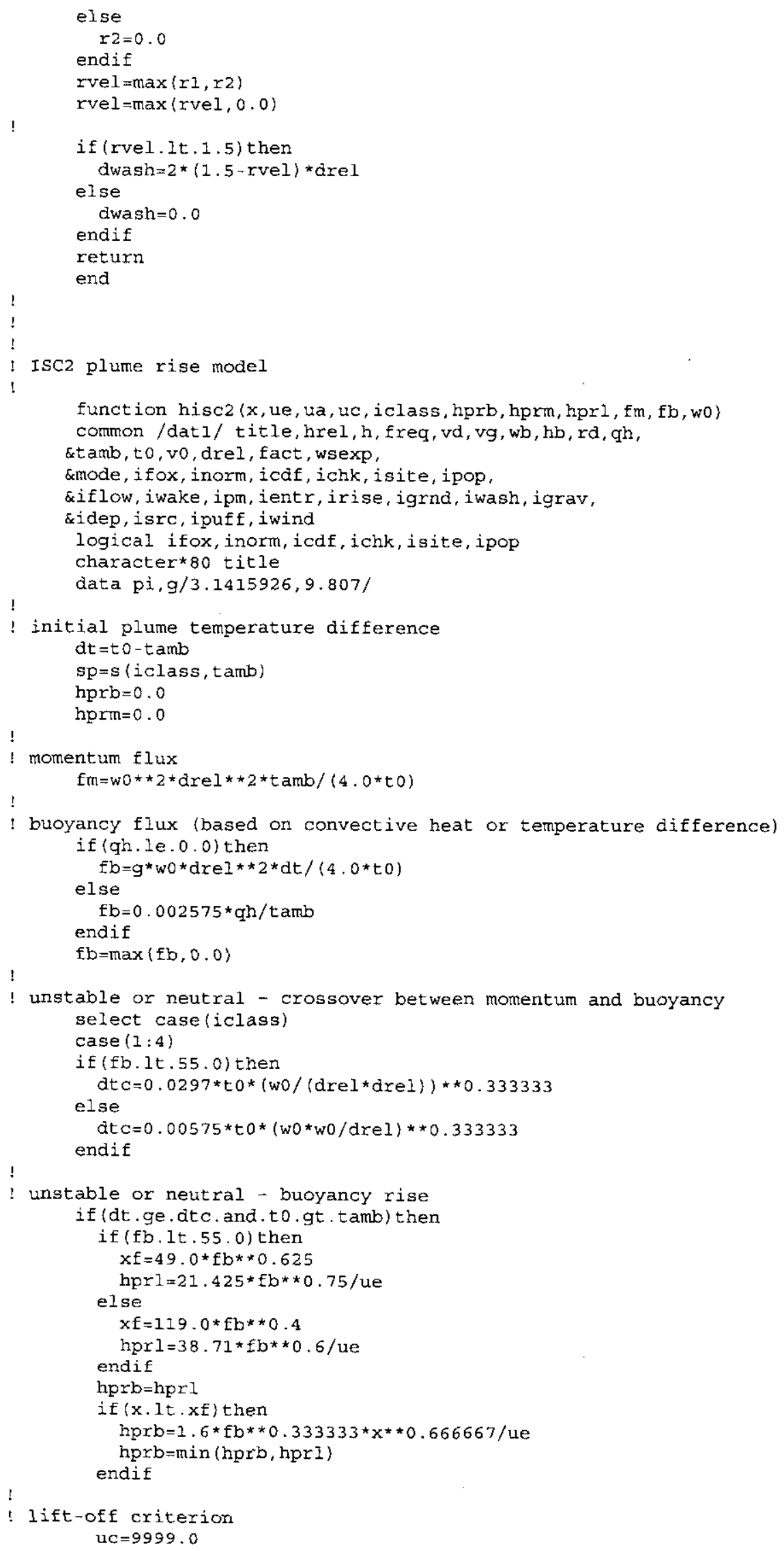




\section{RPP-13482 REV 5}

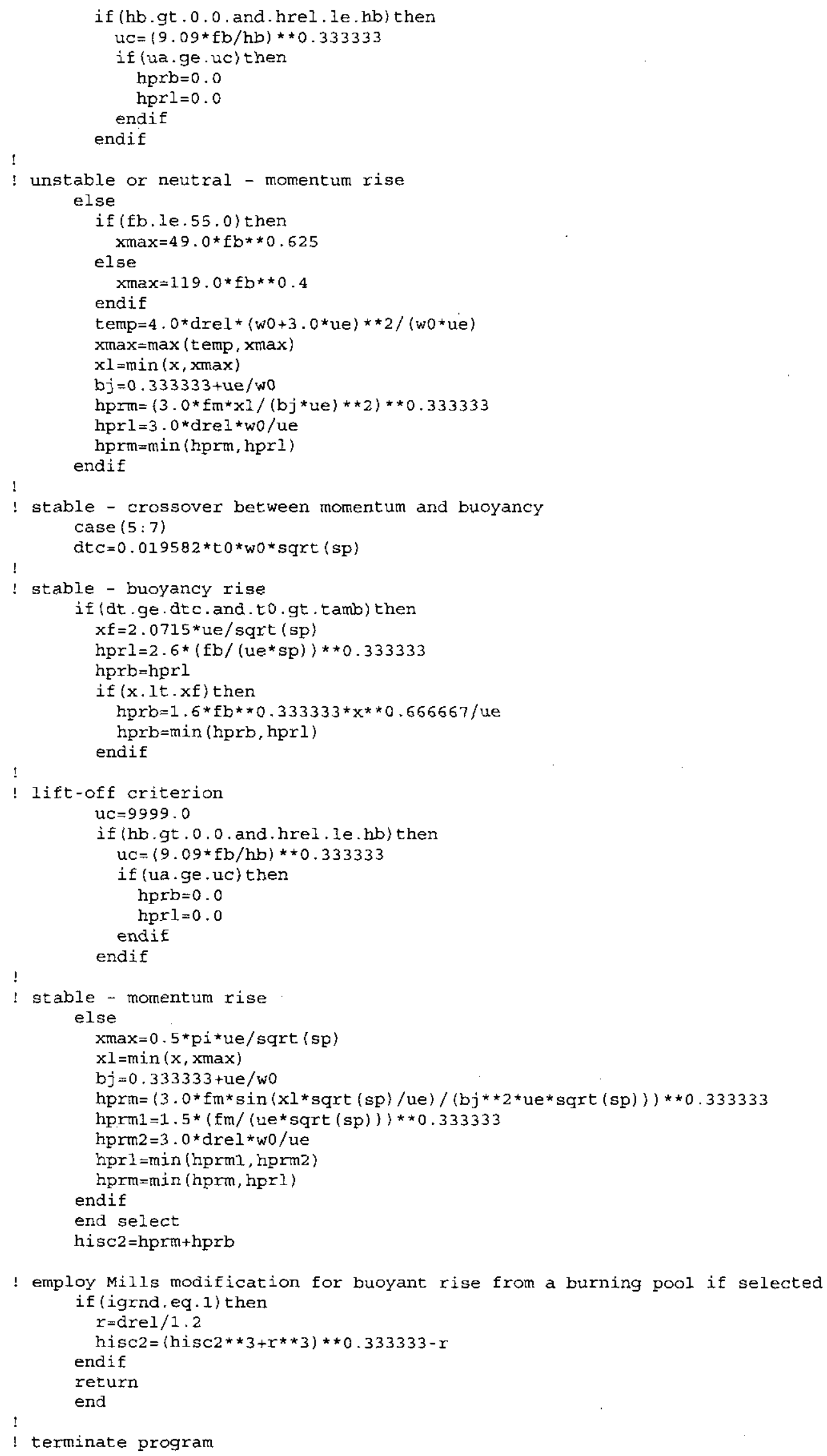


RPP-13482 REV 5

subroutine exit

close (2)

close (3)

close (4)

close (5)

close (8)

stop

end 


\section{RPP-13482 REV 5}

This page intentionally left blank. 
RPP-13482 REV 5

APPENDIX B

SAMPLE INPUT FILE AND RUN FILES FOR BASIC DISPERSION COEFFICIENT CALCULATIONS IN SECTION 2.2

B-i 


\section{RPP-13482 REV 5}

This page intentionally left blank.

B-ii 


\section{APPENDIX B}

\section{SAMPLE INPUT FILE AND RUN FILES FOR BASIC DISPERSION COEFFICIENT CALCULATIONS IN SECTION 2.2}

- Sample input file $-95^{\text {th }}$ percentile overall, $1 \mathrm{hr}, 100 \mathrm{~m}$ and site boundary

- Run file $-95^{\text {th }}$ percentile overall, $1 \mathrm{hr}, 100 \mathrm{~m}$ and site boundary

- Run file $-50^{\text {th }}$ percentile by sector, $1 \mathrm{hr}, 100 \mathrm{~m}$ and site boundary

- Run file $-95^{\text {th }}$ percentile overall, $2 \mathrm{hr}, 100 \mathrm{~m}$ and site boundary

- Run file $-50^{\text {th }}$ percentile by sector, $2 \mathrm{hr}, 100 \mathrm{~m}$ and site boundary

- Run file - annual average by sector, $100 \mathrm{~m}$ and site boundary

- Run file $-95^{\text {th }}$ percentile overall, puff, $100 \mathrm{~m}$ and site boundary

- Run file $-50^{\text {th }}$ percentile by sector, puff, $100 \mathrm{~m}$ and site boundary 


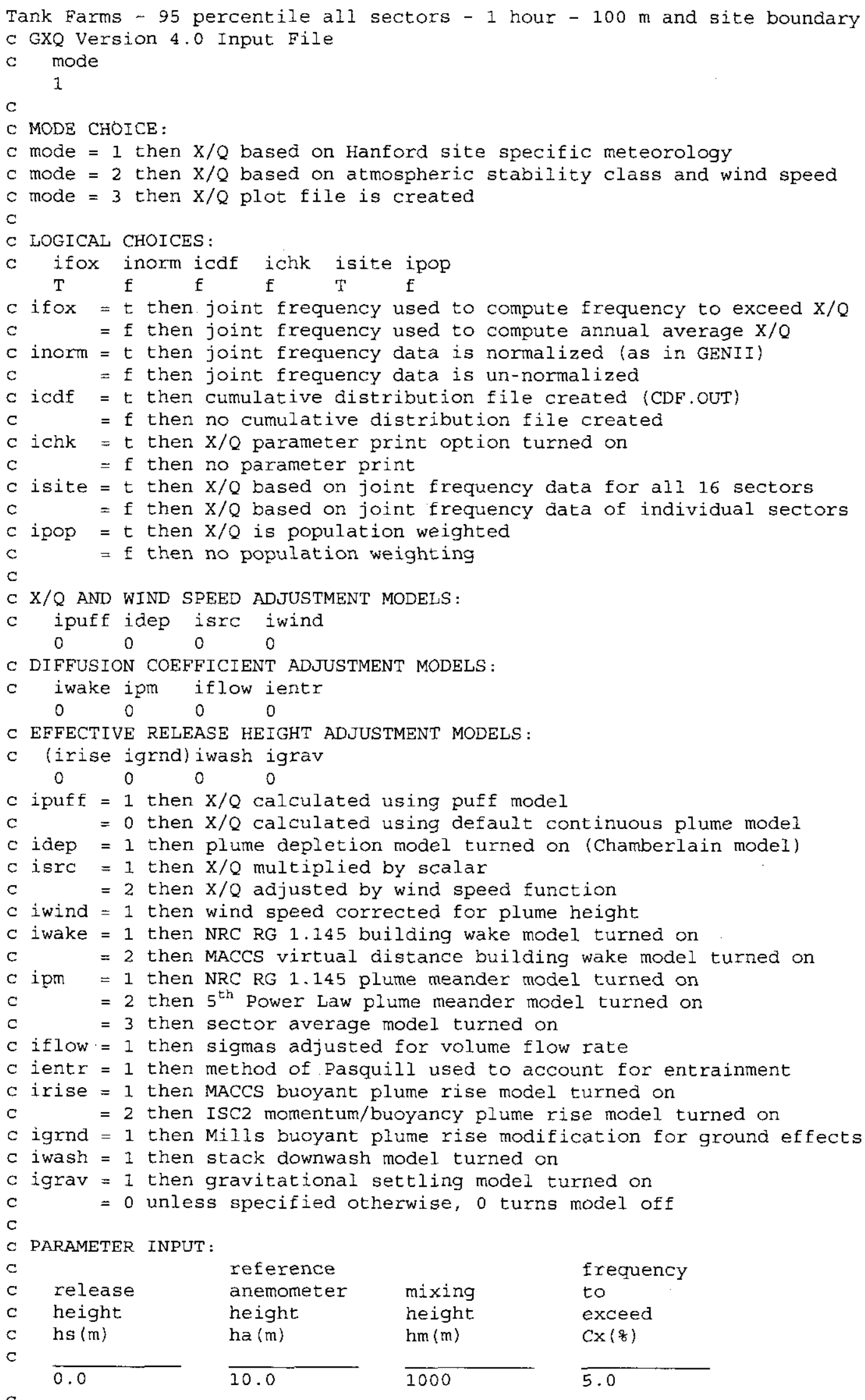




\section{RPP-13482 REV 5}

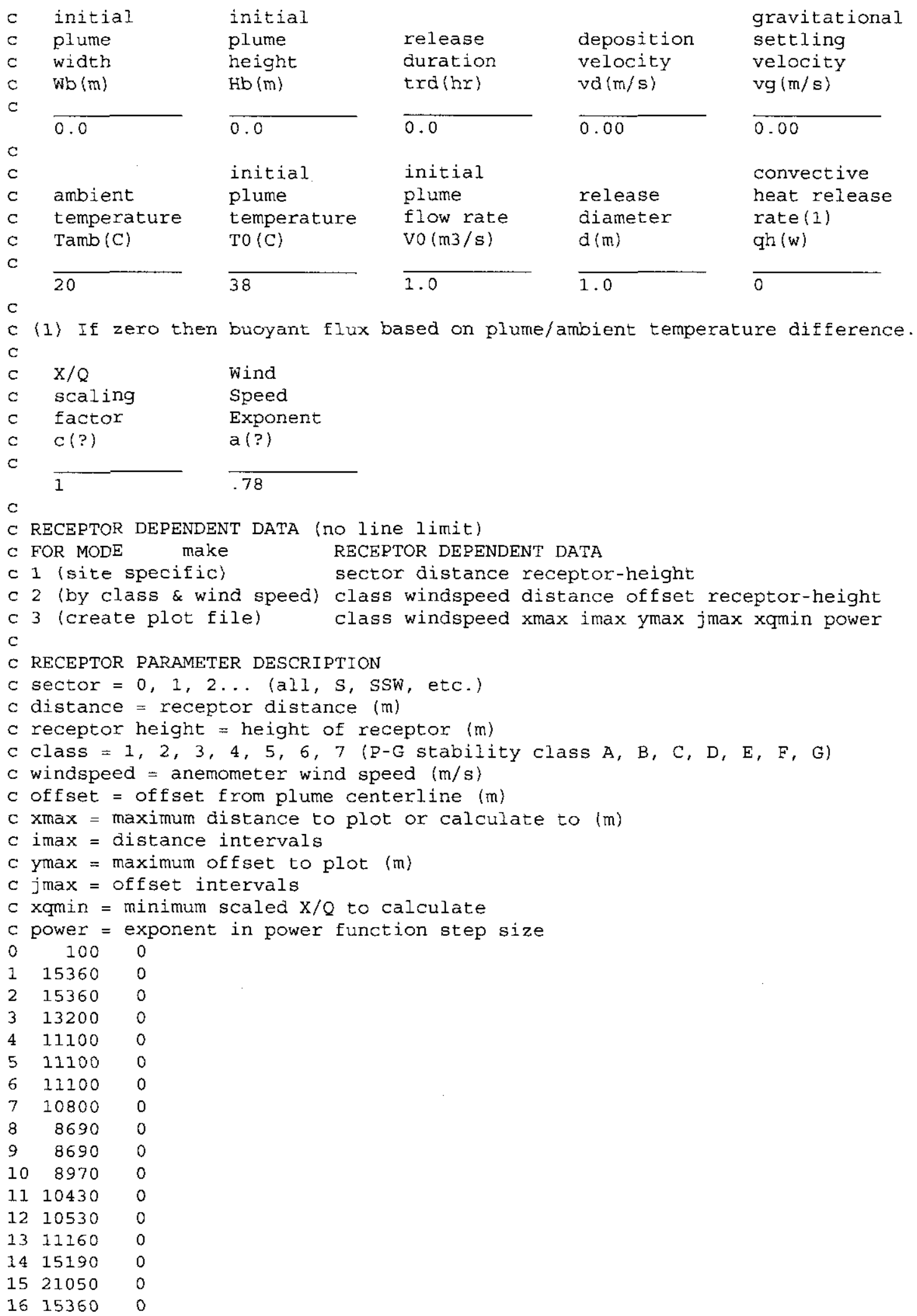

38

\begin{tabular}{l}
$\begin{array}{l}\text { release } \\
\text { duration } \\
\text { trd(hr) }\end{array}$ \\
\hline 0.0 \\
initial \\
plume \\
flow rate \\
vo(m3/s) \\
\hline 1.0
\end{tabular}

\begin{tabular}{l} 
deposition \\
velocity \\
vd (m/s) \\
\hline 0.00 \\
release \\
diameter \\
$d(m)$ \\
1.0
\end{tabular}

gravitational settling velocity $\operatorname{vg}(\mathrm{m} / \mathrm{s})$

0.00

convective heat release rate (1) qh (w)

(1) If zero then buoyant flux based on plume/ambient temperature difference.

\begin{tabular}{ll}
$X / Q$ & Wind \\
scaling & Speed \\
factor & Exponent \\
c(?) & a(?) \\
\hline 1 & $\frac{.78}{}$
\end{tabular}

C RECEPTOR DEPENDENT DATA (no line limit)

C FOR MODE make RECEPTOR DEPENDENT DATA

c 1 (site specific) sector distance receptor-height

c 2 (by class \& wind speed) class windspeed distance offset receptor-height

c 3 (create plot file) class windspeed xmax imax ymax jmax xqmin power

C RECEPTOR PARAMETER DESCRIPTION

C sector $=0,1,2 \ldots$ (all, S, SSW, etc.)

c distance $=$ receptor distance $(\mathrm{m})$

c receptor height $=$ height of receptor $(\mathrm{m})$

C class $=1,2,3,4,5,6,7$ (P-G stability class $A, B, C, D, E, F, G$ )

$c$ windspeed $=$ anemometer wind speed $(\mathrm{m} / \mathrm{s})$

$c$ offset $=$ offset from plume centerline (m)

c $\operatorname{xmax}=$ maximum distance to plot or calculate to (m)

c $i \max =$ distance intervals

c $y \max =$ maximum offset to plot (m)

$c j \max =$ offset intervals

c $x q m i n=$ minimum scaled $X / Q$ to calculate

$c$ power $=$ exponent in power function step size

o $100 \quad 0$

$115360 \quad 0$

$215360 \quad 0$

$313200 \quad 0$

$411100 \quad 0$

$5 \quad 11100 \quad 0$

$611100 \quad 0$

$710800 \quad 0$

$8 \quad 8690 \quad 0$

$98690 \quad 0$

$108970 \quad 0$

$1110430 \quad 0$

$1210530 \quad 0$

$1311160 \quad 0$

$1415190 \quad 0$

$1521050 \quad 0$

$1615360 \quad 0$ 
GXQ Version $4.0 \mathrm{~F}$

october 8, 2002

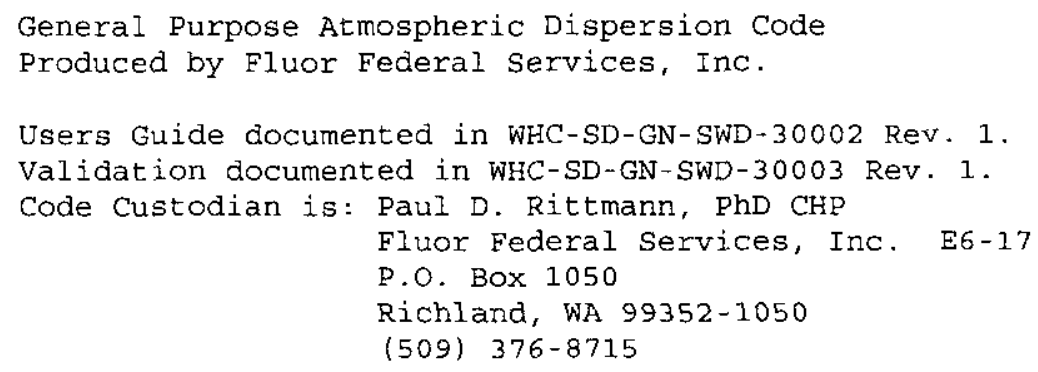




\section{RPP-13482 REV 5}

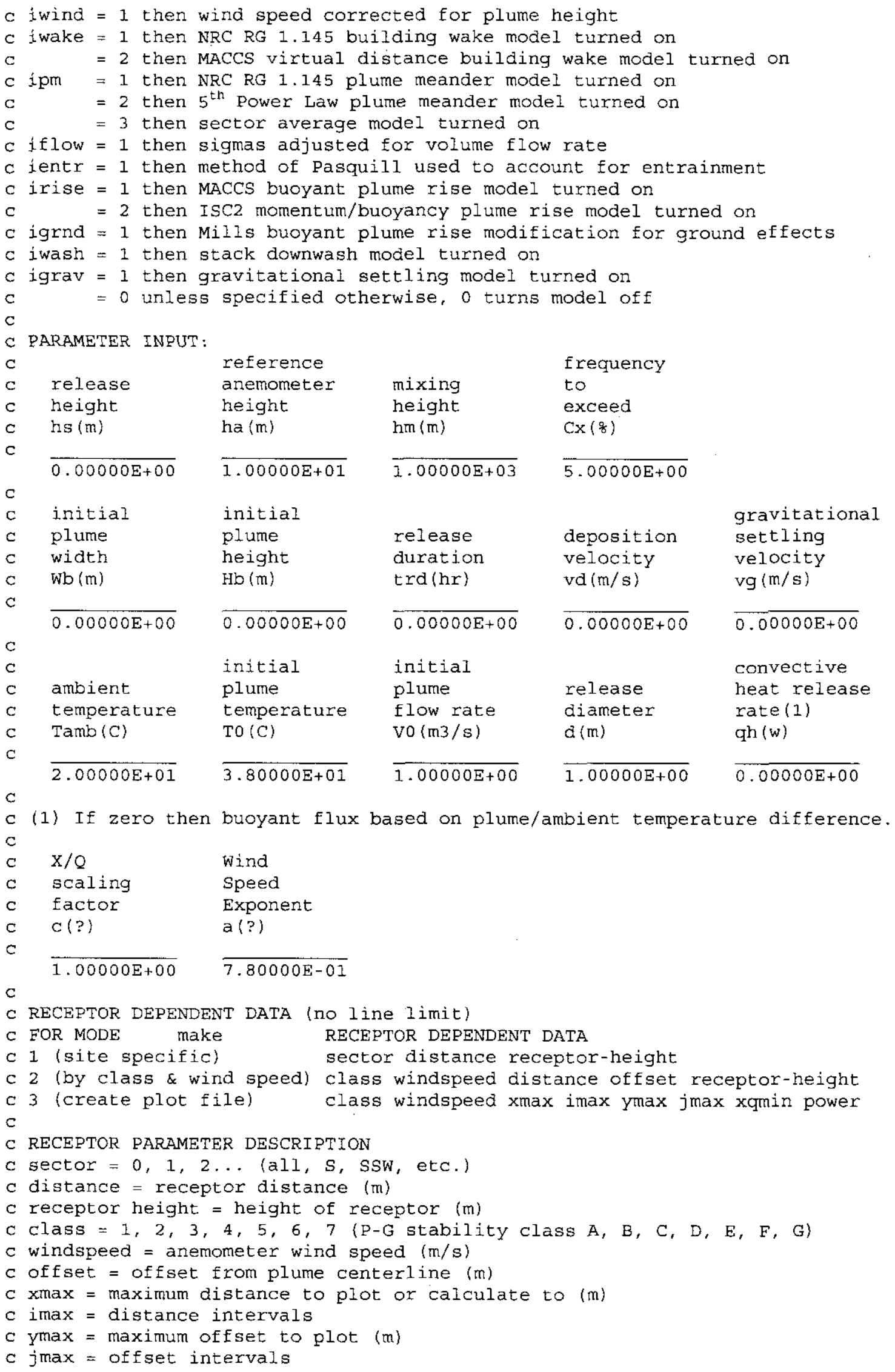




\section{RPP-13482 REV 5}

C xqmin $=$ minimum scaled $\mathrm{X} / \mathrm{Q}$ to calculate

$\mathrm{c}$ power $=$ exponent in power function step size

MODE :

Site specific $x / Q$ calculated.

LOGICAL CHOICES:

Joint frequency used to calculate $X / Q$ based on frequency of exceedance.

No normalization of joint frequency.

$\mathrm{X} / \mathrm{Q}$ calculated for overall site.

MODELS SELECTED:

Time-integrated air concentration calculated (s/m3).

WARNING/ERROR MESSAGES :

JOINT FREQUENCY DATA:

200 AREA (HMS) - 10 M - Pasquill A - G (1983 - 1991 Average)

Created $8 / 26 / 92 \mathrm{KR}$

Tank Farms - 95 percentile all sectors - 1 hour - $100 \mathrm{~m}$ and site boundary

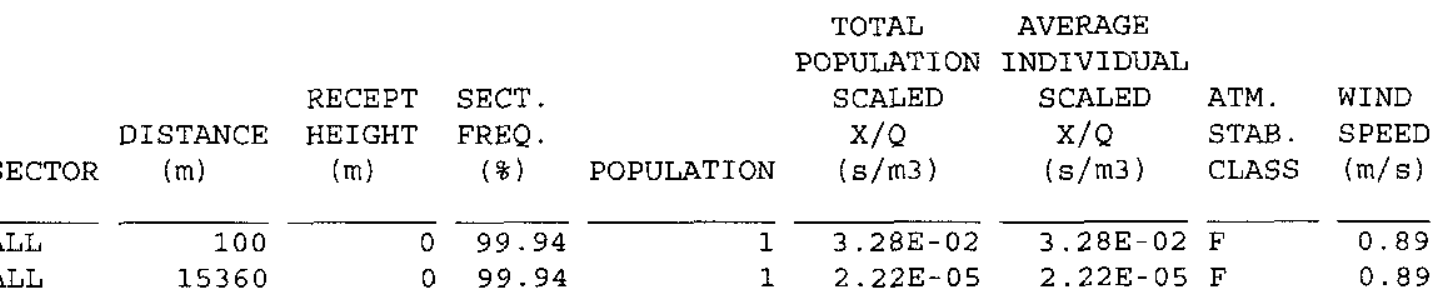




\section{RPP-13482 REV 5}

GXQ Version $4.0 \mathrm{~F}$

october 8, 2002

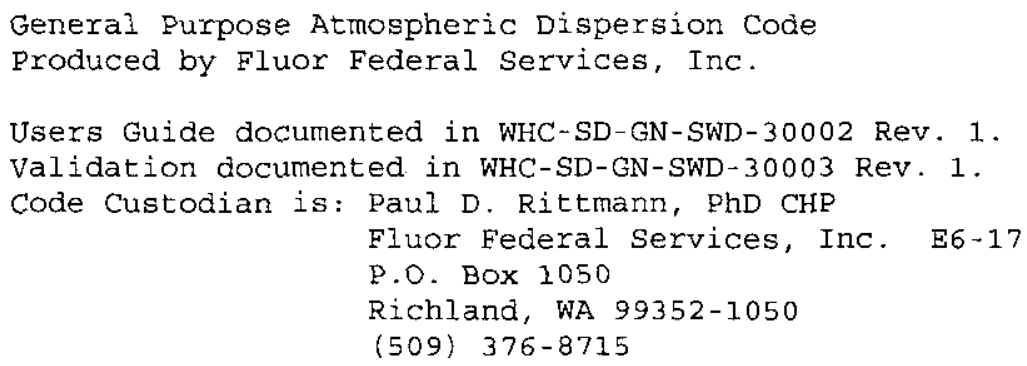




\section{RPP-13482 REV 5}

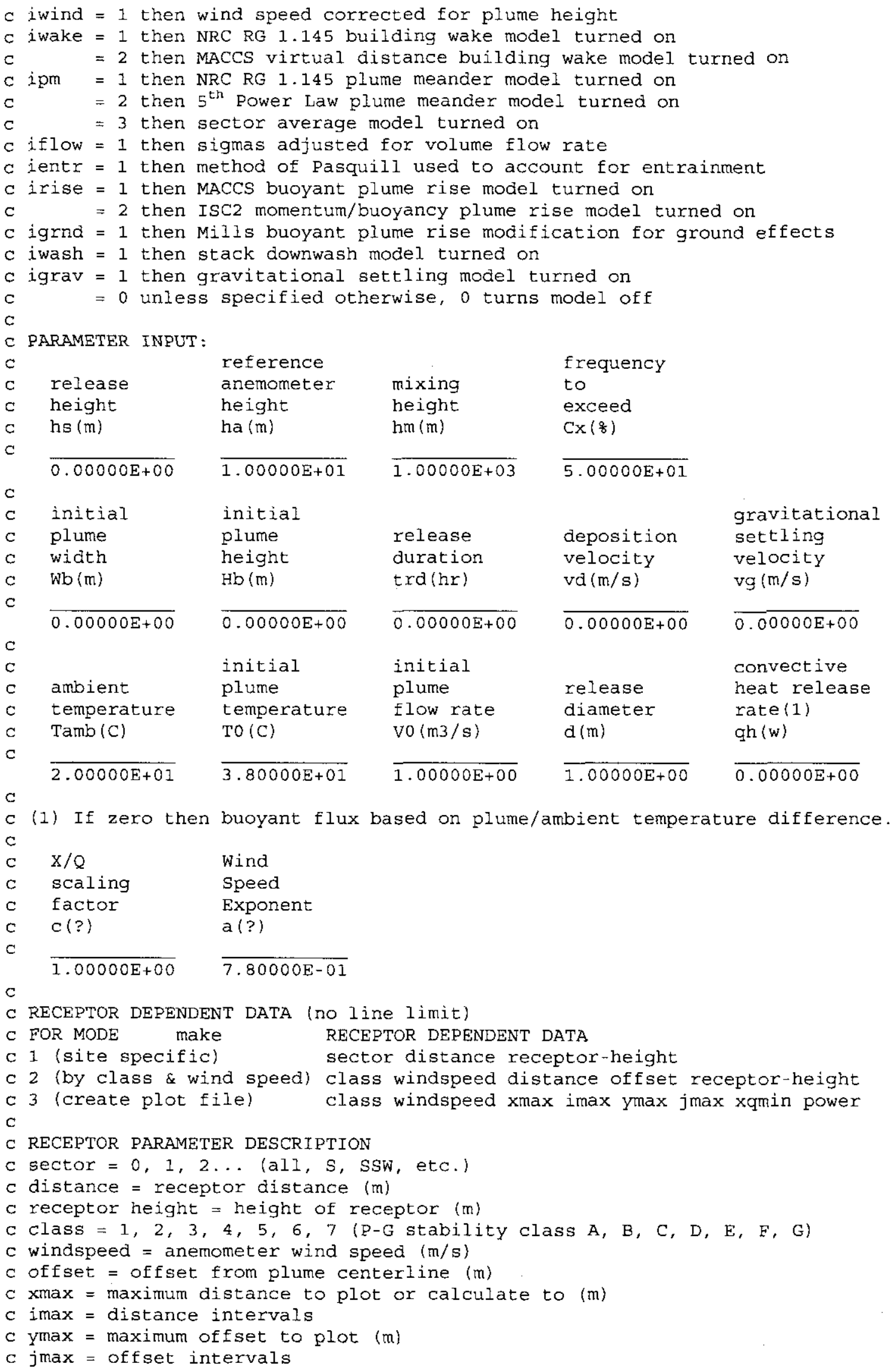


$c$ xqmin = minimum scaled $x / Q$ to calculate

$c$ power $=$ exponent in power function step size

MODE :

Site specific $X / Q$ calculated.

LOGICAL CHOICES:

Joint frequency used to calculate $\mathrm{X} / \mathrm{Q}$ based on frequency of exceedance. Joint frequency data normalized.

$\mathrm{X} / \mathrm{Q}$ calculated for single sector.

MODELS SELECTED:

Time-integrated air concentration calculated (s/m3).

WARNING/ERROR MESSAGES:

JOINT FREQUENCY DATA:

200 AREA (HMS) - 10 M - Pasquill A - G (1983 - 1991 Average)

Created $8 / 26 / 92 \mathrm{KR}$

Tank Farms - 50 percentile by sector - 1 hour - $100 \mathrm{~m}$ and site boundary

\begin{tabular}{|c|c|c|c|c|c|c|c|c|}
\hline SECTOR & $\begin{array}{l}\text { DISTANCE } \\
\text { (m) }\end{array}$ & $\begin{array}{l}\text { RECEPT } \\
\text { HEIGHT } \\
\text { (m) }\end{array}$ & $\begin{array}{c}\text { SECT. } \\
\text { FREQ . } \\
(8)\end{array}$ & POPULATION & $\begin{array}{c}\text { TOTAL } \\
\text { POPULATION } \\
\text { SCALED } \\
\text { X/Q } \\
(\mathrm{s} / \mathrm{m} 3)\end{array}$ & $\begin{array}{l}\text { AVERAGE } \\
\text { INDIVIDUAL } \\
\text { SCALED } \\
X / Q \\
(\mathrm{~s} / \mathrm{m} 3)\end{array}$ & $\begin{array}{l}\text { ATM. } \\
\text { STAB } \\
\text { CLASS }\end{array}$ & $\begin{array}{l}\text { WIND } \\
\text { SPEED } \\
(\mathrm{m} / \mathrm{s})\end{array}$ \\
\hline$S$ & 100 & $\overline{0}$ & $\overline{100.00}$ & $\overline{1}$ & $2.35 E-03$ & $2.35 E-03$ & $\bar{F}$ & $\overline{15.60}$ \\
\hline SSW & 100 & 0 & 100.00 & 1 & 1. $73 \mathrm{E}-03$ & $1.73 E-0.3$ & $\mathrm{~F}$ & 19.00 \\
\hline SW & 100 & 0 & 100.00 & 1 & $2.86 E-03$ & $2.86 E-03$ & $E$ & 4.70 \\
\hline WSW & 100 & 0 & 100.00 & 1 & $3.36 \mathrm{E}-03$ & $3.36 \mathrm{E}-03$ & $\mathrm{C}$ & 0.89 \\
\hline W & 100 & 0 & 100.00 & 1 & $2.97 E-03$ & $2.97 \mathrm{E}-03$ & $\mathrm{E}$ & 4.70 \\
\hline WNW & 100 & 0 & 100.00 & 1 & $3.07 \mathrm{E}-03$ & $3.07 \mathrm{E}-03$ & $\mathrm{E}$ & 4.70 \\
\hline NW & 100 & 0 & 100.00 & 1 & $3.19 E-03$ & 3. $19 \mathrm{E}-03$ & $E$ & 4.70 \\
\hline NNW & 100 & 0 & 100.00 & 1 & $4.92 E-03$ & $4.92 \mathrm{E}-03$ & $\mathrm{E}$ & 2.65 \\
\hline $\mathrm{N}$ & 100 & 0 & 100.00 & 1 & $5.33 E-03$ & $5.33 \mathrm{E}-03$ & $\mathrm{E}$ & 2.65 \\
\hline NNE & 100 & 0 & 100.00 & 1 & $3.91 E-03$ & $3.91 E-03$ & $\mathrm{C}$ & 0.89 \\
\hline $\mathrm{NE}$ & 100 & 0 & 100.00 & 1 & $2.41 E-03$ & $2.41 \mathrm{E}-03$ & $D$ & 2.65 \\
\hline ENE & 100 & 0 & 100.00 & 1 & $1.98 \mathrm{E}-03$ & $1.98 \mathrm{E}-03$ & $\mathrm{E}$ & 7.15 \\
\hline $\mathrm{E}$ & 100 & 0 & 100.00 & 1 & $4.65 E-03$ & $4.65 \mathrm{E}-03$ & $F$ & 7.15 \\
\hline ESE & 100 & 0 & 100.00 & 1 & $2.89 \mathrm{E}-03$ & $2.89 \mathrm{E}-03$ & $\mathrm{E}$ & 4.70 \\
\hline$S E$ & 100 & 0 & 100.00 & 1 & $2.81 \mathrm{E}-03$ & $2.81 E-03$ & $\mathrm{D}$ & 2.65 \\
\hline SSE & 100 & 0 & 100.00 & 1 & $2.86 \mathrm{E}-03$ & $2.86 E-03$ & $\mathrm{E}$ & 4.70 \\
\hline S & 15360 & 0 & 100.00 & 1 & $7.65 E-07$ & $7.65 E-07$ & $\mathrm{E}$ & 7.15 \\
\hline SSW & 15360 & 0 & 100.00 & 1 & $4.50 \mathrm{E}-07$ & $4.50 E-07$ & $\mathrm{D}$ & 4.70 \\
\hline SW & 13200 & 0 & 100.00 & 1 & $1.06 E-06$ & $1.06 \mathrm{E}-06$ & $\mathrm{D}$ & 2.65 \\
\hline WSW & 11100 & 0 & 100.00 & 1 & $1.56 \mathrm{E}-06$ & $1.56 \mathrm{E}-06$ & $E$ & 4.70 \\
\hline W & 11100 & 0 & 100.00 & 1 & $1.59 E-06$ & $1.59 E-06$ & $E$ & 4.70 \\
\hline WNW & 11100 & 0 & 100.00 & 1 & $1.65 E-06$ & $1.65 \mathrm{E}-06$ & $E$ & 4.70 \\
\hline NW & 10800 & 0 & 100.00 & 1 & $1.82 E-06$ & $1.82 \mathrm{E}-06$ & $\mathrm{E}$ & 4.70 \\
\hline NNW & 8690 & 0 & 100.00 & I & $4.24 \mathrm{E}-06$ & $4.24 \mathrm{E}-06$ & $\mathrm{E}$ & 2.65 \\
\hline $\mathrm{N}$ & 8690 & 0 & 100.00 & $I$ & $4.48 E-06$ & $4.48 \mathrm{E}-06$ & $E$ & 2.65 \\
\hline NNE & 8970 & 0 & 100.00 & 1 & $3.18 E-06$ & $3.18 \mathrm{E}-06$ & $\mathrm{E}$ & 4.70 \\
\hline $\mathrm{NE}$ & 10430 & 0 & 100.00 & 1 & I. $33 \mathrm{E}-06$ & 1. $33 \mathrm{E}-06$ & E & 7.15 \\
\hline ENE & 10530 & 0 & 100.00 & 1 & $1.25 \mathrm{E}-06$ & $1.25 \mathrm{E}-06$ & $E$ & 7.15 \\
\hline $\mathrm{E}$ & 11160 & 0 & 100.00 & 1 & $2.96 E-06$ & $2.96 \mathrm{E}-06$ & $\mathrm{~F}$ & 7.15 \\
\hline ESE & 15190 & 0 & 100.00 & 1 & $1.13 \mathrm{E}-06$ & $1.13 E-06$ & $\mathrm{E}$ & 4.70 \\
\hline $\mathrm{SE}$ & 21050 & 0 & 1.00 .00 & 1 & $5.11 \mathrm{E}-07$ & $5.11 E-07$ & $D$ & 2.65 \\
\hline SSE & 15360 & 0 & 100.00 & 1 & $9.36 E-07$ & $9.36 E-07$ & $D$ & 2.65 \\
\hline
\end{tabular}


GXQ Version $4.0 F$

October 8,2002

General Purpose Atmospheric Dispersion Code Produced by Fluor Federal Services, Inc.

Users Guide documented in WHC-SD-GN-SWD-30002 Rev. 1. Validation documented in WHC-SD-GN-SWD-30003 Rev. 1 . Code Custodian is: Paul D. Rittmann, PhD CHP

Fluor Federal Services, Inc. E6-17

P.O. Box 1050

Richland, WA 99352-1050

(509) $376-8715$

Run Date $=10 / 09 / 02$

Run $\mathrm{Time}=09: 26: 46.95$

INPUT ECHO:

Tank Farms - 95 percentile all sectors - 2 hour - $100 \mathrm{~m}$ and site boundary C GXQ Version 4.0 Input File

C mode

1

$\mathrm{C}$

C MODE CHOICE:

$\mathrm{C}$ mode $=1$ then $\mathrm{X} / \mathrm{Q}$ based on Hanford site specific meteorology

$\mathrm{C}$ mode $=2$ then $\mathrm{X} / \mathrm{Q}$ based on atmospheric stability class and wind speed

$\mathrm{c}$ mode $=3$ then $\mathrm{X} / \mathrm{Q}$ plot file is created

$\mathrm{C}$

C LOGICAL CHOICES:

c ifox inorm icdf ichk isite ipop

$\begin{array}{llllll}T & F & F & F & T & F\end{array}$

$c$ ifox $=t$ then joint frequency used to compute frequency to exceed $X / Q$

$c=f$ then joint frequency used to compute annual average $\mathrm{X} / \mathrm{Q}$

$c$ inorm $=t$ then joint frequency data is normalized (as in GENII)

$c=f$ then joint frequency data is un-normalized

$c$ icdf $=t$ then cumulative distribution file created (CDF.OUT)

$\mathrm{C}=\mathrm{f}$ then no cumulative distribution file created

$\mathrm{c}$ ichk $=\mathrm{t}$ then $\mathrm{X} / \mathrm{Q}$ parameter print option turned on

c $\quad=\mathrm{f}$ then no parameter print

$\mathrm{c}$ isite $=\mathrm{t}$ then $\mathrm{X} / \mathrm{Q}$ based on joint frequency data for all 16 sectors

$\mathrm{C}=\mathrm{f}$ then $\mathrm{X} / \mathrm{Q}$ based on joint frequency data of individual sectors

$c$ ipop $=t$ then $\mathrm{X} / \mathrm{Q}$ is population weighted

$\mathrm{c}=\mathrm{f}$ then no population weighting

$\mathrm{C}$

C X/Q AND WIND SPEED ADJUSTMENT MODELS:

C ipuff idep isrc iwind

$$
0000
$$

C DIFFUSION COEFFICIENT ADJUSTMENT MODELS:

C iwake ipm iflow ientr

$$
0 \quad 1 \quad 0 \quad 0
$$

C EFFECTIVE RELEASE HEIGHT ADJUSTMENT MODELS:

C (irise igrnd) iwash igrav

$$
\begin{array}{llll}
0 & 0 & 0 & 0
\end{array}
$$

$C$ ipuff $=1$ then $X / Q$ calculated using puff model

$c=0$ then $X / Q$ calculated using default continuous plume model

$c$ idep $=1$ then plume depletion model turned on (Chamberlain model)

$\mathrm{C}$ isrc $=1$ then $\mathrm{X} / \mathrm{Q}$ multiplied by scalar

$c=2$ then $X / Q$ adjusted by wind speed function 


\section{RPP-13482 REV 5}

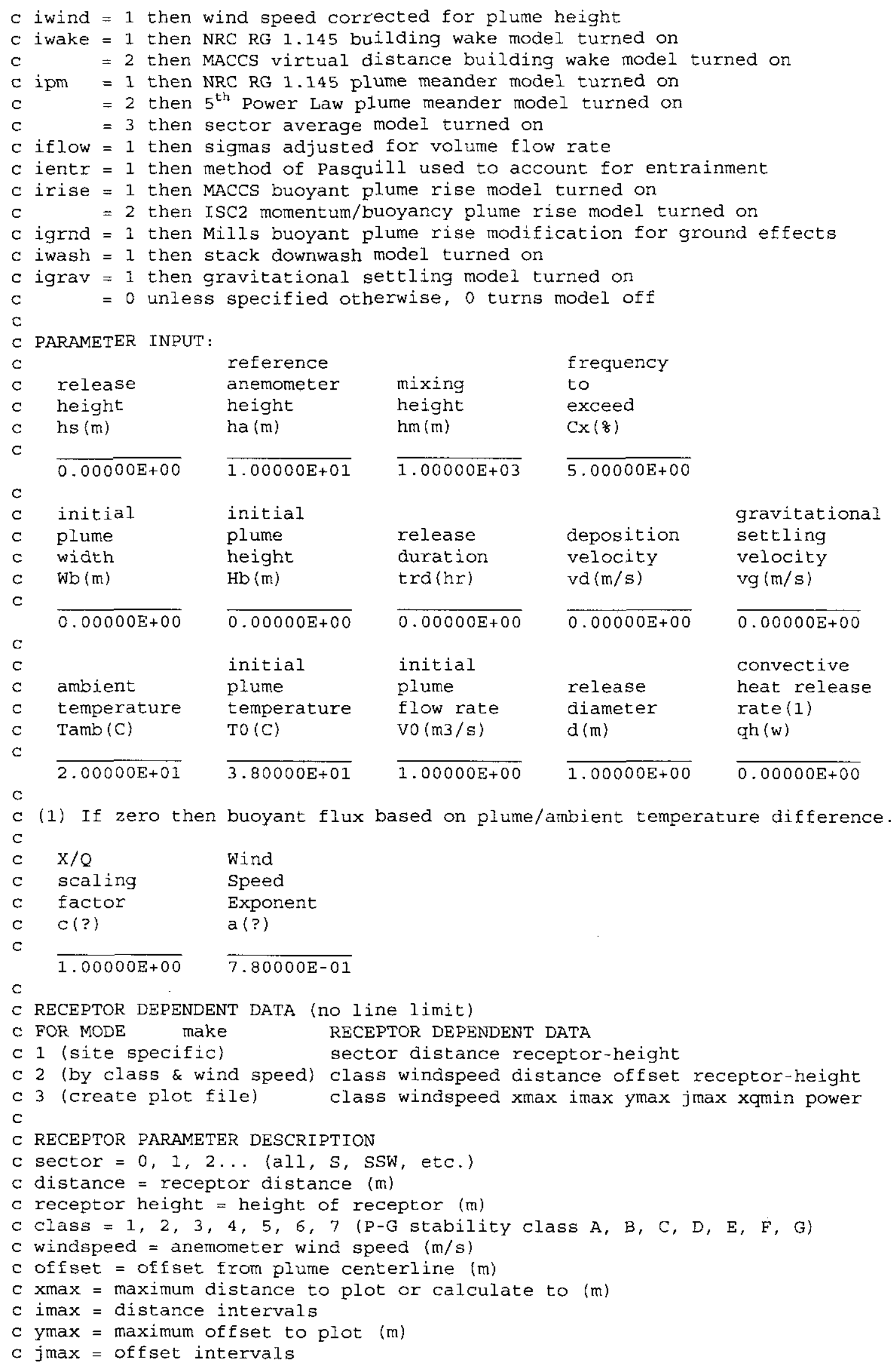




\section{RPP-13482 REV 5}

$c$ xqmin $=$ minimum scaled $\mathrm{X} / \mathrm{Q}$ to calculate

$c$ power $=$ exponent in power function step size

MODE :

Site specific $X / Q$ calculated.

LOGICAL CHOICES:

Joint frequency used to calculate $X / Q$ based on frequency of exceedance.

No normalization of joint frequency.

$\mathrm{X} / \mathrm{Q}$ calculated for overall site.

MODELS SELECTED:

Time-integrated air concentration calculated (s/m3).

NRC RG 1.145 plume meander model selected.

WARNING/ERROR MESSAGES:

JOINT FREQUENCY DATA:

200 AREA (HMS) - 10 M - Pasquill A - G (1983 - 1991 Average)

Created $8 / 26 / 92 \mathrm{KR}$

Tank Farms - 95 percentile all sectors - 2 hour - $100 \mathrm{~m}$ and site boundary

\begin{tabular}{|c|c|c|c|c|c|c|c|c|}
\hline SECTOR & $\begin{array}{c}\text { DISTANCE } \\
(\mathrm{m})\end{array}$ & $\begin{array}{l}\text { RECEPT } \\
\text { HEIGHT } \\
\text { (m) }\end{array}$ & $\begin{array}{c}\text { SECT. } \\
\text { FREQ. } \\
(8)\end{array}$ & POPULATION & $\begin{array}{c}\text { TOTAL } \\
\text { POPULATION } \\
\text { SCALED } \\
X / Q \\
(\mathrm{~s} / \mathrm{m} 3)\end{array}$ & $\begin{array}{c}\text { AVERAGE } \\
\text { INDIVIDUAL } \\
\text { SCALED } \\
\text { X/Q } \\
(\mathrm{s} / \mathrm{m} 3)\end{array}$ & $\begin{array}{l}\text { ATM. } \\
\text { STAB. } \\
\text { CLASS }\end{array}$ & $\begin{array}{l}\text { WIND } \\
\text { SPEED } \\
\text { (m/s) }\end{array}$ \\
\hline & 100 & $\overline{0}$ & 99.94 & 1 & $9.40 E-03$ & $9.40 \mathrm{E}-03$ & F & 0.89 \\
\hline ALL & 15360 & 0 & 99.94 & 1 & $1.74 E-05$ & $1.74 \mathrm{E}-05$ & $\mathrm{~F}$ & 0.89 \\
\hline
\end{tabular}




\section{RPP-13482 REV 5}

GXQ Version $4.0 F$

October 9, 2002

General Purpose Atmospheric Dispersion Code Produced by Fluor Federal services, Inc.

Users Guide documented in WHC-SD-GN-SWD-30002 Rev. 1. Validation documented in WHC-SD-GN-SWD-30003 Rev. 1. Code Custodian is: Paul D. Rittmann, PhD CHP

Fluor Federal Services, Inc. E6-17

P.O. Box 1050

Richland, WA 99352-1050

(509) $376-8715$

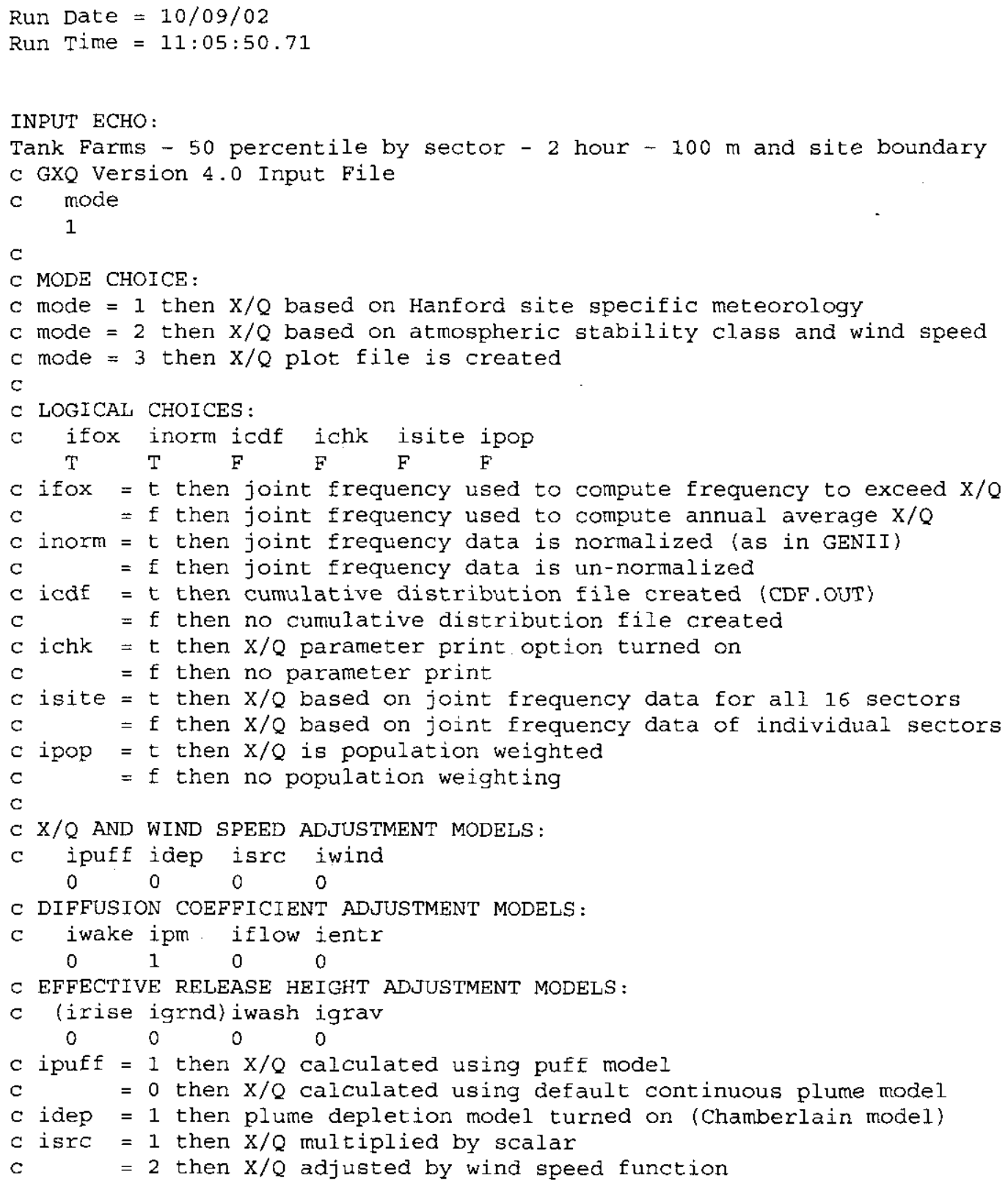




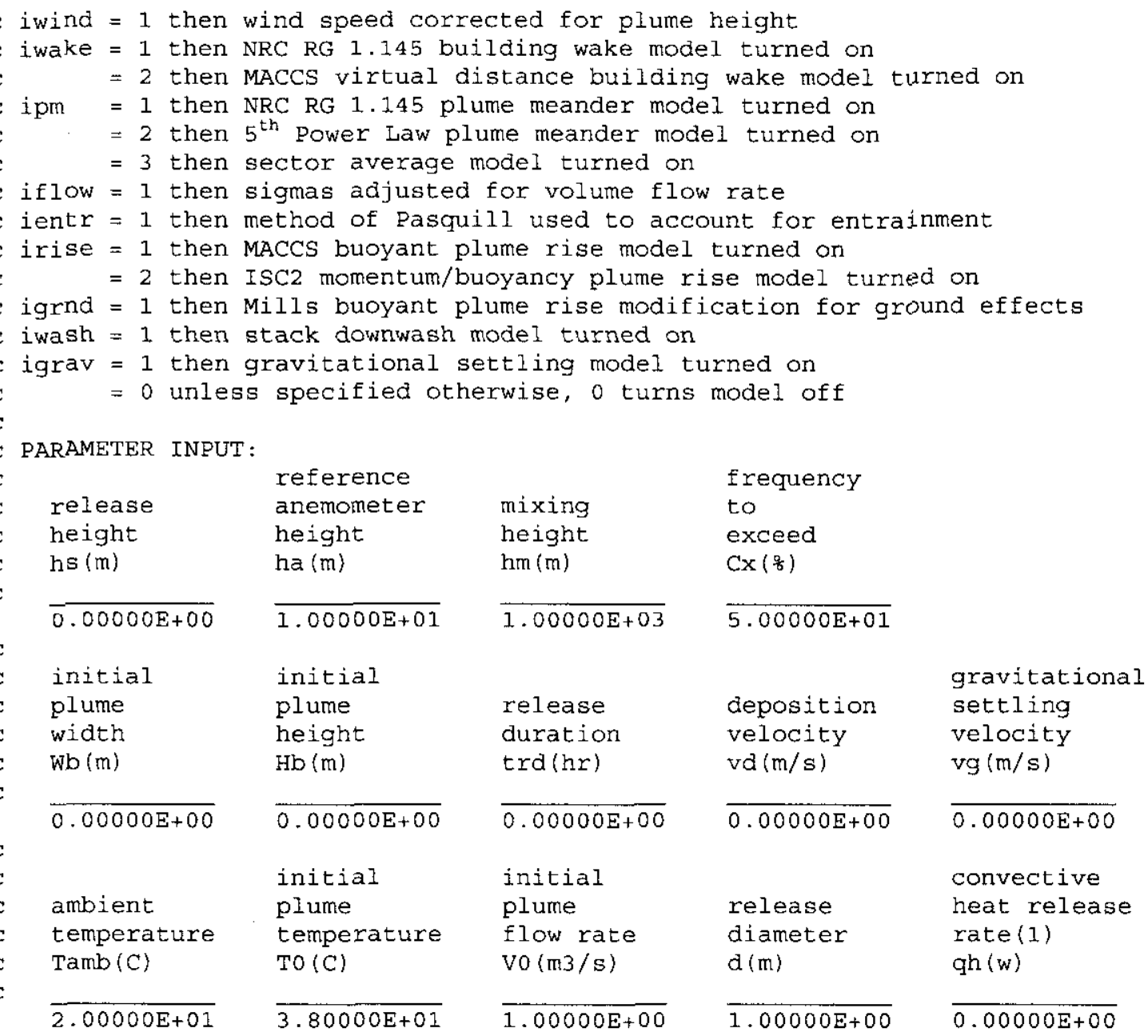

c (1) If zero then buoyant flux based on plume/ambient temperature difference.

$$
\begin{array}{ll}
X / Q & \text { Wind } \\
\text { scaling } & \text { Speed }
\end{array}
$$$$
\text { factor Exponent }
$$$$
\text { c(?) a(?) }
$$$$
\overline{1.00000 E+00} \quad \overline{7.80000 E-01}
$$

$C$

C RECEPTOR DEPENDENT DATA (no line limit)

C FOR MODE make RECEPTOR DEPENDENT DATA

C 1 (site specific) sector distance receptor-height

c 2 (by class \& wind speed) class windspeed distance offset receptor-height

c 3 (create plot file) class windspeed xmax imax ymax jmax xqmin power

C

C RECEPTOR PARAMETER DESCRIPTION

C sector $=0,1,2 \ldots($ all, S, SSW, etc. $)$

$c$ distance $=$ receptor distance $(\mathrm{m})$

$c$ receptor height $=$ height of receptor $(\mathrm{m})$

C class $=1,2,3,4,5,6,7$ (P-G stability class A, B, C, D, E, F, G)

$c$ windspeed $=$ anemometex wind speed $(\mathrm{m} / \mathrm{s})$

$c$ offset $=$ offset from plume centerline (m)

$c x \max =$ maximum distance to plot or calculate to $(\mathrm{m})$

$c$ imax = distance intervals

$c y \max =\operatorname{maximum}$ offset to plot $(\mathrm{m})$

$c$ jmax $=$ offset intervals 


\section{RPP-13482 REV 5}

c $x q m i n=$ minimum scaled $x / Q$ to calculate

$\mathrm{C}$ power $=$ exponent in power function step size

MODE :

Site specific $X / Q$ calculated.

LOGICAL CHOICES:

Joint frequency used to calculate $X / Q$ based on frequency of exceedance.

Joint frequency data normalized.

$\mathrm{X} / \mathrm{Q}$ calculated for single sector.

MODELS SELECTED:

Time-integrated air concentration calculated (s/m3) .

NRC RG 1.145 plume meander model selected.

WARNING/ERROR MESSAGES :

JOINT FREQUENCY DATA:

200 AREA (HMS) - 10 M - pasquill A - G (1983 - 1991 Average)

Created 8/26/92 KR

Tank Farms - 50 percentile by sector - 2 hour - $100 \mathrm{~m}$ and site boundary

\begin{tabular}{|c|c|c|c|c|c|c|c|c|}
\hline SECTOR & $\begin{array}{l}\text { DISTANCE } \\
\text { (m) }\end{array}$ & $\begin{array}{l}\text { RECEPT } \\
\text { HEIGHT } \\
\text { (m) }\end{array}$ & $\begin{array}{c}\text { SECT. } \\
\text { FREQ } \\
(8)\end{array}$ & POPULATION & $\begin{array}{c}\text { TOTAL } \\
\text { POPULATION } \\
\text { SCALED } \\
X / Q \\
(\mathrm{~s} / \mathrm{m} 3)\end{array}$ & $\begin{array}{l}\text { AVERAGE } \\
\text { INDIVIDUAL } \\
\text { SCALED } \\
X / Q \\
(s / \mathrm{m} 3)\end{array}$ & $\begin{array}{l}\text { ATM. } \\
\text { STAB } \\
\text { CLASS }\end{array}$ & $\begin{array}{l}\text { WIND } \\
\text { SPEED } \\
\text { (m/s) }\end{array}$ \\
\hline $\mathrm{S}$ & 100 & $\ddot{0}$ & 100.00 & $\overline{1}$ & $1.67 \mathrm{E}-03$ & $1.67 \mathrm{E}-03$ & $\bar{D}$ & 2.65 \\
\hline SSW & 100 & 0 & 100.00 & 1 & $1.62 E-03$ & $1.62 E-03$ & F & 19.00 \\
\hline SW & 100 & 0 & 100.00 & 1 & $1.85 E-03$ & $1.85 \mathrm{E}-03$ & B & 0.89 \\
\hline WSW & 100 & 0 & 100.00 & 1 & $2.22 \mathrm{E}-03$ & $2.22 \mathrm{E}-03$ & $\mathrm{E}$ & 2.65 \\
\hline W & 100 & 0 & 100.00 & 1 & $2.07 E-03$ & $2.07 E-03$ & $\mathrm{E}$ & 2.65 \\
\hline WNW & 100 & 0 & 100.00 & 1 & $2.04 E-03$ & $2.04 E-03$ & B & 0.89 \\
\hline $\mathrm{NW}$ & 100 & 0 & 100.00 & 1 & $2.10 \mathrm{E}-03$ & $2.10 \mathrm{E}-03$ & $\mathrm{E}$ & 2.65 \\
\hline $\mathrm{NNW}$ & 100 & 0 & 100.00 & 1 & $2.27 \mathrm{E}-03$ & $2.27 E-03$ & $\mathrm{E}$ & 4.70 \\
\hline $\mathrm{N}$ & 100 & 0 & 100.00 & 1 & $2.27 \mathrm{E}-03$ & $2.27 \mathrm{E}-03$ & $\mathrm{E}$ & 4.70 \\
\hline NNE & 100 & 0 & 100.00 & 1 & $2.27 E-03$ & $2.27 E-03$ & $\mathrm{E}$ & 2.65 \\
\hline $\mathrm{NE}$ & 100 & 0 & 100.00 & 1 & 1. $81 \mathrm{E}-03$ & $1.81 E-03$ & $\mathrm{~B}$ & 0.89 \\
\hline ENE & 100 & 0 & 100.00 & 1 & 1. $75 \mathrm{E}-03$ & $1.75 E-03$ & $\mathrm{D}$ & 2.65 \\
\hline$E$ & 100 & 0 & 100.00 & 1 & $2.27 \mathrm{E}-03$ & $2.27 E-03$ & $\mathrm{E}$ & 4.70 \\
\hline ESE & 100 & 0 & 100.00 & 1 & $2.27 E-03$ & $2.27 E-03$ & $E$ & 2.65 \\
\hline$S E$ & 100 & 0 & 100.00 & 1 & $1.87 \mathrm{E}-03$ & $1.87 \mathrm{E}-0.3$ & $\mathrm{~B}$ & 0.89 \\
\hline SSE & 100 & 0 & 100.00 & 1 & $1.85 E-03$ & $1.85 E-03$ & $\mathrm{~B}$ & 0.89 \\
\hline S & 15360 & 0 & 100.00 & 1 & $7.57 E-07$ & $7.57 \mathrm{E}-07$ & $E$ & 7.15 \\
\hline SSW & 15360 & 0 & 100.00 & 1 & $4.45 E-07$ & $4.45 E-07$ & $\mathrm{D}$ & 4.70 \\
\hline SW & 13200 & 0 & 100.00 & 1 & $1.01 E-06$ & $1.01 E-06$ & D & 2.65 \\
\hline WSW & 11100 & 0 & 100.00 & 1 & $1.50 E-06$ & $1.50 \mathrm{E}-06$ & $\mathrm{E}$ & 4.70 \\
\hline W & 11100 & 0 & 100.00 & 1 & $1.54 \mathrm{E}-06$ & $1.54 \mathrm{E}-06$ & $E$ & 4.70 \\
\hline WNW & 11100 & 0 & 100.00 & 1 & $1.59 \mathrm{E}-06$ & $1.59 E-06$ & $\mathrm{E}$ & 4.70 \\
\hline$N W$ & 10800 & 0 & 100.00 & 1 & 1. $77 \mathrm{E}-06$ & $1.77 E-06$ & $\mathrm{E}$ & 4.70 \\
\hline NNW & 8690 & 0 & 100.00 & 1 & $3.58 E-06$ & $3.58 E-06$ & $E$ & 2.65 \\
\hline $\mathrm{N}$ & 8690 & 0 & 100.00 & 1 & $3.83 E-06$ & $3.83 E-06$ & $\mathrm{E}$ & 2.65 \\
\hline $\mathrm{NNE}$ & 8970 & 0 & 100.00 & $I$ & $2.91 E-06$ & $2.91 E-06$ & $\mathrm{E}$ & 4.70 \\
\hline $\mathrm{NE}$ & 10430 & 0 & 100.00 & 1 & $1.29 E-06$ & $1.29 \mathrm{E}-06$ & $\mathrm{E}$ & 7.15 \\
\hline ENE & 10530 & 0 & 100.00 & 1 & $1.25 \mathrm{E}-06$ & $1.25 E-06$ & $E$ & 7.15 \\
\hline $\mathrm{E}$ & 11160 & 0 & 100.00 & 1 & $2.54 \mathrm{E}-06$ & $2.54 \mathrm{E}-06$ & $E$ & 2.65 \\
\hline ESE & 15190 & 0 & 100.00 & 1 & $1.11 \mathrm{E}-06$ & $1.11 \mathrm{E}-06$ & $E$ & 4.70 \\
\hline$S E$ & 21050 & 0 & 100.00 & 1 & $4.95 E-07$ & $4.95 E-07$ & $E$ & 7.15 \\
\hline SSE & 15360 & 0 & 100.00 & 1 & $9.05 \mathrm{E}-07$ & $9.05 \mathrm{E}-07$ & $D$ & 2.65 \\
\hline
\end{tabular}




\section{RPP-13482 REV 5}

GXQ Version $4.0 F$

October 8, 2002

Gerieral Purpose Atmospheric Dispersion Code Produced by Fluor Federal Services, Inc.

Users Guide documented in WHC-SD-GN-SWD-30002 Rev. 1 . Validation documented in WHC-SD-GN-SWD-30003 Rev. 1. Code Custodian is: Paul D. Rittmann, PhD CHP

Fluor Federal Services, Inc. E6-17

P.O. Box 1050

Richland, WA 99352-1050

(509) $376-8715$

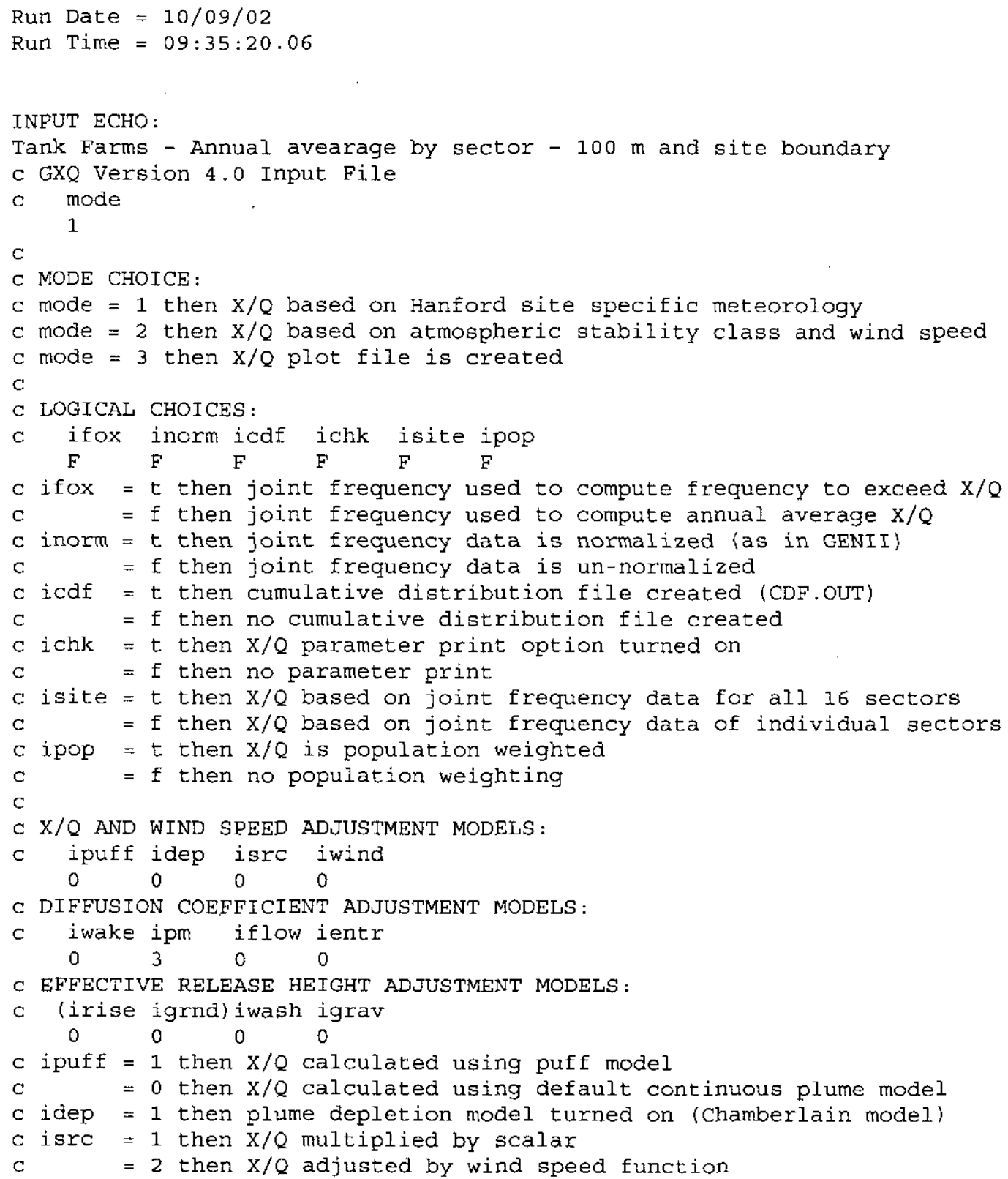




\section{RPP-13482 REV 5}

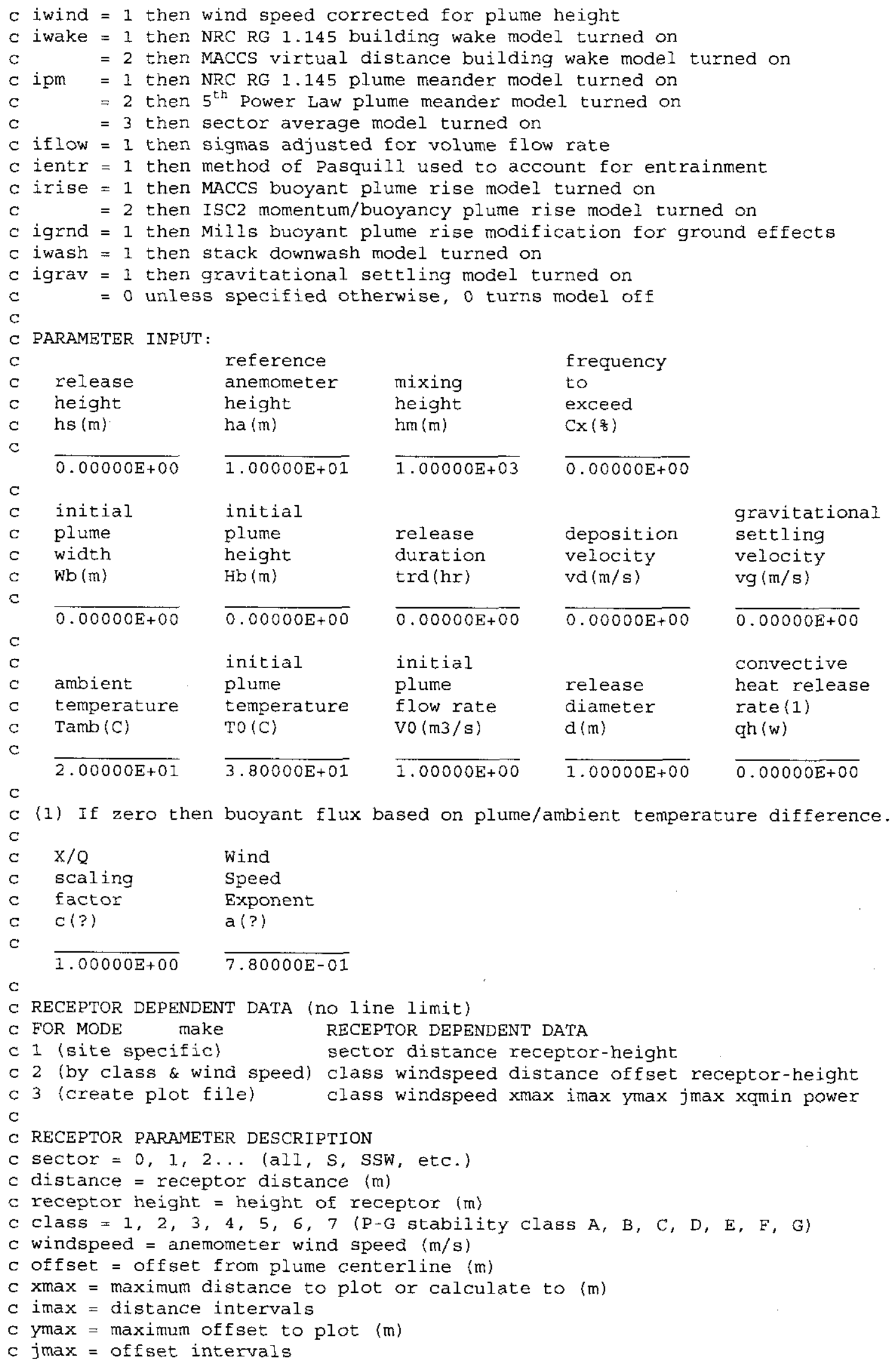




\section{RPP-13482 REV 5}

C $x$ qmin $=$ minimum scaled $X / Q$ to calculate

$c$ power $=$ exponent in power function step size

MODE :

Site specific $X / Q$ calculated.

LOGICAL CHOICES:

Joint frequency used to calculate annual average $X / Q$.

No normalization of joint frequency.

$X / Q$ calculated for single sector.

MODELS SELECTED:

Time-integrated air concentration calculated (s/m3) .

sector average model selected.

WARNING/ERROR MESSAGES :

JOINT FREQUENCY DATA:

200 AREA (HMS) - 10 M - Pasquill A - G (1983 - 1991 Average)

Created $8 / 26 / 92 \mathrm{KR}$

Tank Farms - Annual avearage by sector - $100 \mathrm{~m}$ and site boundary

\begin{tabular}{|c|c|c|c|c|c|c|c|c|}
\hline SECTOR & $\begin{array}{c}\text { DISTANCE } \\
\text { (m) }\end{array}$ & $\begin{array}{l}\text { RECEPT } \\
\text { HEIGHT } \\
\text { (m) }\end{array}$ & $\begin{array}{c}\text { SECT. } \\
\text { FREQ. } \\
\left(\frac{8}{\delta}\right)\end{array}$ & POPULATION & $\begin{array}{c}\text { TOTAL } \\
\text { POPULATION } \\
\text { SCALED } \\
\text { X/Q } \\
(\mathrm{s} / \mathrm{m} 3)\end{array}$ & $\begin{array}{c}\text { AVERAGE } \\
\text { INDIVIDUAL } \\
\text { SCALED } \\
X / Q \\
(\mathrm{~s} / \mathrm{m} 3)\end{array}$ & $\begin{array}{l}\text { ATM. } \\
\text { STAB. } \\
\text { CLASS }\end{array}$ & $\begin{array}{l}\text { WIND } \\
\text { SPEED } \\
(\mathrm{m} / \mathrm{s})\end{array}$ \\
\hline $\bar{S}$ & 100 & $\overline{0}$ & 6.30 & $\overline{1}$ & $1.68 E-04$ & $1.68 \mathrm{E}-04$ & & \\
\hline SSW & 100 & 0 & 4.53 & 1 & $1.04 \mathrm{E}-04$ & 1.04E-04 & & \\
\hline SW & 100 & 0 & 2.93 & 1 & $9.93 E-05$ & $9.93 E-05$ & & \\
\hline WSW & 100 & 0 & 2.72 & 1 & $9.97 E-05$ & $9.97 E-05$ & & \\
\hline $\mathrm{W}$ & 100 & 0 & 4.80 & 1 & $1.73 E-04$ & $1.73 \mathrm{E}-04$ & & \\
\hline WNW & 100 & 0 & 3.98 & 1 & $1.39 E-04$ & $1.39 E-04$ & & \\
\hline NW & 100 & 0 & 4.72 & 1 & $1.57 \mathrm{E}-04$ & $1.57 E-04$ & & \\
\hline $\mathrm{NNW}$ & 100 & 0 & 4.58 & 1 & $1.54 \mathrm{E}-04$ & 1. $54 E-04$ & & \\
\hline $\mathrm{N}$ & 100 & 0 & 4.36 & 1 & $1.61 \mathrm{E}-04$ & $1.61 \mathrm{E}-04$ & & \\
\hline NNE & 100 & 0 & 2.49 & 1 & $9.04 \mathrm{E}-05$ & $9.04 \mathrm{E}-05$ & & \\
\hline $\mathrm{NE}$ & 100 & 0 & 3.90 & 1 & $1.07 E-04$ & $1.07 E-04$ & & \\
\hline ENE & 100 & 0 & 6.17 & 1 & 1. $42 \mathrm{E}-04$ & 1. $42 \mathrm{E}-04$ & & \\
\hline$E$ & 100 & 0 & 14.05 & 1 & $3.78 \mathrm{E}-04$ & $3.78 E-04$ & & \\
\hline ESE & 100 & 0 & 18.80 & 1 & $4.03 E-04$ & $4.03 E-04$ & & \\
\hline $\mathrm{SE}$ & 100 & 0 & 10.83 & 1 & 2. $52 \mathrm{E}-04$ & $2.52 \mathrm{E}-04$ & & \\
\hline SSE & 100 & 0 & 4.78 & 1 & $1.47 \mathrm{E}-04$ & $1.47 E-04$ & & \\
\hline$S$ & 15360 & 0 & 6.30 & 1 & $3.50 E-08$ & $3.50 E-08$ & & \\
\hline SSW & 15360 & 0 & 4.53 & 1 & $2.10 E-08$ & $2.10 E-08$ & & \\
\hline SW & 13200 & 0 & 2.93 & 1 & $2.57 \mathrm{E}-08$ & $2.57 E-08$ & & \\
\hline WSW & 11100 & 0 & 2.72 & 1 & $3.30 E-08$ & $3.30 E-08$ & & \\
\hline $\mathrm{W}$ & 11100 & 0 & 4.80 & 1 & $5.94 E-08$ & $5.94 E-08$ & & \\
\hline WNW & 11100 & 0 & 3.98 & 1 & $4.91 E-08$ & $4.91 E-08$ & & \\
\hline $\mathrm{NW}$ & 10800 & 0 & 4.72 & 1 & $5.95 E-08$ & $5.95 E-08$ & & \\
\hline NNW & 8690 & 0 & 4.58 & 1 & $8.25 E-08$ & $8.25 E-08$ & & \\
\hline $\mathrm{N}$ & 8690 & 0 & 4.36 & 1 & $8.76 E-08$ & $8.76 E-08$ & & \\
\hline NNE & 8970 & 0 & 2.49 & 1 & $4.67 E-08$ & $4.67 E-08$ & & \\
\hline $\mathrm{NE}$ & 10430 & 0 & 3.90 & 1 & $4.44 \mathrm{E}-08$ & $4.44 E-08$ & & \\
\hline$E N E$ & 10530 & 0 & 6.17 & 1 & $5.83 E-08$ & $5.83 E-08$ & & \\
\hline $\mathrm{E}$ & 11160 & 0 & 14.05 & 1 & I. $47 \mathrm{E}-07$ & $1.47 E-07$ & & \\
\hline ESE & 15190 & 0 & 18.80 & 1 & 1.00E-07 & $1.00 \mathrm{E}-07$ & & \\
\hline$S E$ & 21050 & 0 & 10.83 & 1 & $3.78 \mathrm{E}-08$ & $3.78 \mathrm{E}-08$ & & \\
\hline SSE & 15360 & 0 & 4.78 & 1 & $3.22 E-08$ & $3.22 \mathrm{E}-08$ & & \\
\hline
\end{tabular}


RPP-13482 REV 5

GXQ Version $4.0 \mathrm{~F}$

October 8, 2002

General Purpose Atmospheric Dispersion Code Produced by Fluor Federal Services, Inc.

Users Guide documented in WHC-SD-GN-SWD-30002 Rev. 1.

Validation documented in WHC-SD-GN-SWD-30003 Rev. 1.

Code Custodian is: Paul D. Rittmann, PhD CHP

Fluor Federal Services, Inc. E6-17

P.O. Box 1050

Richland, WA 99352-1050

(509) 376-8715

Run Date $=10 / 09 / 02$

Run Time $=09: 37: 59.29$

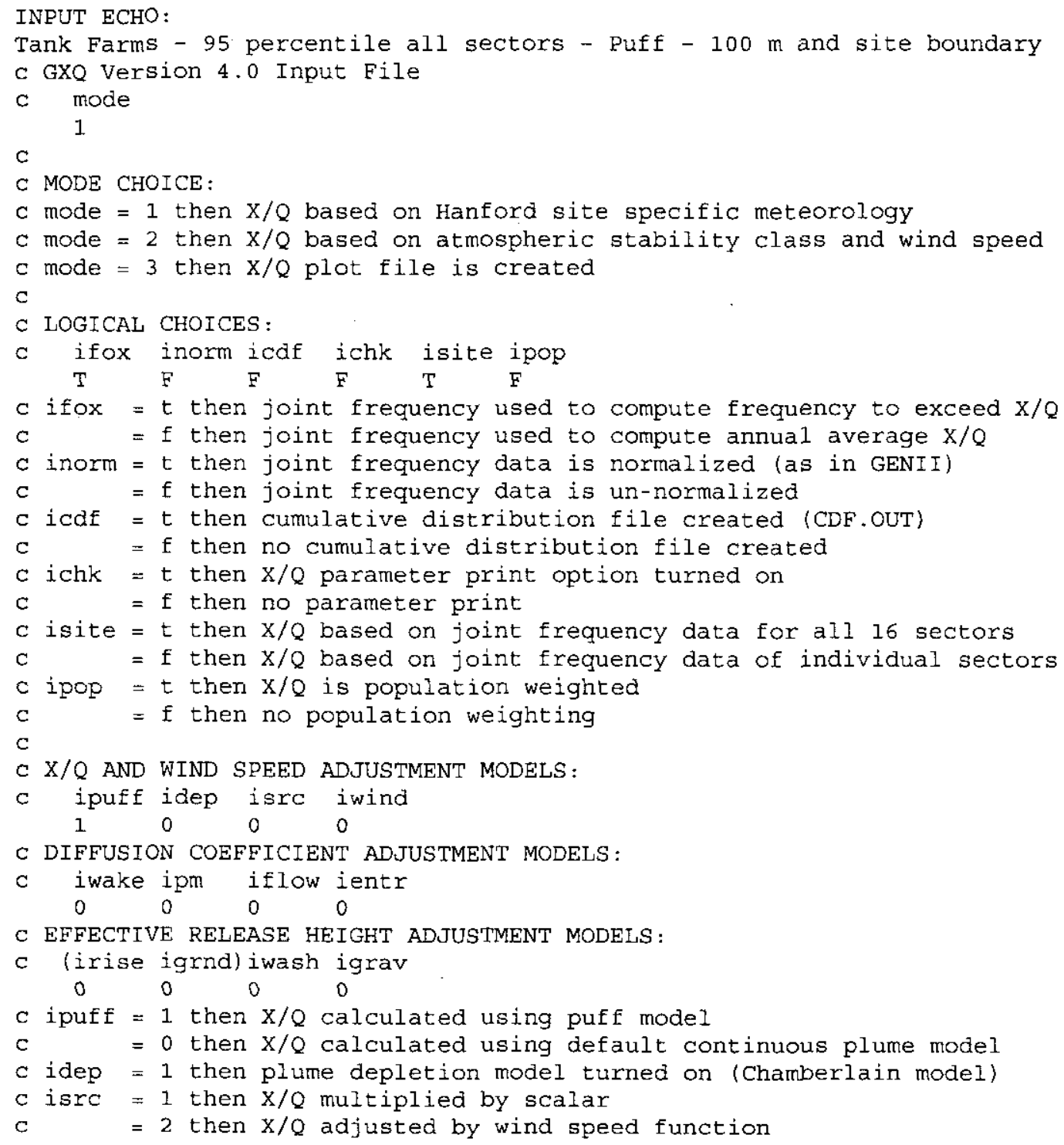




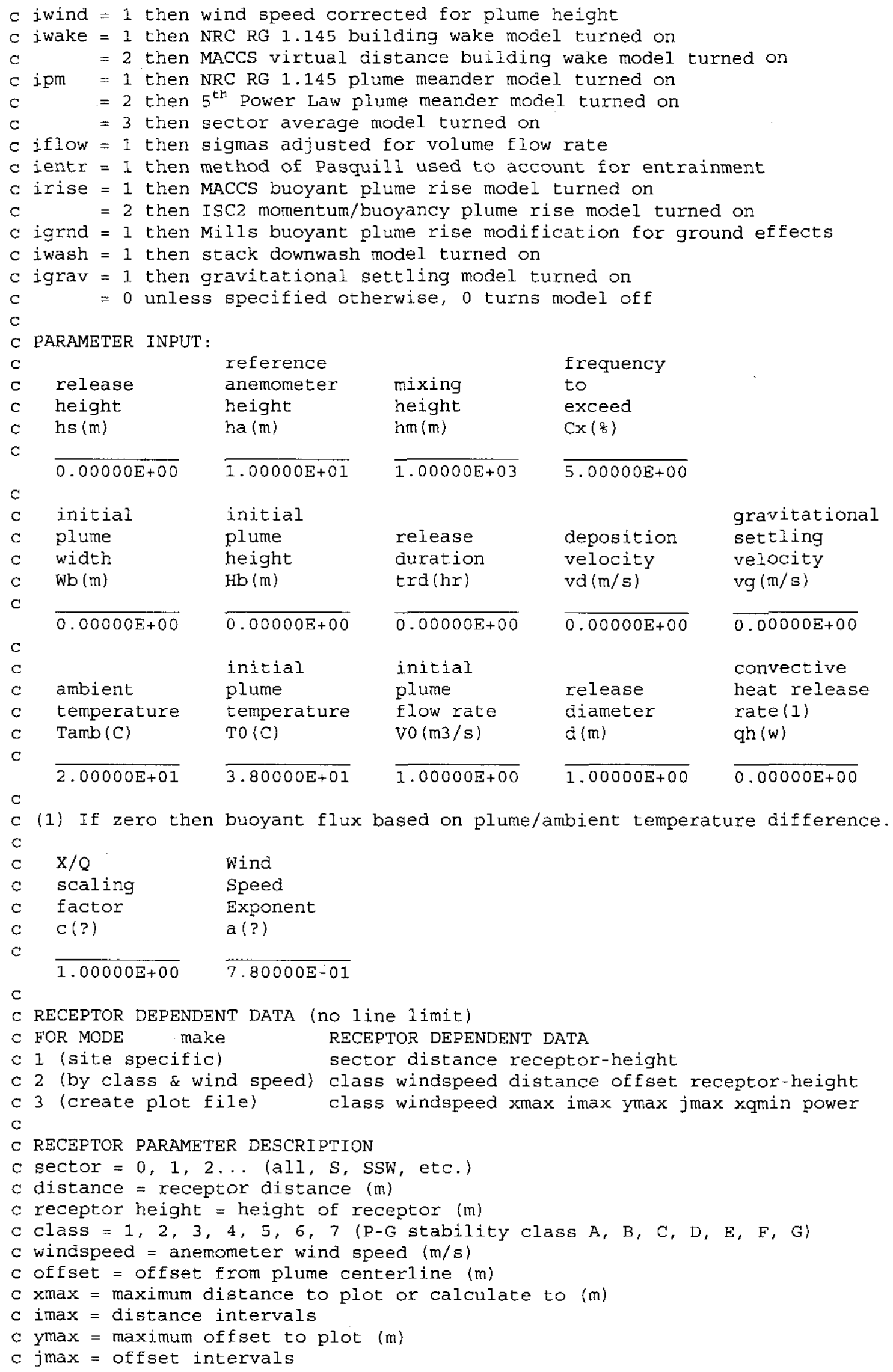




\section{RPP-13482 REV 5}

c $x$ qmin $=$ minimum scaled $x / Q$ to calculate

$c$ power $=$ exponent in power function step size

MODE :

Site specific $X / Q$ calculated.

LOGICAL CHOICES:

Joint frequency used to calculate $\mathrm{X} / \mathrm{Q}$ based on frequency of exceedance. No normalization of joint frequency.

$X / Q$ calculated for overall site.

MODELS SELECTED:

Air concentrations will be calculated $(1 / \mathrm{m} 3)$.

WARNING/ERROR MESSAGES:

JOINT FREQUENCY DATA:

200 AREA (HMS) - 10 M - Pasquill A - G (1983 - 1991 Average)

Created $8 / 26 / 92 \mathrm{KR}$

Tank Farms - 95 percentile all sectors - Puff - $100 \mathrm{~m}$ and site boundary

\begin{tabular}{|c|c|c|c|c|c|c|c|c|}
\hline & & & & & $\begin{array}{c}\text { TOTAL } \\
\text { POPULATION }\end{array}$ & $\begin{array}{l}\text { AVERAGE } \\
\text { INDIVIDUAL }\end{array}$ & & \\
\hline & & & & & SCALED & SCALED & ATM. & WIND \\
\hline SECTOR & $\begin{array}{l}\text { DISTANCE } \\
(\mathrm{m})\end{array}$ & $\begin{array}{l}\text { HEIGHT } \\
\text { (m) }\end{array}$ & $\begin{array}{c}\text { FREQ. } \\
(8)\end{array}$ & POPULATION & $\begin{array}{l}X / Q \\
(I / m 3)\end{array}$ & $\begin{array}{l}X / Q \\
(1 / \mathrm{m} 3)\end{array}$ & $\begin{array}{l}\text { STAB. } \\
\text { CLASS }\end{array}$ & $\begin{array}{l}\text { SPEED } \\
(\mathrm{m} / \mathrm{s})\end{array}$ \\
\hline LL & 100 & 0 & 99 & & $8.88 E-03$ & $8.88 \mathrm{E}-$ & G & 0. \\
\hline ALL & 15360 & 0 & 99.94 & 1 & $5.06 \mathrm{E}-08$ & $5.06 E-08$ & G & 0.89 \\
\hline
\end{tabular}


GXQ Version $4.0 \mathrm{~F}$

October 8,2002

General Purpose Atmospheric Dispersion Code produced by Fluor Federal Services, Inc.

Users Guide documented in WHC-SD-GN-SWD-30002 Rev. 1 . validation documented in WHC-SD-GN-SWD-30003 Rev. 1 .

code Custodian is: Paul D. Rittmann, PhD CHP

Fluor Federal Services, Inc. E6-17

p.O. Box 1050

Richland, WA 99352-1050

(509) $376-8715$

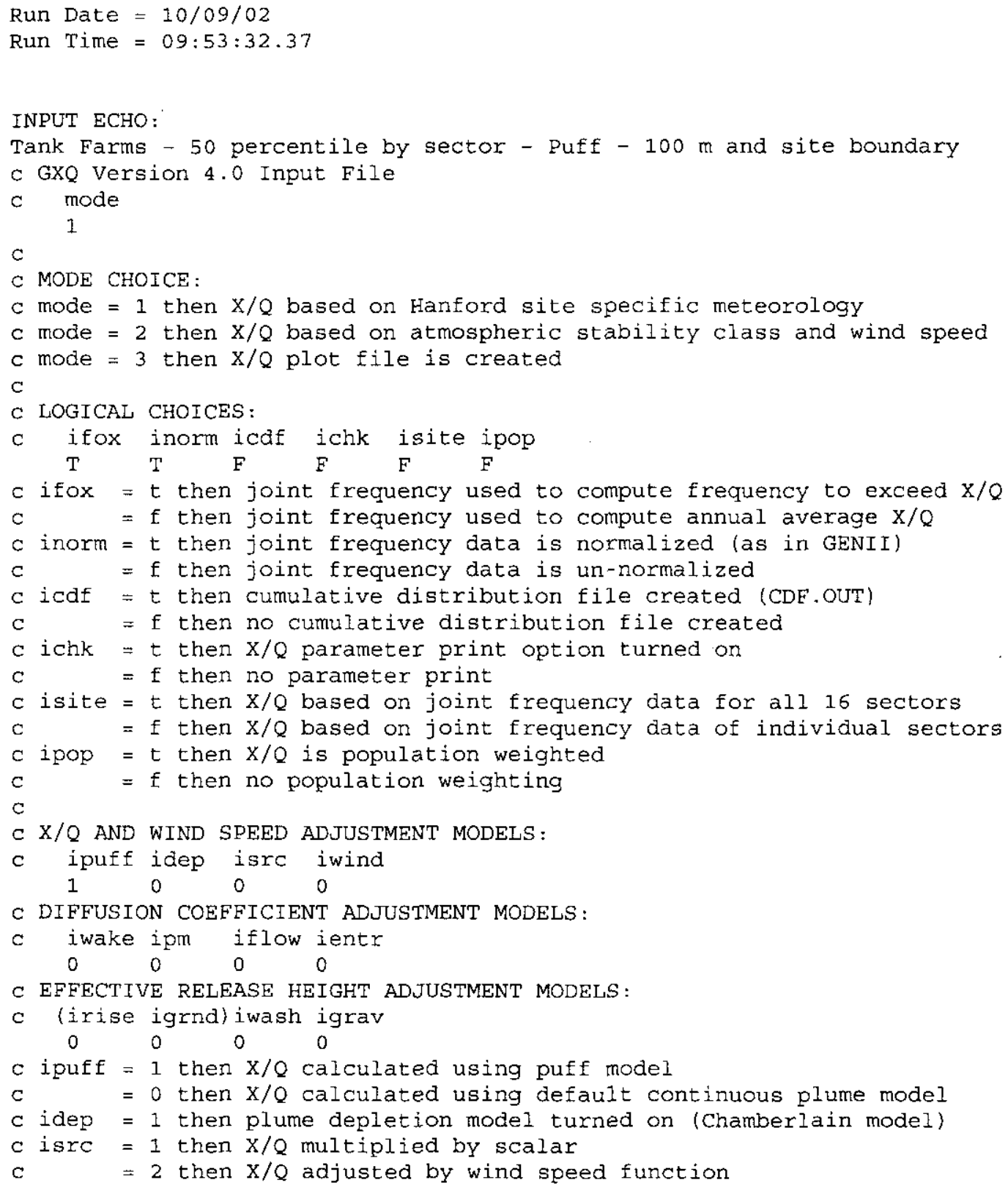




\section{RPP-13482 REV 5}

C iwind $=1$ then wind speed corrected for plume height

$c$ iwake $=1$ then NRC RG 1.145 building wake model turned on

c $=2$ then MACCS virtual distance building wake model turned on

ipm $=1$ then NRC RG 1.145 plume meander model turned on

$=2$ then $5^{\text {th }}$ Power Law plume meander model turned on

$=3$ then sector average model turned on

iflow $=1$ then sigmas adjusted for volume flow rate

ientr $=1$ then method of Pasquill used to account for entrainment

irise $=1$ then MACCS buoyant plume rise model turned on

$=2$ then ISC2 momentum/buoyancy plume rise model turned on

igrnd $=1$ then Mills buoyant plume rise modification for ground effects

iwash $=1$ then stack downwash model turned on

igrav $=1$ then gravitational settling model turned on

$=0$ unless specified otherwise, 0 turns model off

PARAMETER INPUT:

\begin{tabular}{|c|c|c|c|c|}
\hline $\begin{array}{l}\text { release } \\
\text { height } \\
\text { hs }(\mathrm{m})\end{array}$ & $\begin{array}{l}\text { reference } \\
\text { anemometer } \\
\text { height } \\
\text { ha }(m)\end{array}$ & $\begin{array}{l}\text { mixing } \\
\text { height } \\
\text { hm (m) }\end{array}$ & $\begin{array}{l}\text { frequency } \\
\text { to } \\
\text { exceed } \\
\text { Cx }(8)\end{array}$ & \\
\hline $0.00000 E+00$ & $1.00000 E+01$ & $1.00000 E+03$ & $5.00000 \mathrm{E}+01$ & \\
\hline $\begin{array}{l}\text { initial } \\
\text { plume } \\
\text { width } \\
\text { Wb }(m)\end{array}$ & $\begin{array}{l}\text { initial } \\
\text { plume } \\
\text { height } \\
\mathrm{Hb}(\mathrm{m})\end{array}$ & $\begin{array}{l}\text { release } \\
\text { duration } \\
\text { trd(hr) }\end{array}$ & $\begin{array}{l}\text { deposition } \\
\text { velocity } \\
\operatorname{vd}(\mathrm{m} / \mathrm{s})\end{array}$ & $\begin{array}{l}\text { gravitationa } \\
\text { settling } \\
\text { velocity } \\
\operatorname{vg}(\mathrm{m} / \mathrm{s})\end{array}$ \\
\hline $0.00000 \mathrm{E}+00$ & $0.00000 \mathrm{E}+00$ & $0.00000 \mathrm{E}+00$ & $0.00000 \mathrm{E}+00$ & $0.00000 \mathrm{E}+00$ \\
\hline $\begin{array}{l}\text { ambient } \\
\text { temperature } \\
\text { Tamb (C) }\end{array}$ & $\begin{array}{l}\text { initial } \\
\text { plume } \\
\text { temperature } \\
\text { To(C) }\end{array}$ & $\begin{array}{l}\text { initial } \\
\text { plume } \\
\text { flow rate } \\
\text { Vo }(\mathrm{m} 3 / \mathrm{s})\end{array}$ & $\begin{array}{l}\text { release } \\
\text { diameter } \\
d(m)\end{array}$ & $\begin{array}{l}\text { Convective } \\
\text { heat release } \\
\text { rate (1) } \\
\text { qh }(w)\end{array}$ \\
\hline $2.00000 \mathrm{E}+01$ & $\overline{3.80000 E+01}$ & $1.00000 \mathrm{E}+00$ & $\overline{1.00000 E+00}$ & $0.00000 \mathrm{E}+00$ \\
\hline
\end{tabular}

$\mathrm{C}$

c (1) If zero then buoyant flux based on plume/ambient temperature difference.

$\mathrm{C}$

C $\mathrm{X} / \mathrm{Q}$ Wind

$c$ scaling speed

C factor Exponent

c $c(?) \quad a(?)$

C $\overline{1.00000 \mathrm{E}+00} \quad \overline{7.80000 \mathrm{E}-01}$

C

C RECEPTOR DEPENDENT DATA (no line limit)

C FOR MODE make RECEPTOR DEPENDENT DATA

c 1 (site specific) sector distance receptor-height

c 2 (by class \& wind speed) class windspeed distance offset receptor-height

c 3 (create plot file) class windspeed xmax imax ymax jmax xqmin power

$\mathrm{C}$

C RECEPTOR PARAMETER DESCRIPTION

C sector $=0,1,2 \ldots($ all $, S, S s w$, etc.)

C distance $=$ receptor distance $(\mathrm{m})$

c receptor height $=$ height of receptor $(\mathrm{m})$

C class $=1,2,3,4,5,6,7$ (P-G stability class $A, B, C, D, E, F, G)$

$c$ windspeed $=$ anemometer wind $\operatorname{speed}(\mathrm{m} / \mathrm{s})$

$c$ offset $=$ offset from plume centerline $(\mathrm{m})$

$c$ max $=$ maximum distance to plot or calculate to $(\mathrm{m})$

c imax = distance intervals

$c$ ymax $=$ maximum offset to plot $(m)$

$c$ jmax $=$ offset intervals 


\section{RPP-13482 REV 5}

c $x q m i n=$ minimum scaled $X / Q$ to calculate

$c$ power $=$ exponent in power function step size

MODE :

Site specific $X / Q$ calculated.

LOGICAL CHOICES:

Joint frequency used to calculate $X / Q$ based on frequency of exceedance.

Joint frequency data normalized.

$\mathrm{X} / \mathrm{Q}$ calculated for single sector.

MODELS SELECTED:

Air concentrations will be calculated $(1 / \mathrm{m} 3)$.

WARNING/ERROR MESSAGES :

JOINT FREQUENCY DATA:

200 AREA (HMS) - 10 M - Pasquill A - G (1983 - 1991 Average)

Created $8 / 26 / 92 \mathrm{KR}$

Tank Farms - 50 percentile by sector - Puff - $100 \mathrm{~m}$ and site boundary

\begin{tabular}{|c|c|c|c|c|c|c|c|c|}
\hline SECTOR & $\begin{array}{l}\text { DISTANCE } \\
(\mathrm{m})\end{array}$ & $\begin{array}{c}\text { RECEPT } \\
\text { HEIGHT } \\
\text { (m) }\end{array}$ & $\begin{array}{c}\text { SECT. } \\
\text { FREQ } \\
\left(\frac{8}{8}\right)\end{array}$ & POPULATION & $\begin{array}{c}\text { TOTAL } \\
\text { POPULATION } \\
\text { SCALED } \\
\text { X/Q } \\
(1 / \mathrm{m} 3)\end{array}$ & $\begin{array}{l}\text { AVERAGE } \\
\text { INDIVIDUAL } \\
\text { SCALED } \\
X / Q \\
(1 / \mathrm{m} 3)\end{array}$ & $\begin{array}{l}\text { ATM. } \\
\text { STAB. } \\
\text { CLASS }\end{array}$ & $\begin{array}{l}\text { WIND } \\
\text { SPEED } \\
(\mathrm{m} / \mathrm{s})\end{array}$ \\
\hline $\mathrm{S}$ & 100 & $\overline{0}$ & 100.00 & 1 & $2.59 E-04$ & $2.59 \mathrm{E}-04$ & $D$ & 2.65 \\
\hline SSW & 100 & 0 & 100.00 & 1 & $2.54 \mathrm{E}-04$ & $2.54 \mathrm{E}-04$ & $\mathrm{D}$ & 2.65 \\
\hline SW & 100 & 0 & 100.00 & 1 & $2.59 \mathrm{E}-04$ & $2.59 \mathrm{E}-04$ & $\mathrm{D}$ & 0.89 \\
\hline WSW & 100 & 0 & 100.00 & 1 & $2.50 \mathrm{E}-04$ & $2.50 E-04$ & $\mathrm{D}$ & 2.65 \\
\hline $\mathrm{W}$ & 100 & 0 & 100.00 & 1 & $2.92 E-04$ & $2.92 \mathrm{E}-04$ & $\mathrm{D}$ & 2.65 \\
\hline WNW & 100 & 0 & 100.00 & 1 & $3.38 E-04$ & $3.38 E-04$ & $\mathrm{D}$ & 2.65 \\
\hline $\mathrm{NW}$ & 100 & 0 & 100.00 & 1 & $4.68 \mathrm{E}-04$ & $4.68 \mathrm{E}-04$ & $\mathrm{D}$ & 2.65 \\
\hline NNW & 100 & 0 & 100.00 & 1 & $6.48 \mathrm{E}-04$ & $6.48 E-04$ & $\mathrm{E}$ & 2.65 \\
\hline $\mathrm{N}$ & 100 & 0 & 100.00 & 1 & $7.07 E-04$ & $7.07 E-04$ & E & 2.65 \\
\hline NNE & 100 & 0 & 100.00 & 1 & $6.28 \mathrm{E}-04$ & $6.28 \mathrm{E}-04$ & $\mathrm{E}$ & 2.65 \\
\hline $\mathrm{NE}$ & 100 & 0 & 100.00 & 1 & $5.32 E-04$ & $5.32 E-04$ & $\mathrm{D}$ & 4.70 \\
\hline ENE & 100 & 0 & 100.00 & 1 & $5.21 E-04$ & $5.21 E-04$ & $\mathrm{D}$ & 4.70 \\
\hline$E$ & 100 & 0 & 100.00 & 1 & $9.48 \mathrm{E}-04$ & $9.48 E-04$ & $\mathrm{E}$ & 2.65 \\
\hline ESE & 100 & 0 & 100.00 & 1 & $7.61 \mathrm{E}-04$ & $7.61 E-04$ & $E$ & 2.65 \\
\hline$S E$ & 100 & 0 & 100.00 & 1 & $5.01 E-04$ & $5.01 \mathrm{E}-04$ & $\mathrm{D}$ & 4.70 \\
\hline SSE & 100 & 0 & 100.00 & 1 & $3.36 \mathrm{E}-04$ & $3.36 \mathrm{E}-04$ & D & 2.65 \\
\hline $\mathrm{S}$ & 15360 & 0 & 100.00 & 1 & $7.39 \mathrm{E}-10$ & $7.39 E-10$ & $\mathrm{D}$ & 2.65 \\
\hline SSW & 15360 & 0 & 100.00 & 1 & $7.23 E-10$ & $7.23 E-10$ & $\mathrm{D}$ & 2.65 \\
\hline SW & 13200 & 0 & 100.00 & $\lambda$ & $1.06 \mathrm{E}-09$ & $1.06 \mathrm{E}-09$ & $\mathrm{D}$ & 0.89 \\
\hline WSW & 11100 & 0 & 100.00 & 1 & $1.53 E-09$ & $1.53 E-09$ & $\mathrm{D}$ & 2.65 \\
\hline w & 11100 & 0 & 100.00 & 1 & $1.87 E-09$ & $1.87 \mathrm{E}-09$ & $\mathrm{D}$ & 2.65 \\
\hline WNW & 11100 & 0 & 100.00 & 1 & $2.29 E-09$ & $2.29 \mathrm{E}-09$ & $\mathrm{D}$ & 2.65 \\
\hline $\mathrm{NW}$ & 10800 & 0 & 100.00 & $I$ & $3.83 E-09$ & $3.83 E-09$ & $\mathrm{D}$ & 2.65 \\
\hline NNW & 8690 & 0 & 100.00 & 1 & $9.40 \mathrm{E}-09$ & $9.40 \mathrm{E}-09$ & $\mathrm{E}$ & 2.65 \\
\hline $\mathrm{N}$ & 8690 & 0 & 100.00 & 1 & $1.04 E-08$ & $1.04 \mathrm{E}-08$ & $\mathrm{E}$ & 2.65 \\
\hline NNE & 8970 & 0 & 100.00 & 1 & $8.42 E-09$ & $8.42 \mathrm{E}-09$ & $\mathrm{E}$ & 2.65 \\
\hline $\mathrm{NE}$ & 10430 & 0 & 100.00 & 1 & $4.89 E-09$ & $4.89 E-09$ & $\mathrm{D}$ & 4.70 \\
\hline ENE & 10530 & 0 & 100.00 & 1 & $4.65 \mathrm{E}-09$ & $4.65 \mathrm{E}-09$ & $D$ & 4.70 \\
\hline$E$ & 11160 & 0 & 100.00 & 1 & $8.28 E-09$ & $8.28 \mathrm{E}-09$ & $\mathrm{E}$ & 2.65 \\
\hline ESE & 15190 & 0 & 100.00 & 1 & $3.24 E-09$ & $3.24 \mathrm{E}-09$ & $E$ & 2.65 \\
\hline $\mathrm{SE}$ & 21050 & 0 & 100.00 & 1 & $9.20 \mathrm{E}-10$ & $9.20 \mathrm{E}-10$ & $\bar{D}$ & 4.70 \\
\hline SSE & 15360 & 0 & 100.00 & 1 & $1.06 E-09$ & $1.06 E-09$ & $\mathrm{D}$ & 2.65 \\
\hline
\end{tabular}


RPP-13482 REV 5

\section{APPENDIX C}

SAMPLE RUN FILES FOR MODIFICATIONS TO THE BASIC DISPERSION COEFFICIENTS 
RPP-13482 REV 5

This page intentionally left blank.

C-ii 


\section{APPENDIX C \\ SAMPLE RUN FILES FOR MODIFICATIONS TO THE BASIC DISPERSION COEFFICIENTS IN SECTION 2.3}

- Run file $-95^{\text {th }}$ percentile overall, $1 \mathrm{hr}$, with deposition $(0.15 \mathrm{~cm} / \mathrm{s})$

- Run file $-95^{\text {th }}$ percentile overall, $1 \mathrm{hr}$, elevated source with no momentum rise (9.5-ft stack, $\left.1,000 \mathrm{ft}^{3} / \mathrm{min}\right)$

- Run file $-95^{\text {th }}$ percentile overall, $1 \mathrm{hr}$, elevated source with momentum rise (9.5-ft stack, $1,000 \mathrm{ft}^{3} / \mathrm{min}, 10$-in.-diameter opening)

- Run file $-95^{\text {th }}$ percentile overall, $1 \mathrm{hr}$, initial source width of $50 \mathrm{~m}$

- Run file $-95^{\text {th }}$ percentile overall, $1 \mathrm{hr}$, wind entrainment from 50 -m-diameter pool

- Run file $-95^{\text {th }}$ percentile overall, $1 \mathrm{hr}, 100 \mathrm{~kW}$ ground-level fire with 5 -m-diameter

- Run file $-95^{\text {th }}$ percentile overall, $1 \mathrm{hr}$, release from building with $300 \mathrm{~m}^{2}$ minimum cross-section 


\section{RPP-13482 REV 5}

GXQ Version $4.0 \mathrm{~F}$

October 8,2002

General Purpose Atmospheric Dispersion Code

Produced by Fluor Federal Services, Inc.

Users Guide documented in WHC-SD-GN-SWD-30002 Rev. 1.

validation documented in WHC-SD-GN-SWD-30003 Rev. 1.

Code Custodian is: Paul D. Rittmann, PhD CHP

Fluor Federal Services, Inc. E6-17

P.O. Box 1050

Richland, WA 99352-1050

(509) $376-8715$

Run Date $=10 / 09 / 02$

Run Time $=10: 05: 10.85$

INPUT ECHO:

Tank Farms - 95 percentile all sectors - 1 hour - with deposition

c GXQ Version 4.0 Input File

C mode

1

$c$

C MODE CHOICE :

$c$ mode $=1$ then $X / Q$ based on Hanford site specific meteorology

$c$ mode $=2$ then $X / Q$ based on atmospheric stability class and wind speed

$c$ mode $=3$ then $X / Q$ plot file is created

$\mathrm{c}$

C LOGICAL CHOICES:

C ifox inorm icdf ichk isite ipop

$\begin{array}{llllll}T & F & F & F & T & F\end{array}$

$c$ ifox $=t$ then joint frequency used to compute frequency to exceed $x / Q$

$\mathrm{C}=\mathrm{f}$ then joint frequency used to compute annual average $\mathrm{X} / \mathrm{Q}$

c inorm $=t$ then joint frequency data is normalized (as in GENII)

$\mathrm{c}=\mathrm{f}$ then joint frequency data is un-normalized

$\mathrm{c}$ icdf $=\mathrm{t}$ then cumulative distribution file created (CDF.OUT)

$\mathrm{C}=\mathrm{I}$ then no cumulative distribution file created

$\mathrm{c} i \mathrm{chk}=\mathrm{t}$ then $\mathrm{X} / \mathrm{Q}$ parameter print option turned on

$\mathrm{C} \quad \mathrm{f}$ then no parameter print

$c$ isite $=t$ then $X / Q$ based on joint frequency data for all 16 sectors

$\mathrm{C}=\mathrm{f}$ then $\mathrm{X} / \mathrm{Q}$ based on joint frequency data of individual sectors

$C$ ipop $=t$ then $X / Q$ is population weighted

$\mathrm{C}=\mathrm{f}$ then no population weighting

C X/Q AND WIND SPEED ADUUSTMENT MODELS:

$C$ ipuff idep isrc iwind

$0 \quad 1 \quad 0 \quad 0$

C DIFFUSION COEFFICIENT ADJUSTMENT MODELS:

C iwake ipm iflow ientr

00000

C EFFECTIVE RELEASE HEIGHT ADJUSTMENT MODELS:

C (irise igrnd) iwash igrav

$\begin{array}{llll}0 & 0 & 0 & 0\end{array}$

$c$ ipuff $=1$ then $X / Q$ calculated using puff model

$c \quad=0$ then $X / Q$ calculated using default continuous plume model

$c$ idep $=1$ then plume depletion model turned on (Chamberlain model)

$C$ isrc $=1$ then $X / Q$ multiplied by scalar

$c \quad=2$ then $X / Q$ adjusted by wind speed function 


\section{RPP-13482 REV 5}

c iwind $=1$ then wind speed corrected for plume height

c iwake $=1$ then NRC RG 1.145 building wake model turned on

$\mathrm{c}=2$ then MACCS virtual distance building wake model turned on

$\mathrm{c}$ ipm $=1$ then NRC RG 1.145 plume meander model turned on

$c \quad=2$ then $5^{\text {th }}$ Power Law plume meander model turned on

$=3$ then sector average model turned on

iflow $=1$ then sigmas adjusted for volume flow rate

ientr $=1$ then method of Pasquill used to account for entrainment

irise $=1$ then MACCS buoyant plume rise model turned on

$=2$ then ISC2 momentum/buoyancy plume rise model turned on

igrnd $=1$ then Mills buoyant plume rise modification for ground effects

iwash $=1$ then stack downwash model turned on

igrav = 1 then gravitational settling model turned on

$=0$ unless specified otherwise, 0 turns model of

PARAMETER INPUT:

\begin{tabular}{|c|c|c|c|c|}
\hline $\begin{array}{l}\text { release } \\
\text { height } \\
\text { hs (m) }\end{array}$ & $\begin{array}{l}\text { reference } \\
\text { anemometer } \\
\text { height } \\
\text { ha }(\mathrm{m})\end{array}$ & $\begin{array}{l}\text { mixing } \\
\text { height } \\
\mathrm{hm}(\mathrm{m})\end{array}$ & $\begin{array}{l}\text { frequency } \\
\text { to } \\
\text { exceed } \\
\text { cx }(8)\end{array}$ & \\
\hline $0.00000 \mathrm{E}+00$ & $1.00000 \mathrm{E}+01$ & $1.00000 \mathrm{E}+03$ & $5.00000 \mathrm{E}+00$ & \\
\hline $\begin{array}{l}\text { initial } \\
\text { plume } \\
\text { width } \\
\text { Wb (m) }\end{array}$ & $\begin{array}{l}\text { initial } \\
\text { plume } \\
\text { height } \\
\mathrm{Hb}(\mathrm{m})\end{array}$ & $\begin{array}{l}\text { release } \\
\text { duration } \\
\text { trd(hr) }\end{array}$ & $\begin{array}{l}\text { deposition } \\
\text { velocity } \\
\text { vd }(\mathrm{m} / \mathrm{s})\end{array}$ & $\begin{array}{l}\text { gravitational } \\
\text { settling } \\
\text { velocity } \\
\mathrm{vg}(\mathrm{m} / \mathrm{s})\end{array}$ \\
\hline $0.00000 E+00$ & $0.00000 \mathrm{E}+00$ & $0.00000 \mathrm{E}+00$ & $1.50000 \mathrm{E}-03$ & $0.00000 \mathrm{E}+00$ \\
\hline $\begin{array}{l}\text { ambient } \\
\text { temperature } \\
\text { Tamb (C) }\end{array}$ & $\begin{array}{l}\text { initial } \\
\text { plume } \\
\text { temperature } \\
\text { To(C) }\end{array}$ & $\begin{array}{l}\text { initial } \\
\text { plume } \\
\text { flow rate } \\
\text { V0 (m3/s) }\end{array}$ & $\begin{array}{l}\text { release } \\
\text { diameter } \\
d(m)\end{array}$ & $\begin{array}{l}\text { convective } \\
\text { heat release } \\
\text { rate }(1) \\
\text { gh }(w)\end{array}$ \\
\hline $2.00000 E+01$ & $2.00000 \mathrm{E}+01$ & $1.00000 E+00$ & $1.00000 \mathrm{E}+00$ & $0.00000 \mathrm{E}+00$ \\
\hline
\end{tabular}

(1) If zero then buoyant flux based on plume/ambient temperature difference.

C $\mathrm{X} / \mathrm{Q} \quad$ Wind

C scaling speed

C factor Exponent

C $c(?) \quad a(?)$

c $\overline{1.00000 E+00} \quad \overline{7.80000 E-01}$

C

C RECEPTOR DEPENDENT DATA (no line limit)

C FOR MODE make RECEPTOR DEPENDENT DATA

C 1 (site specific) sector distance receptor-height

c 2 (by class \& wind speed) class windspeed distance offset receptor-height

c 3 (create plot file) class windspeed xmax imax ymax jmax xqmin power

C

c RECEPTOR PARAMETER DESCRIPTION

C sector $=0,1,2 \ldots($ all,$S$, SSW, etc.)

$c$ distance = receptor distance $(\mathrm{m})$

$c$ receptor height $=$ height of receptor $(\mathrm{m})$

C class $=1,2,3,4,5,6,7$ (P-G stability class A, B, C, D, E, F, G)

$\mathrm{c}$ windspeed $=$ anemometer wind speed $(\mathrm{m} / \mathrm{s})$

$c$ offset $=$ offset from plume centerline (m)

$c$ max $=$ maximum distance to plot or calculate to (m)

c $i \max =$ distance intervals

c ymax = maximum offset to plot $(\mathrm{m})$

c jmax $=$ offset intervals 


\section{RPP-13482 REV 5}

c $x q m i n=$ minimum scaled $X / Q$ to calculate

$c$ power $=$ exponent in power function step size

MODE:

Site specific $X / Q$ calculated.

LOGICAL CHOICES :

Joint frequency used to calculate $X / Q$ based on frequency of exceedance.

No normalization of joint frequency.

$\mathrm{X} / \mathrm{Q}$ calculated for overall site.

MODELS SELECTED:

Time-integrated air concentration calculated (s/m3).

Source depletion model selected.

WARNING/ERROR MESSAGES :

JOINT FREQUENCY DATA:

200 AREA (HMS) - 10 M - Pasquill A - G (1983 - 1991 Average)

Created $8 / 26 / 92 \mathrm{KR}$

Tank Farms - 95 percentile all sectors - 1 hour - $100 \mathrm{~m}$ and site boundary

\begin{tabular}{|c|c|c|c|c|c|c|c|c|}
\hline \multirow[b]{3}{*}{ SECTOR } & & & & & $\begin{array}{l}\text { TOTAL } \\
\text { POPULATION }\end{array}$ & $\begin{array}{l}\text { AVERAGE } \\
\text { INDIVIDUAL }\end{array}$ & & \\
\hline & & RECEPT & SECT. & & SCALED & SCALED & ATM & WIND \\
\hline & $\begin{array}{l}\text { DISTANCE } \\
\text { (m) }\end{array}$ & $\begin{array}{l}\text { HETGHT } \\
(m)\end{array}$ & $\begin{array}{c}\text { FREQ. } \\
\left(\frac{q}{b}\right)\end{array}$ & POPULATION & $\begin{array}{l}x / Q \\
(s / m 3)\end{array}$ & $\begin{array}{l}X / Q \\
(\mathrm{~s} / \mathrm{m} 3)\end{array}$ & $\begin{array}{l}\text { STAB. } \\
\text { CLASS }\end{array}$ & $\begin{array}{l}\text { SPEED } \\
(\mathrm{m} / \mathrm{s})\end{array}$ \\
\hline IL & 100 & 0 & 99.94 & 1 & $2.84 \mathrm{E}-02$ & $2.84 \mathrm{E}-02$ & $\mathrm{~F}$ & 0.89 \\
\hline ALL & 15360 & 0 & 99.94 & 1 & $1.14 \mathrm{E}-05$ & 1. $14 \mathrm{E}-0.5$ & $F$ & 0.89 \\
\hline
\end{tabular}




\section{RPP-13482 REV 5}

GXQ Version $4.0 F$

October 9,2002

Gereral Purpose Atmospheric Dispersion Code Produced by Fluor Federal Services, Inc.

Users Guide documented in WHC-SD-GN-SWD-30002 Rev. 1 .

Validation documented in WHC-SD-GN-SWD-30003 Rev. 1 .

Code Custodian is: Paul D. Rittmann, PhD CHP

Fluor Federal Services, Inc. E6-17

P.O. Box 1050

Richland, WA 99352-1050

(509) $376-8715$

Run Date $=10 / 15 / 02$

Run Time $=15: 08: 16.90$

INPUT ECHO:

Tank Farms - 95\% all sectors - 1 hour - volume rate source - no momentum c GXQ Version 4.0 Input File

c mode

1

$\mathrm{C}$

C MODE CHOICE:

$\mathrm{C}$ mode $=1$ then $\mathrm{X} / \mathrm{Q}$ based on Hanford site specific meteorology

$c$ mode $=2$ then $X / Q$ based on atmospheric stability class and wind speed

$c$ mode $=3$ then $X / Q$ plot file is created

$\mathrm{C}$

C LOGICAL CHOICES:

C ifox inorm icdf ichk isite ipop

$\begin{array}{lllllll}T & F & F & F & T & F\end{array}$

$c$ ifox $=t$ then joint frequency used to compute frequency to exceed $X / Q$

$\mathrm{C}=\mathrm{f}$ then joint frequency used to compute annual average $\mathrm{X} / \mathrm{Q}$

$c$ inorm $=t$ then joint frequency data is normalized (as in GENII)

$c \quad=f$ then joint frequency data is un-normalized

$c$ icdf $=t$ then cumulative distribution file created (CDF.OUT)

$\mathrm{C}=\mathrm{f}$ then no cumulative distribution file created

$c$ ichk $=t$ then $x / Q$ parameter print option turned on

C $\quad=f$ then no parameter print

$c$ isite $=t$ then $X / Q$ based on joint frequency data for all 16 sectors

$\mathrm{C} \quad=\mathrm{f}$ then $\mathrm{X} / \mathrm{Q}$ based on joint frequency data of individual sectors

$c$ ipop $=t$ then $X / Q$ is population weighted

$c=\mathrm{f}$ then no population weighting

$C X / Q$ AND WIND SPEED ADJUSTMENT MODELS:

C ipuff idep isrc iwind

$$
\begin{array}{llll}
0 & 0 & 0 & 1
\end{array}
$$

C DIFFUSION COEFFICIENT ADJUSTMENT MODELS:

C iwake ipm iflow ientr

$$
\begin{array}{llll}
0 & 0 & 1 & 0
\end{array}
$$

C EFFECTIVE RELEASE HEIGHT ADJUSTMENT MODELS:

C (irise igrnd) iwash igrav

$$
\begin{array}{llll}
0 & 0 & 1 & 0
\end{array}
$$

$C$ ipuff $=1$ then $X / Q$ calculated using puff model

$\mathrm{C}=0$ then $\mathrm{X} / \mathrm{Q}$ calculated using default continuous plume model

c idep $=1$ then plume depletion model turned on (Chamberlain model)

$\mathrm{C}$ isrc $=1$ then $\mathrm{X} / \mathrm{Q}$ multiplied by scalar

$c=2$ then $X / Q$ adjusted by wind speed function 


\section{RPP-13482 REV 5}

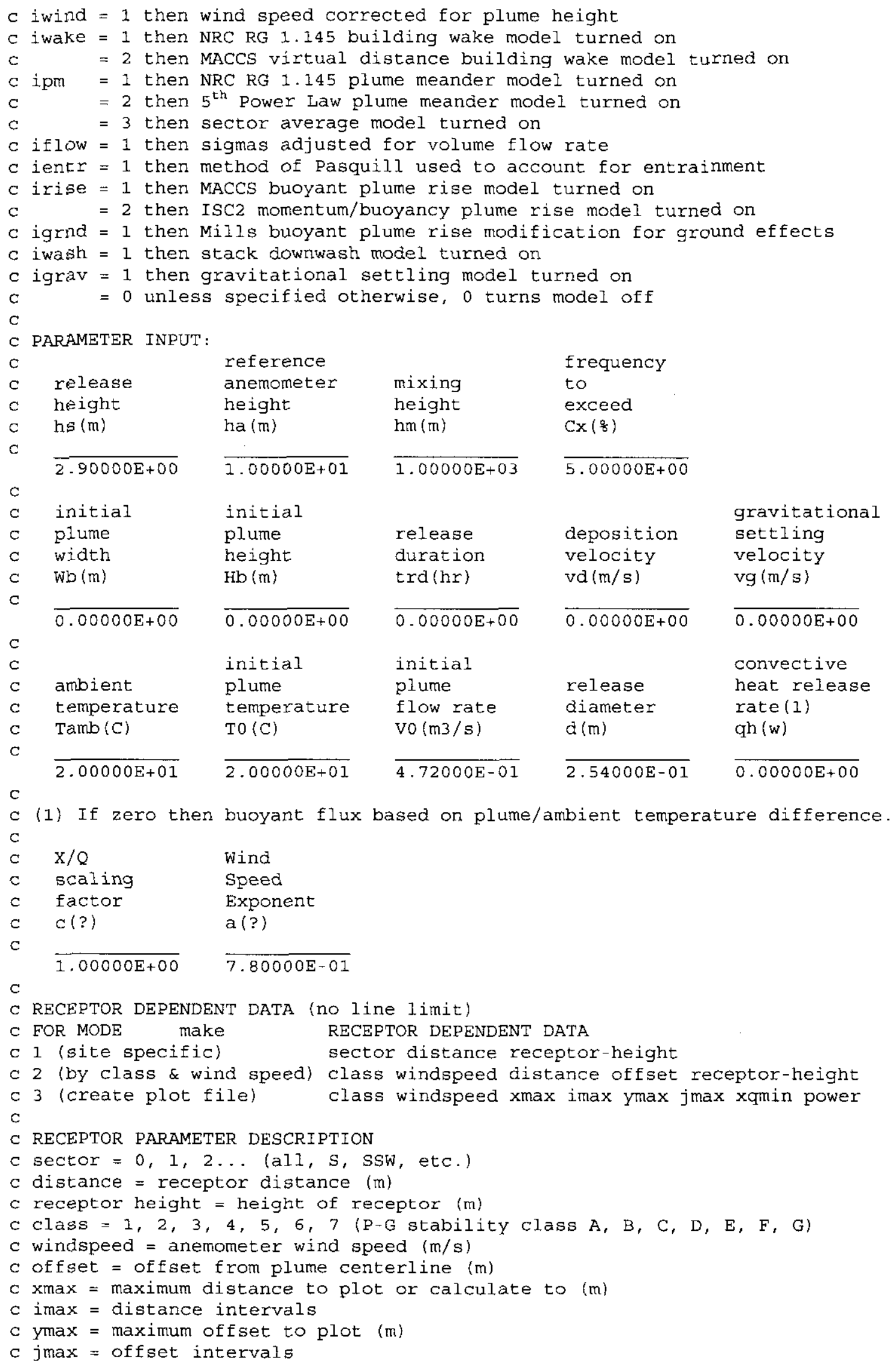




\section{RPP-13482 REV 5}

$c$ xqmin $=$ minimum scaled $x / Q$ to calculate

$c$ power $=$ exponent in power function step size

MODE :

Site specific $x / Q$ calculated.

LOGICAL CHOICES:

Joint frequency used to calculate $\mathrm{X} / \mathrm{Q}$ based on frequency of exceedance.

No normalization of joint frequency.

$\mathrm{X} / \mathrm{Q}$ calculated for overall site.

MODELS SELECTED:

Time-integrated air concentration calculated (s/m3).

Flow rate adjustment model.

wind velocity corrected for average plume height.

WARNING/ERROR MESSAGES:

JOINT FREQUENCY DATA:

200 AREA (HMS) - 10 M - Pasquill A - G (1983 - 1991 Average)

Created $8 / 26 / 92 \mathrm{KR}$

Tank Farms - 95\% all sectors - 1 hour - volume rate source - no momentum

\begin{tabular}{|c|c|c|c|c|c|c|c|c|}
\hline & & & & & $\begin{array}{c}\text { TOTAL } \\
\text { POPULATION }\end{array}$ & $\begin{array}{l}\text { AVERAGE } \\
\text { INDIVIDUAL }\end{array}$ & & \\
\hline & & RECEPT & SECT. & & SCALED & SCALED & ATM. & WIND \\
\hline SECTOR & $\begin{array}{l}\text { DISTANCE } \\
(\mathrm{m})\end{array}$ & $\begin{array}{l}\text { HEIGHT } \\
\text { (m) }\end{array}$ & $\begin{array}{c}\text { FREQ. } \\
(z)\end{array}$ & POPULATION & $\begin{array}{l}X / Q \\
(s / m 3)\end{array}$ & $\begin{array}{l}X / Q \\
(s / m 3)\end{array}$ & $\begin{array}{l}\text { STAB. } \\
\text { CLASS }\end{array}$ & $\begin{array}{l}\text { SPEED } \\
(\mathrm{m} / \mathrm{s})\end{array}$ \\
\hline ALL & 100 & 2 & 99.94 & 1 & $1.44 \mathrm{E}-02$ & $1.44 \mathrm{E}-02$ & F & 0.89 \\
\hline ALL & 15360 & 2 & 99.94 & 1 & $2.21 E-05$ & $2.21 \mathrm{E}-05$ & F & 0.89 \\
\hline
\end{tabular}




\section{RPP-13482 REV 5}

GXQ Version $4.0 \mathrm{~F}$

October 9, 2002

General Purpose Atmospheric Dispersion Code

Produced by Fluor Federal Services, Inc.

Users Guide documented in WHC-SD-GN-SWD-30002 Rev. 1.

Validation documented in WHC-SD-GN-SWD-30003 Rev. 1.

Code Custodian is: Paul D. Rittmann, PhD CHP

Fluor Federal Services, Inc. E6-17

P.O. Box 1050

Richland, WA $99352-1050$

(509) $376-8715$

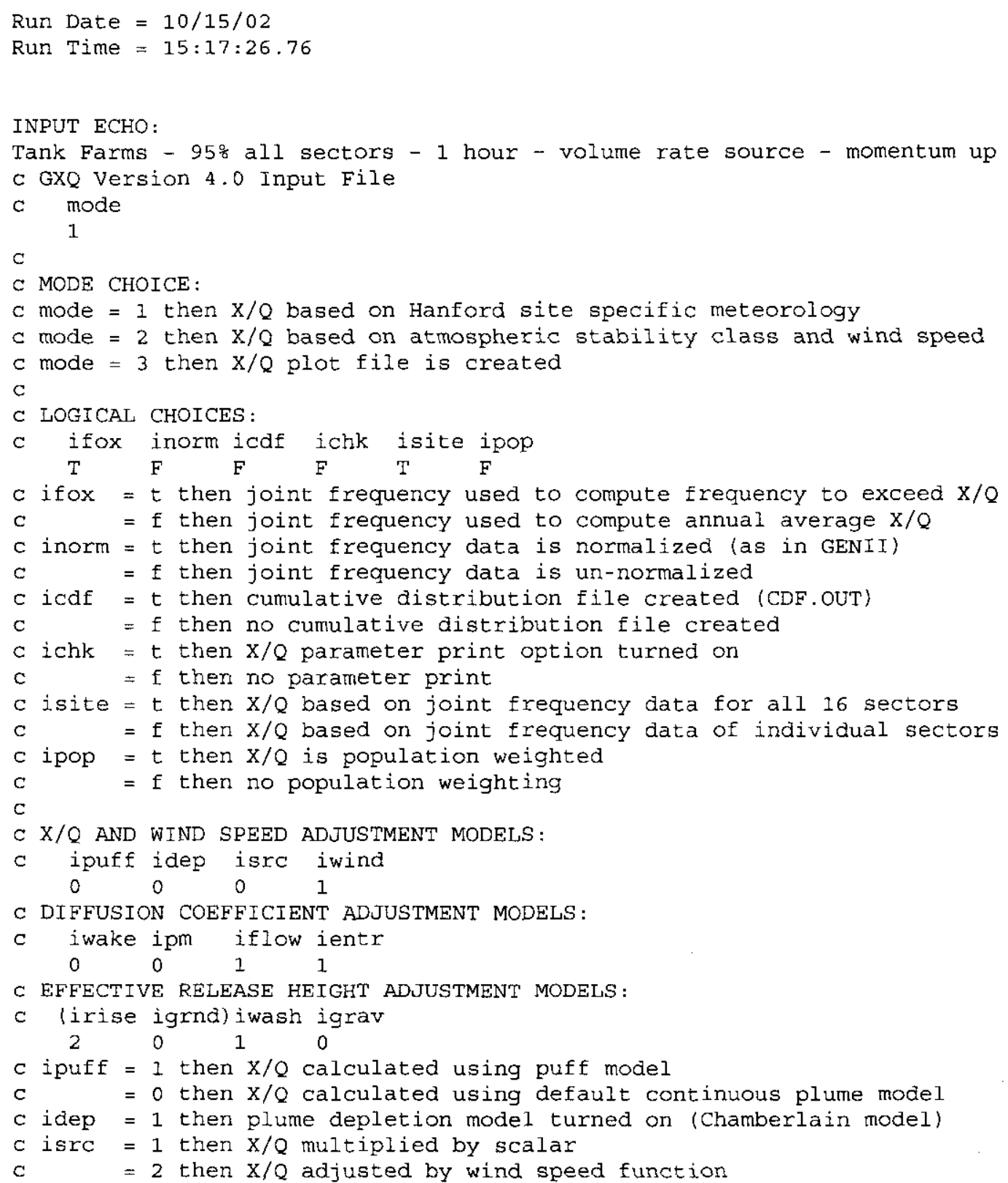




\section{RPP-13482 REV 5}

C iwind $=1$ then wind speed corrected for plume height

c iwake $=1$ then NRC RG 1.145 building wake model turned on

c $=2$ then MACCS virtual distance building wake model turned on

$c$ ipm = I then NRC RG 1.145 plume meander model turned on

$c=2$ then $5^{\text {th }}$ Power Law plume meander model turned on

$\mathrm{C}=3$ then sector average model turned on

$c$ iflow $=1$ then sigmas adjusted for volume flow rate

$c$ ientr $=1$ then method of Pasquill used to account for entrainment

c irise $=1$ then MACCS buoyant plume rise model turned on

$c=2$ then ISC2 momentum/buoyancy plume rise model turned on

igrnd $=1$ then Milis buoyant plume rise modification for ground effects

c iwash $=1$ then stack downwash model turned on

igrav $=1$ then gravitational settling model turned on

c $=0$ unless specified otherwise, 0 turns model off

$\mathrm{C}$

PARAMETER INPUT :

$\mathrm{C}$

C

reference

release anemometer

height

height

hs $(m)$

ha $(\mathrm{m})$

$$
\overline{2.90000 E+00}
$$

$\overline{1.00000 \mathrm{E}+01}$

$1.00000 \mathrm{E}+03$

mixing

height

$\mathrm{hm}(\mathrm{m})$

Erequency

initial

plume

width

$\mathrm{Wb}(\mathrm{m})$

initial

plume

height

$\mathrm{Hb}(\mathrm{m})$

$0.00000 E+00$

$\overline{0.00000 E+00}$

$0.00000 \mathrm{E}+00$

release

duration

$\operatorname{trd}(\mathrm{hr})$

ambient

temperature

initial

Tamb (C)

plume

temperature

initial

plume

TO (C)

flow rate

$\mathrm{Vo}(\mathrm{m} 3 / \mathrm{s})$

\section{$\overline{2.00000 E+01}$}

$\overline{2.00000 E+01}$

$\overline{4.72000 \mathrm{E}-01}$

to

exceed

$\mathrm{CX}(\%)$

(1) If zero then buoyant flux based on plume/ambient temperature difference.

C

c

C

c

$\mathrm{X} / \mathrm{Q}$

Wind

scaling

Speed

actor

xponent

$c($ ?)

a(?)

$\overline{1.00000 \mathrm{E}+00} \overline{7.80000 \mathrm{E}-01}$

C

C RECEPTOR DEPENDENT DATA (no line limit)

C FOR MODE make RECEPTOR DEPENDENT DATA

C 1 (site specific) sector distance receptor-height

c 2 (by class \& wind speed) class windspeed distance offset receptor-height

c 3 (create plot file) class windspeed xmax imax ymax jmax xqmin power

$\mathrm{C}$

C RECEPTOR PARAMETER DESCRIPTION

C sector $=0,1,2 \ldots($ alI $, S, S S W$, etc. $)$

c distance $=$ receptor distance $(\mathrm{m})$

c receptor height $=$ height of receptor $(\mathrm{m})$

C class $=1,2,3,4,5,6,7$ (P-G stability class A, B, C, D, E, F, G)

$c$ windspeed $=$ anemometer wind speed $(\mathrm{m} / \mathrm{s})$

$c$ offset = offset from plume centerline (m)

$c \operatorname{xmax}=$ maximum distance to plot or calculate to $(\mathrm{m})$

c imax = distance intervals

c $y \max =$ maximum offset to plot (m)

$c j \max =$ offset intervals 


\section{RPP-13482 REV 5}

c $x$ qmin $=$ minimum scaled $x / Q$ to calculate

$\mathrm{c}$ power $=$ exponent in power function step size

MODE :

Site specific $X / Q$ calculated.

LOGICAL CHOICES :

Joint frequency used to calculate $X / Q$ based on frequency of exceedance.

No normalization of joint frequency.

$\mathrm{X} / \mathrm{Q}$ calculated for overall site.

MODELS SELECTED:

Time-integrated air concentration calculated $(\mathrm{s} / \mathrm{m} 3)$.

Flow rate adjustment model.

plume rise air entrainment model selected.

ISC2 momentum/buoyancy plume model based on temperature difference.

stack downwash model selected.

Wind velocity corrected for average plume height.

WARNING/ERROR MESSAGES :

JOINT FREQUENCY DATA:

200 AREA (HMS) - 10 M - Pasquill A - G (1983 - 1991 Average)

Created $8 / 26 / 92 \mathrm{KR}$

Tank Farms - 958 al1 sectors - 1 hour - volume rate source - momentum up

\begin{tabular}{|c|c|c|c|c|c|c|c|c|}
\hline & & & & & $\begin{array}{c}\text { TOTAL } \\
\text { POPULATION }\end{array}$ & $\begin{array}{l}\text { AVERAGE } \\
\text { INDIVIDUAL }\end{array}$ & & \\
\hline SECTOR & $\begin{array}{l}\text { DISTANCE } \\
\text { (m) }\end{array}$ & $\begin{array}{c}\text { RECEPT } \\
\text { HEIGHT } \\
\text { (m) }\end{array}$ & $\begin{array}{c}\text { SECT. } \\
\text { FREQ . } \\
\left(\frac{\circ}{6}\right)\end{array}$ & POPULATION & $\begin{array}{c}\text { SCALED } \\
\mathrm{X} / \mathrm{Q} \\
(\mathrm{s} / \mathrm{m} 3)\end{array}$ & $\begin{array}{c}\text { SCALED } \\
\mathrm{X} / \mathrm{Q} \\
(\mathrm{s} / \mathrm{m} 3)\end{array}$ & $\begin{array}{l}\text { ATM. } \\
\text { STAB. } \\
\text { CLASS }\end{array}$ & $\begin{array}{l}\text { WIND } \\
\text { SPEED } \\
(\mathrm{m} / \mathrm{s})\end{array}$ \\
\hline I & 100 & 2 & 99.94 & 1 & $1.85 E-03$ & $1.85 \mathrm{E}-03$ & G & 4.70 \\
\hline ALE & 15360 & 2 & 99.94 & 1 & $2.18 E-05$ & $2.18 E-05$ & F & 0.89 \\
\hline
\end{tabular}




\section{RPP-13482 REV 5}

GXQ Version $4.0 \mathrm{~F}$

October 9, 2002

General Purpose Atmospheric Dispersion Code Produced by Eluor Federal Services, Inc.

Users Guide documented in WHC-SD-GN-SWD-30002 Rev. 1. Validation documented in WHC-SD-GN-SWD-30003 Rev. 1 . Code Custodian is: Paul D. Rittmann, PhD CHP

Fluor Federal Services, Inc. E6-17 P.O. Box 1050

Richland, WA 99352-1050

(509) $376-8715$

Run Date $=10 / 17 / 02$

Run Time $=09: 30: 53.35$

INPUT ECHO:

Tank Farms - 95 percentile all sectors - 1 hour - wide source c GXQ Version 4.0 Input File

C mode

1

$\mathrm{C}$

C MODE CHOICE:

$C$ mode $=1$ then $X / Q$ based on Hanford site specific meteorology

$c$ mode $=2$ then $x / Q$ based on atmospheric stability class and wind speed

$c$ mode $=3$ then $X / Q$ plot file is created

$\mathrm{C}$

c LOGICAL CHOICES:

c ifox inorm icdf ichk isite ipop

$$
\begin{array}{llllll}
T & F & F & F & T & F
\end{array}
$$

$c$ ifox $=t$ then joint frequency used to compute frequency to exceed $x / Q$

$\mathrm{c} \quad \mathrm{f}$ then joint frequency used to compute annual average $\mathrm{X} / \mathrm{Q}$

$c$ inorm $=t$ then joint frequency data is normalized (as in GENII)

$\mathrm{c}=\mathrm{E}$ then joint frequency data is un-normalized

$c$ icdf $=t$ then cumulative distribution file created (CDF.OUT)

$\mathrm{c}=\mathrm{f}$ then no cumulative distribution file created

$c$ ichk $=t$ then $x / Q$ parameter print option turned on

$\mathrm{C}=\mathrm{f}$ then no parameter print

$\mathrm{C}$ isite $=t$ then $\mathrm{X} / \mathrm{Q}$ based on joint frequency data for all 16 sectors

$c= \pm$ then $X / Q$ based on joint frequency data of individual sectors

$c$ ipop $=t$ then $X / Q$ is population weighted

$\mathrm{c}=\mathrm{f}$ then no population weighting

$\mathrm{C}$

C $\mathrm{X} / \mathrm{Q}$ AND WIND SPEED ADJUSTMENT MODELS:

C ipuff idep isrc iwind

$\begin{array}{llll}0 & 0 & 0 & 0\end{array}$

C DIFFUSION COEFFICIENT ADJUSTMENT MODELS:

C iwake ipm iflow ientr

$$
20 \begin{array}{lll}
1 & 0 & 0
\end{array}
$$

C EFFECTIVE RELEASE HEIGHT ADUUSTMENT MODELS:

C (irise igrnd) iwash igrav

$$
\begin{array}{llll}
0 & 0 & 0 & 0
\end{array}
$$

$c$ ipuff $=1$ then $X / Q$ calculated using puff model

$\mathrm{C} \quad=0$ then $\mathrm{X} / \mathrm{Q}$ calculated using default continuous plume model

$c$ idep $=1$ then plume depletion model turned on (Chamberlain model)

$c$ isrc $=I$ then $\mathrm{X} / \mathrm{Q}$ multiplied by scalar

$\mathrm{C} \quad=2$ then $\mathrm{X} / \mathrm{Q}$ adjusted by wind speed function 


\section{RPP-13482 REV 5}

C iwind = 1 then wind speed corrected for plume height

c iwake $=1$ then NRC RG 1.145 building wake model turned on

$\mathrm{c}=2$ then MACCS virtual distance building wake model turned on

$c$ ipm $=1$ then NRC RG 1.145 plume meander model turned on

$\mathrm{C} \quad=2$ then $5^{\text {th }}$ Power Law plume meander model turned on

$\mathrm{c}=3$ then sector average model turned on

$c$ iflow $=1$ then sigmas adjusted for volume flow rate

$c$ ientr $=1$ then method of Pasquill used to account for entrainment

c irise $=1$ then MACCS buoyant plume rise model turned on

$\mathrm{C} \quad=2$ then ISC2 momentum/buoyancy plume rise model turned on

igrnd $=1$ then Mills buoyant plume rise modification for ground effects

$c$ iwash $=1$ then stack downwash model turned on

$c$ igrav $=1$ then gravitational settling model turned on

c $\quad=0$ unless specified otherwise, 0 turns model off

$\mathrm{C}$

C PARAMETER INPUT:

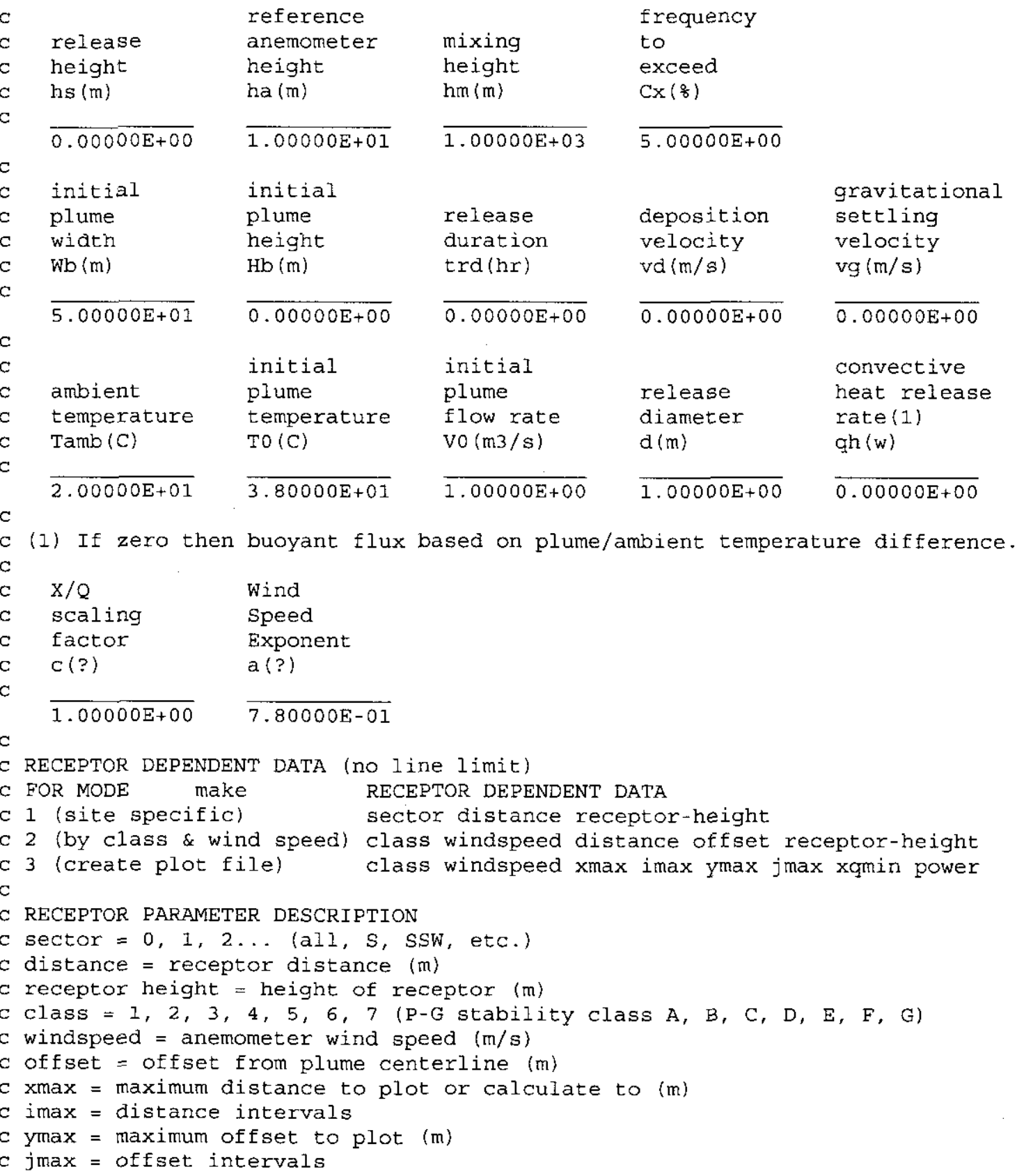




\section{RPP-13482 REV 5}

$c$ xgmin $=$ minimum scaled $X / Q$ to calculate

$c$ power $=$ exponent in power function step size

MODE :

Site specific $X / Q$ calculated.

LOGICAL CHOICES:

Joint frequency used to calculate $X / Q$ based on frequency of exceedance.

No normalization of joint frequency.

$X / Q$ calculated for overall site.

MODELS SELECTED:

Time-integrated air concentration calculated (s/m3) .

MACCS Virtual source building wake model selected.

WARNING/ERROR MESSAGES:

JOINT FREQUENCY DATA:

200 AREA (HMS) - 10 M - Pasquill A - G (1983 - 1991 Average)

Created $8 / 26 / 92 \mathrm{KR}$

Tank Farms - 95 percentile all sectors - 1 hour - $100 \mathrm{~m}$ and site boundary

\begin{tabular}{|c|c|c|c|c|c|c|c|c|}
\hline & & & & & $\begin{array}{c}\text { TOTAL } \\
\text { POPULATION }\end{array}$ & $\begin{array}{l}\text { AVERAGE } \\
\text { INDIVIDUAL }\end{array}$ & & \\
\hline SECTOR & $\begin{array}{l}\text { DI STANCE } \\
\text { (m) }\end{array}$ & $\begin{array}{l}\text { RECEPT } \\
\text { HEIGHT } \\
\text { (m) }\end{array}$ & $\begin{array}{c}\text { SECT. } \\
\text { FREQ. } \\
(z)\end{array}$ & POPULATION & $\begin{array}{c}\text { SCALED } \\
X / Q \\
(\mathrm{~s} / \mathrm{m} 3)\end{array}$ & $\begin{array}{c}\text { SCALED } \\
X / Q \\
(s / \mathrm{m} 3)\end{array}$ & $\begin{array}{l}\text { ATM. } \\
\text { STAB. } \\
\text { CLASS }\end{array}$ & $\begin{array}{l}\text { WIND } \\
\text { SPEED } \\
\text { (m/s) }\end{array}$ \\
\hline$L L$ & 100 & $c$ & 99.94 & 1 & $9.21 \mathrm{E}-03$ & $9.21 \mathrm{E}-03$ & $\mathrm{~F}$ & 0.89 \\
\hline ALL & 15360 & c & 99.94 & $I$ & $2.16 \mathrm{E}-05$ & $2.16 \mathrm{E}-05$ & $\mathrm{~F}$ & 0.89 \\
\hline
\end{tabular}




\section{RPP-13482 REV 5}

Current Input File Name: zimm4e.IN

GXQ Version $4.0 \mathrm{~F}$

October 9, 2002

General Purpose Atmospheric Dispersion Code

Produced by Fluor Federal Services, Inc.

0

Users Guide documented in WHC-SD-GN-SWD-30002 Rev. 1.

Validation documented in WHC-SD-GN-SWD-30003 Rev. 1.

Code Custodian is: PauI D. Rittmann, PhD CHP

Fluor Federal Services, Inc. E6-17

P.O. Box 1050

Richland, WA $99352-1050$

(509) $376-8715$

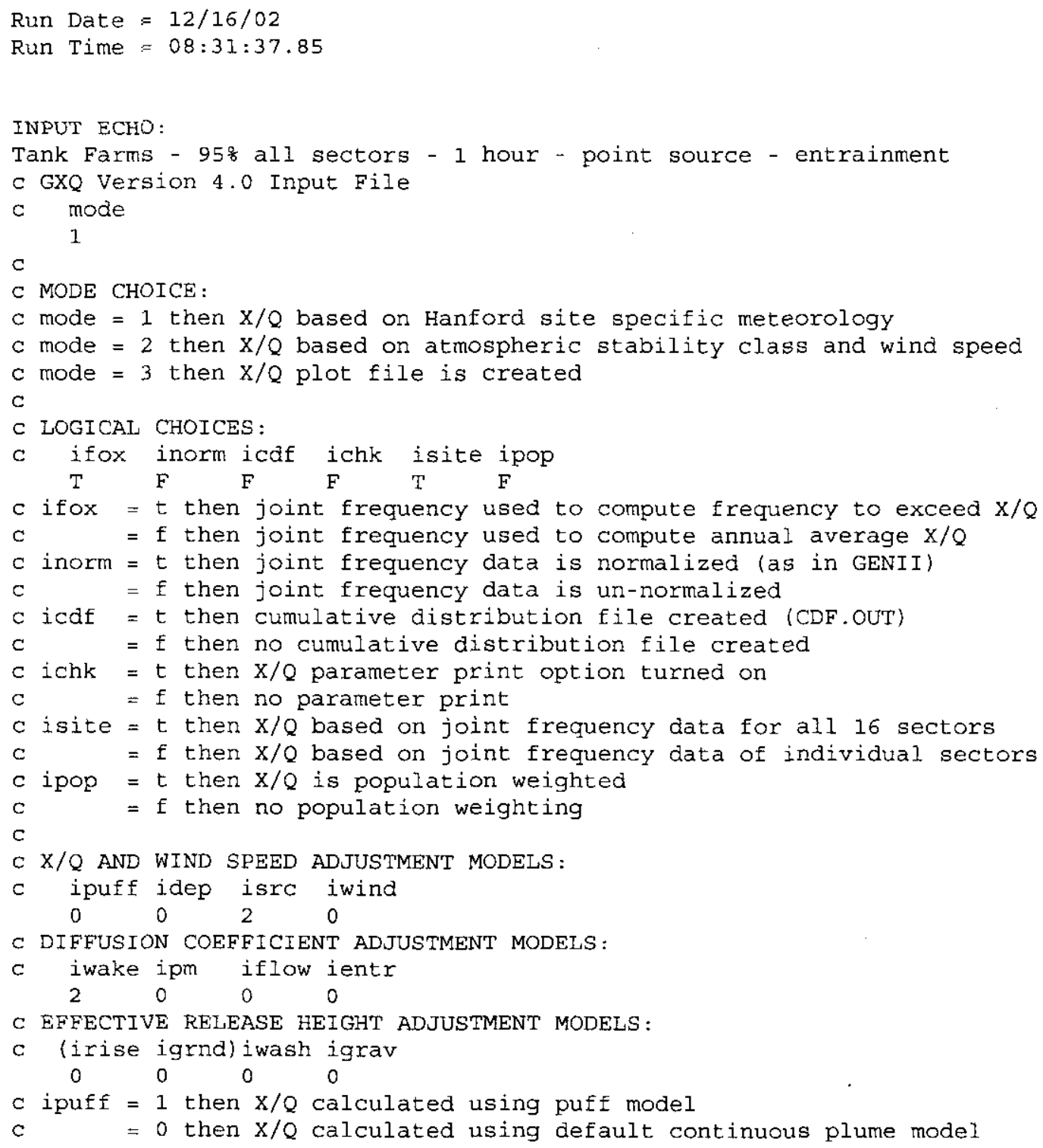




\section{RPP-13482 REV 5}

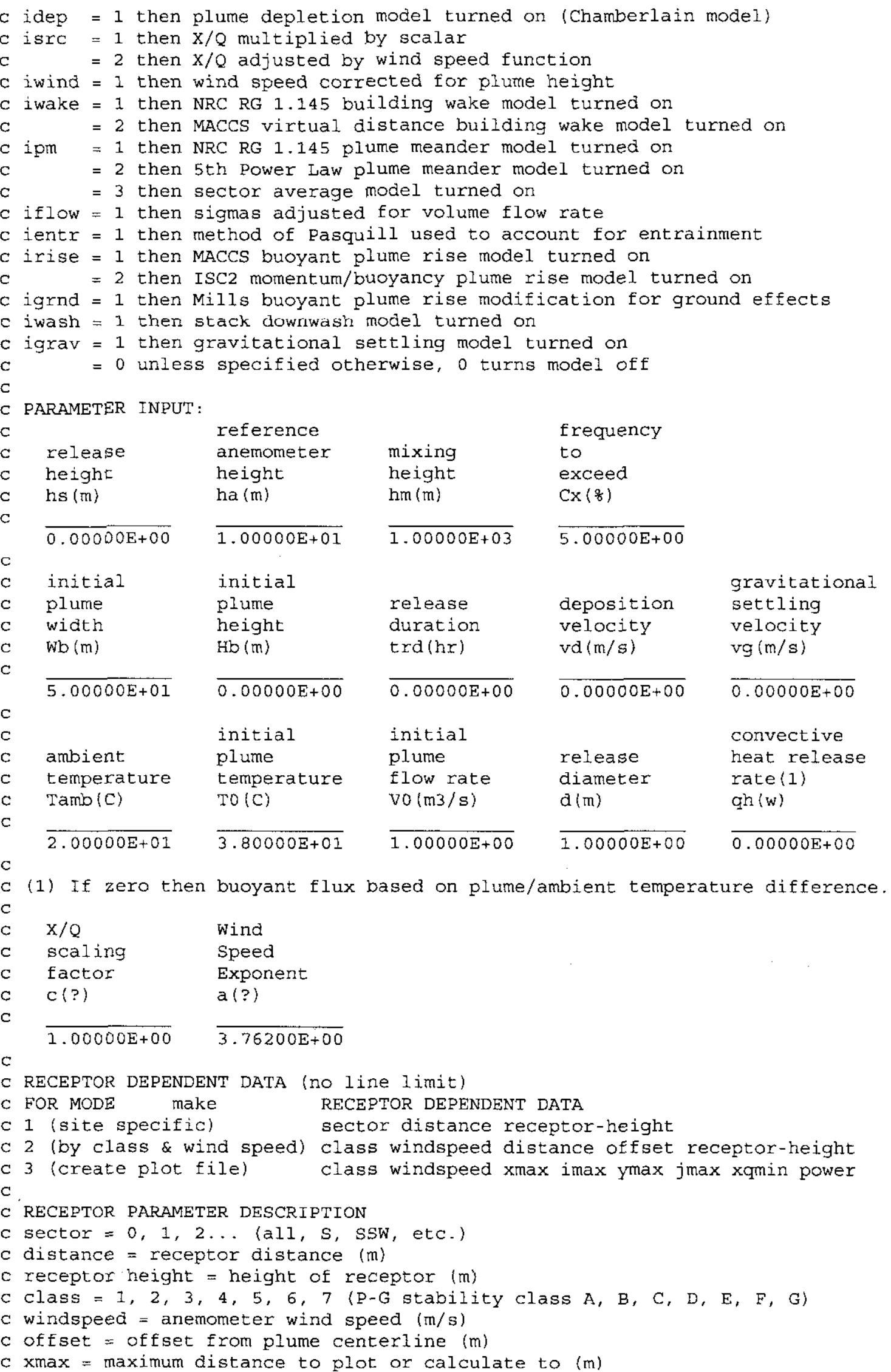




\section{RPP-13482 REV 5}

c imax = distance intervals

c $y \max =$ maximum offset to plot $(\mathrm{m})$

c jmax $=$ offset intervals

c xomin = minimum scaled $\mathrm{x} / \mathrm{Q}$ to calculate

$c$ power $=$ exponent in power function step size

MODE :

Site specific $x / Q$ calculated.

LOGICAL CHOICES:

Joint frequency used to calculate $X / Q$ based on frequency of exceedance.

No normalization of joint frequency.

$\mathrm{X} / \mathrm{Q}$ calculated for overall site.

MODELS SELECTED:

Time-integrated air concentration calculated $(\mathrm{s} / \mathrm{m} 3)$.

MACCS Virtual source building wake model selected.

$X / Q$ adjusted for wind speed dependent source term ( $c$ u^a).

WARNING/ERROR MESSAGES :

JOINT FREQUENCY DATA:

200 AREA (HMS) - 10 M - Pasquill A - G (1983 - 1991 Average)

Created $8 / 26 / 92 \mathrm{KR}$

Tank Farms - 95\% all sectors - 1 hour - point source - entrainment

\begin{tabular}{|c|c|c|c|c|c|c|c|c|}
\hline & & & & & $\begin{array}{c}\text { TOTAL } \\
\text { POPULATION }\end{array}$ & $\begin{array}{l}\text { AVERAGE } \\
\text { INDIVIDUAL }\end{array}$ & & \\
\hline & & RECEPT & SECT. & & SCALED & SCALED & ATM. & WIND \\
\hline SECTOR & $\begin{array}{l}\text { DISTANCE } \\
\text { (m) }\end{array}$ & $\begin{array}{l}\text { HEIGHT } \\
\text { (m) }\end{array}$ & $\begin{array}{c}\text { FREQ. } \\
\left(\frac{8}{8}\right)\end{array}$ & POPULATION & $\mathrm{X} / \mathrm{Q}$ & $\mathrm{X} / \mathrm{Q}$ & $\begin{array}{l}\text { STAB. } \\
\text { CLASS }\end{array}$ & $\begin{array}{l}\text { SPEED } \\
(\mathrm{m} / \mathrm{s})\end{array}$ \\
\hline دآل & 100 & c & 99.94 & 1 & $1.28 \mathrm{E}$ & 1. $28 \mathrm{E}+00$ & $\mathrm{~A}$ & 15.60 \\
\hline ALL & 15360 & c & 99.94 & 1 & $1.99 \mathrm{E}-03$ & $1.99 E-03$ & D & 9.80 \\
\hline
\end{tabular}




\section{RPP-13482 REV 5}

GXQ Version $4.0 \mathrm{~F}$

October 9, 2002

General Purpose Atmospheric Dispersion Code Produced by Fluor Federal Services, Inc.

Users Guide documented in WHC-SD-GN-SWD-30002 Rev. 1 .

Validation documented in WHC-SD-GN-SWD-30003 Rev. 1.

Code Custodian is: Paul D. Rittmann, PhD CHP

Fluor Federal Services, Inc. E6-17

P.O. Box 1050

Richland, WA 99352-1050

(509) $376-8715$

Run Date $=10 / 11 / 04$

Run Time $=09: 15: 54.76$

INPUT ECHO:

generic pool fire $5 \mathrm{~m}$ diameter, $100 \mathrm{~kW}$

c GXQ Version 4.0 Input File

1

C MODE SELECTION:

C 1 - X/Q based on site-specific wind data from JOINTFRE. IN

c $2-\mathrm{X} / \mathrm{Q}$ based on input stability class and wind speed

c $3-\mathrm{X} / \mathrm{Q}$ plot file table is created

c

C SITE WIND \& POPULATION OPTIONS:

C ifox inorm icaf ichk isite ipop

$\begin{array}{llllll}T & F & F & F & T & F\end{array}$

$C$ ifox $=T$ compute probabilistic $\mathrm{X} / \mathrm{Q}$ from a cumulative distribution

$c \quad=F$ compute annual average $X / Q$ (usually sector average with ipm=3)

$\mathrm{C}$ inorm $=\mathrm{T}$ normalize joint frequency data in a sector (as in GENII)

$\mathrm{C} \quad \mathrm{F}$ use joint frequency data as is

$\mathrm{C}$ icdf $=\mathrm{T}$ put cumulative distributions in the CDF.OUT file

$\quad=\mathrm{F}$ no cumulative distribution file created

C ichk $=\mathrm{T}$ show details. for each $\mathrm{X} / \mathrm{Q}$ (long output)

$=\mathrm{F}$ standard length output

isite $=T$ compute overall site $X / Q$ (need groups of 16 sectors)

$=F$ compute $X / Q$ for individual sectors

C ipop = T population-weighted using the file POP.IN (use ipm=3)

$=\mathrm{F}$ no population weighting

C GAUSSIAN PLUME/PUFF MODEL OPTIONS: (enter 0 to inactivate option)

$C$ ipuff idep isrc iwind

$\begin{array}{llll}0 & 0 & 0 & 1\end{array}$

iwake ipm iflow ientr

$\begin{array}{llrl}0 & 0 & 0 & 1 \\ \text { irise igrnd iwash igrav }\end{array}$

$1 \quad 1 \quad 0 \quad 000$

ipuff $=0$ compute time-integrated air concentrations $(\mathrm{s} / \mathrm{m} 3)$

c $=1$ compute air concentrations $(1 / \mathrm{m} 3)$ (need release duration)

idep $=1$ plume depletion model (source depletion)

isrc $=1$ multiply $X / Q$ by scale factor (input below)

$=2$ multiply by wind speed function: (factor)* [speed** (exponent)]

$=3$ multiply by wind speed function: (factor)* [10** (speed*exponent)]

iwind $=1$ wind speed corrected for plume height using power law

iwake = 1 NRC Reg Guide 1.145 building wake model

c $=2$ MACCS virtual source building wake model 


\section{RPP-13482 REV 5}

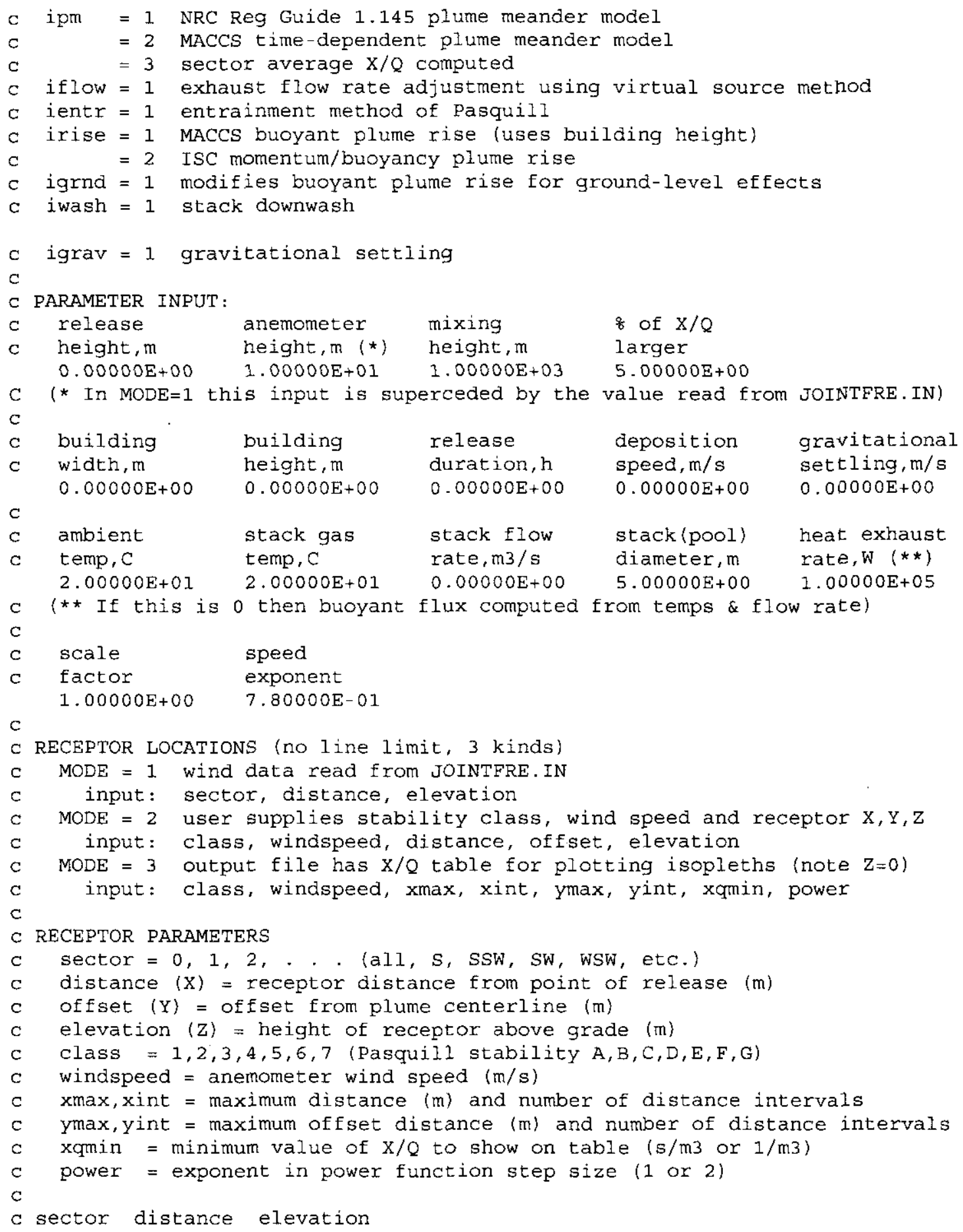

MODE :

Site specific $X / Q$ calculated.

LOGICAL CHOICES:

Joint frequency used to calculate $X / Q$ based on frequency of exceedance.

No normalization of joint frequency.

$\mathrm{X} / \mathrm{Q}$ calculated for overall site.

MODELS SELECTED: 


\section{RPP-13482 REV 5}

Time-integrated air concentration calculated ( $/ \mathrm{m} 3)$.

Plume rise air entrainment model selected.

MACCS buoyancy plume rise model based on convective heat.

Milis buoyant rise modification for pool fire selected.

wind velocity corrected for average plume height.

WARNING/ERROR MESSAGES :

JOINT FREQUENCY DATA:

200 AREA (HMS) - 10 M - Pasquill A - G (1983 - 1991 Average)

Created $8 / 26 / 92 \mathrm{KR}$

generic pool fire $5 \mathrm{~m}$ diameter, $100 \mathrm{~kW}$

\begin{tabular}{|c|c|c|c|c|c|c|c|c|}
\hline SECTOR & $\begin{array}{l}\text { DISTANCE } \\
\text { (m) }\end{array}$ & $\begin{array}{c}\text { RECEPT } \\
\text { HEIGHT } \\
\text { (m) }\end{array}$ & $\begin{array}{c}\text { SECT. } \\
\text { FREQ. } \\
\left(\frac{8}{8}\right)\end{array}$ & POPULATION & $\begin{array}{c}\text { TOTAL } \\
\text { POPULATION } \\
\text { SCALED } \\
X / Q \\
(\mathrm{~s} / \mathrm{m} 3)\end{array}$ & $\begin{array}{c}\text { AVERAGE } \\
\text { INDTVIDUAL } \\
\text { SCALED } \\
\text { X/Q } \\
\text { (s/m3) }\end{array}$ & $\begin{array}{l}\text { ATM } \\
\text { STAB. } \\
\text { CLASS }\end{array}$ & $\begin{array}{l}\text { WIND } \\
\text { SPEED } \\
(\mathrm{m} / \mathrm{s})\end{array}$ \\
\hline ALL & 100 & 0 & 99.94 & 1 & $1.93 E-03$ & $1.93 E-03$ & $F$ & 15.60 \\
\hline ALL & 110 & 0 & 99.94 & 1. & $1.63 E-03$ & $1.63 \mathrm{E}-03$ & $\mathrm{~F}$ & 15.60 \\
\hline ALL & 120 & 0 & 99.94 & 1 & 1. $39 \mathrm{E}-03$ & $1.39 E-03$ & $\mathrm{~F}$ & 15.60 \\
\hline ALL & 130 & 0 & 99.94 & 1 & $1.17 \mathrm{E}-03$ & $1.17 \mathrm{E}-03$ & $\mathrm{~F}$ & 15.60 \\
\hline ALL & 140 & 0 & 99.94 & 1 & $9.59 \mathrm{E}-04$ & $9.59 \mathrm{E}-04$ & $\mathrm{E}$ & 7.15 \\
\hline ALL & 150 & 0 & 99.94 & 1 & $8.34 \mathrm{E}-04$ & $8.34 E-04$ & $E$ & 7.15 \\
\hline ALL & 100 & 1 & 99.94 & 1 & $2.39 E-03$ & $2.39 \mathrm{E}-03$ & $\mathrm{~F}$ & 4.70 \\
\hline ALL & 110 & 1 & 99.94 & 1 & $1.91 E-03$ & $1.91 \mathrm{E}-03$ & $\mathrm{G}$ & 4.70 \\
\hline ALL & 120 & 1 & 99.94 & 1 & $1.45 E-03$ & $1.45 \mathrm{E}-03$ & G & 4.70 \\
\hline ALL & 130 & 1 & 99.94 & 1 & 1. $13 \mathrm{E}-03$ & $1.13 E-03$ & G & 4.70 \\
\hline ALL & 140 & 1 & 99.94 & 1 & $1.01 E-03$ & $1.01 \mathrm{E}-03$ & $F$ & 15.60 \\
\hline ALL & 150 & 1 & 99.94 & 1 & $8.73 E-04$ & $8.73 E-04$ & $\mathrm{~F}$ & 15.60 \\
\hline ALL & 100 & 2 & 99.94 & 1 & $2.77 \mathrm{E}-03$ & $2.77 E-03$ & $F$ & 7.15 \\
\hline ALL & 110 & 2 & 99.94 & 1 & $2.08 E-03$ & $2.08 E-03$ & $\mathrm{~F}$ & 4.70 \\
\hline ALL & 120 & 2 & 99.94 & 1 & $1.75 \mathrm{E}-03$ & $1.75 \mathrm{E}-03$ & $\mathrm{~F}$ & 4.70 \\
\hline ALL & 130 & 2 & 99.94 & 1 & $1.49 \mathrm{E}-03$ & $1.49 E-03$ & $\mathrm{~F}$ & 4.70 \\
\hline ALL & 140 & 2 & 99.94 & 1. & $1.23 E-03$ & $1.23 \mathrm{E}-03$ & $\mathrm{~F}$ & 4.70 \\
\hline ALL & 150 & 2 & 99.94 & 1 & $1.02 \mathrm{E}-03$ & $1.02 E-03$ & $F$ & 4.70 \\
\hline ALL & 15360 & 0 & 99.94 & 1 & $1.82 E-05$ & $1.82 \mathrm{E}-05$ & G & 2.65 \\
\hline
\end{tabular}


GXQ Version 4.OF

October 9, 2002

General Purpose Atmospheric Dispersion Code Produced by Fluor Federal Services, Inc.

Users Guide documented in WHC-SD-GN-SWD-30002 Rev. 1. Validation documented in WHC-SD-GN-SWD-30003 Rev. 1 .

Code custodian is: Paul D. Rittmann, PhD CHP

Fluor Federal Services, Inc. E6-17

P.O. BOX 1050

Richland, WA 99352-1050

(509) $376-8715$

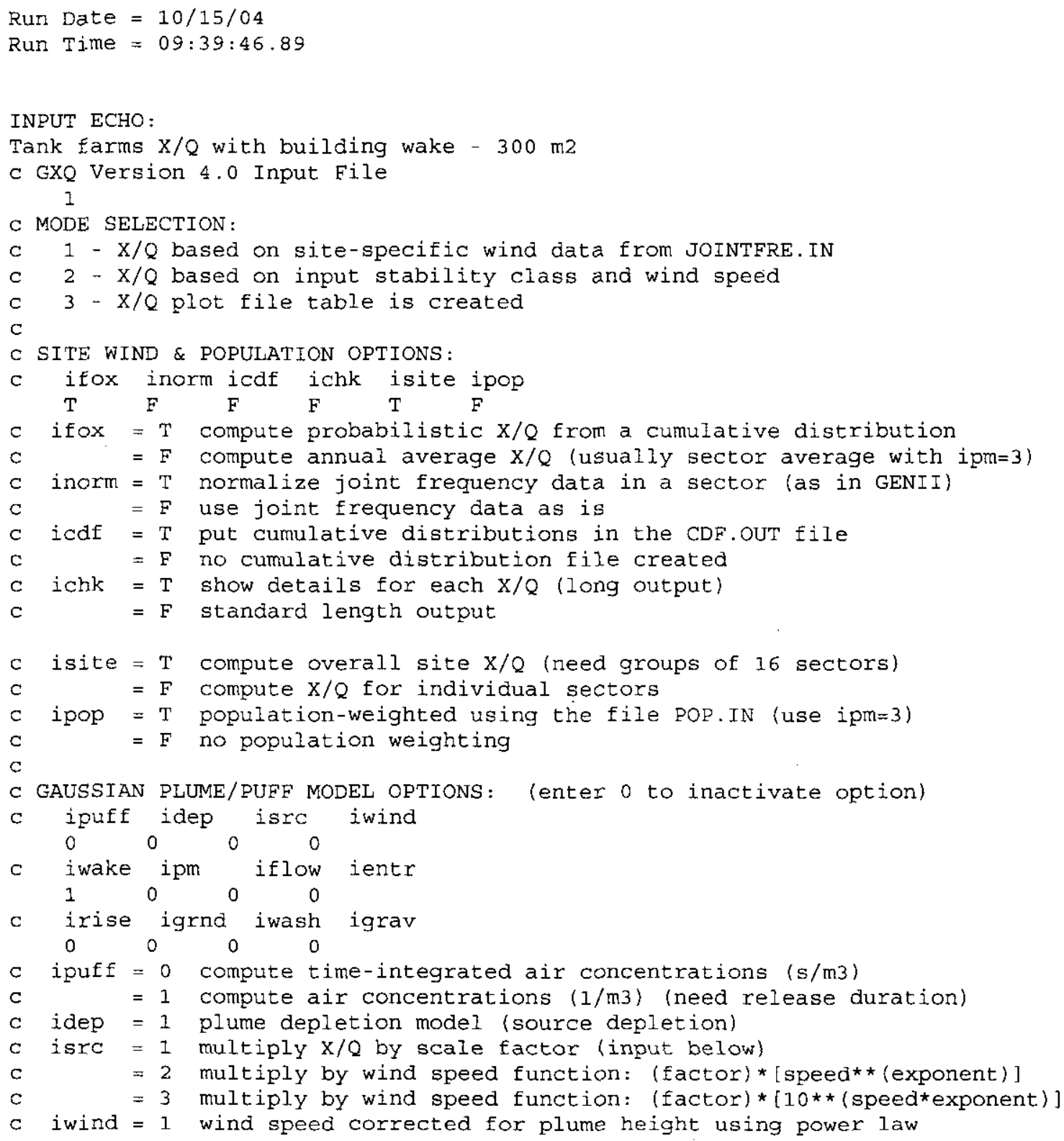




\section{RPP-13482 REV 5}

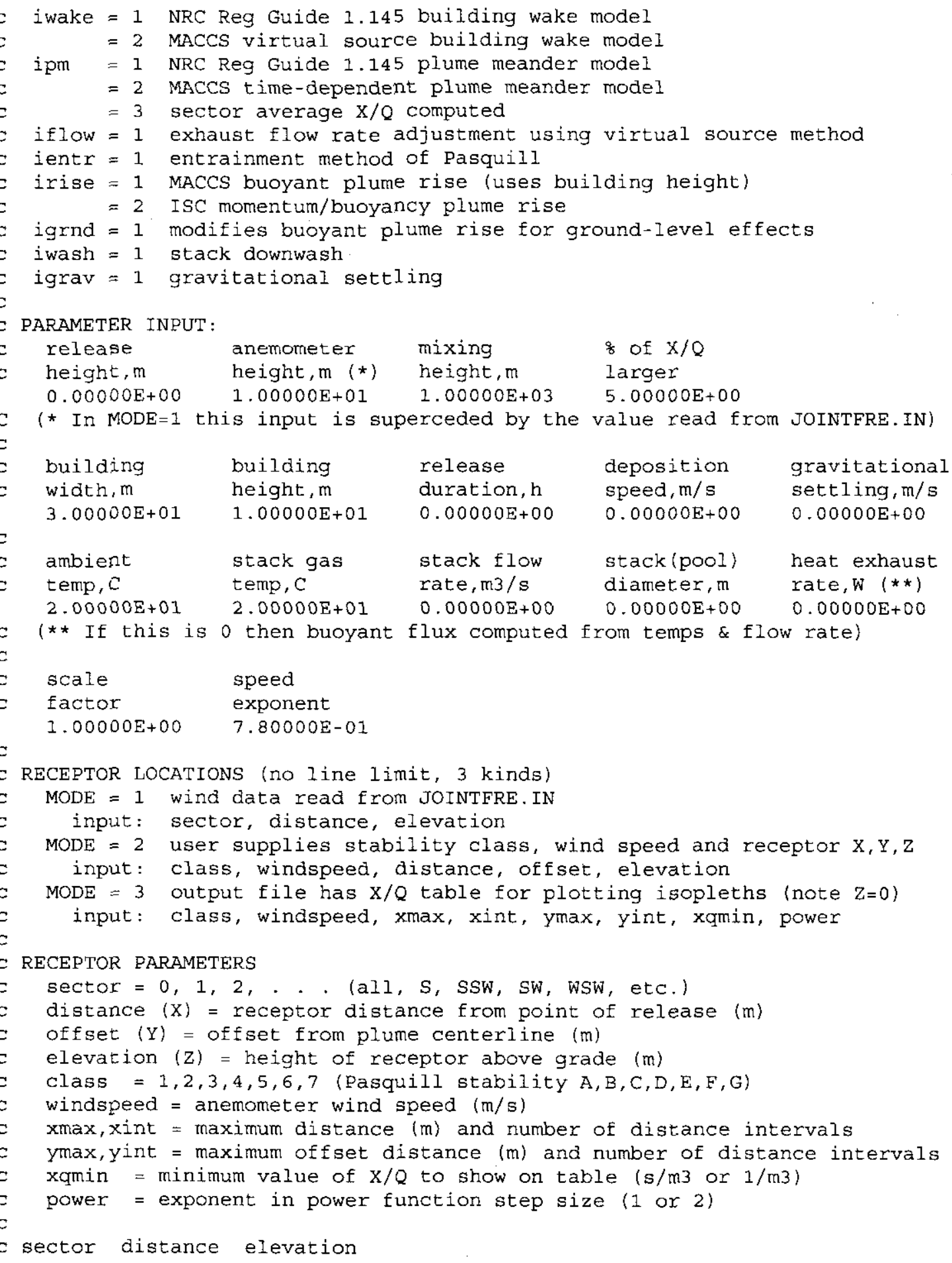

MODELS SELECTED: 


\section{RPP-13482 REV 5}

Time-integrated air concentration calculated (s/m3).

NRC RG 1.145 building wake model selected.

WARNING/ERROR MESSAGES :

JOINT FREOUENCY DATA:

200 AREA (HMS) - 10 M - Pasquill A - G (1983 - 1991 Average)

Created $8 / 26 / 92 \mathrm{KR}$

Tank farms $\mathrm{X} / \mathrm{Q}$ with building wake - $300 \mathrm{~m} 2$

\begin{tabular}{|c|c|c|c|c|c|c|c|c|}
\hline \multirow[b]{3}{*}{ SECTOR } & & & & & $\begin{array}{c}\text { TOTAL } \\
\text { POPULATION }\end{array}$ & $\begin{array}{l}\text { AVERAGE } \\
\text { INDIVIDUAL }\end{array}$ & & \\
\hline & & RECEPT & SECT. & & SCALED & SCALED & ATM. & WIND \\
\hline & $\begin{array}{l}\text { DISTANCE } \\
\text { (m) }\end{array}$ & $\begin{array}{l}\text { HEIGHT } \\
\text { (m) }\end{array}$ & $\begin{array}{c}\text { FREQ } \\
\left(\frac{q}{8}\right)\end{array}$ & POPULATION & $\begin{array}{l}X / Q \\
(s / m 3)\end{array}$ & $\begin{array}{l}X / Q \\
(s / m 3)\end{array}$ & $\begin{array}{l}\text { STAB. } \\
\text { CLASS }\end{array}$ & $\begin{array}{c}\text { SPEED } \\
(\mathrm{m} / \mathrm{s})\end{array}$ \\
\hline ALL & 100 & 0 & 99.94 & 1 & $1.09 \mathrm{E}-02$ & $1.09 \mathrm{E}-02$ & $\mathrm{~F}$ & 0.89 \\
\hline ALL & 15360 & 0 & 99.94 & 1 & $2.21 E-05$ & $2.21 E-05$ & $\mathrm{~F}$ & 0.89 \\
\hline
\end{tabular}


RPP-13482 REV 5

\section{APPENDIX D}

GXQ CDF OUTPUT FOR THE BASE CASE CENTERLINE PLUME 
RPP-13482 REV 5

This page intentionally left blank.

D-ii 


\section{APPENDIX D}

\section{GXQ CDF OUTPUT FOR THE BASE CASE CENTERLINE PLUME}

GXQ Version $4.0 F$

october 9,2002

General Purpose Atmospheric Dispersion Code

produced by Fluor Federal Services, Inc.

Users Guide documented in WHC-SD-GN-SWD-30002 Rev. 1.

Validation documented in WHC-SD-GN-SWD-30003 Rev. 1 .

Code Custodian is: Paul D. Rittmann, PhD CHP

Fluor Federal Services, Inc. E6-17

P.O. Box 1050

Richland, WA 99352-1050

(509) $376-8715$

Run Date $=10 / 24 / 02$

Run Time $=08: 45: 12.01$

Ground Level, Plume, 95th Percentile

CUMULATIVE DISTRIBUTION

ATM. WIND SECTR CUM. SCALED

DISTANCE STAB. SPEED FREQ FREQ. $\mathrm{X} / \mathrm{Q}$

\begin{tabular}{|c|c|c|c|c|c|c|}
\hline SECTOR & (m) & CLASS & $(\mathrm{m} / \mathrm{s})$ & $\begin{array}{l}\text { FREQ } \\
(8)\end{array}$ & $\begin{array}{l}\text { FRE } \\
\left(\frac{8}{8}\right)\end{array}$ & $(\mathrm{s} / \mathrm{m} 3)$ \\
\hline S & 100 . & G & 0.89 & 1.87 & 0.935 & $8.540 \mathrm{E}-02$ \\
\hline SSW & 100 & $F$ & 0.89 & 4.16 & 3.950 & $3.444 \mathrm{E}-02$ \\
\hline SSW & 100 & $\mathrm{G}$ & 2.65 & 3.20 & 7.630 & $2.868 E-02$ \\
\hline$S$ & 100 & G & 4.70 & 1.85 & 10.155 & $1.617 \mathrm{E}-02$ \\
\hline SSW & 100 & $E$ & 0.89 & 5.45 & 13.805 & $1.531 \mathrm{E}-02$ \\
\hline SW & 100 & $F$ & 2.65 & 7.23 & 20.145 & $1.157 \mathrm{E}-02$ \\
\hline NNW & 100 & G & 7.15 & 0.02 & 23.770 & $1.063 \mathrm{E}-02$ \\
\hline$S W$ & 100. & D & 0.89 & 7.42 & 27.490 & $8.337 E-03$ \\
\hline SW & 100 & $\mathrm{E}$ & 4.70 & 3.98 & 33.190 & $6.522 \mathrm{E}-03$ \\
\hline WSW & 100 . & $\mathrm{E}$ & 2.65 & 8.57 & 39.465 & $5.142 \mathrm{E}-03$ \\
\hline $\mathrm{NNW}$ & 100 & $F$ & 7.15 & 0.29 & 43.895 & $4.287 E-03$ \\
\hline SSW & 100 & G & 19.00 & 0.01 & 44.045 & $4.000 E-03$ \\
\hline WSW & 100. & $\mathrm{C}$ & 0.89 & 1.17 & 44.635 & $3.566 \mathrm{E}-03$ \\
\hline $\mathrm{N}$ & 100 & $E$ & 9.80 & 0.03 & 45.235 & $3.128 E-03$ \\
\hline$S$ & 100 & $\mathrm{E}$ & 4.70 & 7.12 & 48.810 & $2.899 E-03$ \\
\hline W & 100 & $\mathrm{D}$ & 2.65 & 9.21 & 56.975 & $2.800 \mathrm{E}-03$ \\
\hline SSW & 100 & $F$ & 15.60 & 0.02 & 61.590 & 1. $965 E-03$ \\
\hline $\mathrm{NW}$ & 100. & $E$ & 7.15 & 3.71 & 63.455 & $1.906 \mathrm{E}-03$ \\
\hline $\mathrm{W}$ & 100. & $\mathrm{~B}$ & 0.89 & 1.21 & 65.915 & $1.866 \mathrm{E}-03$ \\
\hline SSW & 100. & $\mathrm{~F}$ & 19.00 & 0.08 & 66.560 & $1.613 E-03$ \\
\hline $\mathrm{W}$ & 100. & $\mathrm{D}$ & 4.70 & 5.73 & 69.465 & $1.579 E-03$ \\
\hline SW & 100. & $E$ & 9.80 & 0.95 & 72.805 & $1.390 \mathrm{E}-03$ \\
\hline SSW & 100. & $\mathrm{C}$ & 2.65 & 1.69 & 74.125 & $1.198 \mathrm{E}-03$ \\
\hline SW & 100. & $E$ & 12.70 & 0.19 & 75.065 & $1.073 E-03$ \\
\hline NW & 100. & A & 0.89 & 2.80 & 76.560 & $1.068 \mathrm{E}-03$ \\
\hline WNW & 100. & D & 7.15 & 3.46 & 79.690 & $1.038 \mathrm{E}-03$ \\
\hline
\end{tabular}


RPP-13482 REV 5

\begin{tabular}{|c|c|c|c|c|c|c|}
\hline SSW & 100. & $\mathrm{E}$ & 15.60 & 0.04 & 81.440 & $8.735 E-04$ \\
\hline $\mathrm{SW}$ & 100. & D & 9.80 & 1.49 & 82.205 & $7.571 E-04$ \\
\hline$S$ & 100. & $E$ & 19.00 & 0.19 & 83.045 & $7.172 \mathrm{E}-04$ \\
\hline NW & 100. & $\mathrm{C}$ & 4.70 & 0.82 & 83.550 & $6.754 E-04$ \\
\hline WSW & 100. & B & 2.65 & 1.69 & 84.805 & $6.266 \mathrm{E}-04$ \\
\hline S & 100. & D & 12.70 & 0.43 & 85.865 & $5.842 E-04$ \\
\hline SSW & 100. & $\mathrm{D}$ & 15.60 & 0.11 & 86.135 & $4.756 E-04$ \\
\hline$S$ & 100. & C & 7.15 & 0.39 & 86.385 & $4.439 \mathrm{E}-04$ \\
\hline$S$ & 100. & D & 19.00 & 0.11 & 86.635 & $3.905 E-04$ \\
\hline$S$ & 100. & A & 2.65 & 5.76 & 89.570 & $3.588 \mathrm{E}-04$ \\
\hline W & 100. & B & 4.70 & 0.93 & 92.915 & $3.533 E-04$ \\
\hline $\mathrm{N}$ & 100. & $\mathrm{C}$ & 9.80 & 0.20 & 93.480 & $3.239 E-04$ \\
\hline $\mathrm{NE}$ & 100. & C & 12.70 & 0.06 & 93.610 & 2. $499 \mathrm{E}-04$ \\
\hline SSW & 100. & B & 7.15 & 0.46 & 93.870 & $2.322 \mathrm{E}-04$ \\
\hline SSW & 100. & C & 15.60 & 0.03 & 94.115 & $2.035 \mathrm{E}-04$ \\
\hline NW & 100. & A & 4.70 & 2.98 & 95.620 & $2.023 \mathrm{E}-04$ \\
\hline SSW & 100. & B & 9.80 & 0.19 & 97.205 & $1.694 E-04$ \\
\hline $\mathrm{S}$ & 100. & C & 19.00 & 0.03 & 97.315 & $1.671 \mathrm{E}-04$ \\
\hline SW & 100. & A & 7.15 & 1.56 & 98.110 & 1. $330 \mathrm{E}-04$ \\
\hline $\mathrm{NE}$ & 100. & $B$ & 12.70 & 0.05 & 98.915 & $1.308 \mathrm{E}-04$ \\
\hline SSW & 100. & B & 15.60 & 0.01 & 98.945 & $1.064 \mathrm{E}-04$ \\
\hline SSW & 100. & A & 9.80 & 0.73 & 99.315 & $9.702 \mathrm{E}-05$ \\
\hline$S$ & 100. & B & 19.00 & 0.02 & 99.690 & $8.740 \mathrm{E}-05$ \\
\hline $\mathrm{NE}$ & 100. & A & 12.70 & 0.16 & 99.780 & $7.486 \mathrm{E}-05$ \\
\hline$S$ & 100. & A & 15.60 & 0.04 & 99.880 & $6.095 \mathrm{E}-05$ \\
\hline SSW & 100. & A & 19.00 & 0.04 & 99.920 & $5.004 \mathrm{E}-05$ \\
\hline WNW & 100. & A & 9.80 & 0.00 & 99.940 & $0.000 E+00$ \\
\hline SSE & 100. & G & 19.00 & 0.00 & 99.940 & $0.000 E+00$ \\
\hline NNW & 8690. & G & 0.89 & 0.31 & 0.155 & $7.859 \mathrm{E}-05$ \\
\hline $\mathrm{NNE}$ & 8970 & G & 0.89 & 0.09 & 0.355 & $7.546 \mathrm{E}-05$ \\
\hline $\mathrm{NE}$ & 10430. & G & 0.89 & 0.10 & 0.450 & $6.226 \mathrm{E}-05$ \\
\hline ENE & 10530. & G & 0.89 & 0.09 & 0.545 & $6.151 \mathrm{E}-05$ \\
\hline NW & 10800. & G & 0.89 & 0.13 & 0.655 & $5.956 \mathrm{E}-05$ \\
\hline WSW & 11100. & G & 0.89 & 0.34 & 0.890 & $5.753 E-05$ \\
\hline$E$ & 11160. & G & 0.89 & 0.22 & 1.170 & $5.714 E-05$ \\
\hline SW & 13200. & G & 0.89 & 0.08 & 1.320 & $4.624 \mathrm{E}-05$ \\
\hline ESE & 15190. & $\mathrm{G}$ & 0.89 & 0.14 & 1.430 & $3.879 \mathrm{E}-05$ \\
\hline SSW & 15360 . & G & 0.89 & 0.23 & 1.615 & $3.826 \mathrm{E}-05$ \\
\hline NNW & 8690 & F & 0.89 & 0.61 & 2.035 & $3.137 \mathrm{E}-05$ \\
\hline NNE & 8970. & F & 0.89 & 0.23 & 2.455 & $3.012 \mathrm{E}-05$ \\
\hline NNW & 8690 & G & 2.65 & 0.43 & 2.785 & $2.640 \mathrm{E}-05$ \\
\hline$S E$ & 21050 . & G & 0.89 & 0.14 & 3.070 & $2.590 \mathrm{E}-05$ \\
\hline NNE & 8970 & G & 2.65 & 0.08 & 3.180 & $2.534 \mathrm{E}-05$ \\
\hline $\mathrm{NE}$ & 10430. & F & 0.89 & 0.22 & 3.330 & $2.485 \mathrm{E}-05$ \\
\hline ENE & 10530 . & F & 0.89 & 0.27 & 3.575 & $2.455 \mathrm{E}-05$ \\
\hline $\mathrm{NW}$ & 10800. & F & 0.89 & 0.28 & 3.850 & $2.377 E-05$ \\
\hline WSW & 11100 . & F & 0.89 & 0.68 & 4.330 & $2.296 \mathrm{E}-05$ \\
\hline $\mathrm{E}$ & 11160. & F & 0.89 & 0.48 & 4.910 & $2.281 \mathrm{E}-05$ \\
\hline $\mathrm{NE}$ & 10430 . & G & 2.65 & 0.10 & 5.200 & $2.091 E-05$ \\
\hline ENE & 10530. & G & 2.65 & 0.20 & 5.350 & $2.066 \mathrm{E}-05$ \\
\hline NW & 10800. & G & 2.65 & 0.20 & 5.550 & $2.000 E-05$ \\
\hline WSW & 11100. & G & 2.65 & 0.22 & 5.760 & $1.932 \mathrm{E}-05$ \\
\hline$E$ & 11160. & G & 2.65 & 0.82 & 6.280 & $1.919 E-05$ \\
\hline SW & 13200 . & $F$ & 0.89 & 0.12 & 6.750 & $1.846 \mathrm{E}-05$ \\
\hline SW & 13200. & G & 2.65 & 0.02 & 6.820 & 1. $553 E-05$ \\
\hline ESE & 15190. & F & 0.89 & 0.36 & 7.010 & $1.549 \mathrm{E}-05$ \\
\hline SSW & 15360 . & F & 0.89 & 0.59 & 7.485 & 1. $527 \mathrm{E}-05$ \\
\hline NNW & 8690 & G & 4.70 & 0.16 & 7.860 & $1.488 E-05$ \\
\hline $\mathrm{NNE}$ & 8970 & G & 4.70 & 0.01 & 7.945 & $1.429 E-05$ \\
\hline ESE & 15190. & G & 2.65 & 0.69 & 8.295 & $1.303 E-05$ \\
\hline
\end{tabular}


RPP-13482 REV 5

$\begin{array}{lrlrlll}\text { NNW } & 8690 . & \text { E } & 0.89 & 0.64 & 8.960 & 1.298 \mathrm{E}-05 \\ \text { SSW } & 15360 . & \text { G } & 2.65 & 0.14 & 9.350 & 1.285 \mathrm{E}-05 \\ \text { NNE } & 8970 . & \text { E } & 0.89 & 0.21 & 9.525 & 1.244 \mathrm{E}-05 \\ \text { NE } & 10430 . & \text { G } & 4.70 & 0.02 & 9.640 & 1.179 \mathrm{E}-05 \\ \text { ENE } & 10530 . & \text { G } & 4.70 & 0.09 & 9.695 & 1.165 \mathrm{E}-05 \\ \text { NW } & 10800 . & \text { G } & 4.70 & 0.01 & 9.745 & 1.128 \mathrm{E}-05 \\ \text { WNW } & 11100 . & \text { G } & 4.70 & 0.01 & 9.755 & 1.089 \mathrm{E}-05 \\ \text { E } & 11160 . & \text { G } & 4.70 & 0.56 & 10.040 & 1.082 \mathrm{E}-05 \\ \text { NNW } & 8690 . & \text { F } & 2.65 & 0.89 & 10.765 & 1.053 \mathrm{E}-05 \\ \text { SE } & 21050 . & \text { F } & 0.89 & 0.32 & 11.370 & 1.034 \mathrm{E}-05 \\ \text { NE } & 10430 . & \text { E } & 0.89 & 0.25 & 11.655 & 1.015 \mathrm{E}-05\end{array}$

\begin{tabular}{|c|c|c|c|c|c|c|}
\hline NNE & 8970 . & $F$ & 2.65 & 0.21 & 11.885 & $1.012 \mathrm{E}-05$ \\
\hline ENE & 10530. & E & 0.89 & 0.29 & 12.135 & $1.003 E-05$ \\
\hline NNW & 8690 & G & 7.15 & 0.01 & 12.285 & $9.783 \mathrm{E}-06$ \\
\hline NW & 10800 . & $\mathrm{E}$ & 0.89 & 0.31 & 12.445 & $9.692 \mathrm{E}-06$ \\
\hline WSW & 11100 . & $E$ & 0.89 & 1.05 & 13.125 & $9.343 E-06$ \\
\hline $\mathrm{E}$ & 11160. & $\mathrm{E}$ & 0.89 & 0.49 & 13.895 & $9.276 \mathrm{E}-06$ \\
\hline SE & 21050. & G & 2.65 & 0.30 & 14.290 & $8.698 \mathrm{E}-06$ \\
\hline $\mathrm{NE}$ & 10430 . & $F$ & 2.65 & 0.27 & 14.575 & 8. $346 \mathrm{E}-06$ \\
\hline ENE & 10530. & $F$ & 2.65 & 0.46 & 14.940 & $8.245 \mathrm{E}-0$ \\
\hline NW & 10800 . & $\mathrm{F}$ & 2.65 & 0.39 & 15.365 & $7.985 \mathrm{E}-0$ \\
\hline WSW & 11100 . & $F$ & 2.65 & 0.42 & 15.770 & $7.712 \mathrm{E}-06$ \\
\hline$E$ & 11160. & $F$ & 2.65 & 1.60 & 16.780 & $7.660 \mathrm{E}-06$ \\
\hline SW & 13200 . & $E$ & 0.89 & 0.28 & 17.720 & $7.419 \mathrm{E}-0$ \\
\hline ESE & 15190. & $G$ & 4.70 & 0.84 & 18.280 & $7.346 \mathrm{E}-0$ \\
\hline S & 15360 . & G & 4.70 & 0.02 & 18.710 & $7.244 \mathrm{E}-06$ \\
\hline SW & 13200 . & $F$ & 2.65 & 0.05 & 18.745 & $6.200 \mathrm{E}-06$ \\
\hline ESE & 15190. & $\mathrm{E}$ & 0.89 & 0.44 & 18.990 & $6.16 I E-06$ \\
\hline SSW & 15360 . & $E$ & 0.89 & 1.04 & 19.730 & $6.07 I E-0$ \\
\hline NNW & 8690 & $F$ & 4.70 & 0.31 & 20.405 & $5.940 \mathrm{E}-06$ \\
\hline NNE & 8970 . & $F$ & 4.70 & 0.03 & 20.575 & $5.703 E-06$ \\
\hline NNW & 8690. & $\mathrm{D}$ & 0.89 & 0.59 & 20.885 & $5.487 \mathrm{E}-06$ \\
\hline NNE & 8970 & $\mathrm{D}$ & 0.89 & 0.19 & 21.275 & $5.236 \mathrm{E}-06$ \\
\hline ESE & 15190. & $F$ & 2.65 & 1.69 & 22.215 & $5.201 \mathrm{E}-0$ \\
\hline S & 15360 . & $F$ & 2.65 & 0.43 & 23.275 & $5.129 E-0$ \\
\hline$S E$ & 21050 . & G & 4.70 & 0.13 & 23.555 & $4.904 E-06$ \\
\hline ESE & 15190. & $\mathrm{G}$ & 7.15 & 0.01 & 23.625 & $4.829 \mathrm{E}-06$ \\
\hline $\mathrm{NE}$ & 10430. & $F$ & 4.70 & 0.07 & 23.665 & $4.706 \mathrm{E}-0$ \\
\hline ENE & 10530. & $\mathrm{~F}$ & 4.70 & 0.20 & 23.800 & $4.649 E-0$ \\
\hline NW & 10800. & F & 4.70 & 0.05 & 23.925 & $4.502 \mathrm{E}-0$ \\
\hline NNW & 8690. & $E$ & 2.65 & 0.98 & 24.440 & $4.359 E-0$ \\
\hline WSW & 11100. & $\mathrm{~F}$ & 4.70 & 0.04 & 24.950 & $4.348 E-06$ \\
\hline $\mathrm{E}$ & 11160. & $\mathrm{~F}$ & 4.70 & 1. 19 & 25.565 & $4.319 E-0$ \\
\hline
\end{tabular}

$\begin{array}{lrlllll}\text { NE } & 10430 . & \text { D } & 0.89 & 0.21 & 26.265 & 4.195 \mathrm{E}-06 \\ \text { NNE } & 8970 . & \text { E } & 2.65 & 0.21 & 26.475 & 4.176 E-06 \\ \text { ENE } & 10530 . & \text { D } & 0.89 & 0.17 & 26.665 & 4.136 E-06 \\ \text { SE } & 21050 . & \text { E } & 0.89 & 0.45 & 26.975 & 4.015 E-06 \\ \text { NW } & 10800 . & \text { D } & 0.89 & 0.43 & 27.415 & 3.986 E-06 \\ \text { NNW } & 8690 . & \text { F } & 7.15 & 0.03 & 27.645 & 3.904 E-06 \\ \text { WSW } & 11100 . & \text { D } & 0.89 & 1.86 & 28.590 & 3.829 E-06 \\ \text { E } & 11160 . & \text { D } & 0.89 & 0.40 & 29.720 & 3.798 E-06 \\ \text { SW } & 13200 . & \text { F } & 4.70 & 0.01 & 29.925 & 3.495 E-06 \\ \text { SE } & 21050 . & \text { F } & 2.65 & 0.82 & 30.340 & 3.473 E-06 \\ \text { NE } & 10430 . & \text { E } & 2.65 & 0.29 & 30.895 & 3.410 E-06 \\ \text { ENE } & 10530 . & \text { E } & 2.65 & 0.48 & 31.280 & 3.367 E-06 \\ \text { NW } & 10800 . & \text { E } & 2.65 & 0.47 & 31.755 & 3.255 E-06 \\ \text { WSW } & 11100 . & \text { E } & 2.65 & 0.78 & 32.380 & 3.138 E-06 \\ \text { E } & 11160 . & \text { E } & 2.65 & 1.58 & 33.560 & 3.115 E-06 \\ \text { NE } & 10430 . & \text { F } & 7.15 & 0.01 & 34.355 & 3.093 E-06\end{array}$


RPP-13482 REV 5

\begin{tabular}{|c|c|c|c|c|c|c|}
\hline ENE & 10530. & $\mathrm{~F}$ & 7.15 & 0.02 & 34.370 & $3.056 \mathrm{E}-06$ \\
\hline SW & 13200. & $\mathrm{D}$ & 0.89 & 0.59 & 34.675 & $2.971 E-06$ \\
\hline ESE & 15190. & $F$ & 4.70 & 1.60 & 35.770 & $2.933 \mathrm{E}-06$ \\
\hline SSW & 15360 . & $\mathrm{F}$ & 4.70 & 0.16 & 36.650 & $2.892 \mathrm{E}-06$ \\
\hline $\mathrm{N}$ & 8690 & $F$ & 9.80 & 0.01 & 36.735 & $2.849 E-06$ \\
\hline E & 11160. & $\mathrm{~F}$ & 7.15 & 0.07 & 36.775 & $2.839 E-06$ \\
\hline SW & 13200. & $E$ & 2.65 & 0.11 & 36.865 & $2.492 E-06$ \\
\hline $\mathrm{NNW}$ & 8690 & $E$ & 4.70 & 0.47 & 37.155 & $2.458 E-06$ \\
\hline ESE & 15190. & $\mathrm{D}$ & 0.89 & 0.44 & 37.610 & $2.420 \mathrm{E}-06$ \\
\hline S & 15360. & $\mathrm{D}$ & 0.89 & 2.00 & 38.830 & $2.381 E-06$ \\
\hline NNE & 8970 & $\mathrm{E}$ & 4.70 & 0.12 & 39.890 & $2.355 E-06$ \\
\hline ESE & 15190. & $\mathrm{E}$ & 2.65 & 1.68 & 40.790 & $2.069 E-06$ \\
\hline SSW & 15360 . & $\mathrm{E}$ & 2.65 & 0.88 & 42.070 & $2.039 E-06$ \\
\hline $\mathrm{SE}$ & 21050. & $F$ & 4.70 & 0.32 & 42.670 & $1.958 E-06$ \\
\hline ESE & 15190. & $F$ & 7.15 & 0.08 & 42.870 & $1.928 \mathrm{E}-06$ \\
\hline $\mathrm{NE}$ & 10430 . & $\mathrm{E}$ & 4.70 & 0.18 & 43.000 & $1.923 \mathrm{E}-06$ \\
\hline$S$ & 15360. & $F$ & 7.15 & 0.05 & 43.115 & $1.901 E-06$ \\
\hline ENE & 10530. & $\mathrm{E}$ & 4.70 & 0.39 & 43.335 & 1. $898 E-06$ \\
\hline NNW & 8690 & $\mathrm{D}$ & 2.65 & 0.88 & 43.970 & $1.843 E-06$ \\
\hline $\mathrm{NW}$ & 10800. & $\mathrm{E}$ & 4.70 & 0.15 & 44.485 & $1.835 E-06$ \\
\hline SSW & 15360. & G & 19.00 & 0.01 & 44.565 & $1.792 E-06$ \\
\hline WSW & 11100. & $\mathrm{E}$ & 4.70 & 0.13 & 44.635 & 1. $769 \mathrm{E}-06$ \\
\hline NNE & 8970. & D & 2.65 & 0.18 & 44.790 & $1.759 E-06$ \\
\hline$E$ & 11160. & $\mathrm{E}$ & 4.70 & 1.98 & 45.870 & $1.757 \mathrm{E}-06$ \\
\hline NNW & 8690 & $E$ & 7.15 & 0.12 & 46.920 & $1.616 \mathrm{E}-06$ \\
\hline NNE & 8970 & $\mathrm{E}$ & 7.15 & 0.08 & 47.020 & $1.548 \mathrm{E}-06$ \\
\hline $\mathrm{SE}$ & 21050. & D & 0.89 & 0.54 & 47.330 & $1.505 \mathrm{E}-06$ \\
\hline $\mathrm{NE}$ & 10430. & $D$ & 2.65 & 0.24 & 47.720 & 1. $409 \mathrm{E}-06$ \\
\hline SW & 13200. & $\mathrm{E}$ & 4.70 & 0.04 & 47.860 & 1. $405 \mathrm{E}-06$ \\
\hline ENE & 10530. & $\mathrm{D}$ & 2.65 & 0.28 & 48.020 & $1.389 \mathrm{E}-06$ \\
\hline S & 15360 . & $\mathrm{F}$ & 9.80 & 0.02 & 48.170 & $1.387 \mathrm{E}-06$ \\
\hline$S E$ & 21050. & $\mathrm{E}$ & 2.65 & 1.11 & 48.735 & $1.348 E-06$ \\
\hline NW & 10800 . & $D$ & 2.65 & 0.75 & 49.665 & 1. $339 \mathrm{E}-06$ \\
\hline$S E$ & 21050. & $\mathrm{~F}$ & 7.15 & 0.03 & 50.055 & 1. $287 E-06$ \\
\hline WSW & 11100. & $D$ & 2.65 & 1.56 & 50.850 & $1.286 E-06$ \\
\hline$E$ & 11160. & $\mathrm{D}$ & 2.65 & 0.69 & 51.975 & $1.276 \mathrm{E}-06$ \\
\hline $\mathrm{NE}$ & 10430. & $\mathrm{E}$ & 7.15 & 0.17 & 52.405 & $1.264 E-06$ \\
\hline ENE & 10530 . & $E$ & 7.15 & 0.30 & 52.640 & $1.248 E-06$ \\
\hline NW & 10800 . & $\mathrm{E}$ & 7.15 & 0.01 & 52.795 & $1.206 \mathrm{E}-06$ \\
\hline $\mathrm{N}$ & 8690 & $E$ & 9.80 & 0.01 & 52.805 & $1.179 E-06$ \\
\hline ESE & 15190. & $\mathrm{E}$ & 4.70 & 2.50 & 54.060 & $1.167 E-06$ \\
\hline$E$ & 11160. & $E$ & 7.15 & 0.65 & 55.635 & $1.155 E-06$ \\
\hline SSW & 15360 . & $\mathrm{E}$ & 4.70 & 0.41 & 56.165 & $1.150 E-06$ \\
\hline $\mathrm{NNE}$ & 8970 & $\mathrm{E}$ & 9.80 & 0.05 & 56.395 & $1.129 \mathrm{E}-06$ \\
\hline NNW & 8690. & $\mathrm{C}$ & 0.89 & 0.08 & 56.460 & $1.083 \mathrm{E}-06$ \\
\hline NNW & 8690. & $D$ & 4.70 & 0.51 & 56.755 & $1.039 E-06$ \\
\hline NNE & 8970 & $\mathrm{C}$ & 0.89 & 0.02 & 57.020 & $1.023 E-06$ \\
\hline SW & 13200. & D & 2.65 & 0.40 & 57.230 & $9.977 \mathrm{E}-07$ \\
\hline $\mathrm{NNE}$ & 8970 & $\mathrm{D}$ & 4.70 & 0.13 & 57.495 & $9.916 \mathrm{E}-07$ \\
\hline SW & 13200. & $\mathrm{E}$ & 7.15 & 0.01 & 57.565 & $9.235 E-07$ \\
\hline $\mathrm{NE}$ & 10430. & $\mathrm{E}$ & 9.80 & 0.11 & 57.625 & $9.222 E-07$ \\
\hline ENE & 10530. & $\mathrm{E}$ & 9.80 & 0.15 & 57.755 & $9.105 \mathrm{E}-07$ \\
\hline $\mathrm{NNE}$ & 8970 & $E$ & 12.70 & 0.01 & 57.835 & $8.714 \mathrm{E}-07$ \\
\hline S & 15360. & $\mathrm{~F}$ & 15.60 & 0.02 & 57.850 & $8.714 E-07$ \\
\hline $\mathrm{E}$ & 11160 . & $E$ & 9.80 & 0.06 & 57.890 & $8.424 \mathrm{E}-07$ \\
\hline ESE & 15190. & $\mathrm{D}$ & 2.65 & 1.09 & 58.465 & $8.127 E-07$ \\
\hline SSW & 15360. & $\mathrm{D}$ & 2.65 & 2.09 & 60.055 & $7.996 \mathrm{E}-07$ \\
\hline $\mathrm{NE}$ & 10430. & $\mathrm{D}$ & 4.70 & 0.23 & 61.215 & $7.943 E-07$ \\
\hline ENE & 10530. & $D$ & 4.70 & 0.39 & 61.525 & $7.833 E-07$ \\
\hline $\mathrm{NE}$ & 10430. & $\mathrm{C}$ & 0.89 & 0.02 & 61.730 & $7.787 E-07$ \\
\hline ESE & 15190. & $\mathrm{E}$ & 7.15 & 1.75 & 62.615 & $7.669 E-07$ \\
\hline ENE & 10530. & C & 0.89 & 0.02 & 63.500 & $7.654 \mathrm{E}-07$ \\
\hline$S E$ & 21050. & $\mathrm{E}$ & 4.70 & 0.75 & 63.885 & $7.602 \mathrm{E}-07$ \\
\hline
\end{tabular}


RPP-13482 REV 5

\begin{tabular}{|c|c|c|c|c|c|c|}
\hline SSW & 15360. & $E$ & 7.15 & 0.21 & 64.365 & $7.557 E-07$ \\
\hline NW & 10800 . & $\mathrm{D}$ & 4.70 & 0.25 & 64.595 & $7.547 E-07$ \\
\hline NW & 10800. & C & 0.89 & 0.06 & 64.750 & $7.315 E-07$ \\
\hline WSW & 11100 . & $\mathrm{D}$ & 4.70 & 0.27 & 64.915 & $7.250 E-07$ \\
\hline $\mathrm{E}$ & 11160. & $\mathrm{D}$ & 4.70 & 0.83 & 65.465 & $7.193 E-07$ \\
\hline S & 15360. & $\mathrm{~F}$ & 19.00 & 0.08 & 65.920 & $7.154 E-07$ \\
\hline $\mathrm{NE}$ & 10430 . & $\mathrm{E}$ & 12.70 & 0.04 & 65.980 & $7.116 \mathrm{E}-07$ \\
\hline ENE & 10530 . & $\mathrm{E}$ & 12.70 & 0.02 & 66.010 & $7.026 \mathrm{E}-07$ \\
\hline W & 11100 . & C & 0.89 & 0.36 & 66.200 & $6.965 E-07$ \\
\hline $\mathrm{E}$ & 11160. & $\mathrm{C}$ & 0.89 & 0.04 & 66.400 & $6.898 E-07$ \\
\hline $\mathrm{NNW}$ & 8690 & $\mathrm{D}$ & 7.15 & 0.17 & 66.505 & $6.830 E-07$ \\
\hline SW & 13200 . & $\mathrm{E}$ & 9.80 & 0.01 & 66.595 & $6.737 E-07$ \\
\hline NNE & 8970 . & $\mathrm{D}$ & 7.15 & 0.11 & 66.655 & $6.518 \mathrm{E}-07$ \\
\hline$E$ & 11160. & $E$ & 12.70 & 0.01 & 66.715 & $6.501 E-07$ \\
\hline NE & 10430. & $E$ & 15.60 & 0.01 & 66.725 & $5.793 E-07$ \\
\hline SW & 13200. & D & 4.70 & 0.09 & 66.775 & $5.625 E-07$ \\
\hline ESE & 15190. & $E$ & 9.80 & 0.38 & 67.010 & $5.595 E-07$ \\
\hline S & 15360. & $E$ & 9.80 & 0.07 & 67.235 & $5.514 \mathrm{E}-07$ \\
\hline $\mathrm{NE}$ & 10430 . & D & 7.15 & 0.25 & 67.395 & $5.222 E-07$ \\
\hline SW & 13200 . & $E$ & 12.70 & 0.01 & 67.525 & $5.199 E-07$ \\
\hline SW & 13200 & $\mathrm{C}$ & 0.89 & 0.09 & 67.575 & $5.152 \mathrm{E}-07$ \\
\hline ENE & 10530. & D & 7.15 & 0.38 & 67.810 & $5.149 \mathrm{E}-07$ \\
\hline$S E$ & 21050 . & $\mathrm{D}$ & 2.65 & 1.05 & 68.525 & $5.054 E-07$ \\
\hline$S E$ & 21050 & $E$ & 7.15 & 0.41 & 69.255 & $4.997 E-07$ \\
\hline $\mathrm{N}$ & 8690 . & $\mathrm{D}$ & 9.80 & 0.02 & 69.470 & $4.983 E-07$ \\
\hline NW & 10800. & $\mathrm{D}$ & 7.15 & 0.03 & 69.495 & $4.961 E-07$ \\
\hline WNW & 11100. & $\mathrm{D}$ & 7.15 & 0.02 & 69.520 & $4.766 E-07$ \\
\hline NNE & 8970 & D & 9.80 & 0.07 & 69.565 & $4.755 E-07$ \\
\hline $\mathrm{E}$ & 11160. & $\mathrm{D}$ & 7.15 & 0.58 & 69.890 & $4.728 E-07$ \\
\hline ESE & 15190. & D & 4.70 & 1.46 & 70.910 & $4.582 \mathrm{E}-07$ \\
\hline NNW & 8690 & $\mathrm{~B}$ & 0.89 & 0.08 & 71.680 & $4.527 E-07$ \\
\hline S & 15360. & $\mathrm{D}$ & 4.70 & 0.73 & 72.085 & $4.508 E-07$ \\
\hline NNE & 8970 & B & 0.89 & 0.02 & 72.460 & $4.388 \mathrm{E}-07$ \\
\hline ESE & 15190. & $E$ & 12.70 & 0.05 & 72.495 & $4.317 E-07$ \\
\hline$S$ & 15360 . & $\mathrm{E}$ & 12.70 & 0.02 & 72.530 & $4.255 E-07$ \\
\hline ESE & 15190. & C & 0.89 & 0.04 & 72.560 & 4. $114 E-07$ \\
\hline SSW & 15360 . & $\mathrm{C}$ & 0.89 & 0.34 & 72.750 & $4.046 E-07$ \\
\hline$N E$ & 10430. & B & 0.89 & 0.01 & 72.925 & $3.829 E-07$ \\
\hline $\mathrm{NE}$ & 10430. & $D$ & 9.80 & 0.16 & 73.010 & $3.810 E-07$ \\
\hline ENE & 10530. & B & 0.89 & 0.03 & 73.105 & $3.796 \mathrm{E}-07$ \\
\hline ENE & 10530 . & $D$ & 9.80 & 0.24 & 73.240 & $3.757 E-07$ \\
\hline NW & 10800. & $\mathrm{~B}$ & 0.89 & 0.07 & 73.395 & $3.711 E-07$ \\
\hline SW & 13200 . & $\mathrm{D}$ & 7.15 & 0.03 & 73.445 & $3.698 E-07$ \\
\hline NNE & 8970 & $\mathrm{D}$ & 12.70 & 0.02 & 73.470 & $3.670 E-07$ \\
\hline $\mathrm{SE}$ & 21050 & $E$ & 9.80 & 0.11 & 73.535 & $3.646 E-07$ \\
\hline NNW & 8690 & $\mathrm{C}$ & 2.65 & 0.16 & 73.670 & $3.638 E-07$ \\
\hline WNW & 11100. & $B$ & 0.89 & 0.36 & 73.930 & $3.620 E-07$ \\
\hline$E$ & 11160. & $\mathrm{~B}$ & 0.89 & 0.04 & 74.130 & $3.602 \mathrm{E}-07$ \\
\hline$S$ & 15360. & $\mathrm{E}$ & 15.60 & 0.03 & 74.165 & $3.464 E-07$ \\
\hline $\mathrm{E}$ & 11160. & $\mathrm{D}$ & 9.80 & 0.13 & 74.245 & $3.450 \mathrm{E}-07$ \\
\hline NNE & 8970 & $C$ & 2.65 & 0.02 & 74.320 & $3.435 E-07$ \\
\hline NNW & 8690. & A & 0.89 & 0.20 & 74.430 & $3.396 E-07$ \\
\hline NNE & 8970 & $A$ & 0.89 & 0.06 & 74.560 & $3.300 \mathrm{E}-07$ \\
\hline Sw & 13200. & B & 0.89 & 0.10 & 74.640 & $3.096 \mathrm{E}-07$ \\
\hline ESE & 15190. & $\mathrm{D}$ & 7.15 & 1.14 & 75.260 & $3.012 \mathrm{E}-07$ \\
\hline$S$ & 15360 . & $\mathrm{D}$ & 7.15 & 0.25 & 75.955 & $2.963 \mathrm{E}-07$ \\
\hline $\mathrm{NE}$ & 10430 . & $D$ & 12.70 & 0.09 & 76.125 & $2.940 \mathrm{E}-07$ \\
\hline ENE & 10530. & D & 12.70 & 0.09 & 76.215 & $2.899 \mathrm{E}-07$ \\
\hline NE & 10430 . & A & 0.89 & 0.06 & 76.290 & $2.880 \mathrm{E}-07$ \\
\hline ENE & 10530. & A & 0.89 & 0.06 & 76.350 & $2.855 E-07$ \\
\hline $\mathrm{SE}$ & 21050. & $\mathrm{D}$ & 4.70 & 0.84 & 76.800 & $2.850 E-07$ \\
\hline
\end{tabular}


RPP-13482 REV 5

\begin{tabular}{|c|c|c|c|c|c|c|}
\hline SSW & 15360. & $E$ & 19.00 & 0.19 & 77.315 & $2.844 E-07$ \\
\hline$S E$ & 21050. & $E$ & 12.70 & 0.03 & 77.425 & $2.813 E-07$ \\
\hline NW & 10800. & A & 0.89 & 0.17 & 77.525 & $2.791 E-07$ \\
\hline ESE & 15190. & B & 0.89 & 0.05 & 77.635 & $2.727 E-07$ \\
\hline WNW & 11100 . & A & 0.89 & 0.90 & 78.110 & $2.722 E-07$ \\
\hline SE & 21050. & $\mathrm{C}$ & 0.89 & 0.10 & 78.610 & $2.721 E-07$ \\
\hline $\mathrm{E}$ & 11160. & A & 0.89 & 0.10 & 78.710 & $2.709 E-07$ \\
\hline SSW & 15360. & $B$ & 0.89 & 0.38 & 78.950 & $2.700 E-07$ \\
\hline SW & 13200 . & D & 9.80 & 0.01 & 79.145 & $2.698 \mathrm{E}-07$ \\
\hline $\mathrm{E}$ & 11160 . & D & 12.70 & 0.03 & 79.165 & $2.662 \mathrm{E}-07$ \\
\hline $\mathrm{NE}$ & 10430. & $\mathrm{C}$ & 2.65 & 0.03 & 79.195 & $2.615 E-07$ \\
\hline ENE & 10530. & $\mathrm{C}$ & 2.65 & 0.05 & 79.235 & $2.571 E-07$ \\
\hline $\mathrm{NW}$ & 10800 . & $\mathrm{C}$ & 2.65 & 0.19 & 79.355 & $2.457 \mathrm{E}-07$ \\
\hline $\mathrm{NE}$ & 10430 . & D & 15.60 & 0.03 & 79.465 & $2.393 E-07$ \\
\hline ENE & 10530. & D & 15.60 & 0.03 & 79.495 & $2.360 E-07$ \\
\hline WNW & 11100. & $\mathrm{C}$ & 2.65 & 0.35 & 79.685 & $2.339 \mathrm{E}-07$ \\
\hline SW & 13200. & A & 0.89 & 0.23 & 79.975 & $2.328 E-07$ \\
\hline $\mathrm{E}$ & 11160 . & C & 2.65 & 0.08 & 80.130 & $2.317 \mathrm{E}-07$ \\
\hline ESE & 15190. & $\mathrm{D}$ & 9.80 & 0.50 & 80.420 & $2.198 \mathrm{E}-07$ \\
\hline $\mathrm{E}$ & 11160. & D & 15.60 & 0.02 & 80.680 & $2.167 \mathrm{E}-07$ \\
\hline$S$ & 15360. & $\mathrm{D}$ & 9.80 & 0.07 & 80.725 & $2.162 \mathrm{E}-07$ \\
\hline NNW & 8690. & C & 4.70 & 0.09 & 80.805 & $2.051 \mathrm{E}-07$ \\
\hline ESE & 15190. & A & 0.89 & 0.10 & 80.900 & $2.051 E-07$ \\
\hline$S E$ & 21050 . & B & 0.89 & 0.07 & 80.985 & $2.031 \mathrm{E}-07$ \\
\hline S & 15360 . & A & $0: 89$ & 0.78 & 81.410 & $2.030 E-07$ \\
\hline NNE & 8970 & $\mathrm{C}$ & 4.70 & 0.02 & 81.810 & 1. $937 \mathrm{E}-07$ \\
\hline SE & 21050. & D & 7.15 & 0.50 & 82.070 & $1.873 E-07$ \\
\hline SW & 13200. & C & 2.65 & 0.06 & 82.350 & $1.730 \mathrm{E}-07$ \\
\hline ESE & 15190. & $\mathrm{D}$ & 12.70 & 0.07 & 82.415 & $1.696 \mathrm{E}-07$ \\
\hline SSW & 15360 . & D & 12.70 & 0.05 & 82.475 & $1.668 \mathrm{E}-07$ \\
\hline $\mathrm{SE}$ & 21050 . & A & 0.89 & 0.14 & 82.570 & $1.527 \mathrm{E}-07$ \\
\hline NNW & 8690 & B & 2.65 & 0.17 & 82.725 & 1. $520 \mathrm{E}-07$ \\
\hline $\mathrm{NE}$ & 10430 . & C & 4.70 & 0.03 & 82.825 & 1. $475 \mathrm{E}-07$ \\
\hline $\mathrm{NNE}$ & 8970 & B & 2.65 & 0.04 & 82.860 & $3.474 \mathrm{E}-07$ \\
\hline ENE & 10530. & $\mathrm{C}$ & 4.70 & 0.06 & 82.910 & $1.449 \mathrm{E}-07$ \\
\hline NW & 10800. & C & 4.70 & 0.04 & 82.960 & $1.385 \mathrm{E}-07$ \\
\hline ESE & 15190. & C & 2.65 & 0.10 & 83.030 & $1.382 \mathrm{E}-07$ \\
\hline$S E$ & 21050 & D & 9.80 & 0.29 & 83.225 & $1.367 \mathrm{E}-07$ \\
\hline $\mathrm{S}$ & 15360 . & $\mathrm{C}$ & 2.65 & 0.46 & 83.600 & I. $359 \mathrm{E}-07$ \\
\hline SSW & 15360. & D & 15.60 & 0.03 & 83.845 & 1. $358 \mathrm{E}-07$ \\
\hline NNW & 8690 & C & 7.15 & 0.03 & 83.875 & 1. $348 \mathrm{E}-07$ \\
\hline $\mathrm{W}$ & 11100 . & $\mathrm{C}$ & 4.70 & 0.05 & 83.915 & $1.319 \mathrm{E}-07$ \\
\hline$E$ & 11160. & C & 4.70 & 0.09 & 83.985 & 1. $306 \mathrm{E}-07$ \\
\hline $\mathrm{NE}$ & 10430. & B & 2.65 & 0.03 & 84.045 & $1.286 \mathrm{E}-07$ \\
\hline ENE & 10530. & B & 2.65 & 0.05 & 84.085 & $1.275 \mathrm{E}-07$ \\
\hline NNE & 8970 & C & 7.15 & 0.01 & 84.115 & 1.273E-07 \\
\hline NW & 10800. & B & 2.65 & 0.13 & 84.185 & I. $246 \mathrm{E}-07$ \\
\hline WSW & 11100 . & B & 2.65 & 0.37 & 84.435 & 1. $216 \mathrm{E}-07$ \\
\hline$E$ & 11160. & B & 2.65 & 0.07 & 84.655 & $1.210 \mathrm{E}-07$ \\
\hline NNW & 8690 & A & 2.65 & 0.53 & 84.955 & 1.140E-07 \\
\hline SSW & 15360 . & D & 19.00 & 0.11 & 85.275 & $1.115 \mathrm{E}-07$ \\
\hline $\mathrm{NNE}$ & 8970 & A & 2.65 & 0.12 & 85.390 & $1.108 \mathrm{E}-07$ \\
\hline$S E$ & 21050. & $\mathrm{D}$ & 12.70 & 0.08 & 85.490 & $1.055 \mathrm{E}-07$ \\
\hline SW & 13200. & B & 2.65 & 0.06 & 85.560 & $1.040 \mathrm{E}-07$ \\
\hline $\mathrm{N}$ & 8690 & $\mathrm{C}$ & 9.80 & 0.01 & 85.595 & $9.837 \mathrm{E}-08$ \\
\hline SW & 13200 . & $\mathrm{C}$ & 4.70 & 0.03 & 85.615 & $9.755 E-08$ \\
\hline NE & 10430 . & $\mathrm{C}$ & 7.15 & 0.02 & 85.640 & $9.693 E-08$ \\
\hline $\mathrm{NE}$ & 10430 . & A & 2.65 & 0.17 & 85.735 & $9.672 \mathrm{E}-08$ \\
\hline ENE & 10530 . & A & 2.65 & 0.19 & 85.915 & $9.589 E-08$ \\
\hline ENE & 10530 . & $\mathrm{C}$ & 7.15 & 0.07 & 86.045 & $9.528 E-08$ \\
\hline NW & 10800 . & A & 2.65 & 0.45 & 86.305 & $9.372 E-08$ \\
\hline
\end{tabular}


RPP-13482 REV 5

\begin{tabular}{|c|c|c|c|c|c|c|}
\hline ESE & 15190. & $\mathrm{~B}$ & 2.65 & 0.09 & 86.575 & $9.158 E-08$ \\
\hline W & 11100 . & A & 2.65 & 1.43 & 87.335 & $9.143 E-08$ \\
\hline$S E$ & 21050 . & $\mathrm{C}$ & 2.65 & 0.19 & 88.145 & $9.138 E-08$ \\
\hline$E$ & 11160. & A & 2.65 & 0.25 & 88.365 & $9.098 E-08$ \\
\hline$S$ & 15360 . & $B$ & 2.65 & 0.52 & 88.750 & $9.066 E-08$ \\
\hline $\mathrm{E}$ & 11160. & C & 7.15 & 0.06 & 89.040 & $8.587 E-08$ \\
\hline NNW & 8690 & B & 4.70 & 0.08 & 89.110 & $8.572 E-08$ \\
\hline NNE & 8970 & B & 4.70 & 0.02 & 89.160 & $8.309 E-08$ \\
\hline SW & 13200 . & $A$ & 2.65 & 0.29 & 89.315 & $7.819 E-08$ \\
\hline ESE & 15190. & C & 4.70 & 0.13 & 89.525 & $7.791 \mathrm{E}-08$ \\
\hline S & 15360. & $\mathrm{C}$ & 4.70 & 0.16 & 89.670 & $7.662 E-08$ \\
\hline $\mathrm{NE}$ & 10430. & B & 4.70 & 0.05 & 89.775 & $7.251 \mathrm{E}-08$ \\
\hline ENE & 10530. & B & 4.70 & 0.07 & 89.835 & $7.189 \mathrm{E}-0.8$ \\
\hline $\mathrm{NE}$ & 10430. & C & 9.80 & 0.02 & 89.880 & $7.072 \mathrm{E}-08$ \\
\hline NW & 10800. & B & 4.70 & 0.04 & 89.910 & $7.026 \mathrm{E}-08$ \\
\hline ENE & 10530. & $\mathrm{C}$ & 9.80 & 0.05 & 89.955 & $6.952 E-08$ \\
\hline ESE & 15190. & A & 2.65 & 0.30 & 90.130 & $6.887 \mathrm{E}-08$ \\
\hline W & 11100. & B & 4.70 & 0.07 & 90.315 & $6.855 \mathrm{E}-08$ \\
\hline $\mathbf{E}$ & 11160. & B & 4.70 & 0.10 & 90.400 & $6.821 \mathrm{E}-08$ \\
\hline$S E$ & 21050 . & B & 2.65 & 0.16 & 90.530 & $6.821 E-08$ \\
\hline$S$ & 15360. & A & 2.65 & 1.61 & 91.415 & $6.818 \mathrm{E}-08$ \\
\hline $\mathrm{N}$ & 8690 & A & 4.70 & 0.25 & 92.345 & $6.430 \mathrm{E}-08$ \\
\hline SW & 13200. & $\mathrm{C}$ & 7.15 & 0.01 & 92.475 & $6.413 E-08$ \\
\hline$E$ & 11160. & $\mathrm{C}$ & 9.80 & 0.02 & 92.490 & $6.265 \mathrm{E}-08$ \\
\hline NNE & 8970 & A & 4.70 & 0.07 & 92.535 & $6.249 \mathrm{E}-08$ \\
\hline SW & 13200 . & B & 4.70 & 0.03 & 92.585 & $5.862 E-08$ \\
\hline $\mathrm{NNW}$ & 8690 & B & 7.15 & 0.03 & 92.615 & $5.635 E-08$ \\
\hline $\mathrm{NNE}$ & 8970 & B & 7.15 & 0.01 & 92.635 & $5.462 \mathrm{E}-08$ \\
\hline $\mathrm{NE}$ & 10430. & $\mathrm{C}$ & 12.70 & 0.02 & 92.650 & $5.457 \mathrm{E}-08$ \\
\hline $\mathrm{NE}$ & 10430. & $\mathrm{~A}$ & 4.70 & 0.14 & 92.730 & $5.453 \mathrm{E}-08$ \\
\hline ENE & 10530. & A & 4.70 & 0.34 & 92.970 & $5.406 \mathrm{E}-08$ \\
\hline ENE & 10530. & $\mathrm{C}$ & 12.70 & 0.01 & 93.145 & $5.364 \mathrm{E}-08$ \\
\hline NW & 10800. & $A$ & 4.70 & 0.10 & 93.200 & $5.284 \mathrm{E}-08$ \\
\hline ESE & 15190. & B & 4.70 & 0.14 & 93.320 & $5.164 E-08$ \\
\hline WSW & 11100. & A & 4.70 & 0.21 & 93.495 & $5.155 E-08$ \\
\hline$S E$ & 21050 . & $\mathrm{C}$ & 4.70 & 0.12 & 93.660 & $5.153 E-08$ \\
\hline$E$ & 11160. & A & 4.70 & 0.35 & 93.895 & $5.130 \mathrm{E}-08$ \\
\hline$S E$ & 21050. & A & 2.65 & 0.42 & 94.280 & $5.130 E-08$ \\
\hline ESE & 15190. & C & 7.15 & 0.07 & 94.525 & $5.121 E-08$ \\
\hline$S$ & 15360. & B & 4.70 & 0.21 & 94.665 & $5.112 \mathrm{E}-08$ \\
\hline$s$ & 15360. & $C$ & 7.15 & 0.06 & 94.800 & $5.036 \mathrm{E}-08$ \\
\hline $\mathrm{NE}$ & 10430. & B & 7.15 & 0.04 & 94.850 & $4.766 E-08$ \\
\hline ENE & 10530. & B & 7.15 & 0.08 & 94.910 & $4.726 E-08$ \\
\hline WSW & 11100. & $\mathrm{~B}$ & 7.15 & 0.01 & 94.955 & $4.506 \mathrm{E}-08$ \\
\hline$E$ & 11160. & $\mathrm{~B}$ & 7.15 & 0.06 & 94.990 & $4.484 E-08$ \\
\hline SW & 13200. & A & 4.70 & 0.10 & 95.070 & $4.408 E-08$ \\
\hline ENE & 10530. & $\mathrm{C}$ & 15.60 & 0.01 & 95.125 & $4.367 E-08$ \\
\hline $\mathrm{N}$ & 8690 & A & 7.15 & 0.07 & 95.165 & $4.227 E-08$ \\
\hline $\mathrm{NNE}$ & 8970 & A & 7.15 & 0.04 & 95.220 & $4.108 E-08$ \\
\hline ESE & 15190. & A & 4.70 & 0.35 & 95.415 & $3.883 E-08$ \\
\hline SW & 13200 . & B & 7.15 & 0.01 & 95.595 & $3.853 E-08$ \\
\hline $\mathrm{SE}$ & 21050 . & B & 4.70 & 0.12 & 95.660 & $3.846 E-08$ \\
\hline SSW & 15360. & A & 4.70 & 0.67 & 96.055 & $3.844 \mathrm{E}-08$ \\
\hline ESE & 15190. & $\mathrm{C}$ & 9.80 & 0.03 & 96.405 & $3.736 \mathrm{E}-08$ \\
\hline S & 15360. & $\mathrm{C}$ & 9.80 & 0.02 & 96.430 & $3.674 \mathrm{E}-08$ \\
\hline $\mathrm{NE}$ & 10430 . & A & 7.15 & 0.11 & 96.495 & $3.585 E-08$ \\
\hline ENE & 10530. & A & 7.15 & 0.25 & 96.675 & $3.554 \mathrm{E}-08$ \\
\hline NE & 10430. & B & 9.80 & 0.02 & 96.810 & $3.478 E-08$ \\
\hline $\mathrm{NW}$ & 10800. & A & 7.15 & 0.01 & 96.825 & $3.474 E-08$ \\
\hline
\end{tabular}


RPP-13482 REV 5

APPENDIX E

GXQ CDF OUTPU'T FOR THE CENTERLINE PLUME WITH MEANDER

$\mathrm{E}-\mathrm{i}$ 


\section{APPENDIX E}

\section{GXQ CDF OUTPUT FOR THE CENTERLINE PLUME WITH MEANDER}

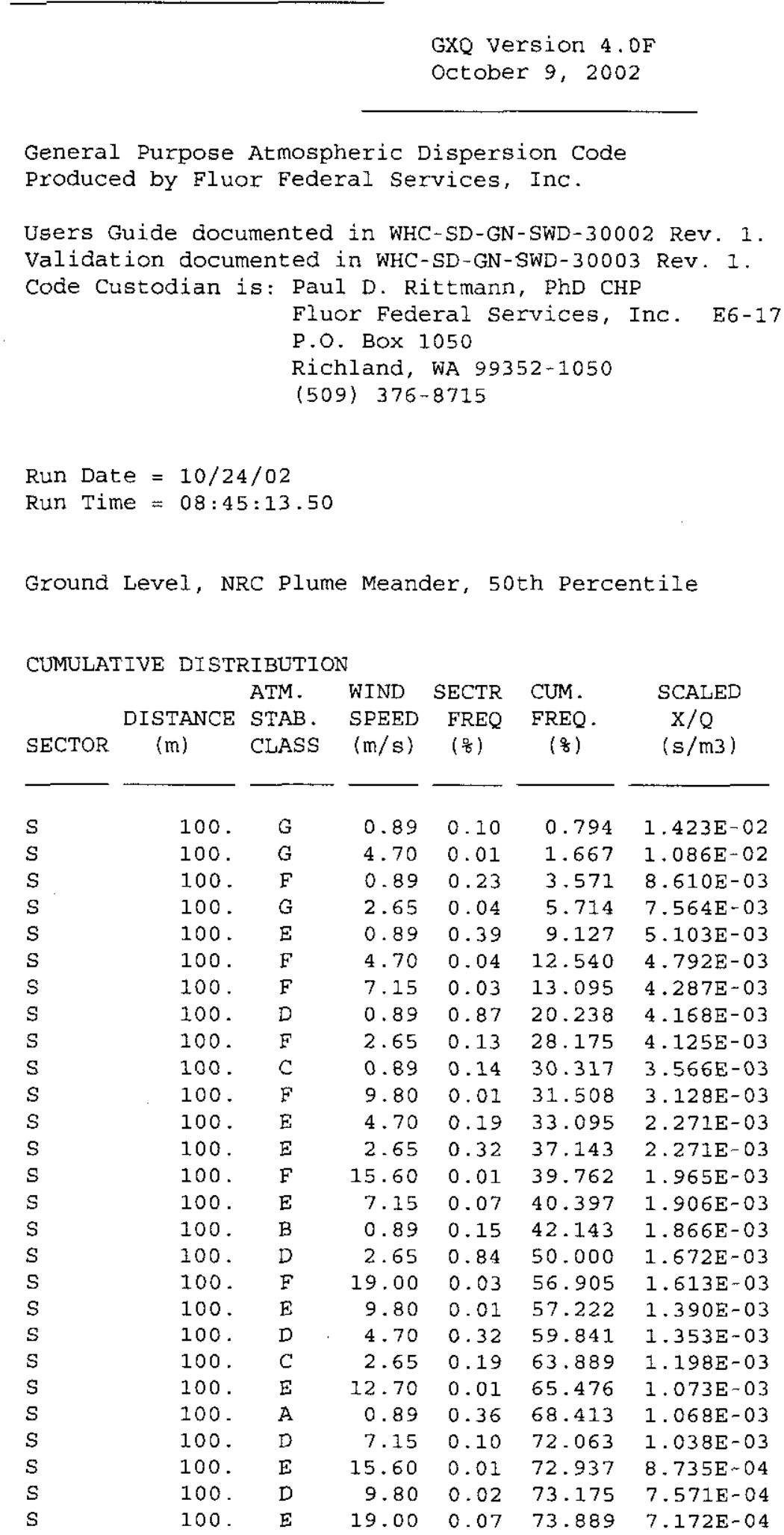


RPP-13482 REV 5

\begin{tabular}{|c|c|c|c|c|c|c|}
\hline$S$ & 100. & $\mathrm{C}$ & 4.70 & 0.08 & 75.079 & $6.754 \mathrm{E}-04$ \\
\hline$S$ & 100 & B & 2.65 & 0.21 & 77.381 & $6.266 E-04$ \\
\hline$S$ & 100. & $\mathrm{D}$ & 12.70 & 0.02 & 79.206 & $5.842 \mathrm{E}-04$ \\
\hline$s$ & 100 . & $\mathrm{D}$ & 15.60 & 0.01 & 79.444 & $4.756 \mathrm{E}-04$ \\
\hline S & 100 & C & 7.15 & 0.02 & 79.683 & $4.439 E-04$ \\
\hline$S$ & 100 & $\mathrm{D}$ & 19.00 & 0.04 & 80.159 & $3.905 E-04$ \\
\hline S & 100. & A & 2.65 & 0.69 & 85.952 & $3.588 E-04$ \\
\hline$S$ & 100. & B & 4.70 & 0.09 & 92.143 & $3.533 E-04$ \\
\hline$S$ & 100 & C & 9.80 & 0.01 & 92.936 & $3.239 E-04$ \\
\hline$S$ & 100 & B & 7.15 & 0.02 & 93.175 & $2.322 E-04$ \\
\hline$S$ & 100 & C & 15.60 & 0.01 & 93.413 & $2.035 \mathrm{E}-04$ \\
\hline S & 100. & A & 4.70 & 0.26 & 95.556 & $2.023 E-04$ \\
\hline$S$ & 100. & B & 9.80 & 0.01 & 97.698 & $1.694 E-04$ \\
\hline$S$ & 100. & C & 19.00 & 0.01 & 97.857 & $1.671 E-04$ \\
\hline S & 100 & A & 7.15 & 0.07 & 98.492 & $1.330 E-04$ \\
\hline$S$ & 100. & A & 9.80 & 0.02 & 99.206 & $9.702 E-05$ \\
\hline$S$ & 100 & B & 19.00 & 0.01 & 99.444 & $8.740 E-05$ \\
\hline S & 100 . & A & 15.60 & 0.01 & 99.603 & $6.095 E-05$ \\
\hline$S$ & 100 & A & 19.00 & 0.02 & 99.841 & $5.004 \mathrm{E}-05$ \\
\hline$S$ & 100 . & G & 12.70 & 0.00 & 100.000 & $0.000 \mathrm{E}+00$ \\
\hline$S$ & 100 & G & 19.00 & 0.00 & 100.000 & $0.000 \mathrm{E}+00$ \\
\hline SSW & 100. & G & 0.89 & 0.04 & 0.442 & $1.423 \mathrm{E}-02$ \\
\hline SSW & 100. & $F$ & 0.89 & 0.13 & 2.318 & $8.610 E-03$ \\
\hline SSW & 100 & G & 2.65 & 0.02 & 3.974 & $7.564 \mathrm{E}-03$ \\
\hline SSW & 100. & $\mathrm{E}$ & 0.89 & 0.26 & 7.064 & $5.103 E-03$ \\
\hline SSW & 100. & F & 4.70 & 0.06 & 10.596 & $4.792 \mathrm{E}-03$ \\
\hline SSW & 100. & $\mathrm{E}$ & 7.15 & 0.02 & 11.479 & $4.287 \mathrm{E}-03$ \\
\hline SSW & 100. & D & 0.89 & 0.58 & 18.102 & $4.168 \mathrm{E}-03$ \\
\hline SSW & 100 & $F$ & 2.65 & 0.05 & 25.055 & $4.125 \mathrm{E}-03$ \\
\hline SSW & 100. & G & 19.00 & 0.01 & 25.717 & $4.000 \mathrm{E}-03$ \\
\hline SSW & 100. & C & 0.89 & 0.10 & 26.932 & $3.566 \mathrm{E}-03$ \\
\hline SSW & 100 & F & 9.80 & 0.01 & 28.146 & $3.128 \mathrm{E}-03$ \\
\hline SSW & 100. & $E$ & 4.70 & 0.09 & 29.249 & $2.271 \mathrm{E}-03$ \\
\hline SSW & 100 & $E$ & 2.65 & 0.17 & 32.119 & $2.271 E-03$ \\
\hline SSW & 100 & F & 15.60 & 0.01 & 34.106 & $1.965 E-03$ \\
\hline SSW & 100 & E & 7.15 & 0.12 & 35.541 & 1. $906 \mathrm{E}-03$ \\
\hline SSW & 100. & B & 0.89 & 0.13 & 38.300 & $1.866 \mathrm{E}-03$ \\
\hline SSW & 100. & D & 2.65 & 0.48 & 45.033 & $1.672 \mathrm{E}-03$ \\
\hline SSW & 100. & F & 19.00 & 0.05 & 50.883 & $1.613 E-03$ \\
\hline SSW & 100 & $\mathrm{E}$ & 9.80 & 0.06 & 52.097 & $1.390 \mathrm{E}-03$ \\
\hline SSW & 100. & $\mathrm{D}$ & 4.70 & 0.20 & 54.967 & $1.353 E-03$ \\
\hline SSW & 100. & $\mathrm{C}$ & 2.65 & 0.12 & 58.499 & $1.198 E-03$ \\
\hline SSW & 100. & $\mathrm{E}$ & 12.70 & 0.01 & 59.934 & $1.073 E-03$ \\
\hline SSW & 100 & A & 0.89 & 0.20 & 62.252 & $1.068 E-03$ \\
\hline SSW & 100 & D & 7.15 & 0.10 & 65.563 & $1.038 \mathrm{E}-03$ \\
\hline SSW & 100. & $E$ & 15.60 & 0.02 & 66.887 & $8.735 E-04$ \\
\hline SSW & 100 & D & 9.80 & 0.04 & 67.550 & $7.571 \mathrm{E}-04$ \\
\hline SSW & 100. & $\mathrm{E}$ & 19.00 & 0.12 & 69.316 & $7.172 \mathrm{E}-04$ \\
\hline SSW & 100. & $\mathrm{C}$ & 4.70 & 0.05 & 71.192 & $6.754 \mathrm{E}-04$ \\
\hline SSW & 100. & B & 2.65 & 0.15 & 73.400 & $6.266 \mathrm{E}-04$ \\
\hline SSW & 100. & D & 12.70 & 0.03 & 75.386 & $5.842 E-04$ \\
\hline SSW & 100. & $\mathrm{D}$ & 15.60 & 0.02 & 75.938 & $4.756 \mathrm{E}-04$ \\
\hline SSW & 100 . & $\mathrm{C}$ & 7.15 & 0.03 & 76.490 & $4.439 \mathrm{E}-04$ \\
\hline SSW & 100 & D & 19.00 & 0.07 & 77.594 & $3.905 E-04$ \\
\hline SSW & 100. & A & 2.65 & 0.44 & 83.223 & $3.588 E-04$ \\
\hline SSW & 100. & B & 4.70 & 0.06 & 88.742 & $3.533 E-04$ \\
\hline SSW & 100. & $\mathrm{C}$ & 9.80 & 0.01 & 89.514 & $3.239 E-04$ \\
\hline SSW & 100. & C & 12.70 & 0.01 & 89.735 & $2.499 E-04$ \\
\hline SSW & 100. & B & 7.15 & 0.03 & 90.177 & $2.322 \mathrm{E}-04$ \\
\hline SSW & 100 & C & 15.60 & 0.01 & 90.618 & $2.035 E-04$ \\
\hline SSW & 100. & A & 4.70 & 0.24 & 93.377 & $2.023 E-04$ \\
\hline SSW & 100. & B & 9.80 & 0.01 & 96.137 & I. $694 \mathrm{E}-04$ \\
\hline
\end{tabular}


RPP-13482 REV 5

\begin{tabular}{|c|c|c|c|c|c|c|}
\hline SSW & 100 & $\mathrm{C}$ & 19.00 & 0.02 & 96.468 & $1.671 \mathrm{E}-0.4$ \\
\hline SSW & 100. & A & 7.15 & 0.07 & 97.461 & $1.330 \mathrm{E}-04$ \\
\hline SSW & 100. & $\mathrm{~B}$ & 15.60 & 0.01 & 98.344 & $1.064 \mathrm{E}-04$ \\
\hline SSW & 100. & A & 9.80 & 0.02 & 98.675 & $9.702 \mathrm{E}-05$ \\
\hline SSW & 100. & $\mathrm{~B}$ & 19.00 & 0.01 & 99.007 & $8.740 \mathrm{E}-05$ \\
\hline SSW & 100. & A & 12.70 & 0.01 & 99.227 & $7.486 \mathrm{E}-05$ \\
\hline SSW & 100 & A & 15.60 & 0.01 & 99.448 & $6.095 E-05$ \\
\hline SSW & 100. & A & 19.00 & 0.02 & 99.779 & $5.004 \mathrm{E}-05$ \\
\hline SSW & 100. & G & 15.60 & 0.00 & 100.000 & $0.000 E+00$ \\
\hline SSW & 100 & $\mathrm{~F}$ & 12.70 & 0.00 & 100.000 & $0.000 E+00$ \\
\hline SW & 100. & $G$ & 0.89 & 0.08 & 1.365 & 1. $423 \mathrm{E}-02$ \\
\hline SW & 100. & $E$ & 0.89 & 0.12 & 4.778 & $8.610 \mathrm{E}-03$ \\
\hline SW & 100. & $G$ & 2.65 & 0.02 & 7.167 & $7.564 \mathrm{E}-03$ \\
\hline SW & 100. & $\mathrm{E}$ & 0.89 & 0.28 & 12.287 & $5.103 E-03$ \\
\hline SW & 100. & $\mathrm{~F}$ & 4.70 & 0.01 & 17.235 & $4.792 \mathrm{E}-03$ \\
\hline SW & 100. & $\mathrm{D}$ & 0.89 & 0.59 & 27.474 & $4.168 \mathrm{E}-03$ \\
\hline SW & 100 & $F$ & 2.65 & 0.05 & 38.396 & $4.125 E-03$ \\
\hline SW & 100. & $C$ & 0.89 & 0.09 & 40.785 & $3.566 \mathrm{E}-03$ \\
\hline SW & 100. & $E$ & 4.70 & 0.04 & 43.003 & $2.271 \mathrm{E}-03$ \\
\hline SW & 100. & $E$ & 2.65 & 0.11 & 45.563 & $2.271 E-03$ \\
\hline SW & 100. & $E$ & 7.15 & 0.01 & 47.611 & $1.906 E-03$ \\
\hline SW & 100 . & $B$ & 0.89 & 0.10 & 49.488 & $1.866 E-03$ \\
\hline SW & 100. & $D$ & 2.65 & 0.40 & 58.020 & $1.672 \mathrm{E}-03$ \\
\hline SW & 100. & $E$ & 9.80 & 0.01 & 65.017 & $1.390 E-03$ \\
\hline SW & 100. & $\mathrm{D}$ & 4.70 & 0.09 & 66.724 & 1. $353 E-03$ \\
\hline SW & 100 & $C$ & 2.65 & 0.06 & 69.283 & $1.198 \mathrm{E}-03$ \\
\hline SW & 100. & $E$ & 12.70 & 0.01 & 70.478 & $1.073 E-03$ \\
\hline SW & 100. & A & 0.89 & 0.23 & 74.573 & I. $068 \mathrm{E}-03$ \\
\hline SW & 100. & $\mathrm{D}$ & 7.15 & 0.03 & 79.010 & I. $038 \mathrm{E}-03$ \\
\hline SW & 100 & $D$ & 9.80 & 0.01 & 79.693 & $7.571 E-04$ \\
\hline SW & 100 & C & 4.70 & 0.03 & 80.375 & $6.754 E-04$ \\
\hline SW & 100. & B & 2.65 & 0.06 & 81.911 & $6.266 E-04$ \\
\hline SW & 100. & $C$ & 7.15 & 0.01 & 83.106 & $4.439 E-04$ \\
\hline SW & 100. & A & 2.65 & 0.29 & 88.225 & $3.588 \mathrm{E}-04$ \\
\hline SW & 100. & B & 4.70 & 0.03 & 93.686 & $3.533 \mathrm{E}-04$ \\
\hline SW & 100 . & B & 7.15 & 0.01 & 94.369 & $2.322 \mathrm{E}-04$ \\
\hline SW & 100. & $A$ & 4.70 & 0.10 & 96.246 & $2.023 E-04$ \\
\hline SW & 100. & A & 7.15 & 0.05 & 98.805 & $1.330 \mathrm{E}-04$ \\
\hline SW & 100. & A & 9.80 & 0.01 & 99.829 & $9.702 \mathrm{E}-05$ \\
\hline SW & 100. & $B$ & 9.80 & 0.00 & 100.000 & $0.000 E+00$ \\
\hline SW & 100. & $G$ & 19.00 & 0.00 & 100.000 & $0.000 E+00$ \\
\hline WSW & 100 . & $G$ & 0.89 & 0.08 & 1.471 & $1.423 E-02$ \\
\hline WSW & 100 . & $F$ & 0.89 & 0.14 & 5.515 & $8.610 E-03$ \\
\hline WSW & 100. & G & 2.65 & 0.03 & 8.640 & $7.564 E-03$ \\
\hline WSW & 100. & $E$ & 0.89 & 0.25 & 13.787 & $5.103 E-03$ \\
\hline WSW & 100. & $\mathrm{~F}$ & 4.70 & 0.01 & 18.566 & $4.792 \mathrm{E}-03$ \\
\hline WSW & 100. & $\mathrm{D}$ & 0.89 & 0.59 & 29.596 & $4.168 \mathrm{E}-03$ \\
\hline WSW & 100. & $E$ & 2.65 & 0.05 & 41.360 & $4.125 \mathrm{E}-03$ \\
\hline WSW & 100. & $C$ & 0.89 & 0.12 & 44.485 & $3.566 E-03$ \\
\hline WSW & 100. & $E$ & 4.70 & 0.01 & 46.875 & $2.271 E-03$ \\
\hline WSW & 100. & $E$ & 2.65 & 0.13 & 49.449 & $2.271 E-03$ \\
\hline WSW & 100. & B & 0.89 & 0.11 & 53.860 & $1.866 \mathrm{E}-03$ \\
\hline WSW & 100. & $\mathrm{D}$ & 2.65 & 0.33 & 61.949 & $1.672 \mathrm{E}-03$ \\
\hline WSW & 100 & $D$ & 4.70 & 0.04 & 68.750 & $1.353 E-03$ \\
\hline WSW & 100. & $C$ & 2.65 & 0.09 & 71.140 & $1.198 E-03$ \\
\hline WSW & 100. & A & 0.89 & 0.26 & 77.574 & $1.068 E-03$ \\
\hline WSW & 100. & $\mathrm{D}$ & 7.15 & 0.01 & 82.537 & $1.038 \mathrm{E}-03$ \\
\hline WSW & 100. & C & 4.70 & 0.01 & 82.904 & $6.754 \mathrm{E}-04$ \\
\hline WSW & 100. & $\mathrm{~B}$ & 2.65 & 0.08 & 84.559 & $6.266 E-04$ \\
\hline WSW & 100. & A & 2.65 & 0.32 & 91.912 & $3.588 \mathrm{E}-04$ \\
\hline WSW & 100. & B & 4.70 & 0.01 & 97.978 & $3.533 \mathrm{E}-04$ \\
\hline
\end{tabular}


RPP-13482 REV 5

\begin{tabular}{|c|c|c|c|c|c|c|}
\hline WSW & 100. & B & 7.15 & 0.01 & 98.346 & $2.322 \mathrm{E}-04$ \\
\hline WSW & 100. & A & 4.70 & 0.03 & 99.081 & $2.023 E-04$ \\
\hline WSW & 100. & A & 7.15 & 0.01 & 99.816 & $1.330 \mathrm{E}-04$ \\
\hline WSW & 100. & C & 7.15 & 0.00 & 100.000 & $0.000 \mathrm{E}+00$ \\
\hline WSW & 100 & $G$ & 19.00 & 0.00 & 100.000 & $0.000 E+00$ \\
\hline$W$ & 100 & G & 0.89 & 0.13 & 1.354 & 1. $423 \mathrm{E}-02$ \\
\hline w & 100. & F & 0.89 & 0.31 & 5.938 & $8.610 E-03$ \\
\hline W & 100 & G & 2.65 & 0.09 & 10.104 & $7.564 \mathrm{E}-03$ \\
\hline W & 100. & $E$ & 0.89 & 0.46 & 15.833 & $5.103 E-03$ \\
\hline $\mathrm{W}$ & 100. & $F$ & 4.70 & 0.01 & 20.729 & $4.792 E-03$ \\
\hline W & 100. & D & 0.89 & 0.77 & 28.854 & $4.168 E-03$ \\
\hline $\mathrm{W}$ & 100. & $F$ & 2.65 & 0.16 & 38.542 & $4.125 E-03$ \\
\hline W & 100. & $\mathrm{C}$ & 0.89 & 0.14 & 41.667 & $3.566 \mathrm{E}-03$ \\
\hline W & 100. & $E$ & 4.70 & 0.06 & 43.750 & $2.271 E-03$ \\
\hline W & 100. & $E$ & 2.65 & 0.31 & 47.604 & $2.271 E-03$ \\
\hline W & 100. & B & 0.89 & 0.16 & 52.500 & $1.866 \mathrm{E}-03$ \\
\hline W & 100. & $\mathrm{D}$ & 2.65 & 0.66 & 61.042 & $1.672 E-03$ \\
\hline W & 100. & D & 4.70 & 0.12 & 69.167 & $1.353 E-03$ \\
\hline W & 100. & C & 2.65 & 0.13 & 71.771 & $1.198 \mathrm{E}-03$ \\
\hline $\mathrm{W}$ & 100 & A & 0.89 & 0.40 & 77.292 & $1.068 \mathrm{E}-03$ \\
\hline W & 100 & C & 4.70 & 0.02 & 81.667 & $6.754 \mathrm{E}-04$ \\
\hline W & 100. & B & 2.65 & 0.16 & 83.542 & $6.266 \mathrm{E}-04$ \\
\hline$W$ & 100. & A & 2.65 & 0.60 & 91.458 & $3.588 E-04$ \\
\hline W & 100 & $B$ & 4.70 & 0.03 & 98.021 & $3.533 E-04$ \\
\hline $\mathrm{W}$ & 100. & A & 4.70 & 0.08 & 99.167 & $2.023 \mathrm{E}-04$ \\
\hline W & 100. & G & 4.70 & 0.00 & 100.000 & $0.000 \mathrm{E}+00$ \\
\hline W & 100. & G & 19.00 & 0.00 & 100.000 & $0.000 E+00$ \\
\hline WNW & 100. & G & 0.89 & 0.13 & 1.633 & $1.423 \mathrm{E}-02$ \\
\hline WNW & 100. & G & 4.70 & 0.01 & 3.392 & $1.086 \mathrm{E} \cdot 02$ \\
\hline WNW & 100. & $F$ & 0.89 & 0.23 & 6.407 & $8.610 E-03$ \\
\hline WNW & 100 & G & 2.65 & 0.10 & 10.553 & $7.564 \mathrm{E}-03$ \\
\hline WNW & 100. & $E$ & 0.89 & 0.34 & 16.080 & $5.103 E-03$ \\
\hline WNW & 100. & F & 4.70 & 0.02 & 20.603 & 4.792E-03 \\
\hline WNW & 100 & D & 0.89 & 0.50 & 27.136 & $4.168 \mathrm{E}-03$ \\
\hline WNW & 100 & $F$ & 2.65 & 0.21 & 36.055 & $4.125 E-03$ \\
\hline WNW & 100. & $c$ & 0.89 & 0.10 & 39.950 & $3.566 E-03$ \\
\hline WNW & 100. & $\mathrm{E}$ & 4.70 & 0.06 & 41.960 & $2.271 E-03$ \\
\hline WNW & 100. & $E$ & 2.65 & 0.34 & 46.985 & $2.271 \mathrm{E}-03$ \\
\hline WNW & 100. & B & 0.89 & 0.09 & 52.387 & $1.866 \mathrm{E}-03$ \\
\hline WNW & 100. & D & 2.65 & 0.57 & 60.678 & $1.672 \mathrm{E}-03$ \\
\hline WNW & 100. & D & 4.70 & 0.11 & 69.221 & $1.353 E-03$ \\
\hline WNW & 100. & C & 2.65 & 0.13 & 72.236 & $1.198 E-03$ \\
\hline WNW & 100 & A & 0.89 & 0.24 & 76.884 & $1.068 \mathrm{E}-03$ \\
\hline WNW & 100. & $D$ & 7.15 & 0.01 & 80.025 & $1.038 \mathrm{E}-03$ \\
\hline WNW & 100. & C & 4.70 & 0.02 & 80.402 & $6.754 E-04$ \\
\hline WNW & 100 & B & 2.65 & 0.13 & 82.286 & $6.266 \mathrm{E}-04$ \\
\hline WNW & 100 . & A & 2.65 & 0.51 & 90.327 & $3.588 E-04$ \\
\hline WNW & 100. & $\mathrm{~B}$ & 4.70 & 0.03 & 97.111 & $3.533 E-04$ \\
\hline WNW & 100. & A & 4.70 & 0.10 & 98.744 & $2.023 E-04$ \\
\hline WNW & 100. & B & 7.15 & 0.00 & 100.000 & $0.000 E+00$ \\
\hline WNW & 100. & G & 19.00 & 0.00 & 100.000 & $0.000 \mathrm{E}+00$ \\
\hline NW & 100. & $G$ & 0.89 & 0.13 & 1.377 & $1.423 E-02$ \\
\hline NW & 100. & G & 4.70 & 0.01 & 2.860 & $1.086 \mathrm{E}-02$ \\
\hline NW & 100. & $F$ & 0.89 & 0.28 & 5.932 & $8.610 \mathrm{E}-03$ \\
\hline NW & 100. & $\mathrm{G}$ & 2.65 & 0.20 & 11.017 & $7.564 \mathrm{E}-03$ \\
\hline NW & 100 & $E$ & 0.89 & 0.31 & 16.419 & $5.103 E-03$ \\
\hline NW & 100 & $\mathrm{~F}$ & 4.70 & 0.05 & 20.233 & $4.792 E-03$ \\
\hline NW & 100 & $D$ & 0.89 & 0.43 & 25.318 & $4.168 E-03$ \\
\hline NW & 100. & $F$ & 2.65 & 0.39 & 34.004 & $4.125 E-03$ \\
\hline NW & 100. & C & 0.89 & 0.06 & 38.771 & $3.566 E-03$ \\
\hline
\end{tabular}




\begin{tabular}{|c|c|c|c|c|c|c|}
\hline $\mathrm{NW}$ & 100. & $E$ & 4.70 & 0.15 & 40.996 & $2.271 \mathrm{E}-03$ \\
\hline $\mathrm{NW}$ & 100. & $E$ & 2.65 & 0.47 & 47.564 & $2.271 E-03$ \\
\hline $\mathrm{NW}$ & 100. & $\mathrm{E}$ & 7.15 & 0.01 & 52.648 & $1.906 E-03$ \\
\hline $\mathrm{NW}$ & 100. & $B$ & 0.89 & 0.07 & 53.496 & $1.866 E-03$ \\
\hline $\mathrm{NW}$ & 100. & $D$ & 2.65 & 0.75 & 62.182 & $1.672 \mathrm{E}-03$ \\
\hline $\mathrm{NW}$ & 100. & $D$ & 4.70 & 0.25 & 72.775 & $1.353 E-03$ \\
\hline $\mathrm{NW}$ & 100. & C & 2.65 & 0.19 & 77.436 & $1.198 E-03$ \\
\hline $\mathrm{NW}$ & 100. & A & 0.89 & 0.17 & 81.250 & $1.068 E-03$ \\
\hline NW & 100. & $D$ & 7.15 & 0.03 & 83.369 & $1.038 E-03$ \\
\hline $\mathrm{NW}$ & 100. & $\mathrm{C}$ & 4.70 & 0.04 & 84.110 & $6.754 E-04$ \\
\hline $\mathrm{NW}$ & 100. & $B$ & 2.65 & 0.13 & 85.911 & $6.266 \mathrm{E}-04$ \\
\hline NW & 100. & A & 2.65 & 0.45 & 92.055 & $3.588 E-04$ \\
\hline NW & 100. & $B$ & 4.70 & 0.04 & 97.246 & $3.533 E-04$ \\
\hline $\mathrm{NW}$ & 100. & A & 4.70 & 0.10 & 98.729 & $2.023 E-04$ \\
\hline $\mathrm{NW}$ & 100. & A & 7.15 & 0.01 & 99.894 & $1.330 E-04$ \\
\hline $\mathrm{NW}$ & 100. & $B$ & 7.15 & 0.00 & 100.000 & $0.000 E+00$ \\
\hline $\mathrm{NW}$ & 100. & $G$ & 19.00 & 0.00 & 100.000 & $0.000 \mathrm{E}+00$ \\
\hline NNW & 100. & $G$ & 0.89 & 0.14 & 1.528 & $1.423 \mathrm{E}-02$ \\
\hline NNW & 100. & $G$ & 4.70 & 0.09 & 4.039 & $1.086 E-02$ \\
\hline $\mathrm{NNW}$ & 100. & $G$ & 7.15 & 0.01 & 5.131 & $1.063 E-02$ \\
\hline NNW & 100. & $\mathrm{~F}$ & 0.89 & 0.26 & 8.079 & 8.610E-03 \\
\hline NNW & 100. & $G$ & 2.65 & 0.23 & 13.428 & $7.564 \mathrm{E}-03$ \\
\hline NNW & 100. & $E$ & 0.89 & 0.30 & 19.214 & $5.103 \mathrm{E}-03$ \\
\hline NNW & 100. & $F$ & 4.70 & 0.17 & 24.345 & $4.792 E-03$ \\
\hline NNW & 100. & $\mathrm{~F}$ & 7.15 & 0.01 & 26.310 & $4.287 \mathrm{E}-03$ \\
\hline NNW & 100. & $D$ & 0.89 & 0.32 & 29.913 & $4.168 E-03$ \\
\hline NNW & 100. & $F$ & 2.65 & 0.44 & 38.210 & $4.125 \mathrm{E}-03$ \\
\hline NNW & 100. & $C$ & 0.89 & 0.04 & 43.450 & $3.566 \mathrm{E}-03$ \\
\hline NNW & 100. & $\mathrm{E}$ & 4.70 & 0.25 & 46.616 & $2.271 E-03$ \\
\hline NNW & 100. & $E$ & 2.65 & 0.52 & 55.022 & $2.271 E-03$ \\
\hline NNW & 100. & $E$ & 7.15 & 0.05 & 61.245 & $1.906 \mathrm{E}-03$ \\
\hline NNW & 100. & $\mathrm{~B}$ & 0.89 & 0.03 & 62.118 & $1.866 \mathrm{E}-03$ \\
\hline NNW & 100. & $D$ & 2.65 & 0.53 & 68.231 & $1.672 \mathrm{E}-03$ \\
\hline NNW & 100. & $D$ & 4.70 & 0.27 & 76.965 & $1.353 E-03$ \\
\hline NNW & 100. & $C$ & 2.65 & 0.10 & 81.004 & 1. $198 \mathrm{E}-03$ \\
\hline NNW & 100. & A & 0.89 & 0.10 & 83.188 & 1. $.068 E-03$ \\
\hline NNW & 100. & $D$ & 7.15 & 0.07 & 85.044 & $1.038 E-03$ \\
\hline NNW & 100. & $c$ & 4.70 & 0.04 & 86.245 & $6.754 \mathrm{E}-04$ \\
\hline $\mathrm{NNW}$ & 100. & $B$ & 2.65 & 0.09 & 87.664 & $6.266 \mathrm{E}-04$ \\
\hline NNW & 100. & $C$ & 7.15 & 0.01 & 88.755 & $4.439 E-04$ \\
\hline NNW & 100. & A & 2.65 & 0.29 & 92.031 & $3.588 E-04$ \\
\hline NNW & 100. & $B$ & 4.70 & 0.05 & 95.742 & $3.533 E-04$ \\
\hline NNW & 100. & $\mathrm{~B}$ & 7.15 & 0.01 & 96.397 & $2.322 \mathrm{E}-04$ \\
\hline NNW & 100 . & A & 4.70 & 0.13 & 97.926 & $2.023 E-04$ \\
\hline NNW & 100. & A & 7.15 & 0.03 & 99.672 & $1.330 \mathrm{E}-04$ \\
\hline NNW & 100. & $A$ & 9.80 & 0.00 & 100.000 & $0.000 E+00$ \\
\hline NNW & 100. & $G$ & 19.00 & 0.00 & 100.000 & $0.000 E+00$ \\
\hline $\mathrm{N}$ & 100. & $G$ & 0.89 & 0.17 & 1.950 & 1. $423 \mathrm{E}-02$ \\
\hline $\mathrm{N}$ & 100 . & $G$ & 4.70 & 0.07 & 4.702 & $1.086 \mathrm{E}-02$ \\
\hline $\mathrm{N}$ & 100. & $\mathrm{~F}$ & 0.89 & 0.35 & 9.518 & $8.610 \mathrm{E}-0$ \\
\hline $\mathrm{N}$ & 100. & $G$ & 2.65 & 0.20 & 15.826 & $7.564 \mathrm{E}-03$ \\
\hline $\mathrm{N}$ & 100 . & $E$ & 0.89 & 0.34 & 22.018 & $5.103 \mathrm{E}-03$ \\
\hline $\mathrm{N}$ & 100. & $\mathrm{~F}$ & 4.70 & 0.14 & 27.523 & $4.792 E-03$ \\
\hline $\mathrm{N}$ & 100. & $F$ & 7.15 & 0.02 & 29.358 & $4.287 E-03$ \\
\hline $\mathrm{N}$ & 100. & $\mathrm{D}$ & 0.89 & 0.27 & 32.683 & $4.168 \mathrm{E}-03$ \\
\hline $\mathrm{N}$ & 100. & $F$ & 2.65 & 0.45 & 40.940 & $4.125 E-03$ \\
\hline $\mathbf{N}$ & 100. & $C$ & 0.89 & 0.04 & 46.560 & $3.566 \mathrm{E}-03$ \\
\hline $\mathrm{N}$ & 100. & $F$ & 9.80 & 0.01 & 47.133 & $3.128 E-03$ \\
\hline $\mathrm{N}$ & 100. & $E$ & 4.70 & 0.22 & 49.771 & $2.271 \mathrm{E}-03$ \\
\hline $\mathrm{N}$ & 100. & $E$ & 2.65 & 0.46 & 57.569 & $2.271 E-03$ \\
\hline $\mathrm{N}$ & 100. & $\mathrm{E}$ & 7.15 & 0.07 & 63.647 & $1.906 \mathrm{E}-0$ \\
\hline
\end{tabular}




\begin{tabular}{|c|c|c|c|c|c|c|}
\hline $\mathrm{N}$ & 100. & $\mathrm{~B}$ & 0.89 & 0.05 & 65.023 & $1.866 \mathrm{E}-03$ \\
\hline $\mathrm{N}$ & 100. & $\mathrm{D}$ & 2.65 & 0.35 & 69.610 & $1.672 E-03$ \\
\hline $\mathrm{N}$ & 100. & $\mathrm{E}$ & 9.80 & 0.01 & 73.739 & $1.390 \mathrm{E}-03$ \\
\hline $\mathrm{N}$ & 100. & $\mathrm{D}$ & 4.70 & 0.24 & 76.605 & $1.353 E-03$ \\
\hline $\mathrm{N}$ & 100. & $\mathrm{C}$ & 2.65 & 0.06 & 80.046 & $1.198 \mathrm{E}-03$ \\
\hline $\mathrm{N}$ & 100. & A & 0.89 & 0.10 & 81.881 & $1.068 E-03$ \\
\hline $\mathrm{N}$ & 100. & $\mathrm{D}$ & 7.15 & 0.10 & 84.174 & $1.038 E-03$ \\
\hline $\mathrm{N}$ & 100. & $\mathrm{D}$ & 9.80 & 0.02 & 85.550 & $7.571 E-04$ \\
\hline $\mathrm{N}$ & 100. & $\mathrm{C}$ & 4.70 & 0.05 & 86.353 & $6.754 E-04$ \\
\hline $\mathrm{N}$ & 100. & $\mathrm{~B}$ & 2.65 & 0.08 & 87.844 & $6.266 E-04$ \\
\hline $\mathrm{N}$ & 100. & $\mathrm{C}$ & 7.15 & 0.02 & 88.991 & $4.439 \mathrm{E}-04$ \\
\hline $\mathbf{N}$ & 100. & $A$ & 2.65 & 0.24 & 91.972 & $3.588 E-04$ \\
\hline $\mathrm{N}$ & 100. & $\mathrm{~B}$ & 4.70 & 0.03 & 95.069 & $3.533 E-04$ \\
\hline $\mathrm{N}$ & 100 . & $\mathrm{C}$ & 9.80 & 0.01 & 95.528 & $3.239 E-04$ \\
\hline $\mathrm{N}$ & 100. & $\mathrm{~B}$ & 7.15 & 0.02 & 95.872 & $2.322 E-04$ \\
\hline $\mathrm{N}$ & 100. & $\mathrm{~A}$ & 4.70 & 0.12 & 97.477 & $2.023 \mathrm{E}-04$ \\
\hline $\mathrm{N}$ & 100. & A & 7.15 & 0.04 & 99.312 & $1.330 \mathrm{E}-04$ \\
\hline $\mathrm{N}$ & 100. & A & 9.80 & 0.01 & 99.885 & $9.702 \mathrm{E}-05$ \\
\hline $\mathrm{N}$ & 100. & G & 7.15 & 0.00 & 100.000 & $0.000 E+00$ \\
\hline $\mathrm{N}$ & 100. & G & 19.00 & 0.00 & 100.000 & $0.000 \mathrm{E}+00$ \\
\hline NNE & 100. & G & 0.89 & 0.09 & 1.807 & $1.423 E-02$ \\
\hline NNE & 100. & $\mathrm{G}$ & 4.70 & 0.01 & 3.815 & $1.086 \mathrm{E}-02$ \\
\hline NNE & 100. & $\mathrm{~F}$ & 0.89 & 0.23 & 8.635 & $8.610 \mathrm{E}-03$ \\
\hline NNE & 100. & G & 2.65 & 0.08 & 14.859 & $7.564 \mathrm{E}-03$ \\
\hline NNE & 100. & $E$ & 0.89 & 0.21 & 20.683 & $5.103 E-03$ \\
\hline NNE & 100. & $F$ & 4.70 & 0.03 & 25.502 & $4.792 \mathrm{E}-03$ \\
\hline $\mathrm{NNE}$ & 100. & $\mathrm{D}$ & 0.89 & 0.19 & 29.920 & $4.168 \mathrm{E}-03$ \\
\hline NNE & 100. & $F$ & 2.65 & 0.21 & 37.952 & $4.125 \mathrm{E}-03$ \\
\hline NNE & 100. & $\mathrm{C}$ & 0.89 & 0.02 & 42.570 & $3.566 \mathrm{E}-03$ \\
\hline NNE & 100. & $\mathrm{E}$ & 4.70 & 0.12 & 45.382 & $2.271 E-03$ \\
\hline $\mathrm{NNE}$ & 100. & $E$ & 2.65 & 0.21 & 52.008 & $2.271 \mathrm{E}-03$ \\
\hline NNE & 100. & $E$ & 7.15 & 0.08 & 57.831 & $1.906 \mathrm{E}-03$ \\
\hline NNE & 100. & $\mathrm{~B}$ & 0.89 & 0.02 & 59.839 & $1.866 E-03$ \\
\hline NNE & 100 & $\mathrm{D}$ & 2.65 & 0.18 & 63.855 & $1.672 \mathrm{E}-03$ \\
\hline NNE & 100. & $E$ & 9.80 & 0.05 & 68.474 & $1.390 E-03$ \\
\hline $\mathrm{NNE}$ & 100. & $\mathrm{D}$ & 4.70 & 0.13 & 72.088 & $1.353 E-03$ \\
\hline NNE & 100 . & $\mathrm{C}$ & 2.65 & 0.02 & 75.100 & $1.198 \mathrm{E}-03$ \\
\hline NNE & 100. & $\mathrm{E}$ & 12.70 & 0.01 & 75.703 & $1.073 E-03$ \\
\hline $\mathrm{NNE}$ & 100. & A & 0.89 & 0.06 & 77.108 & $1.068 E-03$ \\
\hline NNE & 100. & $D$ & 7.15 & 0.11 & 80.522 & $1.038 E-03$ \\
\hline NNE & 100. & $\mathrm{D}$ & 9.80 & 0.07 & 84.137 & $7.571 \mathrm{E}-04$ \\
\hline NNE & 100. & $\mathrm{C}$ & 4.70 & 0.02 & 85.944 & $6.754 \mathrm{E}-04$ \\
\hline NNE & 100. & B & 2.65 & 0.04 & 87.149 & $6.266 \mathrm{E}-0$ \\
\hline $\mathrm{NNE}$ & 100 . & $\mathrm{D}$ & 12.70 & 0.02 & 88.353 & $5.842 E-04$ \\
\hline NNE & 100. & $\mathrm{C}$ & 7.15 & 0.01 & 88.956 & $4.439 \mathrm{E}-04$ \\
\hline NNE & 100. & A & 2.65 & 0.12 & 91.566 & $3.588 E-04$ \\
\hline NNE & 100. & B & 4.70 & 0.02 & 94.377 & $3.533 \mathrm{E}-04$ \\
\hline NNE & 100. & $\mathrm{~B}$ & 7.15 & 0.01 & 94.980 & $2.322 \mathrm{E}-04$ \\
\hline NNE & 100. & A & 4.70 & 0.07 & 96.586 & $2.023 E-0$ \\
\hline $\mathrm{NNE}$ & 100. & A & 7.15 & 0.04 & 98.795 & 1. $330 \mathrm{E}-04$ \\
\hline NNE & 100. & A & 9.80 & 0.01 & 99.799 & $9.702 \mathrm{E}-05$ \\
\hline NNE & 100. & $\mathrm{~B}$ & 9.80 & 0.00 & 100.000 & $0.000 \mathrm{E}+00$ \\
\hline NNE & 100. & $\mathrm{G}$ & 19.00 & 0.00 & 100.000 & $0.000 E+0$ \\
\hline $\mathrm{NE}$ & 100. & $G$ & 0.89 & 0.10 & 1.282 & $1.423 \mathrm{E}-0$ \\
\hline $\mathrm{NE}$ & 100. & G & 4.70 & 0.02 & 2.821 & $1.086 E-02$ \\
\hline $\mathrm{NE}$ & 100. & $\mathrm{~F}$ & 0.89 & 0.22 & 5.897 & $8.610 E-03$ \\
\hline $\mathrm{NE}$ & 100. & G & 2.65 & 0.10 & 10.000 & $7.564 \mathrm{E}-03$ \\
\hline $\mathrm{NE}$ & 100. & $\mathrm{E}$ & 0.89 & 0.25 & 14.487 & $5.103 E-03$ \\
\hline $\mathrm{NE}$ & 100. & $F$ & 4.70 & 0.07 & 18.590 & $4.792 \mathrm{E}-0$ \\
\hline $\mathrm{NE}$ & 100. & $\mathrm{~F}$ & 7.15 & 0.01 & 19.615 & $4.287 E-03$ \\
\hline $\mathrm{NE}$ & 100. & $\mathrm{D}$ & 0.89 & 0.21 & 22.436 & $4.168 \mathrm{E}-0$ \\
\hline
\end{tabular}


RPP-13482 REV 5

\begin{tabular}{|c|c|c|c|c|c|c|}
\hline $\mathrm{NE}$ & 100. & $\mathrm{~F}$ & 2.65 & 0.27 & 28.590 & $4.125 E-03$ \\
\hline $\mathrm{NE}$ & 100. & $\mathrm{C}$ & 0.89 & 0.02 & 32.308 & $3.566 \mathrm{E}-03$ \\
\hline $\mathrm{NE}$ & 100. & $E$ & 4.70 & 0.18 & 34.872 & $2.271 E \rightarrow 03$ \\
\hline $\mathrm{NE}$ & 100. & $E$ & 2.65 & 0.29 & 40.897 & $2.271 E-03$ \\
\hline$N E$ & 100. & $E$ & 7.15 & 0.17 & 46.795 & $1.906 \mathrm{E}-03$ \\
\hline $\mathrm{NE}$ & 100. & $\mathrm{~B}$ & 0.89 & 0.01 & 49.103 & $1.866 \mathrm{E}-03$ \\
\hline $\mathrm{NE}$ & 100 & $\mathrm{D}$ & 2.65 & 0.24 & 52.308 & $1.672 \mathrm{E}-03$ \\
\hline $\mathrm{NE}$ & 100 & $\mathrm{E}$ & 9.80 & 0.11 & 56.795 & $1.390 \mathrm{E}-03$ \\
\hline $\mathrm{NE}$ & 100. & $\mathrm{D}$ & 4.70 & 0.23 & 61.154 & $1.353 E-03$ \\
\hline $\mathrm{NE}$ & 100. & $C$ & 2.65 & 0.03 & 64.487 & $1.198 E-03$ \\
\hline $\mathrm{NE}$ & 100. & $\mathrm{E}$ & 12.70 & 0.04 & 65.385 & $1.073 E-03$ \\
\hline $\mathrm{NE}$ & 100. & $\mathrm{~A}$ & 0.89 & 0.06 & 66.667 & $1.068 E-03$ \\
\hline $\mathrm{NE}$ & 100 . & $D$ & 7.15 & 0.25 & 70.641 & $1.038 E-03$ \\
\hline $\mathrm{NE}$ & 100. & $E$ & 15.60 & 0.01 & 73.974 & $8.735 E-04$ \\
\hline $\mathrm{NE}$ & 100. & $\mathrm{D}$ & 9.80 & 0.16 & 76.154 & $7.571 E-04$ \\
\hline $\mathrm{NE}$ & 100. & $\mathrm{C}$ & 4.70 & 0.03 & 78.590 & $6.754 E-04$ \\
\hline $\mathrm{NE}$ & 100 & $\mathrm{~B}$ & 2.65 & 0.03 & 79.359 & $6.266 \mathrm{E}-04$ \\
\hline $\mathrm{NE}$ & 100. & $\mathrm{D}$ & 12.70 & 0.09 & 80.897 & $5.842 E-04$ \\
\hline $\mathrm{NE}$ & 100 . & $D$ & 15.60 & 0.03 & 82.436 & $4.756 E-04$ \\
\hline $\mathrm{NE}$ & 100 & $\mathrm{C}$ & 7.15 & 0.02 & 83.077 & $4.439 \mathrm{E}-04$ \\
\hline $\mathrm{NE}$ & 100. & $\mathrm{~A}$ & 2.65 & 0.17 & 85.513 & $3.588 E-04$ \\
\hline $\mathrm{NE}$ & 100. & $\mathrm{~B}$ & 4.70 & 0.05 & 88.333 & $3.533 E-04$ \\
\hline $\mathrm{NE}$ & 100. & $\mathrm{C}$ & 9.80 & 0.02 & 89.231 & $3.239 E-04$ \\
\hline $\mathrm{NE}$ & 100. & $\mathrm{C}$ & 12.70 & 0.02 & 89.744 & $2.499 E-04$ \\
\hline $\mathrm{NE}$ & 100. & B & 7.15 & 0.04 & 90.513 & $2.322 E-04$ \\
\hline $\mathrm{NE}$ & 100. & $\mathrm{~A}$ & 4.70 & 0.14 & 92.821 & $2.023 E-04$ \\
\hline $\mathrm{NE}$ & 100. & $\mathrm{~B}$ & 9.80 & 0.02 & 94.872 & I. $694 \mathrm{E}-04$ \\
\hline $\mathrm{NE}$ & 100 & $A$ & 7.15 & 0.11 & 96.538 & $1.330 E-04$ \\
\hline $\mathrm{NE}$ & 100. & $B$ & 12.70 & 0.01 & 98.077 & $1.308 \mathrm{E}-04$ \\
\hline $\mathrm{NE}$ & 100. & $\mathrm{~A}$ & 9.80 & 0.05 & 98.846 & $9.702 \mathrm{E}-05$ \\
\hline NE & 100. & A & 12.70 & 0.02 & 99.744 & $7.486 \mathrm{E}-05$ \\
\hline $\mathrm{NE}$ & 100. & $\mathrm{~F}$ & 9.80 & 0.00 & 100.000 & $0.000 \mathrm{E}+00$ \\
\hline $\mathrm{NE}$ & 100 & $\mathrm{G}$ & 19.00 & 0.00 & 100.000 & $0.000 \mathrm{E}+00$ \\
\hline ENE & 100. & $G$ & 0.89 & 0.09 & 0.729 & 1. $423 \mathrm{E}-02$ \\
\hline ENE & 100. & $\mathrm{G}$ & 4.70 & 0.09 & 2.188 & $1.086 \mathrm{E}-02$ \\
\hline ENE & 100. & $\mathrm{~F}$ & 0.89 & 0.27 & 5.105 & $8.610 E-03$ \\
\hline ENE & 100. & $\mathrm{G}$ & 2.65 & 0.20 & 8.914 & $7.564 E-03$ \\
\hline ENE & 100. & $\mathrm{E}$ & 0.89 & 0.29 & 12.885 & $5.103 E-03$ \\
\hline ENE & 100. & $\mathrm{~F}$ & 4.70 & 0.20 & 16.856 & $4.792 \mathrm{E}-03$ \\
\hline ENE & 100. & $F$ & 7.15 & 0.02 & 18.639 & $4.287 E-03$ \\
\hline ENE & 100 . & $D$ & 0.89 & 0.17 & 20.178 & $4.168 \mathrm{E}-03$ \\
\hline ENE & 100. & $\mathrm{~F}$ & 2.65 & 0.46 & 25.284 & $4.125 E-03$ \\
\hline ENE & 100. & $\mathrm{C}$ & 0.89 & 0.02 & 29.173 & $3.566 \mathrm{E}-03$ \\
\hline ENE & 100. & $\mathrm{E}$ & 4.70 & 0.39 & 32.496 & $2.271 E-03$ \\
\hline ENE & 100. & $\mathrm{E}$ & 2.65 & 0.48 & 39.546 & $2.271 E-03$ \\
\hline ENE & 100. & $E$ & 7.15 & 0.30 & 45.867 & I. $906 \mathrm{E}-03$ \\
\hline ENE & 100. & $\mathrm{~B}$ & 0.89 & 0.03 & 48.541 & I. $866 \mathrm{E}-03$ \\
\hline ENE & 100. & $\mathrm{D}$ & 2.65 & 0.28 & 51.053 & $1.672 \mathrm{E}-03$ \\
\hline ENE & 100. & $E$ & 9.80 & 0.15 & 54.538 & $1.390 \mathrm{E}-0.3$ \\
\hline ENE & 100. & $\mathrm{D}$ & 4.70 & 0.39 & 58.914 & $1.353 E-03$ \\
\hline ENE & 100. & $\mathrm{C}$ & 2.65 & 0.05 & 62.480 & $1.198 \mathrm{E}-03$ \\
\hline ENE & 100. & $E$ & 12.70 & 0.02 & 63.047 & $1.073 E-03$ \\
\hline ENE & 100. & A & 0.89 & 0.06 & 63.695 & $1.068 \mathrm{E}-0$ \\
\hline ENE & 100 & $\mathrm{D}$ & 7.15 & 0.38 & 67.261 & $1.038 \mathrm{E}-03$ \\
\hline ENE & 100. & $D$ & 9.80 & 0.24 & 72.285 & $7.571 E-04$ \\
\hline ENE & 100. & $\mathrm{C}$ & 4.70 & 0.06 & 74.716 & $6.754 \mathrm{E}-04$ \\
\hline ENE & 100. & $B$ & 2.65 & 0.05 & 75.608 & $6.266 \mathrm{E}-04$ \\
\hline ENE & 100. & $\mathrm{D}$ & 12.70 & 0.09 & 76.742 & $5.842 E-04$ \\
\hline ENE & 100. & $\mathrm{D}$ & 15.60 & 0.03 & 77.715 & $4.756 \mathrm{E}-04$ \\
\hline ENE & 100. & $\mathrm{C}$ & 7.15 & 0.07. & 78.525 & $4.439 \mathrm{E}-0$ \\
\hline ENE & 100. & $\mathrm{~A}$ & 2.65 & 0.19 & 80.632 & $3.588 \mathrm{E}-0$ \\
\hline ENE & 100. & B & 4.70 & 0.07 & 82.739 & $3.533 \mathrm{E}-0$ \\
\hline
\end{tabular}


RPP-13482 REV 5

\begin{tabular}{|c|c|c|c|c|c|c|}
\hline ENE & 100. & C & 9.80 & 0.05 & 83.711 & $3.239 E-04$ \\
\hline ENE & 100. & C & 12.70 & 0.01 & 84.198 & $2.499 E-04$ \\
\hline ENE & 100. & B & 7.15 & 0.08 & 84.927 & $2.322 \mathrm{E}-04$ \\
\hline ENE & 100. & $\mathrm{C}$ & 15.60 & 0.01 & 85.656 & $2.035 \mathrm{E}-04$ \\
\hline ENE & 100. & $A$ & 4.70 & 0.34 & 88.493 & $2.023 \mathrm{E}-04$ \\
\hline ENE & 100. & B & 9.80 & 0.04 & 91.572 & $1.694 \mathrm{E}-04$ \\
\hline ENE & 100. & A & 7.15 & 0.25 & 93.922 & $1.330 \mathrm{E}-04$ \\
\hline ENE & 100. & $\mathrm{~B}$ & 12.70 & 0.02 & 96.110 & $1.308 \mathrm{E}-04$ \\
\hline ENE & 100. & $A$ & 9.80 & 0.16 & 97.569 & $9.702 \mathrm{E}-05$ \\
\hline ENE & 100. & A & 12.70 & 0.06 & 99.352 & $7.486 \mathrm{E}-05$ \\
\hline ENE & 100. & A & 15.60 & 0.01 & 99.919 & $6.095 E-05$ \\
\hline ENE & 100. & $F$ & 12.70 & 0.00 & 100.000 & $0.000 E+00$ \\
\hline ENE & 100. & G & 19.00 & 0.00 & 100.000 & $0.000 \mathrm{E}+00$ \\
\hline$E$ & 100. & $\mathrm{G}$ & 0.89 & 0.22 & 0.783 & $1.423 E-02$ \\
\hline $\mathrm{E}$ & 100. & G & 4.70 & 0.56 & 3.559 & $1.086 \mathrm{E}-02$ \\
\hline $\mathrm{E}$ & 100. & $\mathrm{~F}$ & 0.89 & 0.48 & 7.260 & $8.610 E-03$ \\
\hline $\mathrm{E}$ & 100. & G & 2.65 & 0.82 & 11.886 & $7.564 E-03$ \\
\hline$E$ & 100 & $\mathrm{E}$ & 0.89 & 0.49 & 16.548 & $5.103 E-03$ \\
\hline$E$ & 100. & $\mathrm{~F}$ & 4.70 & 1.19 & 22.527 & $4.792 E-03$ \\
\hline $\mathrm{E}$ & 100. & $F$ & 7.15 & 0.07 & 27.011 & 4. $287 \mathrm{E}-03$ \\
\hline$E$ & 100. & D & 0.89 & 0.40 & 28.683 & $4.168 \mathrm{E}-03$ \\
\hline $\mathrm{E}$ & 100 . & $\mathrm{F}$ & 2.65 & 1.60 & 35.801 & $4.125 E-03$ \\
\hline E & 100. & $\mathrm{C}$ & 0.89 & 0.04 & 41.637 & $3.566 \mathrm{E}-03$ \\
\hline $\mathrm{E}$ & 100 & $\mathrm{E}$ & 4.70 & 1.98 & 48.826 & $2.271 \mathrm{E}-03$ \\
\hline $\mathrm{E}$ & 100. & $\mathrm{E}$ & 2.65 & 1.58 & 61.495 & $2.271 E-03$ \\
\hline $\mathrm{E}$ & 100. & $E$ & 7.15 & 0.65 & 69.431 & $1.906 \mathrm{E}-03$ \\
\hline $\mathrm{E}$ & 100 & $B$ & 0.89 & 0.04 & 71.886 & $1.866 \mathrm{E}-03$ \\
\hline $\mathrm{E}$ & 100. & $\mathrm{D}$ & 2.65 & 0.69 & 74.484 & $1.672 \mathrm{E}-03$ \\
\hline $\mathrm{E}$ & 100. & $E$ & 9.80 & 0.06 & 77.153 & $1.390 \mathrm{E}-03$ \\
\hline$E$ & 100. & $D$ & 4.70 & 0.83 & 80.320 & $1.353 \mathrm{E}-03$ \\
\hline$E$ & 100. & $\mathrm{C}$ & 2.65 & 0.08 & 83.559 & $1.198 \mathrm{E}-03$ \\
\hline$E$ & 100. & $E$ & 12.70 & 0.01 & 83.879 & I. $073 E-03$ \\
\hline $\mathrm{E}$ & 100. & $A$ & 0.89 & 0.10 & 84.270 & 1. $068 \mathrm{E}-03$ \\
\hline $\mathrm{E}$ & 100. & $\mathrm{D}$ & 7.15 & 0.58 & 86.690 & $1.038 \mathrm{E}-03$ \\
\hline $\mathrm{E}$ & 100. & $\mathrm{D}$ & 9.80 & 0.13 & 89.217 & $7.571 \mathrm{E}-04$ \\
\hline $\mathrm{E}$ & 100. & $\mathrm{C}$ & 4.70 & 0.09 & 90.000 & $6.754 E-04$ \\
\hline $\mathrm{E}$ & 100. & B & 2.65 & 0.07 & 90.569 & $6.266 E-04$ \\
\hline $\mathrm{E}$ & 100. & $\mathrm{D}$ & 12.70 & 0.03 & 90.925 & $5.842 E-04$ \\
\hline$E$ & 100. & $\mathrm{D}$ & 15.60 & 0.02 & 91.103 & $4.756 E-04$ \\
\hline$\Sigma$ & 100. & C & 7.15 & 0.06 & 91.388 & $4.439 E-04$ \\
\hline $\mathrm{E}$ & 100. & A & 2.65 & 0.25 & 92.491 & $3.588 E-04$ \\
\hline$E$ & 100. & $\mathrm{~B}$ & 4.70 & 0.10 & 93.737 & $3.533 E-04$ \\
\hline$E$ & 100. & $\mathrm{C}$ & 9.80 & 0.02 & 94.164 & $3.239 \mathrm{E}-04$ \\
\hline $\mathrm{E}$ & 100. & $\mathrm{~B}$ & 7.15 & 0.06 & 94.448 & $2.322 \mathrm{E}-04$ \\
\hline E & 100. & $A$ & 4.70 & 0.35 & 95.907 & $2.023 E-04$ \\
\hline $\mathrm{E}$ & 100. & B & 9.80 & 0.02 & 97.224 & $1.694 \mathrm{E}-04$ \\
\hline $\mathrm{E}$ & 100. & A & 7.15 & 0.25 & 98.185 & $1.330 \mathrm{E}-04$ \\
\hline $\mathrm{E}$ & 100. & $\mathrm{~B}$ & 12.70 & 0.01 & 99.110 & $1.308 \mathrm{E}-04$ \\
\hline$E$ & 100. & A & 9.80 & 0.10 & 99.502 & $9.702 \mathrm{E}-05$ \\
\hline $\mathrm{E}$ & 100. & A & 12.70 & 0.02 & 99.929 & $7.486 \mathrm{E}-0.5$ \\
\hline$E$ & 100. & C & 12.70 & 0.00 & 100.000 & $0.000 E+00$ \\
\hline $\mathrm{E}$ & 100. & G & 19.00 & 0.00 & 100.000 & $0.000 E+00$ \\
\hline ESE & 100. & $\mathrm{G}$ & 0.89 & 0.14 & 0.372 & I. $423 \mathrm{E}-02$ \\
\hline ESE & 100. & G & 4.70 & 0.84 & 2.979 & $1.086 \mathrm{E}-02$ \\
\hline ESE & 100. & $\mathrm{G}$ & 7.15 & 0.01 & 5.239 & $1.063 \mathrm{E}-02$ \\
\hline ESE & 100. & $F$ & 0.89 & 0.36 & 6.223 & $8.610 E-03$ \\
\hline ESE & 100. & G & 2.65 & 0.69 & 9.016 & $7.564 E-03$ \\
\hline ESE & 100. & $E$ & 0.89 & 0.44 & 12.021 & $5.103 E-03$ \\
\hline ESE & 100. & $\mathrm{~F}$ & 4.70 & 1.60 & 17.447 & $4.792 \mathrm{E}-03$ \\
\hline ESE & 100 & $F$ & 7.15 & 0.08 & 21.915 & $4.287 \mathrm{E}-03$ \\
\hline ESE & 100. & D & 0.89 & 0.44 & 23.298 & $4.168 \mathrm{E}-03$ \\
\hline
\end{tabular}


RPP-13482 REV 5

\begin{tabular}{|c|c|c|c|c|c|c|}
\hline ESE & 100. & $\mathrm{~F}$ & 2.65 & 1.69 & 28.963 & $4.125 \mathrm{E}-03$ \\
\hline ESE & 100. & C & 0.89 & 0.04 & 33.564 & $3.566 \mathrm{E}-03$ \\
\hline ESE & 100 . & $\mathrm{E}$ & 4.70 & 2.50 & 40.319 & $2.271 E-03$ \\
\hline ESE & 100. & $\mathrm{E}$ & 2.65 & 1.68 & 51.436 & $2.271 E-03$ \\
\hline ESE & 100. & $\mathrm{E}$ & 7.15 & 1.75 & 60.559 & $1.906 \mathrm{E}-03$ \\
\hline ESE & 100. & $\mathrm{~B}$ & 0.89 & 0.05 & 65.346 & $1.866 E-03$ \\
\hline ESE & 100. & $D$ & 2.65 & 1.09 & 58.378 & $1.672 E-03$ \\
\hline ESE & 100. & $E$ & 9.80 & 0.38 & 72.287 & $1.390 E-03$ \\
\hline ESE & 100. & $\mathrm{D}$ & 4.70 & 1.46 & 77.181 & $1.353 E-03$ \\
\hline ESE & 100. & $\mathrm{C}$ & 2.65 & 0.10 & 81.330 & $1.198 \mathrm{E}-03$ \\
\hline ESE & 100. & $\mathrm{E}$ & 12.70 & 0.05 & 81.729 & $1.073 \mathrm{E}-03$ \\
\hline ESE & 100. & A & 0.89 & 0.10 & 82.128 & $1.068 \mathrm{E}-03$ \\
\hline ESE & 100. & $\mathrm{D}$ & 7.15 & 1.14 & 85.426 & $1.038 E-03$ \\
\hline ESE & 100 & $\mathrm{D}$ & 9.80 & 0.50 & 89.787 & $7.571 \mathrm{E}-04$ \\
\hline ESE & 100. & $\mathrm{C}$ & 4.70 & 0.13 & 91.463 & $6.754 \mathrm{E}-04$ \\
\hline ESE & 100 . & $\mathrm{B}$ & 2.65 & 0.09 & 92.048 & $6.266 \mathrm{E}-04$ \\
\hline ESE & 100. & D & 12.70 & 0.07 & 92.473 & $5.842 \mathrm{E}-04$ \\
\hline ESE & 100. & C & 7.15 & 0.07 & 92.846 & $4.439 E-04$ \\
\hline ESE & 100. & A & 2.65 & 0.30 & 93.830 & $3.588 \mathrm{E}-04$ \\
\hline ESE & 100 & B & 4.70 & 0.14 & 95.000 & $3.533 E-04$ \\
\hline ESE & 100. & $\mathrm{C}$ & 9.80 & 0.03 & 95.452 & $3.239 \mathrm{E}-04$ \\
\hline ESE & 100. & C & 12.70 & 0.01 & 95.559 & $2.499 E-04$ \\
\hline ESE & 100. & B & 7.15 & 0.07 & 95.771 & $2.322 \mathrm{E}-04$ \\
\hline ESE & 100. & A & 4.70 & 0.35 & 96.888 & $2.023 E \times 04$ \\
\hline ESE & 100. & 8 & 9.80 & 0.03 & 97.899 & $1.694 \mathrm{E}-04$ \\
\hline ESE & 100. & $\mathrm{~A}$ & 7.15 & 0.25 & 98.644 & $1.330 \mathrm{E}-04$ \\
\hline ESE & 100. & $A$ & 9.80 & 0.11 & 99.601 & $9.702 \mathrm{E}-05$ \\
\hline $\mathrm{ESE}$ & 100. & A & 12.70 & 0.02 & 99.947 & $7.486 E-05$ \\
\hline ESE & 100 & $F$ & 9.80 & 0.00 & 100.000 & $0.000 E+00$ \\
\hline ESE & 100. & G & 19.00 & 0.00 & 100.000 & $0.000 \mathrm{E}+00$ \\
\hline$S E$ & 100. & G & 0.89 & 0.14 & 0.646 & $1.423 \mathrm{E}-02$ \\
\hline$S E$ & 100. & $\mathrm{G}$ & 4.70 & 0.13 & 1.893 & $1.086 \mathrm{E}-02$ \\
\hline$S E$ & 100 & $F$ & 0.89 & 0.32 & 3.970 & $8.610 \mathrm{E}-03$ \\
\hline$S E$ & 100. & $\mathrm{G}$ & 2.65 & 0.30 & 6.833 & $7.564 \mathrm{E}-03$ \\
\hline$S E$ & 100. & $\mathrm{E}$ & 0.89 & 0.45 & 10.295 & $5.103 E-03$ \\
\hline$S E$ & 100. & $F$ & 4.70 & 0.32 & 13.850 & $4.792 \mathrm{E}-03$ \\
\hline$S E$ & 100. & $F$ & 7.15 & 0.03 & 15.466 & $4.287 \mathrm{E}-03$ \\
\hline$S E$ & 100. & $\mathrm{D}$ & 0.89 & 0.54 & 18.098 & $4.168 \mathrm{E}-03$ \\
\hline$S E$ & 100. & $F$ & 2.65 & 0.82 & 24.377 & $4.125 E-03$ \\
\hline$S E$ & 100 . & $\mathrm{C}$ & 0.89 & 0.10 & 28.624 & $3.566 \mathrm{E}-03$ \\
\hline$S E$ & 100. & $\mathrm{E}$ & 4.70 & 0.75 & 32.548 & $2.271 E-03$ \\
\hline SE & 100 & $E$ & 2.65 & 1.11 & 41.136 & $2.271 E-03$ \\
\hline$S E$ & 100. & $E$ & 7.15 & 0.41 & 48.153 & $1.906 \mathrm{E}-03$ \\
\hline$S E$ & 100. & $\mathrm{~B}$ & 0.89 & 0.07 & 50.369 & $1.866 E-03$ \\
\hline$S E$ & 100. & D & 2.65 & 1.05 & 55.540 & $1.672 E-03$ \\
\hline$S E$ & 100. & $E$ & 9.80 & 0.11 & 60.896 & 1.390E-03 \\
\hline$S E$ & 100. & $\mathrm{D}$ & 4.70 & 0.84 & 65.282 & $1.353 \mathrm{E}-03$ \\
\hline $\mathrm{SE}$ & 100. & $\mathrm{C}$ & 2.65 & 0.19 & 70.037 & $1.198 \mathrm{E}-03$ \\
\hline$S E$ & 100. & $E$ & 12.70 & 0.03 & 71.053 & $1.073 \mathrm{E}-03$ \\
\hline$S E$ & 100. & $\mathrm{~A}$ & 0.89 & 0.24 & 71.837 & $1.068 \mathrm{E}-03$ \\
\hline$S E$ & 100. & $\mathrm{D}$ & 7.15 & 0.50 & 74.792 & $1.038 E-03$ \\
\hline$S E$ & 100 . & $\mathrm{D}$ & 9.80 & 0.29 & 78.440 & $7.571 \mathrm{E}-04$ \\
\hline$S E$ & 100. & C & 4.70 & 0.12 & 80.332 & $6.754 \mathrm{E}-04$ \\
\hline$S E$ & 100. & $\mathrm{~B}$ & 2.65 & 0.16 & 81.625 & $6.266 \mathrm{E}-04$ \\
\hline$S E$ & 100. & $\mathrm{D}$ & 12.70 & 0.08 & 82.733 & $5.842 E-04$ \\
\hline$S E$ & 100 . & $\mathrm{C}$ & 7.15 & 0.06 & 83.380 & $4.439 E-04$ \\
\hline$S E$ & 100. & A & 2.65 & 0.42 & 85.596 & $3.588 E-04$ \\
\hline$S E$ & 100. & B & 4.70 & 0.12 & 88.089 & $3.533 \mathrm{E}-04$ \\
\hline$S E$ & 100. & C & 9.80 & 0.05 & 88.873 & $3.239 E-04$ \\
\hline$S E$ & 100. & $\mathrm{C}$ & 12.70 & 0.01 & 89.151 & $2.499 \mathrm{E}-04$ \\
\hline$S E$ & 100. & $\mathrm{~B}$ & 7.15 & 0.09 & 89.612 & $2.322 \mathrm{E}-0$ \\
\hline$S E$ & 100. & $\mathrm{~A}$ & 4.70 & 0.40 & 91.874 & $2.023 \mathrm{E}-0$ \\
\hline
\end{tabular}


RPP-13482 REV 5

\begin{tabular}{|c|c|c|c|c|c|c|}
\hline$S E$ & 100 & B & 9.80 & 0.06 & 93.998 & 1. $694 \mathrm{E}-04$ \\
\hline$S E$ & 100. & A & 7.15 & 0.33 & 95.799 & $1.330 \mathrm{E}-04$ \\
\hline$S E$ & 100. & $B$ & 12.70 & 0.01 & 97.368 & $1.308 E-04$ \\
\hline SE & 100. & A & 9.80 & 0.24 & 98.523 & $9.702 \mathrm{E}-05$ \\
\hline$S E$ & 100. & A & 12.70 & 0.03 & 99.769 & $7.486 \mathrm{E}-05$ \\
\hline$S E$ & 100. & A & 15.60 & 0.01 & 99.954 & $6.095 \mathrm{E}-05$ \\
\hline$S E$ & 100. & $\mathrm{G}$ & 9.80 & 0.00 & 100.000 & $0.000 E+00$ \\
\hline$S E$ & 100. & $\mathrm{G}$ & 19.00 & 0.00 & 100.000 & $0.000 E+00$ \\
\hline SSE & 100. & G & 0.89 & 0.09 & 0.941 & 1. $423 \mathrm{E}-02$ \\
\hline SSE & 100 . & G & 4.70 & 0.01 & 1.987 & $1.086 \mathrm{E}-02$ \\
\hline SSE & 100. & $F$ & 0.89 & 0.23 & 4.498 & 8. $610 \mathrm{E}-03$ \\
\hline SSE & 100. & G & 2.65 & 0.08 & 7.741 & $7.564 \mathrm{E}-03$ \\
\hline SSE & 100 & $\mathrm{E}$ & 0.89 & 0.39 & 12.657 & $5.103 E-03$ \\
\hline SSE & 100. & $F$ & 4.70 & 0.06 & 17.364 & $4.792 E-03$ \\
\hline SSE & 100. & $\mathrm{D}$ & 0.89 & 0.55 & 23.745 & $4.168 \mathrm{E}-03$ \\
\hline SSE & 100 . & $\mathrm{F}$ & 2.65 & 0.25 & 32.113 & $4.125 E-03$ \\
\hline SSE & 100 & $\mathrm{C}$ & 0.89 & 0.10 & 35.774 & $3.566 E-03$ \\
\hline SSE & 100 & $E$ & 4.70 & 0.13 & 38.180 & $2.271 E-03$ \\
\hline SSE & 100. & $E$ & 2.65 & 0.39 & 43.619 & $2.271 E-03$ \\
\hline SSE & 100. & $E$ & 7.15 & 0.02 & 47.908 & $1.906 \mathrm{E}-03$ \\
\hline SSE & 100 & $\mathrm{~B}$ & 0.89 & 0.10 & 49.163 & $1.866 \mathrm{E}-03$ \\
\hline SSE & 100. & $\mathrm{D}$ & 2.65 & 0.77 & 58.264 & $1.672 \mathrm{E}-03$ \\
\hline SSE & 100 & $D$ & 4.70 & 0.21 & 68.515 & $1.353 E-03$ \\
\hline SSE & 100. & C & 2.65 & 0.15 & 72.280 & $1.198 \mathrm{E}-03$ \\
\hline SSE & 100. & A & 0.89 & 0.22 & 76.151 & $1.068 \mathrm{E}-03$ \\
\hline SSE & 100. & $\mathrm{D}$ & 7.15 & 0.05 & 78.975 & $1.038 \mathrm{E}-03$ \\
\hline SSE & 100. & $\mathrm{D}$ & 9.80 & 0.01 & 79.603 & $7.571 E-04$ \\
\hline SSE & 100. & $\mathrm{C}$ & 4.70 & 0.03 & 80.021 & $6.754 \mathrm{E}-04$ \\
\hline SSE & 100 & $\mathrm{~B}$ & 2.65 & 0.16 & 82.008 & $6.266 \mathrm{E}-04$ \\
\hline SSE & 100 . & $\mathrm{C}$ & 7.15 & 0.01 & 83.787 & $4.439 \mathrm{E}-04$ \\
\hline SSE & 100. & A & 2.65 & 0.48 & 88.912 & $3.588 \mathrm{E}-04$ \\
\hline SSE & 100. & $\mathrm{~B}$ & 4.70 & 0.06 & 94.561 & $3.533 E-04$ \\
\hline SSE & 100 & B & 7.15 & 0.01 & 95.293 & $2.322 E-04$ \\
\hline SSE & 100 & A & 4.70 & 0.17 & 97.176 & $2.023 E-04$ \\
\hline SSE & 100. & A & 7.15 & 0.05 & 99.477 & $1.330 E-04$ \\
\hline SSE & 100 & G & 7.15 & 0.00 & 100.000 & $0.000 E+00$ \\
\hline SSE & 100. & G & 19.00 & 0.00 & 100.000 & $0.000 \mathrm{E}+00$ \\
\hline$S$ & 15360 . & $\mathrm{G}$ & 0.89 & 0.10 & 0.794 & $2.841 E-05$ \\
\hline$S$ & 15360 . & $F$ & 0.89 & 0.23 & 3.413 & $1.264 \mathrm{E}-05$ \\
\hline$S$ & 15360. & $\mathrm{G}$ & 2.65 & 0.04 & 5.556 & $1.076 \mathrm{E}-05$ \\
\hline$S$ & 15360. & G & 4.70 & 0.01 & 5.952 & $7.007 E-06$ \\
\hline s & 15360. & $E$ & 0.89 & 0.39 & 9.127 & $5.332 \mathrm{E}-06$ \\
\hline$S$ & 15360. & $\mathrm{~F}$ & 2.65 & 0.13 & 13.254 & $4.559 E-06$ \\
\hline$S$ & 15360. & $\mathrm{~F}$ & 4.70 & 0.04 & 14.603 & $2.822 \mathrm{E}-06$ \\
\hline$S$ & 15360. & $D$ & 0.89 & 0.87 & 21.825 & $2.226 \mathrm{E}-06$ \\
\hline$S$ & 15360 . & $F$ & 7.15 & 0.03 & 28.968 & $1.901 \mathrm{E}-06$ \\
\hline$S$ & 15360 . & $\mathrm{E}$ & 2.65 & 0.32 & 31.746 & $1.875 E-06$ \\
\hline$S$ & 15360. & $F$ & 9.80 & 0.01 & 34.365 & $1.387 E-06$ \\
\hline$S$ & 15360. & $E$ & 4.70 & 0.19 & 35.952 & $1.128 E-06$ \\
\hline$S$ & 15360 . & $\mathrm{F}$ & 15.60 & 0.01 & 37.540 & $8.714 \mathrm{E}-07$ \\
\hline S & 15360 . & $\mathrm{D}$ & 2.65 & 0.84 & 44.286 & $7.638 \mathrm{E}-07$ \\
\hline$S$ & 15360 . & $\mathrm{E}$ & 7.15 & 0.07 & 51.508 & $7.557 \mathrm{E}-07$ \\
\hline$S$ & 15360 . & $F$ & 19.00 & 0.03 & 52.302 & $7.154 \mathrm{E}-07$ \\
\hline$S$ & 15360 . & $\mathrm{E}$ & 9.80 & 0.01 & 52.619 & $5.514 \mathrm{E}-07$ \\
\hline$S$ & 15360. & $\mathrm{D}$ & 4.70 & 0.32 & 55.238 & $4.457 \mathrm{E}-07$ \\
\hline$S$ & 15360. & $\mathrm{E}$ & 12.70 & 0.01 & 57.857 & $4.255 \mathrm{E}-07$ \\
\hline$S$ & 15360 . & C & 0.89 & 0.14 & 59.048 & $4.046 \mathrm{E}-07$ \\
\hline$S$ & 15360 . & $E$ & 15.60 & 0.01 & 60.238 & $3.464 \mathrm{E}+0^{\circ}$ \\
\hline$S$ & 15360 . & D & 7.15 & 0.10 & 61.111 & $2.963 E-0$ \\
\hline$S$ & 15360. & $E$ & 19.00 & 0.07 & 62.460 & $2.844 E-0$ \\
\hline
\end{tabular}


RPP-13482 REV 5

\begin{tabular}{|c|c|c|c|c|c|c|}
\hline$S$ & 15360. & B & 0.89 & 0.15 & 64.206 & $2.700 \mathrm{E}-07$ \\
\hline$S$ & 15360 . & $\mathrm{D}$ & 9.80 & 0.02 & 65.556 & $2.162 E-07$ \\
\hline$S$ & 15360. & A & 0.89 & 0.36 & 68.571 & $2.030 \mathrm{E}-07$ \\
\hline$S$ & 15360 . & $D$ & 12.70 & 0.02 & 71.587 & $1.668 \mathrm{E}-07$ \\
\hline$S$ & 15360 . & C & 2.65 & 0.19 & 73.254 & 1. 359E-07 \\
\hline$S$ & 15360 . & $\mathrm{D}$ & 15.60 & 0.01 & 74.841 & $1.358 E-07$ \\
\hline$S$ & 15360 . & D & 19.00 & 0.04 & 75.238 & $1.115 \mathrm{E}-07$ \\
\hline$S$ & 15360 . & B & 2.65 & 0.21 & 77.222 & $9.066 \mathrm{E}-08$ \\
\hline$S$ & 15360. & $\mathrm{C}$ & 4.70 & 0.08 & 79.524 & $7.662 \mathrm{E}-08$ \\
\hline$S$ & 15360 & A & 2.65 & 0.69 & 85.635 & $6.818 E-08$ \\
\hline$S$ & 15360 . & B & 4.70 & 0.09 & 91.825 & $5.112 \mathrm{E}-08$ \\
\hline$S$ & 15360. & C & 7.15 & 0.02 & 92.698 & $5.036 \mathrm{E}-08$ \\
\hline$S$ & 15360. & A & 4.70 & 0.26 & 94.921 & $3.844 \mathrm{E}-08$ \\
\hline S & 15360. & C & 9.80 & 0.01 & 97.063 & $3.674 \mathrm{E}-08$ \\
\hline $\mathrm{S}$ & 15360. & B & 7.15 & 0.02 & 97.302 & $3.360 E-08$ \\
\hline$S$ & 15360. & A & 7.15 & 0.07 & 98.016 & $2.527 E-08$ \\
\hline$S$ & 15360. & B & 9.80 & 0.01 & 98.651 & $2.452 \mathrm{E}-08$ \\
\hline$S$ & 15360 . & C & 15.60 & 0.01 & 98.810 & $2.308 E-08$ \\
\hline$S$ & 15360 . & $C$ & 19.00 & 0.01 & 98.968 & I. $895 E-08$ \\
\hline$S$ & 15360. & A & 9.80 & 0.02 & 99.206 & $1.844 \mathrm{E}-08$ \\
\hline$S$ & 15360. & B & 19.00 & 0.01 & 99.444 & 1. $265 E-08$ \\
\hline$S$ & 15360. & A & 15.60 & 0.01 & 99.603 & 1.158E-08 \\
\hline$S$ & 15360. & A & 19.00 & 0.02 & 99.841 & $9.510 \mathrm{E}-09$ \\
\hline$S$ & 15360 . & B & 12.70 & 0.00 & 100.000 & $0.000 \mathrm{E}+00$ \\
\hline S & 15360. & G & 19.00 & 0.00 & 100.000 & $0.000 \mathrm{E}+00$ \\
\hline SSW & 15360. & $G$ & 0.89 & 0.04 & 0.442 & $2.841 \mathrm{E}-0.5$ \\
\hline SSW & 15360. & $F$ & 0.89 & 0.13 & 2.318 & $1.264 \mathrm{E}-05$ \\
\hline SSW & 15360. & G & 2.65 & 0.02 & 3.974 & $1.076 \mathrm{E}-05$ \\
\hline SSW & 15360. & $E$ & 0.89 & 0.26 & 7.064 & $5.332 \mathrm{E}-06$ \\
\hline SSW & 15360 . & $\mathrm{F}$ & 2.65 & 0.05 & 10.486 & $4.559 E-06$ \\
\hline SSW & 15360. & $\mathrm{~F}$. & 4.70 & 0.06 & 11.700 & $2.822 E-06$ \\
\hline SSW & 15360. & $\mathrm{D}$ & 0.89 & 0.58 & 18.764 & $2.226 E-06$ \\
\hline SSW & 15360 . & $\mathrm{F}$ & 7.15 & 0.02 & 25.386 & $1.901 \mathrm{E}-06$ \\
\hline SSW & 15360 . & $E$ & 2.65 & 0.17 & 27.483 & $1.875 E-06$ \\
\hline SSW & 15360 . & G & 19.00 & 0.01 & 29.470 & 1. $792 \mathrm{E}-06$ \\
\hline SSW & 15360 . & $\mathrm{F}$ & 9.80 & 0.01 & 29.691 & $1.387 \mathrm{E}-06$ \\
\hline SSW & 15360. & $E$ & 4.70 & 0.09 & 30.795 & $1.128 \mathrm{E}-06$ \\
\hline SSW & 15360. & $\mathrm{~F}$ & 15.60 & 0.01 & 31.898 & $8.714 E-07$ \\
\hline SSW & 15360 . & $\mathrm{D}$ & 2.65 & 0.48 & 37.307 & $7.638 E-07$ \\
\hline SSW & 15360. & $\mathrm{E}$ & 7.15 & 0.12 & 43.929 & $7.557 \mathrm{E}-07$ \\
\hline SSW & 15360. & $\mathrm{~F}$ & 19.00 & 0.05 & 45.806 & $7.154 \mathrm{E}-07$ \\
\hline SSW & 15360 . & $E$ & 9.80 & 0.06 & 47.020 & $5.514 \mathrm{E}-07$ \\
\hline SSW & 15360. & $\mathrm{D}$ & 4.70 & 0.20 & 49.890 & $4.457 \mathrm{E}-07$ \\
\hline SSW & 15360 . & $E$ & 12.70 & 0.01 & 52.208 & $4.255 E-07$ \\
\hline SSW & 15360 . & C & 0.89 & 0.10 & 53.422 & $4.046 \mathrm{E}-07$ \\
\hline SSW & 15360. & $\mathrm{E}$ & 15.60 & 0.02 & 54.746 & $3.464 \mathrm{E}-07$ \\
\hline SSW & 15360 . & $\mathrm{D}$ & 7.15 & 0.10 & 56.071 & $2.963 E-07$ \\
\hline SSW & 15360. & $E$ & 19.00 & 0.12 & 58.499 & $2.844 E-07$ \\
\hline SSW & 15360. & $\mathrm{~B}$ & 0.89 & 0.13 & 61.258 & $2.700 \mathrm{E}-07$ \\
\hline SSW & 15360 . & $\mathrm{D}$ & 9.80 & 0.04 & 63.135 & $2.162 E-07$ \\
\hline SSW & 15360 . & A & 0.89 & 0.20 & 65.784 & $2.030 E-07$ \\
\hline SSW & 15360. & D & 12.70 & 0.03 & 68.322 & $1.668 \mathrm{E}-07$ \\
\hline SSW & 15360 . & $\mathrm{C}$ & 2.65 & 0.12 & 69.978 & $1.359 E-07$ \\
\hline SSW & 15360 . & $\mathrm{D}$ & 15.60 & 0.02 & 71.523 & $1.358 \mathrm{E}-07$ \\
\hline SSW & 15360. & $\mathrm{D}$ & 19.00 & 0.07 & 72.517 & 1.115E-07 \\
\hline SSW & 15360. & $\mathrm{~B}$ & 2.65 & 0.15 & 74.945 & $9.066 E-08$ \\
\hline SSW & 15360. & $\mathrm{C}$ & 4.70 & 0.05 & 77.152 & $7.662 E-08$ \\
\hline SSW & 15360 . & A & 2.65 & 0.44 & 82.561 & $6.818 \mathrm{E}-08$ \\
\hline SSW & 15360 . & B & 4.70 & 0.06 & 88.079 & $5.112 E-08$ \\
\hline SSW & 15360. & C & 7.15 & 0.03 & 89.073 & $5.036 E-08$ \\
\hline SSW & 15360. & A & 4.70 & 0.24 & 92.053 & $3.844 E-08$ \\
\hline SSW & 15360. & $\mathrm{C}$ & 9.80 & 0.01 & 94.812 & $3.674 \mathrm{E}-08$ \\
\hline
\end{tabular}


RPP-13482 REV 5

\begin{tabular}{|c|c|c|c|c|c|c|}
\hline SSW & 15360 . & $B$ & 7.15 & 0.03 & 95.254 & $3.360 E-08$ \\
\hline SSW & 15360. & $\mathrm{C}$ & 12.70 & 0.01 & 95.695 & $2.835 E-08$ \\
\hline SSW & 15360 . & A & 7.15 & 0.07 & 96.578 & 2. $527 \mathrm{E}-08$ \\
\hline SSW & 15360. & B & 9.80 & 0.01 & 97.461 & $2.452 \mathrm{E}-08$ \\
\hline SSW & 15360. & $\mathrm{C}$ & 15.60 & 0.01 & 97.682 & $2.308 E-08$ \\
\hline SSW & 15360 . & $\mathrm{C}$ & 19.00 & 0.02 & 98.013 & $1.895 E-08$ \\
\hline SSW & 15360 . & A & 9.80 & 0.02 & 98.455 & 1. $844 E-08$ \\
\hline SSW & 15360 . & B & 15.60 & 0.01 & 98.786 & $1.540 \mathrm{E}-08$ \\
\hline SSW & 15360. & A & 22.70 & 0.01 & 99.007 & $1.423 \mathrm{E}-08$ \\
\hline SSW & 15360 . & B & 19.00 & 0.01 & 99.227 & I. $265 E-08$ \\
\hline SSW & 15360. & A & 15.60 & 0.01 & 99.448 & $1.158 \mathrm{E}-08$ \\
\hline SSW & 15360. & A & 19.00 & 0.02 & 99.779 & $9.510 \mathrm{E}-09$ \\
\hline SSW & 15360 . & G & 15.60 & 0.00 & 100.000 & $0.000 E+00$ \\
\hline SSW & 15360. & G & 7.15 & 0.00 & 100.000 & $0.000 \mathrm{E}+00$ \\
\hline SW & 13200 . & $G$ & 0.89 & 0.08 & 1.365 & $3.309 E-05$ \\
\hline SW & 13200 . & $F$ & 0.89 & 0.12 & 4.778 & $1.490 \mathrm{E}-05$ \\
\hline SW & 13200 & G & 2.65 & 0.02 & 7.167 & $1.271 \mathrm{E}-05$ \\
\hline SW & 13200 . & $\mathrm{E}$ & 0.89 & 0.28 & 12.287 & $6.401 \mathrm{E}-06$ \\
\hline SW & 13200 . & $F$ & 2.65 & 0.05 & 17.918 & $5.422 \mathrm{E}-06$ \\
\hline SW & 13200 . & $F$ & 4.70 & 0.01 & 18.942 & $3.398 \mathrm{E}-06$ \\
\hline SW & 13200 . & $\mathrm{D}$ & 0.89 & 0.59 & 29.181 & $2.752 \mathrm{E}-06$ \\
\hline SW & 13200 . & $\mathrm{E}$ & 2.65 & 0.11 & 41.126 & $2.264 \mathrm{E}-06$ \\
\hline SW & 13200 . & $\mathrm{E}$ & 4.70 & 0.04 & 43.686 & $1.375 \mathrm{E}-06$ \\
\hline SW & 13200 . & $D$ & 2.65 & 0.40 & 51.195 & $9.469 E-07$ \\
\hline SW & 13200 . & $\mathrm{E}$ & 7.15 & 0.01 & 58.191 & $9.235 \mathrm{E}-07$ \\
\hline SW & 13200 . & $E$ & 9.80 & 0.01 & 58.532 & $6.737 E-07$ \\
\hline SW & 13200 . & $D$ & 4.70 & 0.09 & 60.239 & $5.552 E-07$ \\
\hline SW & 13200 . & $\mathrm{E}$ & 12.70 & 0.01 & 61.945 & $5.199 \mathrm{E}-07$ \\
\hline SW & 13200. & $C$ & 0.89 & 0.09 & 63.652 & $5.152 E-07$ \\
\hline SW & 13200 . & $D$ & 7.15 & 0.03 & 65.700 & $3.698 E-07$ \\
\hline SW & 13200 . & B & 0.89 & 0.10 & 67.918 & $3.096 \mathrm{E}-07$ \\
\hline SW & 13200 . & $D$ & 9.80 & 0.01 & 69.795 & $2.698 E-07$ \\
\hline SW & 13200. & A & 0.89 & 0.23 & 73.891 & $2.328 E-07$ \\
\hline SW & 13200 . & $\mathrm{C}$ & 2.65 & 0.06 & 78.840 & $1.730 \mathrm{E}-07$ \\
\hline SW & 13200. & $B$ & 2.65 & 0.06 & 80.887 & $1.040 E-07$ \\
\hline SW & 13200. & $c$ & 4.70 & 0.03 & 82.423 & $9.755 E-08$ \\
\hline SW & 13200. & A & 2.65 & 0.29 & 87.884 & $7.819 E-08$ \\
\hline SW & 13200 . & $\mathrm{C}$ & 7.15 & 0.01 & 93.003 & $6.413 E-08$ \\
\hline SW & 13200 . & $B$ & 4.70 & 0.03 & 93.686 & $5.862 E-08$ \\
\hline SW & 13200 & A & 4.70 & 0.10 & 95.904 & $4.408 E-08$ \\
\hline SW & 13200. & B & 7.15 & 0.01 & 97.782 & $3.853 E-08$ \\
\hline SW & 13200. & A & 7.15 & 0.05 & 98.805 & $2.898 \mathrm{E}-08$ \\
\hline SW & 13200 . & A & 9.80 & 0.01 & 99.829 & $2.114 \mathrm{E}-08$ \\
\hline SW & 13200. & B & 9.80 & 0.00 & 100.000 & $0.000 E+00$ \\
\hline SW & 13200 . & $G$ & 19.00 & 0.00 & 100.000 & $0.000 E+00$ \\
\hline WSW & 11100. & $G$ & 0.89 & 0.08 & I. 471 & $3.927 \mathrm{E}-05$ \\
\hline WSW & 11100. & $F$ & 0.89 & 0.14 & 5.515 & $1.795 E-05$ \\
\hline WSW & 11100. & G & 2.65 & 0.03 & 8.640 & $1.534 \mathrm{E}-05$ \\
\hline WSW & 11100 . & $E$ & 0.89 & 0.25 & 13.787 & $7.878 E-06$ \\
\hline WSW & 11100. & $\mathrm{~F}$ & 2.65 & 0.05 & 19.301 & $6.604 E-06$ \\
\hline WSW & 11100. & $F$ & 4.70 & 0.01 & 20.404 & $4.207 E-06$ \\
\hline WSW & 11100 . & $D$ & 0.89 & 0.59 & 31.434 & $3.503 E-06$ \\
\hline WSW & 11100. & $E$ & 2.65 & 0.13 & 44.669 & $2.808 E-06$ \\
\hline WSW & 11100. & $E$ & 4.70 & 0.01 & 47.243 & 1. $725 E-06$ \\
\hline WSW & 11100. & $\mathrm{D}$ & 2.65 & 0.33 & 53.493 & $1.210 E-06$ \\
\hline WSW & 11100. & D & 4.70 & 0.04 & 60.294 & $7.139 E-07$ \\
\hline WSW & 11100. & $C$ & 0.89 & 0.12 & 63.235 & $6.965 E-07$ \\
\hline WSW & 11100. & $\mathrm{D}$ & 7.15 & 0.01 & 65.625 & $4.766 \mathrm{E}-07$ \\
\hline WSW & 11100. & B & 0.89 & 0.11 & 67.831 & $3.620 \mathrm{E}-07$ \\
\hline WSW & 11100. & A & 0.89 & 0.26 & 74.632 & $2.722 \mathrm{E}-07$ \\
\hline WSW & 11100. & $\mathrm{C}$ & 2.65 & 0.09 & 81.066 & $2.339 E-07$ \\
\hline
\end{tabular}


RPP-13482 REV 5

\begin{tabular}{|c|c|c|c|c|c|c|}
\hline WSW & 11100 & $\mathrm{C}$ & 4.70 & 0.01 & 82.904 & $1.319 \mathrm{E}-07$ \\
\hline WSW & 11100. & $B$ & 2.65 & 0.08 & 84.559 & $1.216 \mathrm{E}-07$ \\
\hline WSW & 11100 & A & 2.65 & 0.32 & 91.912 & $9.143 \mathrm{E}-08$ \\
\hline WSW & 11100. & $B$ & 4.70 & 0.01 & 97.978 & $6.855 E-08$ \\
\hline WSW & 11100 . & A & 4.70 & 0.03 & 98.713 & $5.155 E-08$ \\
\hline WSW & 11100. & B & 7.15 & 0.01 & 99.449 & $4.506 \mathrm{E}-08$ \\
\hline WSW & 11100. & A & 7.15 & 0.01 & 99.816 & $3.389 E-08$ \\
\hline WSW & 11100. & $\mathrm{C}$ & 7.15 & 0.00 & 100.000 & $0.000 E+00$ \\
\hline WSW & 11100 & $G$ & 19.00 & 0.00 & 100.000 & $0.000 E+00$ \\
\hline W & 11100. & $\mathrm{G}$ & 0.89 & 0.13 & 1.354 & $3.927 \mathrm{E}-05$ \\
\hline W & 11100. & $\mathrm{~F}$ & 0.89 & 0.31 & 5.938 & $1.795 E-05$ \\
\hline W & 11100 . & G & 2.65 & 0.09 & 10.104 & $1.534 \mathrm{E}-05$ \\
\hline W & 11100. & $E$ & 0.89 & 0.46 & 15.833 & $7.878 E-06$ \\
\hline W & 11100. & $\mathrm{~F}$ & 2.65 & 0.16 & 22.292 & $6.604 \mathrm{E}-06$ \\
\hline W & 11100 . & $F$ & 4.70 & 0.01 & 24.063 & $4.207 E-06$ \\
\hline w & 11100 . & $\mathrm{D}$ & 0.89 & 0.77 & 32.188 & $3.503 E-06$ \\
\hline W & 11100. & $E$ & 2.65 & 0.31 & 43.438 & $2.808 E-06$ \\
\hline $\mathrm{W}$ & 11100 . & $\mathrm{E}$ & 4.70 & 0.06 & 47.292 & 1. $725 E-06$ \\
\hline W & 11100. & $D$ & 2.65 & 0.66 & 54.792 & $1.210 E-06$ \\
\hline W & 11100. & $D$ & 4.70 & 0.12 & 62.917 & $7.139 E-07$ \\
\hline W & 11100. & $C$ & 0.89 & 0.14 & 65.625 & $6.965 \mathrm{E}-07$ \\
\hline W & 11100 . & $\mathrm{B}$ & 0.89 & 0.16 & 68.750 & $3.620 \mathrm{E}-07$ \\
\hline W & 11100 . & $A$ & 0.89 & 0.40 & 74.583 & $2.722 \mathrm{E}-07$ \\
\hline $\mathrm{W}$ & 11100. & C & 2.65 & 0.13 & 80.104 & $2.339 \mathrm{E}-07$ \\
\hline$W$ & 11100. & $\mathrm{C}$ & 4.70 & 0.02 & 81.667 & I. $319 \mathrm{E}-07$ \\
\hline W & 11100. & B & 2.65 & 0.16 & 83.542 & $1.216 \mathrm{E}-07$ \\
\hline W & 11100. & A & 2.65 & 0.60 & 91.458 & $9.143 \mathrm{E}-08$ \\
\hline W & 11100. & $\mathrm{~B}$ & 4.70 & 0.03 & 98.021 & $6.855 E-08$ \\
\hline W & 11100. & A & 4.70 & 0.08 & 99.167 & $5.155 \mathrm{E}-08$ \\
\hline W & 11100. & $\mathrm{G}$ & 4.70 & 0.00 & 100.000 & $0.000 \mathrm{E}+00$ \\
\hline$W$ & 11100. & $G$ & 19.00 & 0.00 & 100.000 & $0.000 \mathrm{E}+00$ \\
\hline WNW & 11100. & G & 0.89 & 0.13 & 1.633 & $3.927 \mathrm{E}-05$ \\
\hline WNW & 11100 . & $\mathrm{F}$ & 0.89 & 0.23 & 6.156 & 1. $795 \mathrm{E}-05$ \\
\hline WNW & 11100 . & G & 2.65 & 0.10 & 10.302 & $1.534 \mathrm{E}-0.5$ \\
\hline WNW & 11100. & G & 4.70 & 0.01 & 11.683 & $1.042 \mathrm{E}-05$ \\
\hline WNW & 11100. & $E$ & 0.89 & 0.34 & 16.080 & $7.878 E-06$ \\
\hline WNW & 11100. & $\mathrm{~F}$ & 2.65 & 0.21 & 22.990 & $6.604 \mathrm{E}-06$ \\
\hline WNW & 11100. & $\mathrm{~F}$ & 4.70 & 0.02 & 25.879 & $4.207 \mathrm{E}-06$ \\
\hline WNW & 11100. & $D$ & 0.89 & 0.50 & 32.412 & $3.503 \mathrm{E}-06$ \\
\hline WNW & 11100 . & $E$ & 2.65 & 0.34 & 42.965 & $2.808 \mathrm{E}-06$ \\
\hline WNW & 11300. & $E$ & 4.70 & 0.06 & 47.990 & $1.725 E-06$ \\
\hline WNW & 11100. & $D$ & 2.65 & 0.57 & 55.905 & 1. $210 E-06$ \\
\hline WNW & 11100. & $D$ & 4.70 & 0.11 & 64.447 & $7.139 \mathrm{E}-07$ \\
\hline WNW & 11100 . & $\mathrm{C}$ & 0.89 & 0.10 & 67.085 & $6.965 \mathrm{E}-07$ \\
\hline WNW & 11100 . & $\mathrm{D}$ & 7.15 & 0.01 & 68.467 & $4.766 E-07$ \\
\hline WNW & 11100. & $\mathrm{~B}$ & 0.89 & 0.09 & 69.724 & $3.620 E-07$ \\
\hline WNW & 11100. & A & 0.89 & 0.24 & 73.869 & $2.722 E-07$ \\
\hline WNW & 11100. & $\mathrm{C}$ & 2.65 & 0.13 & 78.518 & $2.339 E-07$ \\
\hline WNW & 11100. & $\mathrm{C}$ & 4.70 & 0.02 & 80.402 & $1.319 E-07$ \\
\hline WNW & 11100 . & $\mathrm{B}$ & 2.65 & 0.13 & 82.286 & 1. $216 \mathrm{E}-07$ \\
\hline WNW & 11100. & $A$ & 2.65 & 0.51 & 90.327 & $9.143 \mathrm{E}-08$ \\
\hline WNW & 11100. & $\mathrm{~B}$ & 4.70 & 0.03 & 97.111 & $6.855 \mathrm{E}-08$ \\
\hline WNW & 11100. & A & 4.70 & 0.10 & 98.744 & $5.155 \mathrm{E}-08$ \\
\hline WNW & 11100. & B & 7.15 & 0.00 & 100.000 & $0.000 \mathrm{E}+00$ \\
\hline WNW & 11100. & G & 19.00 & 0.00 & 100.000 & $0.000 \mathrm{E}+00$ \\
\hline NW & 10800. & $G$ & 0.89 & 0.13 & 1.377 & $4.034 \mathrm{E}-05$ \\
\hline NW & 10800. & $F$ & 0.89 & 0.28 & 5.720 & $1.849 \mathrm{E}-0$ \\
\hline NW & 10800. & G & 2.65 & 0.20 & 10.805 & $1.580 \mathrm{E}-0$ \\
\hline NW & 10800. & G & 4.70 & 0.01 & 13.030 & $1.078 \mathrm{E}-0$ \\
\hline NW & 10800. & $\mathrm{E}$ & 0.89 & 0.31 & 16.419 & $8.140 E-06$ \\
\hline
\end{tabular}




\begin{tabular}{|c|c|c|c|c|c|c|}
\hline NW & 10800 & F & 2.65 & 0.39 & 23.835 & $6.813 E-06$ \\
\hline NW & 10800 & F & 4.70 & 0.05 & 28.496 & $4.352 \mathrm{E}-06$ \\
\hline NW & 10800 . & $\mathrm{D}$ & 0.89 & 0.43 & 33.581 & $3.639 \mathrm{E}-06$ \\
\hline NW & 10800 . & $\mathrm{E}$ & 2.65 & 0.47 & 43.114 & $2.905 E-06$ \\
\hline NW & 10800 . & $E$ & 4.70 & 0.15 & 49.682 & 1. $788 \mathrm{E}-06$ \\
\hline NW & 10800 . & D & 2.65 & 0.75 & 59.216 & $1.258 \mathrm{E}-06$ \\
\hline NW & 10800 . & $E$ & 7.15 & 0.01 & 67.267 & $1.206 \mathrm{E}-06$ \\
\hline NW & 10800 . & D & 4.70 & 0.25 & 70.021 & $7.429 E-07$ \\
\hline NW & 10800 . & C & 0.89 & 0.06 & 73.305 & $7.315 E-07$ \\
\hline NW & 10800 . & $D$ & 7.15 & 0.03 & 74.258 & $4.961 E-07$ \\
\hline NW & 10800 . & B & 0.89 & 0.07 & 75.318 & $3.711 E-07$ \\
\hline NW & 10800 . & A & 0.89 & 0.17 & 77.860 & $2.791 \mathrm{E}-07$ \\
\hline NW & 10800. & C & 2.65 & 0.19 & 81.674 & $2.457 \mathrm{E}-07$ \\
\hline NW & 10800 & c & 4.70 & 0.04 & 84.110 & $1.385 \mathrm{E}-07$ \\
\hline NW & 10800 & B & 2.65 & 0.13 & 85.911 & $1.246 \mathrm{E}-07$ \\
\hline NW & 10800 & $A$ & 2.65 & 0.45 & 92.055 & $9.372 \mathrm{E}-08$ \\
\hline $\mathrm{NW}$ & 10800 . & $\mathrm{B}$ & 4.70 & 0.04 & 97.246 & $7.026 \mathrm{E}-08$ \\
\hline NW & 10800 . & A & 4.70 & 0.10 & 98.729 & $-5.284 E-08$ \\
\hline $\mathrm{NW}$ & 10800 . & A & 7.15 & 0.01 & 99.894 & $3.474 \mathrm{E}-08$ \\
\hline $\mathrm{NW}$ & 10800 & B & 7.15 & 0.00 & 100.000 & $0.000 \mathrm{E}+00$ \\
\hline $\mathrm{NW}$ & 10800. & $\mathrm{G}$ & 19.00 & 0.00 & 100.000 & $0.000 E+00$ \\
\hline $\mathrm{NNW}$ & 8690. & $\mathrm{G}$ & 0.89 & 0.14 & 1.528 & $4.974 E-05$ \\
\hline NNW & 8690. & F & 0.89 & 0.26 & 5.895 & $2.327 \mathrm{E}-05$ \\
\hline NNW & 8690 . & $G$ & 2.65 & 0.23 & 11.245 & $1.994 \mathrm{E}-05$ \\
\hline $\mathrm{N} N \mathrm{~W}$ & 8690. & $\mathrm{G}$ & 4.70 & 0.09 & 14.738 & $1.408 \mathrm{E}-05$ \\
\hline $\mathrm{NNW}$ & 8690 . & $E$ & 0.89 & 0.30 & 18.996 & $1.053 E-05$ \\
\hline NNW & 8690. & G & 7.15 & 0.01 & 22.380 & $9.783 \mathrm{E}-06$ \\
\hline NNW & 8690. & $F$ & 2.65 & 0.44 & 27.293 & $8.711 \mathrm{E}-06$ \\
\hline NNW & 8690 . & $\mathrm{F}$ & 4.70 & 0.17 & 33.952 & $5.701 E-06$ \\
\hline NNW & 8690. & $\mathrm{D}$ & 0.89 & 0.32 & 39.301 & 4. $916 \mathrm{E}-06$ \\
\hline NNW & 8690. & $F$ & 7.15 & 0.01 & 42.904 & $3.904 \mathrm{E}-06$ \\
\hline NNW & 8690. & $E$ & 2.65 & 0.52 & 48.690 & $3.801 E-06$ \\
\hline $\mathrm{NNW}$ & 8690. & $E$ & 4.70 & 0.25 & 57.096 & $2.381 E-06$ \\
\hline NNW & 8690. & $\mathrm{D}$ & 2.65 & 0.53 & 65.611 & $1.709 \mathrm{E}-06$ \\
\hline NNW & 8690 . & $E$ & 7.15 & 0.05 & 71.943 & $1.616 \mathrm{E}-06$ \\
\hline NNW & 8690. & $\mathrm{C}$ & 0.89 & 0.04 & 72.926 & $1.083 E-06$ \\
\hline $\mathrm{NNW}$ & 8690. & $\mathrm{D}$ & 4.70 & 0.27 & 76.310 & $1.019 \mathrm{E}-06$ \\
\hline $\mathrm{NNW}$ & 8690 . & $\mathrm{D}$ & 7.15 & 0.07 & 80.022 & $6.830 \mathrm{E}-07$ \\
\hline $\mathrm{NNW}$ & 8690. & B & 0.89 & 0.03 & 81.114 & $4.527 E-07$ \\
\hline NNW & 8690. & $\mathrm{C}$ & 2.65 & 0.10 & 82.533 & $3.638 E-07$ \\
\hline $\mathrm{NNW}$ & 8690 . & A & 0.89 & 0.10 & 84.716 & $3.396 E-07$ \\
\hline NNW & 8690. & $\mathrm{C}$ & 4.70 & 0.04 & 86.245 & $2.051 E-07$ \\
\hline NNW & 8690 . & B & 2.65 & 0.09 & 87.664 & 1. $520 \mathrm{E}-07$ \\
\hline NNW & 8690 . & $\mathrm{C}$ & 7.15 & 0.01 & 88.755 & $1.348 \mathrm{E}-07$ \\
\hline NNW & 8690 . & A & 2.65 & 0.29 & 92.031 & $1.140 E-07$ \\
\hline NNW & 8690. & $\mathrm{~B}$ & 4.70 & 0.05 & 95.742 & $8.572 E-08$ \\
\hline $\mathrm{NNW}$ & 8690. & A & 4.70 & 0.13 & 97.707 & $6.430 \mathrm{E}-08$ \\
\hline $\mathrm{NNW}$ & 8690 . & B & 7.15 & 0.01 & 99.236 & $5.635 E-08$ \\
\hline NNW & 8690. & $\mathrm{~A}$ & 7.15 & 0.03 & 99.672 & $4.227 \mathrm{E}-\mathrm{O}$ \\
\hline NNW & 8690. & A & 9.80 & 0.00 & 100.000 & $0.000 \mathrm{E}+0$ \\
\hline NNW & 8690. & G & 19.00 & 0.00 & 100.000 & $0.000 E+0$ \\
\hline $\mathrm{N}$ & 8690. & G & 0.89 & 0.17 & 1.950 & $4.974 \mathrm{E}-0$ \\
\hline $\mathrm{N}$ & 8690 . & $F$ & 0.89 & 0.35 & 7.913 & $2.327 \mathrm{E}-0$ \\
\hline $\mathrm{N}$ & 8690. & G & 2.65 & 0.20 & 14.220 & 1. $994 \mathrm{E}-0$ \\
\hline $\mathrm{N}$ & 8690 . & G & 4.70 & 0.07 & 17.317 & $1.408 \mathrm{E}-05$ \\
\hline $\mathrm{N}$ & 8690. & $\mathrm{E}$ & 0.89 & 0.34 & 22.018 & $1.053 \mathrm{E}-05$ \\
\hline $\mathrm{N}$ & 8690. & $F$ & 2.65 & 0.45 & 31.078 & $8.711 E-0$ \\
\hline $\mathrm{N}$ & 8690. & $\mathrm{~F}$ & 4.70 & 0.14 & 37.844 & $5.701 \mathrm{E}-06$ \\
\hline $\mathrm{N}$ & 8690. & $\mathrm{D}$ & 0.89 & 0.27 & 42.546 & $4.916 \mathrm{E}-0$ \\
\hline $\mathrm{N}$ & 8690. & $\mathrm{~F}$ & 7.15 & 0.02 & 45.872 & $3.904 E-0$ \\
\hline $\mathrm{N}$ & 8690. & $\mathrm{E}$ & 2.65 & 0.46 & 51.376 & $3.801 \mathrm{E}-0$ \\
\hline
\end{tabular}


RPP-13482 REV 5

\begin{tabular}{|c|c|c|c|c|c|c|}
\hline $\mathrm{N}$ & 8690. & $\mathrm{~F}$ & 9.80 & 0.01 & 56.766 & $2.849 E-06$ \\
\hline $\mathrm{N}$ & 8690 . & E & 4.70 & 0.22 & 59.404 & $2.38 I E-06$ \\
\hline $\mathrm{N}$ & 8690. & D & 2.65 & 0.35 & 65.940 & $1.709 E-06$ \\
\hline $\mathrm{N}$ & 8690. & $\mathrm{E}$ & 7.15 & 0.07 & 70.757 & $1.616 \mathrm{E}-06$ \\
\hline $\mathrm{N}$ & 8690. & $\mathrm{E}$ & 9.80 & 0.01 & 71.674 & $1.179 \mathrm{E}-06$ \\
\hline $\mathrm{N}$ & 8690. & C & 0.89 & 0.04 & 72.248 & I. $083 \mathrm{E}-06$ \\
\hline $\mathrm{N}$ & 8690. & $\mathrm{D}$ & 4.70 & 0.24 & 75.459 & 1.019E-06 \\
\hline $\mathrm{N}$ & 8690. & $\mathrm{D}$ & 7.15 & 0.10 & 79.358 & $6.830 E-07$ \\
\hline $\mathrm{N}$ & 8690. & $\mathrm{D}$ & 9.80 & 0.02 & 80.734 & $4.983 E-07$ \\
\hline $\mathrm{N}$ & 8690. & B & 0.89 & 0.05 & 81.537 & $4.527 E-07$ \\
\hline $\mathrm{N}$ & 8690. & $\mathrm{C}$ & 2.65 & 0.06 & 82.798 & $3.638 E-07$ \\
\hline $\mathrm{N}$ & 8690 . & A & 0.89 & 0.10 & 84.633 & $3.396 \mathrm{E}-07$ \\
\hline $\mathrm{N}$ & 8690 . & C & 4.70 & 0.05 & 86.353 & $2.051 E-07$ \\
\hline $\mathrm{N}$ & 8690. & B & 2.65 & 0.08 & 87.844 & $1.520 E-07$ \\
\hline $\mathrm{N}$ & 8690. & c & 7.15 & 0.02 & 88.991 & 1. $348 \mathrm{E}-07$ \\
\hline$N$ & 8690. & A & 2.65 & 0.24 & 91.972 & $1.140 \mathrm{E}-07$ \\
\hline$N$ & 8690. & C & 9.80 & 0.01 & 94.839 & $9.837 E-08$ \\
\hline $\mathrm{N}$ & 8690. & B & 4.70 & 0.03 & 95.298 & $8.572 \mathrm{E}-08$ \\
\hline $\mathrm{N}$ & 8690. & A & 4.70 & 0.12 & 97.018 & $6.430 E-08$ \\
\hline $\mathrm{N}$ & 8690 . & B & 7.15 & 0.02 & 98.624 & $5.635 E-08$ \\
\hline $\mathrm{N}$ & 8690. & A & 7.15 & 0.04 & 99.312 & $4.227 E-08$ \\
\hline $\mathrm{N}$ & 8690. & A & 9.80 & 0.01 & 99.885 & $3.084 E-08$ \\
\hline $\mathrm{N}$ & 8690. & G & 7.15 & 0.00 & 100.000 & $0.000 E+00$ \\
\hline $\mathrm{N}$ & 8690. & G & 19.00 & 0.00 & 100.000 & $0.000 \mathrm{E}+00$ \\
\hline NNE & 8970. & G & 0.89 & 0.09 & 1.807 & $4.826 E-05$ \\
\hline NNE & 8970 . & F & 0.89 & 0.23 & 8.233 & $2.251 E-05$ \\
\hline NNE & 8970. & G & 2.65 & 0.08 & 14.458 & $1.928 \mathrm{E}-05$ \\
\hline NNE & 8970. & G & 4.70 & 0.01 & 16.265 & $1.354 \mathrm{E}-05$ \\
\hline NNE & 8970. & $\mathrm{E}$ & 0.89 & 0.21 & 20.683 & $1.015 E-05$ \\
\hline NNE & 8970 . & $F$ & 2.65 & 0.21 & 29.116 & $8.405 E-06$ \\
\hline $\mathrm{NNE}$ & 8970 . & $\mathrm{F}$ & 4.70 & 0.03 & 33.936 & $5.480 E-06$ \\
\hline NNE & 8970. & D & 0.89 & 0.19 & 38.353 & $4.706 E-06$ \\
\hline NNE & 8970 . & $E$ & 2.65 & 0.21 & 46.386 & $3.655 E-06$ \\
\hline NNE & 8970. & $E$ & 4.70 & 0.12 & 53.012 & $2.284 \mathrm{E}-06$ \\
\hline NNE & 8970. & $\mathrm{D}$ & 2.65 & 0.18 & 59.036 & $1.634 \mathrm{E}-06$ \\
\hline NNE & 8970. & $E$ & 7.15 & 0.08 & 64.257 & $1.548 E-06$ \\
\hline NNE & 8970. & $\mathrm{E}$ & 9.80 & 0.05 & 66.867 & 1. $129 E-06$ \\
\hline NNE & 8970. & $\mathrm{C}$ & 0.89 & 0.02 & 68.273 & $1.023 E-06$ \\
\hline $\mathrm{NNE}$ & 8970. & $D$ & 4.70 & 0.13 & 71.285 & $9.733 E-07$ \\
\hline NNE & 8970. & $\mathrm{E}$ & 12.70 & 0.01 & 74.096 & $8.714 \mathrm{E}-07$ \\
\hline NNE & 8970 . & $\mathrm{D}$ & 7.15 & 0.11 & 76.506 & $6.518 \mathrm{E}-07$ \\
\hline NNE & 8970. & $\mathrm{D}$ & 9.80 & 0.07 & 80.120 & $4.755 \mathrm{E}-07$ \\
\hline NNE & 8970 . & $B$ & 0.89 & 0.02 & 81.928 & $4.388 E-07$ \\
\hline NNE & 8970 . & $\mathrm{D}$ & 12.70 & 0.02 & 82.731 & $3.670 E-07$ \\
\hline NNE & 8970 . & $\mathrm{C}$ & 2.65 & 0.02 & 83.534 & $3.435 E-07$ \\
\hline NNE & 8970 . & A & 0.89 & 0.06 & 85.141 & $3.300 \mathrm{E}-07$ \\
\hline NNE & 8970. & $\mathrm{C}$ & 4.70 & 0.02 & 86.747 & $1.937 \mathrm{E}-07$ \\
\hline NNE & 8970. & B & 2.65 & 0.04 & 87.952 & $1.474 E-07$ \\
\hline NNE & 8970. & $\mathrm{C}$ & 7.15 & 0.01 & 88.956 & $1.273 E-07$ \\
\hline $\mathrm{NNE}$ & 8970. & $A$ & 2.65 & 0.12 & 91.566 & $1.108 \mathrm{E}-07$ \\
\hline $\mathrm{NNE}$ & 8970. & $\mathrm{~B}$ & 4.70 & 0.02 & 94.377 & $8.309 E-08$ \\
\hline $\mathrm{NNE}$ & 8970. & $\mathrm{~A}$ & 4.70 & 0.07 & 96.185 & $6.249 \mathrm{E}-08$ \\
\hline NNE & 8970. & B & 7.15 & 0.01 & 97.791 & $5.462 E-08$ \\
\hline NNE & 8970. & A & 7.15 & 0.04 & 98.795 & $4.108 E-08$ \\
\hline NNE & 8970 . & A & 9.80 & 0.01 & 99.799 & $2.997 \mathrm{E}-08$ \\
\hline NNE & 8970 . & G & 7.15 & 0.00 & 100.000 & $0.000 \mathrm{E}+0 \mathrm{C}$ \\
\hline NNE & 8970 . & $\mathrm{G}$ & 19.00 & 0.00 & 100.000 & $0.000 \mathrm{E}+0 \mathrm{C}$ \\
\hline $\mathrm{NE}$ & 10430. & $G$ & 0.89 & 0.10 & 1.282 & $4.173 \mathrm{E}-05$ \\
\hline $\mathrm{NE}$ & 10430. & $\mathrm{~F}$ & 0.89 & 0.22 & 5.385 & 1. $919 \mathrm{E}-05$ \\
\hline $\mathrm{NE}$ & 10430 & G & 2.65 & 0.10 & 9.487 & $1.640 \mathrm{E}-05$ \\
\hline $\mathrm{NE}$ & 10430. & $\mathrm{G}$ & 4.70 & 0.02 & 11.026 & $1.125 E-05$ \\
\hline
\end{tabular}




\section{RPP-13482 REV 5}

\begin{tabular}{|c|c|c|c|c|c|c|}
\hline NE & 10430. & $\mathrm{E}$ & 0.89 & 0.25 & 14.487 & $8.485 E-06$ \\
\hline $\mathrm{NE}$ & 10430 . & $F$ & 2.65 & 0.27 & 21.154 & $7.088 \mathrm{E}-06$ \\
\hline $\mathrm{NE}$ & 10430. & $F$ & 4.70 & 0.07 & 25.513 & $4.544 E-06$ \\
\hline NE & 10430 . & D & 0.89 & 0.21 & 29.103 & $3.819 \mathrm{E}-06$ \\
\hline$N E$ & 10430 . & $F$ & 7.15 & 0.01 & 31.923 & $3.093 E-06$ \\
\hline $\mathrm{NE}$ & 10430 . & $E$ & 2.65 & 0.29 & 35.769 & $3.033 E-06$ \\
\hline NE & 10430. & $\mathrm{E}$ & 4.70 & 0.18 & 41.795 & $1.872 E-06$ \\
\hline NE & 10430 . & $\mathrm{D}$ & 2.65 & 0.24 & 47.179 & $1.321 \mathrm{E}-06$ \\
\hline $\mathrm{NE}$ & 10430 . & $\mathrm{E}$ & 7.15 & 0.17 & 52.436 & $1.264 E-06$ \\
\hline $\mathrm{NE}$ & 10430 . & $E$ & 9.80 & 0.11 & 56.026 & $9.222 E-07$ \\
\hline $\mathrm{NE}$ & 10430 . & $\mathrm{D}$ & 4.70 & 0.23 & 60.385 & $7.815 \mathrm{E}-07$ \\
\hline $\mathrm{NE}$ & 10430. & C & 0.89 & 0.02 & 63.590 & $7.787 \mathrm{E}-07$ \\
\hline $\mathrm{NE}$ & 10430. & $E$ & 12.70 & 0.04 & 64.359 & $7.116 \mathrm{E}-07$ \\
\hline $\mathrm{NE}$ & 10430. & $E$ & 15.60 & 0.01 & 65.800 & $5.793 E-07$ \\
\hline $\mathrm{NE}$ & 10430 . & D & 7.15 & 0.25 & 68.333 & $5.222 E-07$ \\
\hline $\mathrm{NE}$ & 10430. & B & 0.89 & 0.01 & 71.667 & $3.829 E-07$ \\
\hline $\mathrm{NE}$ & 10430 . & D & 9.80 & 0.16 & 73.846 & $3.810 E-07$ \\
\hline $\mathrm{NE}$ & 10430 & D & 12.70 & 0.09 & 77.051 & $2.940 \mathrm{E}-07$ \\
\hline $\mathrm{NE}$ & 10430 . & A & 0.89 & 0.06 & 78.974 & $2.880 E-07$ \\
\hline $\mathrm{NE}$ & 10430. & C & 2.65 & 0.03 & 80.128 & $2.615 \mathrm{E}-07$ \\
\hline $\mathrm{NE}$ & 10430. & $D$ & 15.60 & 0.03 & 80.897 & $2.393 E-07$ \\
\hline $\mathrm{NE}$ & 10430 . & $c$ & 4.70 & 0.03 & 81.667 & $1.475 \mathrm{E}-07$ \\
\hline $\mathrm{NE}$ & 10430 . & B & 2.65 & 0.03 & 82.436 & $1.286 E-07$ \\
\hline $\mathrm{NE}$ & 10430 . & $\mathrm{C}$ & 7.15 & 0.02 & 83.077 & $9.693 E-08$ \\
\hline $\mathrm{NE}$ & 10430. & A & 2.65 & 0.17 & 85.513 & $9.672 E-08$ \\
\hline $\mathrm{NE}$ & 10430 . & B & 4.70 & 0.05 & 88.333 & $7.251 \mathrm{E}-08$ \\
\hline NE & 10430 . & $\mathrm{C}$ & 9.80 & 0.02 & 89.231 & $7.072 \mathrm{E}-08$ \\
\hline NE & 10430. & $\mathrm{C}$ & 12.70 & 0.02 & 89.744 & $5.457 E-08$ \\
\hline NE & 10430. & A & 4.70 & 0.14 & 91.795 & $5.453 E-08$ \\
\hline NE & 10430 . & B & 7.15 & 0.04 & 94.103 & $4.766 \mathrm{E}-08$ \\
\hline NE & 10430. & A & 7.15 & 0.11 & 96.026 & $3.585 E-08$ \\
\hline $\mathrm{NE}$ & 10430. & B & 9.80 & 0.02 & 97.692 & $3.478 E-08$ \\
\hline NE & 10430 . & B & 12.70 & 0.01 & 98.077 & $2.683 E-08$ \\
\hline NE & 10430. & A & 9.80 & 0.05 & 98.846 & $2.615 E-08$ \\
\hline$N E$ & 10430 . & A & 12.70 & 0.02 & 99.744 & $2.018 E-08$ \\
\hline NE & 10430. & F & 9.80 & 0.00 & 100.000 & $0.000 E+00$ \\
\hline $\mathrm{NE}$ & 10430 . & G & 19.00 & 0.00 & 100.000 & $0.000 E+00$ \\
\hline ENE & 10530. & G & 0.89 & 0.09 & 0.729 & $4.134 E-05$ \\
\hline ENE & 10530. & F & 0.89 & 0.27 & 3.647 & I. $899 \mathrm{E}-05$ \\
\hline ENE & 10530 . & G & 2.65 & 0.20 & 7.455 & $1.624 \mathrm{E}-05$ \\
\hline ENE & 10530. & G & 4.70 & 0.09 & 9.806 & $1.112 \mathrm{E}-05$ \\
\hline ENE & 10530. & E & 0.89 & 0.29 & 12.885 & $8.389 E-06$ \\
\hline ENE & 10530 . & F & 2.65 & 0.46 & 18.963 & $7.011 E-06$ \\
\hline ENE & 10530. & $F$ & 4.70 & 0.20 & 24.311 & $4.491 E-06$ \\
\hline ENE & 10530. & $\mathrm{D}$ & 0.89 & 0.17 & 27.310 & $3.769 \mathrm{E}-06$ \\
\hline ENE & 10530. & $F$ & 7.15 & 0.02 & 28.849 & $3.056 E-06$ \\
\hline ENE & 10530. & $E$ & 2.65 & 0.48 & 32.901 & $2.997 E-06$ \\
\hline ENE & 10530. & $\mathrm{E}$ & 4.70 & 0.39 & 39.951 & $1.849 E-06$ \\
\hline ENE & 10530. & D & 2.65 & 0.28 & 45.381 & $1.303 \mathrm{E}-06$ \\
\hline ENE & 10530 . & E & 7.15 & 0.30 & 50.081 & $1.248 E-06$ \\
\hline ENE & 10530. & $E$ & 9.80 & 0.15 & 53.728 & $9.105 E-07$ \\
\hline ENE & 10530 . & $\dot{\mathrm{D}}$ & 4.70 & 0.39 & 58.104 & $7.708 E-07$ \\
\hline ENE & 10530. & C & 0.89 & 0.02 & 61.426 & $7.654 \mathrm{E}-07$ \\
\hline ENE & 10530 & $\mathrm{E}$ & 12.70 & 0.02 & 61.750 & $7.026 \mathrm{E}-07$ \\
\hline ENE & 10530. & D & 7.15 & 0.38 & 64.992 & $5.149 \mathrm{E}-07$ \\
\hline ENE & 10530. & B & 0.89 & 0.03 & 68.314 & $3.796 \mathrm{E}-07$ \\
\hline ENE & 10530. & D & 9.80 & 0.24 & 70.502 & $3.757 \mathrm{E}-07$ \\
\hline ENE & 10530 & D & 12.70 & 0.09 & 73.177 & $2.899 \mathrm{E}-07$ \\
\hline ENE & 10530. & A & 0.89 & 0.06 & 74.392 & $2.855 \mathrm{E}-07$ \\
\hline ENE & 10530. & C & 2.65 & 0.05 & 75.284 & $2.571 E-07$ \\
\hline ENE & 10530. & D & 15.60 & 0.03 & 75.932 & $2.360 \mathrm{E}-07$ \\
\hline ENE & 10530. & C & 4.70 & 0.06 & 76.661 & $1.449 \mathrm{E}-07$ \\
\hline
\end{tabular}

\section{E-16}


RPP-13482 REV 5

\begin{tabular}{|c|c|c|c|c|c|c|}
\hline ENE & 10530. & $\mathrm{~B}$ & 2.65 & 0.05 & 77.553 & $1.275 \mathrm{E}-07$ \\
\hline ENE & 10530 . & A & 2.65 & 0.19 & 79.498 & $9.589 \mathrm{E}-08$ \\
\hline ENE & 10530. & $\mathrm{C}$ & 7.15 & 0.07 & 81.605 & $9.528 E-08$ \\
\hline ENE & 10530. & B & 4.70 & 0.07 & 82.739 & $7.189 \mathrm{E}-08$ \\
\hline ENE & 10530. & C & 9.80 & 0.05 & 83.711 & $6.952 \mathrm{E}-08$ \\
\hline ENE & 10530 . & A & 4.70 & 0.34 & 86.872 & $5.406 E-08$ \\
\hline ENE & 10530 . & C & 12.70 & 0.01 & 89.708 & $5.364 E-08$ \\
\hline ENE & 10530. & B & 7.15 & 0.08 & 90.438 & $4.726 E-08$ \\
\hline ENE & 10530. & C & 15.60 & 0.01 & 91.167 & $4.367 E-08$ \\
\hline ENE & 10530. & A & 7.15 & 0.25 & 93.274 & $3.554 \mathrm{E}-08$ \\
\hline ENE & 10530 . & B & 9.80 & 0.04 & 95.624 & $3.448 E-08$ \\
\hline ENE & 10530. & B & 12.70 & 0.02 & 96.110 & $2.660 \mathrm{E}-08$ \\
\hline ENE & 10530. & A & 9.80 & 0.16 & 97.569 & $2.593 E-08$ \\
\hline ENE & 10530. & A & 12.70 & 0.06 & 99.352 & $2.001 E-08$ \\
\hline ENE & 10530. & A & 15.60 & 0.01 & 99.919 & 1. $629 \mathrm{E}-08$ \\
\hline ENE & 10530. & F & 12.70 & 0.00 & 100.000 & $0.000 E+00$ \\
\hline ENE & 10530. & G & 19.00 & 0.00 & 100.000 & $0.000 \mathrm{E}+00$ \\
\hline $\mathrm{E}$ & 11160. & G & 0.89 & 0.22 & 0.783 & $3.906 E-05$ \\
\hline $\mathrm{E}$ & 11160. & F & 0.89 & 0.48 & 3.274 & $1.785 \mathrm{E}-05$ \\
\hline$E$ & 11160. & G & 2.65 & 0.82 & 7.900 & $1.525 E-05$ \\
\hline $\mathrm{E}$ & 11160. & G & 4.70 & 0.56 & 12.811 & $1.035 \mathrm{E}-05$ \\
\hline$E$ & 11160. & $\mathrm{E}$ & 0.89 & 0.49 & 16.548 & $7.827 E-06$ \\
\hline $\mathrm{E}$ & 11160 . & F & 2.65 & 1.60 & 23.986 & $6.564 \mathrm{E}-06$ \\
\hline $\mathrm{E}$ & 11160 . & $\mathrm{F}$ & 4.70 & 1.19 & 33.915 & $4.179 E-06$ \\
\hline$E$ & 11160. & D & 0.89 & 0.40 & 39.573 & $3.477 \mathrm{E}-06$ \\
\hline$E$ & 11160. & F & 7.15 & 0.07 & 41.246 & $2.839 E-06$ \\
\hline$E$ & 11160 . & $\mathrm{E}$ & 2.65 & 1.58 & 47.117 & $2.789 E-06$ \\
\hline$E$ & 11160. & $E$ & 4.70 & 1.98 & 59.786 & $1.713 E-06$ \\
\hline$E$ & 11160 . & $\mathrm{D}$ & 2.65 & 0.69 & 69.288 & $1.201 \mathrm{E}-06$ \\
\hline $\mathrm{E}$ & 11160. & $\mathrm{E}$ & 7.15 & 0.65 & 74.057 & $1.155 E-06$ \\
\hline$E$ & 11160. & $E$ & 9.80 & 0.06 & 76.584 & $8.424 \mathrm{E}-07$ \\
\hline $\mathrm{E}$ & 11160. & $\mathrm{D}$ & 4.70 & 0.83 & 79.751 & $7.084 E-07$ \\
\hline $\mathrm{E}$ & 11160 . & $\mathrm{C}$ & 0.89 & 0.04 & 82.847 & $6.898 E-07$ \\
\hline $\mathrm{E}$ & 11160. & $\mathrm{E}$ & 12.70 & 0.01 & 83.025 & $6.501 \mathrm{E}-07$ \\
\hline $\mathrm{E}$ & 11160. & $\mathrm{D}$ & 7.15 & 0.58 & 85.125 & $4.728 E-07$ \\
\hline $\mathrm{E}$ & 11160. & $\mathrm{~B}$ & 0.89 & 0.04 & 87.331 & $3.602 \mathrm{E}-07$ \\
\hline $\mathrm{E}$ & 12160. & $\mathrm{D}$ & 9.80 & 0.13 & 87.936 & $3.450 E-07$ \\
\hline $\mathrm{E}$ & 11160. & A & 0.89 & 0.10 & 88.754 & $2.709 \mathrm{E}-07$ \\
\hline$E$ & 11160. & $\mathrm{D}$ & 12.70 & 0.03 & 89.217 & 2. $662 \mathrm{E}-07$ \\
\hline$E$ & 11160. & C & 2.65 & 0.08 & 89.609 & $2.317 \mathrm{E}-07$ \\
\hline $\mathrm{E}$ & 11160. & $\mathrm{D}$ & 15.60 & 0.02 & 89.964 & $2.167 \mathrm{E}-07$ \\
\hline$E$ & 11160 . & C & 4.70 & 0.09 & 90.356 & $1.306 \mathrm{E}-07$ \\
\hline$E$ & 11160. & B & 2.65 & 0.07 & 90.925 & $1.210 E-07$ \\
\hline $\mathrm{E}$ & 11160 . & A & 2.65 & 0.25 & 92.064 & $9.098 E-08$ \\
\hline$E$ & 11160 . & C & 7.15 & 0.06 & 93.167 & $8.587 \mathrm{E}-08$ \\
\hline$E$ & 11160. & $\mathrm{~B}$ & 4.70 & 0.10 & 93.737 & $6.821 \mathrm{E}-08$ \\
\hline $\mathrm{E}$ & 11160. & $C$ & 9.80 & 0.02 & 94.164 & $6.265 \mathrm{E}-08$ \\
\hline $\mathrm{E}$ & 11160. & A & 4.70 & 0.35 & 95.480 & $5.130 E-08$ \\
\hline $\mathrm{E}$ & 11160. & B & 7.15 & 0.06 & 96.939 & $4.484 \mathrm{E}-08$ \\
\hline$E$ & 11160. & A & 7.15 & 0.25 & 98.043 & $3.372 \mathrm{E}-08$ \\
\hline $\mathrm{E}$ & 11160. & $\mathrm{~B}$ & 9.80 & 0.02 & 99.004 & $3.271 E-08$ \\
\hline E & 11160. & B & 12.70 & 0.01 & 99.110 & $2.524 \mathrm{E}-08$ \\
\hline$E$ & 11160. & A & 9.80 & 0.10 & 99.502 & $2.460 E-08$ \\
\hline$E$ & 11160 . & A & 12.70 & 0.02 & 99.929 & $1.899 E-08$ \\
\hline$E$ & 11160 . & $\mathrm{C}$ & 12.70 & 0.00 & 100.000 & $0.000 E+00$ \\
\hline$E$ & 11160. & G & 19.00 & 0.00 & 100.000 & $0.000 \mathrm{E}+00$ \\
\hline $\mathrm{ESE}$ & 15190. & $\mathrm{G}$ & 0.89 & 0.14 & 0.372 & $2.873 E-0$ \\
\hline ESE & 15190. & $\mathrm{~F}$ & 0.89 & 0.36 & 1.702 & $1.280 \mathrm{E}-0$ \\
\hline ESE & 15190. & $\mathrm{G}$ & 2.65 & 0.69 & 4.495 & $1.090 E-0$ \\
\hline ESE & 15190. & $G$ & 4.70 & 0.84 & 8.564 & $7.102 \mathrm{E}-0$ \\
\hline ESE & 15190. & $E$ & 0.89 & 0.44 & 11.968 & $5.404 \mathrm{E}-0$ \\
\hline
\end{tabular}




\begin{tabular}{|c|c|c|c|c|c|c|}
\hline ESE & 15190. & $G$ & 7.15 & 0.01 & 13.165 & $4.829 E-06$ \\
\hline ESE & 15190. & $\mathrm{~F}$ & 2.65 & 1.69 & 17.686 & $4.617 E-06$ \\
\hline ESE & 15190. & $F$ & 4.70 & 1.60 & 26.436 & $2.860 \mathrm{E}-06$ \\
\hline $\mathrm{ESE}$ & 15190. & $\mathrm{D}$ & 0.89 & 0.44 & 31.862 & $2.261 \mathrm{E}-06$ \\
\hline ESE & 15190. & $\mathrm{~F}$ & 7.15 & 0.08 & 33.245 & $1.928 \mathrm{E} \rightarrow 06$ \\
\hline ESE & 15190. & $\mathrm{E}$ & 2.65 & 1.68 & 37.926 & $1.901 \mathrm{E}-06$ \\
\hline ESE & 15190. & $\mathrm{E}$ & 4.70 & 2.50 & 49.043 & $1.144 \mathrm{E}-06$ \\
\hline ESE & 15190. & $D$ & 2.65 & 1.09 & 58.590 & $7.760 E-07$ \\
\hline ESE & 15190. & $\mathrm{E}$ & 7.15 & 1.75 & 66.144 & $7.669 \mathrm{E}-07$ \\
\hline ESE & 15190. & $\mathrm{E}$ & 9.80 & 0.38 & 71.809 & $5.595 \mathrm{E}-07$ \\
\hline ESE & 15190. & $\mathrm{D}$ & 4.70 & 1.46 & 76.702 & $4.529 E-07$ \\
\hline ESE & 15190. & $\mathrm{E}$ & 12.70 & 0.05 & 80.718 & $4.317 \mathrm{E}-07$ \\
\hline ESE & 15190. & $\mathrm{C}$ & 0.89 & 0.04 & 80.957 & $4.114 \mathrm{E}-07$ \\
\hline ESE & 15190. & $\mathrm{D}$ & 7.15 & 1.14 & 84.096 & $3.012 \mathrm{E}-07$ \\
\hline ESE & 15190. & $\mathrm{~B}$ & 0.89 & 0.05 & 87.261 & $2.727 \mathrm{E}-07$ \\
\hline ESE & 15190. & $\mathrm{D}$ & 9.80 & 0.50 & 88.723 & $2.198 \mathrm{E}-07$ \\
\hline ESE & 15190. & A & 0.89 & 0.10 & 90.319 & $2.051 E-07$ \\
\hline ESE & 15190. & $\mathrm{D}$ & 12.70 & 0.07 & 90.771 & $1.696 \mathrm{E}-07$ \\
\hline ESE & 15190. & $\mathrm{C}$ & 2.65 & 0.10 & 91.223 & $1.382 \mathrm{E}-07$ \\
\hline ESE & 15190. & B & 2.65 & 0.09 & 91.729 & $9.158 \mathrm{E}-08$ \\
\hline ESE & 15190. & $\mathrm{C}$ & 4.70 & 0.13 & 92.314 & $7.791 \mathrm{E}-08$ \\
\hline ESE & 15190. & $\mathrm{~A}$ & 2.65 & 0.30 & 93.457 & $6.887 E-08$ \\
\hline ESE & 15190. & B & 4.70 & 0.14 & 94.628 & $5.164 \mathrm{E}-08$ \\
\hline ESE & 15190. & $\mathrm{C}$ & 7.15 & 0.07 & 95.186 & $5.121 \mathrm{E}-08$ \\
\hline ESE & 15190. & A & 4.70 & 0.35 & 96.303 & $3.883 E-08$ \\
\hline ESE & 15190. & $\mathrm{C}$ & 9.80 & 0.03 & 97.314 & $3.736 \mathrm{E}-08$ \\
\hline ESE & 15190. & $\mathrm{~B}$ & 7.15 & 0.07 & 97.580 & $3.394 \mathrm{E}-08$ \\
\hline ESE & 15190. & C & 12.70 & 0.01 & 97.793 & $2.883 E-08$ \\
\hline ESE & 15190. & A & 7.15 & 0.25 & 98.484 & $2.553 E-08$ \\
\hline ESE & 15190. & $\mathrm{~B}$ & 9.80 & 0.03 & 99.229 & $2.476 E-08$ \\
\hline ESE & 15190. & $A$ & 9.80 & 0.11 & 99.601 & $1.862 \mathrm{E}-08$ \\
\hline ESE & 15190. & A & 12.70 & 0.02 & 99.947 & $1.437 \mathrm{E}-08$ \\
\hline ESE & 15190. & G & 9.80 & 0.00 & 100.000 & $0.000 \mathrm{E}+00$ \\
\hline ESE & 15190. & G & 19.00 & 0.00 & 100.000 & $0.000 \mathrm{E}+00$ \\
\hline$S E$ & 21050. & G & 0.89 & 0.14 & 0.646 & $2.054 \mathrm{E}-05$ \\
\hline$S E$ & 21050. & $\mathrm{~F}$ & 0.89 & 0.32 & 2.770 & $8.941 E-06$ \\
\hline$S E$ & 21050. & G & 2.65 & 0.30 & 5.633 & $7.592 E-06$ \\
\hline$S E$ & 21050. & $\mathrm{G}$ & 4.70 & 0.13 & 7.618 & $4.782 E-06$ \\
\hline$S E$ & 21050. & $\mathrm{E}$ & 0.89 & 0.45 & 10.295 & $3.635 E-06$ \\
\hline $\mathrm{SE}$ & 21050. & F & 2.65 & 0.82 & 16.159 & $3.174 E-06$ \\
\hline $\mathrm{SE}$ & 21050 . & $\mathrm{F}$ & 4.70 & 0.32 & 21.422 & $1.922 \mathrm{E}-06$ \\
\hline $\mathrm{SE}$ & 21050 . & $D$ & 0.89 & 0.54 & 25.392 & 1. $430 \mathrm{E}-06$ \\
\hline $\mathrm{SE}$ & 21050. & F & 7.15 & 0.03 & 28.024 & $1.287 E-06$ \\
\hline$S E$ & 21050. & E & 2.65 & 1.11 & 33.287 & $1.265 E-06$ \\
\hline SE & 21050. & $E$ & 4.70 & 0.75 & 41.874 & $7.494 E-07$ \\
\hline SE & 21050 . & $\mathrm{E}$ & 7.15 & 0.41 & 47.230 & $4.997 \mathrm{E}-07$ \\
\hline$S E$ & 21050. & $\mathrm{D}$ & 2.65 & 1.05 & 53.970 & $4.882 \mathrm{E}-07$ \\
\hline$S E$ & 21050. & $E$ & 9.80 & 0.11 & 59.326 & $3.646 E-07$ \\
\hline$S E$ & 21050 & $\mathrm{D}$ & 4.70 & 0.84 & 63.712 & $2.825 E-07$ \\
\hline$S E$ & 21050 . & $\mathrm{E}$ & 12.70 & 0.03 & 67.729 & $2.813 E-07$ \\
\hline$S E$ & 21050 . & C & 0.89 & 0.10 & 68.329 & $2.721 E-07$ \\
\hline$S E$ & 21050. & $\mathrm{~B}$ & 0.89 & 0.07 & 69.114 & $2.031 \mathrm{E}-07$ \\
\hline$S E$ & 21050 . & $\mathrm{D}$ & 7.15 & 0.50 & 71.745 & $1.873 E-07$ \\
\hline SE & 21050. & A & 0.89 & 0.14 & 74.700 & $1.527 \mathrm{E}-07$ \\
\hline$S E$ & 21050. & $\mathrm{D}$ & 9.80 & 0.29 & 76.685 & $1.367 \mathrm{E}-07$ \\
\hline SE & 21050. & $\mathrm{D}$ & 12.70 & 0.08 & 78.393 & $1.055 \mathrm{E}-07$ \\
\hline$S E$ & 21050. & C & 2.65 & 0.19 & 79.640 & $9.138 \mathrm{E}-08$ \\
\hline$S E$ & 21050. & B & 2.65 & 0.16 & 81.256 & $6.821 \mathrm{E}-08$ \\
\hline$S E$ & 21050 . & C & 4.70 & 0.12 & 82.548 & $5.153 E-08$ \\
\hline$S E$ & 21050. & A & 2.65 & 0.42 & 85.042 & $5.130 E-08$ \\
\hline$S E$ & 21050 & B & 4.70 & 0.12 & 87.535 & $3.846 E-08$ \\
\hline $\mathrm{SE}$ & 21050 . & $\mathrm{C}$ & 7.15 & 0.06 & 88.366 & $3.387 E-08$ \\
\hline
\end{tabular}




\section{RPP-13482 REV 5}

\begin{tabular}{|c|c|c|c|c|c|c|}
\hline$S E$ & 21050 . & A & 4.70 & 0.40 & 90.489 & $2.892 \mathrm{E}-08$ \\
\hline SE & 21050 & B & 7.15 & 0.09 & 92.752 & $2.528 \mathrm{E}-08$ \\
\hline SE & 21050 . & $\mathrm{C}$ & 9.80 & 0.05 & 93.398 & $2.471 \mathrm{E}-08$ \\
\hline SE & 21050 . & $\mathrm{C}$ & 12.70 & 0.01 & 93.675 & $1.907 E-08$ \\
\hline $\mathrm{SE}$ & 21050. & A & 7.15 & 0.33 & 95.245 & $1.901 E-08$ \\
\hline SE & 22050 & B & 9.80 & 0.06 & 97.045 & $1.844 \mathrm{E}-08$ \\
\hline SE & 21050 . & B & 12.70 & 0.01 & 97.368 & $1.423 \mathrm{E}-08$ \\
\hline SE & 21050 . & A & 9.80 & 0.24 & 98.523 & $1.387 \mathrm{E}-08$ \\
\hline $\mathrm{SE}$ & 21050 . & A & 12.70 & 0.03 & 99.769 & $1.070 E-08$ \\
\hline SE & 21050. & $\dot{A}$ & 15.60 & 0.01 & 99.954 & $8.714 E-09$ \\
\hline $\mathrm{SE}$ & 21050 . & G & 9.80 & 0.00 & 100.000 & $0.000 E+00$ \\
\hline SE & 21050. & G & 19.00 & 0.00 & 100.000 & $0.000 E+00$ \\
\hline SSE & 15360 . & G & 0.89 & 0.09 & 0.941 & $2.841 E-05$ \\
\hline SSE & 15360 . & F & 0.89 & 0.23 & 4.289 & $1.264 \mathrm{E}-05$ \\
\hline SSE & 15360 . & G & 2.65 & 0.08 & 7.531 & $1.076 \mathrm{E}-05$ \\
\hline SSE & 15360 . & G & 4.70 & 0.01 & 8.473 & $7.007 E-06$ \\
\hline SSE & 15360 . & $E$ & 0.89 & 0.39 & 12.657 & $5.332 E-06$ \\
\hline SSE & 15360 . & $F$ & 2.65 & 0.25 & 19.351 & $4.559 E-06$ \\
\hline SSE & 15360. & $F$ & 4.70 & 0.06 & 22.594 & $2.822 E-06$ \\
\hline SSE & 15360 . & D & 0.89 & 0.55 & 28.975 & $2.226 E-06$ \\
\hline SSE & 15360. & E & 2.65 & 0.39 & 38.808 & $1.875 E-06$ \\
\hline SSE & 15360. & $E$ & 4.70 & 0.13 & 44.247 & $1.128 \mathrm{E}-06$ \\
\hline SSE & 15360 . & $\mathrm{D}$ & 2.65 & 0.77 & 53.661 & $7.638 \mathrm{E}-07$ \\
\hline$S S E$ & 15360. & $E$ & 7.15 & 0.02 & 61.925 & $7.557 \mathrm{E}-07$ \\
\hline SSE & 15360. & $\mathrm{D}$ & 4.70 & 0.21 & 64.331 & $4.457 E-07$ \\
\hline SSE & 15360. & $\mathrm{C}$ & 0.89 & 0.10 & 67.573 & $4.046 E-07$ \\
\hline SSE & 15360. & D & 7.15 & 0.05 & 69.142 & $2.963 E-07$ \\
\hline SSE & 15360 . & B & 0.89 & 0.10 & 70.711 & $2.700 E-07$ \\
\hline SSE & 15360. & D & 9.80 & 0.01 & 71.862 & $2.162 \mathrm{E}-07$ \\
\hline SSE & 15360. & A & 0.89 & 0.22 & 74.268 & $2.030 \mathrm{E}-07$ \\
\hline SSE & 15360. & $\mathrm{C}$ & 2.65 & 0.15 & 78.138 & $1.359 E-07$ \\
\hline SSE & 15360 . & B & 2.65 & 0.16 & 81.381 & $9.066 E-08$ \\
\hline SSE & 15360. & $\mathrm{C}$ & 4.70 & 0.03 & 83.368 & $7.662 \mathrm{E}-08$ \\
\hline SSE & 15360. & A & 2.65 & 0.48 & 88.703 & $6.818 E-08$ \\
\hline SSE & 15360 . & B & 4.70 & 0.06 & 94.351 & $5.112 E-08$ \\
\hline SSE & 15360. & $\mathrm{C}$ & 7.15 & 0.01 & 95.084 & $5.036 \mathrm{E}-08$ \\
\hline$S S E$ & 15360. & A & 4.70 & 0.17 & 96.967 & $3.844 E-08$ \\
\hline SSE & 15360. & B & 7.15 & 0.01 & 98.849 & $3.360 E-08$ \\
\hline SSE & 15360. & A & 7.15 & 0.05 & 99.477 & $2.527 E-08$ \\
\hline SSE & 15360. & G & 7.15 & 0.00 & 100.000 & $0.000 E+00$ \\
\hline SSE & 15360. & G & 19.00 & 0.00 & 100.000 & $0.000 E+00$ \\
\hline
\end{tabular}




\section{RPP-13482 REV 5}

This page intentionally left blank. 
RPP-13482 REV 5

APPENDIX F

GXQ CDF OUTPUT FOR PUFF RELEASE 
RPP-13482 REV 5

This page intentionally left blank.

F-ii 
APPENDIX F

\section{GXQ CDF OUTPUT FOR PUFF RELEASE}

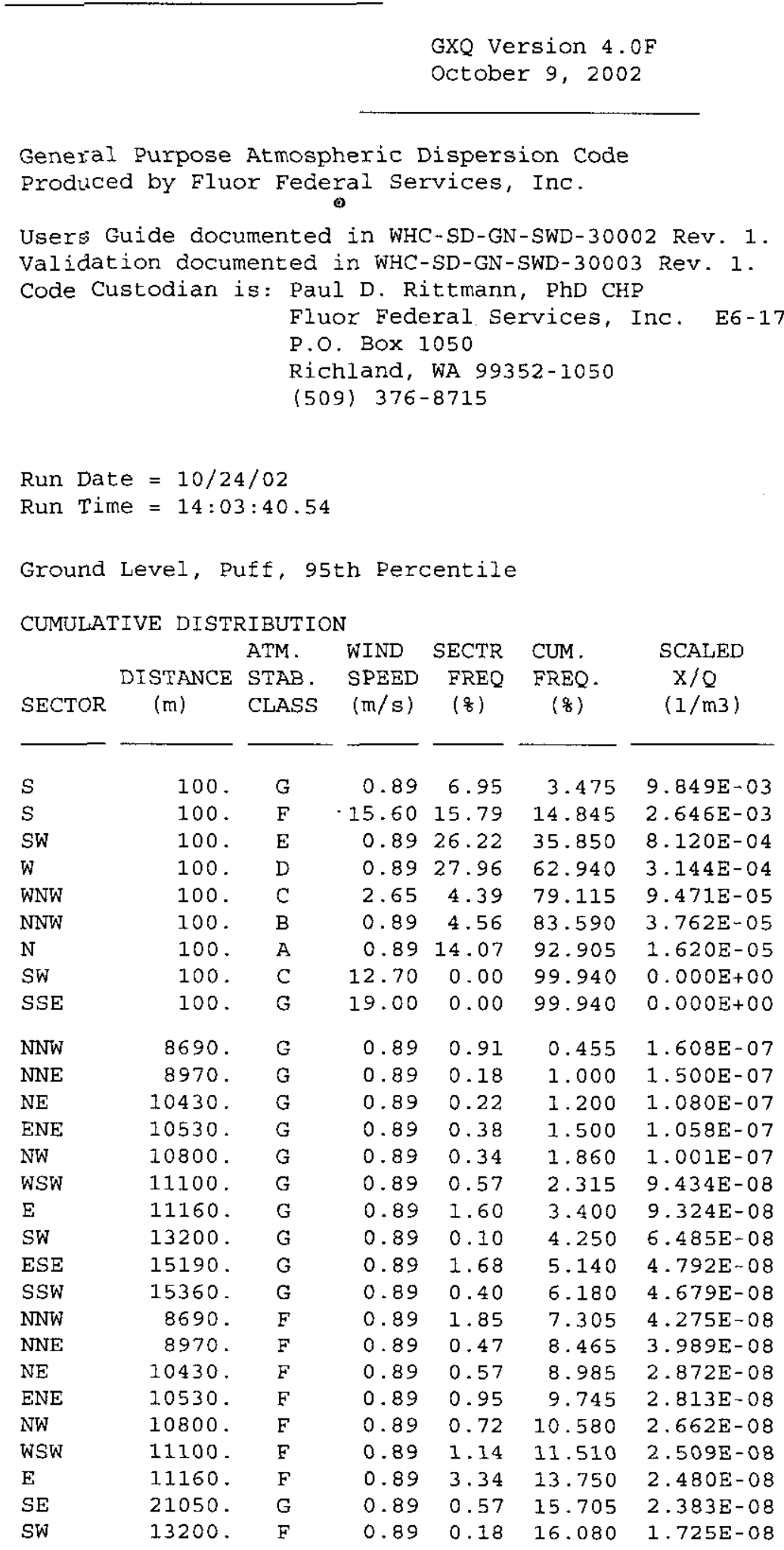


RPP-13482 REV 5

\begin{tabular}{|c|c|c|c|c|c|c|}
\hline ESE & 15190. & F & 0.89 & 3.73 & 18.035 & $1.275 \mathrm{E}-08$ \\
\hline SSW & 15360 . & F & 15.60 & 1.35 & 20.575 & 1. $244 \mathrm{E}-08$ \\
\hline $\mathrm{NNW}$ & 8690 & $E$ & 0.89 & 2.22 & 22.360 & $1.221 \mathrm{E}-08$ \\
\hline NNE & 8970 & $E$ & 0.89 & 0.68 & 23.810 & $1.137 E-08$ \\
\hline $\mathrm{NE}$ & 10430. & $E$ & 0.89 & 1.05 & 24.675 & $8.100 E-09$ \\
\hline ENE & 10530. & $E$ & 0.89 & 1.63 & 26.015 & $7.929 E-09$ \\
\hline NW & 10800. & $E$ & 0.89 & 0.94 & 27.300 & $7.491 E-09$ \\
\hline WSW & 11100. & $E$ & 0.89 & 1.96 & 28.750 & $7.046 \mathrm{E}-09$ \\
\hline $\mathrm{E}$ & 11160. & $E$ & 0.89 & 4.77 & 32.115 & $6.961 E-09$ \\
\hline SE & 21050 . & $\mathrm{F}$ & 0.89 & 1.49 & 35.245 & $6.338 E-09$ \\
\hline SW & 13200. & $\mathrm{E}$ & 9.80 & 0.46 & 36.220 & $4.784 \mathrm{E}-09$ \\
\hline NNW & 8690 & $D$ & 0.89 & 2.17 & 37.535 & $3.670 \mathrm{E}-09$ \\
\hline ESE & 15190. & $E$ & 0.89 & 6.80 & 42.020 & $3.500 E-09$ \\
\hline SSW & 15360 . & $\mathrm{E}$ & 4.70 & 2.85 & 46.845 & $3.414 \mathrm{E}-09$ \\
\hline $\mathrm{NNE}$ & 8970. & $D$ & 0.89 & 0.70 & 48.620 & $3.404 E-09$ \\
\hline $\mathrm{NE}$ & 10430 . & $D$ & 0.89 & 1.21 & 49.575 & $2.379 E-09$ \\
\hline ENE & 10530. & D & 0.89 & 1.58 & 50.970 & $2.326 \mathrm{E}-09$ \\
\hline $\mathrm{NW}$ & 10800 . & $D$ & 0.89 & 1.46 & 52.490 & $2.191 E-09$ \\
\hline W & 11100. & $\mathrm{D}$ & 0.89 & 3.71 & 55.075 & $2.053 \mathrm{E}-09$ \\
\hline $\mathrm{E}$ & 11160. & $D$ & 0.89 & 2.68 & 58.270 & $2.027 E-09$ \\
\hline$S E$ & 21050. & $\mathrm{E}$ & 0.89 & 2.86 & 61.040 & $1.699 E-09$ \\
\hline SW & 13200 . & $D$ & 7.15 & 1.12 & 63.030 & $1.362 \mathrm{E}-09$ \\
\hline ESE & 15190. & $D$ & 0.89 & 4.70 & 65.940 & $9.774 \mathrm{E}-10$ \\
\hline SSW & 15360 . & $D$ & 4.70 & 5.33 & 70.955 & $9.521 \mathrm{E}-10$ \\
\hline NNW & 8690 & C & 0.89 & 0.37 & 73.805 & $5.102 \mathrm{E}-10$ \\
\hline NNE & 8970 & $C$ & 0.89 & 0.07 & 74.025 & $4.681 \mathrm{E}-10$ \\
\hline$S E$ & 21050 . & $D$ & 0.89 & 3.30 & 75.710 & $4.528 E-10$ \\
\hline $\mathrm{NE}$ & 10430 . & $C$ & 0.89 & 0.14 & 77.430 & $3.110 E-10$ \\
\hline ENE & 10530. & C & 0.89 & 0.27 & 77.635 & $3.031 E-10$ \\
\hline NW & 10800. & $\mathrm{C}$ & 0.89 & 0.29 & 77.915 & $2.831 \mathrm{E}-10$ \\
\hline WNW & 11100. & $C$ & 0.89 & 0.76 & 78.440 & $2.630 \mathrm{E}-10$ \\
\hline $\mathrm{E}$ & 11160. & $C$ & 0.89 & 0.29 & 78.965 & $2.592 E-10$ \\
\hline SW & 13200. & $C$ & 7.15 & 0.19 & 79.205 & $1.663 E-10$ \\
\hline NNW & 8690 & B & 0.89 & 0.36 & 79.480 & $1.619 \mathrm{E}-10$ \\
\hline $\mathrm{NNE}$ & 8970 & $B$ & 0.89 & 0.09 & 79.705 & $1.525 \mathrm{E}-10$ \\
\hline ESE & 15190. & $c$ & 0.89 & 0.38 & 79.940 & $1.170 \mathrm{E}-10$ \\
\hline $\mathrm{NE}$ & 10430 . & $B$ & 0.89 & 0.16 & 80.210 & 1. $16 I E-10$ \\
\hline ENE & 10530. & $B$ & 0.89 & 0.29 & 80.435 & $1.142 \mathrm{E}-10$ \\
\hline SSW & 15360 . & $\mathrm{C}$ & 19.00 & 1.10 & 81.130 & $1.139 E-10$ \\
\hline NW & 10800. & B & 0.89 & 0.24 & 81.800 & $1.091 \mathrm{E}-10$ \\
\hline WNW & 11100. & B & 0.89 & 0.81 & 82.325 & $1.038 \mathrm{E}-10$ \\
\hline $\mathrm{E}$ & 11160. & $\mathrm{~B}$ & 0.89 & 0.30 & 82.880 & $1.028 \mathrm{E}-10$ \\
\hline NNW & 8690 & A & 4.70 & 1.06 & 83.560 & $9.134 \mathrm{E}-11$ \\
\hline $\mathrm{NNE}$ & 8970 & A & 0.89 & 0.30 & 84.240 & $8.625 E-11$ \\
\hline SW & 13200 . & B & 0.89 & 0.20 & 84.490 & $7.590 \mathrm{E}-11$ \\
\hline $\mathrm{NE}$ & 10430 . & A & 0.89 & 0.55 & 84.865 & $6.569 E-11$ \\
\hline ENE & 10530 . & $A$ & 0.89 & 1.07 & 85.675 & $6.457 E-11$ \\
\hline $\mathrm{NW}$ & 10800 . & A & 0.89 & 0.73 & 86.575 & $6.168 \mathrm{E}-11$ \\
\hline ESE & 15190. & B & 0.89 & 0.38 & 87.130 & $5.890 E-11$ \\
\hline WSW & 11100. & $A$ & 0.89 & 2.55 & 88.595 & $5.870 \mathrm{E}-11$ \\
\hline $\mathrm{E}$ & 11160 . & A & 0.89 & 1.07 & 90.405 & $5.813 E-11$ \\
\hline$S$ & 15360. & $B$ & 19.00 & 1.22 & 91.550 & $5.772 \mathrm{E}-11$ \\
\hline$S E$ & 21050. & $C$ & 0.89 & 0.53 & 92.425 & $5.764 \mathrm{E}-1$ \\
\hline SW & 13200 . & A & 0.89 & 0.68 & 93.030 & $4.293 \mathrm{E}-11$ \\
\hline ESE & 15190. & $A$ & 0.89 & 1.13 & 93.935 & $3.331 \mathrm{E}-1$ \\
\hline $\mathrm{SE}$ & 21050 & $\mathrm{~B}$ & 0.89 & 0.51 & 94.755 & $3.267 \mathrm{E}-1$ \\
\hline S & 15360 . & A & 2.65 & 3.36 & 96.690 & $3.265 E-11$ \\
\hline$S E$ & 21050 & A & 0.89 & 1.57 & 99.155 & $1.848 \mathrm{E}-1$ \\
\hline $\mathrm{N}$ & 8690 & $A$ & 19.00 & 0.00 & 99.940 & $0.000 E+0$ \\
\hline SSE & 15360. & G & 19.00 & 0.00 & 99.940 & $0.000 E+0$ \\
\hline
\end{tabular}




\section{RPP-13482 REV 5}

\section{APPENDIX G}

\section{SPECIAL $\chi / Q ' S$ FOR THERMALLY LOFTED RELEASES}

AND DISPLACED VOLUMES 
RPP-13482 REV 5

This page intentionally left blank.

G-ii 


\section{APPENDIX G \\ SPECIAL $\chi / Q ' S$ FOR THERMALLY LOFTED RELEASES AND DISPLACED VOLUMES}

\section{G.1 SPECIAL THERMALLY LOFTED RELEASE $\chi / Q ' S$ FOR FIRE IN PIT}

A series of thermally lofted release $\chi / Q$ 's were calculated for a fire in a pit. These scenarios were developed in RPP-13354, Technical Basis for the Release from Contaminated Facility Representative Accident and Associated Represented Hazardous Conditions, and are summarized here. The pit cover was assumed to be removed (otherwise the fire would selfextinguish). Two cases were required: (1) a gasoline spill into the pit, and (2) a fire involving wood and miscellaneous flammable solids. The gasoline fires have defined areas (1 and $2 \mathrm{~m}$ radii) with a specified sensible heat rate per unit area. The wood $/ \mathrm{miscellaneous} \mathrm{fire} \mathrm{was} \mathrm{assumed}$ to cover the bottom of the pit. The pit area is $10 \mathrm{ft}$ by $12 \mathrm{ft}$ with an equivalent diameter of $3.77 \mathrm{~m}$ (circle with same area). A range of total heat rates was specified for the wood/miscellaneous fire. Wind speed was adjusted for plume height. Initial air entrainment due to plume turbulence including ground effect was included. The release was assumed to be from ground level with thermal lofting depending on the fire heat rate. Receptor height was set at $2 \mathrm{~m}$. The fires were conservatively assumed to be of short duration ( $<1 \mathrm{hr})$ so 1 -hr $\chi /$ Q's (i.e., without plume meander effects) were used. The results follow; a corresponding sample GXQ run file is included as Attachment G1.

Table G-1. 1-hr $\chi / Q$ 's for Ground Level Releases From Fire In Pit with Thermal Lofting.

\begin{tabular}{|l|c|c|c|c|}
\hline \multirow{2}{*}{ Fuel type } & \multirow{2}{*}{ Heat rate (MW) } & \multirow{2}{*}{ Fire diameter (m) } & \multicolumn{2}{|c|}{$\chi / \mathbf{Q}^{\prime}\left(\mathbf{s} / \mathbf{m}^{\mathbf{3}}\right)$} \\
\cline { 3 - 5 } & & & Onsite & Offsite \\
\hline \multirow{2}{*}{ Gasoline } & 6.8 & 2.0 & $6.55 \mathrm{E}-5$ & $3.74 \mathrm{E}-6$ \\
\hline \multirow{2}{*}{$\begin{array}{l}\text { Wood/ } \\
\text { miscellaneous }\end{array}$} & 27.1 & 4.0 & $2.27 \mathrm{E}-5$ & $1.18 \mathrm{E}-6$ \\
\cline { 2 - 5 } & 1.0 & 3.77 & $6.32 \mathrm{E}-4$ & $1.03 \mathrm{E}-5$ \\
\hline
\end{tabular}

Note:

$\mathrm{MW}=$ Mega Watt.

\section{G.2 SPECIAL $\chi / Q$ 'S FOR DISPLACED VOLUME RATES OUT OF PIT}

A series of $\chi / Q$ 's were calculated for a flammable gas deflagration in a pit and a load drop into a pit. These scenarios were developed in RPP-13354 and are summarized here. Both of these cases involved a fast $(<60 \mathrm{sec})$ displacement of air out of the pit. These were considered to be ground level releases with no thermal lofting, but with credit taken for the initial dilution caused by the expulsion of air out of the pit. The pit volume was specified to be $10 \mathrm{ft}$ by $12 \mathrm{ft}$ by $6 \mathrm{ft}$ deep $=720 \mathrm{ft}^{3}\left(20.4 \mathrm{~m}^{3}\right)$. In addition, volumes of $500 \mathrm{ft}^{3}\left(14.2 \mathrm{~m}^{3}\right)$ and $1,000 \mathrm{ft}^{3}\left(28.3 \mathrm{~m}^{3}\right)$ were evaluated as a sensitivity study. One pit volume was assumed to be pushed out of the pit in $60 \mathrm{sec}$. This release time is conservative if the actual release time is less than $60 \mathrm{sec}$. No credit was taken for any momentum rise effects. These are short duration $(<60 \mathrm{sec})$ releases so 
1-hr $\chi /$ Q's (i.e., without plume meander effects) were used. The results follow; a corresponding sample GXQ run file is included as Attachment G2.

Table G-2. 1-hr $\chi /$ Q's for Ground Level Initial Volume Displaced Releases From Pit.

\begin{tabular}{|c|c|c|c|c|}
\hline \multicolumn{2}{|c|}{ Displaced volume } & \multirow{2}{*}{$\begin{array}{l}\text { Volume rate } \\
\left(\mathrm{m}^{3} / \mathrm{s}\right)\end{array}$} & \multicolumn{2}{|c|}{$\chi / Q^{\prime}\left(s / m^{3}\right)$} \\
\hline$\left(\mathrm{ft}^{3}\right)$ & $\left(\mathrm{m}^{3}\right)$ & & Onsite & Offsite \\
\hline 500 & 14.2 & 0.237 & $2.95 \mathrm{E}-2$ & $2.22 \mathrm{E}-5$ \\
\hline 720 & 20.4 & 0.340 & $2.89 \mathrm{E}-2$ & $2.22 \mathrm{E}-5$ \\
\hline 1000 & 28.3 & 0.472 & $2.81 \mathrm{E}-2$ & $2.22 \mathrm{E}-5$ \\
\hline
\end{tabular}

\section{G.3 SPECIAL $\chi / Q$ 'S FOR DISPLACED VOLUME RATES OUT OF TANK DUE TO DOME COLLAPSE}

A series of $\chi / Q$ 's were calculated for the tank dome collapse scenario for both single-shell tanks (SST) and double-shell tanks (DST). These scenarios were developed in RPP-12444, Technical Basis for the Tank Failure Due to Excessive Loads Representative Accident and Associated Represented Hazardous Conditions, and are summarized here. Both cases involved a fast $(<60 \mathrm{sec})$ displacement of air out of the tank headspace. These were considered to be ground level releases, but with credit taken for the initial dilution caused by the expulsion of air out of the tank.

SST dome collapse. Displaced volume of air from tank headspace was specified to be 52,000 gal $\left(197 \mathrm{~m}^{3}\right)$ corresponding to the volume of material falling into tank. Twice this displaced volume $\left(394 \mathrm{~m}^{3}\right)$ was also evaluated as a sensitivity study. The displaced volume was assumed to be pushed out of the tank through an opening with a $10-\mathrm{ft}$ radius $(6.10-\mathrm{m}$ diameter $)$ in $60 \mathrm{sec}$. This release time is conservative if the actual release time is less than $60 \mathrm{sec}$. Initial plume width was set at $6.10 \mathrm{~m}$. No credit was taken for any momentum rise effects.

DST dome collapse. Displaced volume of air from tank headspace was specified to be $62,000 \mathrm{gal}\left(235 \mathrm{~m}^{3}\right)$ corresponding to the volume of material falling into tank. Twice this displaced volume $\left(469 \mathrm{~m}^{3}\right)$ was also evaluated as a sensitivity study. The displaced volume was assumed to be pushed out of the tank through an opening with a 10 -ft radius $(6.10-\mathrm{m}$ diameter) in $60 \mathrm{sec}$. This release time is conservative if the actual release time is less than $60 \mathrm{sec}$. Initial plume width was set at $6.10 \mathrm{~m}$. No credit was taken for any momentum rise effects.

These are short duration $(<60 \mathrm{sec}$ ) releases so 1 -hr $\chi / Q$ 's (i.e., without plume meander effects) were used. The results for both the SST and DST cases follow; a corresponding sample GXQ run file is included as Attachment G3. 


\section{RPP-13482 REV 5}

Table G-3. 1-hr $\chi /$ Q's for Ground Level Initial Volume Displaced Releases From Tank Dome Collapse.

\begin{tabular}{|c|c|c|c|c|}
\hline \multirow{2}{*}{ Tank type } & \multirow{2}{*}{$\begin{array}{l}\text { Displaced volume } \\
\qquad\left(\mathrm{m}^{3}\right)\end{array}$} & \multirow{2}{*}{$\begin{array}{l}\text { Volume rate } \\
\left(\mathrm{m}^{3} / \mathrm{s}\right)\end{array}$} & \multicolumn{2}{|c|}{$\chi / Q^{\prime}\left(s / m^{3}\right)$} \\
\hline & & & Onsite & Offsite \\
\hline \multirow{2}{*}{ SST } & 197 & 3.28 & $1.98 \mathrm{E}-2$ & $2.21 \mathrm{E}-5$ \\
\hline & 394 & 6.56 & $1.79 \mathrm{E}-2$ & $2.21 \mathrm{E}-5$ \\
\hline \multirow{2}{*}{ DST } & 235 & 3.91 & $1.94 \mathrm{E}-2$ & $2.21 \mathrm{E}-5$ \\
\hline & 469 & 7.82 & $1.68 \mathrm{E}-2$ & $2.21 \mathrm{E}-5$ \\
\hline
\end{tabular}

Notes:

DST $=$ double-shell tank.

SST $=$ single-shell tank.

\section{References}

RPP-12444, 2003, Technical Basis for the Tank Failure Due to Excessive Loads Representative Accident and Associated Represented Hazardous Conditions, Rev. 1, CH2M HILL Hanford Group, Inc., Richland, Washington.

RPP-13354, 2003, Technical Basis for the Release from Contaminated Facility Representative Accident and Associated Represented Hazardous Conditions, Rev. 1, CH2M HILL Hanford Group, Inc., Richland, Washington. 
RPP-13482 REV 5

\section{ATTACHMENT G1}

\section{SAMPLE GXQ RUN FILE FOR RESULTS IN TABLE G-1 LOFTED RELEASE FROM FIRE IN PIT}

- Wood/Miscellaneous fire (heat rate $4.0 \mathrm{MW}$ - fire diameter $3.77 \mathrm{~m}$ ) 


\section{RPP-13482 REV 5}

Current Input File Name: obergl. IN

GXQ Version $4.0 \mathrm{~F}$

October 9, 2002

General Purpose Atmospheric Dispersion Code

Produced by Fluor Federal Services, Inc.

Users Guide documented in WHC-SD-GN-SWD-30002 Rev. 1.

Validation documented in WHC-SD-GN-SWD-30003 Rev. 1.

Code Custodian is: Paul D. Rittmann, PhD CHP

Fluor Federal Services, Inc. E6-17

P.O. Box 1050

Richland, WA 99352-1050

(509) 376-8715

Run Date $=12 / 26 / 02$

Run Time $=14: 45: 39.92$

INPUT ECHO:

Tank Farms - 95\% all sectors - 1 hour - Case 1 - fire in pit

c GXQ Version 4.0 Input File

C mode

1

$\mathrm{C}$

C MODE CHOICE:

$C$ mode $=1$ then $X / Q$ based on Hanford site specific meteorology

$\mathrm{c}$ mode $=2$ then $\mathrm{X} / \mathrm{Q}$ based on atmospheric stability class and wind speed

$c$ mode $=3$ then $X / Q$ plot file is created

c.

C LOGICAL CHOICES:

C ifox inorm icdf ichk isite ipop

$\begin{array}{llllll}T & F & F & F & T & F\end{array}$

$c$ ifox $=t$ then joint frequency used to compute frequency to exceed $X / Q$

$c=f$ then joint frequency used to compute annual average $\mathrm{X} / \mathrm{Q}$

$c$ inorm $=t$ then joint frequency data is normalized (as in GENII)

c $= \pm$ then joint frequency data is un-normalized

$\mathrm{c}$ icdf $=t$ then cumulative distribution file created (CDF.OUT)

$c \quad=f$ then no cumulative distribution file created

$\mathrm{c}$ ichk $=t$ then $\mathrm{X} / \mathrm{Q}$ parameter print option turned on

$C \quad \Rightarrow \quad E$ then no parameter print

$c$ isite $=t$ then $X / Q$ based on joint frequency data for all 16 sectors

$c=f$ then $X / Q$ based on joint frequency data of individual sectors

$c$ ipop $=t$ then $X / Q$ is population weighted

$\mathrm{C} \quad \mathrm{f}$ then no population weighting

C X/Q AND WIND SPEED ADJUSTMENT MODELS:

C ipuff idep isrc iwind

$\begin{array}{llll}0 & 0 & 0 & 1\end{array}$

C DIFFUSION COEFFICIENT ADJUSTMENT MODELS:

C iwake ipm iflow ientr

$0 \quad 0 \quad 0 \quad 1$

c EFFECTIVE RELEASE HEIGHT ADJUSTMENT MODELS:

C (irise igrnd) iwash igrav

$\begin{array}{llll}1 & 1 & 0 & 0\end{array}$

$c$ ipuff $=1$ then $X / Q$ calculated using puff model

$c \quad=0$ then $X / Q$ calculated using default continuous plume model 


\section{RPP-13482 REV 5}

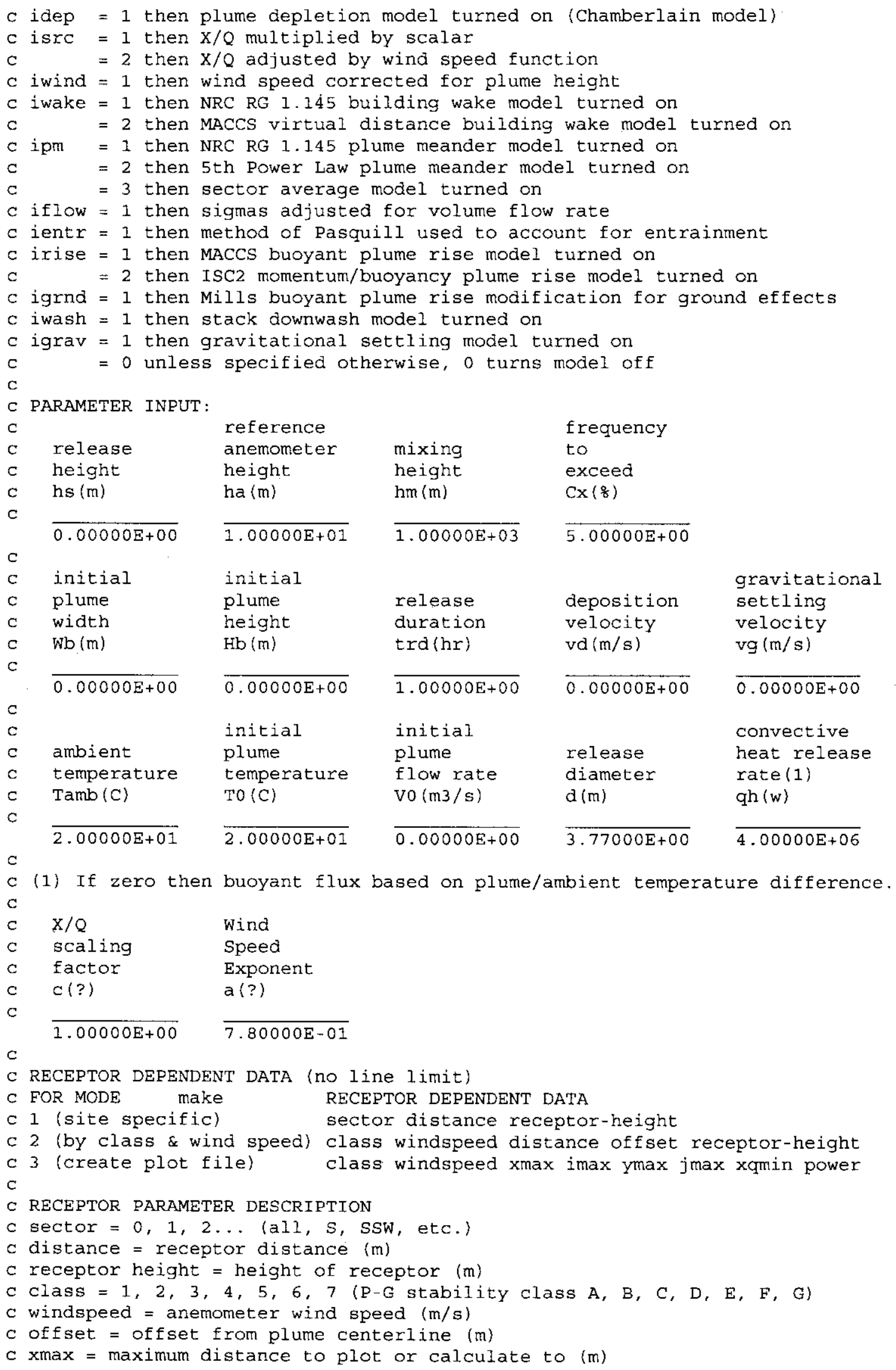




\section{RPP-13482 REV 5}

c imax = distance intervals

$c y \max =$ maximum offset to plot (m)

c $j \max =$ offset intervals

c xqmin $=$ minimum scaled $\mathrm{X} / \mathrm{Q}$ to calculate

$c$ power $=$ exponent in power function step size

MODE :

Site specific $X / Q$ calculated.

LOGICAL CHOICES :

Joint frequency used to calculate $X / Q$ based on frequency of exceedance.

No normalization of joint frequency.

$\mathrm{X} / \mathrm{Q}$ calculated for overall site.

MODELS SELECTED:

Time-integrated air concentration calculated (s/m3) .

Plume rise air entrainment model selected.

MACCS buoyancy plume rise model based on convective heat.

Mills buoyant rise modification for pool fire selected.

Wind velocity corrected for average plume height.

WARNING/ERROR MESSAGES :

JOINT FREQUENCY DATA:

200 AREA (HMS) - 10 M - Pasquill A - G (1983 - 1991 Average)

Created $8 / 26 / 92 \mathrm{KR}$

Tank Farms - 95\% al1 sectors - 1 hour - Case 1 - fire in pit

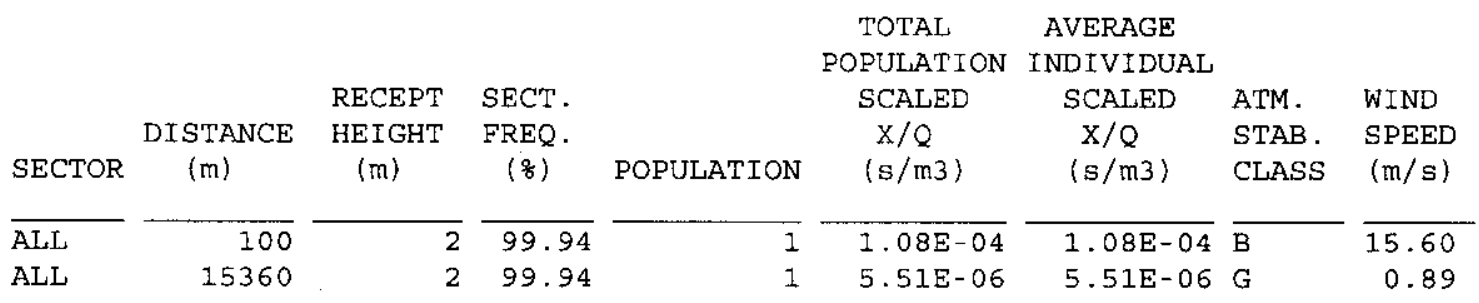


RPP-13482 REV 5

ATTACHMENT G2

\section{SAMPLE GXQ RUN FILE FOR RESULTS IN TABLE G-2 DISPLACED VOLUME RELEASES FROM PIT}

- Flammable Gas Deflagration or Load Drop (displaced volume rate $20.4 \mathrm{~m}^{3} / 60 \mathrm{sec}$ ) 
RPP-13482 REV 5

Current Input File Name: oberg2.IN

GXQ Version $4.0 \mathrm{~F}$

October 9, 2002

General Purpose Atmospheric Dispersion Code Produced by Fluor Federal Services, Inc.

Users Guide documented in WHC-SD-GN-SWD-30002 Rev. 1. Validation documentea in WHC-SD-GN-SWD-30003 Rev. 1.

Code Custodian is: Paul D. Rittmann, PhD CHP

Fluor Federal Services, Inc. E6-17

P.O. Box 1050

Richland, WA 99352-1050

(509) $376-8715$

Run Date $=02 / 20 / 03$

Run Time $=10: 49: 52 \cdot 10^{\circ}$

INPUT ECHO:

Tank Farms - 958 all sectors - 1 hour - release from pit

C GXQ Version 4.0 Input File

C mode

$$
1
$$

$\mathrm{C}$

C MODE CHOICE:

$c$ mode $=1$ then $X / Q$ based on Hanford site specific meteorology

$C$ mode $=2$ then $X / Q$ based on atmospheric stability class and wind speed

$c$ mode $=3$ then $X / Q$ plot file is created

$\mathrm{c}$

C LOGICAL CHOICES:

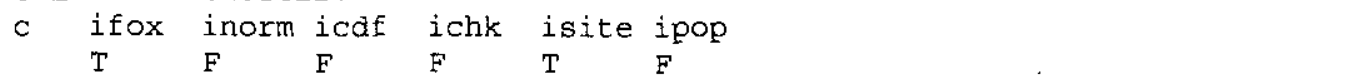

$c$ ifox $=t$ then joint frequency used to compute frequency to exceed $X / Q$

$\mathrm{c} \quad \mathrm{f}$ then joint frequency used to compute annual average $\mathrm{X} / \mathrm{Q}$

$c$ inorm $=t$ then joint Erequency data is normalized (as in GENII)

c $\quad=f$ then joint frequency data is un-normalized

$c$ icdf $=t$ then cumulative distribution file created (CDF.OUT)

$C=f$ then no cumulative distribution file created

c ichk $=t$ then $X / Q$ parameter print option turned on

$\mathrm{C} \quad \mathrm{f}$ then no parameter print

$\mathrm{C}$ isite $=\mathrm{t}$ then $\mathrm{X} / \mathrm{Q}$ based on joint frequency data for all 16 sectors

$\mathrm{c}=\mathrm{f}$ then $\mathrm{X} / \mathrm{Q}$ based on joint frequency data of individual sectors

ipop $=t$ then $X / Q$ is population weighted

$c=f$ then no population weighting

c

C $\mathrm{X} / \mathrm{Q}$ AND WIND SPEED ADJUSTMENT MODELS:

C ipuff idep isrc iwind

$$
\begin{array}{llll}
0 & 0 & 0 & 0
\end{array}
$$

C DIFFUSION COEFFICIENT ADJUSTMENT MODELS:

C iwake ipm iflow ientr

$$
0000
$$

C EFFECTIVE RELEASE HEIGHT ADJUSTMENT MODELS:

C (irise igrnd) iwash igrav

$$
0 \quad 0 \quad 000
$$

c ipuff $=1$ then $X / Q$ calculated using puff model

$c=0$ then $X / Q$ calculated using default continuous plume model 


\section{RPP-13482 REV 5}

c imax = distance intervals

c $y \max =$ maximum off set to plot (m)

c $j \max =$ offset intervals

c $x q m i n=$ minimum scaled $x / Q$ to calculate

$c$ power $=$ exponent in power function step size

MODE :

Site specific $X / Q$ calculated.

LOGICAL CHOICES :

Joint frequency used to calculate $X / Q$ based on frequency of exceedance.

No normalization of joint frequency.

$\mathrm{X} / \mathrm{Q}$ calculated for overall site.

MODELS SELECTED:

Time-integrated air concentration calculated (s/m3) .

Flow rate adjustment model.

WARNING/ERROR MESSAGES :

JOINT FREQUENCY DATA:

200 AREA (HMS) - 10 M - Pasquill A - G (1983 - 1991 Average)

Created $8 / 26 / 92 \mathrm{KR}$

Tank Farms - $95 \%$ all sectors - 1 hour - release from pit

\begin{tabular}{|c|c|c|c|c|c|c|c|c|}
\hline & & & & & $\begin{array}{c}\text { TOTAL } \\
\text { POPULATION }\end{array}$ & $\begin{array}{l}\text { AVERAGE } \\
\text { INDIVIDUAL }\end{array}$ & & \\
\hline SECTOR & $\begin{array}{l}\text { DISTANCE } \\
(\mathrm{m})\end{array}$ & $\begin{array}{l}\text { RECEPT } \\
\text { HEIGHT } \\
(\mathrm{m})\end{array}$ & $\begin{array}{c}\text { SECT. } \\
\text { FREQ. } \\
(\%)\end{array}$ & POPULATION & $\begin{array}{c}\text { SCALED } \\
\mathrm{X} / \mathrm{Q} \\
(\mathrm{s} / \mathrm{m} 3)\end{array}$ & $\begin{array}{c}\text { SCALED } \\
X / Q \\
(\mathrm{~s} / \mathrm{m} 3)\end{array}$ & $\begin{array}{l}\text { ATM. } \\
\text { STAB. } \\
\text { CLASS }\end{array}$ & $\begin{array}{l}\text { WIND } \\
\text { SPEED } \\
(\mathrm{m} / \mathrm{s})\end{array}$ \\
\hline ALI & 100 & $\overline{0}$ & 99.94 & 1 & $2.89 \mathrm{E}-02$ & $2.89 \mathrm{E}-02$ & $F$ & 0.89 \\
\hline ALI & 15360 & 0 & 99.94 & 1 & $2.22 \mathrm{E}-05$ & $2.22 \mathrm{E}-05$ & $\mathrm{~F}$ & 0.89 \\
\hline
\end{tabular}


RPP-13482 REV 5

ATTACHMENT G3

SAMPLE GXQ RUN FILE FOR RESULTS IN TABLE G-3

DISPLACED VOLUME RELEASES FROM TANK DUE TO DOME COLLAPSE

- DST Dome Collapse (displaced volume rate $469 \mathrm{~m}^{3} / 60 \mathrm{sec}$ ) 
Current Input File Name: oberg 3. IN

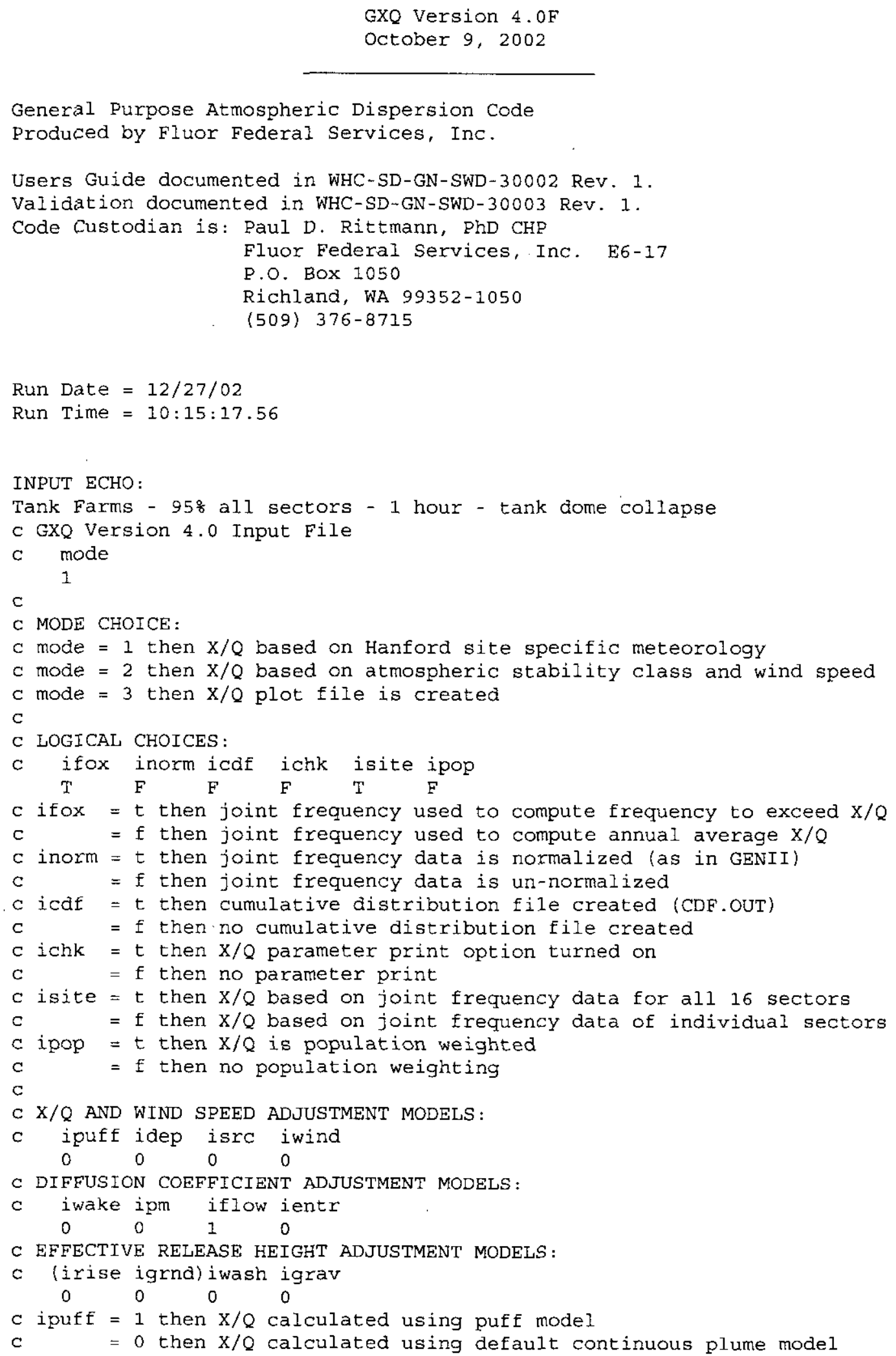


$\mathrm{C}$ idep $=1$ then plume depletion model turned on (Chamberlain model)

$c$ isrc $=1$ then $\mathrm{X} / \mathrm{Q}$ multiplied by scalar

$\mathrm{c} \quad=2$ then $\mathrm{X} / \mathrm{Q}$ adjusted by wind speed function

$\mathrm{c}$ iwind $=1$ then wind speed corrected for plume height

c iwake $=1$ then NRC RG 1.145 building wake model turned on

C $=2$ then MACCS virtual distance building wake model turned on

c ipm $=1$ then NRC RG 1.145 plume meander model turned on

$\mathrm{C}=2$ then 5 th Power Law plume meander model turned on

$c=3$ then sector average model turned on

iflow $=1$ then sigmas adjusted for volume flow rate

$c$ ientr $=1$ then method of Pasquill used to account for entrainment

$c$ irise $=1$ then MACCS buoyant plume rise model turned on

$\mathrm{C} \quad=2$ then ISC2 momentum/buoyancy plume rise model turned on

$c$ igrnd $=1$ then Mills buoyant plume rise modification for ground effects

c $i$ wash $=1$ then stack downwash model turned on

c igrav $=I$ then gravitational settling model turned on

$c=0$ unless specified otherwise, 0 turns model off

PARAMETER INPUT:

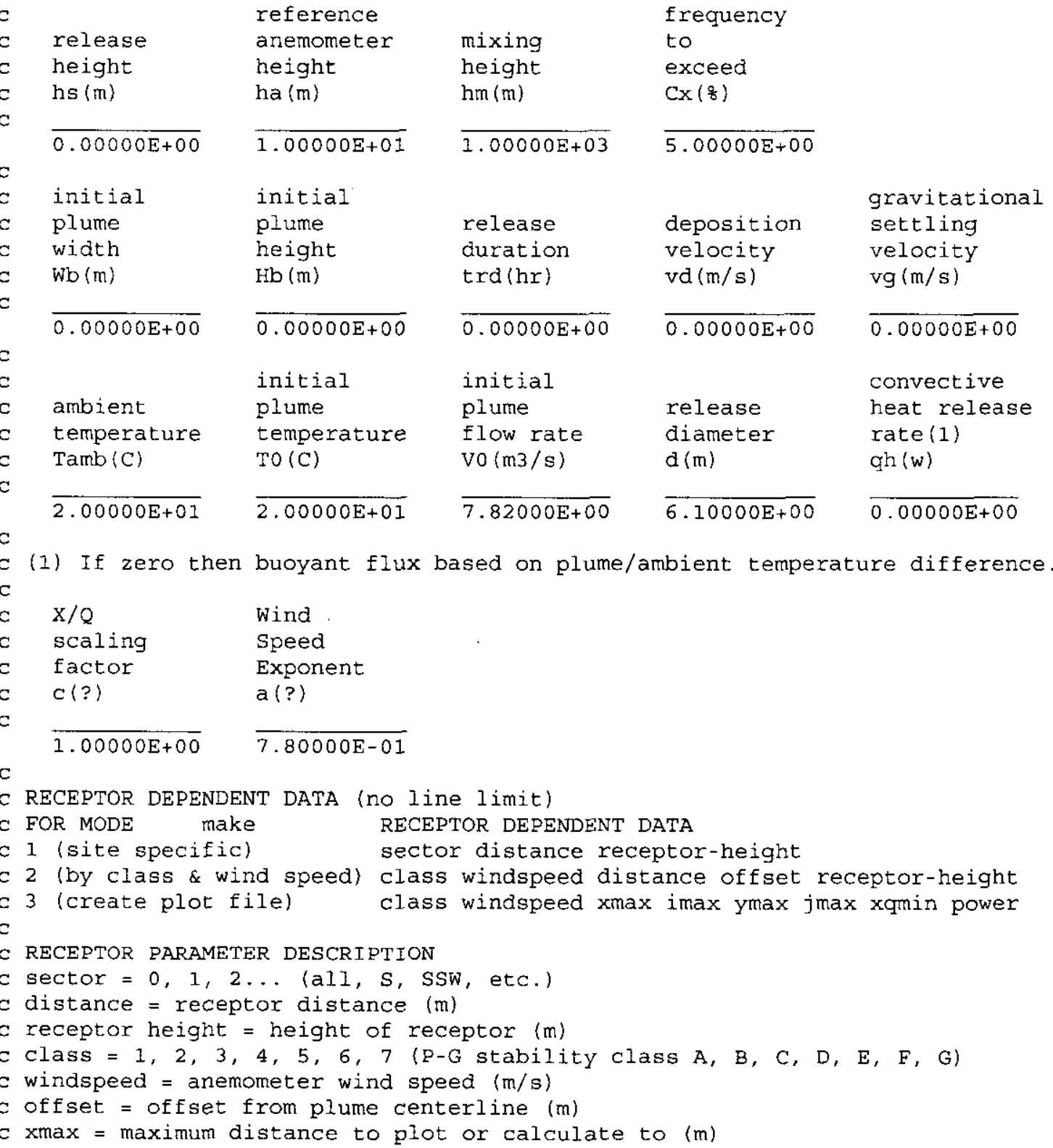




\section{RPP-13482 REV 5}

c imax = distance intervals

c $y \max =$ maximum off set to plot $(m)$

c jmax $=$ offset intervals

c $x q m i n=$ minimum scaled $X / Q$ to calculate

$c$ power $=$ exponent in power function step size

MODE :

Site specific $x / Q$ calculated.

LOGICAL CHOICES :

Joint frequency used to calculate $\mathrm{X} / \mathrm{Q}$ based on frequency of exceedance. No normalization of joint frequency.

$\mathrm{X} / \mathrm{Q}$ calculated for overall site.

MODELS SELECTED:

Time-integrated air concentration calculated (s/m3).

Flow rate adjustment model.

WARNING/ERROR MESSAGES :

JOINT FREQUENCY DATA:

200 AREA (HMS) - 10 M - Pasquill A - G (1983 - 1991 Average)

Created $8 / 26 / 92 \mathrm{KR}$

Tank Farms - $95 \%$ all sectors - 1 hour - tank dome collapse

\begin{tabular}{|c|c|c|c|c|c|c|c|c|}
\hline \multirow[b]{3}{*}{ SECTOR } & & & & & $\begin{array}{c}\text { TOTAL } \\
\text { POPULATION }\end{array}$ & $\begin{array}{l}\text { AVERAGE } \\
\text { INDIVIDUAL }\end{array}$ & & \\
\hline & & RECEPT & SECT. & & SCALED & SCALED & ATM. & WIND \\
\hline & $\begin{array}{l}\text { DISTANCE } \\
(\mathrm{m})\end{array}$ & $\begin{array}{l}\text { HEIGHT } \\
(\mathrm{m})\end{array}$ & $\begin{array}{c}\text { FREQ. } \\
\left(\frac{8}{z}\right)\end{array}$ & POPULATION & $\begin{array}{c}\mathrm{X} / \mathrm{Q} \\
(\mathrm{s} / \mathrm{m} 3)\end{array}$ & $\begin{array}{c}\mathrm{X} / \mathrm{Q} \\
(\mathrm{s} / \mathrm{m} 3)\end{array}$ & $\begin{array}{l}\text { STAB. } \\
\text { CLASS }\end{array}$ & $\begin{array}{l}\text { SPEED } \\
(\mathrm{m} / \mathrm{s})\end{array}$ \\
\hline ALL & 100 & 0 & 99.94 & 1 & $1.68 \mathrm{E}-02$ & $1.68 \mathrm{E}-02$ & $\mathrm{~F}$ & 0.89 \\
\hline ALL & 15360 & 0 & 99.94 & 1 & $2.21 \mathrm{E}-05$ & $2.21 \mathrm{E}-05$ & F & 0.89 \\
\hline
\end{tabular}


RPP-13482 REV 5

This page intentionally left blank.

G-16 
RPP-13482 REV 5

APPENDIX H

SPECIAL $\chi / Q$ S AND $\chi / Q$ 's FOR PUFF RELEASES DUE TO RAPID VENTING OF UNDERGROUND TANK 
RPP-13482 REV 5

This page intentionally left blank. 


\section{APPENDIX H}

\section{SPECIAL $\chi / Q S$ AND $\chi / Q ' S$ FOR PUFF RELEASES DUE TO RAPID VENTING OF UNDERGROUND TANK}

A series of $\chi /$ Qs and $\chi / Q$ 's were calculated for a rapid venting of a large underground waste tank where the tank dome is assumed to fail during a flammable gas deflagration/detonation. These scenarios were developed in RPP-13510, Flammable Gas Technical Basis Document, and relevant parameters are summarized here. The release is modeled as a semi-ellipsoidal puff on the ground above the tank arising from several vent paths out of the tank. Two cases were analyzed:

1. A double-shell tank (DST) with a headspace volume of $961 \mathrm{~m}^{3}$ with initial pressures up to $60 \mathrm{lb} / \mathrm{in}^{2}$ gauge.

2. A single-shell tank (SST) with a headspace volume of $1,987 \mathrm{~m}^{3}$ with initial pressures up to $44 \mathrm{lb} / \mathrm{in}^{2}$ gauge.

The DST and SST headspace volumes are assumptions supported by information contained in RPP-13019, Determination of Hanford Waste Tank Volumes. The DST headspace volume of $961 \mathrm{~m}^{3}$ is based on the fact that the majority of DSTs are essentially full. When filled to an operating level of 420 in., a DST with a total volume of $5,324 \mathrm{~m}^{3}$ will have a headspace volume of $953 \mathrm{~m}^{3}$. For an SST, the assumption is that the tank is essentially one-half full. The total volume of SSTs varies due to differences in design. The "one-half full" assumption leads to volumes roughly equivalent to $1,600 \mathrm{~m}^{3}$ for the $0.5 \mathrm{Mgal}$ tanks, $2,000 \mathrm{~m}^{3}$ for the $0.75 \mathrm{Mgal}$ tanks, and $2,500 \mathrm{~m}^{3}$ for the $1 \mathrm{Mgal}$ tanks. The analyzed SST headspace volume of $1,987 \mathrm{~m}^{3}$ is thus approximately equivalent to a $0.75 \mathrm{Mgal}$ SST that is one-half full. Note that the larger the assumed headspace volume, the bigger the "puff" which reduces the initial concentration which in turn results in lower onsite consequences.

Both tanks have a diameter of $75 \mathrm{ft}(22.9 \mathrm{~m})$. The initial puff at ground level is assumed to be the same diameter as the tank. The height of the puff depends on the volume vented. The resulting puff $\chi / \mathrm{Q}$ are shown in Table $\mathrm{H}-1$ for the ranges of initial pressures required. 
Table H-1. Puff $\chi / \mathrm{Qs}$ for Rapid Venting of Underground Tanks.

\begin{tabular}{|c|c|c|c|c|}
\hline \multirow{2}{*}{ Tank type } & \multirow{2}{*}{$\begin{array}{l}\text { Initial pressure } \\
\text { (lb/in² gauge) }\end{array}$} & \multirow{2}{*}{$\begin{array}{l}\text { Initial puff } \\
\text { volume }\left(\mathbf{m}^{3}\right)\end{array}$} & \multicolumn{2}{|c|}{$\chi / Q\left(1 / \mathrm{m}^{3}\right)$} \\
\hline & & & Onsite & Offsite \\
\hline \multirow{4}{*}{ DST } & 5 & 320 & $6.49 \mathrm{E}-4$ & $4.89 \mathrm{E}-8$ \\
\hline & 15 & 961 & $3.89 \mathrm{E}-4$ & $4.88 \mathrm{E}-8$ \\
\hline & 45 & 2883 & $1.69 \mathrm{E}-4$ & $4.82 \mathrm{E}-8$ \\
\hline & 60 & 3844 & $1.31 \mathrm{E}-4$ & $4.78 \mathrm{E}-8$ \\
\hline \multirow{2}{*}{ SST } & 15 & 1987 & $2.31 \mathrm{E}-4$ & $4.85 \mathrm{E}-8$ \\
\hline & 44 & 5829 & $8.98 \mathrm{E}-5$ & $4.68 \mathrm{E}-8$ \\
\hline
\end{tabular}

Notes:

DST $=$ double-shell tank.

SST $=$ single-shell tank.

The puff $\chi /$ Qs shown above will yield peak air concentrations and can be used to estimate toxicological consequences. To estimate radiological consequences, the time-integrated air concentration is needed. The corresponding $1-\mathrm{hr} \chi / \mathrm{Q}$ 's that will yield the required timeintegrated air concentrations are shown in Table $\mathrm{H}-2$.

Table H-2. Continuous Release 1-hr $\chi / \mathrm{Q}$ 's for Rapid Venting of Underground Tanks.

\begin{tabular}{|c|c|c|c|c|}
\hline \multirow{2}{*}{ Tank type } & \multirow{2}{*}{$\begin{array}{l}\text { Initial pressure } \\
\left(\mathbf{l b} / \text { in }^{2} \text { gauge) }\right.\end{array}$} & \multirow{2}{*}{$\begin{array}{c}\text { Initial puff } \\
\text { volume }\left(\mathrm{m}^{3}\right)\end{array}$} & \multicolumn{2}{|c|}{$\chi / \mathbf{Q}^{\prime}\left(\mathrm{s} / \mathrm{m}^{3}\right)$} \\
\hline & & & Onsite & Offsite \\
\hline \multirow{4}{*}{ DST } & 5 & 320 & $1.06 \mathrm{E}-2$ & $2.18 \mathrm{E}-5$ \\
\hline & 15 & 961 & $7.35 \mathrm{E}-3$ & $2.18 \mathrm{E}-5$ \\
\hline & 45 & 2883 & $3.73 \mathrm{E}-3$ & $2.15 \mathrm{E}-5$ \\
\hline & 60 & 3844 & $2.97 \mathrm{E}-3$ & $2.14 \mathrm{E}-5$ \\
\hline \multirow{2}{*}{ SST } & 15 & 1987 & $4.88 \mathrm{E}-3$ & $2.16 \mathrm{E}-5$ \\
\hline & 44 & 5829 & $2.06 \mathrm{E}-3$ & $2.10 \mathrm{E}-5$ \\
\hline
\end{tabular}

Notes:

DST $=$ double-shell tank.

SST $=$ single-shell tank.

The theory and calculations documenting these $\chi / \mathrm{Q}$ s and $\chi / \mathrm{Q}$ 's are shown in Attachment $\mathrm{H} 1$. A sample GXQ input file and run file are included in the attachment.

\section{Reference}

RPP-13019, 2003, Determination of Hanford Waste Tank Volumes, Rev. 0, CH2M HILL Hanford Group, Inc., Richland, Washington.

RPP-13510, 2003, Flammable Gas Technical Basis Document, Rev. 1, CH2M HILL Hanford Group, Inc., Richland, Washington. 


\title{
ATTACHMENT H1
}

\section{Application of the MACCS Puff Model to Rapid Venting of Tank Headspace}

\author{
by Paul D. Rittmann PhD CHP October 10, 2002
}

Attachment H1A describes the general methodology of using GXQ Version 4.0F to model puff releases with various initial shapes. The following is a specific application of that methodology to the rapid venting of a large underground tank into the air. The vented gas is assumed to be released at multiple locations over the top of the tank so as to form an initial cloud above the tank.

Two tank venting cases are evaluated. The first is a DST with a headspace volume of $961 \mathrm{~m}^{3}$ and the second is a SST with a headspace volume of $1,987 \mathrm{~m}^{3}$. The DST pressures range up to $60 \mathrm{psig}$. The SST pressures range up to $44 \mathrm{lb} / \mathrm{in}^{2}$ gauge. Both tanks have a diameter of $75 \mathrm{ft}$ $(22.9 \mathrm{~m})$. The initial puff is assumed to also have this diameter on the ground above the tank. The height of the puff depends on the volume vented. The height (vertical radius) of the semiellipsoid that has a given diameter and a given volume is calculated as shown in the equation below.

$$
\mathrm{V}_{\text {PUFF }}=\frac{\pi}{6} \mathrm{D}_{\mathrm{H}}^{2} \mathrm{R}_{\mathrm{V}} \quad \text { or } \quad \mathrm{R}_{\mathrm{V}}=\frac{6 \mathrm{~V}_{\text {PUFF }}}{\pi \mathrm{D}_{\mathrm{H}}^{2}}
$$

where:

$$
\begin{aligned}
V_{\text {PUFF }} & =\text { initial volume of the semi-ellipsoidal puff }\left(\mathrm{m}^{3}\right) \\
D_{H} & =\text { horizontal diameter of the puff }(\mathrm{m}) \\
\mathrm{R}_{\mathrm{V}} & =\text { vertical radius of the puff }(\mathrm{m}) .
\end{aligned}
$$

From Attachment $\mathrm{H} 1 \mathrm{~A}$, the formula used to calculate the width and height inputs for the MACCS model are shown below.

$$
\mathrm{W}_{\mathrm{B}}=\frac{2.15 \mathrm{D}_{\mathrm{H}}}{(4.5 \pi)^{1 / 6}} \quad \text { and } \quad \mathrm{H}_{\mathrm{B}}=\frac{2.15 \mathrm{R}_{\mathrm{V}}}{(4.5 \pi)^{1 / 6}}
$$

where:

$$
\begin{aligned}
\mathrm{D}_{\mathrm{H}} & =\text { horizontal diameter of the puff }(\mathrm{m}) \\
\mathrm{R}_{\mathrm{V}} & =\text { vertical radius of the puff }(\mathrm{m}) \\
\mathrm{W}_{\mathrm{B}} & =\text { building width in the MACCS building wake model }(\mathrm{m}) \\
\mathrm{H}_{\mathrm{B}} & =\text { building height in the MACCS building wake model }(\mathrm{m}) .
\end{aligned}
$$

These calculations are readily carried out. The specific pressure and volume assumptions are listed in Table H1-1. The initial puff volume is calculated using the formula below.

$$
\mathrm{V}_{\mathrm{PUFF}}=\frac{\mathrm{P}_{\mathrm{HEAD}}}{15 \mathrm{psi}_{\mathrm{a}}} \mathrm{V}_{\mathrm{HEAD}}
$$


where:

$\mathrm{V}_{\mathrm{PUFF}}=$ initial volume of the semi-ellipsoidal puff $\left(\mathrm{m}^{3}\right)$

$\mathrm{P}_{\mathrm{HEAD}}=$ headspace pressure before venting (psig)

$\mathrm{V}_{\text {HEAD }}=$ volume of the headspace in the underground tank $\left(\mathrm{m}^{3}\right)$.

The initial puff dimensions (width $=22.9 \mathrm{~m}$ and heights shown in Table H1-1) were input to GXQ Version 4.0F. A sample code input is shown in Attachment H1B. The results of the GXQ calculations using 200 area wind data collected from 1982 to 1991 are shown in the last columns of Table H1-1. Note that all $\chi / \mathrm{Q}$ values are for the $95^{\text {th }}$ percentile (overall site $\chi / \mathrm{Q}$ ). For comparison, the $95^{\text {th }}$ percentile puff $\mathrm{X} / \mathrm{Qs}$ for a point source are $8.88 \mathrm{E}-3 \mathrm{~m}^{-3}$ at $100 \mathrm{~m}$ and $5.06 \mathrm{E}-8 \mathrm{~m}^{-3}$ at the worst site boundary location (see Tables $2-4$ and 2-5 in main document).

A sample output (for the 5,829- $\mathrm{m}^{3}$ puff) is included as Attachment $\mathrm{H1C}$. Besides the $100-\mathrm{m}$ (onsite) and the Hanford Site boundary $\chi / \mathrm{Qs}$, the value at a distance of $1 \mathrm{~m}$ was calculated to verify that the initial concentration matches the inverse of the initial puff volume, shown in Table $\mathrm{H} 1-1$ as the "Initial $\chi / \mathrm{Q}$ (at $0 \mathrm{~m})$ ".

The initial $\chi / Q$ at zero distance is simply the inverse of the initial puff volume and is equal to the initial concentration that results from a unit amount released. It also was used as a check on the computed results. At $1 \mathrm{~m}$ (the GXQ code will not accept a 0 -m distance), the GXQ value for $\chi / \mathrm{Q}$ is $1.70 \mathrm{E}-04 \mathrm{~m}^{-3}$ in good agreement with the expected value of $1.72 \mathrm{E}-04 \mathrm{~m}^{-3}$ in Table H1-1 based on the initial puff volume.

Table H1-1. Input Values and $\chi / \mathrm{Q}$ Results for a Puff Release.

\begin{tabular}{|c|c|c|c|c|c|}
\hline \multirow[b]{2}{*}{ Scenario } & \multirow[b]{2}{*}{$\begin{array}{l}\text { Initial Puff } \\
\text { Volume }\left(\mathrm{m}^{3}\right)\end{array}$} & \multirow{2}{*}{$\begin{array}{l}\text { Puff Height for } \\
\text { Input to } \\
\text { GXQ 4.0F (m) }\end{array}$} & \multirow{2}{*}{$\begin{array}{c}\text { Initial } \chi / Q \\
(\text { at } 0 \mathrm{~m}) \\
\left(\mathrm{m}^{-3}\right)\end{array}$} & \multicolumn{2}{|c|}{$\chi / Q$ from GXQ 4.0F $\left(\mathrm{m}^{-3}\right)$} \\
\hline & & & & $\begin{array}{c}\text { Onsite } \\
(100 \mathrm{~m})\end{array}$ & $\begin{array}{c}\text { Hanford Site } \\
\text { Boundary }\end{array}$ \\
\hline DST, 5 psig & 320 & 1.62 & $3.12 \mathrm{E}-03$ & $6.49 \mathrm{E}-04$ & $4.89 \mathrm{E}-08$ \\
\hline DST, 15 psig & 961 & 4.86 & $1.04 \mathrm{E}-03$ & $3.89 \mathrm{E}-04$ & $4.88 \mathrm{E}-08$ \\
\hline SST, 15 psig & 1,987 & 10.04 & $5.03 \mathrm{E}-04$ & $2.31 \mathrm{E}-04$ & $4.85 \mathrm{E}-08$ \\
\hline DST, 45 psig & 2,883 & 14.57 & $3.47 \mathrm{E}-04$ & $1.69 \mathrm{E}-04$ & $4.82 \mathrm{E}-08$ \\
\hline DST, 60 psig & 3,844 & 19.42 & $2.60 \mathrm{E}-04$ & $1.31 \mathrm{E}-04$ & 4.78E-08 \\
\hline SST, 44 psig & 5,829 & 29.45 & $1.72 \mathrm{E}-04$ & $8.98 \mathrm{E}-05$ & $4.68 \mathrm{E}-08$ \\
\hline
\end{tabular}

Notes:

Puff (building) width is $31.6 \mathrm{~m}$ for input to MACCS Building Wake Model in GXQ Version 4.0F.

The GXQ Version $4.0 \mathrm{~F}$ values for $\chi / \mathrm{Q}$ are the $95^{\text {th }}$ percentile overall site numbers.

To estimate radiological consequences, the time-integral of the air concentration is needed. In a Gaussian model of a 3-dimension cloud that is moving along the $\mathrm{x}$-axis at a speed $\mu(\mathrm{m} / \mathrm{s})$, the time integral introduces a factor of the square root of $2 \pi$ times the standard deviation (sigma parameter) divided by the wind speed. This factor is the effective time of exposure. Since the standard deviation increases with distance, the effective time of exposure also increases with distance. 
Using the puff model dimensions derived above, the calculation of time-integrated exposures in $G X Q$ only requires changing the IPUFF $=1$ flag to $I P U F F=0$. The puff (building) width and height remain the same. The GXQ results for the time-integrated $\chi / \mathrm{Q}$ 's are shown in Table H1-2. A sample output is shown in Attachment H1D.

Table H1-2. Input Values and $\chi / Q^{\prime}$ Results for a Puff Release.

\begin{tabular}{|c|c|c|c|c|}
\hline \multirow[b]{2}{*}{ Scenario } & \multirow[b]{2}{*}{$\begin{array}{c}\text { Initial Puff } \\
\text { Volume }\left(\mathrm{m}^{3}\right)\end{array}$} & \multirow{2}{*}{$\begin{array}{l}\text { Puff Height for } \\
\text { Input to } \\
\text { GXQ (m) }\end{array}$} & \multicolumn{2}{|c|}{$\chi / Q^{\prime}$ from GXQ 4.0F $\left(\mathrm{s} / \mathrm{m}^{3}\right)$} \\
\hline & & & $\begin{array}{c}\text { Onsite } \\
(100 \mathrm{~m})\end{array}$ & $\begin{array}{c}\text { Hanford Site } \\
\text { Boundary }\end{array}$ \\
\hline DST, 5 psig & 320 & 1.62 & $1.06 \mathrm{E}-02$ & $2.18 \mathrm{E}-05$ \\
\hline DST, 15 psig & 961 & 4.86 & $7.35 \mathrm{E}-03$ & $2.18 \mathrm{E}-05$ \\
\hline SST, 15 psig & 1,987 & 10.04 & $4.88 \mathrm{E}-03$ & $2.16 \mathrm{E}-05$ \\
\hline DST, $45 \mathrm{psig}$ & 2,883 & 14.57 & $3.73 \mathrm{E}-03$ & $2.15 \mathrm{E}-05$ \\
\hline DST, $60 \mathrm{psig}$ & 3,844 & 19.42 & $2.97 \mathrm{E}-03$ & $2.14 \mathrm{E}-05$ \\
\hline SST, 44 psig & 5,829 & 29.45 & $2.06 \mathrm{E}-03$ & $2.10 \mathrm{E}-05$ \\
\hline
\end{tabular}

Notes:

Puff (building) width is $31.6 \mathrm{~m}$ for input to MACCS Building Wake Model in GXQ Version 4.0F.

The GXQ Version $4.0 \mathrm{~F}$ values for $\chi / \mathrm{Q}^{\prime}$ are the $95^{\text {th }}$ percentile overall site numbers.

The virtual distances used in GXQ depend on the atmospheric stability class. A complete listing is shown in Table $\mathrm{H1}-3$. The $95^{\text {th }}$ percentile results are usually stability class $\mathrm{F}$.

Table H1-3. Virtual Distances Used in the Building Wake Calculation.

\begin{tabular}{|c|c|c|c|c|c|c|c|}
\hline \multirow{2}{*}{$\begin{array}{c}\text { Stability } \\
\text { Class }\end{array}$} & Horizontal & \multicolumn{7}{|c|}{ Vertical Dimension (Height) } \\
\cline { 3 - 8 } & $\mathbf{3 1 . 6 2} \mathbf{~ m}$ & $\mathbf{4 . 8 6} \mathbf{~}$ & $\mathbf{1 0 . 0} \mathbf{~}$ & $\mathbf{1 4 . 6} \mathbf{~}$ & $\mathbf{1 9 . 4} \mathbf{~ m}$ & $\mathbf{2 9 . 5} \mathbf{~ m}$ \\
\hline $\mathrm{A}$ & 27.7 & 4.3 & 13.9 & 30.3 & 45.0 & 61.2 & 95.5 \\
\hline $\mathrm{B}$ & 38.0 & 5.5 & 18.2 & 39.9 & 59.8 & 81.6 & 132 \\
\hline $\mathrm{C}$ & 51.6 & 7.9 & 26.6 & 59.3 & 89.5 & 123 & 194 \\
\hline $\mathrm{D}$ & 76.0 & 12.9 & 45.0 & 103 & 152 & 211 & 346 \\
\hline $\mathrm{E}$ & 111 & 17.3 & 60.9 & 138 & 216 & 311 & 539 \\
\hline $\mathrm{F}$ & 167 & 26.1 & 101 & 244 & 391 & 567 & 979 \\
\hline $\mathrm{G}$ & 262 & 48.4 & 184 & 463 & 752 & 1,105 & 2,095 \\
\hline
\end{tabular}

Notes:

All virtual distances are in meters.

Column labeled "Horizontal" shows the virtual distances needed to give a horizontal spread $\left(\sigma_{\mathrm{y}}\right)$ of $31.6 \mathrm{~m}$.

Columns labeled "Vertical Dimension (Height)" show the virtual distances needed to give the vertical spreads $\left(\sigma_{z}\right)$ shown in the header row. 


\section{ATTACHMENT H1A:}

\section{How to Model Finite Size Puff Releases in GXQ Version 4.0F by Paul D. Rittmann PhD CHP August 12, 2002}

The GXQ software Version 4.0F can be used to model the transport of a puff of toxic material. This essay summarizes the specific inputs for GXQ Version 4.0F to carry out a puff calculation.

The puff forms nearly instantaneously so that any spreading along the direction of wind travel during its formation is small. The puff is assumed to have a length equal to its width in this model. Three initial puff shapes were considered: box, cylinder, and sphere. In all three cases, the formulas were derived for a ground level release $(\mathrm{H}=0)$, with a receptor also located at ground level $(\mathrm{Z}=0)$.

In all three cases, the initial concentration in the puff is the amount initially airborne divided by the initial puff volume. The normalized air concentration is shown in the equations below. The factor of 2.0 in the numerator is the plume reflection factor for a ground level release.

$$
\frac{1}{\mathrm{~V}_{\mathrm{PUFF}}}=\left(\frac{\mathrm{X}}{\mathrm{Q}}\right)_{0}=\frac{(2.0)(4.3)^{2}(2.15)}{(2 \pi)^{1.5} \mathrm{~W}_{\mathrm{B}}^{2} \mathrm{H}_{\mathrm{B}}} \text { or } \mathrm{V}_{\mathrm{PUFF}}=\frac{(2 \pi)^{1.5}}{8(2.15)^{3}} \mathrm{~W}_{\mathrm{B}}^{2} \mathrm{H}_{\mathrm{B}}
$$

where:

$$
\begin{aligned}
\mathrm{V}_{\mathrm{PUFF}}= & \text { initial volume of the puff }\left(\mathrm{m}^{3}\right) \\
(\chi / \mathrm{Q})_{0}= & \text { normalized air concentration }\left(\mathrm{m}^{-3}\right) \text { at zero distance. This is the air } \\
& \text { concentration in the center of the puff divided by the amount initially } \\
& \text { airborne in the puff. Note that the release height is zero. } \\
\mathrm{W}_{\mathrm{B}}= & \begin{array}{l}
\text { building width }(\mathrm{m}) \text { in the MACCS building wake model (input to } \\
\text { GXQ Version } 4.0 \mathrm{~F})
\end{array} \\
\mathrm{H}_{\mathrm{B}}= & \begin{array}{l}
\text { building height }(\mathrm{m}) \text { in the MACCS building wake model (input to } \\
\text { GXQ Version } 4.0 \mathrm{~F}) .
\end{array}
\end{aligned}
$$

An instantaneous puff at ground level can then be modeled in GXQ Version 4.0F using the following inputs:

(1) puff model calculations are selected (IPUFF $=1$ )

(2) MACCS building wake model selected (IWAKE=2)

(3) release height is set to zero

(4) release duration is set to zero

(5) building width and height are input according to the equations derived below.

The influence of the ground is taken into account by GXQ through the plume reflection factor. If the puff is well above ground level initially, then the reflection factor is 1 . However, in this case the puff volume should be twice as great since the puff extends both upward and downward from the point of release. This doubling restores the factor of 2 . Thus, the equations derived below apply to elevated puffs as well as ground level puffs. Intermediate elevations may have small 


\section{RPP-13482 REV 5}

differences between the volume correction and the plume reflection factor, so the formulas are not exact in those cases.

\section{INITIAL PUFF AS A BOX}

Assuming the initial puff has a rectangular shape, the volume of the puff is the product of the width squared and the height, as shown in the equation below. The puff is assumed to have a square base (length equal to width), because isotropic conditions in the $x$-y (horizontal) plane are assumed in this model.

$$
\mathrm{V}_{\mathrm{PUFF}}=\mathrm{W}_{\mathrm{P}}^{2} \mathrm{H}_{\mathrm{P}}
$$

where:

$$
\begin{aligned}
\mathrm{V}_{\mathrm{PUFF}} & =\text { initial volume of the rectangular puff }\left(\mathrm{m}^{3}\right) \\
W_{\mathrm{P}} & =\text { initial width of the puff }(\mathrm{m}) \\
H_{\mathrm{P}} & =\text { initial height of the puff }(\mathrm{m}) .
\end{aligned}
$$

Inserting the volume of the box shown above into the first equation for $V_{\text {PUFF }}$ leads to the equation shown below.

$$
\mathrm{W}_{\mathrm{P}}^{2} \mathrm{H}_{\mathrm{P}}=\frac{(2 \pi)^{1.5}}{8(2.15)^{3}} \mathrm{~W}_{\mathrm{B}}^{2} \mathrm{H}_{\mathrm{B}}
$$

The natural solution for $\mathrm{W}_{\mathrm{B}}$ and $\mathrm{H}_{\mathrm{B}}$ is to associate the building height with the initial height of the puff, and the building width with the initial width of the puff. The constant is distributed evenly between the two by taking its cube root. The results of this decomposition are shown below.

$$
\mathrm{W}_{\mathrm{B}}=\frac{4.3 \mathrm{~W}_{\mathrm{P}}}{\sqrt{2 \pi}} \quad \text { and } \quad \mathrm{H}_{\mathrm{B}}=\frac{4.3 \mathrm{H}_{\mathrm{P}}}{\sqrt{2 \pi}}
$$

Using these calculated values for building width and height as input to GXQ, the initial concentration in the puff will be the initial amount airborne divided by the initial volume of the puff.

\section{INITIAL PUFF AS A VERTICAL CYLINDER}

Assuming the initial puff has the shape of a vertical cylinder, the volume of the puff is the product of the base area and the height, as shown in the equation below. The puff is assumed to have a circular base because of the assumed isotropy in the $\mathrm{x}-\mathrm{y}$ plane in this model. 


$$
\mathrm{V}_{\mathrm{PUFF}}=\frac{\pi}{4} \mathrm{D}_{\mathrm{P}}^{2} \mathrm{H}_{\mathrm{P}}
$$

where:

$$
\begin{aligned}
V_{\text {PUFF }} & =\text { initial volume of the cylindrical puff }\left(\mathrm{m}^{3}\right) \\
D_{\mathrm{P}} & =\text { initial diameter of the puff }(\mathrm{m}) \\
H_{\mathrm{P}} & =\text { initial height of the puff }(\mathrm{m}) .
\end{aligned}
$$

Inserting the volume of the cylinder into the first equation for $\mathrm{V}_{\mathrm{PUFF}}$ leads to the equation shown below.

$$
\frac{\pi}{4} D_{\mathrm{P}}^{2} \mathrm{H}_{\mathrm{P}}=\frac{(2 \pi)^{1.5}}{8(2.15)^{3}} \mathrm{~W}_{\mathrm{B}}^{2} \mathrm{H}_{\mathrm{B}}
$$

The natural solution for $\mathrm{W}_{B}$ and $\mathrm{H}_{B}$ is to associate the building height with the initial height of the puff, and the building width with the initial diameter of the puff. The constant is distributed evenly between the two by taking its cube root. The results of this decomposition are shown below.

$$
\mathrm{W}_{\mathrm{B}}=\frac{2.15 \mathrm{D}_{\mathrm{P}}}{(2 \pi)^{1 / 6}} \quad \text { and } \quad \mathrm{H}_{\mathrm{B}}=\frac{2.15 \mathrm{H}_{\mathrm{P}}}{(2 \pi)^{1 / 6}}
$$

Using these calculated values for building width and height as input to GXQ, the initial concentration in the puff will be the initial amount airborne divided by the initial volume of the puff.

\section{INITIAL PUFF AS A HALF-ELLIPSOID}

Assuming the initial puff has the shape of an ellipsoid whose center is at ground level, the volume of the puff is shown in the equation below. As before, the puff is assumed to have a circular base because of the assumed isotropy in the $x-y$ plane.

$$
\mathrm{V}_{\mathrm{PUFF}}=\frac{\pi}{6} \mathrm{D}_{\mathrm{H}}^{2} \mathrm{R}_{\mathrm{V}}
$$

where:

$$
\begin{aligned}
V_{\text {PUFF }} & =\text { initial volume of the half-ellipsoidal puff }\left(\mathrm{m}^{3}\right) \\
D_{H} & =\text { initial horizontal diameter of the puff }(\mathrm{m}) \\
R_{V} & =\text { initial vertical radius of the puff }(\mathrm{m}) .
\end{aligned}
$$




\section{RPP-13482 REV 5}

Inserting the volume of the half-ellipsoid into the first equation for $V_{P U F F}$ leads to the equation shown below.

$$
\frac{\pi}{6} D_{\mathrm{H}}^{2} \mathrm{R}_{\mathrm{V}}=\frac{(2 \pi)^{1.5}}{8(2.15)^{3}} \mathrm{~W}_{\mathrm{B}}^{2} \mathrm{H}_{\mathrm{B}}
$$

The natural solution for $\mathrm{W}_{\mathrm{B}}$ and $\mathrm{H}_{\mathrm{B}}$ is to associate the building height with the initial vertical radius of the puff, and the building width with the initial diameter of the puff. The constant is distributed evenly between the two by taking its cube root. The results of this decomposition are shown below.

$$
\mathrm{W}_{\mathrm{B}}=\frac{2.15 \mathrm{D}_{\mathrm{H}}}{(4.5 \pi)^{1 / 6}} \quad \text { and } \quad \mathrm{H}_{\mathrm{B}}=\frac{2.15 \mathrm{R}_{\mathrm{V}}}{(4.5 \pi)^{1 / 6}}
$$

Using these calculated values for building width and height as input to GXQ, the initial concentration in the puff will be the initial amount airborne divided by the initial volume of the puff. 


\section{ATTACHMENT H1B}

\section{Sample Input File $\left(5,829-\mathrm{m}^{3}\right.$ Puff)}

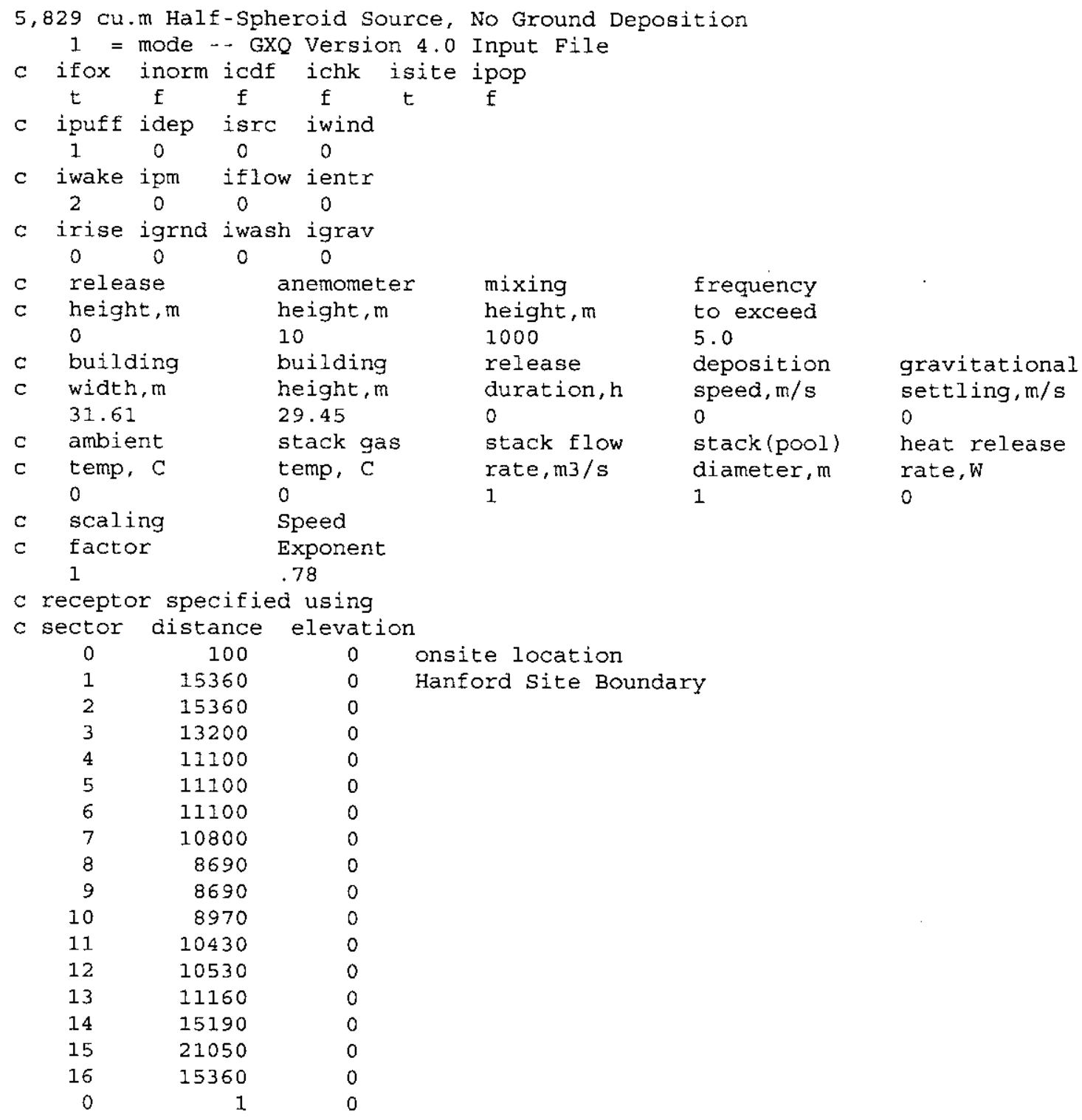


RPP-13482 REV 5

ATTACHMENT H1C

\section{Sample Output File (5,829- $\mathrm{m}^{3}$ Puff)}

Maximum Concentration

GXQ Version $4.0 \mathrm{~F}$

October 9, 2002

General Purpose Atmospheric Dispersion Code

Produced by Fluor Federal Services, Inc.

Users Guide documented in WHC-SD-GN-SWD-30002 Rev, 1 .

Validation documented in WHC-SD-GN-SWD-30003 Rev. 1 .

Code Custodian is: Paul D. Rittmann, PhD CHP

Fluor Federal Services, Inc. E6-17

P.O. Box 1050

Richland, WA 99352-1050

(509) $376-8715$

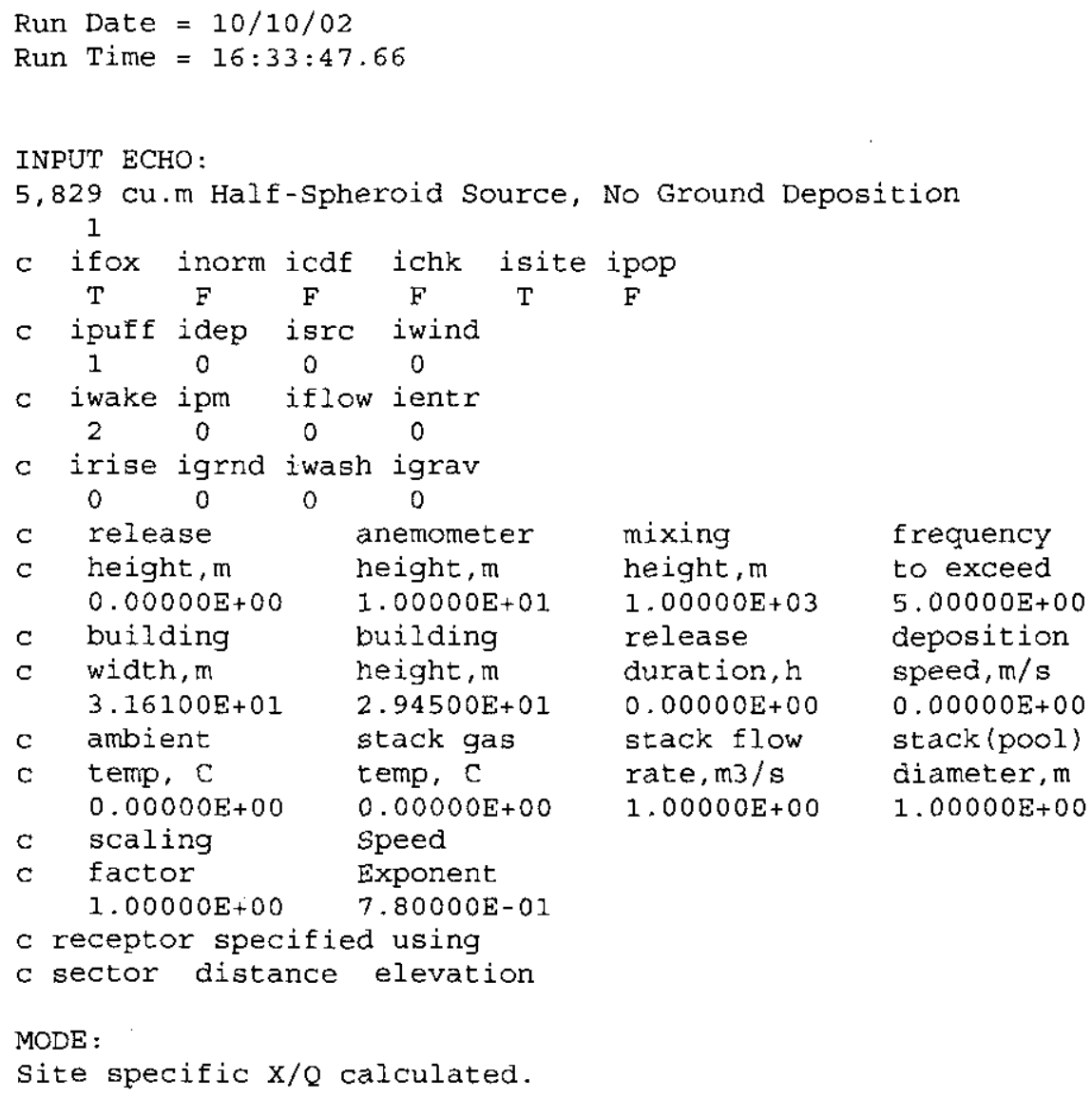




\section{RPP-13482 REV 5}

LOGICAL CHOICES:

Joint frequency used to calculate $X / Q$ based on frequency of exceedance.

No normalization of joint frequency.

$\mathrm{X} / \mathrm{Q}$ calculated for overall site.

MODELS SELECTED:

Air concentrations will be calculated (1/m3).

MACCS Virtual source building wake model selected.

WARNING/ERROR MESSAGES :

JOINT FREQUENCY DATA:

200 AREA (HMS) - 10 M - Pasquill A - G (1983 - 1991 Average)

Created $8 / 26 / 92 \mathrm{KR}$

5,829 cu.m Half-Spheroid Source, No Ground Deposition

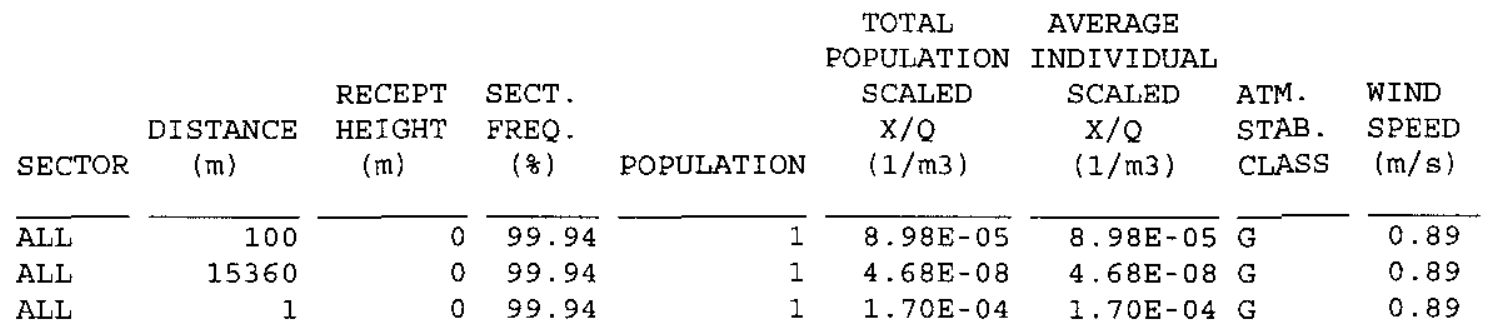


RPP-13482 REV 5

ATT ACHMENT H1D

\section{Example Output File $\left(5,829-\mathrm{m}^{3}\right.$ Puff)}

Time-Integrated Concentration

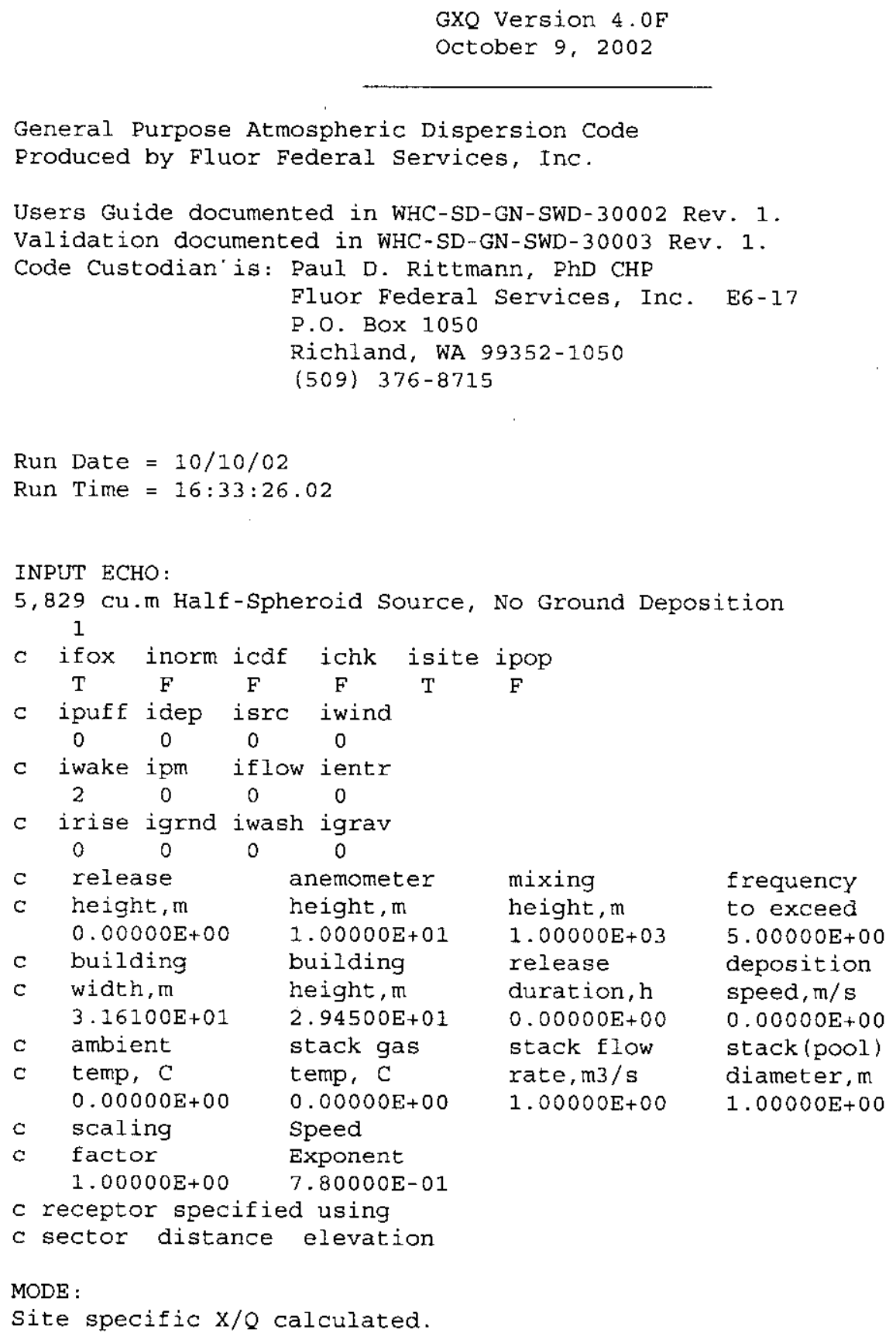




\section{RPP-13482 REV 5}

LOGICAL CHOICES :

Joint frequency used to calculate $X / Q$ based on frequency of exceedance.

No normalization of joint frequency.

$X / Q$ calculated for overall site.

MODELS SELECTED:

Time-integrated air concentration calculated $(\mathrm{s} / \mathrm{m} 3)$.

MACCS Virtual source building wake model selected.

WARNING/ERROR MESSAGES:

JOINT FREQUENCY DATA:

200 AREA (HMS) - 10 M - Pasquill A - G (1983 - 1991 Average)

Created $8 / 26 / 92 \mathrm{KR}$

5,829 cu.m Half-Spheroid Source, No Ground Deposition

\begin{tabular}{|c|c|c|c|c|c|c|c|c|}
\hline SECTOR & $\begin{array}{l}\text { DISTANCE } \\
(\mathrm{m})\end{array}$ & $\begin{array}{c}\text { RECEPT } \\
\text { HEIGHT } \\
\text { (m) }\end{array}$ & $\begin{array}{c}\text { SECT. } \\
\text { FREQ } \\
(\%)\end{array}$ & POPULATION & $\begin{array}{c}\text { TOTAL } \\
\text { POPULATION } \\
\text { SCALED } \\
\text { X/Q } \\
(\mathrm{s} / \mathrm{m} 3)\end{array}$ & $\begin{array}{l}\text { AVERAGE } \\
\text { INDIVIDUAL } \\
\text { SCALED } \\
\text { X/Q } \\
(\mathrm{s} / \mathrm{m} 3)\end{array}$ & $\begin{array}{l}\text { ATM. } \\
\text { STAB. } \\
\text { CIASS }\end{array}$ & $\begin{array}{l}\text { WIND } \\
\text { SPEED } \\
(\mathrm{m} / \mathrm{s})\end{array}$ \\
\hline ALL & 100 & $\overline{0}$ & 99.94 & 1 & $2.06 \mathrm{E}-03$ & $2.06 \mathrm{E}-03$ & $F$ & 0.89 \\
\hline ALL & 15360 & 0 & 99.94 & 1 & $2.10 E-05$ & $2.10 E-05$ & $F$ & 0.89 \\
\hline ALL & 1 & 0 & 99.94 & 1 & $3.53 E-03$ & $3.53 E-03$ & $F$ & 0.89 \\
\hline
\end{tabular}




\section{RPP-13482 REV 5}

\section{APPENDIX I}

\section{SPECIAL GROUND LEVEL RELEASE $\chi / Q ' S$ WITH PLUME DEPLETION}


RPP-13482 REV 5

This page intentionally left blank. 


\section{APPENDIX I}

\section{SPECIAL GROUND LEVEL RELEASE $\chi / Q$ 'S WITH PLUME DEPLETION}

The effects of particle fallout and resulting plume depletion on 100-m onsite and site boundary continuous-release $\chi / \mathrm{Q}$ 's and puff-release $\chi / \mathrm{Q}$ 's were calculated for a series of particle sizes for application to analysis of toxicological consequences for accidental spray releases. These scenarios were developed in RPP-13750, Waste Transfer Leaks Technical Basis Document, and relevant parameters are summarized here. The particles in this case are liquid aerosol droplets with specified sizes of $2,10,20,50,100$, and $200 \mu \mathrm{m}$ (aerodynamic equivalent diameter [AED]), and densities ranging from 1 to $1.5 \mathrm{~g} / \mathrm{cm}^{3}$.

Each particle size is associated with a gravitational deposition velocity, which is just the terminal fall velocity in still air. For deposition velocities above about $1 \mathrm{~cm} / \mathrm{s}$, this is the actual average fall velocity observed. It turns out, however, that the average random vorticity in air is about $1 \mathrm{~cm} / \mathrm{s}$, so that particles with a gravitational fall velocity less than this tend to stay mixed in the air and move where the air moves. Particles in the smaller size range with fall velocities less than about $1 \mathrm{~cm} / \mathrm{s}$ still plate out on the ground and vegetation, but the rate depends more on the nature of the surface and other parameters than on the fall velocity. The deposition rate is characterized by a surface flux per unit air concentration (e.g., $\mathrm{g} / \mathrm{m}^{2} \mathrm{~s}$ per $\mathrm{g} / \mathrm{m}^{3}$ ). This normalized surface flux has the dimensions of velocity and so is called the deposition "velocity." It is easily seen that, for larger particles actually falling through the air, the deposition velocity is the same as the gravitational fall velocity.

The behavior of the deposition velocity as a function of particle size and other parameters is discussed in the main document, Section 2.3.1. It is evident from Figure 2-1 in that section that the variation in deposition velocity over the density range from 1 to $1.5 \mathrm{~g} / \mathrm{cm}^{3}$ is not significant and will be neglected.

Based on Table 2-8 in the main document, the deposition velocities shown in Table I-1 were assumed for the required aerosol particle sizes through $50 \mu \mathrm{m}$. For the larger droplets $(100 \mu \mathrm{m}$ and $200 \mu \mathrm{m}$ ), the fall velocities were taken from Table 3.3 in Aerosol Technology-Properties, Behavior, and Measurement of Airborne Particles (Hinds 1982). The theoretical terminal gravitational fall velocities are shown for comparison. 


\section{RPP-13482 REV 5}

Table I-1. Terminal Fall Velocities and Deposition Velocities.

\begin{tabular}{|c|c|c|}
\hline $\begin{array}{c}\text { Particle size (AED) } \\
(\mu \mathbf{m})\end{array}$ & $\begin{array}{c}\text { Terminal fall velocity } \\
(\mathbf{c m} / \mathbf{s})\end{array}$ & $\begin{array}{c}\text { Deposition velocity } \\
(\mathbf{c m} / \mathbf{s})\end{array}$ \\
\hline 2 & 0.01 & 0.2 \\
\hline 10 & 0.3 & 0.5 \\
\hline 20 & 1 & 1 \\
\hline 50 & 7 & 7 \\
\hline 100 & 25 & 25 \\
\hline 200 & 71 & 71 \\
\hline
\end{tabular}

Note:

$\mathrm{AED}=$ aerodynamic equivalent diameter.

For this study, the continuous release was assumed to take place over a period of less than $1 \mathrm{hr}$ (i.e., no credit was taken for plume meander). Continuous release $\chi / \mathrm{Q}$ 's and puff release $\chi / \mathrm{Qs}$ with deposition effects were calculated for all sectors $\left(95^{\text {th }}\right.$ percentile) at a $100-\mathrm{m}$ radius, and for all sectors around the site boundary at distances defined in Table 2-3 of the main document. A sample GXQ input file and sample run files for continuous and puff releases are shown in Attachment I1.

The resulting continuous-release $\chi / \mathrm{Q}$ 's are shown in Tables I-2 and I-3 for onsite and site boundary receptors, respectively. The reduction factors relative to the $\chi / \mathrm{Q}$ 's with no plume depletion are also shown for information. The values for $\chi / Q^{\prime}$ with no plume depletion were taken from Tables 2-4 and 2-5 of the main document.

Table I-2. $95^{\text {th }}$ Percentile Continuous Release 1-hr $\chi / \mathrm{Q}$ 's for Onsite Receptor at $100 \mathrm{~m}$.

\begin{tabular}{|c|c|c|c|}
\hline $\begin{array}{l}\text { Particle size (AED) } \\
\qquad(\mu \mathrm{m})\end{array}$ & $\begin{array}{c}\chi / Q^{\prime} \text { with no depletion } \\
\left(\mathrm{s} / \mathrm{m}^{3}\right)\end{array}$ & $\begin{array}{c}\chi / Q^{\prime} \text { with depletion } \\
\left(s / \mathbf{m}^{3}\right)\end{array}$ & Reduction factor \\
\hline 2 & \multirow{6}{*}{$3.28 \mathrm{E}-2$} & $2.71 \mathrm{E}-2$ & $8.3 \mathrm{E}-1$ \\
\hline 10 & & $2.11 \mathrm{E}-2$ & $6.4 \mathrm{E}-1$ \\
\hline 20 & & $1.38 \mathrm{E}-2$ & $4.2 \mathrm{E}-1$ \\
\hline 50 & & $1.43 \mathrm{E}-3$ & $4.4 \mathrm{E}-2$ \\
\hline 100 & & $1.51 \mathrm{E}-4$ & $4.6 \mathrm{E}-3$ \\
\hline 200 & & $1.04 \mathrm{E}-5$ & $3.2 \mathrm{E}-4$ \\
\hline
\end{tabular}

Note:

$\mathrm{AED}=$ aerodynamic equivalent diameter 
Table I-3. $95^{\text {th }}$ Percentile Continuous Release 1-hr $\chi / \mathrm{Q}^{\prime}$ s for Site Boundary Receptor.

\begin{tabular}{|c|c|c|c|}
\hline $\begin{array}{l}\text { Particle size (AED) } \\
(\mu \mathrm{m})\end{array}$ & $\begin{array}{c}\chi / Q \text { with no depletion } \\
\left(\mathrm{s} / \mathrm{m}^{3}\right)\end{array}$ & $\begin{array}{c}\chi / Q \text { with depletion } \\
\left(\mathrm{s} / \mathrm{m}^{3}\right)\end{array}$ & Reduction factor \\
\hline 2 & \multirow{6}{*}{$2.22 \mathrm{E}-5$} & $8.86 \mathrm{E}-6$ & $4.0 \mathrm{E}-1$ \\
\hline 10 & & 3.62 E-6 & $1.6 \mathrm{E}-1$ \\
\hline 20 & & $1.61 \mathrm{E}-6$ & $7.3 \mathrm{E}-2$ \\
\hline 50 & & $6.28 \mathrm{E}-8$ & $2.8 \mathrm{E}-3$ \\
\hline 100 & & 3.40 E-9 & $1.5 \mathrm{E}-4$ \\
\hline 200 & & $2.67 \mathrm{E}-11$ & $-1.2 \mathrm{E}-6$ \\
\hline
\end{tabular}

Note:

$\mathrm{AED}=$ aerodynamic equivalent diameter.

Puff-release $\chi /$ Qs are shown in Tables I-4 and I-5 for onsite and site boundary, respectively. The reduction factors relative to the $\chi / \mathrm{Qs}$ with no plume depletion are also shown for information. The values for puff release $\chi / Q$ with no plume depletion were taken from Tables 2-4 and 2-5 of the main document.

Table I-4. $95^{\text {th }}$ Percentile Puff Release $\chi /$ Qs for Onsite Receptor at $100 \mathrm{~m}$.

\begin{tabular}{|c|c|c|c|}
\hline $\begin{array}{l}\text { Particle sixe (AED) } \\
\qquad(\mu \mathrm{m})\end{array}$ & $\begin{array}{c}\chi / Q \text { with no depletion } \\
\left(1 / \mathrm{m}^{3}\right)\end{array}$ & $\begin{array}{c}\chi / Q \text { with depletion } \\
\left(1 / \mathrm{m}^{3}\right)\end{array}$ & Reduction factor \\
\hline 2 & \multirow{6}{*}{$8.88 \mathrm{E}-3$} & $7.83 \mathrm{E}-3$ & $8.8 \mathrm{E}-1$ \\
\hline 10 & & $5.67 \mathrm{E}-3$ & $6.4 \mathrm{E}-1$ \\
\hline 20 & & $2.75 \mathrm{E}-3$ & $3.1 \mathrm{E}-1$ \\
\hline 50 & & $6.21 \mathrm{E}-4$ & $7.0 \mathrm{E}-2$ \\
\hline 100 & & $6.53 \mathrm{E}-5$ & $7.4 \mathrm{E}-3$ \\
\hline 200 & & $2.46 \mathrm{E}-6$ & $2.8 \mathrm{E}-4$ \\
\hline
\end{tabular}

Note:

$\mathrm{AED}=$ aerodynamic equivalent diameter.

Table I-5. $95^{\text {th }}$ Percentile Puff Release $\chi /$ Qs for Site Boundary Receptor.

\begin{tabular}{|c|c|c|c|}
\hline $\begin{array}{l}\text { Particle size (AED) } \\
\qquad(\mu \mathrm{m})\end{array}$ & $\begin{array}{c}\chi / Q \text { with no depletion } \\
\left(1 / \mathrm{m}^{3}\right)\end{array}$ & $\begin{array}{c}\chi / Q \text { with depletion } \\
\left(1 / \mathrm{m}^{3}\right)\end{array}$ & Reduction factor \\
\hline 2 & \multirow{6}{*}{$5.06 \mathrm{E}-8$} & $3.17 \mathrm{E}-8$ & $6.3 \mathrm{E}-1$ \\
\hline 10 & & $1.95 \mathrm{E}-8$ & $3.9 \mathrm{E}-1$ \\
\hline 20 & & 8.35 E-9 & $1.7 \mathrm{E}-1$ \\
\hline 50 & & $2.81 \mathrm{E}-10$ & $5.6 \mathrm{E}-3$ \\
\hline 100 & & $5.93 \mathrm{E}-12$ & $1.2 \mathrm{E}-4$ \\
\hline 200 & & 5.48 E-14 & $1.1 \mathrm{E}-6$ \\
\hline
\end{tabular}

Note:

$\mathrm{AED}=$ aerodynamic equivalent diameter. 


\section{RPP-13482 REV 5}

\section{References}

Hinds, W. C., 1982, Aerosol Technology - Properties, Behavior, and Measurement of Airborne Particles, John Wiley \& Sons, New York, New York.

RPP-13750, 2003, Waste Transfer Leaks Technical Basis Document, Rev. 1, CH2M HILL Hanford Group, Inc., Richland, Washington. 


\section{ATTACHMENT I1}

\section{SAMPLE GXQ INPUT AND RUN FILES GROUND LEVEL RELEASES WITH PLUME DEPLETION DUE TO PARTICLE DEPOSITION}

- Input File

- Sample Run File for Continuous Release (deposition velocity $=0.2 \mathrm{~cm} / \mathrm{s}$ )

- Sample Run File for Puff Release (deposition velocity $=25 \mathrm{~cm} / \mathrm{s}$ ) 


\section{RPP-13482 REV 5}

Caustic spray transport - dep. vel. $=0.2 \mathrm{~cm} / \mathrm{s}$ - No PM

c GXQ Version 4.0 Input File

c mode

1.

$\mathrm{C}$

C MODE CHOICE:

$c$ mode $=1$ then $X / Q$ based on Hanford site specific meteorology

$\mathrm{C}$ mode $=2$ then $\mathrm{X} / \mathrm{Q}$ based on atmospheric stability class and wind speed

$c$ mode $=3$ then $X / Q$ plot file is created

$c$

C LOGICAL CHOICES:

c ifox inorm icdf ichk isite ipop

$T \quad f \quad f \quad f \quad T \quad f$

$c$ ifox $=t$ then joint frequency used to compute frequency to exceed $x / Q$

$\mathrm{C} \quad \mathrm{E}$ then joint Erequency used to compute annual average $\mathrm{X} / \mathrm{Q}$

$c$ inorm $=t$ then joint frequency data is normalized (as in GENII)

$c=\mathrm{f}$ then joint frequency data is un-normalized

$c$ icdf $=t$ then cumulative distribution file created (CDF.OUT)

$c \quad=f$ then no cumulative distribution file created

$c$ ichk $=t$ then $X / Q$ parameter print option turned on

$\mathrm{C}=\mathrm{f}$ then no parametex print

$c$ isite $=t$ then $X / Q$ based on joint frequency data for all 16 sectors

$\mathrm{c} \quad \mathrm{f}$ then $\mathrm{X} / \mathrm{Q}$ based on joint frequency data of individual sectors

ipop $=t$ then $x / Q$ is population weighted

$\mathrm{C}=\mathrm{f}$ then no population weighting

X/Q AND WIND SPEED ADJUSTMENT MODELS:

$C$ ipuff idep isrc iwind

$$
0 \quad 1 \quad 000
$$

C DIFFUSION COEFFICIENT ADUUSTMENT MODELS:

C iwake ipm iflow ientr

0000

C EFFECTIVE RELEASE HEIGHT ADJUSTMENT MODELS:

C (irise igrnd) iwash igrav

0000

$c$ ipuff $=1$ then $X / Q$ calculated using puff model

$\mathrm{C}=0$ then $\mathrm{X} / \mathrm{Q}$ calculated using default continuous plume model

$c$ idep $=1$ then plume depletion model turned on (Chamberlain model)

$c$ isrc $=1$ then $x / Q$ multiplied by scalar

$\mathrm{C} \quad=2$ then $X / Q$ adjusted by wind speed function

$\mathrm{c}$ iwind $=1$ then wind speed corrected for plume height

$c$ iwake = I then NRC RG 1.145 building wake model turned on

$\mathrm{C} \quad=2$ then MACCS virtual distance building wake model turned on

$\mathrm{c}$ ipm = 1 then NRC RG 1.145 plume meander model turned on

$\mathrm{c} \quad=2$ then 5 th Power Law plume meander model turned on

$c \quad=3$ then sector average model turned on

$c$ iflow $=1$ then sigmas adjusted for volume flow rate

$c$ ientr $=1$ then method of Pasquill used to account for entrainment

$c$ irise $=1$ then MACCS buoyant plume rise model turned on

$\mathrm{c} \quad=2$ then ISC2 momentum/buoyancy plume rise model turned on

$\mathrm{c}$ igrnd $=I$ then Mills buoyant plume rise modification for ground effects

c iwash $=1$ then stack downwash model turned on

$c$ igrav $=1$ then gravitational settling model turned on

$\mathrm{C}=0$ unless specified otherwise, 0 turns model off

C

C PARAMETER INPUT:

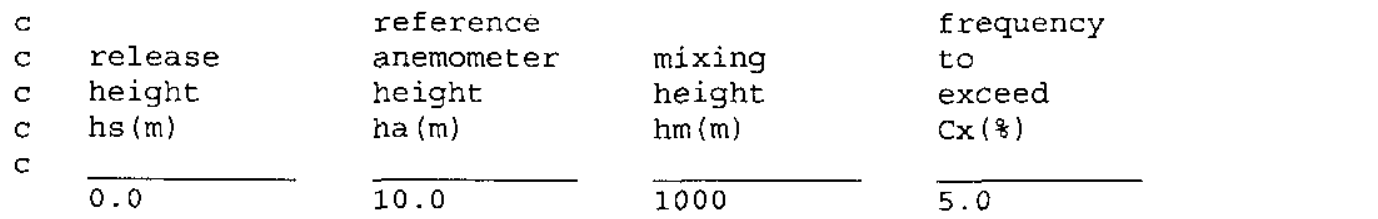

$\mathrm{C}$ 


\section{RPP-13482 REV 5}

\begin{tabular}{|c|c|c|c|c|}
\hline $\begin{array}{l}\text { initial } \\
\text { plume } \\
\text { width } \\
\text { Wb }(m)\end{array}$ & $\begin{array}{l}\text { initial } \\
\text { plume } \\
\text { height } \\
\mathrm{Hb}(\mathrm{m})\end{array}$ & $\begin{array}{l}\text { release } \\
\text { duration } \\
\text { trd(hr) }\end{array}$ & $\begin{array}{l}\text { deposition } \\
\text { velocity } \\
\text { vd }(\mathrm{m} / \mathrm{s})\end{array}$ & $\begin{array}{l}\text { gravitationa } \\
\text { settling } \\
\text { velocity } \\
\mathrm{vg}(\mathrm{m} / \mathrm{s})\end{array}$ \\
\hline 0.0 & 0.0 & 0.0 & 0.002 & 0.00 \\
\hline $\begin{array}{l}\text { ambient } \\
\text { temperature } \\
\text { Tamb (C) }\end{array}$ & $\begin{array}{l}\text { initial } \\
\text { plume } \\
\text { temperature } \\
\text { To(C) }\end{array}$ & $\begin{array}{l}\text { initial } \\
\text { plume } \\
\text { flow rate } \\
\text { V0 (m3/s) }\end{array}$ & $\begin{array}{l}\text { release } \\
\text { diameter } \\
d(m)\end{array}$ & $\begin{array}{l}\text { convective } \\
\text { heat release } \\
\text { rate(1) } \\
\text { qh }(w)\end{array}$ \\
\hline 20 & 38 & 1.0 & $\overline{1.0}$ & 0 \\
\hline
\end{tabular}

(1) If zero then buoyant flux based on plume/ambient temperature difference.

\begin{tabular}{|c|c|}
\hline $\begin{array}{l}X / Q \\
\text { scaling } \\
\text { factor } \\
c(?)\end{array}$ & $\begin{array}{l}\text { Wind } \\
\text { Speed } \\
\text { Exponent } \\
\text { a (?) }\end{array}$ \\
\hline 1 & .78 \\
\hline
\end{tabular}

$\mathrm{C}$

C RECEPTOR DEPENDENT DATA (no line limit)

C FOR MODE make RECEPTOR DEPENDENT DATA

C 1 (site specific) sector distance receptor-height

c 2 (by class \& wind speed) class windspeed distance offset receptor-height

c 3 (create plot file) class windspeed xmax imax ymax jmax xqmin power

$\mathrm{C}$

C RECEPTOR PARAMETER DESCRIPTION

c sector $=0,1,2 \ldots($ all, $S$, SSW, etc. $)$

c distance $=$ receptor distance $(\mathrm{m})$

c receptor height $=$ height of receptor $(\mathrm{m})$

C class $=1,2,3,4,5,6,7$ (P-G stability class A, B, C, D, E, F, G)

$\mathrm{C}$ windspeed $=$ anemometer wind speed $(\mathrm{m} / \mathrm{s})$

$c$ offset $=$ offset from plume centerline $(\mathrm{m})$

c $\operatorname{xmax}=$ maximum distance to plot or calculate to (m)

$c$ imax = distance intervals

c $y \max =\operatorname{maximum}$ offset to plot $(\mathrm{m})$

$c j \max =$ offset intervals

$c$ xqmin = minimum scaled $\mathrm{X} / \mathrm{Q}$ to calculate

$c$ power $=$ exponent in power function step size

1000

$15360 \quad 0$

$15360 \quad 0$

$13200 \quad 0$

$11100 \quad 0$

111000

111000

$10800 \quad 0$

$8690 \quad 0$

86900

$108970 \quad 0$

$1110430 \quad 0$

$1210530 \quad 0$

$1311160 \quad 0$

$\begin{array}{lll}14 & 15190 & 0\end{array}$

$1521050 \quad 0$

$1615360 \quad 0$ 
RPP-13482 REV 5

Current Input File Name: zimm2a.IN

GXQ Version $4.0 \mathrm{~F}$

October 9, 2002

General Purpose Atmospheric Dispersion Code

Produced by Fluor Federal Services, Inc.

Users Guide documented in WHC-SD-GN-SWO-30002 Rev. 1.

Validation documented in WHC-SD-GN-SWD-30003 Rev. 1.

Code Custodian is: Paul D. Rittmann, PhO CHP

Fluor Federat Services, Inc. E6-17

P.0. Box 1050

Richland, WA 99352-1050

(509) $376-8715$

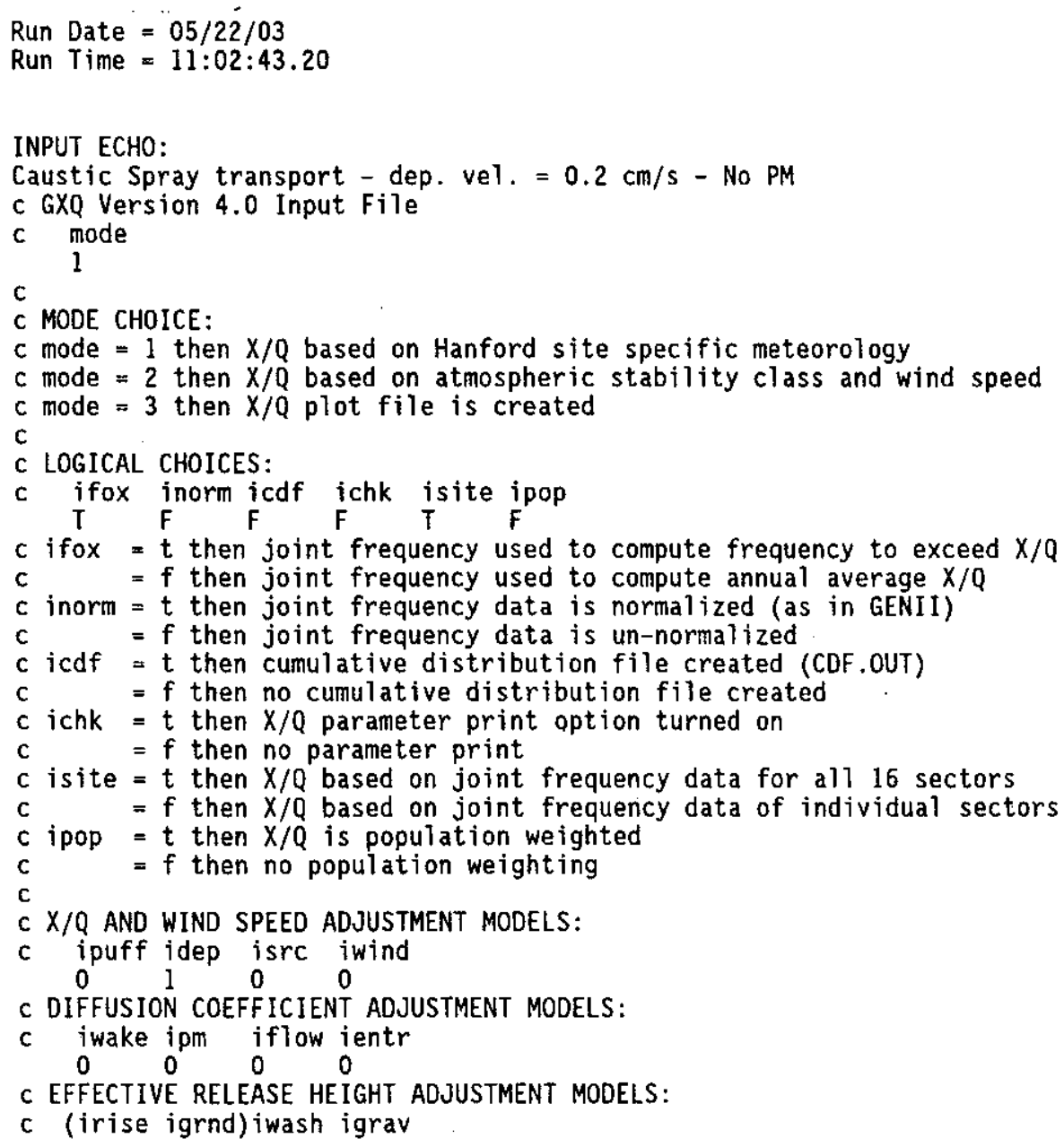




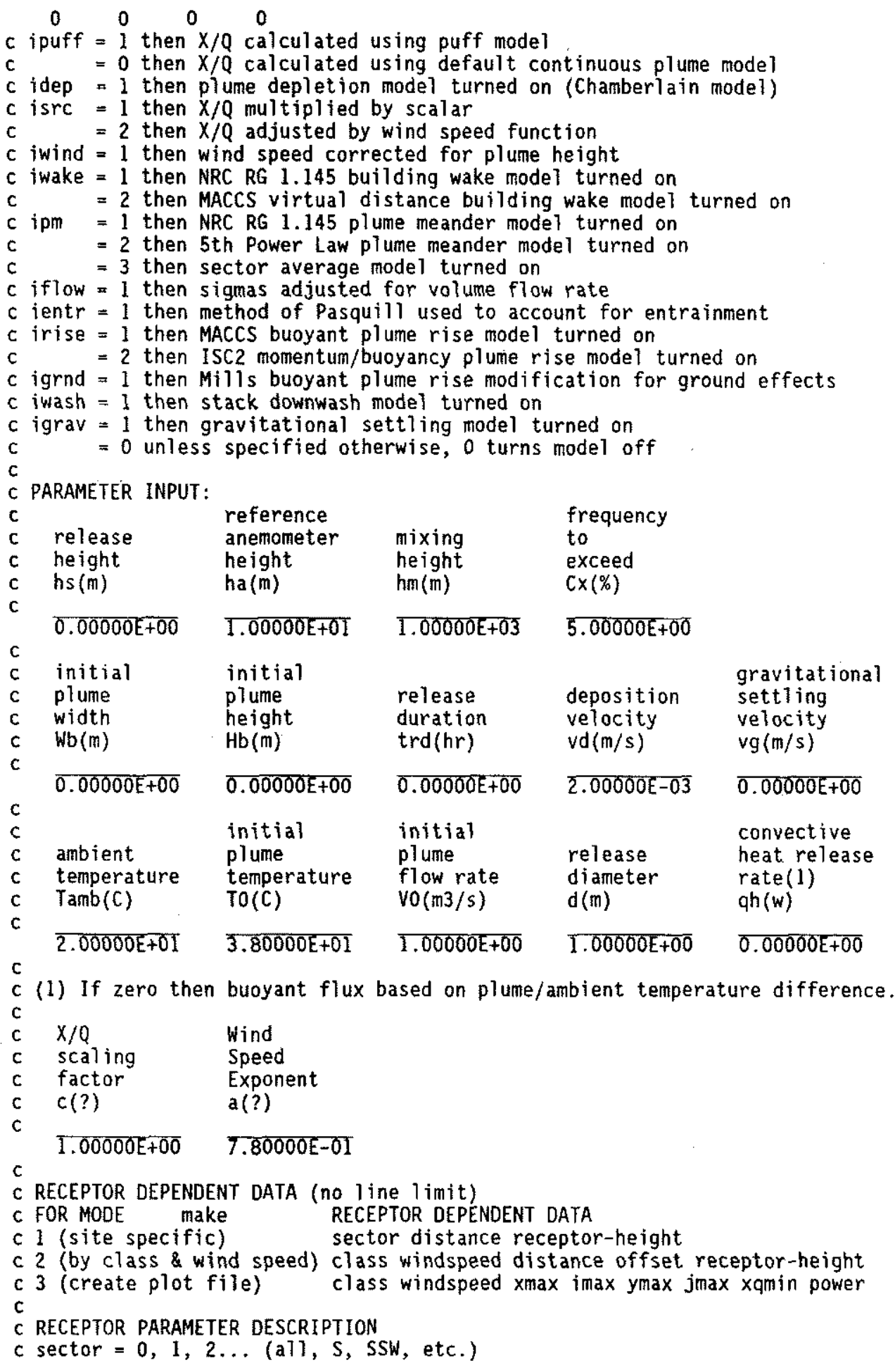




\section{RPP-13482 REV 5}

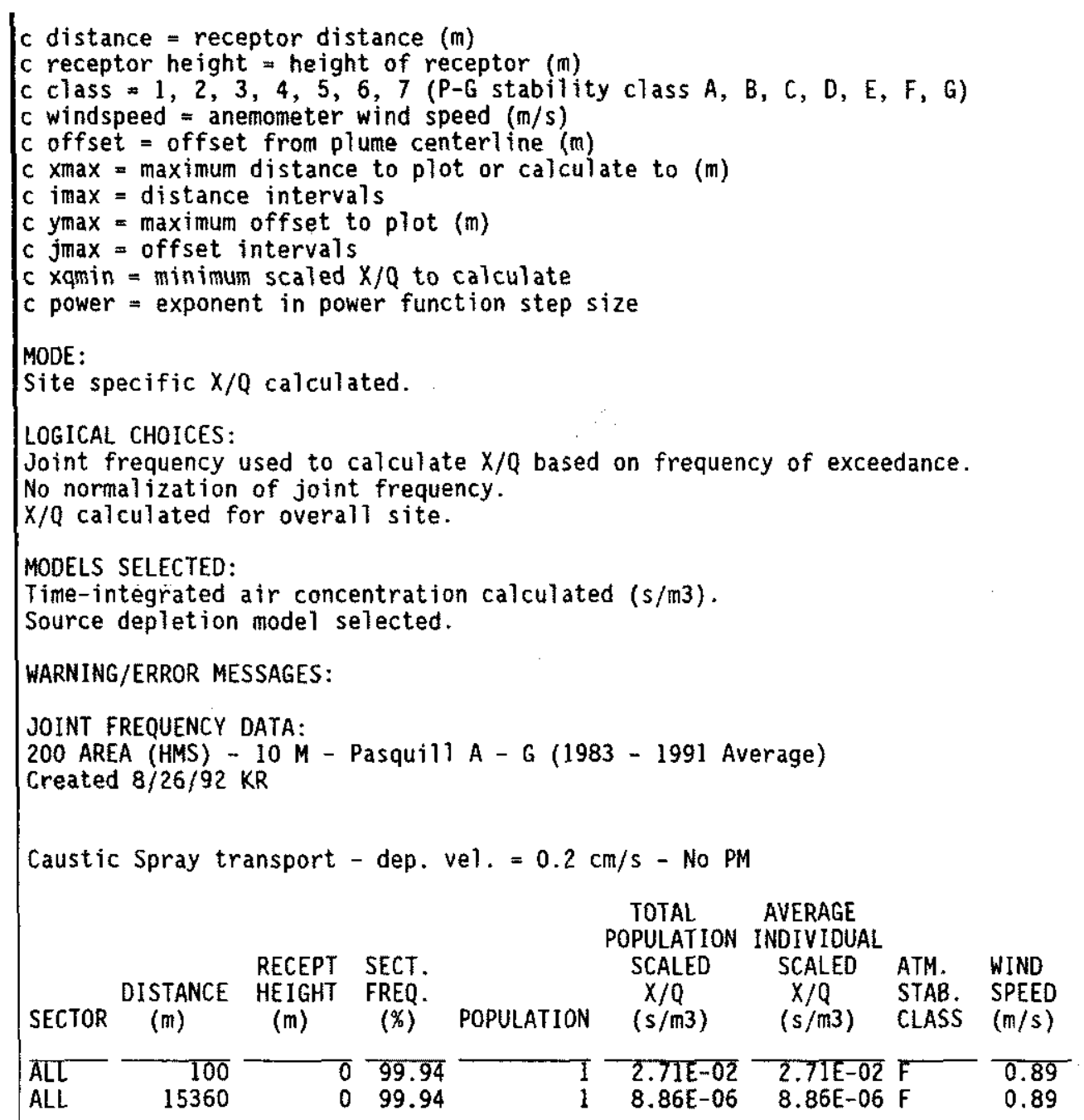


Current Input File Name: zimm2e. IN

GXQ Version $4.0 F$

October 9,2002

General Purpose Atmospheric Dispersion Code

Produced by Fluor Federal Services, Inc.

Users Guide documented in WHC-SD-GN-SWD-30002 Rev. 1.

Validation documented in WHC-SD-GN-SWD-30003 Rev. 1.

Code Custodian is: Paul D. Rittmann, PhD CHP

Fluor Federal Services, Inc. E6-17

P.0. Box 1050

Richl and, WA 99352-1050

(509) $376-8715$

Run Date $=05 / 22 / 03$

Run Time $=13: 33: 58.43$

INPUT ECHO:

caustic Spray transport - dep. vel. $=25 \mathrm{~cm} / \mathrm{s}-$ Puff

c GXQ Version 4.0 Input File

c mode

1

c MODE CHOICE:

c mode $=1$ then $X / Q$ based on Hanford site specific meteorology

$c$ mode $=2$ then $X / Q$ based on atmospheric stability class and wind speed

$c$ mode $=3$ then $X / Q$ plot file is created

c

C LOGICAL CHOICES:

c ifox inorm icdf ichk isite ipop

$c$ ifox $=t$ then joint frequency used to compute frequency to exceed $x / Q$

$c \quad=f$ then joint frequency used to compute annual average $X / Q$

$c$ inorm $=t$ then joint frequency data is normalized (as in GENII)

c $=f$ then joint frequency data is un-normalized

$c$ icdf $=t$ then cumulative distribution file created (CDF.OUT)

$c=f$ then no cumulative distribution file created

$c$ ichk $=t$ then $X / Q$ parameter print option turned on

$c=f$ then no parameter print

$c$ isite $=t$ then $X / Q$ based on joint frequency data for all 16 sectors

$c \quad=f$ then $X / Q$ based on joint frequency data of individual sectors

c ipop $=t$ then $X / Q$ is population weighted

$c=f$ then no population weighting

C $X / Q$ AND WIND SPEED ADJUSTMENT MODELS:

$c$ ipuff idep isrc iwind

$$
10
$$

c DIFFUSION COEFFICIENT ADJUSTMENT MODELS:

C iwake ipm iflow ientr

0 O 0 O 0

c EFFECTIVE RELEASE HEIGHT ADJUSTMENT MODELS:

C (irise igrnd)iwash igrav 


\section{RPP-13482 REV 5}

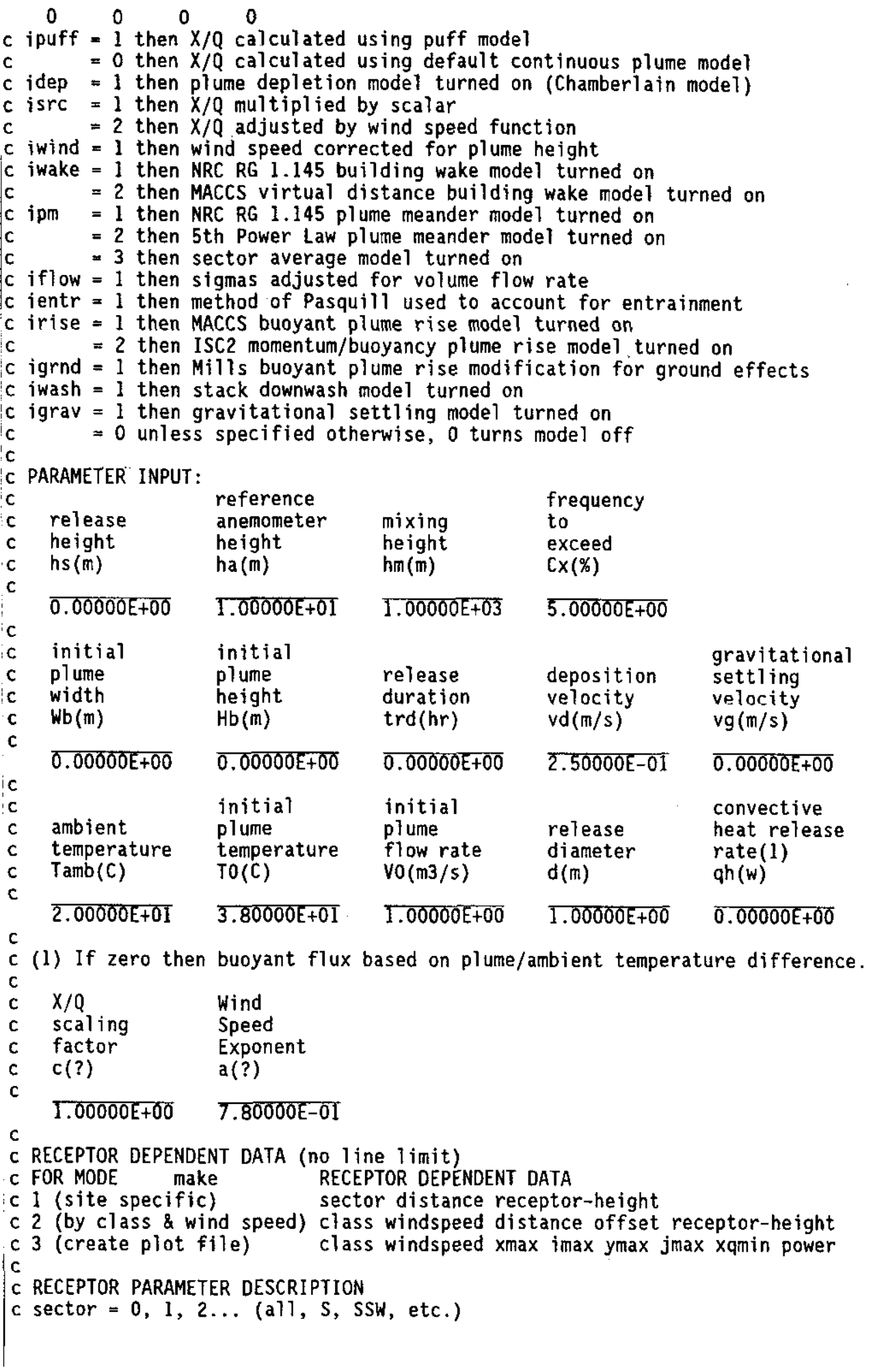




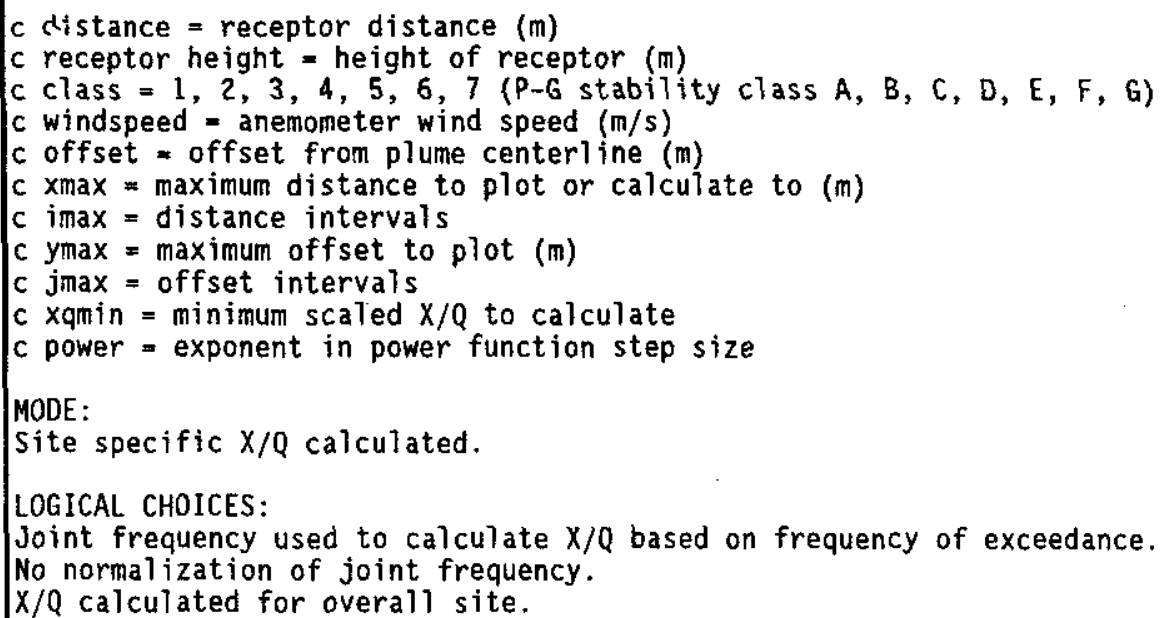

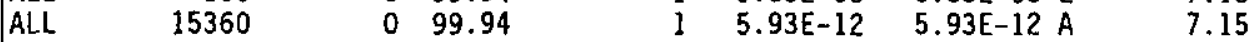




\section{RPP-13482 REV 5}

This page intentionally left blank. 


\section{RPP-13482 REV 5}

\section{APPENDIX J}

\section{SPECIAL $\chi / Q ' S$ FOR GASOLINE POOL FIRES}


RPP-13482 REV 5

This page intentionally left blank. 


\section{APPENDIX J \\ SPECIAL $\chi / Q ' S$ FOR GASOLINE POOL FIRES}

A series of $\chi / Q$ 's were calculated for gasoline fires of various sizes and areal heat rates associated with transportation accidents. These scenarios were developed in RPP-13978, Technical Basis for the Transportation-Related Handling Accidents and Associated Representative Hazardous Conditions, and relevant parameters are summarized here. The fires were assumed to be circular pools with diameters of 2,3 , and $4 \mathrm{~m}$ with areal heat rates of 50,70 , and $90 \mathrm{~kW} / \mathrm{m}^{2}$. The corresponding total heat rates $(\mathrm{kW})$ for the various pool sizes are shown in Table J-1. The dispersion coefficients were calculated using the MACCS buoyant plume rise model as discussed in Section 2.3.2 of the main document. The amount of buoyant plume rise can be based on either the plume ambient temperature difference or on the fire heat rate. If a non-zero fire heat rate is entered (the case here) then it overrides the plume temperature entry which becomes inoperative. The plume temperature is operative only when a thermal plume rise model is turned on (irise $=1$ or 2) and the thermal heat rate is entered as zero. Corrections were also included for the increase in wind speed with plume height and for initial air entrainment due to plume turbulence, including ground effects. Source width correction is included as part of the plume rise model. All receptors were assumed to have a height of $2 \mathrm{~m}$ above the ground in order to maximize exposure to the elevated plume. The resulting 1 -hr $\chi / \mathrm{Q}$ 's (i.e., without plume meander) are shown in Tables J-2 and J-3. As discussed in Section 2.3.3 of the main document, plume meander effects cannot be applied to a large source-corrected $\chi / Q^{\prime}$.

Table J-1. Total Fire Heat Rates.

\begin{tabular}{|c|c|c|c|}
\hline \multirow{2}{*}{$\begin{array}{l}\text { Pool diameter } \\
\text { (m) }\end{array}$} & \multicolumn{3}{|c|}{ Total fire heat rate $(\mathrm{kW})$} \\
\hline & $50 \mathrm{~kW} / \mathrm{m}^{2}$ & $70 \mathrm{~kW} / \mathrm{m}^{2}$ & $90 \mathrm{~kW} / \mathrm{m}^{2}$ \\
\hline 2.0 & 157 & 220 & 283 \\
\hline 3.0 & 353 & 495 & 636 \\
\hline 4.0 & 628 & 880 & 1130 \\
\hline
\end{tabular}

Table J-2. $95^{\text {th }}$ Percentile Onsite 1-hr $\chi / \mathrm{Q}$ 's $(100 \mathrm{~m})$.

\begin{tabular}{|c|c|c|c|}
\hline \multirow{2}{*}{$\begin{array}{l}\text { Pool diameter } \\
\text { (m) }\end{array}$} & \multicolumn{3}{|c|}{ Onsite $\chi / Q^{\prime}\left(\mathbf{s} / \mathbf{m}^{3}\right)$} \\
\hline & $50 \mathrm{~kW} / \mathrm{m}^{2}$ & $70 \mathrm{~kW} / \mathrm{m}^{2}$ & $90 \mathrm{~kW} / \mathrm{m}^{2}$ \\
\hline 2.0 & $1.15 \mathrm{E}-3$ & $1.00 \mathrm{E}-3$ & 8.54 E-4 \\
\hline 3.0 & $9.09 \mathrm{E}-4$ & $7.82 \mathrm{E}-4$ & $7.23 \mathrm{E}-4$ \\
\hline 4.0 & $8.08 \mathrm{E}-4$ & $6.98 \mathrm{E}-4$ & $5.64 \mathrm{E}-4$ \\
\hline
\end{tabular}




\section{RPP-13482 REV 5}

Table J-3. $95^{\text {th }}$ Percentile Offsite 1-hr $\chi / \mathrm{Q}$ 's (Site Boundary).

\begin{tabular}{|c|c|c|c|}
\hline \multirow{2}{*}{$\begin{array}{l}\text { Pool diameter } \\
\text { (m) }\end{array}$} & \multicolumn{3}{|c|}{ Offsite $\chi / Q^{\prime}\left(\mathbf{s} / \mathrm{m}^{3}\right)$} \\
\hline & $50 \mathrm{~kW} / \mathrm{m}^{2}$ & $70 \mathrm{~kW} / \mathrm{m}^{2}$ & $90 \mathrm{~kW} / \mathrm{m}^{2}$ \\
\hline 2.0 & $1.56 \mathrm{E}-5$ & $1.46 \mathrm{E}-5$ & $1.38 \mathrm{E}-5$ \\
\hline 3.0 & $1.35 \mathrm{E}-5$ & $1.24 \mathrm{E}-5$ & $1.16 \mathrm{E}-5$ \\
\hline 4.0 & $1.20 \mathrm{E}-5$ & $1.08 \mathrm{E}-5$ & $9.93 \mathrm{E}-6$ \\
\hline
\end{tabular}

A sample GXQ run file is included as Attachment $J 1$. Note that the onsite $\chi / Q^{\prime}$ was evaluated at $10-\mathrm{m}$ intervals from $10 \mathrm{~m}$ to $110 \mathrm{~m}$ to investigate the elevated plume behavior as it passed the onsite receptor at $100 \mathrm{~m}$.

\section{References}

RPP-13978, 2003, Technical Basis for the Transportation-Related Handling Accidents and Associated Representative Hazardous Conditions, Rev. 1, CH2M HILL Hanford Group, Inc., Richland, Washington. 
RPP-13482 REV 5

\section{ATTACHMENT J1}

SAMPLE GXQ RUN FILE (Fire diameter $=4 \mathrm{~m}$, Heat rate $=90 \mathrm{~kW} / \mathrm{m}^{2}$ ) 


\section{RPP-13482 REV 5}

Current Input File Name: tomas1.IN

GXQ Version $4.0 \mathrm{~F}$

October 9, 2002

General Purpose Atmospheric Dispersion Code

Produced by Fluor Federal Services, Inc.

Users Guide documented in WHC-SD-GN-SWD-30002 Rev. 1.

validation documented in WHC-SD-GN-SWD-30003 Rev. 1.

Code Custodian is: Paul D. Rittmann, PhD CHP

Fluor Federal Services, Inc. E6-17

P.O. Box 1050

Richland, WA 99352-1050

(509) $376-8715$

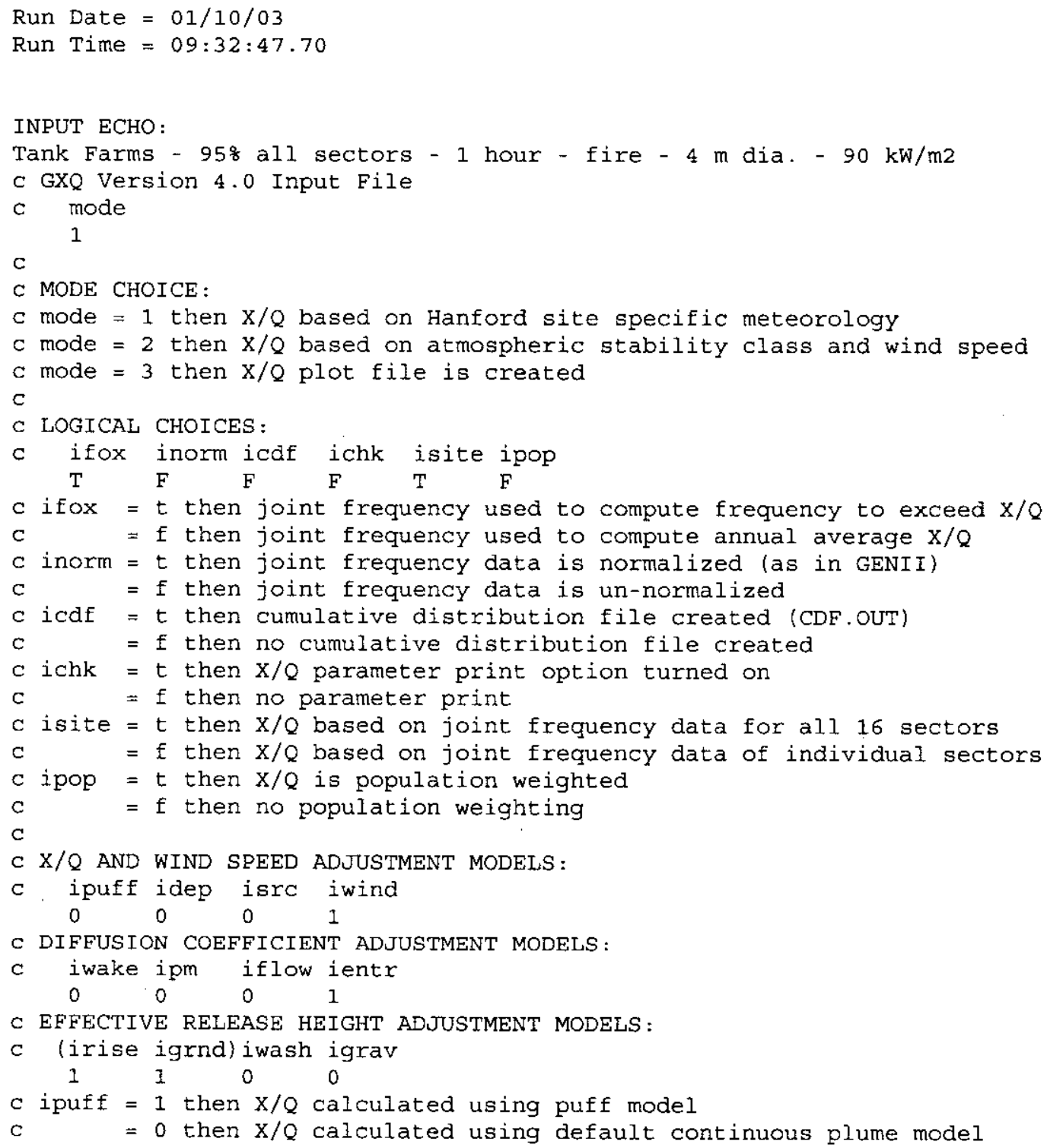




\section{RPP-13482 REV 5}

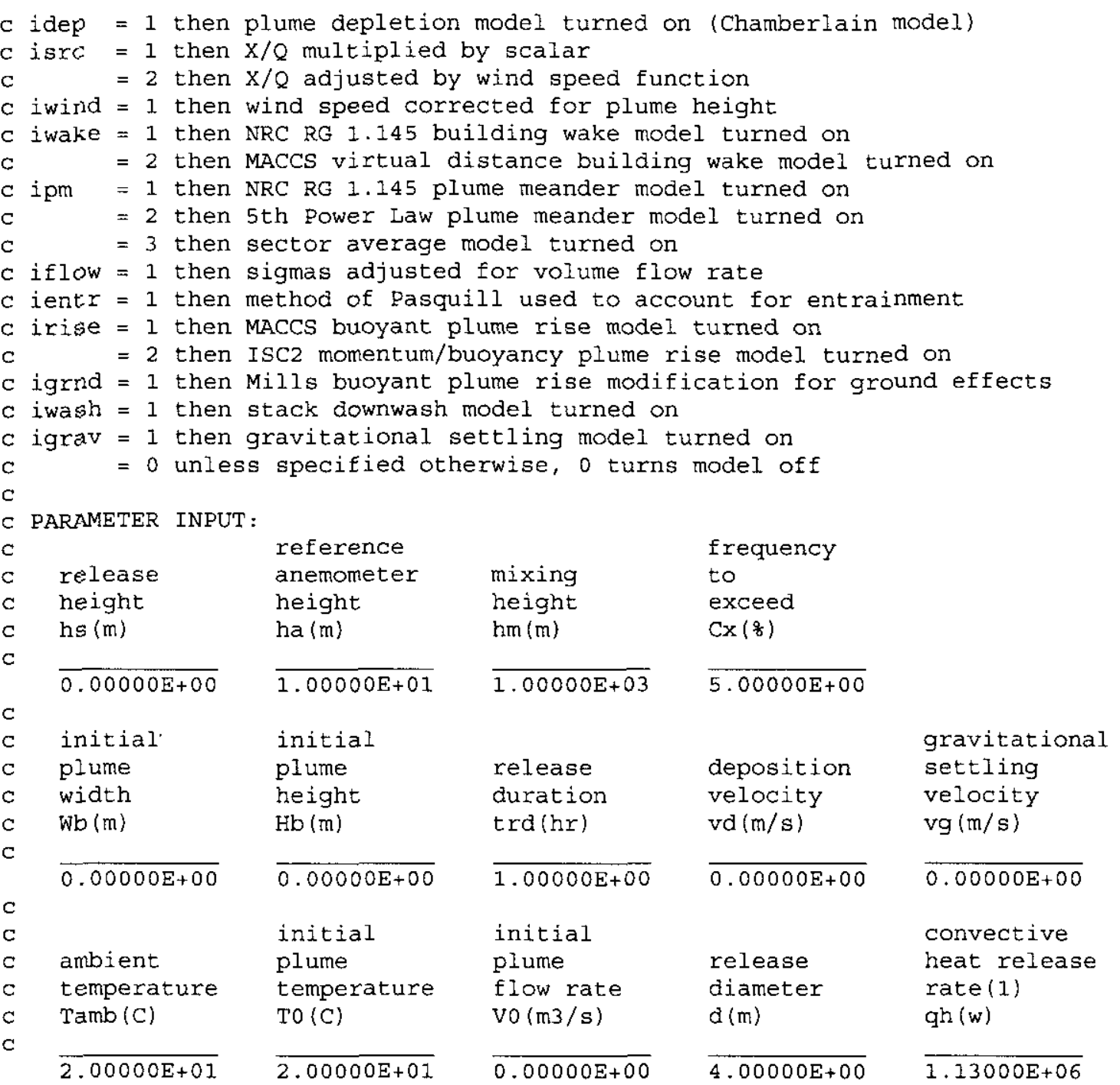

c (1) If zero then buoyant flux based on plume/ambient temperature difference.

c

C $\mathrm{X} / \mathrm{Q}$ Wind

C scaling Speed

C factor Exponent

c $\mathrm{c}($ ?) $\mathrm{a}($ ? $)$

C $\overline{1.00000 \mathrm{E}+00} \quad \overline{7.80000 \mathrm{E}-01}$

C

C RECEPTOR DEPENDENT DATA (no line limit)

C FOR MODE make RECEPTOR DEPENDENT DATA

C 1 (site specific) sector distance receptor-height

c 2 (by class \& wind speed) class windspeed distance offset receptor-height

c 3 (create plot file) class windspeed xmax imax ymax jmax xqmin power

$\mathrm{C}$

C RECEPTOR PARAMETER DESCRIPTION

C sector $=0,1,2 \ldots$ (all, S, SSW, etc.)

C distance $=$ receptor distance $(\mathrm{m})$

$c$ receptor height $=$ height of receptor $(\mathrm{m})$

C class $=1,2,3,4,5,6,7$ (P-G stability class A, B, C, D, E, F, G)

$C$ windspeed $=$ anemometer wind $\operatorname{speed}(\mathrm{m} / \mathrm{s})$

$c$ offset $=$ offset from plume centerline (m)

$c \operatorname{xmax}=$ maximum distance to plot or calculate to $(\mathrm{m})$ 


\section{RPP-13482 REV 5}

c imax = distance intervals

$c y \max =\operatorname{maximum}$ offset to plot (m)

c jmax = offset intervals

$c$ xqmin = minimum scaled $X / Q$ to calculate

$\mathrm{C}$ power $=$ exponent in power function step size

MODE :

Site specific $X / Q$ calculated.

LOGICAL CHOICES :

Joint frequency used to calculate $X / Q$ based on frequency of exceedance.

No normalization of joint frequency.

$\mathrm{X} / \mathrm{Q}$ calculated for overall site.

MODELS SELECTED:

Time-integrated air concentration calculated (s/m3) .

Plume rise air entrainment model selected.

MACCS buoyancy plume rise model based on convective heat.

Mills buoyant rise modification for pool fire selected.

wind velocity corrected for average plume height.

WARNING/ERROR MESSAGES :

JOINT FREQUENCY DATA:

200 AREA (HMS) - 10 M - Pasquill A - G (1983 - 1991 Average)

Created $8 / 26 / 92 \mathrm{KR}$

Tank Farms - 958 all sectors - 1 hour - fire - $4 \mathrm{~m} \mathrm{dia.} \mathrm{-} 90 \mathrm{~kW} / \mathrm{m} 2$

\begin{tabular}{|c|c|c|c|c|c|c|c|c|}
\hline SECTOR & $\begin{array}{l}\text { DISTANCE } \\
(\mathrm{m})\end{array}$ & $\begin{array}{l}\text { RECEPT } \\
\text { HEIGHT } \\
\text { (m) }\end{array}$ & $\begin{array}{c}\text { SECT . } \\
\text { FREQ . } \\
\left(\frac{8}{8}\right)\end{array}$ & POPULATION & $\begin{array}{c}\text { TOTAL } \\
\text { POPULATION } \\
\text { SCALED } \\
X / Q \\
(\mathrm{~s} / \mathrm{m} 3)\end{array}$ & $\begin{array}{c}\text { AVERAGE } \\
\text { INDIVIDUAL } \\
\text { SCALED } \\
X / Q \\
(\mathrm{~s} / \mathrm{m} 3)\end{array}$ & $\begin{array}{l}\text { ATM. } \\
\text { STAB. } \\
\text { CLASS }\end{array}$ & $\begin{array}{l}\text { WIND } \\
\text { SPEED } \\
(\mathrm{m} / \mathrm{s})\end{array}$ \\
\hline$\overline{A L L}$ & 10 & $\overline{2}$ & 99.94 & $\overline{1}$ & $3.54 \mathrm{E}-02$ & $3.54 \mathrm{E}-02$ & $\mathrm{~F}$ & 2.65 \\
\hline ALL & 20 & 2 & 99.94 & 1 & $2.33 E-02$ & $2.33 E-02$ & $\mathrm{~F}$ & 4.70 \\
\hline ALL & 30 & 2 & 99.94 & 1 & $5.04 E-03$ & $5.04 E-03$ & G & 4.70 \\
\hline ALL & 40 & 2 & 99.94 & 1 & $3.34 E-03$ & $3.34 \mathrm{E}-03$ & $E$ & 9.80 \\
\hline AIL & 50 & 2 & 99.94 & 1 & $2.25 E-03$ & $2.25 \mathrm{E}-03$ & $\mathrm{~F}$ & 15.60 \\
\hline ALL & 60 & 2 & 99.94 & 1 & $1.44 \mathrm{E}-03$ & $1.44 \mathrm{E}-03$ & $\mathrm{E}$ & 7.15 \\
\hline ALL & 70 & 2 & 99.94 & 1 & $9.69 \mathrm{E}-04$ & $9.69 \mathrm{E}-04$ & $E$ & 7.15 \\
\hline ALL & 80 & 2 & 99.94 & 1 & $7.01 E-04$ & $7.01 E-04$ & $E$ & 7.15 \\
\hline ALL & 90 & 2 & 99.94 & 1 & $6.27 E-04$ & $6.27 \mathrm{E}-04$ & $\mathrm{D}$ & 7.15 \\
\hline ALL & 100 & 2 & 99.94 & 1 & $5.64 \mathrm{E}-04$ & $5.64 \mathrm{E}-04$ & $\mathrm{D}$ & 7.15 \\
\hline ALL & 110 & 2 & 99.94 & 1 & $5.12 \mathrm{E}-04$ & $5.12 \mathrm{E}-04$ & $\mathrm{D}$ & 7.15 \\
\hline ALL & 15360 & 2 & 99.94 & 1 & $9.93 E-06$ & $9.93 E-06$ & $\mathrm{G}$ & 2.65 \\
\hline
\end{tabular}


RPP-13482 REV 5

APPENDIX K

SPECIAL $\chi / Q ' S$ FOR RELEASES FROM THE 242-A EVAPORATOR

K-i 
RPP-13482 REV 5

This page intentionally left blank.

K-ii 


\section{APPENDIX K}

\section{SPECIAL $\chi / Q ' S$ FOR RELEASES FROM THE 242-A EVAPORATOR}

A special set of $\chi / Q$ 's were calculated for releases from the 242-A Evaporator. This facility is located at the east end of the 200 East Area between the 241-AX and 241-AW Tank Farms, and is within the tank farms area with regard to sector distances to the Hanford Site boundary. The Hanford Site boundary distances shown in Table 2-3 of the main document were used to determine the $\chi / Q^{\prime}$ for the site boundary receptor (maximum offsite individual [MOI]). In addition, $\chi / \mathrm{Q}$ 's are required for the onsite receptor (collocated worker [CW]) at $100 \mathrm{~m}$ and an onsite public receptor at $8 \mathrm{~km}$ (Highway 240$)$.

These $\chi / Q$ 's are to be applied to the two bounding accidents (a spill and a fire) in HNF-14755, Documented Safety Analysis for the 242-A Evaporator. No credit was taken for thermal lofting from the fire due to the fact that the fire is assumed to occur within the intact building and to cool before entering the environment. However, mixing of the release plume with the building wake was assumed. Minimum dimensions of the facility are given as $23 \mathrm{~m}$ wide by $19 \mathrm{~m}$ high in Section 3.4.2.2.2 of HNF-14755. The resulting building wake-corrected $95^{\text {th }}$ percentile $\chi / Q^{\prime}$ 's over all sectors were calculated using the methodology described in Section 2.3.5 of the main document and are shown in Table K-1 below.

Table K-1. $95^{\text {th }}$ percentile $\chi / Q^{\prime}$ 's for 242-A Evaporator.

\begin{tabular}{|c|c|}
\hline Receptor & $\chi / \mathbf{Q}^{\prime}\left(\mathbf{s} / \mathbf{m}^{3}\right)$ \\
\hline CW at $100 \mathrm{~m}$ & $1.09 \mathrm{E}-2$ \\
\hline Onsite public at $8 \mathrm{~km}$ & $3.30 \mathrm{E}-5$ \\
\hline MOI at site boundary & $2.21 \mathrm{E}-5$ \\
\hline
\end{tabular}

Notes:

$\mathrm{CW}=$ collocated worker.

MOI $=$ maximum offsite individual.

The GXQ input and run file with these results is attached.

\section{Reference}

HNF-14755, 2004, Documented Safety Analysis for the 242-A Evaporator, Rev. 1, CH2M HILL Hanford Group, Inc., Richland Washington. 
RPP-13482 REV 5

\section{ATTACHMENT K1}

GXQ INPUT AND RUN FILES FOR RELEASES FROM 242-A EVAPORATOR WITH BUILDING WAKE CORRECTION 


\section{RPP-13482 REV 5}

242-A Evaporator X/Q update for DSA

c GXQ Version 4.0 Input File

1 = mode

C MODE SELECTION:

C $1-X / Q$ based on site-specific wind data from JOINTFRE.IN

c $2-X / Q$ based on input stability class and wind speed

c $3-\mathrm{X} / \mathrm{Q}$ plot file table is created

$\mathrm{C}$

C SITE WIND \& POPULATION OPTIONS:

C ifox inorm icdf ichk isite ipop

$$
T \quad f \quad f \quad f \quad T f f
$$

ifox $=\mathrm{T}$ compute probabilistic $\mathrm{X} / \mathrm{Q}$ from a cumulative distribution

$=F$ compute annual average $X / Q$ (usually sector average with ipm=3)

inorm $=\mathrm{T}$ normalize joint frequency data in a sector (as in GENII)

$=F$ use joint frequency data as is

icdf $=T$ put cumulative aistributions in the CDF. OUT file

$=F$ no cumulative distribution file created

ichk $=T$ show details for each $\mathrm{X} / \mathrm{Q}$ (long output)

$=F$ standard length output

isite $=T$ compute overall site $X / Q$ (need groups of 16 sectors)

$=F$ compute $\mathrm{X} / \mathrm{Q}$ for individual sectors

ipop $=T$ population-weighted using the file POP.IN (use ipm=3)

$=F$ no population weighting

C GAUSSIAN PLUME/PUFF MODEL OPTIONS: (enter 0 to inactivate option)

ipuff idep isrc iwind

0000

c iwake ipm iflow ientr

1000

irise igrnd iwash igrav

$0 \quad 0000$

ipuff $=0$ compute time-integrated air concentrations $(\mathrm{s} / \mathrm{m} 3)$

$=1$ compute air concentrations $\left(1 / \mathrm{m}_{3}\right)$ (need release duration)

idep $=1$ plume depletion model (source depletion)

isrc $=1$ multiply $\mathrm{X} / \mathrm{Q}$ by scale factor (input below)

$=2$ multiply by wind speed function: (factor)* [speed** (exponent)]

$=3$ multiply by wind speed function: (factor)* [10** (speed*exponent)]

iwind $=1$ wind speed corrected for plume height using power law

iwake = 1 NRC Reg Guide 1.145 building wake model

$=2$ MACCS virtual source building wake model

ipm $=1$ NRC Reg Guide 1.145 plume meander model

$=2$ MACCS time-dependent plume meander model

$=3$ sector average $X / Q$ computed

iflow $=1$ exhaust flow rate adjustment using virtual source method

ientr $=1$ entrainment method of Pasquill

irise $=$ I MACCS buoyant plume rise (uses building height)

$=2$ ISC momentum/buoyancy plume rise

igrnd $=1$ modifies buoyant plume rise for ground-level effects

iwash $=1$ stack downwash

igrav = 1 gravitational settling

PARAMETER INPUT:

release anemometer mixing of of $\mathrm{X} / \mathrm{Q}$

height, $m$ height, $m(*)$ height, $m$ larger

$0010 \quad 1000 \quad 5.0$

(* In MODE=1 this input is superceded by the value read from JOINTFRE.IN)

C

c building building release deposition gravitational

c width,m height,m duration, h speed,m/s settling,m/s

23.0

$$
19.0
$$

0

ambient

stack gas

temp, $\mathrm{c}$

stack flow

rate, $\mathrm{m} 3 / \mathrm{s}$

0

0

stack (pool)

diameter, m

heat exhaust

rate, $\mathrm{w}(* *)$ 


\section{RPP-13482 REV 5}

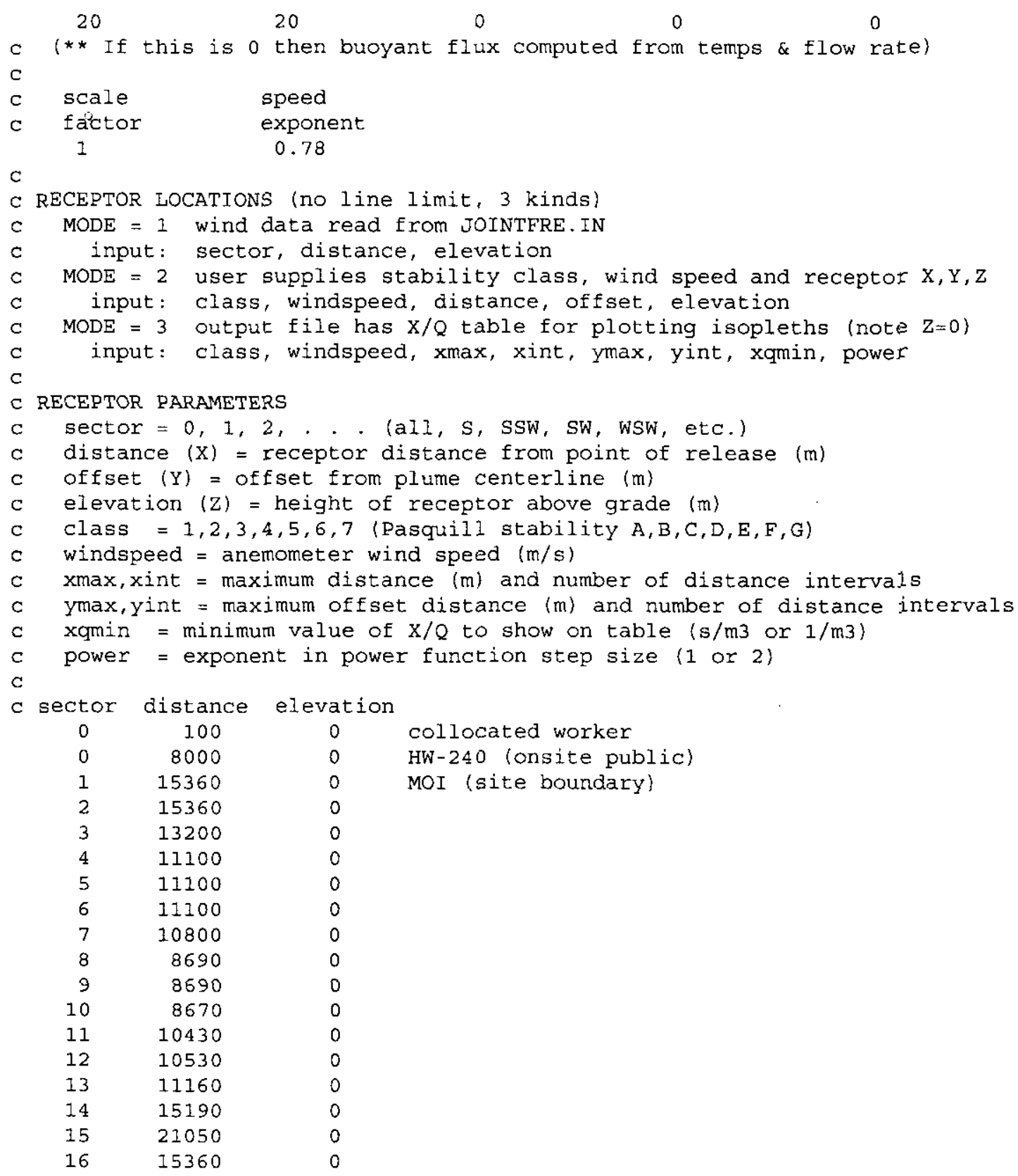




\section{RPP-13482 REV 5}

GXQ Version $4.0 \mathrm{~F}$

october 9, 2002

General Purpose Atmospheric Dispersion Code Produced by Fluor Federal Services, Inc.

Users Guide documented in WHC-SD-GN-SWD-30002 Rev. 1. Validation documented in WHC-SD-GN-SWD-30003 Rev. 1 .

Code Custodian is: PauI D. Rittmann, PhD CHP

Fluor Federal Services, Inc. E6-17

P.O. Box 1050

Richland, WA 99352-1050

(509) 376-8715

Run Date $=09 / 27 / 04$

Run Time $=13: 56: 05.32$

INPUT ECHO:

242-A Evaporator X/Q update for DSA

C GXQ Version 4.0 Input File

1

C MODE SELECTION:

c 1 - $\mathrm{X} / \mathrm{Q}$ based on site-specific wind data from JOINTFRE. IN

c $2-x / Q$ based on input stability class and wind speed

3 - X/Q plot file table is created

$\mathrm{C}$

C SITE WIND \& POPULATION OPTIONS:

C ifox inorm icaf ichk isite ipop

$\begin{array}{llllll}T & F & F & F & T & F\end{array}$

$C$ ifox $=T$ compute probabilistic $X / Q$ from a cumulative distribution

c $\quad=F$ compute annual average $X / Q$ (usually sector average with ipm=3)

$c$ inorm $=\mathrm{T}$ normalize joint frequency data in a sector (as in GENII)

$=F$ use joint frequency data as is

icdf $=T$ put cumulative distributions in the CDF.OUT file

$=F$ no cumulative distribution file created

ichk $=\mathrm{T}$ show details for each $\mathrm{X} / \mathrm{Q}$ (long output)

$=F$ standard length output

isite $=\mathrm{T}$ compute overall site $\mathrm{X} / \mathrm{Q}$ (need groups of 16 sectors)

$=\mathrm{F}$ compute $\mathrm{X} / \mathrm{Q}$ for individual sectors

ipop $=T$ population-weighted using the file POP.IN (use ipm=3)

$=F$ no population weighting

GAUSSIAN PLUME/PUFF MODEL OPTIONS: (enter 0 to inactivate option)

C ipuff idep isrc iwind

0 ipuf 0 isep 0 iwind

c iwake ipm iflow ientr

$\begin{array}{llr}1 & 0 & 0 \\ \text { irise igrnd iwash igrav }\end{array}$

0000000

ipuff $=0$ compute time-integrated air concentrations (s/m3)

$=1$ compute air concentrations $(1 / \mathrm{m} 3)$ (need release duration)

idep $=1$ plume depletion model (source depletion)

isrc $=1$ multiply $x / Q$ by scale factor (input below)

$=2$ multiply by wind speed function: (factor)* [speed** (exponent)]

$=3$ multiply by wind speed function: (factor)*[10** (speed*exponent)]

iwind $=1$ wind speed corrected for plume height using power law 


\section{RPP-13482 REV 5}

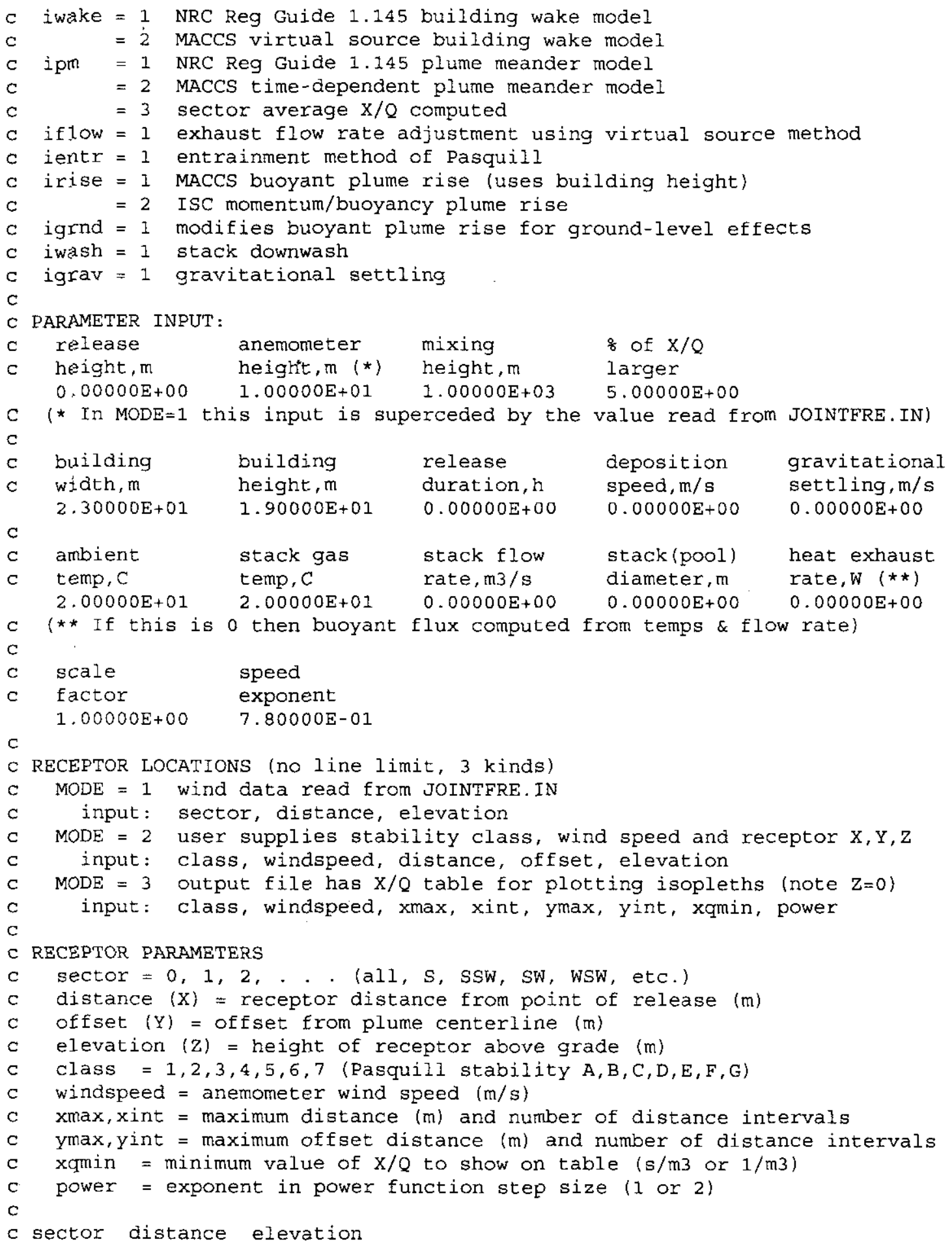




\section{RPP-13482 REV 5}

Time-jntegrated air concentration calculated (s/m3) . NRC RG 1.145 building wake model selected.

WARNING/ERROR MESSAGES:

JOINT FREQUENCY DATA:

200 AREA (HMS) - 10 M - Pasquill A - G (1983 - 1991 Average)

Created $8 / 26 / 92 \mathrm{KR}$

242-A Evaporator $X / Q$ update for DSA

\begin{tabular}{|c|c|c|c|c|c|c|c|c|}
\hline SECTOR & $\begin{array}{l}\text { DISTANCE } \\
(\mathrm{m})\end{array}$ & $\begin{array}{c}\text { RECEPT } \\
\text { HEIGHT } \\
\text { (m) }\end{array}$ & $\begin{array}{c}\text { SECT. } \\
\text { FREQ. } \\
(8)\end{array}$ & POPULATION & $\begin{array}{c}\text { TOTAL } \\
\text { POPULATION } \\
\text { SCALED } \\
X / Q \\
(\mathrm{~s} / \mathrm{m} 3)\end{array}$ & $\begin{array}{c}\text { AVERAGE } \\
\text { INDIVIDUAL } \\
\text { SCALED } \\
X / Q \\
(\mathrm{~s} / \mathrm{m} 3)\end{array}$ & $\begin{array}{l}\text { ATM. } \\
\text { STAB. } \\
\text { CLASS }\end{array}$ & $\begin{array}{l}\text { WIND } \\
\text { SPEED } \\
(\mathrm{m} / \mathrm{s})\end{array}$ \\
\hline$\overline{\mathrm{ALL}}$ & 100 & 0 & 99.94 & $\overline{1}$ & $1.09 \mathrm{E}-02$ & $1.09 \mathrm{E}-02$ & $\bar{F}$ & 0.89 \\
\hline ALI & 8000 & 0 & 99.94 & 1 & $3.30 E-05$ & $3.30 \mathrm{E}-05$ & $\mathrm{~F}$ & 0.89 \\
\hline ALL & 15360 & 0 & 99.94 & 1 & $2.21 E-05$ & $2.21 E-05$ & $F$ & 0.89 \\
\hline
\end{tabular}




\section{RPP-13482 REV 5}

This page intentionally left blank.

K-8 


\section{RPP-13482 REV 5}

\section{APPENDIX L}

\section{SPECIAL $\chi / Q ' S$ FOR RELEASES FROM THE 222-S LABORATORY}




\section{RPP-13482 REV 5}

This page intentionally left blank. 


\section{APPENDIX L \\ SPECIAL $\chi / Q ' S$ FOR RELEASES FROM THE 222-S LABORATORY}

A special set of $\chi / \mathrm{Q}$ 's were calculated for releases from the 222-S Laboratory. This facility is located at the south end of the 200 West Area, and is slightly outside the tank farms area with regard to sector distances to the Hanford Site boundary. The Hanford Site boundary distances shown in Table 2-3 of the main document therefore cannot be used to determine the $\chi / Q^{\prime}$ for the site boundary receptor (maximum offsite individual [MOI]). The site boundary distances used to calculate the site boundary $\chi / \mathrm{Q}^{\prime}$ are shown below in Table L-1. These site boundary distances were generated in the same way as the distances shown in Table 2-3, i.e. the distance in each $22.5^{\circ}$ sector was based on the minimum distance within a $45^{\circ}$ sector centered on the same direction. In addition, $\chi / \mathrm{Q}$ 's are required for the onsite receptor (collocated worker [CW]) at $100 \mathrm{~m}$ and an onsite public receptor at $3.4 \mathrm{~km}$ (Highway 240).

Table L-1. Site Boundary Distances for the 222-S Laboratory.

\begin{tabular}{|c|c|}
\hline Sector & $\begin{array}{c}\text { Minimum distance within } \\
\mathbf{a} \mathbf{4 5}^{\circ} \text { sector }(\mathbf{m})\end{array}$ \\
\hline S & 12,580 \\
\hline SSW & 12,580 \\
\hline SW & 13,620 \\
\hline WSW & 12,950 \\
\hline W & 12,950 \\
\hline WNW & 12,950 \\
\hline NW & 14,110 \\
\hline NNW & 17,130 \\
\hline N & 19,070 \\
\hline NNE & 24,170 \\
\hline NE & 24,530 \\
\hline NNE & 23,160 \\
\hline E & 23,160 \\
\hline ESE & 26,540 \\
\hline SE & 19,400 \\
\hline SSE & 14,570 \\
\hline
\end{tabular}

The following $\chi / \mathrm{Q}$ 's are to be applied to the bounding accident (a building-wide fire) in HNF-12125, 222-S Laboratory Documented Safety Analysis. No credit was taken for thermal lofting from the fire due to the fact that the fire is assumed to occur within the intact building and to cool before entering the environment. However, mixing of the release plume with the building wake was assumed. Minimum dimensions of the facility are $32.6 \mathrm{~m}$ wide by $9.1 \mathrm{~m}$ high. The resulting building wake-corrected $95^{\text {th }}$ percentile $\chi / \mathrm{Q}$ 's over all sectors were calculated 


\section{RPP-13482 REV 5}

using the methodology described in Section 2.3.5 of the main document and are shown in Table L-2.

Table L-2. $95^{\text {th }}$ percentile $\chi / Q^{\prime}$ s for 222-S Laboratory.

\begin{tabular}{|c|c|}
\hline Receptor & $\chi / \mathbf{Q}^{\prime}\left(\mathrm{s} / \mathbf{m}^{3}\right)$ \\
\hline CW at $100 \mathrm{~m}$ & $1.09 \mathrm{E}-2$ \\
\hline Onsite public at $3.4 \mathrm{~km}$ & $1.02 \mathrm{E}-4$ \\
\hline MOI at site boundary & $1.13 \mathrm{E}-5$ \\
\hline Notes: & \\
$\mathrm{CW}=$ collocated worker. \\
MOI $=$ maximum offsite individual.
\end{tabular}

The GXQ input and run file with these results is attached.

\section{Reference}

HNF-12125, 2004, 222-S Laboratory Documented Safety Analysis, Rev. 1, CH2M HILL Hanford Group, Inc., Richland Washington. 
RPP-13482 REV 5

ATTACHMENT L1

GXQ INPUT AND RUN FILES FOR RELEASES FROM 222-S LABORATORY WITH BUILDING WAKE CORRECTION 


\section{RPP-13482 REV 5}

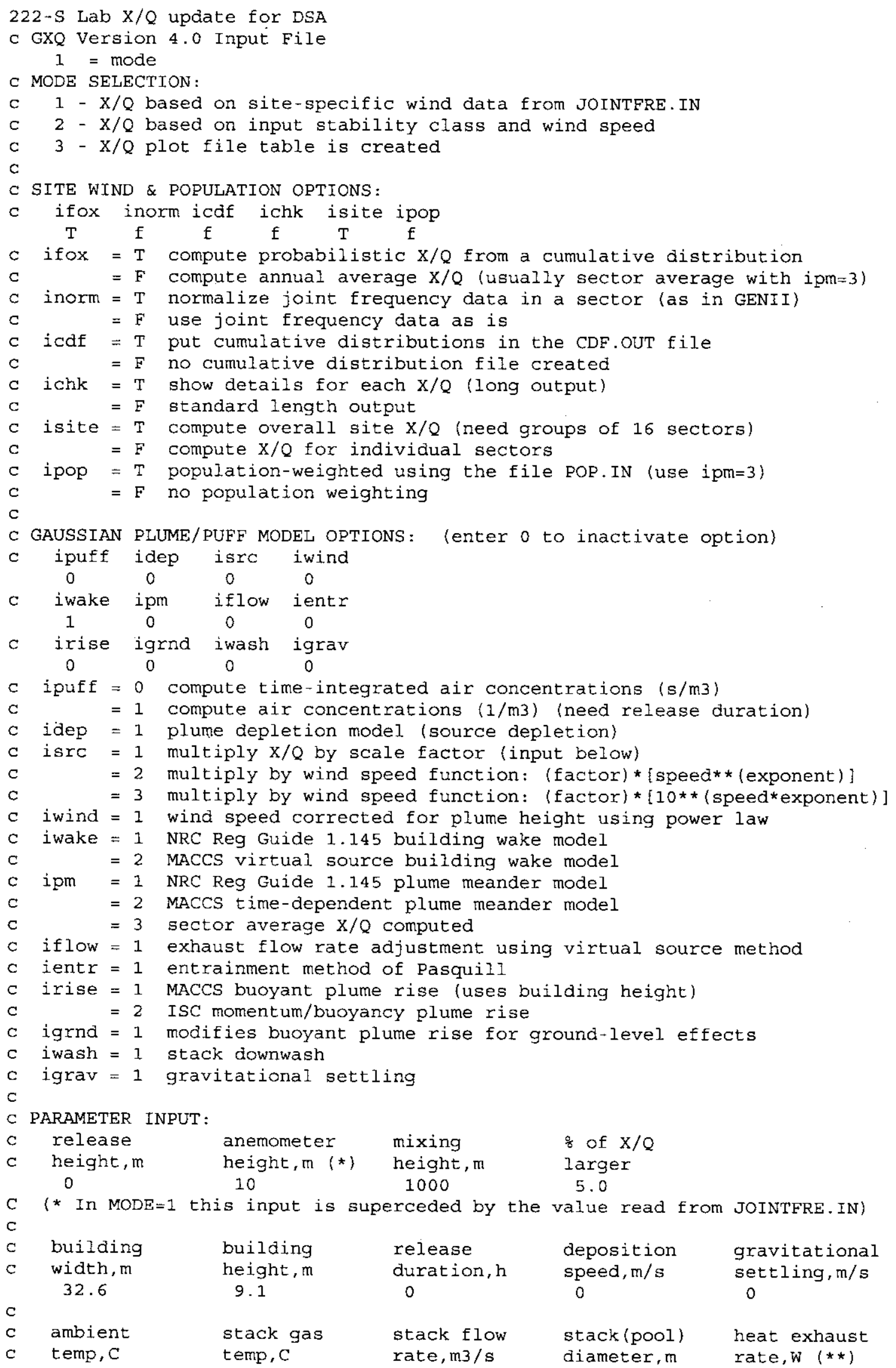




\section{RPP-13482 REV 5}

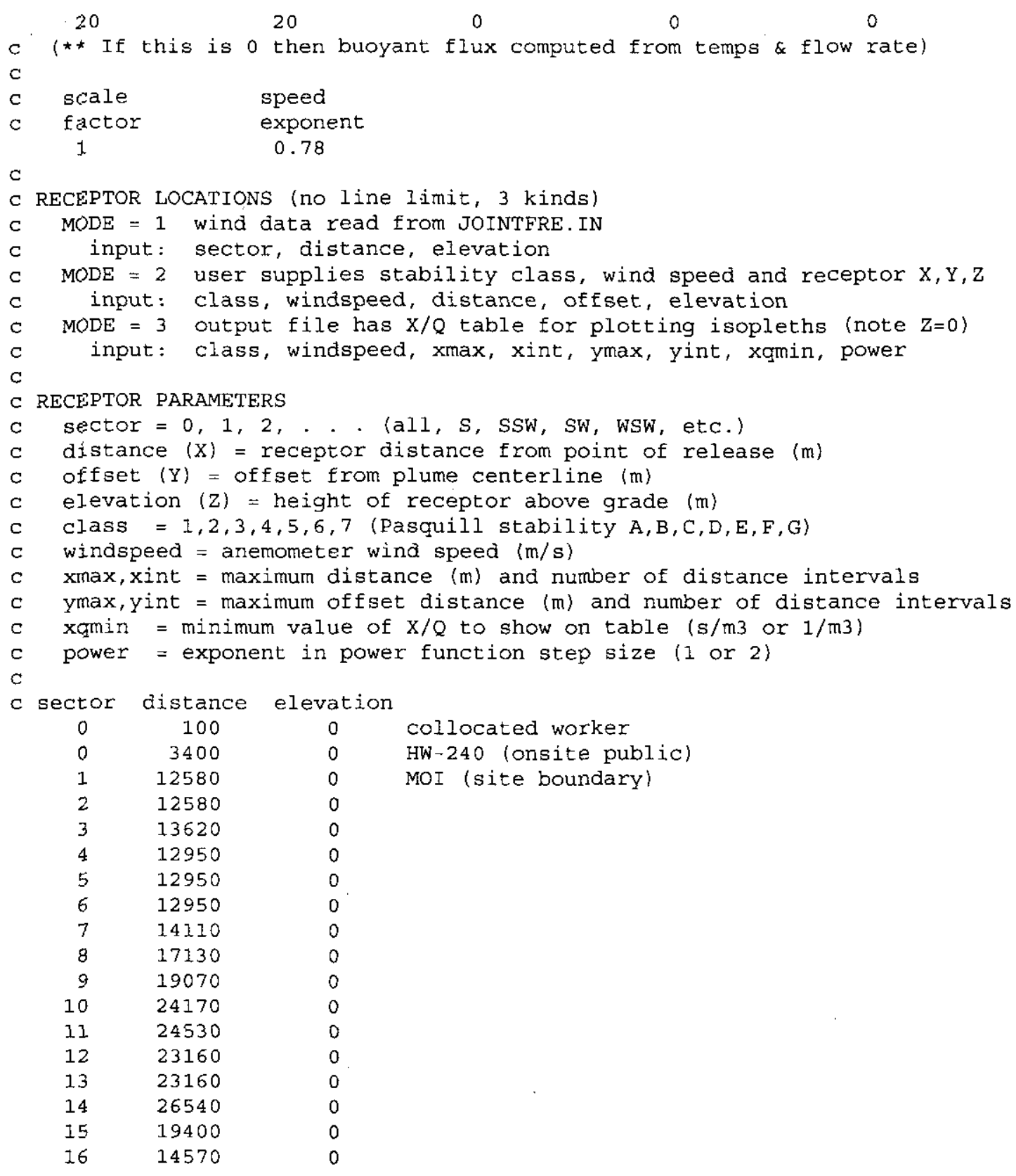




\section{RPP-13482 REV 5}

GXQ Version $4.0 F$

October 9, 2002

General Purpose Atmospheric Dispersion Code Produced by Fluor Federal Services, Inc.

Users Guide documented in WHC-SD-GN-SWD-30002 Rev. 1. Validation documented in WHC-SD-GN-SWD-30003 Rev. 1.

Code Custodian is: Paul D. Rittmann, PhD CHP

Fluor Federal Services, Inc. E6-17

P.O. Box 1050

Richland, WA 99352-1050

(509) $376-8715$

Run Date $=09 / 27 / 04$

Run Time $=13: 51: 29.92$

INPUT ECHO:

$222-S$ Lab X/Q update for DSA

c GXQ Version 4.0 Input File

1

C MODE SELECTION:

C $1-X / Q$ based on site-specific wind data from JOINTFRE. IN

c $2-x / Q$ based on input stability class and wind speed

c $3-X / Q$ plot file table is created

C SITE WIND \& POPULATION OPTIONS:

C ifox inorm icdf ichk isite ipop
$\mathrm{T}$
F
$\mathrm{T}$

$\mathrm{F}$

$\mathrm{F}$

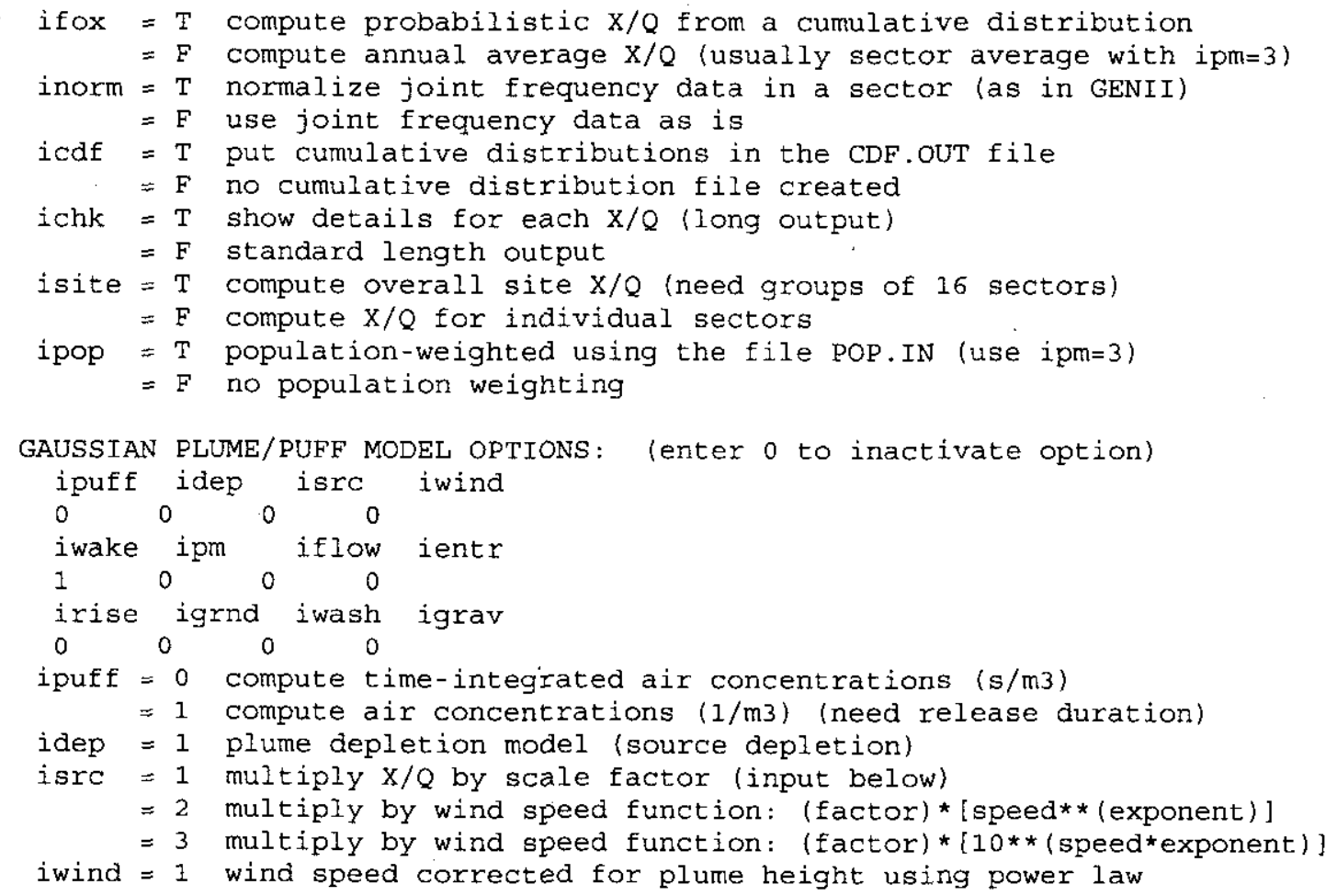




\section{RPP-13482 REV 5}

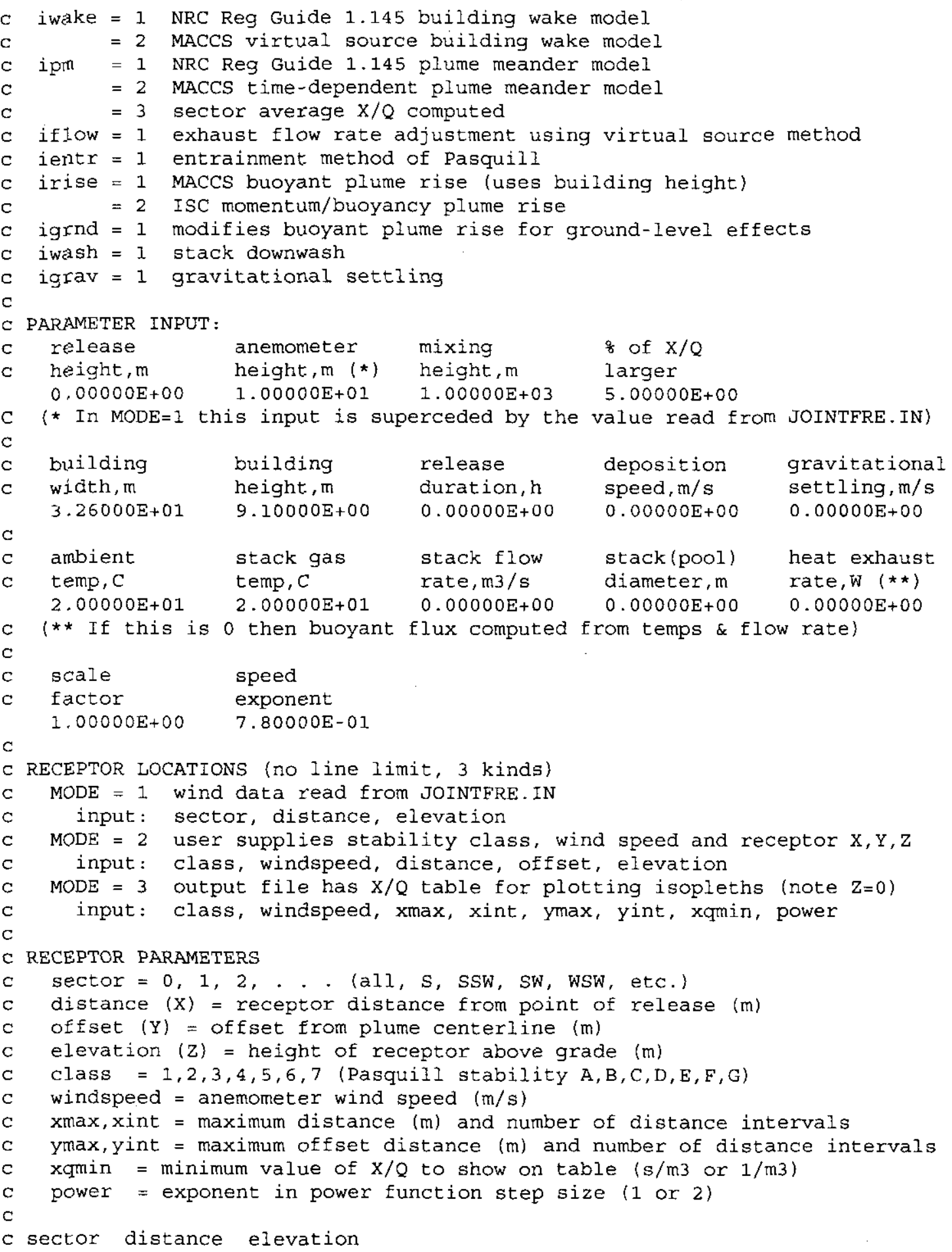

MODE :

Site specific $X / Q$ calculated.

LOGICAL CHOICES:

Joint frequency used to calculate $x / Q$ based on fxequency of exceedance.

No normalization of joint frequency.

$\mathrm{X} / \mathrm{Q}$ calculated for overall site.

MODELS SELECTED: 


\section{RPP-13482 REV 5}

Time-integrated air concentration calculated $(\mathrm{s} / \mathrm{m} 3)$. NRC RG 1.145 building wake model selected.

WARNING/ERROR MESSAGES :

JOINT FREQUENCY DATA:

200 AREA (HMS) - 10 M - Pasquill A - G (1983 - 1991 Average) Created $8 / 26 / 92 \mathrm{KR}$

222-S Lab X/Q update for DSA

\begin{tabular}{|c|c|c|c|c|c|c|c|c|}
\hline & $\begin{array}{c}{ }^{\circ} \\
\text { DISTANCE }\end{array}$ & $\begin{array}{l}\text { RECEPT } \\
\text { HEIGHT }\end{array}$ & $\begin{array}{l}\text { SECT. } \\
\text { FREQ. }\end{array}$ & & $\begin{array}{c}\text { TOTAL } \\
\text { POPULATION } \\
\text { SCALED } \\
\text { X/Q }\end{array}$ & $\begin{array}{l}\text { AVERAGE } \\
\text { INDIVIDUAL } \\
\text { SCALED } \\
X / Q\end{array}$ & $\begin{array}{l}\text { ATM. } \\
\text { STAB. }\end{array}$ & $\begin{array}{l}\text { WIND } \\
\text { SPEED }\end{array}$ \\
\hline SECTOR & $(\mathrm{m})$ & (m) & $(8)$ & POPULATION & $(s / m 3)$ & $(\mathrm{s} / \mathrm{m} 3)$ & CLASS & $(\mathrm{m} / \mathrm{s})$ \\
\hline ALL & 100 & 0 & 99.94 & 1 & $1.09 \mathrm{E}-02$ & $1.09 \mathrm{E}-02$ & $\mathrm{~F}$ & 0.89 \\
\hline ALL & 3400 & 0 & 99.94 & 1 & $1.02 E-04$ & $1.02 E-04$ & $\mathrm{~F}$ & 0.89 \\
\hline ALL & 14570 & 0 & 99.94 & 1 & 1. $13 \mathrm{E}-05$ & $1.13 E-05$ & $\mathrm{~F}$ & 0.89 \\
\hline
\end{tabular}


RPP-13482 REV 5

\section{APPENDIX M}

SPECIAL $\chi / Q ' S$ FOR POOL FIRES AT THE DEMONSTRATION BULK VITRIFICATION SYSTEM 


\section{RPP-13482 REV 5}

This page intentionally left blank.

M-ii 


\section{APPENDIX M \\ SPECIAL $\chi / Q$ 'S FOR POOL FIRES AT THE DEMONSTRATION BULK VITRIFICATION SYSTEM}

A set of $\chi / Q$ 's was calculated for several postulated liquid fuel pool fires at the Demonstration Bulk Vitrification System (DBVS) using GXQ version 4.0F. These fires, corresponding to 100 gal, 800 gal, and 10,000 gal spills are shown with their specified convective heat rates and fire diameters in Table M-1. The resulting $\chi / \mathrm{Q}^{\prime}$ values are shown for the collocated worker $(\mathrm{CW})$ and the maximum offsite individual (MOI). The $\chi / \mathrm{Q}^{\prime} \mathrm{s}$ for the MOI were calculated assuming the site boundary distances shown in Table 2-3 of the main document. The convective heat rates shown are the heat rates applied to the gases issuing from the fire. They do not include radiation or other losses.

Table M-1. 95 ${ }^{\text {th }}$ Percentile 1-hr X/Q's for Pool Fires at the Demonstration Bulk Vitrification System.

\begin{tabular}{|c|c|c|c|c|}
\hline \multirow{2}{*}{$\begin{array}{l}\text { Spill Size } \\
\text { (gal) }\end{array}$} & \multirow{2}{*}{$\begin{array}{c}\text { Convective } \\
\text { Heat Rate } \\
\text { (MW) }\end{array}$} & \multirow{2}{*}{$\begin{array}{c}\text { Pool Diameter } \\
\text { (m) }\end{array}$} & \multicolumn{2}{|c|}{$\mathbf{X} / \mathbf{Q}^{\prime}\left(\mathbf{s} / \mathbf{m}^{3}\right)$} \\
\hline & & & CW & MOI \\
\hline 100 & 24.3 & 5.25 & $3.04 \mathrm{E}-5$ & $1.36 \mathrm{E}-6$ \\
\hline 800 & 128.2 & 13 & $6.28 \mathrm{E}-6$ & $2.95 \mathrm{E}-7$ \\
\hline 10,000 & 1880 & 43 & $6.04 \mathrm{E}-7$ & $1.47 \mathrm{E}-7$ \\
\hline
\end{tabular}

Notes:

$\mathrm{CW}=$ collocated worker.

MOI $=$ maximum offsite individual.

These $\chi / Q$ 's were calculated using the MACCS buoyant plume model for ground fires as discussed in Section 2.3 of the main document. Corrections were included for the increase in wind speed with plume height and for initial air entrainment due to plume turbulence, including ground effects. Source width correction is included as part of the plume rise model. Plume meander effects cannot be applied to elevated plumes, so the 2-hr $\chi / \mathrm{Q}$ 's are the same as the 1-hr $\chi / Q ' s$ in this case.

A sample GXQ run file is included as Attachment X1. Note that the onsite $\chi / Q$ 's were calculated at $10-\mathrm{m}$ intervals from $100 \mathrm{~m}$ to $150 \mathrm{~m}$ and for receptor heights of 0,1 , and $2 \mathrm{~m}$ to establish the worst cases. For all the cases shown in Table $\mathrm{M}-1$ the maximum onsite $\chi / \mathrm{Q}^{\prime}$ occurred at $100 \mathrm{~m}$ with a receptor height of $2 \mathrm{~m}$. The site boundary is far enough from the release point that receptor height is not a factor. 
RPP-13482 REV 5

\section{ATTACHMENT M1}

SAMPLE GXQ RUN FILE (Fire diameter $=13 \mathrm{~m}$, Heat rate $=128.2 \mathrm{MW}$ ) 


\section{RPP-13482 REV 5}

GXQ Version $4.0 \mathrm{~F}$

October 9, 2002

General Purpose Atmospheric Dispersion Code Produced by Fluor Federal Services, Inc.

Users Guide documented in WHC-SD-GN-SWD-30002 Rev. I.

Validation documented in WHC-SD-GN-SWD-30003 Rev. 1.

Code Custodian is: Paul D. Rittmann, PhD CHP

Fluor Federal Services, Inc. E6-17

P.O. Box 1050

Richland, WA 99352-1050

(509) $376-8715$

Run Date $=12 / 30 / 04$

Run Time $=14: 42: 04.06$

INPUT ECHO:

Bulk Vit pool fire $13.0 \mathrm{~m}$ diameter, $128.2 \mathrm{MW}$

c GXQ Version 4.0 Input File

1

C MODE SELECTION:

1 - $X / Q$ based on site-specific wind data from JOINTFRE. IN

2 - X/Q based on input stability class and wind speed

3 - X/Q plot file table is created

SITE WIND \& POPULATION OPTIONS:

C ifox inorm icdf ichk isite ipop

$\begin{array}{llllll}T & F & F & F & T & F\end{array}$

ifox $=\mathrm{T}$ compute probabilistic $\mathrm{X} / \mathrm{Q}$ from a cumulative distribution

$=F$ compute annual average $X / Q$ (usually sector average with ipm=3)

inorm $=\mathrm{T}$ normalize joint frequency data in a sector (as in GENII)

$=F$ use joint frequency data as is

icdf $=T$ put cumulative distributions in the CDF. OUT file

$=F$ no cumulative distribution file created

ichk $=T$ show details for each $\mathrm{X} / \mathrm{Q}$ (long output)

$=F$ standard length output

isite $=T$ compute overall site $X / Q$ (need groups of 16 sectors)

= $F$ compute $\mathrm{X} / \mathrm{Q}$ for individual sectors

ipop $=\mathrm{T}$ population-weighted using the file POP.IN (use ipm=3)

$=F$ no population weighting

GAUSSIAN PLUME/PUFF MODEL OPTIONS: (enter 0 to inactivate option)

C ipuff idep isrc iwind

$\begin{array}{llll}0 & 0 & 0 & 1 \\ \text { iwake ipm } & \text { iflow ientr }\end{array}$

$\begin{array}{llrr}0 & 0 & 0 & 1\end{array}$

irise igrnd ${ }_{1}$ iwash igrav

ipuff $=0$ compute time-integrated air concentrations (s/m 3 )

$=1$ compute air concentrations (1/m3) (need release duration)

idep = 1 plume depletion model (source depletion)

isrc $=1$ multiply $X / Q$ by scale factor (input below)

$=2$ multiply by wind speed function: (factor)* [speed** (exponent)]

$=3$ multiply by wind speed function: (factor) $[10 * *$ (speed*exponent)]

iwind $=1$ wind speed corrected for plume height using power law 


\section{RPP-13482 REV 5}

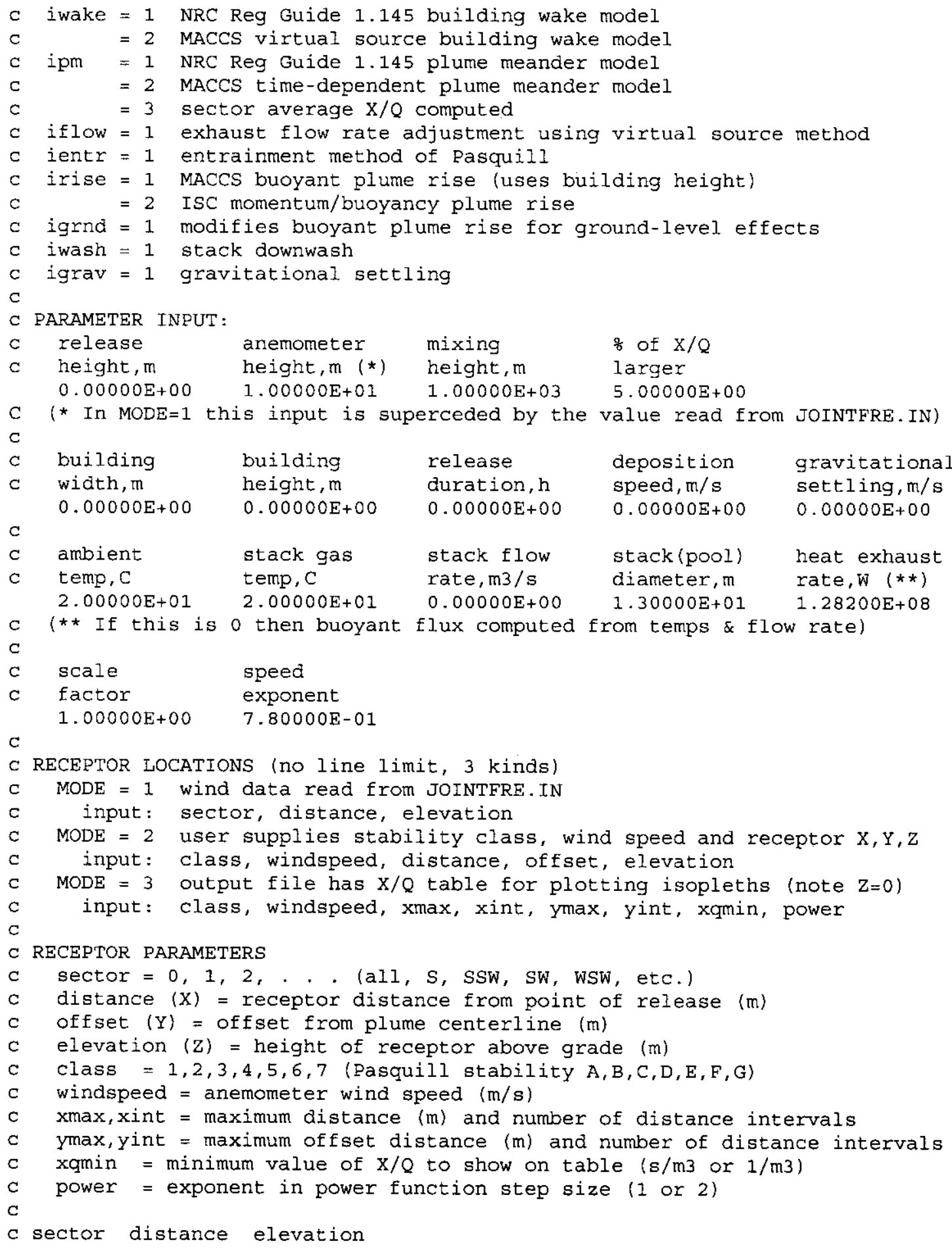




\section{RPP-13482 REV 5}

Time-integrated air concentration calculated (s/m3) . Plume rise air entrainment model selected.

MACCS buoyancy plume rise model based on convective heat. Mills buoyant rise modification for pool fire selected.

Wind velocity corrected for average plume height.

WARNING/ERROR MESSAGES :

JOINT FREQUENCY DATA:

200 AREA (HMS) - 10 M - Pasquill A - G (1983 - 1991 Average)

Created $8 / 26 / 92 \mathrm{KR}$

Bulk Vit pool fire $13.0 \mathrm{~m}$ diameter, $128.2 \mathrm{MW}$

\begin{tabular}{|c|c|c|c|c|c|c|c|c|}
\hline SECTOR & $\begin{array}{c}\text { DISTANCE } \\
(\mathrm{m})\end{array}$ & $\begin{array}{l}\text { RECEPT } \\
\text { HEIGHT } \\
(\mathrm{m})\end{array}$ & $\begin{array}{c}\text { SECT } \\
\text { FREQ . } \\
\text { (\&) }\end{array}$ & POPULATION & $\begin{array}{c}\text { TOTAL } \\
\text { POPULATION } \\
\text { SCALED } \\
\text { X/Q } \\
(\mathrm{s} / \mathrm{m} 3)\end{array}$ & $\begin{array}{c}\text { AVERAGE } \\
\text { INDIVIDUAL } \\
\text { SCALED } \\
\text { X/Q } \\
(\mathrm{s} / \mathrm{m} 3)\end{array}$ & $\begin{array}{l}\text { ATM. } \\
\text { STAB . } \\
\text { CLASS }\end{array}$ & $\begin{array}{l}\text { WIND } \\
\text { SPEED } \\
(\mathrm{m} / \mathrm{s})\end{array}$ \\
\hline$\overline{A L I}$ & 100 & 0 & 99.94 & $\overline{1}$ & $5.80 E-06$ & $5.80 E-06$ & $\overline{\mathrm{B}}$ & 7.15 \\
\hline AII & 110 & 0 & 99.94 & 1 & $4.98 \mathrm{E}-06$ & $4.98 E-06$ & B & 7.15 \\
\hline ALI & 120 & 0 & 99.94 & 1 & $4.36 E-06$ & $4.36 \mathrm{E}-06$ & $\mathrm{~B}$ & 7.15 \\
\hline ALL & 130 & 0 & 99.94 & 1. & $3.87 E-06$ & $3.87 E-06$ & B & 7.15 \\
\hline ALL & 140 & 0 & 99.94 & 1 & $3.48 \mathrm{E}-06$ & $3.48 \mathrm{E}-06$ & $\mathrm{~B}$ & 7.15 \\
\hline ALL & 150 & 0 & 99.94 & 1 & $3.16 \mathrm{E}-06$ & $3.16 E-06$ & B & 7.15 \\
\hline ALL & 100 & 1 & 99.94 & 1 & $5.97 E-06$ & $5.97 E-06$ & $\mathrm{~B}$ & 7.15 \\
\hline ALL & 110 & 1 & 99.94 & 1 & $5.10 \mathrm{E}-06$ & $5.10 E-06$ & B & 7.15 \\
\hline ALI & 120 & 1 & 99.94 & 1 & $4.45 \mathrm{E}-06$ & $4.45 E-06$ & $\mathrm{~B}$ & 7.15 \\
\hline ALL & 130 & 1 & 99.94 & 1 & $3.94 \mathrm{E}-06$ & $3.94 \mathrm{E}-06$ & $\mathrm{~B}$ & 7.15 \\
\hline ALL & 140 & 1 & 99.94 & 1 & $3.54 E-06$ & $3.54 E-06$ & $\mathrm{~B}$ & 7.15 \\
\hline ALL & 150 & 1 & 99.94 & 1 & $3.21 \mathrm{E}-06$ & $3.21 E-06$ & $\mathrm{~B}$ & 7.15 \\
\hline ALL & 100 & 2 & 99.94 & 1 & $6.28 \mathrm{E}-06$ & $6.28 \mathrm{E}-06$ & $E$ & 9.80 \\
\hline ALL & 110 & 2 & 99.94 & 1 & $5.30 E-06$ & $5.30 E-06$ & $E$ & 9.80 \\
\hline ALL & 120 & 2 & 99.94 & 1 & $4.57 E-06$ & $4.57 E-06$ & $E$ & 9.80 \\
\hline ALL & 130 & 2 & 99.94 & 1 & $4.01 \mathrm{E}-06$ & $4.01 E-06$ & $E$ & 9.80 \\
\hline ALL & 140 & 2 & 99.94 & 1 & $3.57 E-06$ & $3.57 \mathrm{E}-06$ & $E$ & 9.80 \\
\hline ALL & 150 & 2 & 99.94 & 1 & $3.22 E-06$ & $3.22 \mathrm{E}-06$ & $\mathrm{E}$ & 9.80 \\
\hline ALL & 15360 & 0 & 99.94 & 1. & $2.95 E-07$ & $2.95 E-07$ & F & 2.65 \\
\hline
\end{tabular}


RPP-13482 REV 5

This page intentionally left blank.

M-6 


\section{RPP-13482 REV 5}

\section{APPENDIX N}

SPECIAL $\chi / Q ' S$ FOR POOL FIRES AT THE CONTACT-HANDLED TRANSURANIC MIXED WASTE PACKAGING UNIT 


\section{RPP-13482 REV 5}

This page intentionally left blank. 


\section{APPENDIX N}

\section{SPECIAL $\chi / Q ' S$ FOR POOL FIRES AT THE CONTACT-HANDLED TRANSURANIC MIXED WASTE PACKAGING UNIT}

A set of $\chi / Q$ 's was calculated for two postulated liquid fuel pool fires at the Contact-Handled Transuranic Mixed (CH-TRUM) Waste Packaging Unit using GXQ version 4.0F. These fires are shown with their specified convective heat rates and fire diameters in Table $\mathrm{N}-1$. The resulting $\chi / Q^{\prime}$ values are shown for the collocated worker $(\mathrm{CW})$ and the maximum offsite individual (MOI). The $\chi / \mathrm{Q}$ 's for the MOI were calculated assuming the site boundary distances shown in Table 2-3 of the main document. The convective heat rates shown are the heat rates applied to the gases issuing from the fire. They do not include radiation or other losses.

Table N-1. $95^{\text {th }}$ Percentile 1-hr $\chi / \mathrm{Q}$ 's for Pool Fires at the ContactHandled Transuranic Mixed Waste Packaging Unit.

\begin{tabular}{|c|c|c|c|}
\hline \multirow{2}{*}{$\begin{array}{c}\text { Convective Heat } \\
\text { Rate } \\
\text { (MW) }\end{array}$} & $\begin{array}{c}\text { Pool Diameter } \\
(\mathbf{M})\end{array}$ & \multicolumn{2}{|c|}{$\chi / \mathbf{Q}^{\mathbf{\prime}}\left(\mathbf{s} / \mathbf{m}^{3}\right)$} \\
\cline { 3 - 4 } & $\mathbf{C W}$ & MOI \\
\hline 24.2 & 4.8 & $2.89 \mathrm{E}-5$ & $1.35 \mathrm{E}-6$ \\
\hline 289 & 16.9 & $2.59 \mathrm{E}-6$ & $1.71 \mathrm{E}-7$ \\
\hline
\end{tabular}

These $\chi / \mathrm{Q}$ 's were calculated using the MACCS buoyant plume model for ground fires as discussed in Section 2.3 of the main document. Corrections were included for the increase in wind speed with plume height and for initial air entrainment due to plume turbulence, including ground effects. Source width correction is included as part of the plume rise model. Plume meander effects cannot be applied to elevated plumes, so the 2-hr $\chi / \mathrm{Q}$ 's are the same as the 1-hr $\chi / \mathrm{Q}$ 's in this case.

A sample GXQ run file is included as Attachment N1. Note that the onsite $\chi / Q^{\prime}$ s were calculated at $10-\mathrm{m}$ intervals from $100 \mathrm{~m}$ to $150 \mathrm{~m}$ and for receptor heights of 0,1 , and $2 \mathrm{~m}$ to establish the worst cases. For all the cases shown in Table $\mathrm{N}-1$ the maximum onsite $\chi / \mathrm{Q}^{\prime}$ occurred at $100 \mathrm{~m}$ with a receptor height of $2 \mathrm{~m}$. The site boundary is far enough from the release point that receptor height is not a factor. 
RPP-13482 REV 5

\section{ATTACHMENT N1}

SAMPLE GXQ RUN FILE (Fire diameter $=4.8 \mathrm{~m}$, Heat rate $=24.2 \mathrm{MW}$ ) 


\section{RPP-13482 REV 5}

GXQ Version $4.0 F$

October 9,2002

General Purpose Atmospheric Dispersion Code Produced by Fluor Federal Services, Inc.

Users Guide documented in WHC-SD-GN-SWD-30002 Rev. I. Validation documented in WHC-SD-GN-SWD-30003 Rev. 1.

Code Custodian is: Paul D. Rittmann, PhD CHP

Fluor Federal Services, Inc. E6-17

P.O. Box 1050

Richland, WA 99352-1050

(509) 376-8715

Run Date $=02 / 09 / 05$

Run Time $=15: 34: 49.80$

INPUT ECHO:

CH-TRUM pool fire $4.8 \mathrm{~m}$ diameter, $24.2 \mathrm{MW}$

c GXQ Version 4.0 Input File

1

C MODE SELECTION:

C $1-X / Q$ based on site-specific wind data from JOINTFRE. IN

c $2-X / Q$ based on input stability class and wind speed

c $3-\mathrm{X} / \mathrm{Q}$ plot file table is created

C SITE WIND \& POPULATION OPTIONS:

c ifox inorm icdf ichk isite ipop

$\begin{array}{llllll}T & F & F & F & T & F\end{array}$

ifox $=\mathrm{T}$ compute probabilistic $\mathrm{X} / \mathrm{Q}$ from a cumulative distribution

$=\mathrm{F}$ compute annual average $\mathrm{X} / \mathrm{Q}$ (usually sector average with ipm=3)

inorm $=\mathrm{T}$ normalize joint frequency data in a sector (as in GENII)

$=F$ use joint trequency data as is

icaf $=T$ put cumulative distributions in the CDF.OUT file

$=F$ no cumulative distribution file created

ichk $=\mathrm{T}$ show details for each $\mathrm{X} / \mathrm{Q}$ (long output)

$=\mathrm{F}$ standard length output

isite $=T$ compute overall site $X / Q$ (need groups of 16 sectors)

$=F$ compute $X / Q$ for individual sectors

ipop $=T$ population-weighted using the file POP.IN (use ipm=3)

$=F$ no population weighting

GAUSSIAN PLUME/PUFF MODEL OPTIONS: (enter 0 to inactivate option)

ipuff idep isrc iwind

$\begin{array}{llll}0 & 0 & 0 & 1\end{array}$

iwake ipm iflow ientr

$\begin{array}{llll}0 & 0 & 0 & 1\end{array}$

irise igrnd iwash igrav

$1 \quad 1 \quad 0$

ipuff $=0$ compute time-integrated air concentrations $(\mathrm{s} / \mathrm{m} 3)$

c $=1$ compute air concentrations $(1 / \mathrm{m} 3$ ) (need release duration)

idep $=1$ plume depletion model (source depletion)

isrc $=1$ multiply $X / Q$ by scale factor (input below)

$=2$ multiply by wind speed function: (factor)* [speed** (exponent)]

$=3$ multiply by wind speed function: (factor)* [10** (speed*exponent)] 
RPP-13482 REV 5

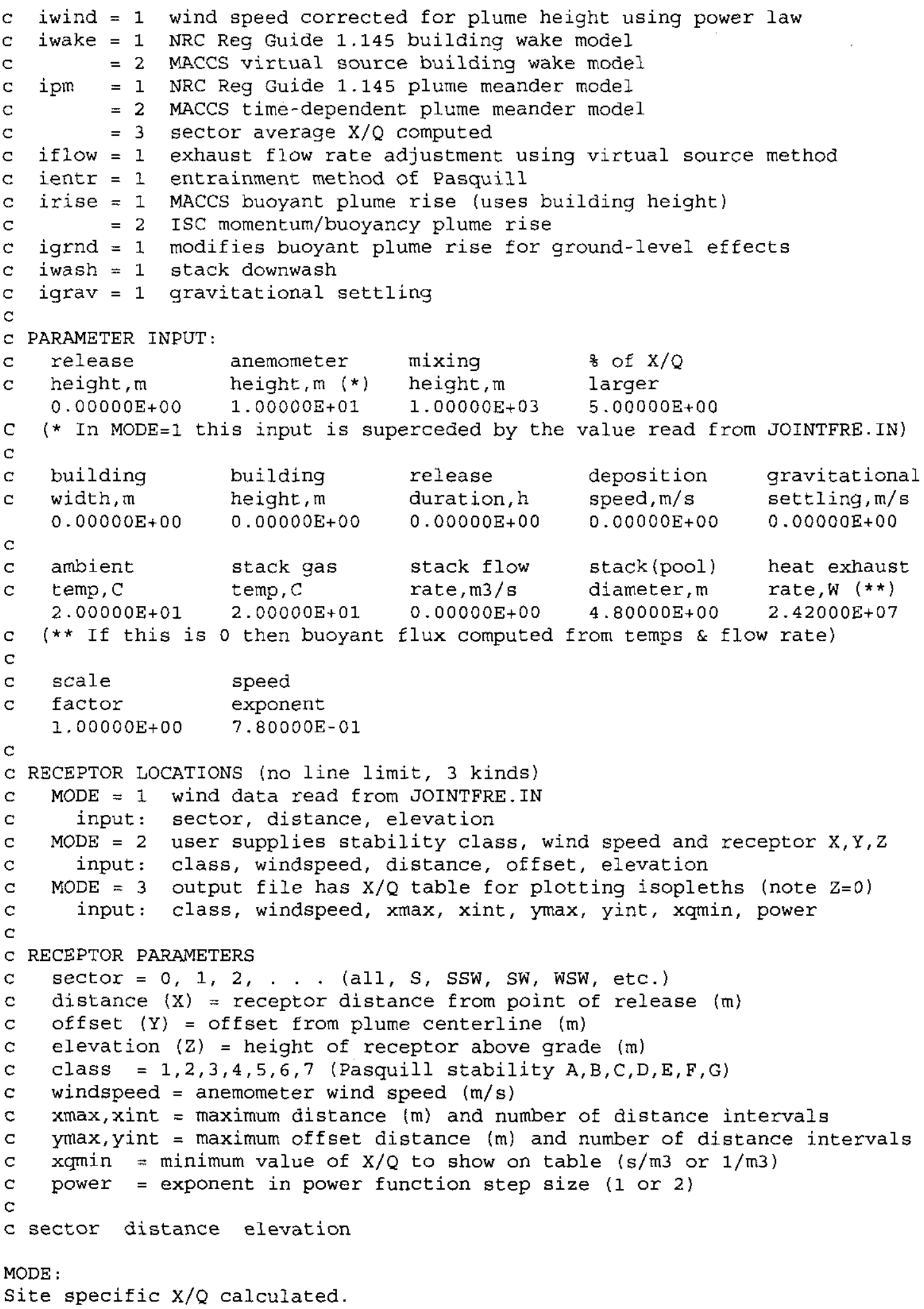

LOGICAL CHOICES:

Joint frequency used to calculate $X / Q$ based on frequency of exceedance.

No normalization of joint frequency.

$\mathrm{X} / \mathrm{Q}$ calculated for overall site. 


\section{RPP-13482 REV 5}

MODELS SELECTED:

Time-integrated air concentration calculated $(\mathrm{s} / \mathrm{m} 3)$.

Plume rise air entrainment model selected.

MACCS buoyancy plume rise model based on convective heat.

Mills buoyant rise modification for pool fire selected.

wind velocity corrected for average plume height.

WARNING/ERROR MESSAGES :

JOINT FREQUENCY DATA:

200 AREA (HMS) - 10 M - Pasquill A - G (1983 - 1991 Average)

Created $8 / 26 / 92 \mathrm{KR}$

CH-TRUM pool fire $4.8 \mathrm{~m}$ diameter, $24.2 \mathrm{MW}$ 
RPP-13482 REV 5

\begin{tabular}{|c|c|c|c|c|c|c|c|c|}
\hline SECTOR & $\begin{array}{l}\text { DISTANCE } \\
\text { (m) }\end{array}$ & $\begin{array}{l}\text { RECEPT } \\
\text { HEIGHT } \\
\text { (m) }\end{array}$ & $\begin{array}{c}\text { SECT. } \\
\text { FREQ. } \\
(\%)\end{array}$ & POPULATION & $\begin{array}{l}\text { SCALED } \\
\mathrm{X} / \mathrm{Q} \\
(\mathrm{s} / \mathrm{m} 3)\end{array}$ & $\begin{array}{l}\text { SCALED } \\
X / Q \\
(\mathrm{~s} / \mathrm{m} 3)\end{array}$ & $\begin{array}{l}\text { ATM. } \\
\text { STAB. } \\
\text { CLASS }\end{array}$ & $\begin{array}{l}\text { WIND } \\
\text { SPEED } \\
(\mathrm{m} / \mathrm{s})\end{array}$ \\
\hline$\overline{A L L}$ & 100 & 0 & 99.94 & 1 & $2.58 \mathrm{E}-05$ & $2.58 \mathrm{E}-05$ & $\overline{\mathrm{G}}$ & 19.00 \\
\hline ALL & 110 & 0 & 99.94 & 1 & $2.14 E-05$ & $2.14 \mathrm{E}-05$ & G & 19.00 \\
\hline ALI & 120 & 0 & 99.94 & 1 & $1.83 E-05$ & $1.83 E-05$ & G & 19.00 \\
\hline AIL & 130 & 0 & 99.94 & 1 & $1.58 E-05$ & $1.58 E-05$ & G & 19.00 \\
\hline ALL & 140 & 0 & 99.94 & 1 & $1.39 \mathrm{E}-05$ & 1. $39 \mathrm{E}-05$ & G & 19.00 \\
\hline ALL & 150 & 0 & 99.94 & 1 & $1.52 \mathrm{E}-05$ & $1.52 E-05$ & $\mathrm{~B}$ & 7.15 \\
\hline ALL & 100 & 1 & 99.94 & 1 & $2.67 \mathrm{E}-0.5$ & $2.67 E-05$ & $\mathrm{~B}$ & 7.15 \\
\hline ALL & 110 & 1 & 99.94 & 1 & $2.34 E-05$ & $2.34 \mathrm{E}-05$ & B & 7.15 \\
\hline AI」 & 120 & 1 & 99.94 & 1 & $2.08 \mathrm{E}-05$ & $2.08 E-05$ & $\mathrm{~B}$ & 7.15 \\
\hline ALL & 130 & 1 & 99.94 & 1 & $1.87 E-05$ & $1.87 \mathrm{E}-05$ & B & 7.15 \\
\hline ALL & 140 & 1 & 99.94 & 1 & $1.73 E-05$ & $1.73 E-05$ & $G$ & 19.00 \\
\hline ALL & 150 & 1 & 99.94 & 1 & $1.52 \mathrm{E}-05$ & $1.52 \mathrm{E}-05$ & G & 19.00 \\
\hline ALL & 100 & 2 & 99.94 & 1 & $2.89 E-05$ & $2.89 \mathrm{E}-0.5$ & $B$ & 7.15 \\
\hline ALL & 110 & 2 & 99.94 & 1 & $2.50 \mathrm{E}-05$ & $2.50 \mathrm{E}-0.5$ & $\mathrm{~B}$ & 7.15 \\
\hline ALI & 120 & 2 & 99.94 & 1 & $2.20 E-05$ & $2.20 \mathrm{E}-05$ & $\mathrm{~B}$ & 7.15 \\
\hline ALL & 130 & 2 & 99.94 & 1 & $1.96 E-05$ & $1.96 \mathrm{E}-05$ & $\mathrm{~B}$ & 7.15 \\
\hline ALL & 140 & 2 & 99.94 & 1 & $1.77 E-05$ & $1.77 E-05$ & B & 7.15 \\
\hline ALL & 150 & 2 & 99.94 & 1 & $1.61 \mathrm{E}-05$ & $1.61 \mathrm{E}-05$ & $B$ & 7.15 \\
\hline ALL & 15360 & 0 & 99.94 & 1 & $1.35 \mathrm{E}-06$ & $1.35 \mathrm{E}-06$ & $\mathrm{G}$ & 0.89 \\
\hline
\end{tabular}




\section{RPP-13482 REV 5}

\section{APPENDIX 0}

PEER REVIEW CHECKLISTS

O-i 
RPP-13482 REV 5

This page intentionally left blank.

O-ii 


\section{APPENDIX O}

\section{PEER REVIEW CHECKLIST}

\section{CHECKLIST FOR TECHNICAL PEER REVIEW}

Document Reviewed: RPP-13482

Scope of Review (e.g., document section or portion of calculation): Reviewed entire document via spot check method.

Yes No NA*

[] [] [X] 1. Previous reviews are complete and cover the analysis, up to the scope of this review, with no gaps.

[X] [] [ ] 2. Problem is completely defined.

[ ] [] [X] 3. Accident scenarios are developed in a clear and logical manner.

[X] [ ] [ ] 4. Analytical and technical approaches and results are reasonable and appropriate. (ORP QAPP criterion 2.8)

[X] [] [ ] 5. Necessary assumptions are reasonable, explicitly stated, and supported. (ORP QAPP criterion 2.2)

[X] [ ] [ ] 6. Computer codes and data files are documented.

[X] [ ] [ ] 7. Data used in calculations are explicitly stated.

[] [] [X] 8. Bases for calculations, including assumptions and data, are consistent with the supported safety basis document (e.g., the Tank Farms Final Safety Analysis Report).

[X] [ ] [ ] 9. Data were checked for consistency with original source information as applicable. (ORP QAPP criterion 2.9)

[X] [ ] [ ] 10. For both qualitative and quantitative data, uncertainties are recognized and discussed, as appropriate. (ORP QAPP criterion 2.17)

[X] [ ] [ ] 11. Mathematical derivations were checked including dimensional consistency of results. (ORP QAPP criterion 2.16)

[X] [ ] [ ] 12. Models are appropriate and were used within their established range of validity or adequate justification was provided for use outside their established range of validity.

[X] [] [ ] 13. Spreadsheet results and all hand calculations were verified. Spot check

[X] [ ] [ ] 14. Calculations are sufficiently detailed such that a technically qualified person can understand the analysis without requiring outside information. (ORP $Q A P P$ criterion 2.5) Qualified meaning qualified in atmospheric dispersion methods.

[X] [ ] [ ] 15. Software input is correct and consistent with the document reviewed.

[X] [] [ ] 16. Software output is consistent with the input and with the results reported in the document reviewed.

[X] [] [ ] 17. Software verification and validation are addressed adequately. (ORP QAPP criterion 2.6)

[] [] [X] 18. Limits/criteria/guidelines applied to the analysis results are appropriate and referenced. Limits/criteria/guidelines were checked against references. (ORP QAPP criterion 2.9) 
[] [ ] [X] 19. Safety margins are consistent with good engineering practices.

[X] [ ] [ ] 20. Conclusions are consistent with analytical results and applicable limits.

[X] [ ] [ ] 21. Results and conclusions address all points in the purpose. (ORP QPP criterion 2.3)

[X] [ ] [ ] 22. All references cited in the text, figures, and tables are contained in the reference list. Spot check

[X] [ ] [ ] 23. Reference citations (e.g., title and number) are consistent between the text callout and the reference list. Spot check

[ ] [ ] [X] 24. Only released (i.e., not draft) references are cited. (ORP QAPP criterion 2.1) Did not check

[X] [] [ ] 25. Referenced documents are retrievable or otherwise available.

[] [] [X] 26. The most recent version of each reference is cited, as appropriate. (ORP $Q A P P$ criterion 2.1) Did not check

[] [ ] [X] 27. There are no duplicate citations in the reference list. Did not check

[] [] [X] 28. Referenced documents are spelled out (title and number) the first time they are cited. Did not check

[] [ ] [X] 29. All acronyms are spelled out the first time they are used.Did not check

[ ] [] [X] 30. The Table of Contents is correct. Did not check

[] [] [X] 31. All figure, table, and section callouts are correct. Did not check

[X] [] [] 32. Unit conversions are correct and consistent.

[X] [ ] [ ] 33. The number of significant digits is appropriate and consistent. Focused on the final results.

[ ] [ ] [X] 34. Chemical reactions are correct and balanced.

[] [ ] [X] 35. All tables are formatted consistently and are free of blank cells. Did not check

[ ] [ ] [X] 36. The document is complete (pages, attachments, and appendices) and in the proper order. Did not check

[] [ ] [X] 37. The document is free of typographical errors. Did not check

[X] [ ] [ ] 38. The tables are internaliy consistent.

[] [ ] [X] 39. The document was prepared in accordance with HNF-2353, Section 4.3,

[X] [] [] Concurrence Attachment B, "Calculation Note Format and Preparation Instructions".

$$
\begin{aligned}
& \text { Robert Marusich Rabertmanusul } \\
& \text { Reviewer (Printed Name and Signature) }
\end{aligned}
$$

- If No or NA is chosen, provide an explanation on this form. See the following. All derivations were checked. Results were spot checked, typically by ratioing based on the important parameters. For those GXQ runs provided, the input and output were checked. Items 24, 26-31, and 35-37 are assumed to be picked up by the editor. Document contains no accident analysis, therefore no limits are necessary. There were no previous reviews.

Software V\&V is done within the document (Chapter 3) 
RPP-13482 REV 5

\section{CHECKLIST FOR TECHNICAL PEER REVIEW}

Document Reviewed:

Scope of Review (e.g., document section or portion of calculation):

Yes No NA*

[ ] [ ] [X] 1. Previous reviews are complete and cover the analysis, up to the scope of this review, with no gaps.

[ ] [] [X] 2. Problem is completely defined.

[] [] [X] 3. Accident scenarios are developed in a clear and logical manner.

[ ] [ ] [X] 4. Analytical and technical approaches and results are reasonable and appropriate. (ORP QAPP criterion 2.8)

[] [] [X] 5. Necessary assumptions are reasonable, explicitly stated, and supported. (ORP QAPP criterion 2.2)

[] [ ] $[\mathrm{X}]$ 6. Computer codes and data files are documented.

[] [ ] [X] 7. Data used in calculations are explicitly stated.

[] [] [X] 8. Bases for calculations, including assumptions and data, are consistent with the supported safety basis document (e.g., the Tank Farms Final Safety Analysis Report).

[] [] [X] 9. Data were checked for consistency with original source information as applicable. (ORP QAPP criterion 2.9)

[] [] [X] 10. For both qualitative and quantitative data, uncertainties are recognized and discussed, as appropriate. (ORP QAPP criterion 2.17)

[ ] [ ] [X] 11. Mathematical derivations were checked including dimensional consistency of results. (ORP QAPP criterion 2.16)

[] [ ] [X] 12. Models are appropriate and were used within their established range of validity or adequate justification was provided for use outside their established range of validity.

[ ] [ ] [X] 13. Spreadsheet results and all hand calculations were verified.

[ ] [ ] [X] 14. Calculations are sufficiently detailed such that a technically qualified person can understand the analysis without requiring outside information. (ORP $Q A P P$ criterion 2.5)

[] [ ] [X] 15. Software input is correct and consistent with the document reviewed.

[ ] [ ] [X] 16. Software output is consistent with the input and with the results reported in the document reviewed.

[] [] [X] 17. Software verification and validation are addressed adequately. (ORP QAPP criterion 2.6)

[ ] [ ] [X] 18. Limits/criteria/guidelines applied to the analysis results are appropriate and referenced. Limits/criteria/guidelines were checked against references. (ORP QAPP crilerion 2.9)

[] [] [X] 19. Safety margins are consistent with good engineering practices.

[] [] [X] 20. Conclusions are consistent with analytical results and applicable limits. 


\section{RPP-13482 REV 5}

[ ] [ ] [ ] 21. Results and conclusions address all points in the purpose. (ORP QAPP criterion 2.3)

14 [] [] 22. All references cited in the text, figures, and tables are contained in the reference list.

L [ ] [ ] 23. Reference citations (e.g., title and number) are consistent between the text callout and the reference list.

24. Only released (i.e., not draft) references are cited. (ORP QAPP criterion 2.1)

25. Referenced documents are retrievable or otherwise available.

26. The most recent version of each reference is cited, as appropriate. (ORP $Q A P P$ criterion 2.1)

X [] [] 27. There are no duplicate citations in the reference list.

X [ ] [ ] 28. Referenced documents are spelled out (title and number) the first time they are cited.

2] [ ] [ ] 29. All acronyms are spelied out the first time they are used.

18 [] [ ] 30. The Table of Contents is correct.

1 [] [] 31. All figure, table, and section callouts are correct.

[] [ ] [X] 32. Unit conversions are correct and consistent.

[] [ ] [X] 33. The number of significant digits is appropriate and consistent.

[] [] [X] 34. Chemical reactions are correct and balanced.

2 [] [ ] 35. All tables are formatted consistently and are free of blank cells. [1] [] 36. The document

X] [ ] [ ] 37. The document is free of typographical errors.

14] [] 38. The tables are internally consistent.

[] [] [X] 39. The document was prepared in accordance with HNF-2353, Section 4.3,

\section{[] [] [] Concurrence} Attachment B, "Calculation Note Format and Preparation Instructions". NA check for those items not responsibility of tech editof.
Laurle L. Kroctmer
Reviewer (Printed Name dad Signature) PPP/3482

* If No or NA is chosen, provide an explanation on this form. 


\section{Calculation Review Checklist.}

Calculation Reviewed: RPP 13482 Rev 1

Scope of Review: Sechows and Append rcies changed by Rev 1 (e.g., document section or portion of calculation)

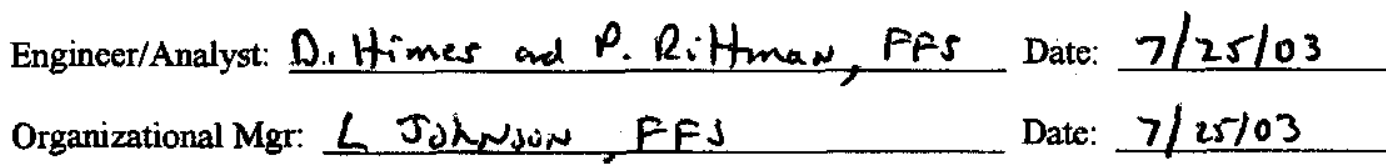

This document consists of pages and the following attachments (if applicable):

Yes No NA*

X [] [] 1. Analytical and technical approaches and results are reasonable and appropriate.

17 [] [] 2. Necessary assumptions are reasonable, explicitly stated, and supported.

13 [] 3. Ensure calculations that use software include a paper printout, microfiche, CD ROM, or other electronic file of the input data and identification to the computer codes and versions used, or provide alternate documentation to uniquely and clearly identify the exact coding and execution process.

* [] [1 4. Input data were checked for consistency with original source information.

DX [ ] [] 5. For both qualitative and quantitative data, uncertainties are recognized and discussed.

\# [ ] [] 6. Mathematical derivations were checked including dimensional consistency of results.

K [] [] 7. Calculations are sufficiently detailed such that a technically qualified person can understand the analysis without requiring outside information.

W [] [] 8. Software verification and validation are addressed adequately.

IK [ ] [] 9. Limits/criteria/guidelines applied to the analysis results are appropriate and referenced. Limits/criteria/guidelines were checked against references.

K [ ] [ ] 10. Conclusions are consistent with analytical results and applicable limits.

$\$ K$ [] [] 11. Results and conclusions address all points in the purpose.

K [] [] 12. Referenced documents are retrievable or otherwise available.

KX [] [1 13. The version or revision of each reference is cited.

[] [] 14. The document was prepared in accordance with Attachment A, "Calculation Format and Preparation Instructions." Did Not Check

* [ ] [] 15. All checker comments have been dispositioned and the design media matches the calculations.

\section{Bobent Maruich Qhertmanusch \\ Checker (Printed Name and Signature)

* If No or NA is chosen, an explanation must be provided on or attached to this form. 
RPP-13482 REV 5

Subcontractor Calculation Review Checklist.

Page 1_ of _1

Subject: Review of Document Prepared by Fluor Federal Services

The subject document has been reviewed by the undersigned.

The checker reviewed and verified the following items as applicable.

Documents Reviewed: RPP-13482, Atmospheric Dispersion Coefficients and Radiological and Toxicological Exposure Methodology for Use in Tank Farms

Analysis Performed By: W.L. Cowley

- Design Input

- Basic Assumptions

- Approach/Design Methodology

- Consistency with item or document supported by the calculation

- Conclusion/Results Interpretation

-

Checker (printed name, sigmature, and date)

Organizational Manager (printed name, signature and date)

-R.J. Stevens_A.J. Steven 1/23/03 


\section{CHECKLIST FOR TECHNICAL PEER REVIEW}

Document Reviewed: RPP- 13482 , Rev. 2

Yes No NA*

[ ] [ ] [ $\mathrm{X}]$ 1. Previous reviews are complete and cover the analysis, up to the scope of this review, with no gaps.

[ ] [ ] [ $X]$ 2. Problem is completely defined.

[ ] [ ] [X] 3. Accident scenarios are developed in a clear and logical manner.

[ ] [ ] [ X ] 4. Analytical and technical approaches and results are reasonable and appropriate. (ORP QAPP criterion 2.8)

[ ] [ ] [ X ] 5. Necessary assumptions are reasonable, explicitly stated, and supported. (ORP QAPP criterion 2.2)

[ ] [ ] [ X ] 6. Computer codes and data files are documented.

[ ] [ ] [ $\mathrm{X}]$ 7. Data used in calculations are explicitly stated.

[ ] [ ] [X] 8. Bases for calculations, including assumptions and data, are consistent with the supported safety basis document (e.g., the Tank Farms Final Safety Analysis Report).

[ ] [ ] [X] 9. Data were checked for consistency with original source information as applicable. (ORP QAPP criterion 2.9)

[ ] [ ] [X] 10. For both qualitative and quantitative data, uncertainties are recognized and discussed, as appropriate. (ORP QAPP criterion 2.17)

[ ] [ ] [X] 11. Mathematical derivations were checked including dimensional consistency of results. (ORP QAPP criterion 2.16)

[ ] [ ] [X] 12. Models are appropriate and were used within their established range of validity or adequate justification was provided for use outside their established range of validity.

[ ] [ ] [ X ] 13. Spreadsheet results and all hand calculations were verified.

[ ] [ ] [ X ] 14. Calculations are sufficiently detailed such that a technically qualified person can understand the analysis without requiring outside information. (ORP QAPP criterion 2.5)

[ ] [ ] [ X ] 15. Software input is correct and consistent with the document reviewed.

[ ] [ ] [X] 16. Software output is consistent with the input and with the results reported in the document reviewed.

[ ] [ ] [X ] 17. Software verification and validation are addressed adequately. (ORP QAPP criterion 2.6)

[ ] [ ] [X ] 18. Limits/criteria/guidelines applied to the analysis results are appropriate and referenced. Limits/criteria/guidelines were checked against references. (ORP $Q A P P$ criterion 2.9)

[ ] [ ] [ X] 19. Safety margins are consistent with good engineering practices.

[ ] [ ] [X] 20. Conclusions are consistent with analytical results and applicable limits. 


\section{Checklist For Technical Peer Review}

Document Reviewed - RPP-13482, Rev 3

Title: Atmospheric Dispersion Coefficients and Radiological/toxicological Exposure Methodology for Use in Tank Farms

Scope of Review: Sections and Appendicies changed by Rev 3.

Author: D. Himes, Paul Rittmann

Date: $12 / 07 / 04$

\begin{tabular}{|c|c|c|}
\hline Yes & $\underline{\text { No }}$ & NA \\
\hline $\mathrm{X}]$ & [ & [ \\
\hline $\mathrm{X}]$ & [ & [ \\
\hline$]$ & [ & [ X \\
\hline $\mathbf{x}]$ & [ & [ \\
\hline X ] & [ & [ \\
\hline$[\mathrm{X}]$ & [ & [ \\
\hline$[\mathbf{X}]$ & [ & [ \\
\hline$X]$ & [ & [ \\
\hline$[\mathbf{X}]$ & I & I \\
\hline$X_{1}$ & I & ] \\
\hline$[X]$ & [ & I \\
\hline$[\mathrm{X}]$ & [ & I \\
\hline [ ] & & \\
\hline$[X]$ & & \\
\hline$[\mathrm{X}]$ & & \\
\hline$[\mathbf{X}]$ & [ & \\
\hline$[\mathbf{X}]$ & [ & \\
\hline & & \\
\hline & & \\
\hline
\end{tabular}

Referenced analyses appropriate.

Problem completely defined and all potential configurations considered.

Accident scenarios developed in a clear and logical manner.

Necessary assumptions explicitly stated and supported.

Computer codes and data files documented.

Data used in calculations explicitly stated in document.

Data checked for consistency with original source information as applicable.

Mathematical derivations checked including dimensional consistency of results.

Models appropriate and used within range of validity, or use outside range of established validity justified.

Hand calculations checked for errors. Spreadsheet results should be treated exactly the same as hand calculations.

Software input correct and consistent with document reviewed.

Software output consistent with input and with results reported in document reviewed.

Limits/criteria/guidelines applied to analysis results are appropriate and referenced. Limits/criteria/guidelines checked against references.

Safety margins consistent with good engineering practices.

Conclusions consistent with analytical results and applicable limits.

Results and conclusions address all points required in the problem statement.

Format consistent with applicable guides or other standards.

** Review calculations, comments, and/or notes are attached.

Document approved (for example, the reviewer affirms the technical accuracy of the document).

Robert Marusich VieflMares

Technical Peer Reviewer (printed name and signature)

$12 / 07 / 04$

Date

" All "no" responses must be explained below or on an additional sheet.

** Any calculations, comments, or notes generated as part of this review should be signed, dated and attached to this checklist. The material should be labeled and recorded in such a manner as to be understandable to a technically qualified third party. 
RPP-13482 REV 5

Subcontractor Calculation Review Checkdist.

Page_1_ of _1

Subject: Review of a Revision Prepared by Fluor Government Group

The subject document has been reviewed by the undersigned.

The checker reviewed and verified the following items as applicable.

Documents Reviewed: Rev. 3 of RPP-13482. Rev. 3 added additional material to the report.

This review covers only the new material added by Rev. 3

Analysis Pefformed By: D.A. Himes and P.D. Rittman, Fluor Government Group

- Design Input

- Basic Assumptions

- Approach/Design Methodology

- Consistency with item or document supported by the calculation

- Conclusion/Results Interpretation - N/A

- Impact on existing requirements

$\bullet$

Checker (printed name, signature, and date)

W.L. Cowley

Organizational Manager (printed name, signature and date)

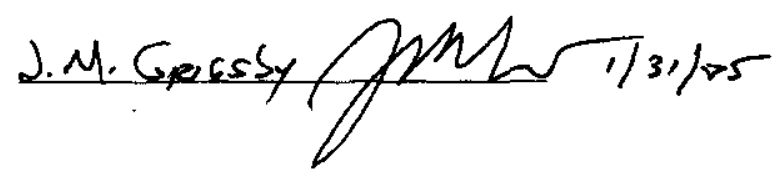




\section{CHECKLIST FOR TECHNICAL PEER REVIEW}

Document Reviewed: RPP-13482, Rev 3

Scope of Review (e.g. document section or portion of calculation): tech edit

\begin{tabular}{|c|c|c|c|c|}
\hline Yes & No & NA* & & \\
\hline [] & [] & {$[\mathrm{X}]$} & 1. & $\begin{array}{l}\text { Previous reviews are complete and cover the analysis, up to the scope of this } \\
\text { review, with no gaps. }\end{array}$ \\
\hline [ & [ ] & {$[\mathrm{X}]$} & 2. & Problem is completely defined. \\
\hline & [ ] & {$[\mathrm{X}]$} & 3. & Accident scenarios are developed in a clear and logical manner. \\
\hline [ ] & [] & {$[\mathrm{X}]$} & 4. & $\begin{array}{l}\text { Analytical and technical approaches and results are reasonable and appropriate. } \\
\text { (ORP } Q A P P \text { criterion } 2.8)\end{array}$ \\
\hline [ ] & [ ] & {$[\mathrm{X}]$} & 5. & $\begin{array}{l}\text { Necessary assumptions are reasonable, explicitly stated, and supported. (ORP } \\
Q A P P \text { criterion } 2.2)\end{array}$ \\
\hline [ ] & [ ] & {$[\mathrm{X}]$} & 6. & Computer codes and data files are documented. \\
\hline & {[} & {$[\mathrm{X}]$} & 7. & Data used in calculations are explicitly stated. \\
\hline [ & {[} & {$[\mathrm{X}]$} & 8. & $\begin{array}{l}\text { Bases for calculations, including assumptions and data, are consistent with the } \\
\text { supported safety basis document (e.g., the Tank Farms Final Safety Analysis } \\
\text { Report). }\end{array}$ \\
\hline [ ] & [ ] & {$[\mathrm{X}]$} & 9. & $\begin{array}{l}\text { Data were checked for consistency with original source information as } \\
\text { applicable. (ORP QAPP criterion 2.9) }\end{array}$ \\
\hline [] & [ ] & {$[\mathrm{X}]$} & 10. & $\begin{array}{l}\text { For both qualitative and quantitative data, uncertainties are recognized and } \\
\text { discussed, as appropriate. (ORP } Q A P P \text { criterion } 2.17 \text { ) }\end{array}$ \\
\hline [ ] & [ ] & {$[\mathrm{X}]$} & 11. & $\begin{array}{l}\text { Mathematical derivations were checked including dimensional consistency of } \\
\text { results. (ORP QAPP criterion } 2.16 \text { ) }\end{array}$ \\
\hline [ ] & [ ] & {$[\mathrm{X}]$} & 12. & $\begin{array}{l}\text { Models are appropriate and were used within their established range of validity } \\
\text { or adequate justification was provided for use outside their established range of } \\
\text { validity. }\end{array}$ \\
\hline & & {$[\mathrm{X}]$} & 13. & Spreadsheet results and all hand calculations were verified. \\
\hline & & {$[\mathrm{X}]$} & 14. & $\begin{array}{l}\text { Calculations are sufficiently detailed such that a technically qualified person } \\
\text { can understand the analysis without requiring outside information. (ORP } \\
Q A P P \text { criterion 2.5) }\end{array}$ \\
\hline & & {$[\mathrm{X}]$} & 15. & Software input is correct and consistent with the document reviewed. \\
\hline & & {$[\mathrm{X}]$} & 16. & $\begin{array}{l}\text { Software output is consistent with the input and with the results reported in the } \\
\text { document reviewed. }\end{array}$ \\
\hline & & {$[\mathrm{X}]$} & 17. & $\begin{array}{l}\text { Software verification and validation are addressed adequately. (ORP QAPP } \\
\text { criterion 2.6) }\end{array}$ \\
\hline [ ] & {[} & {$[X]$} & 18. & $\begin{array}{l}\text { Limits/criteria/guidelines applied to the analysis results are appropriate and } \\
\text { referenced. Limits/criteria/guidelines were checked against references. (ORP } \\
Q A P P \text { criterion 2.9) }\end{array}$ \\
\hline & & {$[\mathrm{X}]$} & 19 & Safety margins are consistent with good engineering practices. \\
\hline & & & & clusions are consistent with analytical results and applicable limits. \\
\hline
\end{tabular}




\section{RPP-13482 REV 5}

[ ] [ ] [X] 21. Results and conclusions address all points in this purpose. (ORP QAPP criterion 2.3)

[X] [ ] [ ] 22. All references cited in the text, figures, and tables are contained in the reference list.

[X] [ ] [ ] 23. Reference citations (e.g., title and number) are consistent between the text callout and the reference list.

[X] [ ] [ ] 24. Only released (i.e., not draft) references are cited. (ORP QAPP criterion 2.1)

[X] [ ] [ ] 25. Referenced documents are retrievable or otherwise available.

[X] [] [ ] 26. The most recent version of each reference is cited, as appropriate. (ORP $Q A P P$ criterion 2.1)

[X] [ ] [ ] 27. There are no duplicate citations in the reference list.

[X] [ ] [ ] 28. Referenced documents are spelled out (title and number) the first time they are cited.

[X] [ ] [ ] 29. All acronyms are spelled out the first time they are used.

[X] [] [] 30. The Table of Contents is correct.

[X] [ ] [] 31. All figure, table, and section callouts are correct.

[X] [ ] [] 32. Unit conversions are correct and consistent.

[ ] [ ] [X] 33. The number of significant digits is appropriate and consistent.

[] [] [X] 34. Chemical reactions are correct and balanced.

[X] [ ] [] 35. All tables are formatted consistently and are free of blank cells.

[X] [ ] [ ] 36. The document is complete (pages, attachments, and appendices) and in the proper order.

[X] [ ] [ ] 37. The document is free of typographical errors.

[X] [ ] [ ] 38. The tables are internally consistent.

[ ] [] [X] 39. The document was prepared in accordance with HNF-2353, Section 4.3, Attachment B, "Calculation Note Format and Preparation Instructions".

Comments:

Tech Edit

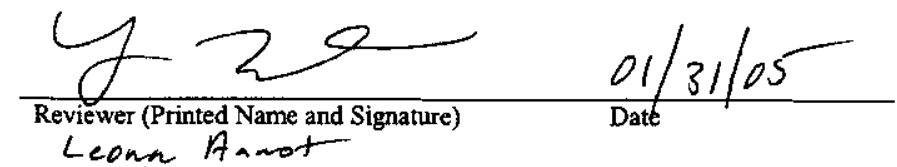

*If No or NA is chosen, an explanation must be provided on this form. 


\title{
CHECKLIST FOR TECHNICAL PEER REVIEW
}

\author{
Document Reviewed: Appendix to RPP-1348 2
Speriel x/Q for Pool fires ot the DBVS
Scope of Review (e.g., document section or portion of calculation):
}

Yes No NA*

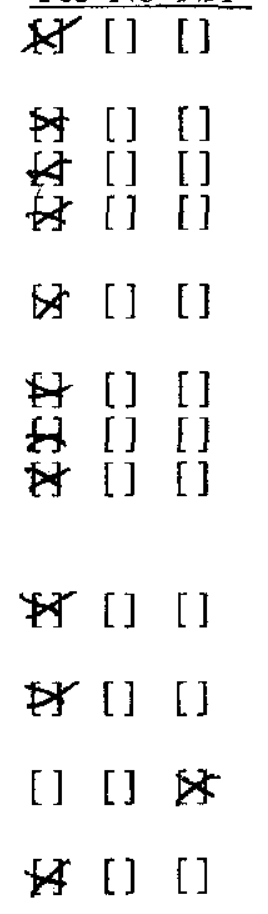

1. Previous reviews are complete and cover the analysis, up to the scope of this review, with no gaps.

2. Problem is completely defined.

3. Accident scenarios are developed in a clear and logical manner.

4. Analytical and technical approaches and results are reasonable and appropriate. (ORP QAPP criterion 2.8)

5. Necessary assumptions are reasonable, explicitly stated, and supported. (ORP QAPP criterion 2.2)

6. Computer codes and data files are documented.

7. Data used in calculations are explicitly stated.

8. Bases for calculations, including assumptions and data, are consistent with the supported safety basis document (e.g., the Tank Farms Final Safety Analysis Report).

9. Data were checked for consistency with original source information as applicable. (ORP QAPP criterion 2.9)

10. For both qualitative and quantitative data, uncertainties are recognized and discussed, as appropriate. (ORP QAPP criterion 2.17)

11. Mathematical derivations were checked including dimensional consistency of results. (ORP QAPP criterion 2.16)

12. Models are appropriate and were used within their established range of validity or adequate justification was provided for use outside their established range of validity.

L4 [] 13. Spreadsheet results and all hand calculations were verified.

54 [ ] [ ] 14. Calculations are sufficiently detailed such that a technically qualified person can understand the analysis without requiring outside information. (ORP $Q A P P$ criterion 2.5)

[ ] [ ] 15. Software input is correct and consistent with the document reviewed.

\$ [ ] [] 16. Software output is consistent with the input and with the results reported in the document reviewed.

\$ [ ] 17. Software verification and validation are addressed adequately. (ORP QAPP criterion 2.6)

[] [] 18 . Limits/criteria/guidelines applied to the analysis results are appropriate and referenced. Limits/criteria/guidelines were checked against references. (ORP QAPP criterion 2.9)

19. Safety margins are consistent with good engineering practices.

20. Conclusions are consistent with analytical results and applicable limits.

21. Results and conclusions address all points in the purpose. (ORP QAPP criterion 2.3)

[1 [] 22. All references cited in the text, figures, and tables are contained in the reference list. 
[ ] [ ] 23. Reference citations (e.g., title and number) are consistent between the text callout and the reference list.

E [] [] 24. Only released (i.e., not draft) references are cited. (ORP QAPP criterion 2.1)

[ [] [] 25. Referenced documents are retrievable or otherwise available.

$\forall$ [ ] [ ] 26. The most recent version of each reference is cited, as appropriate. (ORP QAPP criterion 2.1)

[ [ ] 27. There are no duplicate citations in the reference list.

bf [ ] [] 28. Referenced documents are spelled out (title and number) the first time they are cited.

\T [ ] [ ] 29. All acronyms are spelled out the first time they are used.

[] [] 30. The Table of Contents is correct.

4. [ ] [] 31. All figure, table, and section callouts are correct.

[ [] [] 32. Unit conversions are correct and consistent.

4 [] [] 33. The number of significant digits is appropriate and consistent.

[] [] Y 34. Chemical reactions are correct and balanced.

4 [ ] [] 35. All tables are formatted consistently and are free of blank cells.

4 [1 [] 36. The document is complete (pages, attachments, and appendices) and in the proper order.

X [] [] 37. The document is free of typographical errors.

W [] [] 38. The tables are internally consistent.

[] [] 39. The document was prepared in accordance with HNF-2353, Section 4.3, Attachment B, "Calculation Note Format and Preparation Instructions".

[ ] [] 40. Impacted documents are appropriately identified in Blocks 7 and 25 of the Engineering Change Notice (form A-6003-563.1).

[ ] [ ] [\$ 41. If more than one Technical Peer Reviewer was designated for this document, an overall review of the entire document was performed after resolution of all Technical Peer Review comments and confirmed that the document is selfconsistent and complete.

\section{(X) I] I] Concurrence}

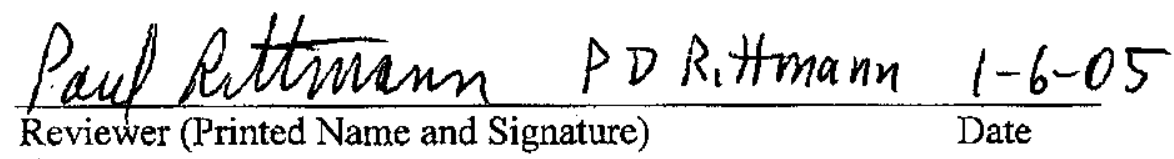

* If No or NA is chosen, provide an explanation on this form.

All "NA" responses are for checklist items that do not apoly to this document, 


\section{CHECKLIST FOR TECHNICAL PEER REVIEW}

Document Reviewed: RPP- 13482 Rev 4

Scope of Review (e.g., document section or portion of calculation): Technical edit

Yes No NA*

[] [ ] [x] 1. Previous reviews are complete and cover the analysis, up to the scope of this review, with no gaps.

[ ] [ ] [x] 2. Problem is completely defined.

[ ] [] [x] 3. Accident scenarios are developed in a clear and logical manner.

[ ] [ ] [x] 4. Analytical and technical approaches and results are reasonable and appropriate. (ORP QAPP criterion 2.8)

[ ] [ ] [x] 5. Necessary assumptions are reasonable, explicitly stated, and supported (ORP QAPP criterion 2.2)

[] [] [x] 6. Computer codes and data files are documented.

[ ] [ ] [x] 7. Data used in calculations are explicitly stated.

[ ] [ ] [ $\mathrm{x}]$ 8. Bases for calculations, including assumptions and data, are consistent with the supported safety basis document (e.g., the Tank Farms Final Safety Analysis Report).

[] [] [x]. 9. Data were checked for consistency with original source information as applicable. (ORP QAPP criterion 2.9)

[ ] [ ] [x] 10. For both qualitative and quantitative data, uncertainties are recognized and discussed, as appropriate. (ORP QAPP criterion 2.17)

[] [] [x] 11. Mathematical derivations were checked including dimensional consistency of results. (ORP QAPP criterion 2.16)

[] [ ] [x] 12. Models are appropriate and were used within their established range of validity or adequate justification was provided for use outside their established range of validity.

[ ] [ ] [x] 13. Spreadsheet results and all hand calculations were verified.

[ ] [ ] [x] 14. Calculations are sufficiently detailed such that a technically qualified person can understand the analysis without requiring outside information. (ORP $Q A P P$ criterion 2.5)

[ ] [ ] [x] 15. Software input is correct and consistent with the document reviewed.

[ ] [ ] [x] 16. Software output is consistent with the input and with the results reported in the document reviewed.

[ ] [ ] [x] 17. Software verification and validation are addressed adequately. (ORP QAPP criterion 2.6)

[] [] [x] 18. Limits/criteria/guidelines applied to the analysis results are appropriate and referenced. Limits/criteria/guidelines were checked against references. (ORP QAPP criterion 2.9)

[ ] [ ] [x] 19. Safety margins are consistent with good engineering practices.

[ ] [ ] [x] 20. Conclusions are consistent with analytical results and applicable limits. 


\section{RPP-13482 REV 5}

\section{CHECKLIST FOR TECHNICAL PEER REVIEW}

[ ] [ ] [ $\mathrm{x}$ ] 21. Results and conclusions address all points in the purpose. (ORP QAPP criterion 2.3)

[x] [.] [ ] 22. All references cited in the text, figures, and tables are contained in the reference list.

[x] [] [ ] 23. Reference citations (e.g., title and number) are consistent between the text callout and the reference list.

[x] [ ] [ ] 24. Only released (i.e., not draft) references are cited. (ORP QAPP criterion 2.1)

[x] [] [] 25. Referenced documents are retrievable or otherwise available.

[x] [] [ ] 26. The most recent version of each reference is cited, as appropriate. (ORP QAPP criterion 2.1)

[x] [] [] 27. There are no duplicate citations in the reference list.

[x] [ ] [ ] 28. Referenced documents are spelled out (title and number) the first time they are cited.

[x] [ ] [ ] 29. All acronyms are spelled out the first time they are used.

[x] [ ] [ ] 30. The Table of Contents is correct.

[x] [] [ ] 31. All figure, table, and section callouts are correct.

[x] [ ] [ ] 32. Unit conversions are correct and consistent.

[x] [ ] [ ] 33. The number of significant digits is appropriate and consistent.

[ ] [ ] [ $\mathrm{x}$ ] 34. Chemical reactions are correct and balanced.

[x] [ ] [ ] 35. All tables are formatted consistently and are free of blank cells.

[x] [ ] [ ] 36. The document is complete (pages, attachments, and appendices) and in the proper order.

[x] [] [ ] 37. The document is free of typographical errors.

[x] [] [ ] 38. The tables are internally consistent.

[x] [ ] [ ] 39. The document was prepared in accordance with HNF.2353, Section 4.3, Attachment B, "Calculation Note Format and Preparation Instructions".

[ ] [ ] [x] 40. Impacted documents are appropriately identified in Blocks 7 and 25 of the Engineering Change Notice (form A-6003-563.1).

[] [ ] [x] 41. If more than one Technical Peer Reviewer was designated for this document, an overall review of the entire document was performed after resolution of all Technical Peer Review comments and confirmed that the document is self-

\section{[x] [1] [1] Concurrence} consistent and complete.

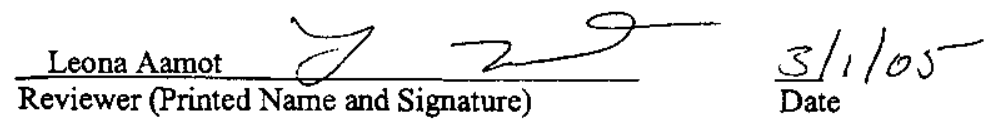

* If No or NA is chosen, provide an explanation on this form.

Technical Edit 


\section{CHECKLIST FOR TECHNICAL PEER REVIEW}

Document Reviewed: Appendix to RPP-13482, Special X/Q's for Pool Fires at the CH-TRUM

Waste Packaging Unit

Scope of Review (e.g., document section or portion of calculation): entire document

Yes No NA*

$X$ [ ] [ ] Previous reviews are complete and cover the analysis, up to the scope of this review, with no gaps.

* [] [ ] 2. Problem is completely defined.

$\forall$ [] [ ] 3. Accident scenarios are developed in a clear and logical manner.

A7 [] [] 4. Analytical and technical approaches and results are reasonable and appropriate. (ORP QAPP criterion 2.8)

4] [ ] 5. Necessary assumptions are reasonable, explicitly stated, and supported. (ORP QAPP criterion 2.2)

D [ ] [ ] 6. Computer codes and data files are documented.

B [ ] [] 7. Data used in calculations are explicitly stated.

X] [] [ ] 8. Bases for calculations, including assumptions and data, are consistent with the supported safety basis document (e.g., the Tank Farms Final Safety Analysis Report).

[ [] [] 9. Data were checked for consistency with original source information as applicable. (ORP QAPP criterion 2.9)

[] [] 10. For both qualitative and quantitative data, uncertainties are recognized and discussed, as appropriate. (ORP QAPP criterion 2.17)

[] [] 11. Mathematical derivations were checked including dimensional consistency of results. (ORP QAPP criterion 2.16)

Q [ ] [ ] 12. Models are appropriate and were used within their established range of validity or adequate justification was provided for use outside their established range of validity.

$\left.\forall \begin{array}{lll}8 & {[1} & {[}\end{array}\right]$

13. Spreadsheet results and all hand calculations were verified.

$\forall$ [] [] 14. Calculations are sufficiently detailed such that a technically qualified person can understand the analysis without requiring outside information. (ORP $Q A P P$ criterion 2.5)

$\forall[1]$

15. Software input is correct and consistent with the document reviewed.

X [] []

16. Software output is consistent with the input and with the results reported in the document reviewed.

D. [] []

17. Software verification and validation are addressed adequately. (ORP QAPP criterion 2.6)

A [ ] [ []

18. Limits/criteria/guidelines applied to the analysis results are appropriate and referenced. Limits/criteria/guidelines were checked against references. (ORP QAPP criterion 2.9)

DX [] [ ] 19. Safety margins are consistent with good engineering practices.

स [ ] [ ] 20. Conclusions are consistent with analytical results and applicable limits.

$\triangle[$ [] [] 21. Results and conclusions address all points in the purpose. (ORP QAPP criterion 2.3)

A [ ] [ ] 22. All references cited in the text, figures, and tables are contained in the 
reference list.

M [ ] [ ] 23. Reference citations (e.g., title and number) are consistent between the text callout and the reference list.

D [ ] [] 24. Only released (i.e., not draft) references are cited. (ORP QAPP criterion 2.1)

[X [] [] 25. Referenced documents are retrievable or otherwise available.

(X] [] [] 26. The most recent version of each reference is cited, as appropriate. (ORP QAPP criterion 2.1)

D [ ] [ ] 27. There are no duplicate citations in the reference list.

W [] [] 28. Referenced documents are spelled out (title and number) the first time they are cited.

29. All acronyms are spelled out the first time they are used.

The Table of Contents is correct.

[] [] X 32. Unit conversions are correct and consistent.

(A [1 [] 33. The number of significant digits is appropriate and consistent.

[] [] $\$ 34. Chemical reactions are correct and balanced.

[ [ ] [] 35. All tables are formatted consistently and are free of blank cells.

D] [] [] 36. The document is complete (pages, attachments, and appendices) and in the proper order.

A [ ] [ ] 37. The document is free of typographical errors.

[X] [ ] [ ] 38. The tables are internally consistent.

W [ ] [ ] 39. The document was prepared in accordance with HNF-2353, Section 4.3, Attachment B, "Calculation Note Format and Preparation Instructions".

X] [] [] 40. Impacted documents are appropriately identified in Blocks 7 and 25 of the Engineering Change Notice (form A-6003-563.1).

A [] [] 41. If more than one Technical Peer Reviewer was designated for this document, an overall review of the entire document was performed after resolution of all Technical Peer Review comments and confirmed that the document is selfconsistent and complete.

\section{A [ ] [] Concurrence}

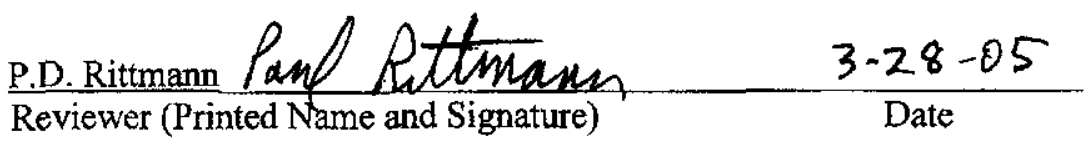

* If No or NA is chosen, provide an explanation on this form.

\section{Items maxked NA do not apply to this document.}




\section{RPP-13482 REV 5}

Subcontractor Calculation Review Checklist.

Page_1_of 1 -

Subject: RPP-13482, Revision 5, prepared by the Fluor Government Group

The subject document has been reviewed by the undersigned.

The checker reviewed and verified the following items as applicable.

Documents Reviewed: RPP-13482, Appendix N

Analysis Performed By: DA Himes and PD Rittman of Fluor Government Group

- Design Input

- Basic Assumptions

- Approach/Design Methodology

- Consistency with item or document supported by the calculation

- Conclusion/Results Interpretation - N/A

- Impact on existing requirements

-

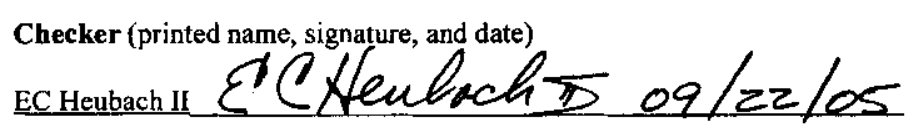

Organizational Manager (printed name, signature and date)

M Grigsby $4 / 22 / 6$

